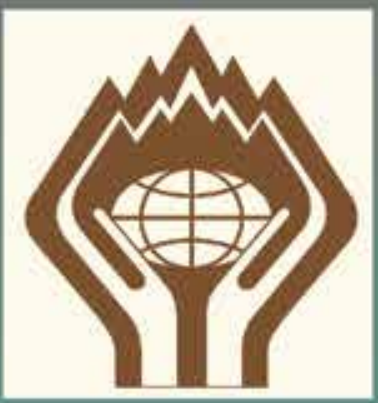

УCTOЙUИBOE ISSN 1998-4502 e-ISSN 2499-975X PABВИTИE

FOPHDX TEPPИTOPИЙ

НАучНЫЙ ЖУРнАл Sustainable Development of Nieuntain Territeries

SeMn - nnarera He пpoorar: A. де Cent-arsionepu

T.10

№4(38),

2018 


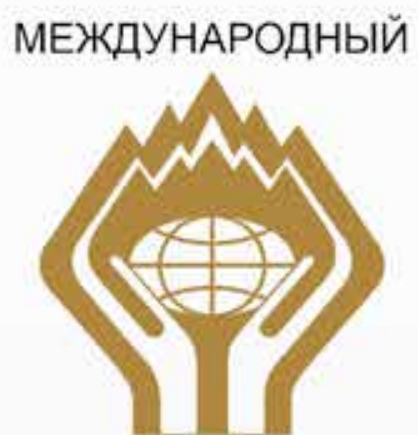

\section{НАУЧНЫЙ ЖУРНАЛ "УСТОЙЧИВОЕ РАЗВИТИЕ ГОРНЫХ ТЕРРИТОРИЙ"}

Журнал входит в Перечень изданий, рекомендованных Высшей аттестационной комиссией (ВАК)

Журнал включен в международную реферативную базу данных и систему цитирования Scopus

\section{Адрес редакции, учредителя, издателя: \\ 362021, РСО-Алания,}

г. Владикавказ, ул. Николаева, 44,

Северо-Кавказский горно-

металлургический институт

(государственный технологический университет)

редакция журнала «Устойчивое развитие горных территорий».

Тел.: 8(8672) 40-73-60, 8(918) 707-39-25 $8(8672)$ 40-72-28

Адрес в Интернете http://www.naukagor.ru E-mail: editor@naukagor.ru

Ответственность за содержание статей несут авторы.

Редакция не имеет возможности возвращать присылаемые материалы. За сведения в рекламных материалах редакция ответственности не несет.

Перепечатка допускается только с разрешения редакции

и с обязательной ссылкой на журнал «Устойчивое развитие горных территорий».

Журнал зарегистрирован в Федеральной службе по надзору за соблюдением законодательства в сфере массовых коммуникаций и охраны культурного наследия.

Свидетельство о регистрации

ПИ №ФС77-27831 от 19.04.2007 г. Издается с 2009 г.

Редактор МИСИКОВА И.А.

Технический перевод ПЕЙКАРОВА Н.И. Компьютерный дизайн и верстка ПРОВОТОРОВА Н.М.

Тираж 500 экз. Заказ №23

Подписано в печать: 25.12.2018 г

Дата фактического выхода: 29.12.2018 г.

Отпечатано в типографии ИП Могилевский Е.С.

344064, г. Ростов-на-Дону, ул. 2-й Пятилетки 23У.

(c) «Устойчивое развитие горных территорий», 2018
УЧРЕДИТЕЛЬ:

СЕВЕРО-КАВКАЗСКИЙ ГОРНО-МЕТАЛЛУРГИЧЕСКИЙ ИНСТИТУТ (ГОСУДАРСТВЕННЫЙ ТЕХНОЛОГИЧЕСКИЙ УНИВЕРСИТЕТ)

\section{РЕДАКЦИОННАЯ КОЛЛЕГИЯ:}

Главный редактор - Дмитрак Юрий Витальевич - доктор технических наук, профессор, ректор Северо-Кавказского горно-металлургического института (государственного технологического университета) (Владикавказ, Россия).

\section{ЗАМЕСТИТЕЛИ ГЛАВНОГО РЕДАКТОРА}

Темираев Р.Б. - доктор сельско-хозяйственных наук, профессор, первый заместитель главного редактора, проректор по научной работе и инновационной деятельности Северо-Кавказского горно-металлургического института (государственного технологического университета (Владикавказ, Россия).

Гуня А.Н. - доктор географических наук, профессор, руководитель горной группы МАВ-6 программы ЮНЕСКО «Человек и биосфера» в Институте географии Российской академии наук, старший научный сотрудник ИГ РАН (Москва, Россия). Клюев РВ - доктор технических наук, профессор, заведующий кафедрой «Электроснабжение промышленных предприятий» Северо-Кавказского горно-металлургического института (государственного технологического университета), ответственный за выпуск номеров журнала (Владикавказ, Россия).

Хосаев Х.C. - доктор технических наук, профессор, заместитель начальника Управления внешних связей и устойчивого развития Северо-Кавказского горно-металлургического института (государственного технологического университета), ответственный за выпуск номеров журнала (Владикавказ, Россия).

ОТВЕТСТВЕННЫЕ СЕКРЕТАРИ (по направлениям):

Науки о Земле - Хацаева Ф.М. - кандидат географических наук, доцент, декан факультета географии и геоэкологии, заведующий кафедрой «Геоэкология и землеустройство» Северо-Осетинского государственного университета им. К.Л. Хетагурова, Председатель отделения Русского географического общества в Республике Северная Осетия-Алания (Владикавказ, Россия)

Экология - Гриднев Е.А. - кандидат технических наук, доцент кафедры «Экология и техносферная безопасность» Северо-Кавказского горно-металлургического института (государственного технологического университета) (Владикавказ, Россия).

Экономические науки - Галачиева С.В. - доктор экономических наук, профессор, заведующий кафедрой экономической теории Северо-Кавказского горно-металлургического института (государственного технологического университета) (Владикавказ, Россия).

Технические науки - Лолаев А.Б - доктор технических наук, заведующий кафедрой «Автомобильные дороги и аэродромы» Северо-Кавказского горно-металлургического института (государственного технологического университета) (Владикавказ, Россия); Хетагуров В.Н. - доктор технических наук, профессор кафедры «Технологические машины и оборудование» Северо-Кавказского горно-металлургического института (государственного технологического университета) (Владикавказ, Россия)

\section{РЕДАКТОРЫ:}

Караев Ю.И. - директор Международного инновационного научно-технологического центра «Устойчивое развитие горных территорий» (МИНТЦ «Горы») Северо-Кавказского горно-металлургического института (государственного технологического университета) (Владикавказ, Россия).

Мисикова И.А. - начальник редакционно-издательского отдела Северо-Кавказского горно-металлургического института (государственного технологического университета) (Владикавказ, Россия).

\section{РЕДАКЦИОННЫЙ СОВЕТ:}

Председатель редакционного совета:

Котляков В.М. - доктор географических наук, академик РАН, Почетный президент Русского географического общества, председатель экспертного совета Национальной премии «Хрустальный компас», член Межправительственной группь экспертов по проблеме изменения климата (Москва, Россия).

\section{СОПРЕДСЕДАТЕЛИ РЕДАКЦИОННОГО СОВЕТА:}

Вейнгартнер Р. - доктор наук, профессор Университета г. Берн (Швейцария), заведующий кафедрой гидрологии Географического института Университета г. Берн. Руководитель Международной Исследовательской Инициативы (MRI) (г. Берн, Швейцария)

Дзасохов А.С. - доктор политических наук, заместитель председателя Комиссии Российской Федерации по делам ЮНЕ СКО (Москва, Россия)

Кавалла Р. - кандидат технических наук, профессор, директор института обработки металлов давлением Фрайбергской Горной Академии (Германия)

Пучков Л.А. - доктор технических наук, профессор, член корр. РАН, профессор кафедры «Безопасность и экология горного производства» Горного института Национального исследовательского технологического университета «Московский институт стали и сплавов» (Москва, Россия)

\section{СОСТАВ РЕДАКЦИОННОГО СОВЕТА}

Айдаралиев А.А. - доктор медицинских наук, академик Национальной Академии наук Республики Кыргызстан, Председатель попечительского Совета УНПК «Международный университет Кыргызстана» (Бишкек, Кыргызская Республика). Бабаян Г.А. - кандидат физико-математических наук, заведующий отделом мониторинга и инноваций Института геологических наук Национальной Академии наук Армении (Ереван, Республика Армения)

Баденков Ю.П. - кандидат геолого-минералогических наук, ведущий научный сотрудник Института географии РАН, научный руководитель горной группы МАВ-6 программы ЮНЕСКО «Человек и биосфера» в Институте географии РАН (Москва, Россия)

Большаков В.Н. - доктор биологических наук, профессор, академик Российской академии наук, Советник РАН, гпавный научный сотрудник, заведующий лабораторией эволюционной экологии Института экологии растений и животных УрО РАН (Москва-Екатеринбург, Россия).

Вагин В.С. - доктор экономических наук, профессор, директор Института международного образования Южно-Российского государственного политехнического университета (Новочеркасского политехнического института) (Новочеркасск, Россия)

Викторов С.Д - доктор технических наук, профессор, заместитель директора по научной работе Института проблем комплексного освоения недр РАН (Москва, Россия).

Глазырина И.П. - доктор экономических наук, кандидат физико-математических наук, профессор, заведующая кафедрой «Прикладная информатика и математика» Забайкальского государственного университета (Чита, Россия).

Голик В.И. - доктор технических наук, профессор; профессор кафедры «Технология разработки месторождений» Северо-Кавказского горно-металлургического института (государственного технологического университета) (Владикавказ, Россия)

Гроппен В.О. - доктор технических наук, профессор, заведующий кафедрой «Автоматизированная обработка информации» Северо-Кавказского горно-металлургического института (государственного технологического университета) (Владикавказ, Россия).

Залиханов М.Ч. - доктор географических наук, профессор, академик РАН, Главный научный сотрудник Высокогорного геофизического института Росгидромета (Нальчик, Россия)

Кондратьев Ю.И. - доктор технических наук, профессор Северо-Кавказского горно-металлургического института (государственного технологического университета) (Владикавказ, Россия)

Лурье П.М. - доктор географических наук, профессор, ведущий метеоролог Северо-Кавказского управления по гидрометеорологии и мониторингу окружающей среды (Ростов-на-Дону, Россия)

Матвеева Л.Г. - доктор экономических наук, профессор, заведующая кафедрой «Информационная экономика» экономического факультета Южного федерального университета (Ростов-на-Дону, Россия).

Минцаев М.Ш. - доктор технических наук, профессор, проректор по научной работе и инновациям Грозненского государственного нефтяного технического университет им. акад. М.Д. Миллионщикова (Грозный, Россия)

Прхалова М. - программный специалист отдела «Экология и науки о Земле» Секретариата ЮНЕСКО, (Париж, Франция) Ревякин В.С. - доктор географических наук, профессор кафедры «Общая географрия» Национального исследовательского Томского государственного университета, руководитель региональной группы «Алтай-Саяны» в составе сети горных центров мира, (Алтай, Россия)

Сысоев Н.И. - доктор технических наук, профессор кафедры «Нефтегазовая техника и технологиии» Южно-Российского государственного политехнического университета (НПИ) имени М.И. Платова, (Новочеркасск, Россия) Штадельбауэр Й. - доктор философских наук, профессор Фрайбургского университета (Германия). 


\section{EDITORIAL TEAM}

Chief Editor - Yuri V. Dmitrak - Professor, Rector of the North Caucasian Institute of Mining and Metallurgy(State Technological University) (Vladikavkaz, Russia)

\section{DEPUTY CHIEF EDITORS:}

First Deputy Chief Editor - Rustem B. Temiraev - Doctor of Agricultural Science, Professor, Head of Publication Finalizing Team, Vice Rector for Research and Innovation, North Caucasian Institute of Mining and Metallurgy (State Technological University) (Vladikavkaz, Russia).

Alexey N. Gunya - Dr. Sci. in Geography, Professor, Head of Mountain Group MAB-6 aided by UNESCO "Man and Biosphere" Program, Institute of Geography, Russian Academy of Science, Senior Research Associate of IG RAS (Moscow, Russia).

Roman V. Klyuev - Doctor of Technical Science, Professor, Head of Department of Power Supply of Industrial Enterprises, North Caucasian Institute of Mining and Metallurgy (State Technological University) (Vladikavkaz, Russia).

Hazbi S. Hosaev - Doctor of Technical Science, Professor, Deputy Director of Centre for International Cooperation, External Relations and Sustainable Development, North Caucasian Institute of Mining and Metallurgy (State Technological University) (Vladikavkaz, Russia).

\section{EXECUTIVE EDITORS (by areas of activity):}

Earth Sciences - Fatima M. Khatsaeva - Cand. Sc. in Geography, Associate Professor, Dean of Faculty of Geography and Geoecology, Head of Department Geoecology and Land Management Department of North Ossetian State University, Chairman of North Ossetian Department of Russian Geographical Society (Vladikavkaz, Russia)

Ecology - Yevgeny A. Gridnev - Cand. Sc. (Engineering), Associate Professor of Department of Ecology and Technosphere Safety, North Caucasian Institute of Mining and Metallurgy (State Technological University) (Vladikavkaz, Russia).

Economic Sciences - Svetlana B. Galachieva - Doctor of Economics, Professor, Head of Department of Economic Theory, North Caucasian Institute of Mining and Metallurgy (State Technological University) (Vladikavkaz, Russia)

Engineering Sciences - Alan B. Lolaev - Doctor in Technical Science, Professor, Head of Department of Automobile Roads and Aerodromes, North Caucasian Institute of Mining and Metallurgy (State Technological University) (Vladikavkaz, Russia).

Valery N. Hetagurov - Doctor of Technical Science, Professor of Department of Technological Science and Equipment, North Caucasian Institute of Mining and Metallurgy (State Technological University) (Vladikavkaz, Russia).

\section{EDITORS:}

Yuri I. Karaev - Director of International Innovation Scientific Technological Centre Sustainable Development of Mountain Territories, North Caucasian Institute of Mining and Metallurgy (State Technological University) (Vladikavkaz, Russia).

Indira A. Misikova - Head of Editorial Department, North Caucasian Institute of Mining and Metallurgy (State Technological University) (Vladikavkaz, Russia).

\section{EDITORIAL BOARD:}

\section{Chairman:}

Vladimir M. Kotlyakov - Dr. Sci. in Geography, Member of Russian Academy of Science, Honorary President of Russian Geographical Society, Chairman of Expert Board of Crystal Compass National Award, Member of Intergovernmental Panel on Climate Change (Moscow, Russia).

\section{CO-CHAIRS}

Rolf Weingartner - Doctor of Science, Professor of University of Bern (Switzerland), Head of Department of Hydrology, Institute of Geography, University of Bern. Supervisor of International Research Initiative (MRI) (Bern, Switzerland).

Alexander S. Dzasokhov - Doctor of Political Science, Deputy Chairman of Russian Commission for UNESCO (Moscow, Russia). Rudolf Kawalla - Doctor of Technical Science, Professor, Director of Institute of Metal Processing Pressure, Freiberg University of Mining and Technology (Germany).

Lev A. Puchkov - Doctor in Technical Science, Professor, Corresponding Member of Russian Academy of Science, Member of Academy of Natural Sciences, Member of International Academy of Higher Education, Professor of Department of Safety and Ecology of Mining Industry, College of Mining, National University of Science and Technology MISiS (Moscow, Russia).

\section{MEMBERS OF EDITORIAL BOARD:}

Asylbek A. Aidaraliev - Dr. habil. in Medicine, Member of National academy of Science of Kyrgyz Republic, Head of UNESCO Department of Sustainable Mountain Development and Chairman of Supervisory Board of Educational Research and Production Complex «International University of Kyrgyzstan» (Bishkek, Kyrgyz Republic).

Hector A. Babayan - Cand. Sc. (Physics and Mathematics), Head of Department of Monitoring and Innovation, Institute of Geological Sciences, National Academy of Science, Republic of Armenia (Yerevan, Republic of Armenia).

Yuri P. Badenkov - Cand. Sc. in Geology and Mineralogy, Leading Research Associate of Institute of Geography of Russian Academy of Science, Scientific Supervisor of Mountain Group MAB-6, Man and Biosphere Program by UNESCO, Institute of Geography of RAS (Moscow, Russia).

Yuri N. Bolshakov - Dr. Sci. in Biology, Professor, Member of Russian Academy of Science, Adviser to RAS, Senior Research Associate, Head of Laboratory of Evolutionary Ecology, Institute of Plant and Animal Ecology, Ural Department of Russian Academy of Science (Moscow-Yekaterinburg, Russia).

Vladimir S. Vagin - Doctor of Economics, Professor, Director of Institute of International Education, South Russian State Polytechnic University (Novocherkassk Polytechnic Institute) (Novocherkassk, Russia)

Sergey D. Viktorov - Doctor in Technical Science, Professor, Deputy Director for Research Institute of Comprehensive Exploitation of Subsoil, Russian Academy of Science (Moscow, Russia).

Irina P. Glazyrina - Doctor in Economics, Cand. Sc. in Physics and Mathematics, Head of Department of Applied Mathematics and Informatics, Trans-Baikal State University (Chita, Russia)

Golik V. I. - Doctor of Technical Sciences, Professor, Professor of the Department "Development of mineral deposits", NorthCaucasian Institute of Mining and Metallurgy (State Technological University) (Vladikavkaz, Russia).

Vitaly O. Groppen - Doctor in Technical Science, Professor, Head of Department of Automated Processing of Information, North Caucasian Institute of Mining and Metallurgy (State Technological University) (Vladikavkaz, Russia).

Mikhail Ch. Zalikhanov - Dr. Sci. in Geography, Professor, Member of Russian Academy of Science, Senior Research Associate, High-Mountain Geophysical Institute of Federal Service for Hydrometeorology and Environmental Monitoring of Russia (Nalchik, Russia).

Yuri I. Kondratyev - Doctor Technical Science, Professor, North Caucasian Institute of Mining and Metallurgy (State Technological University) (Vladikavkaz, Russia).

Pyotr M. Lur'e - Dr. Sci. in Geography, Professor, Leading Meteorologist, North Caucasian Department of Hydrometeorology and Environmental Monitoring (Rostov-on-Don, Russia).

Lyudmila G. Matveeva - Doctor in Economics, Head of Department of Information Economy, Faculty of Economics, South Federal University (Rostov-on-Don, Russia).

Magomed Sh. Mintsaev - Doctor in Technical Science, Professor, Vice Rector for Research and Innovation, Acad. M. D. Millionshchikov Grozny State Oil Technical University (Grozny, Russia).

Marie Prchalova - Programme Specialist, Division of Ecological and Earth Sciences, UNESCO Secretariat.

Viktor S. Revyakin - Dr. Sci. in Geography, Professor of Department of General Geography, National Research Tomsk State University, Head of Altai-Sayans Regional Group of World Mountain Centers Network, Member of Russian Academy of Natural Sciences and Russian Ecological Academy (Barnaul, Russia).

Nikolay I. Sysoev - Doctor in Technical Science, Professor of Department of Petroleum Engineering and Technology, South Russian State Polytechnic University (Novocherkassk Polytechnic Institute) (Novocherkassk, Russia).

Jorg Stadelbauer - Dr. Phil., Professor of University of Freiburg (Germany).

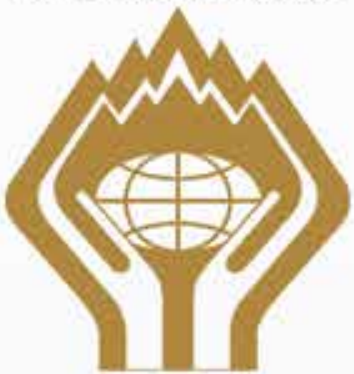

SCIENTIFIC JOURNAL

"SUSTAINABLE DEVELOPMENT OF MOUNTAIN TERRITORIES"

The journal is included in the List of publications recommended by Supreme

Attestation Commission (VAK)

The journal is included in the International

Reference Database and Scopus citation System

Address of the editorial office, founder, publisher:

44 Nikolaev Street, Vladikavkaz, RNO-Alania, 362021 , NORTH CAUCASIAN INSTITUTE OF MINING AND METALLURGY

(STATE TECHNOLOGICAL UNIVERSITY)

Editorial Office of the journal "Sustainable

Development of Mountain Territories". Tel.: +7 (8672) 40-73-60, $+7(918) 707-39-25$, +7 (8672) 40-72-28.

Internet address: http://www.naukagor.ru E-mail: editor@naukagor.ru

Authors are responsible for the content of the articles.

Editorial staff is not in the position to return the submitted materials.

Editorial staff is not responsible for the information in promotional materials. Reprinting is allowed only with the permission of the editorial office and reference to the journal

«Sustainable Development of Mountain Territories» is required

The journal is registered in the Federal Service for Media Law Compliance and Cultural Heritage Protection.

Registration Certificate PI No FS 77-27831 From April, 192007

Published since 2009 Is free Editor MISIKOVA I.A.

Technical translation

PEYKAROVA N.I.

Computer design and make-up PROVOTOROVA N.M.

Covering -500 copies

Order No 23

Signed to print: 25.12 .2018

Date of actual release: 29.12.2018

Printed by IE E.S. Mogilevsky, $23 \mathrm{U} 2$ Pyatiletki st.

344064, Rostov-on-Don 


\section{СОДЕРЖАНИЕ}

\section{НАУКИ О ЗЕМЛЕ}

471

Рудько Г.И., Мятченко А.В.,

Исатаева Ф.М., Портнов В.С.

ГЕОЛОГО-ЭКОНОМИЧЕСКАЯ ОЦЕНКА

ЗАПАСОВ МЕСТОРОЖДЕНИЙ КАЗАХСТАНА

Дегтярева Т.В., Лиховид А.А.,

Лысенко А.В., Караев Ю.И.

РЕГИОНАЛЬНЫЕ СТРУКТУРЫ МИГРАЦИИ

ХИМИЧЕСКИХ ЭЛЕМЕНТОВ В ЛАНДШАФТАХ

СЕВЕРНОГО КАВКАЗА

Киреева В.В., Рассказова Т.Г., Сербулова Н.М. СПОСОБ ПОЛУЧЕНИЯ ОРГАНИЧЕСКОГО УДОБРЕНИЯ ИЗ ОТХОДОВ ПОЛЕВОДСТВА ДЛЯ ПОДДЕРЖАНИЯ ПОЧВЕННОГО ПЛОДОРОДИЯ

Грязев М.В., Качурин Н.М., Стась Г.В. ПЫЛЕГАЗОВЫЕ ВЫБРОСЫ

С ПОВЕРХНОСТИ ПОРОДНЫХ ОТВАЛОВ ЛИКВИДИРОВАННЫХ ШАХТ УГОЛЬНОГО БАССЕЙНА

Заалишвили В. Б., Реквава П. А., Мельков Д. А. РАЗВИТИЕ СЕЙСМОСТОЙКОГО

СТРОИТЕЛЬСТВА НА ГОРНЫХ ТЕРРИТОРИЯХ СЕВЕРНОЙ ОСЕТИИ НА ОСНОВЕ НОВОЙ РЕГИОНАЛЬНОЙ КРИВОЙ КОЭФФИЦИЕНТА ДИНАМИЧНОСТИ

Рыльникова М.В., Струков К.И., Есина Е.Н. ОБЕСПЕЧЕНИЕ УСТОЙЧИВОГО РАЗВИТИЯ ГОРНОТЕХНИЧЕСКОЙ СИСТЕМЫ НА ЗАВЕРШАЮЩЕЙ СТАДИИ ПОДЗЕМНОЙ РАЗРАБОТКИ ЖИЛЬНЫХ ЗОЛОТОРУДНЫХ МЕСТОРОЖДЕНИЙ УРАЛА

Умаров М.У., Гапаев Я.С, Тайсумов М.А. ФЛОРА ПАРАБОЧЕВСКОГО ЗАКАЗНИКА И ЕЕ СИСТЕМАТИЧЕСКИЙ АНАЛИЗ

Рыбак О.О., Рыбак Е.А., Корнева И.А., Поповнин В.В.

МАТЕМАТИЧЕСКОЕ МОДЕЛИРОВАНИЕ ЭВОЛЮЦИИ ЛЕДНИКА ДЖАНКУАТ В СОВРЕМЕННЫХ КЛИМАТИЧЕСКИХ УсЛОВИЯХ

ТЕХНИЧЕСКИЕ НАУКИ

Morkun V.S., Morkun N.V., Tron V.V., Dotsenko I.A. ADAPTIVE CONTROL SYSTEM FOR THE MAGNETIC SEPARATION PROCESS
Гиясов А.А., Тускаева 3.Р., Гиясова И.В. ИСПОЛЬЗОВАНИЕ ОСОБЕННОСТЕЙ СЛОЖНОГО РЕЛЬЕФА ДЛЯ УСТОЙЧИВОГО РАЗВИТИЯ ГОРНЫХ ТЕРРИТОРИЙ

Алешин Б.С., Черноморский А. И., Курис Э.Д. НАЗЕМНЫЕ КОЛЕСНЫЕ ТРАНСПОРТНЫЕ МОДУЛИ ДЛЯ РЕШЕНИЯ ЗАДАЧ МОНИТОРИНГА ОКРУЖАЮЩЕЙ СРЕДЫ ГОРНЫХ ТЕРРИТОРИЙ

Соколов И.В., Смирнов А.А., Никитин И.В. ОБЕСПЕЧЕНИЕ ЭКОЛОГИЧЕСКОЙ БЕЗОПАСНОСТИ ПРИ РАЗРАБОТКЕ КТИ-ТЕБЕРДИНСКОГО ВОЛЬФРАМОВОГО МЕСТОРОЖДЕНИЯ

Хасцаев Б. Д., Маслаков М. П., Карлов В. В., Олисаева О.В.

РАЗРАБОТКА АВТОМАТИЗИРОВАННЫХ СИСТЕМ УПРАВЛЕНИЯ ДЛЯ ГОРНОДОБЫВАЮЩИХ ПРЕДПРИЯТИЙ

Michail M. Buczek, Nguyen Quoc Long,

Xuan-Nam Bui, Hoang Nguyen APPLICATION OF KNOTHE-BUDRYK THEORY AND RIGID BODY CONDITION FOR ASSESSMENT OF SUBSIDENCE

Демин В.Ф., Демина Т.В.,

Кайназаров А.С., Кайназарова А.С. ОЦЕНКА ЭФФЕКТИВНОСТИ ПРИМЕНЕНИЯ ТЕХНОЛОГИЧЕСКИХ СХЕМ ПРОВЕДЕНИЯ ВЫРАБОТОК ДЛЯ

ПОВЫШЕНИЯ УСТОЙЧИВОСТИ ИХ КОНТУРОВ

Лютикова Л.А., Махошева С.А., Шматова Е.В., Кандрокова М.М. РАЗРАБОТКА МЕТОДОВ КОРРЕКТИРУЮЩИХ АЛГОРИТМОВ ДЛЯ ПОСТРОЕНИЯ ОПТИМАЛЬНОЙ СТРАТЕГИИ РАЗВИТИЯ ГОРНЫХ ТЕРРИТОРИЙ

Поспелов П. И., Кортиев А. Л. НОРМЫ ПРОЕКТИРОВАНИЯ ДОРОГ В ГОРНЫХ УСЛОВИЯХ С УЧЕТОМ ОБЕСПЕЧЕНИЯ БЕЗОПАСНОСТИ ДВИЖЕНИЯ

ПОДПИСКА 


\section{CONTENTS}

\section{EARTH AND PLANETARY SCIENCES ENVIRONMENTAL SCIENCES}

G. I. Rudko, A. V. Myatchenko,

F.M. Isataeva, V. S. Portnov

GEOLOGICAL-ECONOMIC ESTIMATION OF

KAZAKHSTAN DEPOSITS

T. V. Degtyareva, A. A. Lichowid,

A. V. Lysenko, Yu. Karaev

REGIONAL PATTERNS OF CHEMICAL ELEMENTS

MIGRATION IN THE LANDSCAPES

OF THE NORTH CAUCASUS

V.V. Kireeva, T.G. Rasskazova,

N.M. Serbulova

MAINTAINING SOIL FERTILITY: A METHOD

FOR ORGANIC FERTILIZER PRODUCTION

FROM CROP FARMING WASTE

493

M.V. Gryazev, N.M. Kachurin, G.V. Stas

DUST AND GAS EMISSIONS FROM THE DUMPS

SURFACES OF THE LIQUIDATED MINES

OF THE MOSCOW COAL BASIN

V.B. Zaalishvili, P.A. Rekvava, D.A. Melkov DEVELOPMENT OF SEISMIC RESISTANCE CONSTRUCTIONS IN THE MOUNTAIN TERRITORIES OF NORTH OSSETIA ON THE BASIS OF A NEW REGIONAL CURVE OF DYNAMICITY COEFFICIENT

M.V. RyInikova, K.I. Strukov, E.N. Esina SUSTAINABLE DEVELOPMENT OF MINING SYSTEM AT THE FINAL STAGE OF UNDERGROUND MINING VEIN GOLD DEPOSITS OF THE URALS

M.U. Umarov, Y.C. Gapaev, M.A. Taisumov PARABOCHEVSCIY RESER FLORA AND ITS SYSTEMATIC ANALYSIS

O.O. Rybak, E.A. Rybak, I.A. Korneva,

V.V Popovnin

MATHEMATICAL MODELING OF DJANKUAT

GLACIER EVOLUTION

IN PRESENT-DAY CLIMATIC CONDITIONS

\section{ENGINEERING}

A. Giyasov, Z.R. Tuskaeva, I.V. Giyasova

471 COMPLEX LANDSCAPES PECULIARITIES USE FOR SUSTAINABLE DEVELOPMENT OF MOUNTAIN TERRITORIES

B. S. Aleshin, A. I. Chernomorskiy, E. D. Kuris GROUND VEHICLE MODULES FOR SOLVING THE TASKS OF ENVIRONMENTAL MONITORING IN THE MOUNTAINOUS AREAS

I.V. Sokolov, A.A. Smirnov, I.V. Nikitin ENSURING ECOLOGICAL SAFETY AT THE MINING OF THE KTI-TEBERDA TUNGSTEN DEPOSIT 577

B. Dz. Khastsaev, M. P. Maslakov, V. V. Karlov, O.V. Olisaeva DEVELOPMENT OF AUTOMATED CONTROL SYSTEMS FOR MINING ENTERPRISE

Michail M. Buczek, Nguyen Quoc Long,

Xuan-Nam Bui, Hoang Nguyen

APPLICATION OF KNOTHE-BUDRYK THEORY AND RIGID BODY CONDITION FOR

ASSESSMENT OF SUBSIDENCE

W.F. Demin, T.In. Demina, A.S. Kaynazarov,

A.S. Kaynazarova

EVALUATION OF THE WORKINGS TECHNOLOGICAL SCHEMES EFFECTIVENESS

TO INCREASE THE STABILITY OF THEIR

CONTOURS

L.A. Lyutikova, C.A. Makhosheva,

E.V. Shmatova, M.M. Kandrokova

METHODS DEVELOPMENT FOR CORRECTING

ALGORITHMS FOR CONSTRUCTING OPTIMAL

STRATEGY OF MOUNTAIN

AREAS DEVELOPMENT

P. I. Pospelov, A. L. Kortiev

DESIGN STANDARDS FOR ROADS IN

MOUNTAINOUS CONDITIONS WITH A VIEW

TO ENSURING TRAFFIC SAFETY

MAGAZINE SUBSCRIPTION

SUBSCRIPTION

635

Morkun V.S., Morkun N.V., Tron V.V., Dotsenko I.A. ADAPTIVE CONTROL SYSTEM FOR THE MAGNETIC SEPARATION PROCESS 
УСТОЙЧИВОЕ $\quad$ No1, 2009

РАЗВИТИЕ

ГОРНЫХ ТЕРРИТОРИЙ
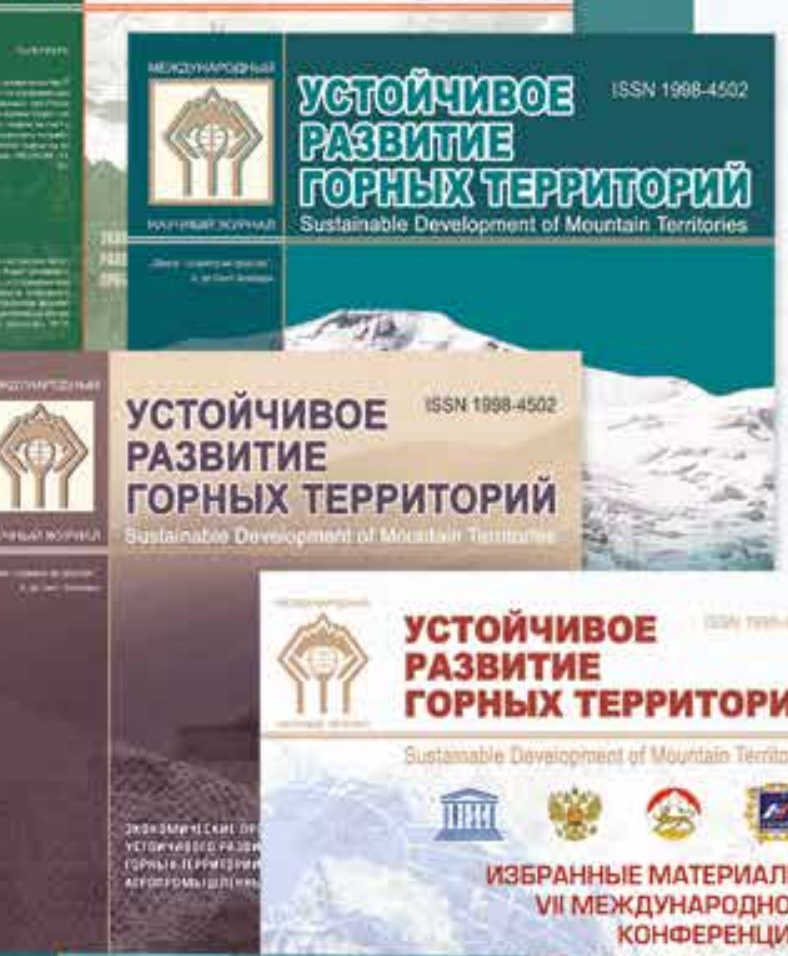

устойчивОЕ

РАЗВИТИЕ

ГОРНЫХ ТЕРРИТОРИЙ

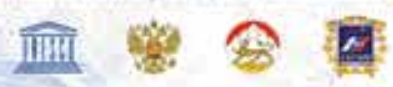

ИЗБРАННЫЕ МАТЕРИАЛЫ VII МЕЖДУНАРОДНОЙ КОНФЕРЕНЦИИ

УСTOЙपИВOE

PA3BИTИE

ГОРНЬX ТЕРРИTOРИЙ

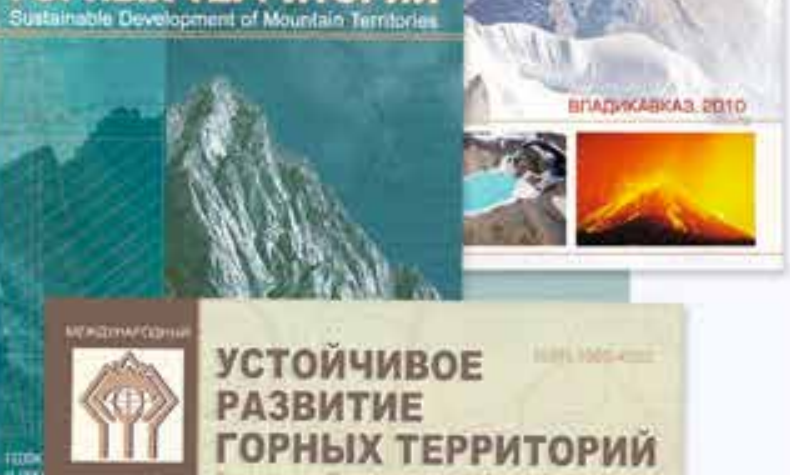

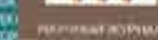

ГОРНЫХ ТЕРРИТОРИЙ

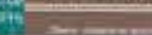

УСТОЙЧИВОЕ

РАЗВИТИЕ

\section{ГОРНЫХ ТЕРРИТОРИЙ}

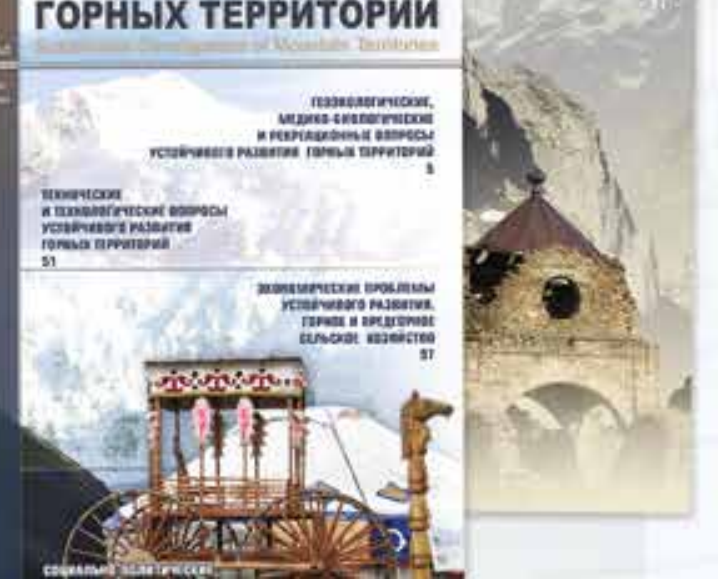

\section{Уважаемые коллеги!}

В соответствии с Заключением Президиума ВАК Минобрнауки РФ от 19.12.2014 г. №47/307 с 2015 года статьи для публикации в журнале «Устойчивое развитие горных территорий» принимаются по следующим группам научных специальностей и отраслям наук:

25.00.00 Науки о Земле (все научные специальности в рамках группы);

05.00.00 Технические науки (три группы научных специальностей):

05.05.00 Транспортное, горное и строительное машиностроение,

05.13.00 Информатика, вычислительная техника и управление,

05.14.00 Энергетика.

08.00.00 Экономические науки (все научные специальности в рамках группы).

Журнал включен в Международную реферативную базу данных и систему цитирования Scopus. Публикации в журнале «Устойчивое развитие горных территорий» принимаются по следующим группам научных специальностей и отраслям наук:

1. Enginering (технические науки).

2. Earth and Planetary Sciences (науки о Земле и планетарные науки).

3. Environmental Science (наука об окружающей среде).

В связи с тем, что журнал «Устойчивое развитие горных территорий» входит в «Перечень российских рецензируемых научных журналов, в которых должны публиковаться основные научные результаты диссертаций на соискание ученых степеней доктора и кандидата наук» и включен в международную реферативную базу данных и систему цитирования Scopus, просьба к авторам:

- соблюдать требования к авторам публикации;

- текст статьи сопровождать необходимыми сопутствующими материалами;

- не выходить за рамки обозначенного допустимого объема статьи;

- выполнять все требования, предъявляемые к рисункам, диаграммам, фотографиям и пр. Напоминаем, что редакция не возвращает авторам присланные материалы равно как на бумажных, так и на электронных носителях.

Сообщаем также, что количество журналов, в рекламных целях рассылавшихся ранее бесплатно, значительно сокращено, в связи с чем информируем, что подписка на журнал продолжается. Те, кто не успел подписаться на 2 полугодие 2018 года в отделениях Роспечати, могут сделать это в самой редакции (подробности стоимости и условий подписки в разделе «Подписка. Реклама» журнала).

Редакция также осуществляет услуги по изготовлению и размещению рекламных материалов на страницах журнала (обложка, цветные вклейки, черно-белые вставки). Вы можете прорекламировать продукцию, разработанную в ваших лабораториях и научных центрах, предложить запатентованное вами оборудование, приборы, новые технологии, сделать предложение о сотрудничестве, предложить услуги научного либо прикладного характера, попытаться привлечь инвестиции под ваши проекты, проанонсировать монографию, т.е. на правах рекламы разместить любую необходимую для вас информацию.

Сделав заявку и прислав текст и примерный вид вашей предполагаемой рекламы, Вы, связавшись с нами по телефону редакции $+7(918) 707-39-25$, обговариваете все детали. Получив от нас счет за выполненную работу, оплачиваете его, а копию платежного получения присылаете на электронный адрес редакции.

Всегда рады сотрудничеству. 


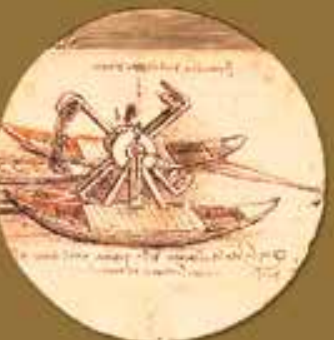

Крупные катастрофы, уюе разоривиие и продолюсающие разорять современный мир, происходят от нежелания человека считаться с законами природы,

от нежелания понять, что голод нельзя утолить, опустошая землю.

Жан ДОРСТ

\section{ГЕОЛОГО-ЭКОНОМИЧЕСКАЯ ОЦЕНКА ЗАПАСОВ МЕСТОРОЖДЕНИЙ КАЗАХСТАНА}

\section{Введение}

Геологическая отрасль Казахстана, ключевым критерием эффективности работы которой является прирост разведанных запасов полезных ископаемых, призвана обеспечить опережающее изучение недр и восполнение минерально-сырьевой базы [1;2]. Природные катастрофы усиливают требования к обоснованности управленческих решений, нацеленных на достижение устойчивости развития и государства, и его регионов [3]. Возрастает роль рационального размещения техногенных объектов, научной обоснованности создания специальных зон, основываясь на картографической и информационной базе данных. Наращивание экспорта минерально-сырьевой казахстанской продукции требует решения сложнейших отраслевых задач: открытие новых месторождений, структурная и технологическая модернизация действующих месторождений, подготовка квалифицированных кадров.

Для соответствия уровню экономического развития богатых природными ресурсами стран, к числу которых относится и Казахстан, требуется интенсификация их добычи, увеличение глубины переработки в готовую продукцию с целью получения добавленной стоимости в обрабатывающей отрасли [4-8]. Не теряет актуальность проблема повышения инвестиционной привлекательности отрасли за счет активизации таких экономических методов, как льготное налогообложение, преференции, лицензии, отмена налога на добавленную стоимость на геолого-разведочные работы и геологическую информацию.

Решение указанных проблем требует не только совершенствования геологических и геофизических исследований. Слабо изученными остаются экономическая сторона геологоразведочной деятельности, достоверность и обоснованность геолого-экономической оценки месторождений, что и определяет актуальность настоящего исследования.

Авторами выдвигается тезис о том, что прогресс Казахстана связан, прежде всего, с наличием природных ресурсов, многолетней практикой, охватывающей все сложности хозяйствования, отработкой защитных механизмов по отстаиванию национальных интересов. Накопленный Казахстаном опыт по индустриально-инновационному развитию может быть полезным для разви-

\footnotetext{
${ }^{1}$ Государственная комиссия Украины по запасам полезных ископаемых, Украина, rudko@dkz.gov.ua.

${ }^{2}$ Геолого-экономическая консалтинговая компания, Караганда, amyatchenko@mail.ru.

${ }^{3}$ Карагандинский государственный технический университет, Караганда, adambekova_farid@mail.ru.
}

1Рудько Г.И., 2Мятченко А.В., "Исатаева Ф.М., ${ }^{3}$ ЗПортнов В.С.
УДK: 553.04(574) DOI: 10.21177/1998-4502-2018-104-471-480

Наращивание зависимости экономики Республики Казахстан от импорта и активизации политики импортозамещения требуют реформирования в сфере недропользования. В свете сказанного актуализируется необходимость роста научной обоснованности геолого-экономической оценки месторождений, ее соответствия международным требованиям. На примере перспективного колчеданномедно-свинцово-цинкового месторождения Кусмурын показаны возможности дальнейшего совершенствования геолого-экономической оценки с учетом внедрения в Казахстане международной системы стандартов отчетности по запасам полезных ископаемых CRIRSCO. Предложены показатели, углубляющие геолого-экономическую оценку. Дополнен методический подход к выбору наиболее целесообразного варианта отработки месторождения.

\section{КЛЮЧЕВЫЕ СЛОВА:}

Казахстан, инвестиции, оценка, месторождение, стандарты CRISCO, инновации

Статья поступила в редакцию 14.06.2018 
вающихся стран, поскольку наглядно показывает, как трансформационные процессы учитывают специфику страны, ее геополитическое положение, традиции и менталитет.

Цель статьи - обосновать направления улучшения геолого-экономической оценки колчеданно-медносвинцово-цинкового месторождения Кусмурын.

Задачи: показать действенные шаги государственного регулирования развития геологической отрасли Казахстана; обобщить результаты геолого-экономической оценки месторождения Кусмурын и обосновать целесообразность ее дальнейшего совершенствования в соответствии с международными стандартами и с учетом социально-экономических и горно-геологических факторов; разработать конкретные предложения по совершенствованию геолого-экономической оценки месторождений.

Информационно-фактологической базой исследования послужили материалы законодательной и нормативной базы Республики Казахстан, результаты научных исследований месторождения Кусмурын и собственные расчеты авторов.

Обоснованность и достоверность полученных результатов определяются сравнительным анализом, использованием достоверной экономической и геологической информации о сырьевой базе Казахстана, месторождении Кусмурын, применением современных методов научного исследования, учетом региональных природно-климатических и горно-геологических условий.

\section{Текущее состояние геологоразведочной отрасли Казахстана}

За годы новой индустриализации Казахстана активизировалось государственное регулирование отрасли: в июне 2016 г. Казахстан стал 10-м членом Комитета CRIRSCO; страна вошла в состав Правления организации Инициатива прозрачности деятельности добывающих отраслей (ИПДДО); на 2018 г. был запланирован перевод на международную систему отчетности по запасам углеводородного сырья SPE-PRMS; в горнорудной отрасли запланирован ввод облегченного метода предоставления права недропользования в соответствии с моделью Западной Австралии, ее принципом «Первый пришел - первый получил»; для исключения повтора информации в отчетах ИПДДО с отчетными данными субъектов и правительства в 2017 г. стартовало пилотное исследование «Маинстриминг»; совместно с Россией создан консорциум «Евразия», открывший возможности изучения казах- станских недр на территории Прикаспийской впадины, три четверти которой расположены в Казахстане, остальное - в России.

Помимо того, что рост добычи опережает темпы восполнения минерально-сырьевой базы Казахстана, сложное положение геологоразведочной отрасли объясняется во многом отсутствием финансирования, которое после распада СССР имело бюджетную основу, что привело не только к сокращению геологоразведочных работ, оттоку кадров, но и дисбалансу между отработанными и приращиваемыми запасами.

От ситуации в геологоразведочной отрасли во многом зависит совершенствование инвестиционного климата в Казахстане. Несмотря на активизацию геологоразведочных работ в последние годы, Казахстан по объему инвестиций в геологоразведку значительно отстает от передовых стран (табл. 1).

В 2018 г. на поиск и разведку месторождений стратегических металлов, таких как медь, золото, редкие и редкоземельные металлы, свинец, цинк, хром, были нацелены 39 инвестиционных проектов. Размер частных инвестиций в геологоразведку составили порядка 4 млрд. тенге.

Укрепление международных позиций Казахстана, применение опыта таких стран, как Германия и Норвегия, делает необходимым обеспечение безвозмездного доступа к информации о недрах и недропользователях, условиях и конечных бенефициарах (лицах и государствах, прямо или косвенно контролирующих недропользователя), восстановление налоговых льгот на добавленную стоимость по геологоразведочным работам, своевременное оформление контрактов на приобретение лицензии [5].

Инвестиции, направляемые на поиски и разведку месторождений полезных ископаемых, носят инновационный характер [6; 7]. В отрасли планируется увеличение доли геологоразведочных работ, выполняемых инновационными технологиями, до 75 \%, в связи с чем система налогообложения геологоразведочной деятельности должна быть скорректирована с учетом повышенного риска в данной сфере деятельности [8-10]. Инновационное развитие откроет возможность через добывающие отрасли с помощью развития 3-4 передела переключиться на обрабатывающий сектор, сделав его инвестиционно-привлекательным. Высокие инвестиционные риски, сопровождающие проекты разведки и разработки месторождений, ужесточают требования инвесторов к подлинности предоставляемых сведений о конкретных ресурсах и обна-

Таблица 1 / Table 1

Динамика финансирования геологического изучения недр за годы индустриальной политики, млрд. тенге [2, 3] Dynamics of financing geological studies of the subsoil within the years of industrial policy, bln. tenges [2, 3]

\begin{tabular}{|c|c|c|c|c|c|c|c|c|}
\hline $\mathbf{2 0 1 1}$ & $\mathbf{2 0 1 2}$ & $\mathbf{2 0 1 3}$ & $\mathbf{2 0 1 4}$ & $\mathbf{2 0 1 5}$ & $\mathbf{2 0 1 6}$ & $\mathbf{2 0 1 7}$ & $\mathbf{2 0 1 8}$ (план) / (plan) & $\mathbf{2 0 1 9}$ (план) / (рlan) \\
\hline 4.3 & 8.7 & 9.4 & 9.1 & 11.4 & 8.2 & 8.2 & 9.3 & 11.8 \\
\hline
\end{tabular}


Твердые полезные ископаемые Казахстана $[2 ; 4 ; 5 ; 10]$

Solid minerals of Kazakhstan [2; 4; 5; 10]

\begin{tabular}{|c|c|c|c|c|c|c|c|}
\hline $\begin{array}{c}\text { Вид полезного } \\
\text { ископаемого } \\
\text { Mineral type }\end{array}$ & $\begin{array}{l}\text { Золото, т } \\
\text { Gold, } t\end{array}$ & $\begin{array}{c}\text { Медь, } \\
\text { млн. т } \\
\text { Copper, } \\
\text { mln.t }\end{array}$ & $\begin{array}{c}\text { Свинец, } \\
\text { млн. т } \\
\text { Lead, mln.t }\end{array}$ & $\begin{array}{c}\text { Цинк, } \\
\text { млн. т } \\
\text { Zinc, } m \ln . t\end{array}$ & $\begin{array}{c}\text { Уран, } \\
\text { тыс. т } \\
\text { Uranium, th.t }\end{array}$ & $\begin{array}{c}\text { Железо, } \\
\text { млрд. т } \\
\text { Iron, bln.t }\end{array}$ & $\begin{array}{c}\text { Уголь, } \\
\text { млн. т } \\
\text { Coal, mln.t }\end{array}$ \\
\hline $\begin{array}{c}\text { Запасы на } \\
\text { государственном } \\
\text { балансе / Reserves on } \\
\text { the state balance }\end{array}$ & 1140 & 30 & 12 & 25 & 904 & 10 & 34103 \\
\hline $\begin{array}{c}\text { Количество } \\
\text { месторождений } \\
\text { Number of deposits }\end{array}$ & 330 & 120 & 96 & 93 & 73 & 60 & 147 \\
\hline $\begin{array}{c}\text { Законтрактовано, \% } \\
\text { Contracted, \% }\end{array}$ & 97 & 98 & 92 & 94 & 77 & 67 & 39 \\
\hline
\end{tabular}

руженных запасах. Общеизвестно, что биржи и банки оказывают доверие горнодобывающим и геологоразведочным предприятиям лишь в случае соответствия их деятельности и представленных отчетных данных международным стандартам.

На текущий период почти три четверти месторождений Казахстана законтрактованы, из действующих 866 контрактов на недропользование 484 приходится на месторождения твердых полезных ископаемых. К наиболее востребованным видам ископаемых относят золото, медь, свинец, цинк, уран. Активизируются работы по металлам (итрий, итербий) в 16 основных рудных провинциях (табл. 2) [11].

C учетом зарубежного опыта, специфики проведения геологоразведочных работ в труднодоступных районах Казахстана и влияния такого фактора, как разнообразие поверхностных и горно-геологических условий, планируется разработка программы по изучению редкоземельных элементов, основанной на оценке перспектив освоения новых участков, с привлечением высокотехнологических японских и корейских компаний [2;12-14].

\section{Геолого-экономическая оценка запасов} месторождения Кусмурын

Индустриально-инновационное развитие Казахстана потребовало перестройку геологоразведочной отрасли в части совершенствования геолого-экономической оценки месторождений, для которых главным остаются социально-экономические и горно-геологические факторы $[15,16]$. Принимаются системные действия по стимулированию геологических и разведочных исследований новых месторождений, призванных стабилизировать сырьевую базу для индустриализации страны $[2 ; 5 ; 17]$.

В свете сказанного, особую значимость приобретает геолого-экономическая оценка тех месторождений, которые располагают прогнозными ресурсами полез- ных ископаемых, однако еще недостаточно изучены и не располагают соответствующей инфраструктурой. К их числу относится колчеданно-медно-свинцовоцинковое месторождение Кусмурын, технико-экономическое обоснование которого разработано еще в советский период.

Реализованный в 1957 г. комплекс детальных геолого-геофизических работ выявил большой по площади интенсивный ореол рассеяния меди, в пределах которого наблюдались повышенные содержания свинца, цинка и следы золота. Проведение первых буровых работ, бурение трех скважин севернее железной шляпы, которыми на различных интервалах были подсечены рудные метосоматически измененные породы с промышленными содержаниями меди, дало возможность отнести рудопроявление к разряду перспективных.

В 1958-1977 гг. буровые работы проводились по стадиям, в результате чего установлено, что это месторождение отличается повышенным содержанием меди и цинка как в приповерхностных смешанных рудах, так и в сульфидных рудах. Были разведаны пять линзовидных рудных тел протяженностью по простиранию до 350 м, по падению - до 650 м при мощности 2-75 м. Первичные руды колчеданные, сплошные и прожилково-вкрапленные, среднее содержание золота $-1,12$ г/т, меди $-3,37 \%$, цинка - $1 \%$. На основе комплексного геолого-геофизического изучения месторождения разработаны кондиции для дальнейшего подсчета запасов руд.

В постсоветский период ТОО «Корпорация Казахмыс» - один из крупнейших производителей меди в Казахстане, начинает отрабатывать месторождение открытым способом с дальнейшей отработкой подземным методом. До 2009 г. месторождение было одним из основных сырьевых источников медной и медноцинковой руды для Карагайлинской обогатительной фабрики, входящей в корпорацию. 
Запасы месторождения Кусмурын [18] Reserves of the Kusmuryn deposit [18]

\begin{tabular}{|c|c|c|c|c|}
\hline \multirow{3}{*}{$\begin{array}{c}\text { № } \\
\mathbf{\Pi} / \mathbf{\Pi} / N o\end{array}$} & \multirow{3}{*}{$\begin{array}{c}\text { Вид полезного ископаемого } \\
\text { Mineral type }\end{array}$} & \multicolumn{3}{|c|}{ Категория запасов / Reserve categories } \\
\hline & & \multicolumn{2}{|c|}{ балансовые / Balance } & \multirow{2}{*}{$\begin{array}{c}\text { забалансовые } \\
\text { Off-balance }\end{array}$} \\
\hline & & $\mathrm{C}_{1}$ & $\mathrm{C}_{2}$ & \\
\hline 1 & Руда, тыс. т / Ore, th.t & 19105.2 & 1862.0 & 1183 \\
\hline 2 & Медь, тыс. т / Copper, th.t & 644.1 & 53.9 & 13.1 \\
\hline 3 & Цинк, тыс. т / Zinc, th.t & 191.0 & 12.5 & 1.0 \\
\hline 4 & Золото, кг / Gold, kg & 21122.0 & 2095.0 & 639 \\
\hline 5 & Серебро, т / Silver, $t$ & 382.6 & 37.3 & 11.9 \\
\hline 6 & Селен, т / Selenium, $t$ & 1764.0 & 177.0 & 97.0 \\
\hline 7 & Теллур, т / Tellurium, $t$ & 809.0 & 81.0 & - \\
\hline \multirow[t]{2}{*}{8} & Сера сульфидная тыс. т / Sulfide sulfur, $t$ & 4766.0 & 452.0 & 209.0 \\
\hline & Содержание: / Content: & & & \\
\hline 1 & Медь, \% / Copper, \% & 3.37 & 2.89 & 1.11 \\
\hline 2 & Цинк, \% / Zinc, \% & 0.99 & 0.67 & 0.08 \\
\hline 3 & Золото, г/т / Gold, g/t & 1.11 & 1.12 & 0.54 \\
\hline 4 & Серебро, г/т / Silver, $g / t$ & 20.03 & 20.25 & 10.05 \\
\hline 5 & Селен, \% / Selenium, \% & 0.0092 & 0.0095 & 0.0082 \\
\hline 6 & Теллур, \% / Tellurium, \% & 0.0042 & 0.0044 & 0.0048 \\
\hline 7 & Сера сульфидная, \% / Sulfide sulfur, \% & 24.95 & 24.27 & 17.67 \\
\hline
\end{tabular}

Однако смешанный тип руд с более высоким содержанием окислов меди и цинка, высокая трудоемкость обогащения медно-цинковых руд, продолжительная транспортировка руды автосамосвалами по грейдерной дороге до обогатительной фабрики и не достаточная изученность технологии переработки медно-цинковых руд отрицательно отразились на себестоимости концентрата, получаемого из них. Поэтому в конце 2009 г. ТОО «Корпорация Казахмыс» вынуждено было остановить добычные работы на месторождении, а в середине 2010 г. было получено разрешение на «консервацию» добычных работ до 2012 г.

В это же время корпорация проводила геологоразведочные работы на месторождении, в том числе для отбора представительной технологической пробы, проведения испытаний и дальнейшей разработки схемы переработки медно-цинковых руд. Доразведка буровыми работами была необходима для отбора кернового материала для технологического картирования, доразведки флангов месторождения как по простиранию, так и по падению. В связи с необходимостью пересмотра глубины отработки месторождения и его изучения планировалось провести инженерно-геологическое бурение с последующим проведением тестов на определение физико-механических свойств пород.

Исследованиями установлено, что большая часть массива горных пород имеет среднюю категорию устойчивости $(70 \div 80 \%)$, остальная часть горного массива, представленная в основном рудной зоной, оказалась неустойчивой.

По результатам химико-аналитических, петрогра- фических, минералографических и технологических работ, выполненных в процессе разведки месторождения, выделено три природных типа руд: первичные сульфидные; смешанные; окисленные.

По своему вещественному составу (пирита до 90 \%) руды месторождения Кусмурын отнесены к меднокочеданному промышленному типу с главными рудообразующими минералами - пиритом, халькопиритом, сфалеритом, галенитом. В соответствии с запасами, месторождение признано мелким (табл. 3).

Внутри промышленного типа по содержанию окисленных и вторичных форм меди и цинка выделены смешанные и первичные сульфидные руды, которые по текстурным особенностям делятся на сплошные и прожилково-вкрапленные, по содержанию меди и цинка - на медные и медно-цинковые. В соответствии с технологическими свойствами и схемами обогащения выделены два технологических сорта: смешанные и первичные сульфидные.

Более детальное исследование керна и рост достоверности геомеханической оценки горного массива были достигнуты благодаря высокому уровню геолого-разведочных работ, принятой схеме вскрытия, системе разработки, выбранной техники и технологии ведения горных работ.

Поскольку месторождение Кусмурын является объектом поискового исследования в рамках государственного задания по изучению перспективных площадей для привлечения инвестиций, в 2013 г. работы по его исследованию были возобновлены. Принимая во внимание значительное влияние крутонаклонного 
залегания некоторых рудных тел на устойчивость массива руд и пород, по мере отработки требовалось расширение геомеханических исследований по контролю над состоянием горного массива, безопасностью горных работ и корректировке технологии ведения горных работ.

Для последующей разработки технологии переработки медно-цинковых руд и строительства новой обогатительной фабрики близ месторождения была осуществлена доразведка месторождения. Были отобраны технологические пробы медных и медно-цинковых руд из керна скважин, пробуренных в контурах рудных тел, с подсечением их на различных горизонтах; изучено структурно-тектоническое строение месторождения посредством бурения скважин с использованием электронного керноориентатора и геотехнической документации; доизучены физикомеханические свойства руд и пород по образцам, отобранным из керна, и оконтуривание месторождения, путем бурения скважины на крайнем северном и южном профиле вкрест простирания.

По сложности строения месторождение Кусмурын относится ко II-й (3-й) группе: сеть пробуренных скважин и горных выработок отвечает требованиям изученности месторождений при этой категории сложности.

В результате отбора лабораторной технологической пробы и технологических исследований обогатимости руд месторождения было подтверждено выделение двух природных типов руд - смешанные и сульфидные, граница между которыми определена только по результатам лабораторных исследований. Оба типа руд подразделяются на сорта: медные и медно-цинковые.

Анализ элементов выполнен методом ICP-OES c предварительным четырехкислотным разложением проб, что способствовало почти полному переводу компонентов порошковой пробы в химический раствор.

Реализация программы доразведки месторождения и программы бурения с целью отбора технологических проб дала положительные результаты, позволила пересмотреть углы бортов как существующего, так и проектного карьера. Программа бурения скважин с целью отбора технологической пробы дала возможность получить в достаточном объеме керновый материал для проведения испытаний и разработки технологического регламента переработки руд месторождения.

До сих пор отсутствуют достоверная информация о качестве и количестве добытой руды и итоговые данные картирования с отбором проб весом до 200 кг, не получены результаты технологических исследований, проведенных в полевой период, что во многом затрудняет решение вопроса о переутверждении кондиций или пересчете запасов месторождения Кусмурын, перевод утвержденных запасов по категории $\mathrm{C}_{1}$ и $\mathrm{C}_{2}$ в более высокие категории.

В этой связи необходимо: провести доразведку месторождения путем бурения колонковых скважин; выполнить повариантный подсчет запасов и ТЭО промышленных кондиций; пересчитать запасы с утверждением в ГКЗ РК.

Только после внесения корректив в обновленные данные, т.е. внутреннее строение запасов медных и медно-цинковых руд, как по месторождению Кусмурын, так и по отдельным рудным телам, их взаиморасположение и условия залегания, будут изменены промышленно-генетические типы руд. В дальнейшем возможен пересчет запасов руд на основании существующих кондиций.

\section{Потенциальные возможности месторождения «Кусмурын»}

В ближайшие годы объем инвестиций ТОО «Корпорация «Казахмыс» значительно увеличится благодаря вводу проектов по строительству новых рудников и инновационного проекта гидрометаллургической переработки чернового медного концентрата с использованием жезказганских руд.

На 2018-2026 годы для стабилизации достигнутого добычного уровня и компенсации выбывающих функционирующих объектов корпорацией «Казахмыс» запланирован ряд проектов, среди которых - с 2019 г. начнутся открытые горные работы и в 2021 г. стартует ввод подземной добычи на месторождении Кусмурын.

В целях снижения себестоимости концентрата меняется система отработки на месторождении Кусмурын. На смену камерно-столбовой системе разработки, позволяющей извлекать все имеющиеся запасы, внедрена другая модель - отработка междукамерных целиков с высоким содержанием металла, что улучшит качество катодной меди.

При выполнении геологоразведочных работ с поверхности используются высокопроизводительные буровые установки Atlas Copco CS-3001, позволяющие бурить скважины глубиной до 1200 метров. Для эксплуатационной разведки используют высокопроизводительные буровые установки Diamec 262 и Sandvik DE 130, применяемые в подземных горных выработках. Активизируются инновационные исследования: проведены томографические поиски рудных тел путем зондирования на глубину 800 метров, запланирован проект микросейсмического зондирования для определения рудных зон.

\section{Совершенствование геолого-экономической} оценки месторождений полезных ископаемых

Одним из первостепенных условий роста инвестиционной привлекательности минерально-сырьевого комплекса Казахстана, возможности определения максимально достоверных геологических и технических сведений по разрабатываемым проектам становится переход на международную систему стандартов отчетности по запасам полезных ископаемых CRIRSCO.

Принципиальных различий в требованиях CRISCO и Государственной комиссии по запасам полезных 
ископаемых Республики Казахстан не наблюдается. Более того, система CRISCO, где запасы и ресурсы оценивает компетентное лицо, выглядит более упрощенной. В Казахстане запасы делились на прогнозные $\mathrm{P}_{1}, \mathrm{P}_{2}, \mathrm{P}_{3}$, промышленной категории $\mathrm{C}_{1}, \mathrm{C}_{2}, \mathrm{~A}+\mathrm{B}$.

B системе CRISCO градация по запасам такова: «подтвержденные», «извлекаемые», «экономически целесообразные». Общим требованием является достоверность всей информации и по запасам, в частности. Запасы минерального сырья не являются неиссякаемыми, необходим строгий учет и контроль над их рациональным использованием.

С внедрением международных стандартов претерпит изменение экономическая оценка месторождений полезных ископаемых. На ее основе будут определены экономическая значимость и целесообразность освоения месторождения, последовательность вовлечения в разработку отдельных его частей, установлены кондиции на минеральное сырье, рассчитаны балансовые запасы месторождения, очерчены ориентиры дальнейших геологоразведочных работ. Итоговые данные экономической оценки могут применяться для нормирования потерь полезного ископаемого при разработке и расчете экономических санкций за их превышение.

Для оптимизации принимаемых решений по дальнейшей эксплуатации месторождений, соединения воедино проблемы удовлетворения потребности общества в конкретных природных ресурсах и экологических требований, на наш взгляд, научная доказательность геолого-экономической оценки месторождений полезных ископаемых повысится за счет расчета дополнительных показателей. Например, сравнительная себестоимость добычи различными приемами с учетом содержания полезных ископаемых и расходов на рекультивации земель; транспортные расходы, связанные с доставкой сырья конкретному потребителю; степень загруженности ключевого оборудования, задействованного в обогащении и извлечении полезных компонентов.

Безусловно, основополагающим принципом, положенным в основу геолого-экономической оценки месторождений, охватывающей все стадии геологоразведочного процесса, должен быть положен принцип наиболее полного вовлечения в национальное хозяйство уже разведанных запасов. На наш взгляд, должны учитываться еще и такие единые принципы, как наилучшее применение уже разведанных запасов полезных ископаемых; достижение доходности добычи и переработки минерального сырья (не ниже отраслевых нормативов); самоокупаемость добычи и переработки по каждой единице балансовых запасов; всесторонний учет и наиболее полное отражение национальных потребностей.

При проведении геолого-экономической оценки необходимо руководствоваться принятой в Казахстане единой методикой технико-экономического обоснова- ния временных кондиций. Это повариантное исследование месторождения для обоснования рациональных способов и систем его разработки, выбора наиболее эффективной технологии переработки сырья [18].

Технико-экономическое обоснование постоянных кондиций разрабатывается по материалам завершенных геологоразведочных работ. Цель - установить масштабы и промышленную ценность месторождения для определения целесообразности и экономической эффективности его промышленного освоения, принятия решения о финансировании инвестиционного проекта на освоение. Все сметно-финансовые расчеты по принятому варианту промышленного освоения месторождения выполняются в рамках реально допустимых значений всех модифицирующих факторов-технических, оперативно-производственных и экономических, от которых зависит жизнеспособность проекта и целесообразность инвестирования дальнейших геологоразведочных работ. Количество принимаемых в расчет факторов должно быть достаточным для установления промышленных запасов. Для повышения достоверности оценки необходимо будет ее завершать финансовым анализом месторождения, оценкой точности расчета совокупных затрат на освоение месторождения.

Ключевым элементом оценки является выбор наиболее целесообразного варианта отработки месторождения по принципу достижения наибольшего экономического эффекта, затрагивающего интересы государства и инвесторов [19]. Повысят обоснованность выводов расчет доходов от эксплуатации месторождения и расходов на эксплуатацию месторождения; чистого дохода инвесторов с учетом уплаты всех обязательных платежей; показателей, отражающих экономическую эффективность инвестиционного проекта по конкретному месторождению, детальный анализ структуры денежных потоков с учетом временного фактора.

Если говорить о будущем геологической отрасли Казахстана, то для всестороннего исследования количественных и качественных характеристик недр, за счет государственного бюджета и государственночастного партнерства запланировано продолжение региональных и полномасштабных разведочных работ, выявление перспективных участков на коммерческое установление полезных ископаемых для последующих разведочных работ по контрактам на недропользование. Внедрение инструментов государственночастного партнерства будет стимулировать частные инвестиции в реализацию проектов по геологическому исследованию недр, проведению наиболее рисковых геологических исследований, что активизирует продвижение инновационных технологий в геологоразведочные работы, ускорит переход на международные стандарты отчетности по запасам [20].

На 2020-2030 годы запланировано проведение 
поисково-оценочных геологоразведочных работ, открытие новых месторождений и подсчет ресурсов полезных ископаемых, обеспечение целесообразного потребления недр на изученных площадях, продолжение региональных и поисковых работ на новых территориях.

В силу того, что геологоразведочное производство принимает отчетливо выявленный научно-исследовательский образ, нельзя не заметить подобие инвестиций, нацеленных на разведывательные операции по месторождениям полезных ископаемых с вложениями в инновационную среду. В случае проведения аналогий между инновациями и геологоразведочными работами первому этапу бюджетного финансирования соответствуют стадии региональных и геолого-съемочных работ. Этап рискоинвестиций сопоставим с работами, предполагающими поисковые, поисково-оценочные действия, и охватывающими начальные стадии разведки. На данном этапе происходит оценка возможного промышленного значения выявленных объектов, утверждение промышленных запасов. Для указанного этапа характерно участие как государства, так и частных компаний. Третьему этапу инновационных инвестиций соответствуют стадии доразведки месторождений и эксплуатационной разведки, т.е. работы, проводимые обычно на фоне промышленной добычи полезных ископаемых.

Исходя из существующей в Казахстане структуры затрат на геологоразведочные работы, очевидно, что почти 90 \% затрат приходится именно на этап рискоинвестиций, причем свыше 70 \% затрат являются наиболее уязвимыми с точки зрения геологического риска, поскольку приходятся на стадии поисков. Об идентичной природе финансирования нововведений и вложении ресурсов в поисково-разведочные действия говорит многое. Это, например, наукоемкий характер подобных шагов, похожесть в оценке экономических рисковых ситуаций и возвращения потраченных средств, обязательность государственной поддержки как в виде конкретного финансирования на начальных производственных этапах, так и в виде поощрения инвестиционных поступлений в дальнейшем.

Как инновационная активность, так и геологоразведочная деятельность должны стимулироваться налоговыми льготами. Но для геологических предприятий необходима оптимизация налоговой политики с учетом геологического риска.

\section{Заключение}

Горно-металлургический комплекс Казахстана, будучи наиболее конкурентоспособным и динамично развивающимся, значительно уступает мировым лидерам по техническому вооружению. Так, оснащение современным оборудованием и развитыми сетями передачи данных на месторождениях составляет $21 \%$, 56 \% месторождений характеризуется отсутствием се- тей либо недостаточным их развитием, 23 \% месторождений требуют полной замены оборудования.

Поэтому уже сегодня акцент делается на адаптацию технологий Индустрии 4.0, принципиально меняющей экосистему поставщиков вокруг горнодобывающих компаний с традиционной на высокотехнологичную. Индустрия 4.0 в горнодобывающей промышленности оказывает содействие росту производительности труда и наращиванию объемом создаваемой продукции для покрытия нарастающего спроса, ускоряет разрешение задач по разработке низкорентабельных руд. Для Казахстана, как обладателя с одной стороны, крупнейших, а с другой - преимущественно непростых для разработки резервов минеральных руд, она несет существенный эффект в виде наращивания ценности ресурсных накоплений и их эксплуатации в будущем.

Государство оказывает поддержку в решении актуальной проблемы оцифровки геологической отрасли с отстаиванием национальных интересов, где объективно необходимы: единая карта геологоразведки страны, переход к интеллектуальным месторождениям, трансферт технологий. Опыт по оцифровке месторождений АО «Эмбамунайгаз» - нефтяной компании, осуществляющей геологоразведку, разработку нефтегазовых месторождений, добычу и подготовку нефти и газа, свидетельствует, что за счет оцифровки мелких месторождений с небольшим количеством скважин можно сэкономить порядка 50-70 млн. тенге. За 2018-2019 годы планируется автоматизировать около 10-20 месторождений, среди которых и месторождение Кусмурын.

Переход от ресурсно-сырьевой к инновационной модели развития экономики Казахстана диктует необходимость принятия стимулирующих и протекционистских мер государством, что ускорит диверсификацию региональной экономики и будет способствовать устойчивому развитию регионов. Эти меры нацелены как на углубленное воспроизведение минеральносырьевой базы, обеспечивающее комплексацию добываемого сырья приростом запасов промышленных категорий, так и на возобновление работ на перспективных, но законсервированных месторождениях, внесение изменений в организацию геологоразведочных работ Казахстана с устранением затратных методов их выполнения. 


\section{ЛИТЕРАТУРА:}

1. О недрах и недропользовании: Кодекс Республики Казахстан от 27 декабря 2017 года № 125-VI ЗРК.

2. Концепция развития геологической отрасли Республики Казахстан до 2030 года. Утверждена постановлением Правительства Республики Казахстан от 13 августа 2012 года № 1042 .

3. Государственная программа индустриально-инновационного развития на 2015-2019 годы. Утверждена Указом Президента Республики Казахстан 1 августа 2014 г. N 874.

4. Программа геологоразведочных работ на 2015-2019 годы. Утверждена постановлением Правительства Республики Казахстан от 21 мая 2014 года N 526.

5. Бестфатер Д.В., Хмара В.В., Кабышев А.М., Лобоцкий Ю.Г. Микропроцессорное управление станциями пневмотранспортной системы на предприятиях горно-металлургического комплекса // Устойчивое развитие горных территорий. 2016. N 3(29). С. 211-221.

6. Milkov Alexei V. Risk tables for less biased and more consistent estimation of probability of geological success (PoS) for segments with conventional oil and gas prospective resources // Earth Science Reviews. 2015. V. 150. Pp. 453-476.

7. Yemez, H. Stigliano, V. Singh and E. Izaguirre Minimum economic field size estimation and its role in exploration project risks assessment: evaluation of different methodologies // First Break. 2016. Vol. 34, No 4. April 2016. Pp. 29-38. DOI:10.3997/1365-2397.2016004.

8. Luo, Y. D., \& Tung, R. L. (2007). International expansion of emerging market enterprises: A springboard perspective // Journal of International Business Studies. 38. Pp. 481-498.

9. План развития разработки редких и редкоземельных металлов в Республике Казахстан на 2015-2019 годы. Утвержден постановлением Правительства Республики Казахстан от 26 ноября 2014 года N 1237.

10. Ставский А. Зарубежный опыт организации геологоразведочных работ на твердые полезные ископаемые и возможности его применения в России // Минеральные ресурсы России. Экономика и управление. 2013. N 1. С.55-57.
11. Klett, T.R., Cook, T.A., Charpentier, R.R., Tennyson, M.E., and Le, P.A., 2015, U.S. Geological Survey assessment of reserve growth outside of the United States: U.S. Geological Survey Scientific Investigations Report 2015-5091, 13 p. http:// dx.doi.org/10.3133/sir20155091.

12. Maghfouri, S., Rastad, E., Mousivand, F. Stratigraphic position, origin and characteristics of manganese mineralization horizons in the Late Cretaceous volcano-sedimentary sequence, south-southwest of Sabzevar // Journal of Economic Geology. 2014. No. 1 (Vol. 6). Pp. 201-216.

13. Каждан А.Н., Кобахидзе Л.П. Геолого-экономическая оценка месторождений полезных ископаемых. М.: Недра, 1985. 205 с.

14. Arndt N., Kesler S., Ganino C. (2015). Metals and Society: An Introduction to Economic Geology. Monograph, Springer. $224 \mathrm{p}$.

15. Гуня А.Н. Модернизация и устойчивое развитие горных территорий // Устойчивое развитие горных территорий. 2016. N 4. C. 325-332.

16. Singh, V., Izaguirre, E., Yemez, I. and Stigliano H. Establishing Minimum Economic Field Size and Analysing its Role in Exploration Project Risks Assessment: Three Examples / The 12th Middle East Geosciences Conference and Exhibition. March 7-10, 2016, Manama, Bahrain.

17. Singh, V., Yemez I., Izaguirre E. and Racero A. (2017). Optimal Subsurface Appraisal: A Key Link to the Success of Development Projects-Few Examples // American Journal of Applied Sciences. Volume 14, Issue 2. Pp. 217-230. DOI: 10.3844/ajassp.2017.217.230.

18. Государственная Программа «Цифровой Казахстан». Утверждена постановлением Правительства Республики Казахстан от 12 декабря 2017 года 827.

19. Об инновационном кластере «Парк инновационных технологий». Закон Республики Казахстан от 10 июня 2014 года N207-V ЗРК.

20. Kerrich R., Goldfarb R.J., and Richards J. Metallogenic provinces in an evolving geodynamic framework: Economic Geology. 100th Anniversary Volume. 2005. Pp. 1097-1136.

\section{СВЕДЕНИЯ ОБ АВТОРАХ / Information about authors:}

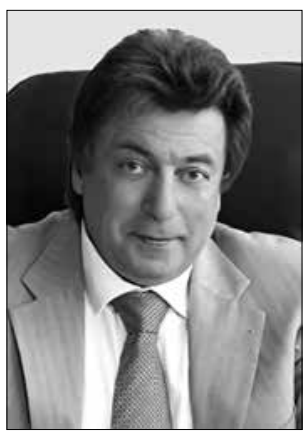

РУДЬКО Георгий Ильич - доктор геолого-минералогических наук, доктор географических наук, доктор технических наук, председатель Государственной комиссии Украины по запасам полезных ископаемых, профессор.

Киевский национальный университет имени Тараса Шевченко, Киев, Украина.

E-mail: rudko@dkz.gov.ua

Georgiy I. RUDKO - Doctor of Geological and Mineralogical Sciences, Doctor of Geographical Sciences, Doctor of Technical Sciences, Chairman of the State Commission of Ukraine for Mineral Resources, Professor. Kyiv National University n.a. Taras Shevchenko, Kyiv, Ukraine; E-mail: rudko@dkz.gov.ua

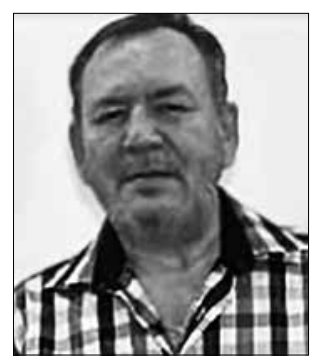

МЯТЧЕНКО Александр Владимрович - главный геолог, геолого-экономическая консалтинговая компания, Караганда, Казахстан.

E-mail: amyatchenko@mail.ru

Alexandr VI. MYATCHENKO - Chief Geologist, Geological and Economic Consulting Company, Karaganda, Kazakhstan. E-mail:amyatchenko@mail.ru 


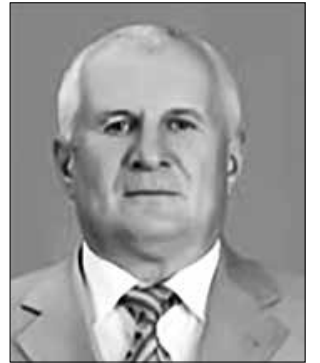

ПОРТНОВ Василий Сергеевич доктор технических наук, профессор.

Карагандинский государственный технический университет, Караганда, Казахстан.

E-mail:vs_portnov@mail.ru

Vasiliy S. PORTNOV-Doctor of Technical Sciences, Professor.

Karaganda State Technical University, Karaganda, Kazakhstan.E-mail:vs_portnov@mail.ru

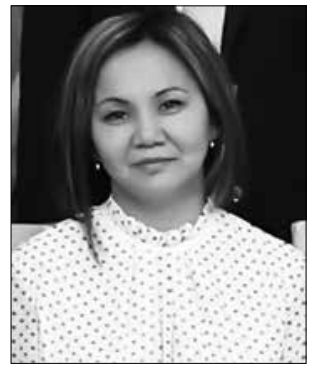

ИСАТАЕВА Фарида Муратовна - докторант специальности 6D070600 «Геология и разведка месторождений полезных ископаемых».

Карагандинский государственный технический университет, Караганда, Казахстан.

E-mail: adambekova_farid@mail.ru

Farida M. ISATAEVA - PhD student of 6D070600 "Geology and exploration of mineral deposits" specialty

Karaganda State Technical University, Karaganda, Kazakhstan. E-mail: adambekova_farid@mail.ru

\section{GEOLOGICAL-ECONOMIC ESTIMATION OF KAZAKHSTAN DEPOSITS}

${ }^{1}$ G. I. Rudko,

${ }^{2}$ A. V. Myatchenko,

${ }^{3}$ F.M. Isataeva,*

${ }^{3}$ V. S. Portnov

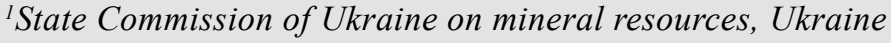

${ }^{2}$ Geologo-economic consulting company, Karaganda

${ }^{3}$ Karaganda State Technical University, Karaganda, adambekova_farid@mail.ru

DOI: $10.21177 / 1998-4502-2018-10-4-471-480$

The thesis is put forward that the progress of Kazakhstan is connected, first of all, with the availability of natural resources; long-term practice, covering the complexity of management; development of protective mechanisms to defend national interests. Kazakhstan's experience in industrial and innovative development can be useful for developing countries, as it clearly shows how the transformation processes take into account the specifics of the country, its geopolitical position, traditions and mentality.

Further development of the geological industry of Kazakhstan, the key criterion for the efficiency of which is the increase in proven mineral reserves, due to the intensification of production and increasing the depth of processing. Along with the improvement of geological and geophysical research, the economic side of geological exploration plays an important role. In light of the above, the article aims to substantiate the directions of improving the geological and economic assessment of the pyrite-copper-lead-zinc Deposit of Kusmuryn.

Objectives: to show the effective steps of state regulation of the geological industry of Kazakhstan; to summarize the results of geological and economic assessment of the copperlead-zinc Deposit Kusmuryn; to justify the need to improve the geological and economic assessment of deposits in accordance with international standards and taking into account socio-economic, geological and geographical factors. Information and factual base of research-materials of the legislative and regulatory framework of the Republic of Kazakhstan, the results of scientific research of the field Kusmuryn, own calculations of the authors. The validity and reliability of the results are determined by comparative analysis, the use of reliable economic and geological information about the raw material base of Kazakhstan, the Kusmuryn Deposit, the use of a set of modern methods of scientific research, taking into account regional climatic and geological conditions.

The results of geological and economic assessment of the Kusmuryn field can be attributed to the category of promising, in the medium term it is planned to enter the field of underground mining. In order to improve the geological and economic assessment of deposits proposed to deepen the feasibility study of permanent conditions, developed on the basis of materials already completed exploration, financial analysis. For the growth of scientific evidence of geological and economic assessment of mineral deposits and optimization of decisions on their further operation, specific indicators are proposed. In conclusion, the article shows how the planned effective measures of state regulation of the geological industry will affect the quality of exploration, their innovative component, and in general, the sustainability of regional development.

Keywords: Kazakhstan, investments, evaluation, deposit, CRISCO standards, innovations.

\section{References}

1. On subsoil and subsoil use. Code of the Republic of Kazakhstan dated December 27, 2017 No 125-VI 3PK.

2. The concept of development of the geological industry of the Republic of Kazakhstan until 2030. Approved by the government of the Republic of Kazakhstan dated August 13, 2012, no 1042.

3. State program of industrial-innovative development for 2015-2019. Approved by the decree of the President of the Republic of Kazakhstan on August 1, 2014, no 874.

4. Exploration program for 2015-2019. Approved by the government of the Republic of Kazakhstan dated may 21, 2014, no 526.

5. Bestvater D. V., Khmara V. V. Kabyshev A. M., Lo- 
botsky J. G. Microprocessor control stations pneumatic conveying systems at the enterprises of mining-metallurgical complex. Sustainable development of mountain territories, 2016, no 3 (29), pp. 211-221.

6. Milkov A. V. (2015). Risk tables for less biased and more consistent estimation of probability of geological success $(\mathrm{PoS})$ for segments with conventional oil and gas prospective resources: Earth Science Reviews, v. 150, pp. 453476.

7. Yemez H., Stigliano V. Singh and E. Izaguirre Minimum economic field size estimation and its role in exploration project risks assessment: evaluation of different methodologies. First Break. April 2016, vol. 34, no 4, pp. 29-38. DOI:10.3997/1365-2397.2016004.

8. Luo Y. D., \& Tung, R. L. (2007). International expansion of emerging market enterprises: A springboard perspective. Journal of International Business Studies, 38, pp. 481498.

9. Development plan for the development of rare and rare earth metals in the Republic of Kazakhstan for 2015-2019. Approved by the government of the Republic of Kazakhstan dated November 26, 2014, no 1237.

10. Stavsky A. Foreign experience in the organization of geological exploration for solid minerals and the possibility of its application in Russia. Mineral resources of Russia. Economics and management, 2013, No. 1, pp. 55-57.

11. Klett, T.R., Cook, T.A., Charpentier, R.R., Tennyson, M.E., and Le, P.A., 2015, U.S. Geological Survey assessment of reserve growth outside of the United States: U.S. Geological Survey Scientific Investigations Report 2015-5091. 13 p. http://dx.doi.org/10.3133/sir20155091.

12. Maghfouri, S., Rastad, E., Mousivand, F. Stratigraphic position, origin and characteristics of manganese mineraliza- tion horizons in the Late Cretaceous volcano-sedimentary sequence, south-southwest of Sabzevar. Journal of Economic Geology, 2014, No 1 (Vol. 6), pp. 201-216.

13. Kazhdan, Kobakhidze L. P. Geological and economic assessment of mineral deposits. Moscow, Nedra, 1985, 205 p.

14. Arndt N., Kesler S., Ganino C. (2015). Metals and Society: An Introduction to Economic Geology. Monograph, Springer. $224 \mathrm{p}$

15. Gong-UN. Modernization and sustainable development of mountain areas. Sustainable development of mountain areas, 2016, no 4, pp. 325-332.

16. Singh, V., Izaguirre, E., Yemez, I. and Stigliano H. Establishing Minimum Economic Field Size and Analysing its Role in Exploration Project Risks Assessment: Three Examples. The 12th Middle East Geosciences Conference and Exhibition. March 7-10, 2016, Manama, Bahrain.

17. Singh, V., Yemez I., Izaguirre E. and Racero A. (2017). Optimal Subsurface Appraisal: A Key Link to the Success of Development Projects-Few Examples American Journal of Applied Sciences, vol. 14, issue 2, pp. 217-230. DOI: 10.3844/ajassp.2017.217.230.

18. State Program "Digital Kazakhstan". Approved by the government of the Republic of Kazakhstan on December 12 , 2017, 827.

19. About innovation cluster "Park of innovative technologies". Law of the Republic of Kazakhstan dated June 10, 2014, No 207-V SAM.

20. Kerrich, R., Goldfarb, R.J., Richards, J., 2005, Metallogenic provinces in an evolving geodynamic framework: Economic Geology 100th Anniversary Volume, pp. 1097-1136.

Article received 14.06.2018 


\section{РЕГИОНАЛЬНЫЕ СТРУКТУРЫ МИГРАЦИИ ХИМИЧЕСКИХ ЭЛЕМЕНТОВ В ЛАНДШАФТАХ СЕВЕРНОГО КАВКАЗА}

'Дегтярева Т.В.*, 'Лиховид А.A., 1 Лысенко А.В., ${ }^{2}$ Караев Ю.И.

\section{Введение}

Для определения состояния природной среды горных регионов, как наиболее уязвимых к воздействиям человека, особое значение имеет их целостное геохимическое изучение и мониторинг фоновых геохимических параметров. Важнейшей составляющей геохимического мониторинга является исследование геохимической структуры природно-территориальных комплексов разного ранга и типа. Вертикальная геохимическая структура ландшафтов формируется в ходе миграционных радиальных взаимодействий в системах типа «литосфера - растительный покров», «почва - растения», «порода - почва - растения»у и др. [1].

С целью выявления сложной картины пространственного распределения химических элементов в геохимической структуре ландшафтов традиционно применяется радиальный анализ миграции химических элементов, использование которого более широко для геосистем локального уровня, элементарных ландшафтов [2]. В современных научных публикациях недостаточно работ по изучению геохимической дифференциации вертикальной структуры региональных геосистем.

Особый интерес представляет изучение миграционных радиальных взаимодействий в региональных геосистемах с однотипным биологическим круговоротом и неоднородными почвообразующими породами. В пределах таких региональных геосистем складывается определенная последовательность изменения интенсивности миграции химических элементов в системе «почва - гетерогенные почвообразующие породы». В результате длительного протекания процессов выветривания и почвообразования в материнских породах и почвах формируется система соединений элементов с различным соотношением их прочносвязанных и подвижных форм [3-6]. Характерный для каждого комплекса почвообразующих пород и почв различный минералогический состав и разная устойчивость минеральной массы к выветриванию приводят к появлению соединений элементов разной растворимости и подвижности [7-9]. Комплексное сочетание факторов внутренней и внешней миграции элементов в конкретных физико-географических условиях региональных геосистем определяет миграционное поведение каждого химического элемента, его радиальное перераспределение [10].

Важнейшим фактором радиальной миграции химических элементов выступает биогенный фактор, который проявляется через характерные для каждого типа БИКа в определенных гидротермических условиях биогеохимические процессы выветривания и почвообразования. В ходе этих процессов происходит биогеохимическая трансформация соединений элементов в материнских породах и почвах с образованием различного количества прочносвязанных и подвижных форм. Когда в пределах региональных геосистем почвообразующие породы представлены несколькими комплексами, то воздействие биогеохимических процессов однотипного БИКа специфично для каждого почвообразующего комплекса и определенным образом влияет на вовлечение химических элементов в миграционные процессы, приводящие к различной интенсивности их перемещения в почвы [11-13].

\footnotetext{
${ }^{1}$ Северо-Кавказский федеральный университет, г. Ставрополь, Россия, e-mail: dtb.70@mail.ru

${ }^{2}$ Северо-Кавказский горно-металлургический институт (государственный технологический университет), г. Владикавказ, Россия.
}

УДК: 550.424

\section{DOI: 10.21171/1998-4502-2018-}

10-4-481-492

Региональная структура миграции химических элементов рассматривается как определенная последовательность изменения интенсивности их миграции между почвой и неоднородными почвообразующими породами в пределах региональных геосистем с однотипным биологическим круговоротом. Изучены региональные структуры миграции химических элементов для высотных геоботанических поясов ландшафтных округов, выделенных в границах высокогорной, среднегорной и низкогорной физико-географических подобластей Северного Кавказа. С помощью кластерного анализа выделены парагенетические ассоциации химических элементов, участвующих в миграционных процессах между почвой и почвообразующими породами. Сопоставление региональных структур миграции химических элементов по высотным поясам ландшафтных округов в пределах разных физикогеографических подобластей Северного Кавказа позволяет говорить о ведущих литогенном или биогенном факторах их формирования.

\section{КЛЮЧЕВЫЕ СЛОВА:}

Северный Кавказ, почвообразующие породы, биологический круговорот, миграция химических элементов

Статья поступила в редакцию 24.10.2018. 
Цель исследования - выявление особенностей миграции химических элементов в системе «почвапочвообразующие породы» в региональных геосистемах Северного Кавказа с однотипным биологическим круговоротом (БИКом) и неоднородными почвообразующими породами. Определение геохимической дифференциации в распределении химических элементов между почвами и почвообразующими породами позволяет установить генетические взаимосвязи между этими компонентами геосистем [14; 15].

Материалы и методы исследований. В качестве региональных геосистем рассмотрены доминант-

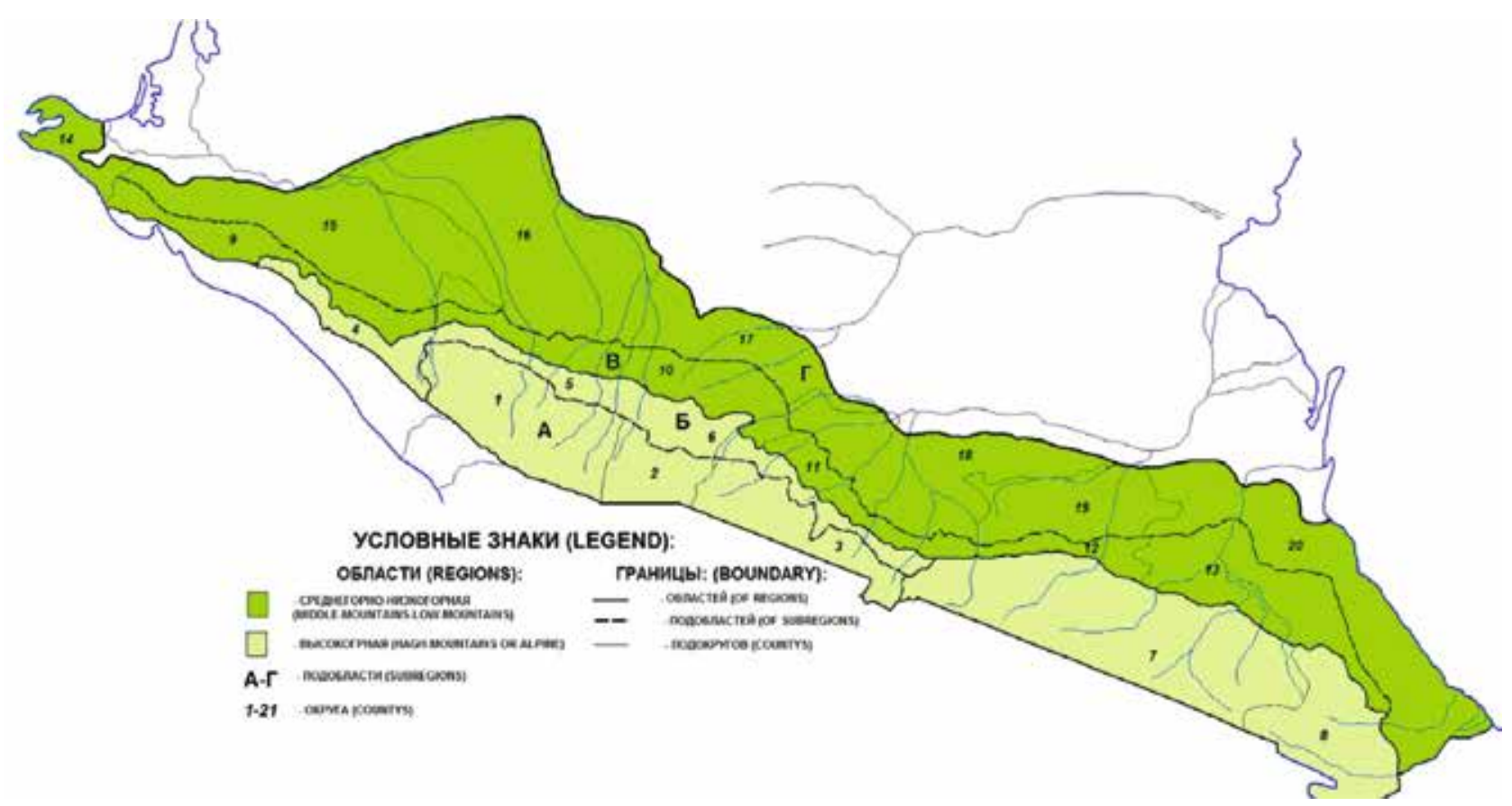

Pис. 1. Схема физико-географического районирования северного склона Большого Кавказа [16]

Fig. 1. Scheme of physical-geographical zoning of the northern slope of the Greater Caucasus [16]

I. Высокогорная область:

А. Эльбрус - Казбековская высокогорная подобласть на складчато-глыбовых структурах. Округа: 1 - Лабино-Тебердинский темнохвойных лесов и альпийских лугов: 2 -Тебердино-Эльбрусский сосновых, сосново-пихтовых лесов и альпийских лугов; 3 - Кубано-Терский сосновых лесов и альпийских лугов.

Б. Североюрско-Дагестанская высокогорно-среднегорная подобласть на раннеальпийских складчато-глыбовых структурах. Округа: 4 - Северогойтхский широколиственных (буковых) лесов; 5 - Кубанский широколиственных лесов и лугов; 6 - Терский субальпийских лугов, широколиственных лесов и горных степей; 7 - Андийско-Аварский альпийских лугов, сосновых лесов и степей с нагорными ксерофитами; 8-Самуро-Уллучайский нагорных ксерофитов и остепненных лугов.

II.Среднегорно-низкогорная область:

В. Кубано-Дагестанская подобласть среднегорий на позднеальпийских складчатых и моноклинальньх структурах. Округа: 9 - Западнокубанский широколиственных лесов; 10 - Лабино-Малкинский лесостепей и остепненных лугов; 11 - Терско-Малкинский широколиственных лесов и лугов; 12 - Внутренний Дагестан нагорных ксерофитов и остепненных лугов; 13 - Сулак-Самурский широколиственных лесов.

Г. Черноморско-Терско-Сунженская подобласть низкогорий на новейших складчатых структурах и предгорных равнинах. Округа: 14 - Керченский степной; 15 - Западноприкубанский иироколиственных лесов и степей; 16 - Прикубанский предгорных остепненных лугов; 17 - Прикубанско-Кавминводский степей и лесостепей; 18 - Терско-Кубанский степей и предгорных степей; 19 - Терско-Сулакский степной; 20 - Сулакско-Прикаспийский польнно-злаковых степей и кустарников.

I. High altitude area:

A. The Elbrus - Kazbek mountain subarea at the fold-hat structures. Districts: 1-Labino-Teberdinsky dark coniferous forests and Alpine meadows: 2 -Teberdino-Elbrus pine, pine-fir forests and Alpine meadows; 3 -Kuban-Terek pine forests and Alpine meadows.

5. Severogoisk-Dagestan highland-mountain subarea of renealmia fold-hat structures. District: 4 - Severogoisk broad-leaved (beech) forests; 5 - Kuban broad-leaved forests and meadows; 6 - Terek subalpine meadows, broadleaved forests and mountain steppes; 7 - Andean-Avar Alpine meadows, pine forests and mountain steppes with xerophytes; 8-Samura-Uluchaisky xerophytes and stupefied meadows.

II. Srednegorie-low mountain area:

B. Kuban-Dagestan sub domain of middle categories on late Alpine folded and monoclonal structures. District: 9 - Westkuban broadleaved forests; 10 - Labino-Malkin steppe meadows; 11 - Terek-Malka broad-leaved forests and meadows; 12 - Inner Dagestan xerophytes and stupefied meadows.; 13 - Sulak-Samur broad-leaved forests.

$\Gamma$. The Black Sea and Terek-Sunzha sub region of the lowlands on the latest folded structures and Piedmont plains. District: $14-$ Kerch steppe; 15 - Westprekuban broad-leaved forests and steppes; 16 - Prekuban steppe meadows; 17 - Kuban-Kavminvodskaya steppes and foreststeppes; 18 - Terek-Kuban steppes and foothill steppes; 19 - Terek-Sulak steppe; 20 -Sulak-Caspian wormwood-cereal steppes and shrubs. 
ные высотные геоботанические пояса ландшафтных округов, имеющие значительное вертикальное развитие и горизонтальную протяженность в пределах высокогорной и среднегорно-низкогорной физикогеографических областей северных склонов Большого Кавказа [16]. Данные крупные геокомплексы имеют региональные различия, позволяющие выделять в них физико-географические подобласти и ландшафтные округа (рис. 1).

В пределах каждой физико-географической подобласти развиты несколько почвообразующих комплексов, отличающихся между собой по генезису, литологии и геохимии $[17 ; 18]$. В Эльбрус-Казбековской высокогорной подобласти Главного, Бокового и Передового хребтов (рис. $1, A$ ) почвы формируются на продуктах выветривания протерозойских кристаллических сланцев и гнейсов, палеозойских гранитоидов, вулканогенных отложений неогена, палеозойских вулканогенно-терригенных и терригенных отложений. В Североюрско-Дагестанской высокогорно-среднегорной подобласти (рис. 1, Б) к морфоструктурным комплексам Гойтского антиклинория в Западном Кавказе и антиклинориям Главного и Бокового хребтов Дагестана приурочены почвообразующие комплексы терригенно-вулканогенных отложений юры.

В Кубано-Дагестанской подобласти среднегорий (рис. $1, B$ ) к морфоструктурному комплексу Скалистого хребта приурочены почвообразующие комплексы терригенно-карбонатных отложений верхней юры и мела. В пределах Пастбищного, Дарьинского, Боргустанского и Джинальского хребтов распространены терригенно-карбонатные отложения мела и палеогена. В Черноморско-Терско-Сунженской подобласти низкогорий (рис. $1, \Gamma$ ) останцы неогеновой куэсты и системы низких горных гряд Лесистого хребта сложены терригенно-карбонатными неогеновыми отложениями. К межкуэстовым депрессиям приурочены терригенные отложения.

Геохимическая специфика почвообразующих комплексов и почв определена по данным В.В.Дьяченко $[17 ; 18]$ о содержании в них 25 химических элементов, полученных в ходе ландшафтно-геохимической съемки Северного Кавказа масштаба 1:500000. На этой базе данных разработана методика изучения региональных структур миграции химических элементов между почвой и гетерогенными почвообразующими породами в пределах высотных геоботанических поясов ландшафтных округов, включающая:

- определение интенсивности миграции химических элементов с использованием коэффициента радиальной дифференциации $R$ (элювиально-аккумулятивного), отражающего генетическую связь почвы с почвообразующей породой [14]. Разная интенсивность радиальной миграции зависит от количества подвижных и прочносвязанных соединений химиче- ских элементов, образующихся в породах и почвах в ходе длительного протекания сложных процессов выветривания и почвообразования при комплексном сочетании факторов внутренней и внешней миграции химических элементов. В случае низкой интенсивности радиальной миграции $(R<1)$ химический элемент в породах находится преимущественно в труднорастворимых и устойчивых к разрушению соединениях и происходит минимальный его переход в почвы. В случае высокой интенсивности радиальной миграции (высокое значение $R$ ) химический элемент в почвообразующих породах легко переходит в подвижные растворимые формы и максимально перемещается в почву;

- ранжирование почв, сформированных на неоднородных почвообразующих породах, по возрастанию коэффициентов радиальной дифференциации, позволяющее получить определенный структурный ряд изменения интенсивности миграции каждого химического элемента между почвой и почвообразующими породами в пределах высотного пояса. Данная структурная дифференциация рассматривается как региональная структура миграции химического элемента, представляющая определенную последовательность изменения интенсивности миграции элемента между почвой и неоднородными почвообразующими породами в пределах геосистемы с однотипным БИК;

- выделение в высотных поясах групп химических элементов с одинаковой региональной структурой миграции, представляющих собой парагенетические ассоциации химических элементов, участвующих в миграции между почвой и почвообразующими породами;

- сопоставление между собой региональных структур миграции химических элементов высотных поясов с одинаковым набором комплексов почвообразующих пород в пределах высокогорной, среднегорной и низкогорной физико-географических подобластей. Выявление ведущих факторов формирования региональных структур миграции химических элементов (использованы данные по 31 высотному поясу).

В данной статье в качестве примера рассмотрены региональные системы миграции химических элементов для двух высотных поясов Лабино-Тебердинского округа, выделяемого на Западном Кавказе в пределах Эльбрус-Казбековской высокогорной подобласти. Округ занимает верховья рек Белой, Большой и Малой Лабы, Урупа, Большого и Малого Зеленчука и Теберды.

\section{Полученные результаты и их обсуждение}

Своеобразие природных условий рассматриваемого округа привело к образованию нескольких высотных поясов: скально-нивального и субнивального, высокогорных лугов, смешанных и хвойных лесов. Почвы во всех высотных поясах формируются на практически одинаковых комплексах почвообразую- 
щих пород: метаморфических кристаллических сланцах и гнейсах протерозоя (метам.PR), метаморфических терригенно-вулканогенных палеозоя (метам.PZ), магматических палеозойских гранитоидах (магм.PZ) и терригенных палеозоя (терр.PZ).

Определение коэффициентов радиальной дифференциации показало, что в почвах двух высотных поясов (скально-нивального и субнивального и пояса высокогорных лугов) преобладает обогащение химическими элементами по сравнению с почвообразующими породами (табл.1).

Ранжирование по возрастанию коэффициентов радиальной дифференциации в пределах высотного пояса дает определенную структуру изменения интенсивности миграции каждого химического элемента между почвой и неоднородными почвообра- зующими породами. Например, структурный ряд изменения интенсивности радиальной миграции в скально-нивальном и субнивальном высотном поясе выглядит как:

для $\mathrm{Cu}-$ «метам.PZ < метам.PR $<$ терр.PZ < магм.PZ»;

для $\mathrm{Zn}$ - «метам.PR $<$ терр.PZ < магм.PZ < метам.PZ»;

для $\mathrm{Pb}$ - «магм.PZ < терр.PZ < метам.PR < метам.PZ» и т.Д.

С помощью кластерного анализа в высотных поясах Лабино-Тебердинского округа выделены группы химических элементов с одинаковыми структурами радиального перераспределения между почвой и гетерогенными почвообразующими породами. Так, результаты кластерного анализа региональных структур миграции химических элементов в скальнонивальном и субнивальном высотном поясе свиде-

Коэффициенты радиальной дифференциации $(R)$ для почв двух высотных поясов Лабино-Тебердинского округа, сформированных на неоднородных почвообразующих породах

Coefficients of radial differentiation (R) for soils of two high-altitude belts of the Labino-Teberda region, formed on heterogeneous soil-forming rocks

\begin{tabular}{|c|c|c|c|c|c|c|c|c|}
\hline \multirow{3}{*}{$\begin{array}{c}\text { Химические } \\
\text { элементы } \\
\text { Chemical } \\
\text { elements }\end{array}$} & \multicolumn{8}{|c|}{ Высотные геоботанические пояса / High-altitude geobotanical belts } \\
\hline & \multicolumn{4}{|c|}{$\begin{array}{c}\text { скально-нивальный и субнивальный } \\
\text { rock-nival and subnival }\end{array}$} & \multicolumn{4}{|c|}{ высокогорные луга / alpine meadows } \\
\hline & I & II & III & IV & I & II & III & IV \\
\hline $\mathrm{Cu}$ & 1,19 & 0,95 & 1,49 & 0,99 & 1,16 & 0,63 & 1,48 & 0,84 \\
\hline $\mathrm{Zn}$ & 2,07 & 2,74 & 2,48 & 1,68 & 1,54 & 2,01 & 2,07 & 2,13 \\
\hline $\mathrm{Pb}$ & 1,51 & 1,80 & 1,41 & 1,79 & 1,19 & 1,48 & 1,21 & 2,07 \\
\hline $\mathrm{Ag}$ & 1,70 & 0,91 & 1,27 & 1,19 & 1,38 & 0,64 & 0,94 & 1,07 \\
\hline $\mathrm{Sn}$ & 1,15 & 1,33 & 0,92 & 0,98 & 1,10 & 1,26 & 0,78 & 0,97 \\
\hline Mo & 1,06 & 1,07 & 1,24 & 1,33 & 0,75 & 0,97 & 0,92 & 0,62 \\
\hline W & 1,33 & 0,96 & 1,76 & 0,82 & 0,81 & 0,58 & 0,82 & 0,73 \\
\hline $\mathrm{Ba}$ & 1,41 & 1,63 & 1,35 & 1,64 & 1,45 & 1,46 & 1,04 & 1,42 \\
\hline $\mathrm{Co}$ & 1,72 & 1,34 & 2,56 & 1,59 & 1,54 & 1,22 & 2,11 & 1,47 \\
\hline $\mathrm{Ni}$ & 1,04 & 1,37 & 3,16 & 1,29 & 0,93 & 1,15 & 2,56 & 1,13 \\
\hline $\mathrm{Mn}$ & 1,22 & 1,48 & 1,93 & 1,46 & 1,33 & 1,48 & 1,70 & 1,42 \\
\hline $\mathrm{Ti}$ & 1,36 & 1,51 & 1,31 & 1,25 & 1,18 & 1,38 & 1,21 & 1,22 \\
\hline $\mathrm{V}$ & 1,37 & 1,45 & 1,77 & 1,33 & 1,13 & 1,13 & 1,52 & 1,11 \\
\hline $\mathrm{Cr}$ & 0,89 & 1,24 & 1,35 & 1,35 & 0,70 & 0,87 & 1,27 & 1,15 \\
\hline $\mathrm{Ga}$ & 1,00 & 1,31 & 0,98 & 1,13 & 1,06 & 1,23 & 0,91 & 1,05 \\
\hline $\mathrm{Ge}$ & 1,38 & 1,56 & 1,50 & 1,31 & 1,31 & 1,25 & 1,31 & 1,28 \\
\hline$P$ & 1,56 & 1,60 & 1,32 & 1,35 & 1,19 & 1,72 & 0,99 & 1,43 \\
\hline $\mathrm{Li}$ & 1,19 & 1,30 & 1,53 & 1,24 & 1,17 & 1,12 & 1,39 & 1,08 \\
\hline $\mathrm{Be}$ & 1,55 & 1,80 & 0,97 & 1,59 & 1,82 & 1,70 & 0,78 & 1,39 \\
\hline $\mathrm{Sr}$ & 1,11 & 1,35 & 1,00 & 1,16 & 1,83 & 0,98 & 0,84 & 1,13 \\
\hline $\mathrm{Y}$ & 1,10 & 1,11 & 1,34 & 0,88 & 1,08 & 0,86 & 1,06 & 0,78 \\
\hline $\mathrm{Yb}$ & 1,35 & 1,17 & 1,33 & 1,00 & 1,41 & 1,04 & 1,28 & 0,92 \\
\hline $\mathrm{Zr}$ & 1,22 & 1,58 & 2,17 & 1,09 & 1,03 & 0,84 & 1,37 & 0,99 \\
\hline $\mathrm{Nb}$ & 0,82 & 1,06 & 1,33 & 1,43 & 1,00 & 0,92 & 1,13 & 1,33 \\
\hline $\mathrm{Sc}$ & 1,71 & 1,07 & 1,49 & 1,50 & 1,03 & 0,82 & 1,13 & 1,21 \\
\hline
\end{tabular}

Примечание: Почвообразующие породы: I - терригенные палеозоя; II - метаморфические палеозоя; III - магматические палеозоя; IV - метаморфические протерозоя / Note: Soil-forming rocks: I-terrigenous Paleozoic; II - metamorphic Paleozoic; III-magmatic Paleozoic; IV-metamorphic Proterozoic. 


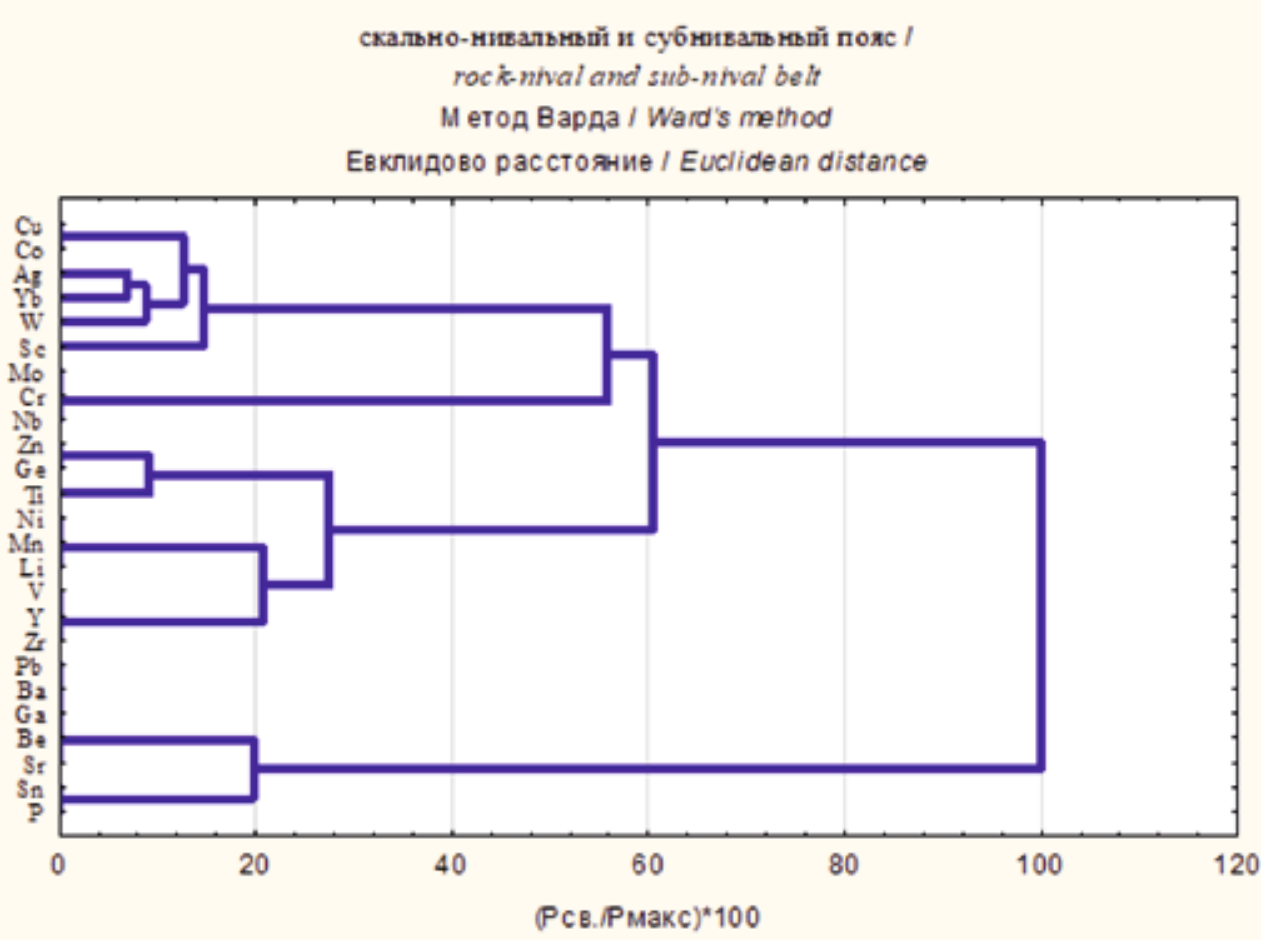

Рис. 2. Результаты кластерного анализа региональных структур миграции химических элементов в скально-нивальном и субнивальном высотном поясе Лабино-Тебердинского округа

Fig. 2. Results of cluster analysis of regional structures of migration of chemical elements in the rock-nival and subliveway high-altitude belt of the Labino-Teberda district тов: $\mathrm{Cu}, \mathrm{Co}, \mathrm{Ge}$ и $\mathrm{Zr} ; \mathrm{V}$ и $\mathrm{Li}$; Y и $\mathrm{Yb} ; \mathrm{Zn}$ и $\mathrm{Cr} ; \mathrm{Sn}$ и $\mathrm{Ga} ; \mathrm{Mo}$ и $\mathrm{W}$ (рис. 3).

Группы химических элементов с одинаковой региональной структурой миграции (рис. 4, 5) могут быть рассмотрены как биогеохимические парагенетические ассоциации элементов, участвующие в миграционных процессах между почвами и неоднородными почвообразующими породами в пространстве региональных геосистем с однотипным БИКом. Полученные данные о преобладании в высокогорной подобласти единичных биогеохимических парагенетических ассоциаций, состав которых образуют небольшие группы химических элементов (от 2 до 5), свидетельствуют о постоянном обновлении состава тельствуют о наличии нескольких таких небольших групп: $\mathrm{Cu}$ и $\mathrm{Co} ; \mathrm{Mo}, \mathrm{Cr}$ и $\mathrm{Nb} ; \mathrm{Zn}$ и $\mathrm{Ge} ; \mathrm{Ni}, \mathrm{Mn}$ и $\mathrm{Li} ; \mathrm{V}$, $\mathrm{Y}$ и $\mathrm{Zr} ; \mathrm{Sr}, \mathrm{Be}, \mathrm{Ga}, \mathrm{Ba}$ и $\mathrm{Pb}$; $\mathrm{Sn}$ и P (рис. 2). В высотном поясе высокогорных лугов одинаковая региональная структура миграции характерна для групп элемен-

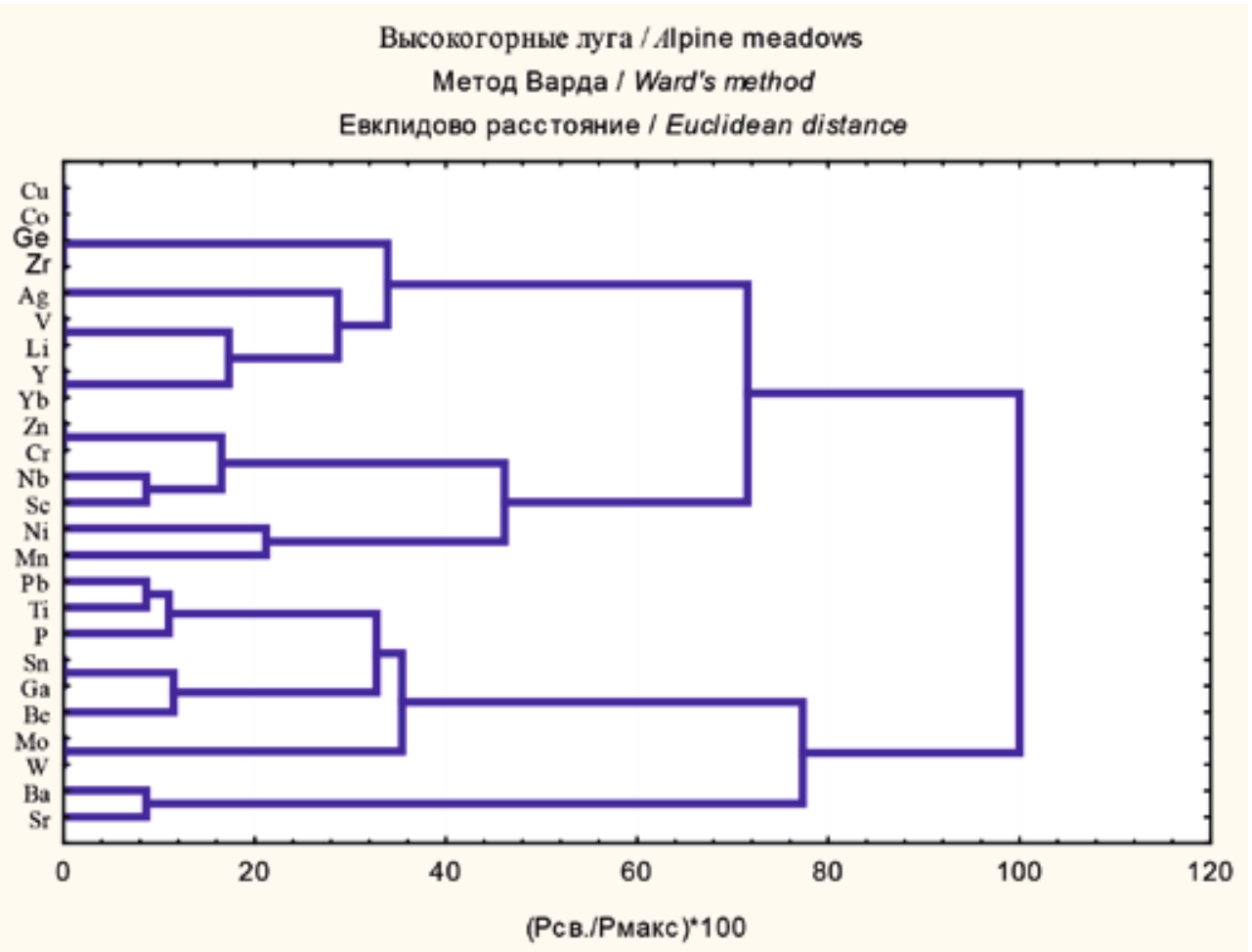

Puс. 3. Результаты кластерного анализа региональных структур миграции химических элементов в поясе высокогорных лугов Лабино-Тебердинского округа

Fig. 3. Results of cluster analysis of regional structures of migration of chemical elements in the high mountain meadow belt of the Labino-Teberda district высокогорных почв за счет сильной механической миграции и выноса вещества.

Одинаковый набор комплексов почвообразующих пород в высотных поясах ландшафтных округов физико-географических подобластей Большого Кавказа дает возможность провести сопоставление в них региональных структур миграции элементов и выявить степень их сходства. Такое сравнение позволяет говорить о ведущих факторах формирования региональных структур миграции элементов между почвами и почвообразующими породами в условиях высокогорий, среднегорий и низкогорий.

При сильном сходстве (до $90-100 \%$ ) в региональных структурах миграции элементов по разным высотным поясам с одинаковым набором комплексов почвообразующих пород, определяющую роль в радиальном перераспределении элементов между почвами и породами играет литогенный фактор. Интенсивность 


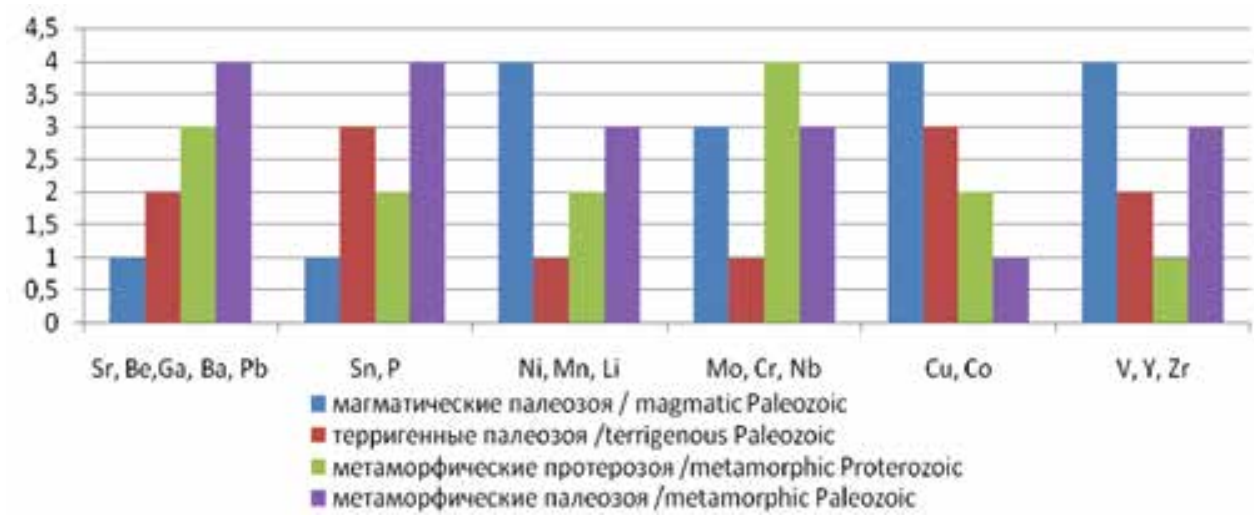

Pис. 4. Региональные структуры миграции отдельных химических элементов в скально-нивальном и субнивальном высотном поясе Лабино-Тебердинского округа

Fig. 4. Regional migration patterns of individual chemical elements in the rock-nival and sublivional high-altitude belt of the Labino-Teberda district

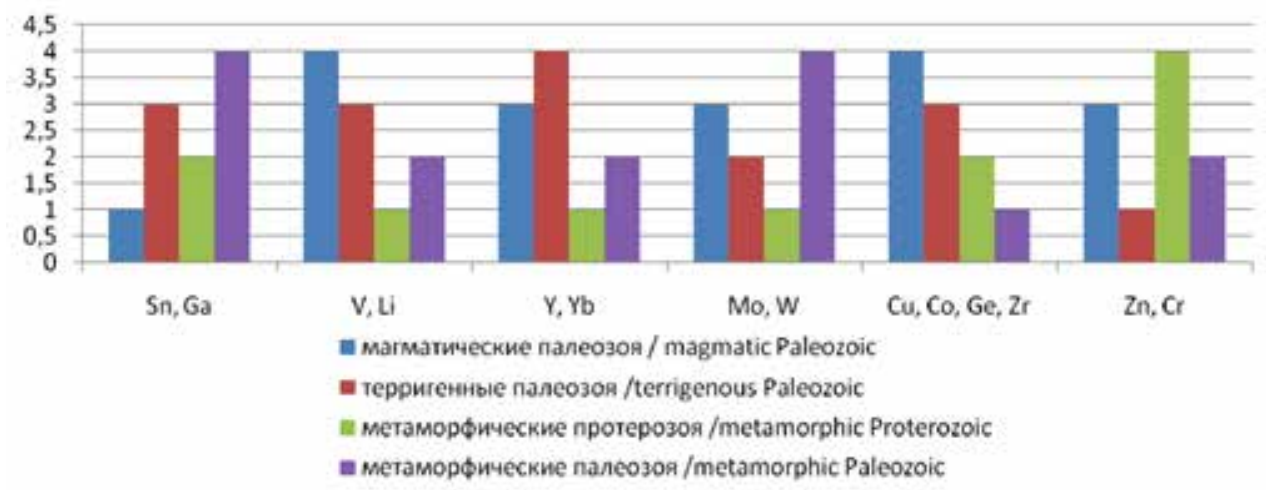

Puc. 5. Региональные структуры миграции отдельных химических элементов в поясе высокогорных лугов Лабино-Тебердинского округа

Fig. 5. Regional structures of migration of individual chemical elements in the high mountain meadow belt of the Labino-Teberda district и направленность радиальной миграции для этих химических элементов в данных физико-географических условиях высотных поясов определяется в первую очередь геохимической специализацией почвообразующих пород, особенностями трансформации минералов пород при выветривании с образованием различного соотношения прочносвязанных или подвижных соединений элементов.

Отсутствие или слабое сходство (от 0 до 10\%) с большими различиями в региональных структурах миграции химических элементов по высотным поясам с одинаковым набором комплексов почвообразующих пород свидетельствует о преобладающем влиянии биогенного фактора. В этом случае, биогеохимические процессы разных типов БИКа, протекающие при выветривании и почвообразовании в высотных геобо-

Таблица 2 / Table 2

Сопоставление региональных структур миграции химических элементов в высотных поясах ЭльбрусКазбековской высокогорной подобласти

Comparison of regional structures of migration of chemical elements in high-altitude belts of the Elbrus-Kazbek Highland Subregion

\begin{tabular}{|c|c|c|c|c|}
\hline \multirow{2}{*}{$\begin{array}{c}\text { Ландшафтный } \\
\text { округ / Landscaping }\end{array}$} & \multirow{2}{*}{$\begin{array}{c}\text { Высотные геоботанические пояса } \\
\text { High-altitude geobotanical belts }\end{array}$} & \multicolumn{3}{|c|}{$\begin{array}{c}\text { Сходство в региональных структурах миграции } \\
\text { Similarity in regional migration structures }\end{array}$} \\
\hline & & $\begin{array}{c}\text { слабое } \\
\text { small } \\
(0-10 \%)\end{array}$ & $\begin{array}{l}\text { среднее / average } \\
\quad(10-90 \%)\end{array}$ & $\begin{array}{l}\text { сильное / strong } \\
\quad(90-100 \%)\end{array}$ \\
\hline $\begin{array}{l}\text { Лабино-Тебердинский } \\
\text { (Западный Кавказ) } \\
\text { Labino-Teberdinsky } \\
\text { (Western Caucasus) }\end{array}$ & $\begin{array}{l}\text { 1) скально-нивальный и субниваль- } \\
\text { ный / rock-nival and subnival } \\
\text { 2) высокогорные луга / alpine meadows } \\
\text { 3) смешанные леса / mixed forests } \\
\text { 4) хвойные леса / coniferous forests }\end{array}$ & $\begin{array}{l}\mathrm{Zn}, \mathrm{Pb}, \mathrm{Ag} \\
\mathrm{Sr}, \mathrm{Ge}, \mathrm{Sc} \\
\mathrm{Be}, \mathrm{P}, \mathrm{Li}\end{array}$ & $\begin{array}{l}\mathrm{Sn}, \mathrm{Ni}, \mathrm{Ga}, \mathrm{Mo}, \mathrm{W} \\
\mathrm{Ba}, \mathrm{Mn}, \mathrm{Ti}, \mathrm{Cr}, \mathrm{Zr}\end{array}$ & $\begin{array}{l}\mathrm{Cu}, \mathrm{Co}, \mathrm{Y}, \mathrm{Yb} \\
\mathrm{Nb}, \mathrm{V}\end{array}$ \\
\hline $\begin{array}{l}\text { Тебердино-Эльбрус- } \\
\text { ский (Центральный } \\
\text { Кавказ) / Teberdino- } \\
\text { Elbrus (Central Cau- } \\
\text { casus) }\end{array}$ & $\begin{array}{l}\text { 1) скально-нивальный и субниваль- } \\
\text { ный / rock-nival and subnival } \\
\text { 2) высокогорные луга / alpine meadows } \\
\text { 3) смешанные леса / mixed forests } \\
\text { 4) хвойные леса / coniferous forests }\end{array}$ & $\begin{array}{l}\mathrm{Zn}, \mathrm{Pb}, \mathrm{Ag} \\
\quad \mathrm{Sr}, \mathrm{Sn}\end{array}$ & $\begin{array}{l}\text { Ni, V, Li, Ga, Be, } \\
\text { Mo, W, Ba, Mn, Ti, } \\
\quad \text { Cr, Ge, P, Sc }\end{array}$ & $\mathrm{Cu}, \mathrm{Co}, \mathrm{Y}, \mathrm{Yb}, \mathrm{Nb}$ \\
\hline $\begin{array}{l}\text { Кубано-Терский } \\
\text { (Восточный Кавказ) } \\
\text { Kuban-Tere (Eastern } \\
\text { Caucasus) }\end{array}$ & $\begin{array}{l}\text { 1) скально-нивальный и субниваль- } \\
\text { ный / rock-nival and subnival } \\
\text { 2) высокогорные луга / alpine meadows } \\
\text { 3) хвойные леса / coniferous forests }\end{array}$ & - & $\begin{array}{c}\mathrm{Zn}, \mathrm{Pb}, \mathrm{Ag}, \mathrm{Mo}, \mathrm{W} \\
\mathrm{Ba}, \mathrm{Mn}, \mathrm{Ti}, \mathrm{Cr}, \mathrm{Ge}, \mathrm{P}, \\
\mathrm{Sr}, \mathrm{Sc}\end{array}$ & $\begin{array}{l}\mathrm{Cu}, \mathrm{Co}, \mathrm{Y}, \mathrm{Yb} \\
\mathrm{Nb}, \mathrm{V}, \mathrm{Sn}, \mathrm{Ni}, \mathrm{Li} \\
\mathrm{Ga}, \mathrm{Be}\end{array}$ \\
\hline
\end{tabular}


таблица 3 / Table 3

Сопоставление региональных структур миграции химических элементов в высотных поясах среднегорных подобластей / Comparison of the regional structures of the radial migration of chemical elements in high-altitude belts of middle subregions

\begin{tabular}{|c|c|c|c|c|}
\hline \multirow{2}{*}{$\begin{array}{c}\text { Ландшафтный округ } \\
\text { Landscaping }\end{array}$} & \multirow{2}{*}{$\begin{array}{l}\text { Высотные геоботанические } \\
\text { пояса } \\
\text { High-altitude geobotanical belts }\end{array}$} & \multicolumn{3}{|c|}{$\begin{array}{l}\text { Сходство в региональных структурах мигра- } \\
\text { ции / Similarity in regional migration structures }\end{array}$} \\
\hline & & $\begin{array}{c}\text { слабое } \\
\text { small } \\
(0-10 \%)\end{array}$ & $\begin{array}{l}\text { среднее / average } \\
\quad(10-90 \%)\end{array}$ & $\begin{array}{l}\text { сильное / strong } \\
\quad(90-100 \%)\end{array}$ \\
\hline $\begin{array}{l}\text { Северогойхотский, Кубанский, } \\
\text { Западнокубанский, Лабино- } \\
\text { Малкинский (Западный Кав- } \\
\text { каз) / Severohoykhotsky, Kuban, } \\
\text { Zapadnokubansky, Labino- } \\
\text { Malkinsky (Western Caucasus) }\end{array}$ & $\begin{array}{l}\text { 1) высокогорные луга } \\
\text { alpine meadows } \\
\text { 2) смешанные леса / mixed forests } \\
\text { 3) лиственные леса } \\
\text { deciduous forests } \\
\text { 4) степи и остепненные луга } \\
\text { steppes and steppe meadows }\end{array}$ & Ag, Mo, W & $\begin{array}{c}\mathrm{Zn}, \mathrm{Pb}, \mathrm{Sr}, \\
\mathrm{Ge}, \mathrm{Sc}, \mathrm{Be}, \mathrm{P}, \mathrm{Sn}, \\
\mathrm{Ni}, \mathrm{Ga}, \mathrm{Mn}, \mathrm{Zr}, \\
\mathrm{Co}, \mathrm{Y}, \mathrm{Yb}, \mathrm{Nb}, \mathrm{V}\end{array}$ & $\mathrm{Cu}, \mathrm{Ba}, \mathrm{Ti}, \mathrm{Cr}, \mathrm{Li}$ \\
\hline $\begin{array}{l}\text { Терский и Терско-Малкинский } \\
\text { (Центральный Кавказ) / Terek } \\
\text { and Terek-Malkinsky (Central } \\
\text { Caucasus) }\end{array}$ & $\begin{array}{l}\text { 1) высокогорные луга } \\
\text { alpine meadows } \\
\text { 2) смешанные леса / mixed forests } \\
\text { 3) лиственные леса } \\
\text { deciduous forests } \\
\text { 4) степи и остепненные луга } \\
\text { steppes and steppe meadows } \\
\end{array}$ & $\mathrm{Ag}, \mathrm{Mn}, \mathrm{Sr}$ & $\begin{array}{c}\mathrm{Zn}, \mathrm{Pb}, \mathrm{Sn}, \mathrm{Ni}, \mathrm{V} \\
\mathrm{Be}, \mathrm{W}, \mathrm{Ge}, \mathrm{P}, \mathrm{Sc} \\
\mathrm{Yb}, \mathrm{Nb}\end{array}$ & $\begin{array}{l}\mathrm{Cu}, \mathrm{Ba}, \mathrm{Ti}, \mathrm{Cr} \\
\mathrm{Li}, \mathrm{Ga}, \mathrm{Mo}, \mathrm{Co}, \mathrm{Y}\end{array}$ \\
\hline $\begin{array}{l}\text { Андийско-Аварский, Суму- } \\
\text { ро-Уллучайский, Внутренний } \\
\text { Дагестан, Сулак-Самурский } \\
\text { (Восточный Кавказ) / Andean- } \\
\text { Avar, Sumuro-Uluchay, Inner } \\
\text { Dagestan, Sulak-Samur (Eastern } \\
\text { Caucasus) }\end{array}$ & $\begin{array}{l}\text { 1) высокогорные луга } \\
\text { alpine meadows } \\
\text { 2) смешанные леса / mixed forests } \\
\text { 3) лиственные леса } \\
\text { deciduous forests } \\
\text { 4) степи и остепненные луга } \\
\text { steppes and steppe meadows }\end{array}$ & - & $\begin{array}{l}\mathrm{Zn}, \mathrm{Pb}, \mathrm{Ag}, \mathrm{Mo}, \mathrm{W}, \\
\mathrm{Ba}, \mathrm{Mn}, \mathrm{Ge}, \mathrm{Sc} \mathrm{Cu}, \\
\text { Yb, Ni, Be }\end{array}$ & $\begin{array}{c}\mathrm{Sn}, \mathrm{Ti}, \mathrm{Cr}, \mathrm{Li}, \\
\mathrm{Ga}, \mathrm{Co}, \mathrm{Y}, \mathrm{V}, \mathrm{Nb}, \\
\mathrm{P}, \mathrm{Sr}\end{array}$ \\
\hline
\end{tabular}

Таблица 4 / Table 4

Сопоставление региональных структур миграции химических элементов в высотных поясах ЧерноморскоТерско-Сунженской подобласти низкогорий и предгорных равнин

Comparison of regional structures of radial migration of chemical elements in high-altitude belts of the Black Sea-Tersko-Sunzhensky subregion of lowlands and foothill plains

\begin{tabular}{|c|c|c|c|c|}
\hline \multirow{2}{*}{$\begin{array}{c}\text { Ландшафтный округ } \\
\text { Landscaping }\end{array}$} & \multirow{2}{*}{$\begin{array}{l}\text { Высотные геоботанические } \\
\text { пояса } \\
\text { High-altitude geobotanical belts }\end{array}$} & \multicolumn{3}{|c|}{$\begin{array}{c}\text { Сходство в региональных структурах миграции } \\
\text { Similarity in regional migration structures }\end{array}$} \\
\hline & & $\begin{array}{l}\text { слабое / small } \\
\quad(0-10 \%)\end{array}$ & $\begin{array}{c}\text { среднее / average } \\
(10-90 \%)\end{array}$ & $\begin{array}{l}\text { сильное strong } \\
\quad(90-100 \%)\end{array}$ \\
\hline $\begin{array}{c}\text { Западноприкубанский и При- } \\
\text { кубанский (Западный Кав- } \\
\text { каз) / West Prikubansky and } \\
\text { Prikubansky (Western Caucasus) }\end{array}$ & $\begin{array}{c}\text { 1) лиственные леса } \\
\text { deciduous forests } \\
\text { 2) степи и остепненные луга } \\
\text { steppes and steppe meadows }\end{array}$ & $\begin{array}{c}\mathrm{Cu}, \mathrm{Zn}, \mathrm{Pb}, \mathrm{Ba}, \\
\mathrm{Sn}, \mathrm{Sr}, \mathrm{Ge}, \mathrm{Be}, \mathrm{P}, \\
\mathrm{Mo}, \mathrm{W}, \mathrm{Ni}, \mathrm{Ga}, \\
\mathrm{Zr}, \mathrm{Y}, \mathrm{Nb}\end{array}$ & $\mathrm{V}, \mathrm{Cr}, \mathrm{Yb}, \mathrm{Li}$ & $\begin{array}{l}\text { Sc, } \mathrm{Ti}, \mathrm{Ag}, \mathrm{Co} \\
\mathrm{Mn}\end{array}$ \\
\hline $\begin{array}{c}\text { Терско-Малкинский и Тер- } \\
\text { ско-Кубанский (Центральный } \\
\text { Кавказ) / Terek-Malka and Terek- } \\
\text { Kuban (Central Caucasus) }\end{array}$ & $\begin{array}{c}\text { 1) лиственные леса } \\
\text { deciduous forests } \\
\text { 2) степи и остепненные луга } \\
\text { steppes and steppe meadows }\end{array}$ & $\begin{array}{l}\mathrm{Cu}, \mathrm{Zn}, \mathrm{Pb}, \mathrm{Ag} \\
\mathrm{Mn}, \mathrm{Ba}, \mathrm{Sn}, \mathrm{W} \\
\quad \mathrm{Ni}, \mathrm{P}, \mathrm{Nb}\end{array}$ & $\begin{array}{l}\mathrm{Be}, \mathrm{Yb}, \mathrm{Ti}, \mathrm{Ga}, \\
\mathrm{Y}, \mathrm{Sr}\end{array}$ & $\begin{array}{l}\mathrm{Sc}, \mathrm{Cr}, \mathrm{Ge}, \mathrm{Li} \\
\mathrm{Mo}, \mathrm{Co}, \mathrm{V}\end{array}$ \\
\hline $\begin{array}{c}\text { Терско-Сулакский (Восточный } \\
\text { Кавказ) / Terek-Sulak (Eastern } \\
\text { Caucasus) }\end{array}$ & $\begin{array}{c}\text { 1) лиственные леса } \\
\text { deciduous forests } \\
\text { 2) степи и остепненные луга } \\
\text { steppes and steppe meadows }\end{array}$ & $\begin{array}{l}\mathrm{Cu}, \mathrm{Zn}, \mathrm{Ag}, \mathrm{Mn} \\
\mathrm{Ba}, \mathrm{Sn}, \mathrm{W}, \mathrm{Ni} \\
\mathrm{P}, \mathrm{Nb}, \mathrm{Li}, \mathrm{Mo} \\
\mathrm{Co}, \mathrm{V}\end{array}$ & $\begin{array}{l}\mathrm{Be}, \mathrm{Yb}, \mathrm{Ti}, \mathrm{Ga}, \\
\quad \mathrm{Y}, \mathrm{Sr}\end{array}$ & $\mathrm{Sc}, \mathrm{Cr}, \mathrm{Pb}, \mathrm{Ge}$ \\
\hline $\begin{array}{c}\text { Сулакско-Прикаспийский (Вос- } \\
\text { точный Кавказ) / Sulak-Caspian } \\
\text { (Eastern Caucasus) }\end{array}$ & $\begin{array}{c}\text { 1) лиственные леса } \\
\text { deciduous forests } \\
\text { 2) степи и остепненные луга } \\
\text { steppes and steppe meadows }\end{array}$ & $\begin{array}{l}\mathrm{Zn}, \mathrm{W}, \mathrm{Ba}, \mathrm{Mn}, \\
\mathrm{Ge}, \mathrm{Cu}, \mathrm{Yb}, \mathrm{Ni} \\
\mathrm{Sn}, \mathrm{Ti}, \mathrm{Li}, \mathrm{Ga} \\
\mathrm{Co}, \mathrm{Y}, \mathrm{Nb}, \mathrm{P}, \mathrm{Sr}\end{array}$ & Ag, V & $\mathrm{Sc}, \mathrm{Cr}, \mathrm{Pb}, \mathrm{Mo}$ \\
\hline
\end{tabular}


танических поясах, приводят к отличиям в структуре миграции химических элементов между почвами и неоднородными почвообразующими породами.

В Эльбрус-Казбековской высокогорной подобласти элементов со слабым сходством в своих региональных структурах миграции между почвами и породами больше всего в высотных поясах ландшафтных округов Западного Кавказа (табл. 2). В то же время, в высотных поясах ландшафтных округов Восточного Кавказа химических элементов с разными структурами миграции нет, а преобладают элементы с близкими или одинаковыми региональными структурами миграции между почвами и породами.

В среднегорных физико-географических подобластях (Североюрско-Дагестанской и Кубано-Дагестанской) в ландшафтных округах Восточного Кавказа также наблюдается увеличение количества химических элементов с сильным сходством в региональных структурах миграции между почвой и неоднородными породами и отсутствие в них химических элементов со слабым сходством, т.е. разными структурами радиального перераспределения (табл. 3).

В Черноморско-Терско-Сунженской подобласти низкогорий и предгорных равнин характерно преобладание химических элементов со слабым сходством в региональных структурах миграции между почвами и породами в высотных поясах ландшафтных округов Западного, Центрального и Восточного Кавказа (табл. 4). В то же время отмечается некоторое увеличение количества химических элементов с сильным сходством в структурах миграции в высотных поясах ландшафтных округов Центрального Кавказа.

\section{Заключение}

Изучение особенностей радиальной дифференциации химических элементов в высотных геоботанических поясах ландшафтных округов физико-географических подобластей Большого Кавказа показало, что в их пределах каждому химическому элементу свойственна своя региональная структура миграции. Она представляет определенную последовательность в изменении интенсивности радиальной миграции химического элемента между почвой и гетерогенными почвообразующими породами в геосистемах с однотипным биологическим круговоротом. Разная интенсивность радиальной миграции химического элемента тесно связана с количеством его подвижных и прочносвязанных соединений, образование которых происходит в породах и почвах в ходе длительных сложных процессов выветривания горных пород и почвообразования. В качестве временного периода формирования региональной структуры миграции химического элемента принимается период образования современных почв.

Единому экологическому пространству высотного пояса присущ однотипный характер комплекса факторов, влияющих на региональную структуру миграции химических элементов $[19 ; 20]$. Для высотных поясов характерны единство гидротермических условий, однотипность БИКа вследствие господства одной растительности, единый характер почвообразовательных процессов, относительная близость геоморфологических условий. Гетерогенный характер структуре миграции химических элементов придают неоднородные почвообразующие породы. Влияние латеральных потоков вещества на радиальную миграцию химических элементов в пределах высотного пояса сведено к минимуму.

В ходе миграционных процессов между почвами и неоднородными почвообразующими породами в высотных поясах складываются парагенетические ассоциации химических элементов с одинаковой региональной структурой миграции. В высокогорной подобласти преобладают единичные парагенетические ассоциации, состав которых образуют небольшие группы химических элементов, что свидетельствует о постоянном обновлении микроэлементного состава высокогорных почв за счет выноса вещества.

Сравнение региональных структур миграции химических элементов на основе имеющихся данных по высотным поясам всех ландшафтных округов высокогорной, среднегорной и низкогорной физико-географических подобластей северных склонов Большого Кавказа позволило сделать следующие выводы:

1. В условиях высокогорий, среднегорий и низкогорий северных склонов Большого Кавказа меняются ведущие факторы формирования региональных структур миграции химических элементов между почвами и почвообразующими породами.

2. В высокогорной и среднегорной подобластях, при движении от Западного к Восточному Кавказу, при формировании региональных структур миграции химических элементов уменьшается влияние биогенного фактора и усиливается роль литогенного фактора. Для высоко- и среднегорных геосистем Западного Кавказа, в связи с их большей увлажненностью и большим количеством поступающей фитомассы в биологический круговорот, свойственна более сильная интенсивность биогеохимических процессов в почвах и почвообразующих породах. В высокогорьях и среднегорьях Восточного Кавказа влияние биогеохимических процессов на радиальную миграцию элементов ослабляется в силу континентальности климата с меньшим количеством осадков, а также меньшей емкости биологического круговорота в связи с понижением продуктивности биоценозов [17;21].

3. Во всей подобласти низкогорий и предгорных равнин (по Западному, Центральному и Восточному Кавказу) в формировании региональных структур 
миграции между почвами и почвообразующими породами для большинства химических элементов основное значение имеет биогенный фактор.

Выявленные особенности радиального перераспределения химических элементов в геосистемах
Северного Кавказа в какой-то мере раскрывают механизмы формирования геохимической и миграционной структур горных ландшафтов, в значительной степени обеспечивающих их устойчивость к различного рода воздействиям.

\section{$\overline{\text { КРИТЕРИИ АВТОРСТВА / }}$ Contribution}

Дегтярева Т.В. - в значительной степени участвовала в написании работы, в ее концепции, в научном дизайне, в анализе и интерпретации материала; Лиховид А. А. - корректировал рукопись до подачи в редакцию; Лысенко А.В. и Караев Ю.И. - несут ответственность при обнаружении плагиата или других неэтических проблем.

Degtyareva T.V. - largely co-wrote the work in its concepts, scientific design, analysis and interpretation of material; A.A. Lihovid - corrected the manuscript before submission to the editor; Lysenko A.V. and Karaev Y.I. - are responsible for detecting plagiarism or other unethical problems.

КОНФЛИКТ ИНТЕРЕСОВ / Conflict of interest

Авторы заявляют об отсутствии конфликта интересов / The authors declare no conflict of interest.

\section{$\overline{Л И Т Е Р А Т У Р А: ~}$}

1. Современные методы географических исследований / К. Н. Дьяконов, Н. С. Касимов, В. С. Тикунов. Москва: Просвещение. 1996.

2. Геохимия ландшафтов и география почв. 100 лет со дня рождения М.А.Глазовской / Под ред. Н.С.Касимова, М.И.Герасимовой. М.: АПР. 2012. 600 с.

3. Fractional and group composition of zinc and lead compounds as an indicator of the environmental status of soils / S. S. Mandzhieva, T. M. Minkina, G. V. Motuzova et al. // Eurasian Soil Science. 2014. Vol. 47, no. 5. Pp. 511518. DOI: $10.1134 / \mathrm{S} 1064229314050159$.

4. Roudposhti, G. M., Karbassi, A., \& Baghvand, A. (2016). A pollution index for agricultural soils. Archives of Agronomy and Soil Science, 62(10), 1411-1424. DOI: 10.1080/03650340.2016.1154542.

5. Adriano D.C. Trace elements in terrestrial environments. Springer-Verlag, New York, Berlin, Heidelberg. 2001. 867 p.

6. Minkina T.M., Motusova G.V., Nazarenko O.G., Mandzhieva S.S. (2010) Heavy Metal Compounds in Soil: Transformation upon Soil Pollution and Ecological Significance, Nova Science Publishers, Inc., $188 \mathrm{p}$.

7. Чижикова Н.П., Хитров Н.Б., Самсонова А.А. и др. Минералы трехкомпонентной пятнистости агрочерноземов Каменной степи // Почвоведение. 2017. N 4. C. $468-482$. DOI: $10.7868 / \mathrm{S} 0032180 \mathrm{X} 17020022$

8. Чижикова Н.П., Сорокина Н.П., Хитров Н.Б., Самсонова А.А. Глинистые минералы в денудационно-аккумулятивной почвенной комбинации // Почвоведение. 2010. N 1. С. 97-105.

9. Scarciglia, F., Critelli, S., Borrelli, L., Coniglio, S., Muto, F., \&Perri, F. (2016). Weathering profiles in granitoid rocks of the sila massif uplands, calabria, southern italy: New

insights into their formation processes and rates. Sedimentary Geology, 336, 46-67. DOI:10.1016 j.sedgeo.2016.01.015

10. Дегтярева Т.В., Шальнев В.А., Лысенко А.В. Геохимические поля горных пород и почв Большого Кавказа: эволюционный подход и методы исследования // Устойчивое развитие горных территорий. 2017. Т.9. N 3 (33). C. 219-232. DOI: 10.21177/1998-4502-2017-9-3-219-232.

11. Глазовская М. А. Денудационно-аккумулятивные структуры почвенного покрова как формы проявления педолитогенеза // Почвоведение. 2000. N 2. С. 134-134.

12. Пузанова Т.А., Исаченкова Л.Б., Богданова М.Д. и др. Педолитогенез: его роль в формировании вещественного состава континентальных отложений и геохимических циклах элементов-органогенов // Информационный бюллетень РФФИ. 1999. Т. 7, N 5. С. 360-360.

13. Добровольский В.В. Основы биогеохимии. М.: Издательский центр «Академия». 2003. 400 с.

14. Мотузова Г.В. Соединения микроэлементов в почвах: системная организация, экологическое значение, мониторинг. Москва: Книжный дом «Либроком», 2009. 168 с.

15. Минкина Т.М., Солдатов А.В., Невидомская Д.Г., Мотузова Г.В., Подковырина Ю.С. Новые подходы в изучении соединений тяжелых металлов в почвах с применением рентгеноспектрального анализа и экстракционного фракционирования // Геохимия. 2016. N 2. С. 212-219. DOI: $10.7868 / \mathrm{S} 0016752515120067$.

16. Шальнев В.А. Эволюция ландшафтов Северного Кавказа. Ставрополь: СГУ. 2007. 309 С.

17. Дьяченко В.В. Геохимия, систематика и оценка состояния ландшафтов Северного Кавказа. Ростов-на-Дону: КомплекС. 2004. 268 c. 
18. Дьяченко В.В., Матасова И.Ю. Региональные кларки химических элементов в почвах европейской части юга России // Почвоведение. 2016. N 10. С.11591166. DOI: $10.7868 / \mathrm{S} 0032180 \mathrm{X} 16100063$.

19. Богатырев Л.Г. Основные концепции, законы и принципы современного почвоведения. М.: МАКС Пресс,. 2015. $196 \mathrm{c}$.
20. Богатырев Л.Г., Воронина М.М., Тюлюбаева И.И. О едином экологическом пространстве // Проблемы агрохимии и экологии. 2010. N 2. С. 55-60.

21. Братков В.В., Салпагаров Д.С. Ландшафты Северо-Западного и Северо-Восточного Кавказа. М.: Илекса. 2001. $256 \mathrm{c}$.

\section{СВЕДЕНИЯ ОБ АВТОРЕ / Information about author:}

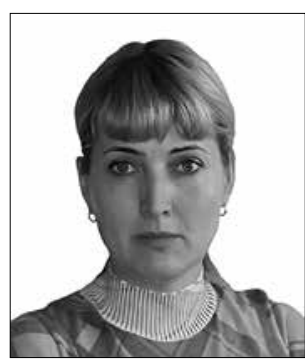

ДЕГТЯРЕВА Татьяна Васильевна - кандидат географических наук, доцент кафедры физической географии и кадастров, Институт математики и естественных наук Северо-Кавказского федерального университета, 355009, г. Ставрополь, Россия.

Тел.: 8(919)731-84-98.

E-mail: dtb.70@mail.ru

Tatyana V. DEGTYAREVA - Candidate of Geographical Sciences, associate professor of the Department of physical geography and cadastres, Institute of mathematics and natural sciences of the North Caucasus Federal University, 355009, Stavropol, Russia

Ph.:+7 (919)731-84-98, e-mail: dtb.70@mail.ru

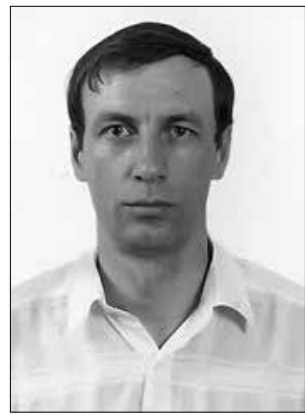

ЛЫСЕНКО Алексей Владимирович - доктор географических наук, профессор кафедры физической географии и кадастров, Институт математики и естественных наук Северо-Кавказского федерального университета, 355009, г. Ставрополь, Россия.

Тел.: 8(905)448-18-74.

E-mail: lysenkostav@yandex.ru

Alexey VI. LYSENKO - Dr. of Geographical Sciences, professor of the Department of physical geography and cadastres, Institute of mathematics and natural sciences of the North Caucasus Federal University, 355009, Stavropol, Russia

Ph.:+7 (905)448-18-74.E-mail: lysenkostav@yandex.ru

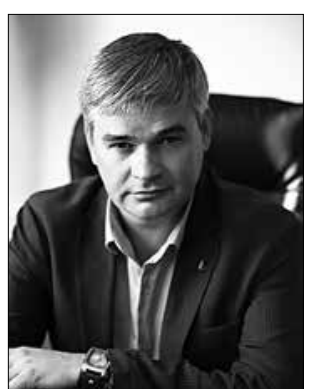

ЛИХОВИД Андрей Александрович - доктор географических наук, кандидат биологических наук, профессор кафедры экологии и природопользования, Институт математики и естественных наук СевероКавказского федерального университета, 355009, г. Ставрополь, Россия.

Тел.: 8(8652) 95-64-87.

E-mail: alikhovid@ncfu.ru

Andrey Al. LIKHOVID - Dr. of Geographical Sciences, Candidate of Biological Sciences, professor of the Department of ecology and nature management, Institute of mathematics and natural sciences of the North Caucasus Federal University, 355009, Stavropol, Russia

Ph.: +7 (8652) 95-64-87; E-mail: alikhovid@ncfu.ru

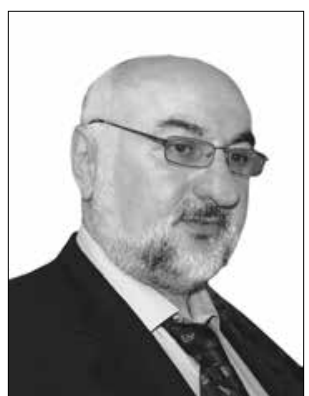

КАРАЕВ Юрий Исаевич - директор Международного инновационного научно-технологического центра «Устойчивое развитие горных территорий» (МИНТЦ «Горы») Северо-Кавказского горно-металлургического института (государственного технологического университета), 362021, Владикавказ, Россия.

Yuri I. KARAEV - Director of the International Innovation Scientific and Technological Center "Sustainable Development of Mountain Areas" (IISTC "Mountains") of the North Caucasian Institute of Mining and Metallurgy (State Technological University), 362021, Vladikavkaz, Russia. 


\title{
REGIONAL PATTERNS OF CHEMICAL ELEMENTS MIGRATION IN THE LANDSCAPES OF THE NORTH CAUCASUS
}

\author{
${ }^{1}$ T. V. Degtyareva,* \\ ${ }^{1}$ A. A. Lichowid, \\ ${ }^{1}$ A. V. Lysenko, \\ ${ }^{2}$ Yu. Karaev \\ ${ }^{1}$ North Caucasus Federal University, 355009, Stavropol, Russia, dtb.70@mail.ru \\ ${ }^{2}$ North-Caucasian Institute of Mining and Metallurgy (State Technological University), 362021, Vladikavkaz, Russia
}

DOI: $10.21177 / 1998-4502-2018-10-4-481-492$

The purpose of the study is to identify the peculiarities of chemical elements migration in the system "soil - soil-forming rocks" in the regional geo - systems of the North Caucasus with the one type biological cycle and heterogeneous soilforming rocks. As the regional geo - systems are high-altitude geo - botanical zones of high-mountain, mid-mountain and low-mountain physical and geographical sub domains landscape of the northern slopes of the greater Caucasus.

Research methods: The object of study is the regional structure of chemical elements migration which are considered on the example of two high-altitude zones of Labino-Teberda landscape district allocated in the Western Caucasus within the Elbrus-Kazbek Alpine sub domain. To determine the intensity of chemical elements migration in the high-altitude zones, the coefficient of radial differentiation $\mathrm{R}$, reflecting the genetic relationship of the soil with the soil-forming rock was used. The allocation of par genetic associations of chemical elements with the same regional structures of migration between the soil and heterogeneous soil-forming rocks within the boundaries of the high-altitude zones of the LabinoTeberdinsky district was performed by the cluster analysis. On the basis of the available data on high-altitude zones of all landscape districts of the mountainous, mid-mountainous and low-mountainous sub domains of the northern slopes of the greater Caucasus, a comparison of the regional structures of chemical elements migration was carried out.

Research results: In geo - systems of the regional level with the same type of biological cycle and non-uniform soilforming rocks the regional structure of chemical elements migration are formed. They represent a certain sequence in changing the element migration intensity between the soil and heterogeneous rocks within the boundaries of the highaltitude zone. Different intensity of radial migration depends on the number of mobile and strongly bound compounds of the chemical elements. Their formation occurs in the rocks and soils during the long course of complex processes of rocks weathering and soil formation with a complex combination of factors of internal and external chemical elements migration.

Conclusions. In geo - systems with the same type of biological cycle and heterogeneous soil-forming rocks within the physical and geographical sub domains of the northern slopes of the greater Caucasus, the peculiarities of regional structures formation of chemical elements migration have been developed.

In the mountainous and mid-mountainous sub-regions, moving from the Western to the Eastern Caucasus during the formation of regional structures of chemical elements migration, the role of the biogenic factor is weakening and the influence of the lithogenic factor is increasing.

All over the low mountains and foothill plains sub-regions (in the Western, Central and Eastern Caucasus), the biogenic factor is of primary importance for the majority of chemical elements in the formation of the regional migration structures.

Keywords: North Caucasus, soil-forming rocks, biological cycle, chemical elements migration.

\section{References}

1. Modern methods of geographical research / KN. Deacons, N. S. Kasimov, V. S. Tikunov. Moscow, Education, 1996.

2. Geochemistry of landscapes and soil geography. 100 years since the birth of M. A. Glazovskaya / under the red.N.S.Kasimova, M. I. Gerasimova. Moscow, APR, 2012, $600 \mathrm{p}$.

3. Fractional and group composition of zinc and lead compounds as an indicator of the environmental status of soils / S. S. Mandzhieva, T. M. Minkina, G. V. Motuzova et al. Eurasian Soil Science, 2014, vol. 47, no 5, pp. 511-518. DOI: $10.1134 / \mathrm{S} 1064229314050159$.

4. Roudposhti G. M., Karbassi, A., Baghvand, A. (2016). A pollution index for agricultural soils. Archives of Agronomy and Soil Science, 62(10), 1411-1424. DOI: 10.1080/03650340.2016.1154542.

5. Adriano D.C. Trace elements in terrestrial environments. Springer-Verlag, New York, Berlin, Heidelberg, 2001, 867 p.

6. Minkina T.M., Motusova G.V., Nazarenko O.G., Mandzhieva S.S. (2010) Heavy Metal Compounds in Soil: Transformation upon Soil Pollution and Ecological Significance, Nova Science Publishers, Inc., 188 p.

7. Chizhikova N. P. Khitrov N. B. Samsonova A. A. and others. Minerals of three-component agronomic steppe spotting. Soil science, 2017, no. 4, pp. 468-482. DOI: 10.7868/ S0032180X17020022

8. Chizhikova N. P., Sorokina N. P., Khitrov N. B., Samsonova A. Clay minerals in the denudation-accumulative soil combination. Soil science, 2010, no 1, pp. 97- 105.

9. Scarciglia F., Critelli S., Borrelli L., Coniglio S., Muto F., Perri F. (2016). Weathering profiles in granitoid rocks of the sila massif uplands, calabria, southern Italy: New insights into their formation processes and rates. Sedimentary Geology, 336, 46-67. DOI:10.1016 j.sedgeo.2016.01.015

10. Degtyareva T. V., Shal'nev V., Lysenko V., Geochemical fields of rocks and soils of the greater Caucasus: evolutionary approach and methods of research . Sustainable development of mountain territories, 2017, T. 9, no3 (33), pp. 219-232. DOI: 10.21177 / 1998-4502-2017-9-3-219-232. 
11. Glazovskaya M. A. Denudation-accumulative soil cover structure as a form of manifestation of politogeneza. Soil science, 2000, no2, pp. 134-134.

12. Puzanova T. A., Isachenkova L. B., Bogdanova M. D., etc. Politogeneza: its role in the formation of the material composition of continental sediments and the geochemical cycles of elements organogenous. Newsletter of Russian Foundation for basic research, 1999, vol. 7, no 5, pp. 360-360.

13. Dobrovolsky V. V. Fundamentals of biogeochemistry. Moscow, Publishing center "Academy", 2003, 400 p.

14. Motuzova G. V. Compounds of microelements in soils: system organization, ecological value, monitoring. Moscow, Book house "Librokom", 2009, 168 p.

15. Minkina T. M., Soldatov A. V., Nevedomskaya D. G., Motuzova G. V., Podkovyrin Yu. S. New approaches in the study of heavy metal compounds in soils with the application of x-ray analysis and extraction fractionation. Geochemistry, 2016, no 2, pp. 212-219. DOI: 10.7868 / S0016752515120067.
16. Shalnev V. A. Evolution of landscapes of the North Caucasus. Stavropol, SSU, 2007, 309 p.

17. Dyachenko V. V. Geochemistry, systematics and assessment of the landscapes of the North Caucasus. Rostov-ondon, Complex, 2004, $268 \mathrm{p}$.

18. Dyachenko V. V., Matasova I. Regional Clarks of chemical elements in soils of the European South of Russia. Soil science, 2016, no10, pp. 1159-1166. DOI: 10.7868 / S0032180X16100063.

19. Bogatyrev L. G. Basic concepts, laws and principles of modern soil science. Moscow, MAKS Press, 2015,196 p.

20. Bogatyrev L. G., Voronina M. M., I. I. Tuleubaeva On a single environmental space. Problems of Agrochemistry and Ecology, 2010, no2, pp. 55-60.

21. Bratkov V. V., Salpagarov D. S. Landscapes of the North-Western and North-Eastern Caucasus. Moscow, Ilex, 2001, 256 p.

Article received 24.10.2018. 


\section{СПОСОБ ПОЛУЧЕНИЯ ОРГАНИЧЕСКОГО УДОБРЕНИЯ ИЗ ОТХОДОВ ПОЛЕВОДСТВА ДЛЯ ПОДДЕРЖАНИЯ ПОЧВЕННОГО ПЛОДОРОДИЯ}

\section{Введение}

Ростовская область почти полностью расположена в районах черноземных почв, для которых характерны два подтипа: чернозем южный и предкавказский или приазовский. Провинция подтипа чернозема предкавказского лежит в южной части области в условиях более теплого и мягкого климата.

Предкавказские черноземы залегают от Азовского моря вплоть до горных территорий Кавказа. Этот подтип черноземов обладает развитым перегнойным горизонтом с мощностью 1,5-1,8 м, высоким содержанием органических веществ, уровнем перегноя 4-6 \% и высокой производительностью [1-3].

Сохранение земельных ресурсов является экологической задачей мирового масштаба для устойчивого развития сельскохозяйственного производства и полеводства в частности. По мере увеличения населения Земли все более важным становится сохранение плодородия почвы для производства сельскохозяйственной продукции.

Активное использование земель под пашню имеет множество последствий. Это изменение гумусного состава, направленности и активности биогеохимических циклов различных биофильных элементов, изменение водного режима, плотности и структуры почв [4; 5].

Как бы ни были богаты черноземы перегноем, но их органическое вещество разрушается, снижается и их производительность. Гумусовое состояние почв обращает на себя внимание в отношении деградационной дегумификации черноземов.

Причины потерь гумуса пахотными почвами следующие:

1. Снижение количества поступающих в почву растительных остатков при переходе естественного агроценоза в агроценоз.

2. Усиление минерализации органических веществ из-за интенсивной обработки почвы и повышения степени ее аэрации.

3. Деградация гумуса в результате применения кислых удобрений и как следствие активация почвенной микрофлоры.

4. Усиление минерализации из-за процессов осушения или орошения.

5. Ветровая и водная эрозия почв.

Нарушение равновесия почвенного плодородия происходит в связи с сокращением притока органических веществ с корневыми и пожнивными остатками культурных растений. Вследствие уборки урожая со сконцентрированнными в нем органическими и минеральными веществами организмы почвообразователи не получают достаточного материала для разложения, минерализации и удовлетворения своих потребностей в веществе и энергии. Это в свою очередь ведет к нежелательному изменению состава почвенной микрофлоры, размножению вредителей.

За последние десятилетия плодородие почв Ростовской области снизилось почти на $15 \%$. До 3,09 \% уменьшилось содержание гумуса, тогда как критическим считается $3,5 \%$. На восстановление всего одного процента данной самой важной части для питания растений почвы требуется более ста лет. Часть ее, разрушенная в настоящее время, может быть навсегда утрачена для последующих поколений [6].

Повышение и поддержание почвенного плодородия - одна из сложных и важных задач, особенно в условиях дороговизны минеральных удобрений, го-

\footnotetext{
${ }^{1}$ Донской государственный технический университет, 344000, г. Ростов-на-Дону, Россия,
}

valeriakireeva@gmail.com
${ }^{1}$ Киреева В.В., *

${ }^{1}$ Рассказова Т.Г., ${ }^{1}$ Сербулова Н.М.

УДК: 636.085.7:036.94 DOI: 10.21177/1998-4502-201810-4-493-499

Цель работы- изучение возможности приготовления жидкого органического удобрения из отходов переработки листостебельной массы люцерны и его влияния на поддержание плодородия почвы черноземов предкавказских. Установлено, что коричневый сок из зеленой массы люцерны содержит существенное количество азота, зольных элементов, фосфора, кальция, калия и других соединений, необходимых для их восполнения в почве и полноценного питания выращиваемых на ней растений. При внесении удобрения под люцерну урожайность зеленой массы за 3 укоса возрастала по сравнению с контрольным участком.

КЛЮЧЕВЫЕ СЛОВА: почвенное плодородие, листостебельная масса растений, органические удобрения

Статья поступила в редакцию 15.04.2018. 
рюче-смазочных материалов, недостаточного использования органических удобрений.

Истощение почвы может быть предотвращено правильной структурой севооборота, внесения удобрений, введения культур многолетних трав, проведения дезинфекции почвы и совокупности организационных и агротехнических мер сельскохозяйственного производства.

Дегумификация ведет к снижению урожаев и, в итоге, к выводу земель из категории сельскохозяйственного использования [7; 8]. Чтобы компенсировать потери гумуса вследствие процессов минерализации (разложения), для улучшения питания возделываемых культур, защиты от фитопатогенных микроорганизмов, снижения потерь сельхозпродукции необходимо вносить в почву органические вещества в составе органических удобрений. В качестве таковых в почву вносят торф, сидераты - зеленые удобрения, навоз, птичий помет, сапропель (озерный ил), компосты, нетрадиционные органические удобрения (отходы деревообработки, коммунально-бытовые отходы, осадки сточных вод). В настоящее время разработаны различные способы получения удобрений из отходов, образующихся при переработке пищевых и сельскохозяйственных производств.

Органическим веществам биологического происхождения принадлежит особая роль. Среди них - белки, жиры, дубильные вещества, воски, смолы, ферменты, фенолы. Особое значение имеют углеводы. Это моносахариды, дисахариды, целлюлоза, гемицеллюлоза, пектиновые вещества. Большая часть углеводов приходится на долю целлюлозы. Основная ее часть поступает с древесными остатками, где ее содержание составляет 50-60\%, в листьях и траве - порядка 30 \%. В почве эти соединения подвергаются окислению, ферментативному гидролизу [9; 10].

Углеводы выполняют в почве специфические функции:

-формирование структуры почвы путем образования водопрочных агрегатов за счет клеящей способности микробной слизи, обусловленной углеводами;

-образование органоминеральных золей, усиление выветривания минералов за счет образования хелатных комплексов;

-участие в ионообменных процессах, влияющих на поглотительную способность почвы;

-влияние на корневое питание растений путем прямого поступления (моносахаридов) и, косвенно, через образование вторичных соединений (полисахаридов);

-ускорение микробиологической трансформации веществ гумуса при наличии углеводов как источника углерода и энергии.

Белки и свободные аминокислоты - главные компоненты органических веществ почвы, которые содержат азот и фосфор [11]. Содержание белков в биомассе различно: в древесине оно составляет менее $1 \%$, траве 5-10\%, тканях грибов $-10-50 \%$, бактериях $-40-80 \%$.
Роль аминокислот в почвах состоит в том, что они служат структурными единицами в синтезе белка, регулятором ферментативных реакций, субстратом для эндогенного дыхания. Особенность аминокислотного состава почв состоит в корреляции с запасами азота и гумуса. Аминокислоты являются важным звеном в системе питания растений, создают условия для развития почвообразовательных процессов и возделывании сельскохозяйственных культур растений [11].

Состав тканей растений включает около 80 химических элементов. Наиболее необходимыми для жизни растений являются 16 элементов: углерод, кислород, азот, фосфор, водород, калий, кальций, магний, желе3о, сера, бор, марганец, молибден, медь, цинк, кобальт. Углерод, кислород, водород и азот являются органогенами, так как при сжигании растений они переходят в газообразное состояние и улетучиваются в воздух [12; 13]. Остальные питательные элементы относятся к зольным. В среднем сухое вещество растений содержит, \%: 45 - углерода, 42 - кислорода, 6,5 - водорода, 1,5 - азота и 5 - золы.

Содержание золы в растительных остатках составляет: около $1 \%$ - в древесных; $10 \%$ - в травах.

Органические удобрения способствуют повышению стабилизации плодородия почв, являются основным энергетическим веществом в составе почвы. При трансформации органических веществ происходят не только процессы минерализации, но и гумификации, ведущие к повышению количества гумуса, запасов азота, макро- и микроэлементов, которые входят в состав всех органических удобрений.

В отличие от минеральных удобрений, органические освобождают в почве питательные вещества постепенно, не повышая концентрацию солей в почвенном растворе, в частности нитратов. Улучшаются физико-химические свойства почвы, водный и воздушный режимы, снижается вредное действие кислотности на рост растений, повышаются поглотительная способность, влагоемкость, буферность, водопроницаемость. Органические удобрения способствуют обогащению почвы микрофлорой, усиливают биологическую активность, выделение углекислоты, снижают сопротивление почвы при обработке, создают оптимальные условия для минерального корневого питания растений. Их внесение в почву улучшает ее фитосанитарное состояние [14].

Плодородие - более широкое понятие, чем агрохимическая характеристика почв и фитосанитарное состояние. Оно включает не только наличие ресурсов, необходимых растению на вегетационный период, но и доступность их для питания растений. При этом уровень почвенного плодородия зависит не от общего содержания гумуса, а от количества его лабильной части, определяющей питание растений, биологические и агрофизические свойства почв $[4 ; 15 ; 16]$.

Существующий в настоящее время дефицит белка 
в кормах для сельскохозяйственных животных определяет необходимость комплексного использования растительных ресурсов, при котором все продукты фракционирования, в том числе образующиеся отходы должны использоваться с максимальной эффективностью.

Исследователями ДГТУ разработана технология комплексной переработки вегетативной массы сельскохозяйственных сеяных бобовых трав с получением кормов для животных. При этом получают кормовой протеиновый зеленый концентрат и пресс-остаток [17]. Пресс-остаток после измельчения на мельницах центробежного [18] или другого типа можно использовать для приготовления травяной муки.

Образующаяся жидкая фракция - депротеинизированный коричневый сок (КС) - является отходом производства и не находит применения. Отчасти его пытаются использовать как добавку в корм животным - в гуменные корма, в качестве сырья для выращивания микроорганизмов. Но обычно он сливается в канализацию и заболачивает ее стоки.

Возможный путь использования коричневого сока - вернуть его снова на поля, с которых были убраны сельскохозяйственные культуры.

При переработке фитомассы по разработанной технологии [17] выход зеленого клеточного сока составляет 55-60 \% от исходной листостебельной массы, а выход депротеинизированного коричневого сока - 90$95 \%$ от количества зеленого сока. При средней урожайности зеленой массы люцерны 550-600 ц/га сбор коричневого сока составляет 270-340 ц/га.

Содержание в коричневом соке хорошо усваиваемых веществ - азотистых соединений, углеводов, минеральных элементов - определяет возможность использования данного отхода как сырья для приготовления жидкого органического удобрения и внесения его в почву для предотвращения истощения плодородия и возврата элементов питания, удаленных с урожаем сельскохозяйственных растений.

В этой связи представлялась актуальной разработка способа приготовления жидкого органического удобрения из отходов переработки вегетативной массы кормовых бобовых трав и внесения их в почву после уборки растений на зеленый корм.

Цель работы состояла в изучении возможности приготовления жидкого органического удобрения из отходов переработки листостебельной массы люцерны и его влияния на поддержание плодородия почвы чернозема предкавказского.

\section{Материал и методы исследований}

Для получения органического удобрения в экспериментах использовалась фитомасса возделываемой на зеленый корм люцерны посевной сорта Манычская, скощенной в фазе бутонизации - начале цветения, когда содержание питательных веществ в ней наибольшее.
Переработка листостебельной массы проводилась по технологии влажного фракционирования [17], которая состоит в дезинтеграции и фракционировании вегетативной листостебельной массы сеяных бобовых трав посредством их механического обезвоживания прессованием с разделением на пресс-остаток и зеленый сок.

Зеленый сок подвергался фракционированию с получением протеинового зеленого концентрата. Образующийся при этом депротеинизированный коричневый сок (КС) являлся отходом переработки.

В экспериментах коричневый сок подвергался анализу химического состава и использовался в качестве сырья для приготовления удобрения, вносимого на поля, с которых была убрана вегетативная масса люцерны.

Химический анализ полученных препаратов коричневого сока проводили общепринятыми методами [19].

В опытах по применению удобрения из коричневого сока в качестве ориентировочного объема внесения принимали величину, соответствующую количеству коричневого сока, полученного с единицы площади за сезон.

Приготовленное удобрение вносили в междурядья после третьего укоса зеленой массы люцерны. Контролем служил участок без внесения удобрения.

Изучение состава почвы проводилось по следующей схеме:

1. Исходная почва в начале вегетации без внесения удобрения из коричневого сока.

2. Исходная почва в конце вегетации без внесения удобрения из КС.

3. Почва в конце вегетационного сезона после введения удобрения из КС.

Образцы почвы отбирались по окончании периода вегетации и также подвергались анализу. В почвенном профиле пробы отбирали на глубине 10,0-40,0 см. При изучении химического состава почвы определяли кислотность $(\mathrm{pH})$ водной суспензии, содержание основных составляющих плодородия почвы - подвижного азота по методу И.В. Тюрина и М.М. Кононовой, поглощенного калия, подвижной фосфорной кислоты - по методу К.Н. Могичинского, содержание гумуса - по методу Тюрина [20]. Анализ химического состава почвы проводился в лаборатории кафедры почвоведения и оценки земельных ресурсов Южного федерального университета.

Для установления целесообразности внесения удобрения под изучаемую культуру определялась урожайность зеленой массы люцерны за период пользования травостоем.

\section{Полученные результаты и их обсуждение}

В результате проведенного химического анализа установлено, что коричневый сок из зеленой массы люцерны содержит существенное количество протеина, зольных элементов, фосфора, кальция, калия и 
Химический состав коричневого сока из листостебельной массы люцерны

Chemical composition of brown juice from herbage of alfalfa

\begin{tabular}{|l|c|c|}
\hline \multicolumn{1}{|c|}{ Компонент / Component } & $\begin{array}{c}\text { Единица } \\
\text { измерения / Unit of measurement }\end{array}$ & Содержание / Contents \\
\hline Сухое вещество / Dry substance & $\%$ & $5,91-6,82$ \\
\hline Общий азот / General nitrogen & $\%$ & $2,73-2,81$ \\
\hline Протеин / Protein & $\%$ & $17,00-17,73$ \\
\hline Зола / Ash & $\%$ & $16,57-16,78$ \\
\hline $\begin{array}{l}\text { Легкогидролизуемые углеводы / } \\
\text { Easily hydrolyzable carbohydrates }\end{array}$ & $\%$ & $10,91-12,84$ \\
\hline Фосфор / Phosphorus & $\%$ & $0,13-0,37$ \\
\hline Кальций / Calcium & мг \% / mg \% & $4,10-4,42$ \\
\hline Калий / Potassium & & $35,2-42,1$ \\
\hline
\end{tabular}

Таблица 2 / Table 2

Химический состав почвы при внесении удобрения

Chemical composition of soil at top-dressing

\begin{tabular}{|c|c|c|c|c|}
\hline \multirow[b]{2}{*}{$\begin{array}{l}\text { Показатель } \\
\text { Index }\end{array}$} & \multirow[b]{2}{*}{$\begin{array}{c}\text { Единицы } \\
\text { измерения } \\
\text { Units of measure } \\
\text { ment }\end{array}$} & \multicolumn{3}{|c|}{ Место отбора проб / Sampling point } \\
\hline & & $\begin{array}{l}\text { Исходная почва, } \\
\text { начало вегетации } \\
\text { Initial soil, beginning } \\
\text { of vegetation }\end{array}$ & $\begin{array}{c}\text { Исходная почва, } \\
\text { конец вегетации } \\
\text { Initial soil, end of } \\
\text { vegetation }\end{array}$ & $\begin{array}{c}\text { Почва после введения } \\
\text { удобрения } \\
\text { Soil after introduction } \\
\text { of fertilizer }\end{array}$ \\
\hline $\mathrm{pH}$ & & 7,98 & 7,91 & 8,02 \\
\hline Гумус / Huтия & $\%$ & 4,382 & 4,355 & 5,557 \\
\hline $\begin{array}{l}\text { Углерод водорастворимого } \\
\text { гумуса } \\
\text { Carbon of water soluble humus }\end{array}$ & $\begin{array}{l}\text { \% углерода } \\
\text { carbon \% }\end{array}$ & 0,0147 & 0,0108 & 0,0202 \\
\hline $\begin{array}{l}\text { Углерод общий } \\
\text { Carbon general }\end{array}$ & $\%$ & 2,617 & 2,688 & 3,362 \\
\hline $\begin{array}{l}\text { Подвижный азот } \\
\text { Movable nitrogen }\end{array}$ & $\begin{array}{l}\mathrm{M \Gamma} / 100 \text { г } \\
m g / 100 g\end{array}$ & 0,16 & 0,10 & 0,17 \\
\hline $\begin{array}{l}\text { Подвижный фосфор } \\
\text { Movable phosphorus }\end{array}$ & $\begin{array}{l}\text { мг } / 100 \text { г } \\
m g / 100 g\end{array}$ & 26,3 & 23,7 & 28,2 \\
\hline $\begin{array}{l}\text { Подвижный калий } \\
\text { Movable potassium }\end{array}$ & $\begin{array}{l}\mathrm{M \Gamma} / 100 \Gamma \\
m g / 100 g\end{array}$ & 27,07 & 17,72 & 26,98 \\
\hline $\begin{array}{l}\text { Поглощенные соли натрия } \\
\text { Eaten up salts of natrium }\end{array}$ & $\begin{array}{l}\mathrm{M \Gamma} / 100 \text { г } \\
m g / 100 g\end{array}$ & 6,1 & 5,7 & 5,7 \\
\hline $\begin{array}{l}\text { Поглощенные соли магния } \\
\text { Eaten up salts of magnesium }\end{array}$ & $\begin{array}{l}\mathrm{Mг} / 100 \text { г } \\
m g / 100 g\end{array}$ & 7,8 & 7,5 & 7,5 \\
\hline
\end{tabular}

других соединений, необходимых для их восполнения в почве и полноценного питания выращиваемых на ней растений (табл. 1).

При изучении химического состава почвы после введения полученного удобрения из показателей влияния химических компонентов почвы на урожайность растений предпочтение было отдано подвижным формам гумуса, фосфора, калия и азота, как наиболее доступным формам для питания растений.

Углерод водорастворимого гумуса - это подвижная часть гумуса, образованная из продуктов разложения растительных остатков и вторично образованных веществ гумуса, которые могут свободно переходить в растворимую форму. Эта часть состава гумуса формирует эффективное почвенное плодородие, служит энергетическим материалом и источником элементов питания и для растений и почвенных микроорганизмов [7].

В исходной почве в начале вегетационного периода содержание водорастворимых гумусовых веществ было невысоким, что вероятно, объяснялось снижением биологической активности чернозема в результате 
уплотнения слоя почвы и снижения количества поступающего кислорода, необходимого микроорганизмам для разложения органических остатков (табл. 2).

В конце вегетационного периода, несмотря на увеличение количества растительных остатков люцерны, образование гумуса и водорастворимых веществ было ниже по сравнению с почвой в начале вегетации, в результате выноса их с урожаем скошенной вегетативной массы люцерны.

После введения органического удобрения из коричневого сока люцерны содержание химических элементов почвы в результате возврата удаленных с урожаем веществ было на том же уровне, что в образцах исходной почвы в начале вегетации.

Урожайность зеленой массы люцерны за вегетационный период определяли после 3-го укоса. При внесении удобрения из КС под люцерну ее урожайность возрастала за год пользования травостоем по сравнению с урожаем на контрольном участке без введения удобрения.

\section{Выводы}

Образующийся при переработке вегетативной массы люцерны отход - коричневый сок содержит ценные химические соединения, что позволяет использовать его как сырье для получения органического удобрения.

После введения органического удобрения содержание химических элементов почвы в результате возврата удаленных с урожаем веществ было на том же уровне, что в исходных образцах почвы в начале вегетации, характерном для черноземов предкавказских.

При внесении удобрения под люцерну урожайность зеленой массы за 3 укоса возрастала по сравнению с контрольным участком.

Разработанный способ комплексного использования растительных ресурсов, кроме корма для животных, позволит получать жидкое органическое удобрение, способствующее снижению истощения почвы и поддержанию ее плодородия.

\section{КРИТЕРИИ АВТОРСТВА / Contribution:}

Киреева В.В. - осуществляла общее руководство проведением исследований, редактирование рукописи, несет ответственность за плагиат; Рассказова Т.Г. - собрала необходимый материал, провела анализ, проанализировала результаты, написала рукопись; Сербулова Н.М. - произвела расчеты, обработку результатов анализа / Kireeva V.V. carried out the General management of research, editing of the manuscript, is responsible for plagiarism; Rasskazova T.G. collected the necessary material, analyzed, analyzed the results, wrote the manuscript; Serbulova N.M. made calculations, processing of the analysis results

\section{КОНФЛИКТ ИНТЕРЕСОВ / Conflict of interest:}

Авторы заявляют об отсутствии конфликта интересов / The authors declare no conflict of interest.

\section{ЛИТЕРАТУРА:}

1. Вальков В. Ф., Казеев К. Ш., Колесников С. И. Почвы Ростовской области: генезис, география и экология. Ростовна-Дону: Издательство Южного федерального университета. $2012.316 \mathrm{c}$.

2. Казеев К. Ш., Тер-Мисакянц Т. А., Колесников С. И., Козунь Ю. С. Биодиагностика экологического состояния почв Западного Кавказа после вырубки леса // Известия Самарского научного центра. 2013. Т.15. N 3(5). С. 1299-1301.

3. Киреева В. В., Рассказова Т. Г. Изучение качественных характеристик почв и разработка способа повышения их плодородия // Качество и жизнь, 2017. N 4. С. 67-71.

4. Колесников С. И., Мясникова М. А., Казеев К. Ш., Вальков В. Ф. Биологическая активность чернозема обыкновенного при длительном использовании под пашню // Почвоведение. 2014. N 6. С. 724-733.

5. Ferrara C., Ranalli F. Soil quality Change and environmental vulnerability in the context of intense urbanization in the suburbs. Soil science, 2014, no 10, pp. 1273-1280

6. Сухомлинова Н. Б., Суханова А. В. Экологическая оценка состояния земель в агроландшафтах Ростовской области // Технические науки - от теории к практике. 2016. N 56. C. $75-78$.

7. Терпелец В. И., Плитинь Ю. С. Гумусное состояние чернозема выщелоченного в агроценозах Азово-Кубанской низменности: монография. Краснодар: Кубанский государственный аграрный университет. 2015. 127 с.

8. Liu X., Herbert S. J., Hashemi A. M., Zhang X., Ding G. Effects of agricultural management on soil organic matter and carbon transformation - a review // Plant, Soil and Environ. 2006 , v. 52 , no. 12 , pp. 531-543.

9. Шарков И. Н., Бреус И. П, Данилова А.А. Роль легкоминерализуемого органического вещества в стабилизации запасов углерода в пахотных почвах // Сибирский экологический журнал. 1994. N 4. С. 363-368.

10. Tisdall, I. M., Oades J. M. Organic matter and water stable aggregates in soils. 1982. V. 3. Pp. 141-163.

11. Фрунзе Н. И. Разнообразие аминокислот чернозема типичного // Почвоведение. 2014. N 12. С. 1483-1489.

12. Kemmitt, S. J. Lanyon C. V., Waite I. S., Wen Q., Addiscott T. M., Bird N.R. A., Donnell A. G. O., Brookes P. C. Mineralization of native soil organic matter is not regulated by the size, activity or composition of the soil microbial biomass a new perspective // Soil Biol. Biochem. 2008. V.40. Pp. 61-73.

13. Nageswara Rao D. Evaluation of soil extractants in terms of growth. Communications in Soil Science and Plant Analysis // 2005. V. 36. Pp. 1513-1523. 
14. Соснина И. Д. Влияние видов органических и минеральных удобрений на урожайность зерновых продуктивность пашни и сохранения плодородия почвы // Достижения науки и техники агропромышленного комплекса. 2015. N 5. C. 32-33.

15. Rekasi M., Filep T. Effect of microelement loads on the element fractions of soil and plant uptake // Agrokemia es Talajtan. 2006. V. 55(1). Pp. 213-222.

16. Sulkowski M., Hirner, A. V. Element fractionation by sequential extraction in a soil with high carbonate content // Applied Geochemistry. 2006. V. 21(1). Pp. 16-28.

17. Киреева В.В. Утилизация вегетативной массы сельскохозяйственных растений с получением кормов для животных. Ростов н/Д, 2015. Депонировано в ВИНИТИ 25.12.15, N 220-B 2015. 162 c.

18. Хетагуров В. Н., Каменецкий Е. С., Минасян Д. Г., Гегелашвили М. В., Исследование движения измельчаемого материала в центробежной мельнице вертикального типа при установке в ее рабочем пространстве коаксиального кольца // Устойчивое развитие горных территорий. 2017. N 3 (33). C. 287-294.

19. Сычев В. Г., Лепешкин В. В. Методические указания по оценке качества и питательности кормов. М., ЦИНАО, $2002.76 \mathrm{c}$.

20. Аринушкина Е. В. Руководство по химическому анализу почв. М.: Издательство Московского государственного университета, 1970. $487 \mathrm{c}$.

\section{СВЕДЕНИЯ ОБ АВТОРАХ / Information about authors:}

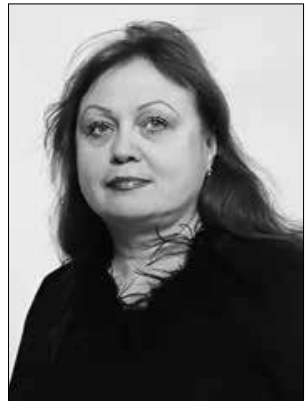

КИРЕЕВА Валерия Васильевна - доктор биологических наук, доцент, профессор кафедры «Безопасность технологических процессов и производств», Донской государственный технический университет, 344000, г. Ростов-на-Дону, Россия.

Тел.: 8 (863)285-91-71;

8(918)541-77-13.

e-mail: valeriakireeva@gmail.com

Valeria V. KIREEVA-Doctor of Biology Sciences, associate Professor, Professor of the Department of «Technological processes and productions Safety",

Don State Technical University, 344000, Rostov-on-Don, Russia. Ph.: +7(863)285-91-71; +7(918)541-77-13.

e-mail:valeriakireeva@gmail.com

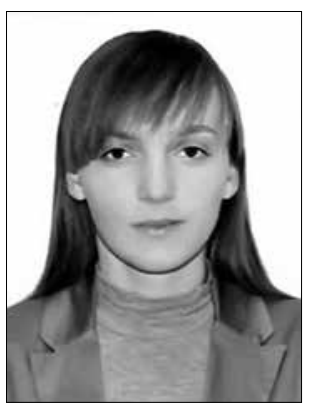

РАССКАЗОВА Татьяна Григорьевна - аспирант кафедры «Безопасность технологических процессов и производств», Донской государственный технический университет, 344000, г. Ростов-на-Дону, Россия.

Тел.: 8(863)-232-33-48;

8 (918) 590-98 76.

e-mail: t.rasskazova@systemco.ru

TATYANA G. RASSKAZOVA-graduate student of the Department of "Technological processes and productions Safety», Don State Technical University, 344000, Rostov-on-Don, Russia.

Ph.: +7(863)-232-33-48; +7(918) 590-98 76

e-mail: t.rasskazova@systemco.ru

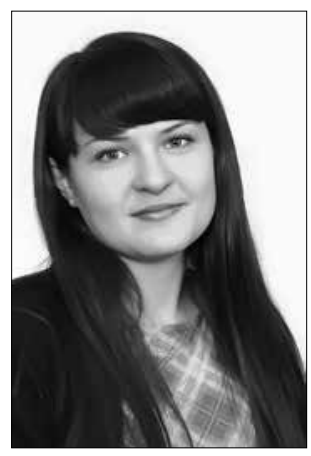

СЕРБУЛОВА Наталья Михайловна - кандидат технических наук, доцент кафедры «Менеджмент и бизнес-технологии», Донской государственный технический университет, 344000 , Ростов-на-Дону, Россия.

Тел.: 8(863)-258-91-84; 8(904)505-71-24

e-mail: nserbulova@mail.ru

NATALIA M. SERBULOVA - Candidate of Technical Sciences,

Associate Professor of the Department of «Management and business technologies chair», Don State Technical University, 344000, Rostov-on-Don, Russia.

Ph.: +7(863)-258-91-84; +7(904)505-71-24

e-mail:nserbulova@mail.ru

\section{MAINTAINING SOIL FERTILITY: A METHOD FOR ORGANIC FERTILIZER PRODUCTION FROM CROP FARMING WASTE}

V.V. Kireeva*,

T.G. Rasskazova,

N.M. Serbulova

Don State Technical University, 344000, Rostov-on-Don, Russia, valeriakireeva@gmail.com

DOI: $10.21177 / 1998-4502-2018-10-4-493-499$

The purpose of this work was to evaluate the opportunities for production of a liquid organic fertilizer from the waste left after processing of alfalfa herbage, and its influence upon preservation of fertility in the black soils of the Ciscaucasian region.

Methods. To produce the fertilizer, we used the phytomass 
of Medicago sativa ('Manychskaya' variety) grown as forage grass and mown during the budding stage and blooming stage beginning.

Herbage was wet-fractionated (including disintegration and fractioning of alfalfa vegetative mass) and dehydrated by means of mechanical compression producing press cake and green juice used further for green protein concentrates. Brown juice also generated in the process was a by-product, which used to be considered a waste.

In our studies, brown juice was employed as a raw material for production of a fertilizer for the fields where alfalfa herbage had been harvested. During the study of brown juice applicability, we assumed the volume corresponding to the brown juice amount gathered from a unit of area within a season to be the reference fertilizer application volume.

Results. It was established that brown juice from alfalfa herbage contains material quantities of nitrogen, ash constituents, phosphorus, calcium, potassium, and other compounds necessary for their replenishment in soil and adequate nutrition of the plants cultivated there.

During chemical analysis of soil composition, priority was focused on active forms of humus, phosphorus, potassium, and nitrogen as the components most readily available for plant nutrition and thus also acting as productivity indicators.

Performed analysis demonstrated that the levels of chemical elements increased following fertilizer distribution due to the return of substances extracted with the gathered herbage reaching practically the same level as in the initial soil samples collected in the vegetation period beginning (typical productivity levels of black soils in the Ciscaucasian region).

Fertilizer application while alfalfa was still growing resulted in herbage yield increase observed throughout 3 hay cuttings in comparison with the control plot.

The method designed for complex utilization of vegetable resources allows to produce besides animal feeding stuff a liquid organic fertilizer minimizing soil depletion and maintaining its productive capacity.

Keywords: soil fertility, herbage, organic fertilizers.

\section{References}

1. Valkov V.F., Kazeev K. Sh., Kolesnikov S.I. Soils of the Rostov region: Genesis, geography and ecology. Rostov-ondon, Publishing House of Southern Federal University, 2012, 316 p. (in Russian)

2. Kazeev K.Sh., Ter-Misakyan T.A., Kolesnikov, Kosun Yu.S. Biodiagnostics of soil ecological condition of the Western Caucasus after felling. News of Samara Scientific Center, 2013, v. 15, no 3 (5), pp. 1299-1301 (in Russian).

3. Kireeva V.V., Rasskazova T.G., Gainutdinov I.I. Study of the qualitative characteristics of soils and the development of a method for increasing their fertility. Quality and Life, 2017, no 4, pp. 67-71 (in Russian).

4. Kolesnikov S.I., Myasnikova M.A., Kazeev K.Sh., Valkov V.F. The Biological activity of ordinary Chernozem in long-term use under cultivation. Soil Science, 2014, no 6, pp. 724-733 (in Russian).

5. Ferrara C., Ranalli F. Soil quality Change and environmental vulnerability in the context of intense urbanization in the suburbs. Soil Science, 2014, no 10, pp. 1273-1280.
6. Sukhomlinova N.B., Sukhanova A.V. Ecological assessment of land condition in agrolandscapes of Rostov region. Technical sciences - from theory to practice, 2016, no 56, pp. 75-78 (in Russian).

7. Terpelets V.I., Plitin Yu.S. Humus state of leached Chernozem in agrocenoses of Azov-Kuban lowland: monograph. Krasnodar, Kuban State Agrarian University, 2015, 127 p. (in Russian).

8. Liu X., Herbert S.J., Hashemi A.M., Zhang X., Ding G. Effects of agricultural management on soil organic matter and carbon transformation - a review. Plant, Soil and Environ, 2006, no 12, pp. 531-543.

9. Sharkov I.N., Breus I.P., Danilova A.A. Role of easily mineralized organic matter in stabilization of carbon stocks in arable soils. The Siberian Ecological Journal, 1994, no 4, pp. 363-368 (in Russian).

10. Tisdall I.M., Oades J.M. Organic matter and water stable aggregates in soils. J. Soil Science, 1982, v. 33, pp. 141163.

11. Frunze N. I. Variety of black earth typical amino acids. Soil Science, 2014, no 12, pp. 1483-1489 (in Russian).

12. Kemmitt S.J. Lanyon C.V., Waite I.S., Wen Q., Addiscott T.M., Bird N.R. A., Donnell A. G.O., Brookes P.C. Mineralization of native soil organic matter is not regulated by the size, activity or composition of the soil microbial biomass - a new perspective. Soil Biol. Biochem., 2008, v.40, pp. $61-73$

13. Nageswara Rao D. Evaluation of soil extractants in terms of growth. Communications in Soil Science and Plant Analysis, 2005, v. 36, pp. 1513-1523

14. Sosnina I.D. Influence of organic and mineral fertilizers on grain yield productivity of arable land and soil fertility preservation. Achievements of science and technology of agroindustrial complex, 2015, no 5, pp. 32-33 (in Russian).

15. Rekasi M., Filep T. Effect of microelement loads on the element fractions of soil and plant uptake. Agrokemia es Talajtan, 2006, v. 55(1), pp. 213-222.

16. Sulkowski M., Hirner, A.V. Element fractionation by sequential extraction in a soil with high carbonate content. Applied Geochemistry, 2006, v. 21(1), pp. 16-28.

17. Kireeva V.V. Utilization of vegetative mass of agricultural plants with receiving forages for animals. Rostovon-Don. 2015. Deposited 25.12.15 in the All-Russian Institute of Scientific and Technical Information, no 220-B2015, 162 p. (in Russian).

18. Khetagurov V.N., Kamenetsky E.S., Minasyan D. G., Gegelashvili M.V. Research of motion of the crushed material in a centrifugal mill of vertical type when installing a coaxial ring in its working space. Sustainable Development of Mountain Territories, 2017, no 3 (33), pp. 287-294 (in Russian).

19. Sychev V.G., Lepeshkin V.V. Methodological guidelines for assessing the quality and nutritional value of feed. Moscow, Central Institute of Agrochemical Services for Agriculture, 2002, 76 p. (in Russian).

20. Arinushkina E.V. Manual on chemical analysis of soils. Moscow, Publishing House of Moscow State University, 1970, 487 p. (in Russian). 
${ }^{1} Г$ рязев М.В., ${ }^{1}$ Качурин Н.M., ${ }^{*}$ ${ }^{1}$ Стась Г.В.

\section{ПЫЛЕГАЗОВЫЕ ВЫБРОСЫ} С ПОВЕРХНОСТИ ПОРОДНЫХ ОТВАЛОВ ЛИКВИДИРОВАННЫХ ШАХТ УГОЛЬНОГО БАССЕЙНА

\section{УДК: 551}

DOI: 10.21177/1998-4502-201810-4-500-508

Статья посвящена проблеме минимизации негативного влияния хвостов добычи и переработки углей на экосистемы окружающей среды путем оптимизации параметров строительства и эксплуатации отвалов. Цель достигается методом математического моделирования аэрогазодинамических процессов на основе системы уравнений Рейнольдса при обтекании воздушными массами породных отвалов.

\section{КЛЮЧЕВЫЕ СЛОВА:}

хвосты добычи и переработки, уголь, окружающая среда, отвал, математическое моделирование, воздушные массы

Статья поступила в редакцию 19.02.2018.

\section{Введение}

Аэрогазодинамические процессы протекают на всех этапах существования шахт и рудников. Практика показывает, что самый длительный этап негативных аэрогазодинамических процессов имеет место после их закрытия или ликвидации [1-5]. Экологическая модель геотехнологических периодов отработки запасов угля подземным способом показывает, что аэрогазодинамические процессы, обусловленные подземной разработкой месторождений, должны быть объектами мониторинга и после закрытия шахт (рис. 1). Для терриконов характерно значительное выделение в атмосферу пыли, которая в сухую ветреную погоду сдувается с поверхности отвала и уносится на значительные расстояния, загрязняя атмосферу и поверхностный почвенный слой [6-8].

Интенсивность пылеобразования на породных отвалах зависит от следующих факторов: типа и размеров отвала, его ориентации в пространстве, количества атмосферных осадков, относительной влажности воздуха, прозрачности атмосферы, облачности, значения альбедо поверхности отвала, минералогического состава породной массы и др. На породных отвалах шахт Подмосковного бассейна максимальная интенсивность пылеобразования составляет около $2,6 \mathrm{mг} / \mathrm{m}^{2} \mathrm{c}$. Выпадение пыли за зимний период на расстоянии 300 м от отвала

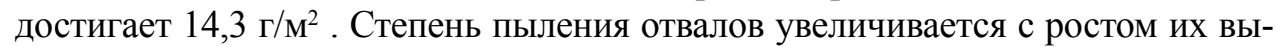
соты. Так, если с отвала высотой 20 м за год сдувается слой пыли толщиной 3,8 см, то с отвала $50 \mathrm{~m}-6,5 \mathrm{~cm}$.

В зависимости от удельного накопления пыли можно выделить три зоны воздействия техногенных массивов на ландшафты:

- максимального воздействия, с высоким пылевым загрязнением поверхности земли и расположенную, как правило, в радиусе 3-10 км от техногенного массива;

- повышенного воздействия, распространяющуюся на расстояние 15-17 км;

- косвенного влияния с радиусом до 50 км.

Натурные наблюдения показали, что поверхность породного отвала является источником выбросов газовых загрязнителей в приземный слой атмосферы [9-12].

В соответствии с программой реструктуризации и стратегией развития угольной промышленности России предусматривается превращение ее в устойчиво функционирующую и рентабельную отрасль. В результате осуществляемой реструктуризации угольной промышленности России и ликвидации нерентабельных угледобывающих предприятий произошла ликвидация угольных шахт Подмосковного угольного бассейна. Но воздействие на атмосферу и техногенная активизация геохимического переноса на территориях этих регионов продолжаются.

\section{Материал и методы исследования}

Натурные наблюдения за выбросами пыли с породных отвалов ликвидированных шахт. На шахтах Подмосковного угольного бассейна преимущественно использовались конические и хребтовые отвалы, при отсыпке которых происходила сегрегация породы по крупности и по составу. Для оценки влияния выпадения пыли на почвы прилегающих к отвалу территорий проведены

\footnotetext{
${ }^{1}$ Тульский государственный университет, Тула, Россия, ecology_tsu_tula@mail.ru
} 


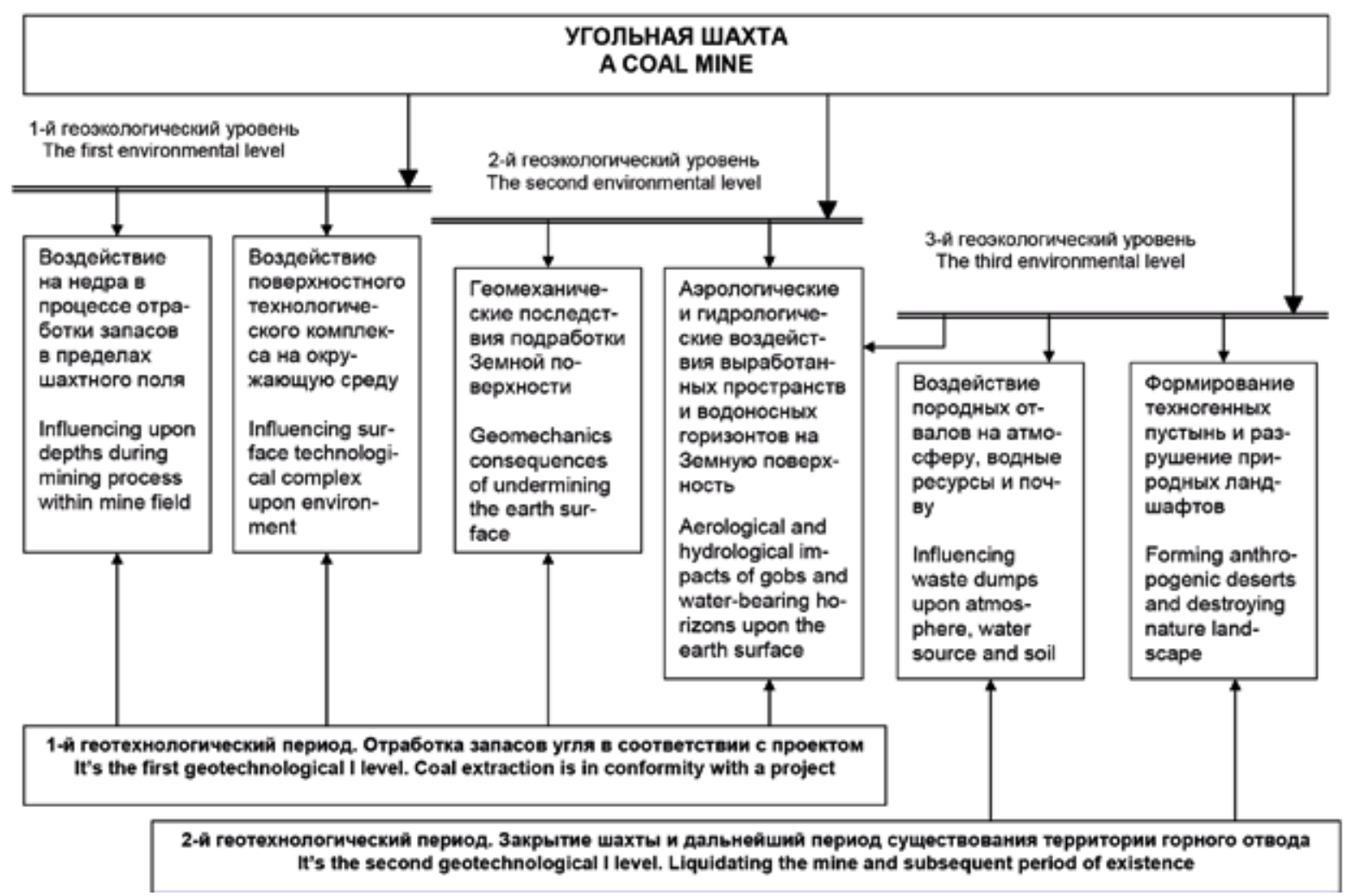

Pис. 1. Экологическая модель геотехнологических периодов отработки запасов угля подземньм способом

Fig. 1. Environmental model of geotechnological levels for mining coal reserves by underground method

анализы содержания тяжелых металлов в пробах, отобранных в тех же точках, где отбирались пробы снежного покрова. В таблице приведены результаты количественного анализа проб снежного покрова.

При интенсивной эмиссии пыли в окружающую среду на прилегающих к породному отвалу территориях происходит существенное загрязнение окружающей среды тяжелыми металлами. Анализ состава породной массы показывает, что по большинству шахт превышения ПДК по тяжелым металлам не наблюдается. Исключение составляет свинец, превышение концентрации которого достигает 8 ПДК. У свинца четко выражена тенденция к накоплению в почве, так как его ионы малоподвижны даже при низких значениях водородного показателя $p H$. Поэтому поступающая с отвалов пыль загрязняет прилегающие территории.

Результаты исследований свидетельствуют о существенных различиях распределения свинца и марганца по угольным месторождениям, и по фракциям породной массы в отвалах. Данные натурных наблюде- ний свидетельствуют о том, что фракционный состав породной массы не оказывает существенного влияния на водородный показатель. Следовательно, пыль любой крупности, поступающая с отвала в окружающую среду, подкисляет почвы.

Моделирование движсния потоков воздуха при обтекании породных отвалов. Моделирование движения воздуха при обтекании породных отвалов действующих и ликвидированных угольных шахт становится одним из основных методов анализа качества предлагаемых экологических решений по защите окружающей среды от вредных воздействий отвалов [13-16]. Моделирование аэрогазодинамических процессов при обтекании породных отвалов основывается в общем случае на системе уравнений О. Рейнольдса, описывающей течение вязкого, сжимаемого теплопроводного газа в трехмерной постановке, которая состоит из уравнений сохранения, включающих плотность воздуха; компоненты средней скорости воздуха; время; пространственные координаты; пульсационные

Содержание тяжелых металлов в пробах снежного покрова на территориях, прилегающих к отвалу ш. № 67 (Тульская область)

Concentration of heavy metal in samples of snow mantle at the territories near the waste dump of the mine No 67

\begin{tabular}{|c|c|c|c|c|}
\hline \multirow{2}{*}{ № п/п } & \multirow{2}{*}{ Место отбора пробы / Sampling point } & \multicolumn{2}{|c|}{ Концентрация, мг/кг / Concentration, milligram/kilogram } \\
\cline { 3 - 5 } & Породный отвал / The waste dump & 91 & $\mathbf{C r}$ & $\mathbf{\text { Ni }}$ \\
\hline 1 & По & 26 & 1,4 \\
\hline 3 & 150 мототвала / 150 m from the waste dump & 44 & 26,6 & 0,66 \\
\hline 4 & 300 мототвала / 300 $m$ from the waste dump & 64 & 27,8 & 2,8 \\
\hline
\end{tabular}


скорости; статическое давление воздуха; энтропию; эффективную, динамическую и турбулентную вязкость; дельта Кронекера; кинетическую энергию турбулентности; полную и статическую энтальпию [10].

Для замыкания данной системы уравнений используется полуэмпирическая модель турбулентности, состоящая из двух уравнений переноса:

- кинетической энергии турбулентности

$$
\begin{aligned}
\frac{\partial(\rho \kappa)}{\partial t} & +\frac{\partial\left(\rho u_{j} \kappa\right)}{\partial x_{j}}=\frac{\partial}{\partial x_{j}}\left\{\left(\mu+\frac{\mu_{t}}{\sigma_{\kappa}}\right) \frac{\partial \kappa}{\partial x_{j}}\right\}+S_{\kappa}+ \\
& +\mu_{t}\left(\frac{\partial u_{i}}{\partial x_{j}}+\frac{\partial u_{j}}{\partial x_{i}}\right) \frac{\partial u_{i}}{\partial x_{j}}-\frac{2}{3}\left(\rho \kappa+\mu_{t} \frac{\partial u_{l}}{\partial x_{l}}\right) \frac{\partial u_{k}}{\partial x_{k}}-\rho \varepsilon
\end{aligned}
$$

- скорости диссипации кинетической энергии турбулентности

$$
\begin{aligned}
& \frac{\partial(\rho \varepsilon)}{\partial t}+\frac{\partial\left(\rho u_{j} \varepsilon\right)}{\partial x_{j}}=\frac{\partial}{\partial x_{j}}\left\{\left(\mu+\frac{\mu_{t}}{\sigma_{\varepsilon}}\right) \frac{\partial \varepsilon}{\partial x_{j}}\right\}+S_{\varepsilon}+ \\
& +\frac{\varepsilon}{\kappa}\left\{c_{\varepsilon 1}\left[\mu_{t}\left(\frac{\partial u_{i}}{\partial x_{j}}+\frac{\partial u_{j}}{\partial x_{i}}\right) \frac{\partial u_{i}}{\partial x_{j}}-\frac{2}{3}\left(\rho \kappa+\mu_{t} \frac{\partial u_{l}}{\partial x_{l}}\right) \frac{\partial u_{k}}{\partial x_{k}}\right]-\rho c_{\varepsilon 2} \varepsilon\right\} \\
& \mu_{t}=\rho c_{\mu} \frac{\kappa^{2}}{\varepsilon}
\end{aligned}
$$

где $C_{\mu}-$ коэффициент к $-\varepsilon$ модели турбулентности.

Дискретизация уравнений осуществляется методом конечных объемов [10-12]. Для описания распределения узлов внутри сеточной подобласти вводится понятие потокового элемента, который по своей сути является конечным элементов и на котором определены функции формы конечного элемента. Фундаментальное преимущество метода конечных объемов означает то, что потоки в точке интегрирования на соприкасающихся поверхностях соседних контрольных объемов равны, т.е. поток, истекающий из одного контрольного объема и втекающий в прилегающий объем, идентичен. Стандартный подход метода конечных элементов (через функции формы конечного элемента) используется для оценки производных всех диффузионных членов. Производная от функции формы в декартовой системе координат может быть выражена в виде локальных производных функции формы через якобиан матрицы преобразования координат. Для повышения устойчивости схемы оценка градиента производится в точках интегрирования, расположенных на пересечении поверхности интегрирования с ребром потокового элемента (линейно-линейная интерполяция).

Конвективно-турбулентный диффузионный перенос пыли в приземном слое атмосферы зоны действия породного отвала. Уравнение конвективно-турбулентной диффузии пыли в приземном слое атмосферы зоны действия отвала имеет следующий вид:

$$
\frac{\partial c_{n}}{\partial t}+u \frac{\partial c_{n}}{\partial x}=D_{n} \frac{\partial^{2} c_{n}}{\partial x^{2}}-k w_{B} c_{n}
$$

где $c_{n}$ - концентрация пыли в воздушном потоке; $u$ средняя скорость воздуха с подветренной стороны отвала; $D_{n}-$ коэффициент турбулентной диффузии пыли в приземном слое атмосферы; $k-$ коэффициент седиментации; $w_{в}$ - скорость витания пыли в воздухе.

Начальные и граничные условия:

$$
c_{n}(x, 0)=0, c_{n}(0, t)=c_{H}=\mathrm{const}, \lim _{x \rightarrow \infty} c_{n} \neq \infty \text {. }
$$

Решение уравнения (5) для условий (6) получено в следующем виде:

$$
\begin{gathered}
c_{n}(x, t)=0,5 c_{n} \exp \left(\frac{0,5 u}{D_{n}} x\right)\left\{\operatorname { e x p } \left[-0,5\left(\sqrt{\left.\frac{u^{2}}{D_{n}^{2}}+\frac{4 k w_{b}}{D_{n}}\right)}\right] \times\right.\right. \\
\times \operatorname{erfc}\left[\frac{0,5 \mathrm{x}}{\sqrt{D_{n} t}}-\sqrt{0,25\left(\frac{u^{2}}{D_{n}}+4 k w_{b}\right)}\right]+\exp \left[0,5\left(\sqrt{\frac{u^{2}}{D_{n}^{2}}+\frac{4 k w_{B}}{D_{n}}}\right) x\right] \times \\
\times \operatorname{erfc}\left[\frac{0,5 \mathrm{x}}{\sqrt{D_{n} t}}+\sqrt{0,25\left(\frac{u^{2}}{D_{n}}+4 k w_{b}\right)}\right] t .
\end{gathered}
$$

Конвективно-турбулентный перенос газовых загрязнителей в приземном слое атмосферы зоны действия породного отвала. Натурные наблюдения показали, что поверхность породного отвала является источником выбросов газовых загрязнителей в приземный слой атмосферы. Газовые загрязнители могут распространяться на значительные расстояния. Уравнение конвективно-турбулентной диффузии газовых загрязнителей в приземном слое атмосферы зоны действия отвала имеет следующий вид:

$$
\frac{\partial c_{2 . n}}{\partial t}+u \frac{\partial c_{2 . n}}{\partial x}=D_{2 . n} \frac{\partial^{2} c_{2 . n}}{\partial x^{2}},
$$

где $c_{2 . n}$ - концентрация газового загрязнителя в воздушном потоке; $D_{n}-$ коэффициент турбулентной диффузии газового загрязнителя в приземном слое атмосферы.

Начальные и граничные условия:

$c_{2 . n}(x, 0)=0, c_{2 . n}(0, t)=c_{1}=$ const, $\lim _{x \rightarrow \infty} c_{2 . n} \neq \infty$.

Решение уравнения (7) для условий (8) получено в следующем виде:

$$
\begin{aligned}
& c_{2 . n}(x, t)=0,5 c_{1} \exp \left(\frac{0,5 u}{D_{2 . n}} x\right)\left\{\exp \left[-0,5\left(\frac{u}{D_{2 . n}}\right)^{2} x\right] \operatorname{erfc}\left[0,5\left(\frac{\mathrm{x}}{\sqrt{D_{2 . n} t}}-u \sqrt{\frac{t}{D_{2 . n}}}\right)\right]+\right. \\
& \left.+\exp \left[0,5\left(\frac{u}{D_{2 . n}}\right)^{2} x\right] \operatorname{erfc}\left[0,5\left(\frac{\mathrm{x}}{\sqrt{D_{2 . n} t}}+u \sqrt{\frac{t}{D_{2 . n}}}\right)\right]\right\} .
\end{aligned}
$$

\section{Полученные результаты и их обсуждение} Движение потоков воздуха при обтекании породных отвалов. Результаты вычислительных экспериментов представлены на рис. 2, 3. В настоящее время есть программные средства для численной реализации предлагаемого алгоритма и численного моделирования движения воздуха при обтекании породных отвалов любой формы. Вычислительные эксперименты были проведены для конических и хребтовых отвалов высотой 15 м при скорости ветра 5 м/с. Полученные результаты ви- 
зуально демонстрируют, что разработанный алгоритм позволяет воспроизводить картину течения воздуха при различных схемах складирования пород на промышленных площадках шахт. Следует также отметить тот факт, что поле скоростей в приземном слое достаточно быстро выравнивается. При моделировании конвективнотурбулентной диффузии пыли и газовых загрязнителей можно использовать одномерное уравнение параболического типа, где конвективный член будет определяться скоростью ветра в приземном слое.

Поля скоростей воздуха при обтекании конического отвала могут превышать значение скорости сдувания твердых частиц практически на $60 \%$ площади поверхности отвала. Площади пылящих поверхностей хребтового отвала не превышают $30 \%$ его общей площади поверхности. Для упрощения расчетов высота струи на входной границе условно принимается не более высоты отвала.

Следующим этапом исследования является инженерный анализ результатов моделирования и разработка технических средств для реализации экологической безопасности территорий, прилегающих к породным отвалам [17-20]. Это позволит повысить качество проектирования и эксплуатации вентиляционных систем.

Одномерная задача о распространении газообразных и пылевых загрязнений дает приемлемые результаты только на некотором расстоянии от отвала, численное значение которого может быть определено решением уравнений Рейнольдса.

Перенос пыли в приземном слое атмосферы зоны действия породного отвала. Результаты вычислительного эксперимента с использованием зависимости (9) представлены рис. 4.

Анализ результатов эксперимента показал, что в процессе переноса пыли происходит довольно интенсивное ее осаждение и накопление на внешней поверхности почвы. При этом интенсивность осаждения пыли во многом определяется величиной скорости витания пыли и значением коэффициента седиментации. В зависимости от скорости ветра
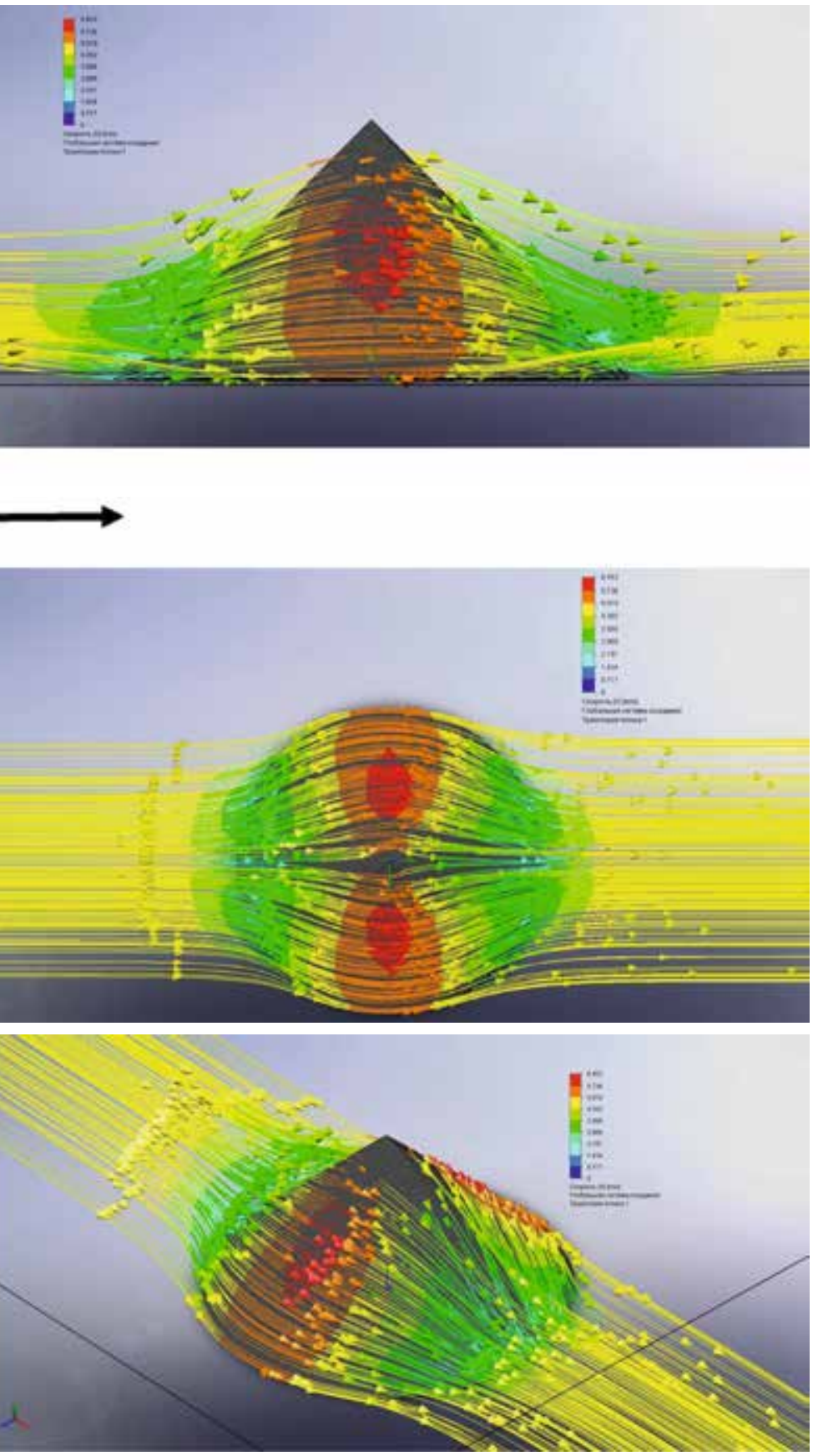

Puc. 2. Обтекание конического отвала высотой $15 \mathrm{M}$, ветер $5 \mathrm{~m} / \mathrm{c}-$ восточный

Fig. 2. Flowing the conical dump with height $15 \mathrm{~m}$, eastern wind velocity $5 \mathrm{~m} / \mathrm{s}$

и длительности его действия пыли малых фракций могут распространяться на значительные расстояния от пылящего отвала. Этот факт подтверждается и результатами натурных наблюдений.

Таким образом, при оценке воздействия пыли породных отвалов на окружающую среду необходимо решать нестационарную задачу, чтобы прогнозировать динамику пылевой ситуации в зоне действия отвала.

Перенос газовых загрязнителей в приземном слое атмосферы зоны действия породного отвала. Зависимость (9) использована для вычислительного эксперимента (рис. 5).

В процессе переноса газового загрязнителя его 


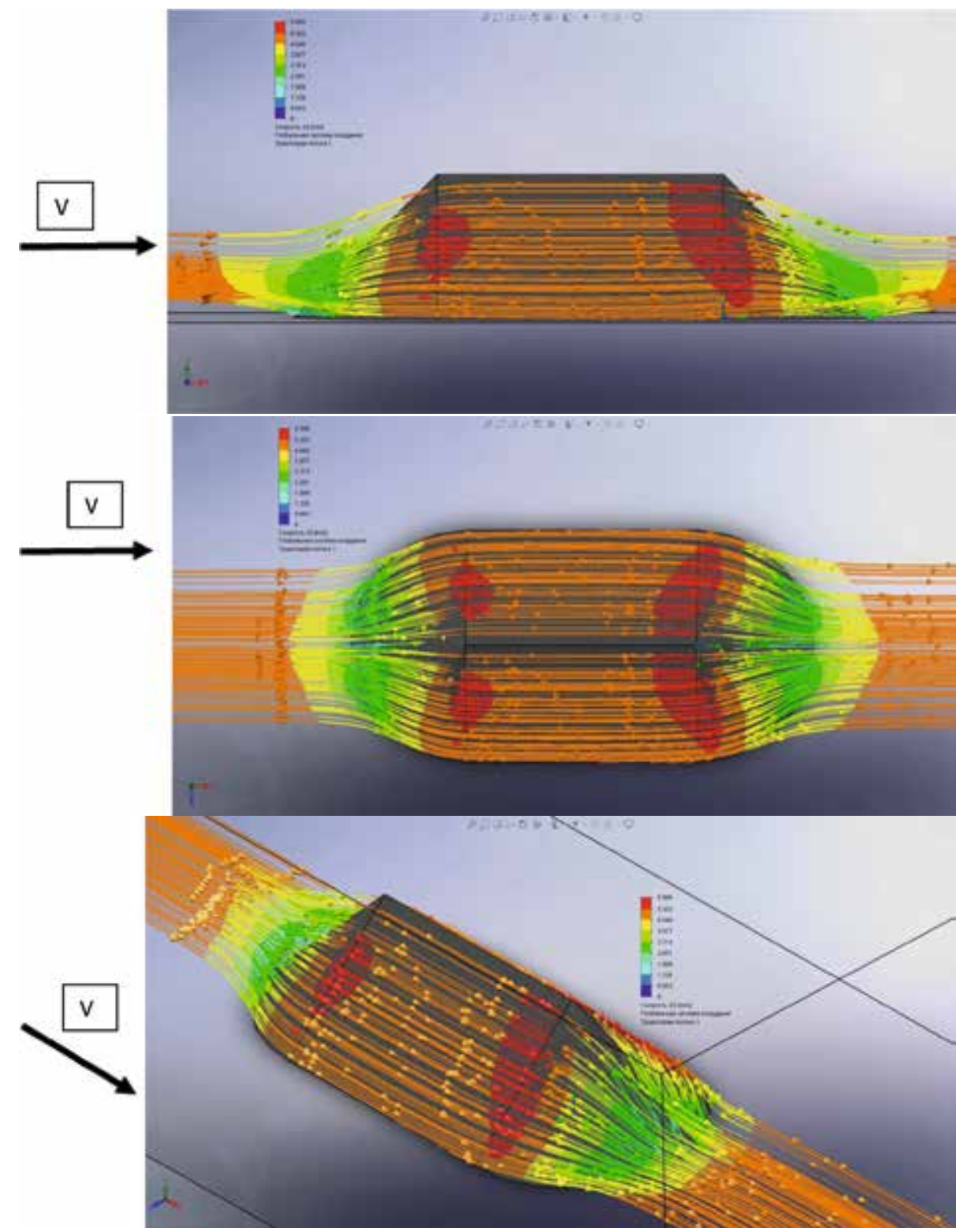

Рис. 3. Обтекание хребтового отвала высотой $15 \mathrm{м}$,ветер $5 \mathrm{M} / \mathrm{c}$ - восточный Fig. 3. Flowing the crest dump with height $15 \mathrm{~m}$, eastern wind velocity $5 \mathrm{~m} / \mathrm{s}$

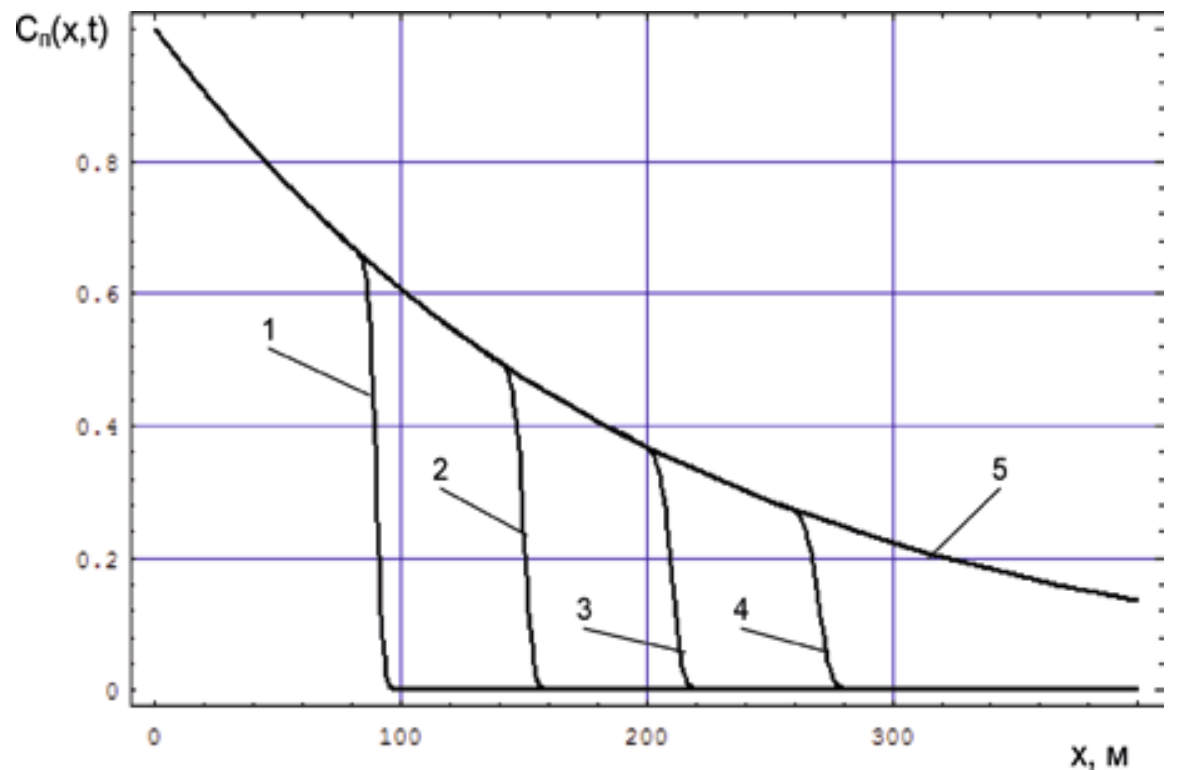

Pис. 4. Распределение пыли в воздухе, обтекающем отвал: $C_{n}(x, t)=c_{n} / c_{b} ; 1-t=3$ мин; $2-t=5$ мин; $3-t=7$ мин; $4-t=9$ мин; $5-t=16$ мин

Fig. 4. Distribution of a dust in air flowing a dump: $C_{n}(x, t)=c_{n} / c_{b} ; 1-t=3$ minute; $2-t=5$ minute; $3-t=7$ minute; $4-t=9$ minute; $5-t=16$ minute 


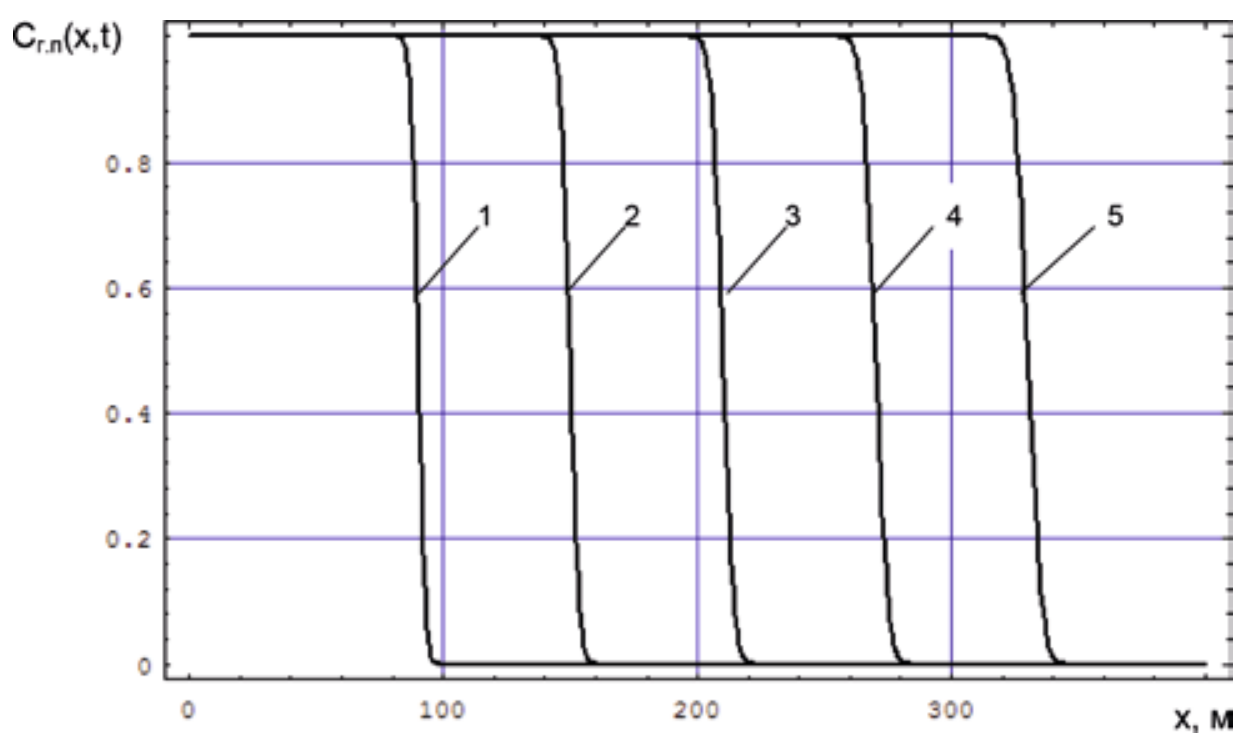

Рис. 5. Кониентрация газовых загрязнителей в приземном слое aтмосферы: $C_{2 . n}(x, t)=c_{2 . n}(x, t) / c_{1} ; 1-t=3$ мин; $2-t=5$ мин; $3-t=7$ мин; $4-t=9$ мин; $5-t=11$ мин

Fig. 5. Gas pollutant concentration in surface layer: $C_{2 . n}(x, t)=c_{2 . n}(x, t) / c_{1}$;

$1-t=3$ minute; $2-t=5$ minute; $3-t=7$ minute; $4-t=9$ minute; $5-t=11$ minute

концентрация меняется незначительно в течение периода действия ветра. При этом выведение газового загрязнителя из воздушного потока осуществляется, в основном, за счет сорбции жидкими и твердыми частицами. В зависимости от скорости ветра и длительности его действия газообразные загрязнители могут распространяться на значительные расстояния от породного отвала, что подтверждается результатами натурных наблюдений.

\section{Выводы}

1. По большинству шахт превышений ПДК по тяжелым металлам не наблюдается. Прилегающие территории загрязняются, преимущественно, свинцом.

2. Аэрогазодинамические процессы обтекания породных отвалов описываются уравнением О. Рейнольдса в трехмерной постановке.

3. Интенсивность осаждения пыли определяется величиной скорости витания пыли и значением коэффициента седиментации.

\section{КРИТЕРИИ АВТОРСТВА / Contribution:}

Грязев М.В. - обосновал физическую модель диффузионной миграции загрязнителей в почвенный слой, разработал математическую модель диффузионного процесса;

Качурин Н.М. - проводил натурные и лабораторные исследования, написал рукопись и несет ответственность за плагиат;

Стась Г.В. - проводила обработку результатов натурных и лабораторных исследований, провела серию вычислительных экспериментов.

Griyzev M. V. - substantiated physical model of diffusion migrating pollutants into soil seam and created mathematical model of diffusion process;

Kachurin N. M. - investigated field observation and laboratory researches, wrote manuscript, and he responds by plagiarism;

Stas $\boldsymbol{G} . \boldsymbol{V}$. - treated data of field observation and laboratory researches and realized calculated experiment.

\section{КОНФЛИКТ ИНТЕРЕСОВ / Conflict of interest:}

Авторы заявляют об отсутствии конфликта интересов / The authors declare no conflict of interest. 


\section{ЛИТЕРАТУРА:}

1. Брикеты из отходов обогатительных фабрик / В.И. Ефимов, С.И. Митичкин, В.Л. Рыбак, Л. Л. Рыбак / Перспективы инновационного развития угольных регионов России. Сборник трудов IV Международной научно-практической конференции. Прокопьевск. КузГТУ. 2014. С. 17-19.

2. Ефимов В. И., Жабин А. Б., Стась Г.В. Аэрогазодинамические процессы, влияющие на радоновую опасность в угольных шахтах // Записки Горного института. СанктПетербургский горный университет. 2017. Т. 223. С. 109-116.

3. Голик В.И., Комащенко В.И., Страданченко С.Г., Масленников С.А. Повышение полноты использования недр путем глубокой утилизации отходов обогащения угля // Горный журнал. 2012. N 9. С. 91-95.

4. Dubilski J. Sustainable Development of Mining Mineral Resources // J. Sustain. Min. 2013. N1. Pp. 1-6.

5. Голик В.И., Комащенко В.И. Отходы обогащения железистых кварцитов как сырье для доизвлечения металлов и использования в качестве закладочных смесей // Горный журнал. 2017. N 3. C. 43-47. DOI 10.17580/GZH.2017.03.08.

6. Harris J. M., Roach B. Environmental and Natural Resource Economics // A Contemporary Approach. M. E. Sharpe, Inc., Armonk, NewYork, 2013. Pp. 67-85.

7. Rolf Dieter Stoll, Christian Niemann-Delius, Carsten Drebenstedt, Klaus Müllensiefen: Der BraunkohlentagebauBedeutung, Planung, Betrieb, Technik, Umwelt. SpringerVerlag, Berlin, Heidelberg. 2009. P. 605.

8. Потокина М.В. Анализ существующих методов утилизации шламов, илов и осадков сточных вод // Инновации молодых: Сборник научных трудов, посвященных 65-летию Победы в Великой Отечественной войне и 15-летию НФИ КемГУ / РИО НФИ «КемГУ». Новокузнецк, 2010. 250 с.

9. Стась Г.В, Агеев И.И., Демина О.В. Алгоритмы и комплекс программных средств для прогноза газообмена в атмосфере шахт Подмосковного угольного бассейна // Безопасность жизнедеятельности. 2010. N5. С. 53-56.

10. Грязев М.В., Качурин Н.М., Стась Г.В. Аэрогазодинамические процессы и аэрологическая безопасность при подземной добыче полезных ископаемых: монография. Тула: Изд-во ТулГУ, 2018. 266 с.
11. Левкин Н.Д., Комиссаров М.С., Рыбак В.Л. Защита территорий от загрязнения стоками полигонов твердых отходов // Безопасность жизнедеятельности. 2012. N 12. C. $48-50$.

12. Алехин В.И., Мигуля П.С., Проскурня Ю.А. Минералого-петрографические и эколого-геохимические особенности пород терриконов Донбасса (на примере Донецко-Макеевского промышленного района) // Сборник научных трудов НГА Украины. Днепропетровск. 1998. Т. 5, N3. C. $35-39$.

13. Broder J. Merkel, Britta Planner-Freidrich. Groundwater Geochemistry-A pratical guide to modeling of natural and contaminated aquatic systems // Springer, Berlin. 2005. Pp. 230-238.

14. Wang Gang, Xie Jun, Xue Sheng, Wang Haiyang. Mining a coal seam below a heating goaf with a force auxiliary ventilation system at Longhua underground coal mine // International Journal of Mining Science and Technology. China. 2015. Vol. 25. Pp. 67-72.

15. Chen H. L. Brief analysis of the technical points about the tailings pond environmental impact assessment // Advanced Materials Research. 2014. Vol. 955-959. Pp. 1685-1689.

16. Леонов П.А., Сурначев Б.А. Породные отвалы угольных шахт. М.: Недра, 1970. 112 с.

17. Wang J.-A., Park H.D. Coal mining above a confined aquifer. International Journal of Rock // Mechanics \& Mining Sciences. 2003. Pp. 537-551.

18. К геоэкологии Донбасса / Панов Б.С., Шевченко О.А., Проскурня Ю.А. и др. // Проблемы экологии. Донецк: ДонГТУ. 1999. ⒈ С. 17-26.

19. Golik V., Komaschenko V., Morkun V., Khasheva $Z$. The effectiveness of combining the stages of ore fields development // Metallurgical and Mining Industry. 2015. T. 7. N5. C. 401-405.

20. Muller N. Z., Mendelsohn R., Nordhaus W. Environmental Accounting for Pollution in the United States Economy // American Economic Review. 2011. Vol. 101. No 5. Pp. 1649-1675.

\section{СВЕДЕНИЯ ОБ АВТОРАХ / Information about authors:}

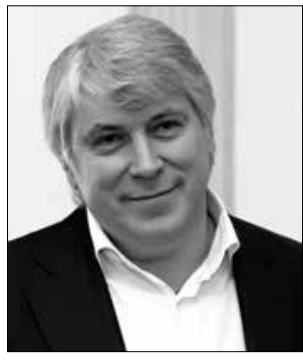

ГРЯЗЕВ Михаил Васильевич доктор технических наук, профессор, ректор, 300012, Тульский государственный университет, Тула, Россия.

Тел.: +7(4872)35-21-55; ecology_tsu_tula@mail.ru

Mihail V. GRIYZEV - Doctor of Sciences, Full Professor, Rector, Tula State University, 300012, Tula, Russia.

Ph.: +7(4872)35-21-55; ecology_tsu_tula@mail.ru

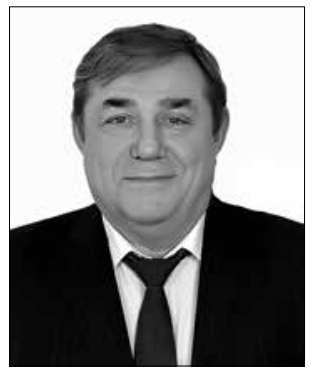

КАЧУРИН Николай Михайлович - доктор технических наук, профессор, заведующий кафедрой. 300012, Тульский государственный университет, Тула, Россия.

Тел.: +7(4872)35-20-41;

ecology_tsu_tula@mail.ru

Nikolai M. KACHURIN - Doctor of Sciences, Full Professor, Chief of a Department, 300012, Tula State University, Tula, Russia. Ph.:+7(4872)35-20-41; ecology_tsu_tula@mail.ru 


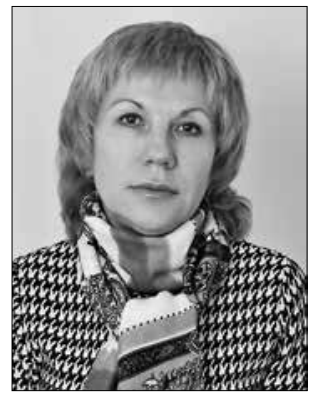

СТАСЬ Галина Викторовна - кандидат технических наук, доцент, Тульский государственный университет, 300012, Тула, Россия.

Тел.: +7(4872)35-20-41; galina_stas@mail.ru

Galina V. STAS - Candidate of Technical Sciences, Docent, Tula State University, 300012, Tula, Russia. Ph.:+7(4872)35-20-41; galina_stas@,mail.ru

\title{
DUST AND GAS EMISSIONS FROM THE DUMPS SURFACES OF THE LIQUIDATED MINES OF THE MOSCOW COAL BASIN
}

\author{
M. V. Gryazev, \\ N. M. Kachurin,* \\ G. V. Stas \\ Tula State University, Tula, Russia, ecology_tsu_tula@mail.ru
}

DOI: $10.21177 / 1998-4502-2018-10-4-500-508$

Purpose. The work deals with the problem of minimizing the negative impact of the tailings of coal mining and processing on the ecosystems of the environment by optimizing the parameters of the construction and operation of the dumps.

Methods. The object is achieved by a method of mathematical modeling aero - gas - dynamics processes based on the system of Reynolds equations in the flow of air masses of waste rock dumps.

Results.

The simulation parameters of aero - gas - dynamics processes in the flow of waste dumps of atmospheric flows were obtained using $\mathrm{O}$. Reynolds equations describing the flow of the viscous, compressible heat-conductive gas in threedimensional formulation which consists of the basic conservation equations. On the basis of the simulation results the generalized geo - ecological model of technological periods of coal mining by underground method is formulated which is a matrix of the physical models of dust and gas pollutants emission processes in the environmental ecosystems and their mathematically formalized description. It is shown that the intensity of dusting rock dumps depends on a number of factors, the main of which are the dispersed composition, dust humidity, as well as the direction and speed of the wind. The analysis of the results of the computational experiment determined that during the transfer of the gas pollutant its concentration under wind action in the simulated space changes slightly. It was found that the intensity of dust deposition in the area of mines is determined by the value of the dust soaring rate and the value of the sedimentation coefficient.

Summary. The territory of the studied mines is polluted mainly with lead. Calculation aero - gas - dynamics processes parameters of waste dumps flow on the basis of Reynolds equations in three-dimensional formulation gives correct results.

Keywords: production and processing tails, coal, environment, dump, mathematical modeling, air masses.

\section{References}

1. The briquettes from waste processing plants / V. I. Efimov, S. I., Mitichkin, V. L. Rybak, L. L. Rybak // prospects of innovative development of coal regions of Russia: SB. papers of the IV International scientific-practical conference // Prokopyevsk, KuzGTU, 2014, pp. 17-19.

2. Efimov, V. I., Zhabin A. B., G. V. Stas Aerogasdynamics processes that influence the radon hazard in the coal mine. Zapiski of the Mining Institute of St. Petersburg mining University, 2017, vol. 223, pp. 109-116.

3. Golik V. I., Komashchenko V. I., Stradanchenko S. G., Maslennikov S. A. increasing the completeness of subsoil use by deep utilization of coal enrichment waste. Gorny Zhurnal, 2012, no 9, pp. 91-95.

4. Dubilski J. Sustainable Development of Mining Mineral Resources. J. Sustain. Min, 2013. no 1, pp. 1-6.

5. Golik V. I., Komashchenko V. I. waste of ferruginous quartzite enrichment as a raw material for metal recovery and use as tab mixtures DOI 10.17580/GZH.2017.03.08. Mining journal, 2017, no 3, pp. 43-47.

6. Harris J. M., Roach B. Environmental and Natural Resource Economics. A Contemporary Approach. M. E. Sharpe, Inc., Armonk, NewYork, 2013, pp.67-85.

7. Rolf Dieter Stoll, Christian Niemann-Delius, Carsten Drebenstedt, Klaus Müllensiefen: Der Braunkohlentagebau - Bedeutung, Planung, Betrieb, Technik, Umwelt. Springer-Verlag, Berlin, Heidelberg, 2009, p. 605.

8. Photokina M. V. Analysis of existing methods of disposal of slimes, sludge and effluent. Innovation young: $S B$. nauch. papers, internat. The 65th anniversary of Victory in the great Patriotic war and the 15th anniversary of NFI Ke$m G U$. Novokuznetsk, RIO NFI "Kemerovo state University", 2010, $250 \mathrm{p}$.

9. Stas G. V, Ageev I. I., Demina O. V. Algorithms and complex of software for prediction of gas exchange in the atmosphere of mines of the near Moscow coal basin. Life Safety, 2010, no 5, pp. 53-56. 
10. Gryazev M. V., Kachurin N. M. Stas G. V. Aerogasdynamics processes and aerological safety in underground mining: monograph. Tula, Izd-vo TulGU, 2018. 266 p.

11. Levkin N. D... Komissarov M. S., Rybak V. L. protection of territories from pollution by runoff of solid waste landfills. Life Safety, 2012, no 12, pp. 48-50.

12. Alekhin V. I., Migulya P. S., Proskurnya Yu. a. Mineralogical and petrography-economic and ecological-geochemical peculiarities of rocks of waste heaps of Donbas (on the example of Donetsk-Makeevka industrial area). Collection of scientific works of NMU of Ukraine, Dnepropetrovsk, 1998, vol. 5, no 3, p. 35-39.

13. Broder J. Merkel, Britta Planner-Freidrich. Groundwater Geochemistry-A pratical guide to modeling of natural and contaminated aquatic systems. Springer, Berlin, 2005, pp. 230-238.

14. Wang Gang, Xie Jun, Xue Sheng, Wang Haiyang. Mining a coal seam below a heating goaf with a force auxiliary ventilation system at Longhua underground coal mine. International Journal of Mining Science and Technology, China, 2015, vol. 25, pp. 67-72.
15. Chen H. L. Brief analysis of the technical points about the tailings pond environmental impact assessment. Advanced Materials Research, 2014, vol. 955-959, pp. 1685-1689.

16. Leonov, P. A., Surnachev B. A. Spoil heaps of coal mines. Moscow, Nedra, 1970, 112 p.

17. J.-A. Wang, H.D. Park. Coal mining above a confined aquifer. International Journal of Rock. Mechanics \& Mining Sciences, 2003, pp. 537-551.

18. To Geoecology of Donbass / Panov B. S., Shevchenko O. A., Proskurnya Yu. a., etc. Problems of ecology. Donetsk, DonSTU, 1999, no 1, pp. 17-26.

19. Golik V., Komaschenko V., Morkun V., Khasheva Z. The effectiveness of combining the stages of ore fields development. Metallurgical and Mining Industry, 2015, v. 7, no 5, pp. 401-405.

20. Muller N. Z., Mendelsohn R., Nordhaus W. Environmental Accounting for Pollution in the United States Economy. American Economic Review, 2011, vol. 101, no 5, pp. 1649-1675.

Article received 19.02.2018 


\section{РАЗВИТИЕ СЕЙСМОСТОЙКОГО СТРОИТЕЛЬСТВА НА ГОРНЫХ ТЕРРИТОРИЯХ СЕВЕРНОЙ ОСЕТИИ НА ОСНОВЕ НОВОЙ РЕГИОНАЛЬНОЙ КРИВОЙ КОЭФФИЦИЕНТА ДИНАМИЧНОСТИ}

1 Заалишвили В. Б., *
2 Реквава П. А. ,

${ }^{1}$ Мельков Д. А.
$\mathrm{C}$ Үеверный Кавказ, характеризуясь умеренной сейсмической активностью, относится к районам с высоким потенциалом сейсмической опасности. В процессе изучения схода ледника Колка в 2002 г. было установлено, что максимальное проявление землетрясений в горных районах Северной Осетии достигало 9-10 баллов. Более того, позже было установлено, что проходящий непосредственно в южной части территории г. Владикавказа, столицы РСО-Алания, разлом может быть источником сильного землетрясения с максимальной ожидаемой магнитудой $\mathrm{M}=7,1$, что может формировать 9-10-балльные величины сейсмической активности непосредственно в густонаселенном городе. Это обстоятельство необходимо учитывать при сейсмостойком проектировании и практическом строительстве. Сейсмическая безопасность - основа устойчивого развития горных территорий.

В условиях умеренной сейсмической активности, когда записи сильных воздействий на исследуемой территории практически отсутствуют, используются различные модели генерирования синтетических акселерограмм. Одним из методов является стохастический метод, основанный на вероятностных моделях с учетом региональных особенностей очагов землетрясений.

Необходимость расчета зданий и сооружений на сейсмические воздействия в разнообразных сейсмотектонических и инженерно-геологических условиях привела к созданию стохастических моделей сейсмических колебаний грунтов [1-3]. Синтетические акселерограммы строятся на основе вероятностных моделей с учетом региональных особенностей очагов землетрясений [4-9]. В результате появляется возможность разработки региональных кривых коэффициента динамичности на основе стохастического моделирования. Данный метод был применен для территории Северной Осетии на основе подхода, предложенного в работе П. Реквава [2] и в дальнейшем используемого автором для оценки сейсмических воздействий для территории г. Тбилиси [10-12].

Синтетическая акселерограмма воспроизводится для набора параметров, задаваемых в зависимости от класса решаемых задач. В нашем случае, для определения реакции здания на сейсмические воздействия рассматриваются колебания с периодом $0,2-0,5$ с и продолжительностью 10-30 С. Данные значения характерны для плотных грунтов. Влияние строения верхней части разреза на спектральный состав колебаний в каждом конкретном случае рассматривается нами отдельно [13-14].

Для моделирования подобных воздействий используется квазистационарная или амплитудно-нестационарная модель. В ней составляющие сейсмического воздействия представляются в виде произведения стационарной случайной функции и детерминистской огибающей. Главной характеристикой стационарного процесса является спектральная плотность, которая, как правило, описывается дробно-рациональной функцией. Поскольку уровень модуляции колебаний не превышает $10-15 \%$, она не учитывается.

\footnotetext{
${ }^{1}$ Геофизический институт ВНЦ РАН, г. Владикавказ, Россия, cgi_ras@mail.ru

${ }^{2}$ Национальная Ассоциация Грузии по сейсмостойкому строительству и инженерной сейсмологии, Тбилиси, Грузия, rekvavapaata@yahoo.com
}

УДК: 550.34

DOI: 10.21171/1998-4502-201810-4-509-517

Северный Кавказ относится к районам с высоким потенциалом сейсмической опасности. Проходящий непосредственно в южной части территориu е. Владикавказа разлом может быть источником сильного землетрясения с максимальной ожидаемой магнитудой $M=7,1$, что может формировать интенсивность 9-10 баллов в густонаселенном городе. В условиях умеренной сейсмической активности, когда записи сильных воздействий на исследуемой территории практически отсутствуют, использован стохастический метод генерирования синтетических акселерограмм, основанный на вероятностных моделях, учитывающих региональные особенности очагов землетрясений. Для наиболее опасных сейсмических зон получены синтетические акселерограммы. Построены кривые коэффициента динамичности и соответствующая огибающая, учитывающая особенности расположения очагов возможных землетрясений на исследуемой территории, учет которых позволит повысить безопасность населения.

\section{КЛЮЧЕВЫЕ СЛОВА:}

сейсмические воздействия, акселерограмма, стохастический метод, коэфффициент динамичности

Статья поступила в редакцию 13.09.2018. 
Таким образом, сейсмическое воздействие моделируется набором нестационарных Гауссовых процессов, которые отличаются друг от друга преобладающим периодом и продолжительностью колебаний [15]. В результате моделируется разнообразная возможная реализация спектров различных землетрясений территории на основе их региональных особенностей. Каждый $i$-й элемент этого набора или ускорение грунта $Z\left(t, \omega_{i}\right)$ представляет собой произведение стационарного Гауссова процесса $X\left(t, \omega_{i}\right)$ с нулевым математическим ожиданием и детерминированной огибающей $A\left(t, \omega_{i}\right)$, обеспечивающей соответствующую нестационарность движения грунта, в диапазоне $\omega_{\min } \leq \omega_{\mathrm{i}} \leq \omega_{\max }$ :

$$
Z\left(t, \omega_{i}\right)=X\left(t, \omega_{i}\right) A\left(t, \omega_{i}\right),
$$

где $\omega_{i}-$ преобладающая частота $i$-го процесса, eе граничные значения $\omega_{\text {min }}$ и $\omega_{\text {max }}$ задаются на основании эмпирических данных.

Соответствующие функции в выражении (1) определяются на основании статистического анализа акселерограмм землетрясений и данных о возможных очагах землетрясений на исследуемой территории, их параметрах (магнитуда, глубина очага) и связях с параметрами воздействий (сейсмическая интенсивность или амплитуда ускорения, преобладающий период, продолжительность колебаний) [16-20].

Анализ инструментальных данных показывает, что даже в пределах одного региона интенсивность, продолжительность и преобладающий период колебаний могут различаться. Поэтому в каждой составляющей в стохастической модели рассматривается диапазон частот $\omega_{\min } \leq \omega \leq \omega_{\max }$, с целью учета вариации частот колебаний при различной реализации.

Тогда модель может быть представлена в форме мультипликативных процессов Гаусса, каждый $i$-й элемент которого рассчитывается по формуле:

$$
Z\left(t, \omega_{i}\right)=A\left(t, \omega_{i}\right) \sigma\left(\omega_{i}\right) x\left(t, \omega_{i}\right),
$$

где $\omega_{\mathrm{i}}-$ круговая частота, соответствующая преобладающей частоте $j$-го процесса;

$\sigma_{\mathrm{i}}\left(t, \omega_{\mathrm{i}}\right)$ - среднеквадратическое значение ускорения;

$x_{i}\left(t, \omega_{\mathrm{i}}\right)-$ нормализованная случайная функция с нулевым математическим ожиданием, которая характеризуется корреляционной функцией:

$$
K(\tau)=e^{-\alpha_{i}|\tau|} \cos \omega_{i} \tau,
$$

или

$$
K(\tau)=e^{-\alpha_{j}|\tau|}\left(\cos \omega_{i} \tau+\alpha_{i} / \omega_{i} \sin \omega_{i}|\tau|\right) .
$$

Нормализованная огибающая функция стационарного процесса для фиксированных значений $\omega_{\mathrm{j}}$ представляется в форме импульса Берлаге:

$$
A\left(t, \omega_{i}\right)=A_{i} t e^{-\varepsilon_{i} t} ; \quad|A|_{\max }=1 .
$$

Учитывая нормирование $\left|\mathrm{A}_{\mathrm{i}}\left(\mathrm{t}, \omega_{\mathrm{j}}\right)\right|_{\max }=1$ формула (5) примет вид:

$$
A\left(t, \omega_{j}\right)=\varepsilon_{j} t e^{1-\varepsilon_{j} t} .
$$

Для моделирования трехкомпонентных записей используются масштабирующие коэффициенты [12]: для горизонтальных компонент 1,0 и 0,85 и для вертикальной компоненты - 0,7.

Для моделирования случайного процесса с заданной корреляционной функцией был использован следующий численный алгоритм:

1. Построение соответствующей корреляционной матрицы.

2. Факторизация корреляционной матрицы по Холецкому и выделение нижнего треугольного сомножителя.

3. Формирование вектора-столбца из независимых случайных чисел с соответствующим законом распределения, нулевым математическим ожиданием и единичной дисперсией.

4. Умножение нижнего треугольного сомножителя на вектор.

Алгоритм был реализован в среде MATLAB.

В результате, в модели учитывается четыре параметра. Вместе с тем каждый сомножитель, соответствующий определенному значению $\omega_{\mathrm{i}}$, задается следующими тремя параметрами:

$\alpha$ - коэффициент корреляции, определяет ширину спектра;

$\varepsilon$ - определяет эффективную продолжительность активной фазы колебаний и нестационарность процесса;

$\sigma$ - интенсивность случайного процесса, которая определяется его дисперсией.

В расчетах была принята следующая функциональная зависимость между параметрами $\alpha, \varepsilon, \sigma$ [15]:

$$
\begin{gathered}
\varepsilon=0,05 \omega, \\
0,36 \omega \leq \alpha \leq 0,5 \omega, \\
\sigma=B \omega^{0,5},
\end{gathered}
$$

где $B=15,30,60$ для интенсивности 7,8 и 9 баллов соответственно.

Для определения преобладающего периода $T$ колебаний грунта, продолжительности колебаний $D$, максимального ускорения $\ddot{U}$ и ожидаемой интенсивности $I$ были использованы эмпирические соотношения, приведенные в работе [16]: 
$\lg T=0,15 M+0,25 \lg R-1,9$,

$\lg D=0,2 M+0,5 \lg R-1,3$,

$\ddot{U}=5600(R+40)^{-2} e^{0,8 M}$,

$I=2,5(\lg \ddot{U}+0,03 D)+1,5$.

Таким образом, исходными данными для расче- тов служат максимальная магнитуда $\mathrm{M}_{\text {макс }}$, глубина очага $h$ и карта разломов.

Используя выражения (9) - (10) для максимальных значений магнитуд и минимальных значений гипоцентральных расстояний, представленных в табл. 1, были вычислены параметры, необходимые для генерирования синтетических акселерограмм

Параметры очагов возможных землетрясений

Таблица 1 / Table 1 Parameters of sources of possible earthquakes

\begin{tabular}{|c|c|c|c|c|}
\hline $\begin{array}{l}\text { Разлом } \\
\text { Fault }\end{array}$ & $\mathbf{M}_{\text {max }}$ & $\begin{array}{l}\text { Глубина очага } \boldsymbol{h}, \text { км } \\
\text { Source depth } h, k m\end{array}$ & $\begin{array}{c}\text { Минимальное расстояние от } \\
\text { зоны до границы города } \Delta, \mathbf{к м} \\
\text { Minimal distance from zone to the } \\
\text { border of the city, } \Delta, \mathrm{km}\end{array}$ & $\begin{array}{c}\text { Ожидаемая максимальная интен- } \\
\text { сивность в г. Владикавказ, I } \\
\text { Expected maximum intensity in } \\
\text { Vladikavkaz, I }\end{array}$ \\
\hline$f v 3$ & 6,5 & 15 & 5 & 8,8 \\
\hline$f 2 \_4$ & 6,5 & 15 & 21 & 8,1 \\
\hline$f_{c} 2$ & 7,0 & 15 & 33 & 8,3 \\
\hline$f v 1$ & 6,5 & 15 & 40 & 7,3 \\
\hline$f_{c \_} 3$ & 7,0 & 15 & 48 & 7,8 \\
\hline fv6 & 6,0 & 15 & 75 & 5,7 \\
\hline$f 23 \_1$ & 5,5 & 15 & 76 & 4,9 \\
\hline$f 1$ & 7,0 & 15 & 77 & 7,2 \\
\hline$f 3$ & 6,5 & 15 & 77 & 6,4 \\
\hline$f_{c} \_l$ & 7,0 & 15 & 99 & 6,8 \\
\hline$f 2 \_2$ & 7,0 & 15 & 120 & 6,5 \\
\hline$f_{c} \_5$ & 6,0 & 15 & 122 & 5,0 \\
\hline$f 9 \_2$ & 5,5 & 15 & 123 & 4,2 \\
\hline$f 9 \_1$ & 5,5 & 15 & 123 & 4,2 \\
\hline$f 2 \_3$ & 6,0 & 15 & 125 & 5,0 \\
\hline$f 9 \_3$ & 5,5 & 15 & 126 & 4,2 \\
\hline$f v 7$ & 7,0 & 15 & 126 & 6,4 \\
\hline$f 7$ & 5,5 & 15 & 141 & 4,0 \\
\hline$f 2 \_l$ & 7,0 & 15 & 142 & 6,3 \\
\hline$f 15$ & 6,5 & 15 & 149 & 5,5 \\
\hline$f 16$ & 6,0 & 15 & 149 & 4,7 \\
\hline$f j \_2$ & 6,5 & 15 & 170 & 5,3 \\
\hline$f j_{-} l$ & 6,5 & 15 & 173 & 5,2 \\
\hline f4 & 6,0 & 15 & 176 & 4,5 \\
\hline f10_3 & 5,0 & 15 & 179 & 2,9 \\
\hline f6 & 6,5 & 15 & 183 & 5,2 \\
\hline fje & 5,0 & 15 & 193 & 2,8 \\
\hline$f 10 \_2$ & 5,0 & 15 & 196 & 2,8 \\
\hline f10_l & 5,0 & 15 & 219 & 2,6 \\
\hline$f_{s}$ & 7,0 & 15 & 224 & 5,6 \\
\hline$f 23 \_4$ & 6,0 & 15 & 237 & 4,0 \\
\hline$f_{c} \_4$ & 6,0 & 15 & 253 & 3,9 \\
\hline$f 23 \_3$ & 5,0 & 15 & 253 & 2,4 \\
\hline$f 4 \_1$ & 5,5 & 15 & 280 & 3,0 \\
\hline$f 23 \_5$ & 6,0 & 15 & 311 & 3,6 \\
\hline$f 22$ & 5,0 & 15 & 330 & 2,0 \\
\hline$f 21$ & 5,0 & 15 & 379 & 1,8 \\
\hline
\end{tabular}



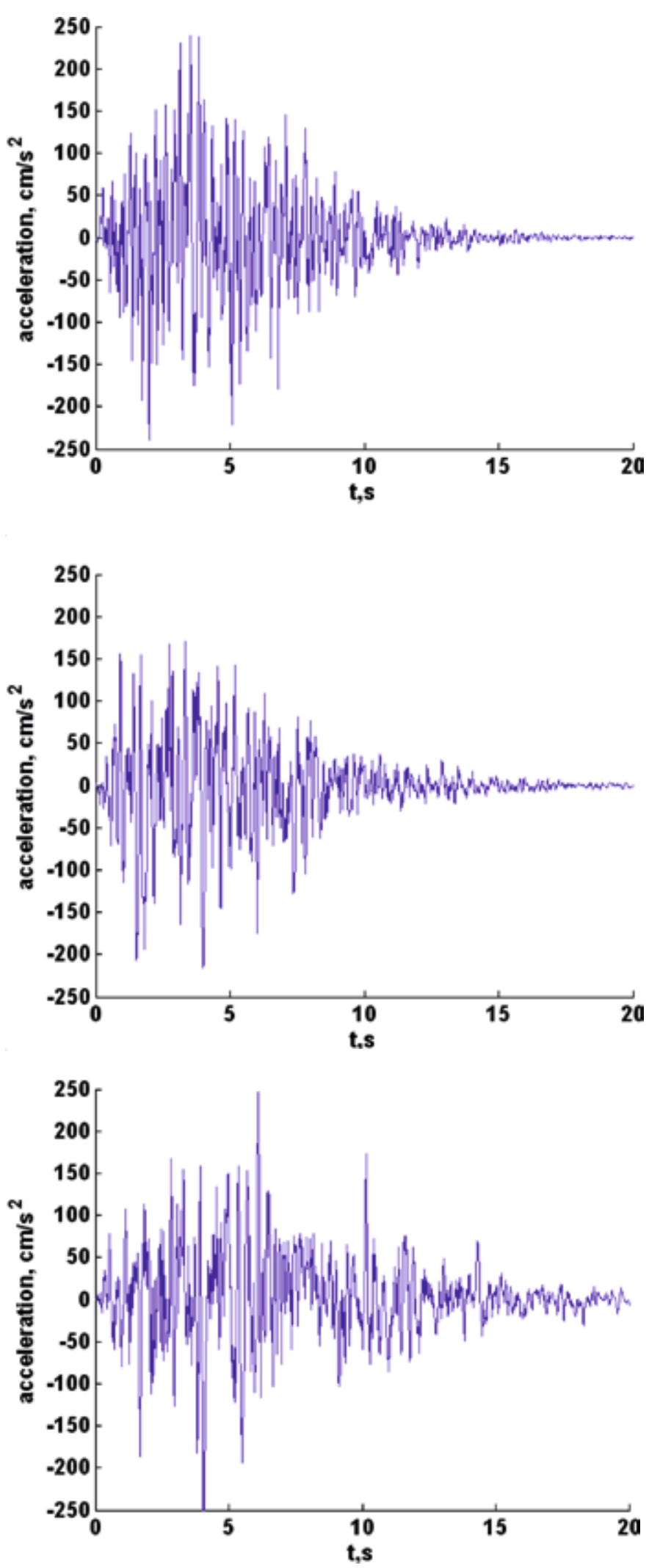

Pис. 1. Синтетические акселерограммы для трех наиболее опасных зон $f v 3, f 2 \_4, f c \_2$

Fig. 1. Synthetic accelerograms for the three most hazardous zones: $f v 3, f 2 \_4, f c_{-} 2$

(табл. 2). При определении параметров прогнозируемых землетрясений принимается одинаковая вероятность возникновения очага в пределах каждой зоны.

На рис. 1 представлены акселерограммы, гене-

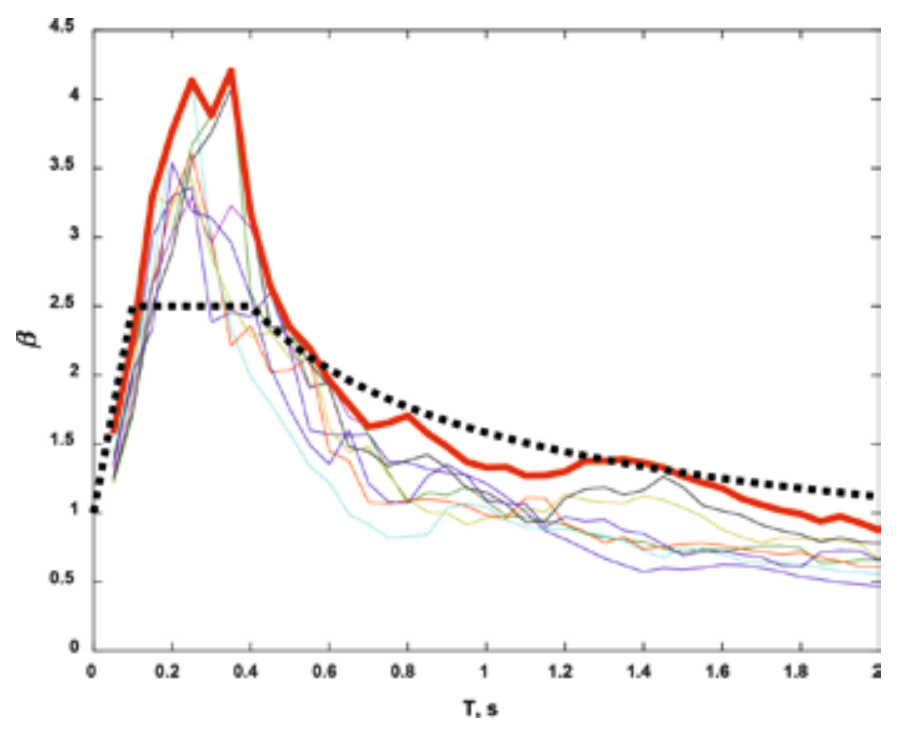

Puc. 2. Стохастическая кривая коэффициента динамичности, полученная в виде огибающей для всех моделируемых зон (красная линия), кривая коэффициента динамичности, согласно действующим строительным нормам (пунктирная линия)

Fig. 2. The stochastic dynamic coefficient curve, obtained in the form of an envelope for all simulated zones (red line), the dynamic coefficient curve, according to the current building codes (dashed line)

рируемые из наиболее опасных зон для территории г. Владикавказа. Третья зона ( $f$ __2 $)$ характеризуется наибольшей магнитудой и эпицентральным расстоянием, в силу чего отмечается преобладание более низких частот и увеличение длительности колебаний.

В результате для всех синтезированных акселерограмм были построены кривые коэффициента динамичности и соответствующая огибающая, представленная на рис. 2. Выполнено сравнение с кривой коэффициента динамичности согласно строительным нормам СП 14.13330.2014 (актуализированного СНиП ІІ-7-81* "Строительство в сейсмических районах"). В области 0,4-2 с полученные значения соответствуют кривой СНиП, в короткопериодной части отдельные значения превышены в 1,6-1,7 раз, что обычно и наблюдается при анализе реальных записей землетрясений. Для средних значений превышение составляет 1.3.

\section{Выводы}

1. Рассчитаны типовые сейсмические воздействия, позволяющие оценить спектры реакции застройки при сильных землетрясениях от наиболее опасных для территории г. Владикавказа разломов.

2. Использована квазистационарная модель, в которой составляющие сейсмического воздействия представляются в виде произведения стационарной случайной функции и детерминистской огибающей.

3. Получена огибающая кривая, учитывающая влияние всех сейсмических источников для территории г. Владикавказа. 
Параметры ожидаемых колебаний

Parameters of expected loadings

\begin{tabular}{|c|c|c|c|c|c|c|c|c|c|}
\hline $\begin{array}{c}\text { Разлом } \\
\text { Fault }\end{array}$ & $\begin{array}{l}\mathbf{R}, \mathbf{\kappa м} \\
R, k m\end{array}$ & $\begin{array}{l}\text { T, c } \\
T, s\end{array}$ & $\begin{array}{l}\mathbf{D}, \mathbf{c} \\
D, s\end{array}$ & $\begin{array}{l}\mathbf{u}, \mathbf{c m} / \mathbf{c}^{2} \\
u, \mathrm{~cm} / \mathrm{s}^{2}\end{array}$ & $\begin{array}{c}\text { I(u,D), балл } \\
I(u, D), \text { intensity degree }\end{array}$ & $\begin{array}{l}\omega, c^{-1} \\
\omega, s^{-1}\end{array}$ & $\begin{array}{l}\alpha, c^{-1} \\
\alpha, s^{-1}\end{array}$ & $\begin{array}{l}\varepsilon, c^{-1} \\
\varepsilon, s^{-1}\end{array}$ & $\begin{array}{l}\sigma, \mathbf{c} / \mathbf{c}^{2} \\
\sigma, \mathrm{cm} / \mathrm{s}^{2}\end{array}$ \\
\hline fv3 & 15,8 & 0,24 & 3,98 & 325,73 & 8,1 & 26,51 & 13,25 & 0,40 & 108,58 \\
\hline $\mathrm{f} 2 \_4$ & 25,8 & 0,27 & 5,08 & 234,67 & 7,8 & 23,46 & 11,73 & 0,35 & 78,22 \\
\hline fc_2 & 36,5 & 0,35 & 7,61 & 258,48 & 8,1 & 18,09 & 9,05 & 0,27 & 86,16 \\
\hline fv1 & 43,2 & 0,30 & 6,57 & 146,73 & 7,4 & 20,62 & 10,31 & 0,31 & 48,91 \\
\hline fc_3 & 50,4 & 0,38 & 8,94 & 185,20 & 7,8 & 16,69 & 8,35 & 0,25 & 61,73 \\
\hline fv6 & 76,1 & 0,30 & 6,93 & 50,46 & 6,3 & 21,27 & 10,64 & 0,32 & 16,82 \\
\hline $\mathrm{f} 23 \ldots 1$ & 77,9 & 0,25 & 5,57 & 32,79 & 5,7 & 25,13 & 12,57 & 0,38 & 10,93 \\
\hline f1 & 78,6 & 0,42 & 11,16 & 107,61 & 7,4 & 14,94 & 7,47 & 0,22 & 35,87 \\
\hline f3 & 78,7 & 0,35 & 8,87 & 72,09 & 6,8 & 17,75 & 8,88 & 0,27 & 24,03 \\
\hline fc_1 & 99,8 & 0,45 & 12,58 & 77,49 & 7,2 & 14,07 & 7,04 & 0,21 & 25,83 \\
\hline $\mathrm{f} 2 \_2$ & 120,8 & 0,47 & 13,84 & 58,56 & 7 & 13,42 & 6,71 & 0,20 & 19,52 \\
\hline fc_5 & 122,5 & 0,33 & 8,79 & 25,78 & 5,7 & 18,89 & 9,44 & 0,28 & 8,59 \\
\hline f9_2 & 123,6 & 0,28 & 7,02 & 17,04 & 5,1 & 22,40 & 11,20 & 0,34 & 5,68 \\
\hline f9_1 & 123,8 & 0,28 & 7,02 & 17,00 & 5,1 & 22,39 & 11,19 & 0,34 & 5,67 \\
\hline f2_3 & 126,4 & 0,34 & 8,93 & 24,59 & 5,6 & 18,74 & 9,37 & 0,28 & 8,20 \\
\hline f9_3 & 127,2 & 0,28 & 7,12 & 16,32 & 5,1 & 22,24 & 11,12 & 0,33 & 5,44 \\
\hline fv7 & 127,3 & 0,47 & 14,20 & 54,13 & 6,9 & 13,24 & 6,62 & 0,20 & 18,04 \\
\hline f7 & 141,4 & 0,29 & 7,50 & 13,86 & 4,9 & 21,65 & 10,83 & 0,32 & 4,62 \\
\hline $\mathrm{f} 2 \_1$ & 143,3 & 0,49 & 15,07 & 45,08 & 6,8 & 12,86 & 6,43 & 0,19 & 15,03 \\
\hline $\mathrm{f} 15$ & 149,6 & 0,42 & 12,23 & 28,25 & 6 & 15,12 & 7,56 & 0,23 & 9,42 \\
\hline f16 & 149,6 & 0,35 & 9,72 & 18,93 & 5,4 & 17,97 & 8,98 & 0,27 & 6,31 \\
\hline fj_2 & 170,7 & 0,43 & 13,06 & 22,87 & 5,9 & 14,63 & 7,31 & 0,22 & 7,62 \\
\hline $\mathrm{fj} \_1$ & 173,9 & 0,43 & 13,19 & 22,19 & 5,9 & 14,56 & 7,28 & 0,22 & 7,40 \\
\hline $\mathrm{f} 4$ & 176,4 & 0,36 & 10,55 & 14,53 & 5,2 & 17,24 & 8,62 & 0,26 & 4,84 \\
\hline f10_3 & 179,2 & 0,26 & 6,71 & 6,36 & 4 & 24,26 & 12,13 & 0,36 & 2,12 \\
\hline f6 & 183,5 & 0,44 & 13,55 & 20,33 & 5,8 & 14,36 & 7,18 & 0,22 & 6,78 \\
\hline fje & 193,8 & 0,26 & 6,98 & 5,59 & 3,9 & 23,79 & 11,89 & 0,36 & 1,86 \\
\hline $\mathrm{f} 10 \_2$ & 196,5 & 0,27 & 7,03 & 5,47 & 3,9 & 23,71 & 11,85 & 0,36 & 1,82 \\
\hline $\mathrm{f} 10 \_1$ & 219,1 & 0,27 & 7,42 & 4,55 & 3,7 & 23,07 & 11,53 & 0,35 & 1,52 \\
\hline fs & 224,4 & 0,55 & 18,86 & 21,66 & 6,3 & 11,49 & 5,75 & 0,17 & 7,22 \\
\hline $\mathrm{f} 23 \_4$ & 237,4 & 0,39 & 12,24 & 8,84 & 4,8 & 16,01 & 8,00 & 0,24 & 2,95 \\
\hline fc_4 & 253,1 & 0,40 & 12,64 & 7,92 & 4,7 & 15,75 & 7,88 & 0,24 & 2,64 \\
\hline $\mathrm{f} 23 \_3$ & 253,1 & 0,28 & 7,97 & 3,56 & 3,5 & 22,25 & 11,13 & 0,33 & 1,19 \\
\hline f4_1 & 280,5 & 0,34 & 10,57 & 4,44 & 3,9 & 18,25 & 9,12 & 0,27 & 1,48 \\
\hline f23_5 & 311,7 & 0,42 & 14,02 & 5,50 & 4,4 & 14,95 & 7,48 & 0,22 & 1,83 \\
\hline f22 & 329,9 & 0,30 & 9,10 & 2,23 & 3,1 & 20,82 & 10,41 & 0,31 & 0,74 \\
\hline f21 & 379,3 & 0,31 & 9,76 & 1,74 & 2,8 & 20,11 & 10,06 & 0,30 & 0,58 \\
\hline
\end{tabular}

4. В интервале периодов $T=0,1-0,4$ с ожидаемого сейсмического воздействия получено превышение в 1,6 раз от нормативной кривой коэффициента динамичности, для средних значений превышение составляет 1,3 , в интервале периодов $T=0,4-2,0$ рассчитанные максимальные значения находятся в пределах проектной кривой.

5. Впервые получена региональная динамиче- ская кривая, которая может быть успешно использована при сейсмостойком проектировании и практическом строительстве

6. Использование новой региональной кривой коэффициента динамичности при сейсмостойком строительстве в Северной Осетии позволит повысить безопасность населения - основу устойчивого развития горных территорий 
Работа выполнена в рамках Программы долгосрочного экономического сотрудничества Российской Федерации и Республики Армения на период до 2020 года (Тема: «Разработка модели динамического регионального показателя (коэффициент динамической кривой) инженерно-сейсмологических условий территории на основе анализа инструментальных записей сильных и разрушительных землетрясений») / The work is carried out under long-term economic cooperation program of the Russian Federation and Armenia fill 2020 (The subject elaboration of the dynamic regional coefficient model for the engineering-seismological areas conditions based on the instrumental records analysis of the strong and breaking earthquakes").

\section{$\overline{\text { КРИТЕРИИ АВТОРСТВА / Contribution: }}$}

Заалишвили В.Б. - руководство исследованием, постановка задач, анализ результатов; Реквава П.А. критический анализ результатов, консультирование по вопросам реализации разрабатываемой методики; Мельков Д.А. - программная реализация алгоритмов, расчеты, подготовка иллюстраций / Zaalishvili V.B. management of research, statement of tasks, analysis of results; Rekwava $\boldsymbol{P} . \boldsymbol{A}$. - critical analysis of results, advice on the implementation of the developed methodology; Melkov D.A. - software implementation of algorithms, calculations, preparation of illustrations.

КОНФЛИКТ ИНТЕРЕСОВ / Conflict of interest:

Авторы заявляют об отсутствии конфликта интересов / The authors declare no conflict of interest.

\section{ЛИТЕРАТУРА:}

1. Boore D.M. (1983). Stochastic simulation of highfrequency ground motions based on seismological models of the radiated spectra // Bull. Seism. Soc. Am., 73. 1983. Pp. 18651894.

2. Rekvava P.A. Use of regional models of seismic effect in building design. 10th European Conference on Earthquake Engineering, Duma (ed.). 1995. Pp. 253-256.

3. Beresnev I.A., Atkinson G.M. Stochastic finite-fault modeling of ground motions from the 1994 Northridge, California earthquake. I. Validation on rock sites. // Bulletin of the Seismological Society of America. 1998. Vol. 88. No 6. pp. 1392-1401.

4. Boore D. Thompson E. Revisions to Some Parameters Used in Stochastic-Method Simulations of Ground Motion // Bulletin of the Seismological Society of America. 2015. Vol. 105, No. 2a. April 2015. DOI: 10.1785/0120140281.

5. Yaghmaei-Sabegh S., Lam N. T. K. Ground motion modelling in Tehran based on the stochastic method // Soil Dynamics and Earthquake Engineering, 2010. Vol. 30, No 7. Pp. 525-535.

6. Medel-Vera C., Ji T. J. A stochastic ground motion accelerogram model for Northwest Europe // Soil Dynamics and Earthquake Engineering. 2016. Vol. 82. Pp. 170-195.

7. Kkallas, C., C. B. Papazachos, B. N. Margaris, D. Boore, C. Ventouzi, and A. Skarlatoudis (2018). Stochastic strong ground motion simulation of the Southern Aegean Sea Benioff zone intermediate-depth earthquakes // Bull. Seismol. Soc. Am. 2018. 108. 946-965

8. Kkallas, C., Papazachos, C. B., Boore, D., Ventouzi, C., \& Margaris, B. N. (2018). Historical intermediate-depth earthquakes in the southern Aegean Sea Benioff zone: modeling their anomalous macroseismic patterns with stochastic ground-motion simulations // Bulletin of Earthquake Engineering. DOI: 10.1007/s10518-018-0342-8.

9. Kkallas C., Papazachos C. B., Margaris B. N., Boore D.,
Ventouzi Ch., and Skarlatoudis A. Stochastic Strong Ground Motion Simulation of the Southern Aegean Sea Benioff Zone Intermediate-Depth Earthquakes // Bulletin of the Seismological Society of America. 2018. Vol. 108, No 2. Pp. 946-965, April 2018. DOI: 10.1785/0120170047.

10. Rekvava P and Mdivani K (2010) Modeling of Earthquake Ground Motion for Tbilisi Region // Global Journal of Researches in Engineering. Revolutions in Engineering. 2010. 10 (3). 2-7.

11. Rekvava P., Mdivani K. (2011). Elaboration of the Seismic Influence Spatial Models for Performance-Based Design Considering Seismological and Engineering-Geological Conditions of Tbilisi Region / Georgian National Science Foundation, Grant N GNSF/ST08/7-484.

12. Rekvava P. and Mdivani K., Qajaia L. (2014) Acceleration response spectra for Tbilisi city with site effects / Proces. Second European Conference on Earthquake Engineering and Seismology, Istanbul, Aug. 25-29. 2014. 11 p.

13. Zaalishvili V.B., Melkov D.A., Kanukov A.S., Dzeranov B.V., Shepelev V.D. Application of microseismic and calculational techniques in engineering-geological zonation // International Journal of GEOMATE. 2016. Vol. 10. No 1. Pp. 1670-1674.

14. Zaalishvili V.B., Kanukov A.S., Melkov D.A., Makiev V.D., Dzobelova L.V. Development of a unified model of geoinformation system for city planning and integration / International Journal of GEOMATE. 2018. Vol. 15. No 51. Pp. 160 166.

15. Айзенберг Я.М. Сооружения с выключающимися связями для сейсмических районов. М.: Стройиздат, 1976. $229 \mathrm{c}$.

16. Аптикаев Ф.Ф., Запольский К.К., Нерсесов И.Л., Штейнберг В.В. Интенсивность землетрясений и количественные характеристики колебаний грунтов // Сейсмическое районирование. М.: Наука, 1980. С. 13-21. 
17. Zaalishvili V.B., Melkov D., Kanukov A.S., Dzeranov B.V. Spectral-temporal features of seismic loadings on the basis of strong motion wavelet database // International Journal of GEOMATE. 2016. Vol. 10. No 1. Pp. 1656-1661.

18. Чернов Ю.К., Чернов А.Ю. Вероятностные модели сейсмических воздействий для прогнозирования сейсмической опасности в инженерных целях // Геология и геофизика Юга России. 2017. N 2. С. 116-128.

19. Чернов Ю.К., Чернов А.Ю. Модели для описания связи пикового ускорения с макросейсмической балльностью сотрясений грунта // Геология и геофизика Юга России. 2017. N 3. С. 117-124.
20. Чернов Ю.К. Реконструкция вероятных спектров колебаний грунта при сильных землетрясениях Северного Кавказа по их макросейсмическому полю (статья в коллективной монографии) // Геолого-геофизические исследования глубинного строения Кавказа: геология и геофизика Кавказа: современные вызовы и методы исследований / Под ред. В.Б. Заалишвили. Владикавказ: ГФИ ВНЦ РАН. 978-5-904868-21-5. 2017. С. 251-257.

\section{СВЕДЕНИЯ ОБ АВТОРАХ / Information about authors:}

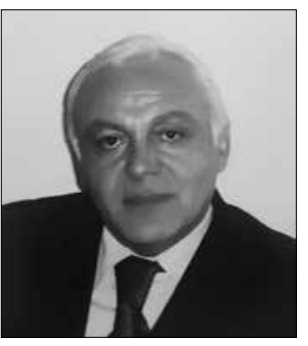

РЕКВАВА Паата Абесаломович - доктор технических наук, профессор, директор, Национальная ассоциация Грузии по сейсмостойкому строительству и инженерной сейсмологии, Тбилиси, Грузия. e-mail: rekvavapaata@yahoo.com

Paata Ab.REKVAVA - Doctor of Technical Sciences, Professor, Director, National Association of Georgia for Earthquake Engineering and Engineering Seismology, Tbilisi, Georgia.e-mail: rekvavapaata@yahoo.com

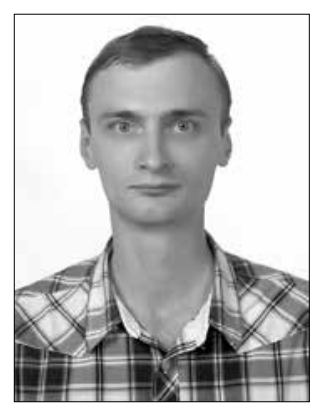

МЕЛЬКОВ Дмитрий Андреевич - кандидат технических наук, ведущий научный сотрудник отдела геофизики, инженерной сейсмологии и геоинформатики. Геофизический институт - филиал Федерального государственного бюджетного учреждения науки Федерального научного центра "Владикавказский научный центр Российской академии наук", 362002, Владикавказ, Россия

Тел.: +7(8672)76-19-28, e-mail: melkovd@mail.ru

Dmitry A. MELKOV - Candidate of Technical Sciences, Leading Researcher of Department of Geophysics, Engineering Seismology and Geo-informatics.

Geophysical Institute - branch of Vladikavkaz Scientific Center of the Russian Academy of Sciences, Vladikavkaz, Russia

Ph.:+7(8672)76-19-28, e-mail: melkovd@mail.ru

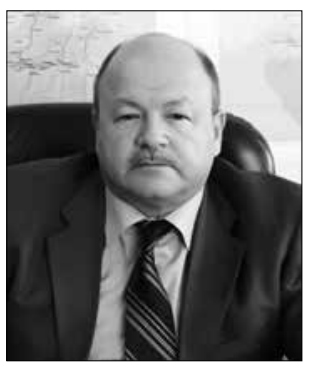

ЗААЛИШВИЛИ Владислав Борисович - доктор физико-математических наук, профессор, директор, заведующий отделом геофизики, инженерной сейсмологии и геоинформатики.

Геофизический институт - филиал Федерального государственного бюджетного учреждения науки Федерального научного центра "Владикавказский научный центр Российской академии наук", 362002, Владикавказ, Россия

Тел.: +7(8672)76-40-84,

e-mail:vzaal@mail.ru

Vladislav B.Zaalishvili - Doctor of Physical-Mathematical Sciences, Director, Head of Department of Geophysics, Engineering Seismology and Geo-informatics.

Geophysical Institute -branch of Vladikavkaz Scientific Center of the Russian Academy of Sciences, Vladikavkaz, Russia

Ph.:+7(8672)76-40-84, e-mail: vzaal@mail.ru 


\title{
DEVELOPMENT OF SEISMIC RESISTANCE CONSTRUCTIONS IN THE MOUNTAIN TERRITORIES OF NORTH OSSETIA ON THE BASIS OF A NEW REGIONAL CURVE OF DYNAMICITY COEFFICIENT
}

\author{
${ }^{1}$ Zaalishvili V.B.,* \\ ${ }^{2}$ Rekvava P.A., \\ ${ }^{1}$ Melkov D.A. \\ ${ }^{1}$ Geophysical Institute,VSC RAS, Vladikavkaz,_Russia,cgi_ras@mail.ru \\ ${ }^{2}$ National Association of Georgia for Earthquake Engineering and Engineering Seismology, Tbilisi, Georgia
}

DOI: $10.21177 / 1998-4502-2018-10-4-509-517$

The Northern Caucasus that is characterized by moderate seismic activity refers to areas with high seismic hazard potential. In the process of investigation the Kolka glacier in 2002, it was found that the maximum earthquake effect for example in the mountainous regions of North Ossetia was reaching 10-11 points. Analysis of instrumental data shows that even within the same region, the intensity, duration, and predominant period of oscillations may vary. Moreover, it was later found out that the fault in the southern part of the city of Vladikavkaz, the capital of the Republic of North Ossetia-Alania, can be a source of a strong earthquake with a maximum expected magnitude of $\mathrm{M}=7.1$, which can form 9-10 points intensity values directly in densely populated city. This circumstance should be taken into account in seismic design and practical construction. Seismic safety is the basis for the sustainable development of mountain areas. In conditions of moderate seismic activity, when there are practically no records of strong motions in the area of interest, different models of generating synthetic accelerograms are used. One of the methods is a stochastic one based on probabilistic models taking into account regional features of earthquake sources. To simulate the effects, a quasi-stationary or amplitude-nonstationary model is used. Components of the seismic action are represented as a product of a stationary random function and a deterministic envelope.

Synthetic accelerograms were obtained for the most dangerous for the territory of the city of Vladikavkaz city seismic zones. Curves of the dynamicity coefficient and the corresponding envelope were constructed, taking into account the particular locations of the sources of possible earthquakes on the investigated territory, accounting for which will increase the safety of the population. In the interval of periods $T=$ $0.1-0.4 \mathrm{~s}$ expected seismic effect is 1.6 times higher than the standard curve of the dynamic coefficient. for average values, the excess is 1.3, in the interval of periods $T=0.4-2.0$, the calculated maximum values are within the calculated curve. For the first time, a regional dynamic curve was obtained which can be successfully used in earthquake-proof design and practical construction.

Keywords: seismic effects, accelerogram, stochastic method, dynamic factor

\section{References}

1. Boore D.M. (1983). Stochastic simulation of highfrequency ground motions based on seismological models of the radiated spectra. Bull. Seism. Soc. Am., 73, 1983, pp. 18651894.

2. Rekvava P.A. Use of regional models of seismic effect in building design. 10th European Conference on Earthquake Engineering, Duma (ed.), 1995, pp. 253-256.
3. Beresnev I.A., Atkinson G.M. Stochastic finite-fault modeling of ground motions from the 1994 Northridge, California earthquake. I. Validation on rock sites. Bulletin of the Seismological Society of America, 1998, Vol. 88, No 6, pp. 1392-1401.

4. Boore D. Thompson E. Revisions to Some Parameters Used in Stochastic-Method Simulations of Ground Motion. Bulletin of the Seismological Society of America, 2015, Vol. 105, No2a. April 2015. DOI: 10.1785/0120140281.

5. Yaghmaei-Sabegh S., Lam N. T. K. Ground motion modelling in Tehran based on the stochastic method. Soil Dynamics and Earthquake Engineering, 2010, Vol. 30, No 7, pp. 525-535.

6. Medel-Vera C., Ji T. J. A stochastic ground motion accelerogram model for Northwest Europe. Soil Dynamics and Earthquake Engineering, 2016, Vol. 82, pp. 170-195.

7. C. Kkallas, C. B. Papazachos, B. N. Margaris, D. Boore, C. Ventouzi, A. Skarlatoudis (2018). Stochastic strong ground motion simulation of the Southern Aegean Sea Benioff zone intermediate-depth earthquakes. Bull. Seismol. Soc. Am, 2018, 108, 946-965

8. Kkallas C., Papazachos C. B., Boore D., Ventouzi C., Margaris B. N. (2018). Historical intermediate-depth earthquakes in the southern Aegean Sea Benioff zone: modeling their anomalous macroseismic patterns with stochastic ground-motion simulations. Bulletin of Earthquake Engineering. DOI: 10.1007/s10518-018-0342-8.

9. Kkallas C., Papazachos C. B., Margaris B. N., Boore D., Ventouzi Ch., and Skarlatoudis A. Stochastic Strong Ground Motion Simulation of the Southern Aegean Sea Benioff Zone Intermediate-Depth Earthquakes. Bulletin of the Seismological Society of America, 2018, Vol. 108, No 2, pp. 946-965, April 2018. DOI: 10.1785/0120170047.

10. Rekvava P., Mdivani K (2010) Modeling of Earthquake Ground Motion for Tbilisi Region. Global Journal of Researches in Engineering. Revolutions in Engineering, 2010, 10 (3), 2-7.

11. Rekvava P., Mdivani K. (2011). Elaboration of the Seismic Influence Spatial Models for Performance-Based Design Considering Seismological and Engineering-Geological Conditions of Tbilisi Region. Georgian National Science Foundation, Grant N GNSF/ST08/7-484.

12. Rekvava P., Mdivani K., Qajaia L. (2014) Acceleration response spectra for Tbilisi city with site effects. Proces. Second European Conference on Earthquake Engineering and Seismology, Istanbul, Aug. 25-29, 2014, 11 p.

13. Zaalishvili V.B., Melkov D.A., Kanukov A.S., Dzeranov B.V., Shepelev V.D. Application of microseismic and 
calculational techniques in engineering-geological zonation. International Journal of GEOMATE, 2016, Vol. 10, No. 1, pp. 1670-1674.

14. Zaalishvili V.B., Kanukov A.S., Melkov D.A., Makiev V.D., Dzobelova L.V. Development of a unified model of geoinformation system for city planning and integration. International Journal of GEOMATE, 2018, Vol. 15, No 51, pp. 160-166.

15. Eisenberg Ya. M. facilities with switch-off links for seismic areas. Moscow, Stroyizdat, 1976, 229 p.

16. Aptikaev F. F., Zapolskiy, K. K., Nersesov, I. L., Steinberg V. the Intensity of earthquakes and quantitative characteristics of fluctuations of soils. Seismic zoning. Moscow, Science, 1980, pp. 13-21.

17. Zaalishvili V. B., Melkov D., Kanukov A. S., Dzeranov B. V., the Spectral-temporal features of seismic loadings on the basis of strong motion wavelet database. International Journal of GEOMATE, 2016, Vol. 10, No1, pp. 1656-1661.
18. Chernov K. K., Chernov A. Yu. Probabilistic models of seismic effects for prediction of seismic hazard for engineering purposes. Geology and Geophysics of the South of Russia, 2017, No2, pp. 116-128.

19. Chernov Y. K., Chernov A. Yu. A model for the description of when peak acceleration from macroseismic by ballinastoe shake the ground. Russian Geology and Geophysics of South of Russia, 2017, No 3, pp. 117-124.

20. Chernov Yu. K. Reconstruction of the probable spectra of the ground motion during strong earthquakes in the North Caucasus in their macroseismic field (article in the collective monograph) . Geophysical study of the deep structure of the Caucasus, Geology and Geophysics of Caucasus: modern challenges and methods of research / Under the editorship of V. B. Zaalishvili. Vladikavkaz: VSC RAS GPI, 2017, pp. 251257. 978-5-904868-21-5.

Article received 13.09.2018. 


\section{ОБЕСПЕЧЕНИЕ УСТОЙЧИВОГО РАЗВИТИЯ ГОРНОТЕХНИЧЕСКОЙ СИСТЕМЫ НА ЗАВЕРШАЮЩЕЙ СТАДИИ ПОДЗЕМНОЙ РАЗРАБОТКИ ЖИЛЬНЫХ ЗОЛОТОРУДНЫХ МЕСТОРОЖДЕНИЙ УРАЛА}

\section{1Рыльникова М.В., * ${ }^{1}$ Струков К.И., 'Есина Е.Н.}

\section{УДК: 622.3}

DOI: 10.21171/1998-4502-201810-4-518-525

\section{Рассмотрены особенности эксплуатации состояния горнотехнических систем на завершающей стадии освоения жильных золоторудных месторождений Урала. Обоснована концепция освоения месторождений на завершающих стадиях эксплуатации, включающая реструктуризацию запасов и компенсацию влияния негативных факторов при доработке месторождения за счет внедрения ресурсосберегающих и энергоэффрективных геотехнологий, в том числе с переходом на использование возобновляемых источников энергии.}

\section{КЛЮЧЕВЫЕ СЛОВА:}

горнотехническая система, устойчивое развитие, подземная геотехнология, завершающая стадия, золоторудные месторождения

Статья поступила в редакцию 02.06.2018.

\section{Введение}

Жильные золоторудные месторождения Урала имеют ряд особенностей: сложные геологическое строение и условия залегания рудных тел; разнообразные физико-механические свойства пород; тектоническая структура руд и вмещающих пород; высокие гравитационно-тектонические напряжения в горных массивах. Значительная часть запасов золотосодержащих руд месторождений сосредоточена в крутопадающих жилах и жилообразных телах, характеризующихся сложной структурой и наличием нескольких типов руд. Их разработка связана с большим разубоживанием руды и высокими коэффициентами вскрыши, что предопределяет значительные эксплуатационные затраты при использовании традиционных технических средств и технологических методов добычи и переработки руд. Кроме того, доработка месторождений влечет тяжелые социальные последствия, а ликвидация предприятия связана с тяжелыми для среды обитания экологическими последствиями. Основное направление для преодоления негативных социальных явлений, снижения неблагоприятных последствий горных работ на состояние окружающей среды и обеспечения устойчивого развития горнотехнической системы на завершающих стадиях эксплуатации месторождений связано с повышением полноты освоения недр и созданием новых ресурсосберегающих и энергоэффективных технологий комплексного освоения месторождений [1-3].

Особенности завершающей стадии освоения месторождений Урала

В настоящее время эксплуатационные работы на жильных золоторудных месторождениях Урала характеризуются сокращением объема воспроизводства ресурсной базы, снижением качественных характеристик добываемых руд, усложнением геомеханической обстановки, выражающимся ростом интенсивности проявлений горного давления в динамической форме, удорожанием добычи, осложнением экологической ситуации и социальных проблем в развитом горнодобывающем регионе.

На современной стадии развития горнотехнических систем в результате длительной эксплуатации месторождений все минерально-сырьевые запасы техногенно изменены, находятся в зоне разгрузки или концентрации касательных и нормальных напряжений, в зоне разупрочнения и обрушения вмещающих пород, подвержены процессам вторичного изменения структуры массива и вещественного состава золотосодержащего сырья [4]. Это обуславливает проявление негативных горно-геологических, горнотехнических и геомеханических факторов, которые в условиях недостоверности горногеологической информации осложняют ведение горных работ и становятся причиной отклонений от проектных технико-экономических показателей разработки месторождений.

При этом наиболее благоприятные для разработки рудные залежи уже извлечены, но остались в недрах локальные выклинки, техногенно измененные участки с элементами деревянной крепи, запасы в охранных целиках. Все эти участки характеризуются более низким, по сравнению со средним в балансовых рудах, содержанием ценных компонентов и более сложными

${ }^{1}$ Институт проблем комплексного освоения недр им. академика Н.В. Мельникова Российской академии наук (ИПКОН РАН), Москва, Россия, rylnikova@mail.ru 
горнотехническими и геомеханическими условиями разработки. Причем, по ряду участков месторождений, исторически многократно вовлекаемых в эксплуатацию, не сохранилась геологическая и техническая документация, поэтому возникают дополнительные трудности с изучением горно-геологических условий залегания и обоснованием горнотехнических параметров разработки.

Анализ практики отработки жильных месторождений показал, что для завершающей стадии их освоения характерно сложное геологическое строение и изменение условий залегания оставшихся геологических запасов, пониженное содержание ценных компонентов в рудах, наличие вторичной минерализации вмещающих пород, повышенные значения вертикальных и горизонтальных составляющих напряжений в горных массивах, высокая скорость понижения горных работ и большая глубина разработки, увеличение интенсивности динамических проявлений горного давления, усложнение условий ведения очистной выемки в техногенно измененном массиве, рост затрат на транспортирование и подъем рудной массы, малый масштаб и мощность рудных тел, высокое разубоживание и засорение добываемых руд, рост объемов твердых отходов горно-обогатительного производства [5].

Выполненный анализ опыта освоения золоторудных месторождений, разрабатываемых Акционерным обществом «Южуралзолото Группа Компаний» (АО «ЮГК»), показал, что для большинства месторождений характерен относительно небольшой объем оставшихся балансовых запасов и, соответственно, ограниченный срок эксплуатации на завершающей стадии, низкое и весьма изменчивое содержание золота в руде, зачастую - длительный и многовековой период освоения, перешедший в завершающую стадию, когда уже доработаны 75 - 80 \% балансовых запасов.

Существующие принципы проектирования горнотехнической системы в данных условиях не обеспечивают стабильных показателей эффективности горного производства и требуемую устойчивость в условиях колебаний цен на металлы, изменчивости содержания металла в руде и др., что приводит к снижению технико-экономических показателей и требует иного и более ответственного подхода к обоснованию концепции и выбору технологий освоения месторождения на завершающей стадии.

В то же время анализ вариантов эксплуатации участка недр свидетельствует, что месторождения полезных ископаемых даже на завершающем этапе разработки балансовых запасов имеют значительные неосвоенные георесурсы, которые могут быть эффективно вовлечены в использование: в недрах Земли остались природно-техногенные запасы в различного рода охранных, барьерных, несущих и предохранительных целиках, в закладочных массивах, зонах обрушения, запасы на больших глубинах, на удаленных участках месторождения, в выклинках рудных тел. Кроме того, остались ранее некондиционные руды, накоплено техногенное сырье, пройдены горные выработки и сформировано выработанное пространство, техногенный ландшафт. В ряде случаев обеспечивается прирост балансовых запасов в ходе эксплуатационных геологоразведочных работ.

Устойчивого развития горнотехнической системы, снижения экологической нагрузки на среду обитания на завершающей стадии возможно добиться путем восполнения производственных мощностей рудников за счет их технического переоснащения и вовлечения в эксплуатацию всего ресурсного потенциала недр комбинированием физико-технических и физико-химических геотехнологий с возможностью утилизации конечных отходов в закладке выработанных пространств [6; 7].

\section{Концепция развития горного предприятия} на завершающей стадии жизненного цикла

Анализ практики эксплуатации месторождений на завершающей стадии показал, что под ней необходимо понимать стадию, когда основные запасы (до 80\% балансовых) по базовому проекту отработаны, но появились новые технологии добычи и переработки полезных ископаемых, условия для пересмотра кондиций, обеспечивающие прирост запасов.

На завершающих стадиях эксплуатации при проектировании устойчивой экологически сбалансированной горнотехнической системы следует исходить из обеспечения выполнения следующих преимуществ освоения недр:

- снижение влияния горно-геологических условий на технологические процессы подземного рудника;

- отказ от первоначальной избирательной отработки наиболее богатых участков месторождения и переход к совместной разработке с возможностью селективной выдачи разносортных руд;

- независимость основных технологических процессов во времени и пространстве;

- высокий уровень информатизации и диспетчеризации технологических процессов;

- формализация и стандартизация основных технологических процессов;

- производство продукции с заданным стабильным качеством;

- стабильность структуры издержек производства в течение основной фазы работы рудника.

Реализация указанных принципов осуществляется на основе воспроизводства новых функций земных недр за счет:

- разработки и совершенствования технологий добычи и переработки руд оставленных запасов с изменением требований к качеству сырья;

- пересмотра кондиций;

- использования выработанных пространств в различных целях; 
- перехода на добычу иных полезных ископаемых;

- отработки законтурных запасов карьера инновационными геотехнологиями;

- освоения запасов полезных ископаемых, которые ранее были отнесены к забалансовым;

- отработки техногенного сырья из отвалов и хвостохранилищ;

- вовлечения в отработку законсервированных запасов в целиках различного назначения;

- повышения энергоэффективности горнотехнической системы путем энергосбережения и использования техногенных возобновляемых источников в ходе техногенного преобразования недр.

Комплексное и многоцелевое использование всех видов георесурсов, которые могут быть эффективно вовлечены в эксплуатацию на конкретном участке литосферы в конкретный период его освоения, предполагает внедрение инновационных ресурсосберегающих и энергоэффективных геотехнологий на базе:

- реструктуризации запасов;

- совершенствования технологий добычи руд и управления качеством рудной массы с целью снижение влияния горно-геологических условий на технологические процессы подземного рудника;

- отказа от первоначальной избирательной отработки наиболее богатых участков месторождения и переход к совместной разработке разносортных руд;

- повышения уровня информатизации, диспетчеризации и стандартизация технологических процессов;

- создания логистической схемы, позволяющей обеспечить перспективный рост производственной мощности рудника;

- перехода на применение комбинированных физико-химических и физико-технических геотехнологий;

- расширения состава вовлекаемых в эксплуатацию георесурсов.

Воспроизводство новых функций земных недр производится согласно алгоритму реструктуризации георесурсов на завершающей стадии, которая включает последовательное выполнение семи этапов: геологических, геомеханических исследований, выбора направления и систем разработки, комплексных и лабораторных испытаний не только природного, но и техногенного сырья (рисунок). Это также определение возможности воспроизводства электроэнергии, определение перспектив использования выработанных пространств и, с учетом всего перечисленного, проведение эколого-экономического обоснования целесообразности вовлечения в эксплуатацию всех определенных в ходе реструктуризации природных и техногенных георесурсов.

Реализация данных требований к освоению месторождений полезных ископаемых на завершающей стадии должна быть основана на применении геотехнологии, обеспечивающей максимальное использование современных достижений в области автоматизации и роботизации производственных процессов с исключением или ограничением присутствия людей в опасных зонах.

Широкое применение автоматизации производственных процессов с обеспечением максимальной эффективности и производительности технологического оборудования в рамках единого технологического комплекса, включающее:

- технологию выемки, обеспечивающую строго упорядоченную добычу различных типов руд во времени и пространстве;

- систему подземной рудоподготовки и транспорта, позволяющую обеспечить требуемые сортность и качество рудной массы;

- $\quad$ технологию закладочных работ, позволяющую за счет утилизации в составе закладочных смесей отходов горного производства и создания закладочного массива с заданными физико-механическими и технологическими свойствами формировать в случае технической возможности и экономической целесообразности новый вид георесурса в виде будущего техногенного месторождения [8], способно минимизировать потребление материальных, энергетических, трудовых и финансовых ресурсов и существенно повысить полноту и комплексность освоения недр Земли.

\section{Использование возобновляемых источников энергии}

Полное раскрытие потенциала ресурсной базы и обеспечение устойчивого безопасного и устойчивого развития горного предприятия на завершающей стадии эксплуатации месторождений неразрывно связаны с рациональным использованием невозобновляемых природных и техногенных источников энергии и переходом на использование возобновляемых источников [10-19]. Для обоснования направлений исследований и поиска технологических решений по повышению энергосбережения и ресурсосбережения горного производства проведена систематизация процессов и устройств для получения возобновляемых источников энергии при комплексном освоении недр.

В результате исследования возможностей использования возобновляемых источников энергии природного и техногенного происхождения в процессе комплексного освоения золоторудных месторождений определен принцип учета потоков гидросмесей. Доказано, что энергетический потенциал этих потоков в горнотехнической системе наибольший и поэтому перспективен для использования в промышленных условиях (рисунок) [20]. Определены условия сбора различных потоков гидросмесей в карьере и в подземных горных выработках. Это - потоки воды шахтного водоотлива, потоки гидросмеси и закладочной смеси.

Доказано, что с увеличением глубины горных работ объемы перепускаемой шахтной воды растут, по- 
Алгоритм реструктуризации георесурсов на завершающей стадии

Algorithm of restructuring of geo-resources at the final stage

\begin{tabular}{|c|c|c|c|}
\hline & $\begin{array}{c}\text { Наименование этапа } \\
\text { The stage name }\end{array}$ & \multicolumn{2}{|l|}{$\begin{array}{c}\text { Содержание работ } \\
\text { Job content }\end{array}$} \\
\hline I & $\begin{array}{l}\text { Геологические исследо- } \\
\text { вания } \\
\text { Geological research }\end{array}$ & \multicolumn{2}{|c|}{$\begin{array}{l}\text { - определение запасов природных и техногенных образований / determination of reserves of natural } \\
\text { and man-made formations; } \\
\text { - картирование / mapping; } \\
\text { - отбор проб / sampling; } \\
\text { - оценка содержания основных ценных компонентов, вредных примесей / assessment of the con- } \\
\text { tent of the main valuable components, harmful impurities. }\end{array}$} \\
\hline II & $\begin{array}{l}\text { Геомеханическая } \\
\text { оценка состояния мас- } \\
\text { сива горных пород } \\
\text { Geomechanical assessment } \\
\text { of rock mass condition }\end{array}$ & \multicolumn{2}{|c|}{$\begin{array}{l}\text { - оценка напряженно-деформированного состояния / stress-strain state assessment; } \\
\text { - оценка структуры массива / assessment of massive structure; } \\
\text { - оценка состояния выработанных пространств / assessment of the state of the developed spaces; } \\
\text { - определение параметров процесса сдвижения / determination of the parameters of the movement } \\
\text { process; } \\
\text { - оценка устойчивости горнотехнической системы / mining system stability assessment; } \\
\text { - съемка техногенного ландшафта / survey of man-made landscape. }\end{array}$} \\
\hline III & $\begin{array}{c}\text { Выбор направления } \\
\text { и систем разработки } \\
\text { Direction and systems } \\
\text { development choice }\end{array}$ & $\begin{array}{l}\text { Нисходящая / Downward: } \\
\text { - подэтажного обрушения / under-floor collapse; } \\
\text { - этажного обрушения / storey collapse; } \\
\text { - с магазинированием / with storage; } \\
\text { - этажно-камерная (самопогашение пустот) / storey chamber } \\
\text { (the backflling); } \\
\text { - этажно-камерная с закладкой / floor-chamber with a filling. }\end{array}$ & $\begin{array}{l}\text { Восходящая / Upward: } \\
\text { - камерная с твердеющей за- } \\
\text { кладкой } \\
\text { chamber with hardening filling; } \\
\text { - камерная с гидрозакладкой } \\
\text { chamber with hydraulic filling; } \\
\text { - подэтажная отбойка } \\
\text { sublevel blasting; } \\
\text { - с закладкой / with filling. }\end{array}$ \\
\hline IV & $\begin{array}{l}\text { Комплексные лабора- } \\
\text { торные испытания при- } \\
\text { родного и техногенного } \\
\text { сырья } \\
\text { Complex laboratory tests of } \\
\text { natural and man-made raw } \\
\quad \text { materials }\end{array}$ & \multicolumn{2}{|c|}{$\begin{array}{l}\text { Изучение вещественного состава, характеристик структуры сырья и физико-механических } \\
\text { свойств / Study of material composition, characteristics of raw material structure and physical and } \\
\text { mechanical properties: } \\
\text { - определение химического и фазового состава / determination of chemical and phase composition; } \\
\text { - минералогический анализ / mineralogical analysis; } \\
\text { - имидж-анализ / image analysis; } \\
\text { - определение гранулярного состава / determination of granular composition; } \\
\text { - изучение: влажности, пористости, крепости, водопоглощения / study: humidity, porosity, } \\
\text { strength, water absorption. }\end{array}$} \\
\hline $\mathrm{V}$ & $\begin{array}{l}\text { Определение возобнов- } \\
\text { ляемых источников } \\
\text { энергии } \\
\text { Definition of renewable en- } \\
\quad \text { ergy sources }\end{array}$ & \multicolumn{2}{|c|}{$\begin{array}{l}\text { - параметры водоотлива / drainage parameters; } \\
\text { - параметры гидросмесей / parameters of hydraulic mixtures; } \\
\text { - параметры твердеющих смесей / parameters of hardening mixtures; } \\
\text { - рекуперация / recovery; } \\
\text { - энергия горного массива / energy of the mine massive; } \\
\text { - энергия силы тяжести большегрузного транспорта / energy of gravity of heavy transport. }\end{array}$} \\
\hline VI & $\begin{array}{l}\text { Определение потенциа- } \\
\text { ла выработанных про- } \\
\text { странств и техногенного } \\
\quad \text { ландшафта } \\
\text { Determination of the poten- } \\
\text { tial of developed spaces and } \\
\quad \text { man-made landscape }\end{array}$ & \multicolumn{2}{|c|}{$\begin{array}{l}\text { - } \text { объемы подземных камер / the volume of the underground chambers; } \\
\text { - параметры карьеров / pit parameters; } \\
\text { - } \text { параметры хвостохранилищ / parameters of tailing dumps; } \\
\text { - параметры отвалов / dump parameters. }\end{array}$} \\
\hline VII & $\begin{array}{l}\text { Эколого-экономическое } \\
\text { обоснование } \\
\text { Environmental and eco- } \\
\text { nomic substantiation }\end{array}$ & \multicolumn{2}{|c|}{$\begin{array}{l}\text { Экологические исследования; экономическая оценка предлагаемых технологий } \\
\text { Environmental studies; economic assessment of proposed technologies: } \\
\text { - масштаб воздействия на сферу обитания / scale of impact on the habitat; } \\
-\quad \text { изменение характеристик среды обитания / changes in habitat characteristics; } \\
- \text { рентабельность использования георесурсов / the profitability of the resources using. }\end{array}$} \\
\hline
\end{tabular}




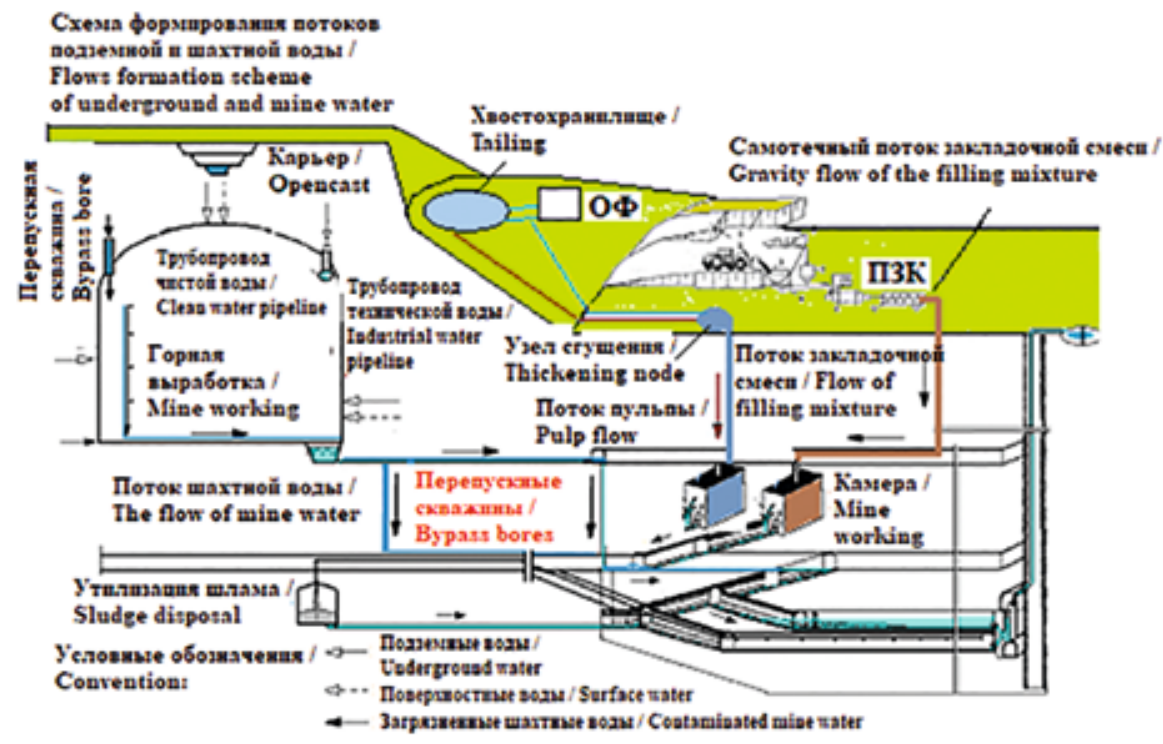

Обобщенная технологическая схема формирования потоков гидросмеси в открытых I (карьер) и в подземных горных выработках II (ГВ) от системы водоотлива поверхностного закладочного комплекса III (ПЗК) и сгущенных хвостов обогащения обогатительной фабрики IV(OФ)

A generalized flow scheme of formation of flow of slurry in open-I (open pit) and underground mining II, from a system of drainage of the surface stowing complex III and the thickened tailings of the concentrator IV

этому повышаются и возможности по их использованию для воспроизводства электроэнергии.

Испытания подтвердили практическую целесообразность и выявили условия воспроизводства электроэнергии от техногенных источников на гидроэлектроустановках малой мощности до 30 кВт. На основе выполненных исследований предложена методика определения воспроизводимой мощности и выбора ГЭУ малой мощности по параметрам рабочих зон в области предпочтительного использования того или иного типа гидротурбин [20]. Проведенными опытно-промышленными испытаниями доказана возможность получения в шахтных условиях возобновляемой энергии от потоков гидросмесей: шахтной воды, гидравлической закладки на основе текущих и сгущенных хвостов обогащения, твердеющей закладочной смеси с учетом их вещественного состава, плотности и вязкости [20].

Внедрение системы воспроизводства электроэнергии от потока перепускаемой воды и закладочной смеси на подземном руднике дополнительно позволит уменьшить потребление электроэнергии до $20 \%$. Предложена каскадная схема последовательного съема на промежуточных горизонтах энергии потоков водоотлива. Для реализации энергетического потенциала потоков гидросмеси разработаны и апробированы в промышленном масштабе конструкции действующих моделей ГЭУ с электрогенераторами малой (до 100 кВТ) мощности с прямоугольными лопастными и ковшовыми рабочими колесами [20].

Комплексное применение закладочных работ на верхних и нижних горизонтах шахт на Кочкарском месторождении позволяет проводить совместное воспроизводство электроэнергии от потоков закладочной смеси и перепускаемых шахтных вод, перемещающихся по вертикальному закладочному трубопроводу в зону обслуживания закладочных работ.

\section{Заключение}

Таким образом, для горного предприятия завершающая стадия - это стадия возможного развития производства на новой концептуальной основе, отличающейся от принятой в базовом проекте разработки месторождения. Она определяется поэтапным и условно неопределенно длительным развитием горнотехнической системы с вовлечением на каждом из этапов нового вида георесурсов в полезное эффективное использование. Этот этап развития предприятия предполагает проектирование устойчивой экологически сбалансированной горнотехнической системы, обеспечивающей комплексную добычу и переработку оставшихся природных и вовлечение в эксплуатацию техногенных георесурсов.

Обоснована концепция освоения месторождений на завершающих стадиях эксплуатации, включающая реструктуризацию запасов и компенсацию влияния негативных факторов при доработке месторождения за счет внедрения ресурсосберегающих и энергоэффективных геотехнологий.

На примере золоторудных месторождений Урала доказано, что полное раскрытие потенциала ресурсной базы и обеспечение устойчивого безопасного и гармоничного развития горного предприятия на завершающей стадии эксплуатации месторождений неразрывно связаны с рациональным использованием невозобновляемых природных и техногенных источников энергии и переходом на использование возобновляемых источников.

Работа выполнена при поддержке гранта РНФ № 14-37-00050 / Work is performed with assistance of a grant of RNF No 14-37-00050 


\section{КОНФЛИКТ ИНТЕРЕСОВ / Conflict of interest:}

Авторы заявляют об отсутствии конфликта интересов / The authors declare no conflict of interest.

\section{ЛИТЕРАТУРА:}

1. Горные науки. Освоение и сохранение недр Земли // Под ред. академика К.Н.Трубецкого. М.: Изд-во Академии горных наук, 1997. 478 C.

2. Трубецкой К.Н. Развитие ресурсосберегающих и ресурсовоспроизводящих геотехнологий комплексного освоения месторождений полезных ископаемых. М.: ИПКОН PAH. 2014. 196 C.

3. Trubetskoy K. N., Galchenko Yu. P. Methodology for estimating promising development paradigm for mineral mining and processing industry // Journal of Mining Science, Vol. 51, No. 2, 2015. Pp. 177-188. DOI: 10.1134/S1062739115020271.

4. Kalmykov V. N., Strukov K. I., Kulsaitov R. V., Esina E. N. Geomechanical features of underground mining at Kochkar deposit // Eurasian mining. 2017. No. 2. P. 12-15. DOI: 10.17580/em.2017.02.03.

5. Струков К.И., Бергер Р.В. Технология горно-обогатительного производства на предприятиях АО «Южуралзолото Группа Компаний» // Горный журнал. 2017. N 9. С. 11-15. DOI: 10.17580/gzh.2017.09.02.

6. Трубецкой К. Н., Каплунов Д. Р., Рыльникова М. В. Принципы обоснования параметров устойчивого и экологически сбалансированного освоения месторождений твердых полезных ископаемых // Горный информационноаналитический бюллетень (научно-технический журнал). Условия устойчивого функционирования минерально-сырьевого комплекса России. 2014. Вып. 2. N 12. С. 3-10.

7. Каплунов Д.Р., Радченко Д.Н. Обоснование полного цикла комплексного освоения недр при разработке месторождений твердых полезных ископаемых // Горный информационно-аналитический бюллетень (научно-технический журнал). 2011. Отдельный выпуск N 1. С.447-455.

8. Голик В.И. Концептуальные подходы к созданию мало- и безотходного горнорудного производства на основе комбинирования физико-технических и физико-химических геотехнологий // Горный журнал. 2013. N 5. С. 93-97.

9. Ильковский К.К., Тимофеев Д.И. Взгляд на энергетику будущего // Горный журнал. 2011. N 12. С. 73-74.

10. Bertani R. Geothermal power generation in the world 2005-2010 update report. Geothermics. 2012. Vol. 41. Pp. 1-29.
11. Tinti F., Boldini D., Ferrari M., Lanconelli M., Kasmaee S. et al. Exploitation of geothermal energy using tunnel lining technology in a mountain environment. A feasibility study for the Brenner Base tunnel-BBT // Tunnelling and Underground Space Technology. 2017. Vol. 70. Pp. 182-203.

12. Тангаев И. А. Энергоемкость процессов добычи и переработки полезных ископаемых. М.: Недра, 1986. 231 С.

13. Bleiwas D. I. Estimates of electricity requirements for the recovery of mineral commodities, with examples applied to sub-Saharan Africa // US GeologicalSurvey, 2011. 108 p.

14. Jarvie-Eggart Michelle E. Responsible Mining: Case Studies in Managing Social \& Environmental Risks in the Developed World // Englewood, Colorado: Society for Mining, Metallurgy and Exploration, 2015. 804 p.

15. Ghoreishi-Madiseh S. A., Hassani F. P., Abbasy F. Development of a novel technique for geothermal energy extraction from backfilled mine stopes / The 11th International Symposium on Mining with Backfill. Perth: Australian Centre for Geomechanics PP. 2014. Pp. 61-72.

16. Каплунов Д.Р., Лейзерович С.Г., Томаев В.К. Энерговоспроизводство при подземных закладочных работах // Горный журнал. 2013. N 4. С. 62-66.

17. Каплунов Д. Р., Рыльникова М.В. Возобновляемые источники энергии как георесурс в системе техногенного преобразования недр // Горный журнал. 2015. N 9. С. 72-75.

18. Kaplunov D.R., Rylnikova M.V., Radchenko D.N. Utilization of renewable energy sources in hard mineral mining // Journal of Mining Science. 2015. T. 51. N 1. Pp. 111-117. DOI: 10.1134/S1062739115010147.

19. Trubetskoy K. N., Kaplunov D. R., Rylnikova M. V., Radchenko D. N. New approaches to designing resourcereproducing technologies for comprehensive extraction of ores // Journal of Mining Science. 2011. Vol. 47. No. 3. Pp. 317-323.

20. Рыльникова М.В., Олизаренко В.В., Линьков С.А., Зубков А.А. Перспективы применения и оценка параметров энергоэффективных геотехнологий при комплексном освоении месторождений // Горный журнал. 2017. N11. C. 7176. DOI: 10.17580/gzh.2017.11.13.

\section{$\overline{\text { СВЕДЕНИЯ ОБ АВТОРАХ / Information about authors: }}$}

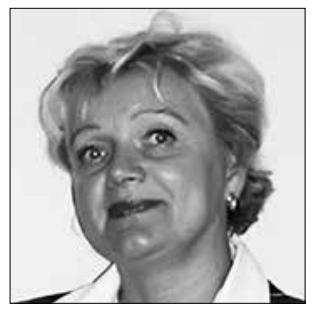

Sciences (IPKON RAS). 111020, Moscow, Russia.

Ph.: +7(495) 360-29-13; e-mail: rylnikova@mail.ru

111020, Москва, Россия. (1)

\author{
3; e-mail: rylnikova@mail.ru
}

РЫЛЬНИкОВА Марина Владимировна - доктор технических наук, профессор, заведующий отделом теории проектирования освоения недр, Институт проблем комплексного освоения недр им. академика Н.В. Мельникова Российской Академии наук (ИПКОН РАН).

Тел.: 8 (495) 360-29-13; e-mail: rylnikova@mail.ru

Marina VI. RYLNIKOVA - doctor of technical Sciences, Professor, head of Department of theory of design development of mineral resources; Institute of Comprehensive Exploitation of Mineral Resources Russian Academy of 


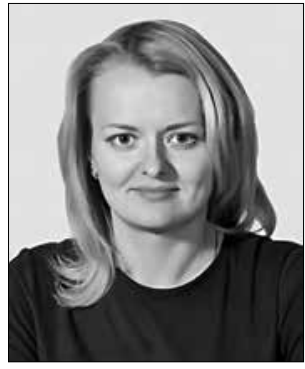

ЕСИНА Екатерина Николаевна - кандидат технических наук, доцент, старший научный сотрудник отдела проблем управления освоением и сохранением недр Земли; Институт проблем комплексного освоения недр им. академика Н.В. Мельникова Российской Академии наук (ИПКОН РАН), 111020 , Москва, Россия

Тел.: 8 (926) 373-46-48; e-mail: esina555@list.ru

Ekaterina N. ESINA - candidate of technical Sciences, associate professor, senior researcher of the Department of problems of management of development and conservation of the Earth's interior; Institute of Comprehensive Exploitation of Mineral Resources Russian Academy of Sciences (IPKON RAS).

Ph.: +7(926)373-46-48; 111020, Moscow, Russia,

e-mail:esina555@list.ru

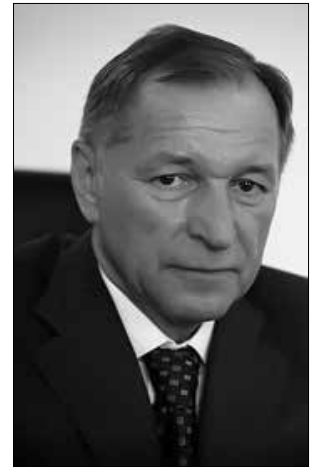

СТРУКОВ Константин Иванович - кандидат технических наук, руководитель обособленного структурного подразделения лаборатории ЭКОН ИПКОН РАН в г. Пласт. Институт проблем комплексного освоения недр им. академика Н.В. Мельникова Российской Академии наук (ИПКОН РАН), 111020, Москва, Россия

Тел.: 8 (495) 360-29-13;

e-mail: ugold@ugold.ru

Konstantin IV. STRUKOV - candidate of technical Sciences, head of the separate structural unit of the laboratory of ECON IPKON RAS; Institute of Comprehensive Exploitation of Mineral Resources Russian Academy of Sciences (IPKON RAS).

Ph.: +7(495)360-29-13; 111020, Moscow, Russia,

e-mail:ugold@ugold.ru

\title{
SUSTAINABLE DEVELOPMENT OF MINING SYSTEM AT THE FINAL STAGE OF UNDERGROUND MINING VEIN GOLD DEPOSITS OF THE URALS
}

\author{
M.V. Rylnikova, * \\ K.I. Strukov, \\ E.N. Esina \\ Institute of Comprehensive Exploitation of Mineral Resources Russian Academy of Sciences (IPKON RAS), \\ rylnikova@mail.ru
}

\section{DOI: $10.21177 / 1998-4502-2018-10-4-518-525$}

At the present stage of development of mining systems as a result of long-term exploitation of gold ore deposits in the Urals, there is a reduction in the volume of reproduction of the resource base, a decrease in the qualitative characteristics of mined ores, the complication of geomechanical conditions, expressed in the increase in the intensity of manifestations of mountain pressure in a dynamic form, the rise in the cost of production, the complication of the environmental situation and social problems in the developed mining region. At the same time on the final stage of development of balance reserves have significant undeveloped, which can be effectively engaged in the use of natural and man-made reserves of different kind of security, barrier, carrier, and safety pillars, backfill areas, areas of collapse, the stocks at greater depths, in remote areas of the field. In addition, it was previously off-grade ore accumulated technogenic raw materials, completed the excavation and formed the mined-out area, man-made landscape. It is proved that the concept of field development at the final stages of operation should include the restructuring of reserves and compensation for the impact of negative factors in the refinement of the field through the introduction of resource-saving and energy-efficient geotechnologies. It is shown that the full disclosure of the potential of the resource base and ensuring the sustainable safe and harmonious development of the mining enterprise at the final stage of field operation are inextricably linked with the rational use of non-renewable natural and man-made sources of energy and the transition to the use of renewable sources.
Keywords: mining system, sustainable development, underground geotechnology, the final stage, gold deposits.

\section{References}

1. Mining science. Development and conservation of the Earth's subsoil / edited by academician K. N. Trubetskoy. Moscow, Publishing House of the Academy of mining Sciences, 1997. 478 p. (in Russian)

2. Trubetskoy K. N. Development of resource-saving and resource-reproducing geotechnologies of complex development of mineral deposits. Moscow, IPKON RAS. 2014. 196 p. (in Russian)

3. Trubetskoy K. N., Galchenko Yu. P. Methodology for estimating promising development paradigm for mineral mining and processing industry. Journal of Mining Science, 2015, vol. 51, no 2, pp. 177-188. DOI: 10.1134/ S1062739115020271. (in Russian)

4. Kalmykov V. N., Strukov K. I., Kulsaitov R. V., Esina E. N. Geomechanical features of underground mining at Kochkar deposit. Eurasian mining. 2017, no 2, pp. 12-15. DOI: $10.17580 / \mathrm{em} .2017 .02 .03$.

5. Strukov K. I., Berger R. V. Technology of mining and processing production at the enterprises of "Yuzhuralzoloto Group of Companies". Mining journal, 2017, no 9, pp. 1115. DOI: 10.17580/gzh.2017.09.02. (in Russian)

6. Trubetskoy K. N., Kaplunov D. R., Rylnikova, M. V. Principles of substantiation of the parameters of a sustainable and ecologically balanced development of the solid minerals mining. Mining information-analytical Bulletin (scientific and technical journal). The conditions for the 
sustainable functioning of mineral-raw material complex of Russia. 2014, issue 2, 12, pp. 3-10. (in Russian)

7. Kaplunov D. R., Radchenko D. N. Substantiation of the full cycle of integrated subsoil development in the development of solid mineral deposits. Mining information and analytical Bulletin (scientific and technical journal), 2011, Separate issue no 1, pp. 447-455. (in Russian)

8. Golik V. I. Conceptual approaches to the creation of low - and non-waste mining production based on a combination of physico-technical and physicochemical geotechnologies. Mining journal, 2013, no 5, pp. 93-97. (in Russian)

9. Ilkovsky K. K., Timofeev D. I. View on the energy of the future. Mining journal, 2012, no 11, pp. 73-74. (in Russian)

10. Bertani R. Geothermal power generation in the world 2005-2010 update report. Geothermics, 2012, vol. 41, pp. 1-29.

11. Tinti F., Boldini D., Ferrari M., Lanconelli M., Kasmaee S. et al. Exploitation of geothermal energy using tunnel lining technology in a mountain environment. A feature study for the Brenner Base tunnel - BBT. Tunnelling and Underground Space Technology, 2017, vol. 70, pp. 182-203.

12. Tangaev I. A. Energy Intensity of mining and processing of minerals. Moscow, Subsoil, 1986, 231 p. (in Russian)

13. Bleiwas D. I. Estimates of electricity requirements for the recovery of mineral commodities, with examples applied to sub-Saharan Africa. US Geological Survey, 2011, 108 p.

14. Jarvie-Eggart Michelle E. Responsible Mining: Case Studies in Managing Social \& Environmental Risks in the
Developed World. Englewood, Colorado: Society for Mining, Metallurgy and Exploration, 2015, 804 p.

15. Ghoreishi-Madiseh S. A., Hassani F. P., Abbey F. Development of a novel technique for geothermal energy extraction from backfilled mine stops. The 11th International Symposium on Mining with Backfill. Perth: Australian Centre for Geomechanics PP, 2014, pp. 61-72.

16. Kaplunov D. R., Leizerovich G. S., Tomaev V. K. Energy reproduction in underground backfilling operations. Mining journal, 2013, no 4, pp. 62-66. (in Russian)

17. Kaplunov D. R., Rylnikova M. V. Renewable energy as georesurs in the system of technogenic transformation of the interior. Mining journal, 2015, no 9, pp. 72-75. DOI: 10.17580/gzh.2015.09.16. (in Russian)

18. Kaplunov D. R., Rylnikova M. V., Radchenko D. N. Utilization of renewable energy sources in hard mineral mining. Journal of Mining Science, 2015, vol. 51, no 1, pp. 111117. DOI: 10.1134/S1062739115010147. (in Russian)

19. Trubetskoy K. N., Kaplunov D. R., Rylnikova M. V., Radchenko D. N. New approaches to designing resource-reproducing technologies for comprehensive extraction of ores. Journal of Mining Science, 2011, vol. 47, no 3, pp. 317-323.

20. Rylnikova M. V., Olizarenko V. V., Linkov S. A., Zubkov A. A. Prospects of application and assessment of parameters of energy-efficient geotechnologies in the complex development of deposits. Mining journal, 2017, no. 11, pp. 71-76. DOI: 10.17580/gzh.2017.11.13. (in Russian)

Article received 02.06.2018. 
1,2 Умаров М.У.,* 1,2Гапаев Я.С,

1,2Тайсумов М.А.

\section{ФЛОРА ПАРАБОЧЕВСКОГО ЗАКАЗНИКА И ЕЕ СИСТЕМАТИЧЕСКИЙ АНАЛИЗ}

\section{Введение}

Одна из важнейших современных проблем - сохранение биоразнообразия, служащего главным средообразующим резервом планеты и обеспечивающим возможность ее устойчивого развития, сохранения естественной среды обитания и биологических ресурсов. Интенсивное использование обществом ресурсов природы неизбежно сопровождается нарушением естественных экосистем, среды и местообитания живых организмов, сокращением их ареала, численности популяций и даже исчезновением отдельных видов. Особо охраняемые природные территории - заповедники, заказники и другие - с их ограниченным режимом хозяйственной деятельности наименее подвержены негативным воздействиям и должны служить целям сохранения естественной среды, охраны и воспроизводства всего биоразнообразия. Но, к сожалению, они не всегда соответствуют своему функциональному назначению.

«Парабочевский» государственный биологический заказник - один из восьми заказников республиканского подчинения. Он основан в 1963 году в долине p. Терек (Шелковской район Чеченской Республики). Его общая площадь - 12,0 тыс. га, в том числе 6 тыс. га лесного фонда. Основное назначение заказника охрана и восстановление редких и исчезающих видов растений и животных или видов, ценных в хозяйственном научном и культурном отношении природных комплексов и поддержание экологического баланса [1].

К сожалению, до сих пор не изучено современное состояние экосистем, растительного покрова и животного населения заказника. Нет сведений о составе его флоры, в том числе о раритетных, реликтовых и ценных в научном и практическом отношении видов, нуждающихся в охране, без чего невозможна эффективная природоохраннная и экологически ориентированная деятельность заказника.

Изучение флоры любой територии основывается на инвентаризации видового состава, на котором базируется комплексный ее анализ (таксономической, хронологической, эколого-географической, экологической, биологической и эколого-фенотической и др.). Это необходимо и для оценки флоры в целом, состояния популяций конкретных видов и фиторесурсного потенциала, а также для научного обоснования мероприятий по рациональному использованию, сохранению и воспроизводству биоразнообразия.

Вопросы анализа флоры разрабатывались многими исследователями: BraunBlanquet J. [2-4], Koch W. [5], Лавренко E.M. [6]; Буш Н.A. [7], Davis P.H. [8], Walter H. et. al. [9], Толмачев А.И. [10; 11], Камелин Р.В. [12], Юрцев Б.А. [13], Середин Р.М. [14] и др. Теоретические и методические вопросы применительно к Предкавказью разработаны в работах А.Л. Иванова [15; 16]. Растительный покров территории Чеченской Республики по высотным поясам описан в работе А.И. Галушко [17], в которой дается также общее описание флоры и растительности пойменным лесам, в том числе долины p. Терек. Одна из важнейших задач современности - сохранение среды обитания и биологического разнообразия, как необходимого условия для гармоничного и устойчивого развития

${ }^{1}$ Комплексный научно-исследовательский институт им. Х.И. Ибрагимова Российской академии наук, г. Грозный, Россия, umarovbiolog@mail.ru

${ }^{2}$ Академия наук Чеченской Республики, г. Грозный, Россия 
природы и общества. Изучение видового состава конкретных флор позволяет познать их фиторесурсный потенциал, историю и тенденции развития растительного покрова конкретных территорий.

Цель исследований. Изучение состава и систематический анализ флоры особо охраняемой природной территории - Парабочевского заказника, выявление раритетных, реликтовых и ресурсно полезных видов.

\section{Объект и методика исследований.}

Флористические исследования на территории Парабочевского заказника нами проводились в течение 2012-2015 годов. Для детального знакомства с флорой были разработаны маршруты, охватывающие с севера на юг и с запада на восток разные участки и местообитания заказника. Полевые исследования проводились в разные сезоны года - весной, летом, осенью. Для уточнения видов использована 3-томная «Флора Северного Кавказа» (1978-1980) А.И. Галушко [18]. Важным аспектом флористических исследований является общий систематический анализ флоры, позволяющий обоснованно подойти к пониманию вопросов флорогенеза. Традиционно такой анализ охватывает всю флору конкретной территории (как единое целое), что вполне оправдано. Предпринятый нами систематический анализ флоры Парабочевского заказника базируется на теоретических разработках А.Л. Иванова [15; 16] с ипользованием системы Энглера [19].

Результаты исследований. За этот период наблюдений на территории заказника выявлено 266 видов сосудистых растений из 205 родов и 71 семейства. Представители некоторых семейств распространены на территории Чеченской Республики практически во всех пойменных лесах и на равнинных территориях, относящихся в той или иной мере к поймам рек, хотя доля участия конкретных родов и видов в формировании растительного покрова по отдельным лесным кварталам неодинакова. Систематическая структура является самой важной характеристикой любой флоры, а анализ численных взаимоотношений между таксонами (семействами, родами и видами) позволяет определить специфику видов, выявить закономерности, связанные с историческим развитием флоры той или иной территории.

Систематический анализ флоры исследуемого заказника приводится в таблице.

К крупнейшим семействам Парабочевского заказника относятся семейства Asteraceae (13,16\% видов флоры заказника), Rosaceae (7,52\%), Lamiaceae (6,76\%), Fabaceae (5,64\%), Poaceae (4,51\%), Boraginaceae (4,13\%), Brassicaceae (3,75\%), Caryophyllaceae (3,00\%), Apiaceae (3,00\%), Malvaceae (2,63\%). На них приходится $111(54,1 \%)$ родов и 145 (64,4\%) видов.

Первое, что привлекает внимание - это положение семейств Asteraceae, Rosaceae u Lamiaceae в списках семейств флор Предкавказья (Иванов, 1998) и Парабочевского заказника. Первая тройка семейств совпадает. Ранги остальных общих для сравниваемых флор семейств в спектрах разнятся. Из этого вытекает важное заключение: несмотря на экологическую специфичность, основное ядро флоры Парабочевского заказника принадлежит семействам, определяющим ее общую систематическую структуру, но с некоторым повышением роли полупустынных и пустынных семейств (Caryophyllaceae и Boraginaceae). Первые 25 $(35,2 \%)$ семейств, содержащие три и более видов, суммарно объединяют 163 рода (79,1 \% от общего числа родов) и 205 видов (77,1 \% всей флоры). Во флоре заказника относительно высокий процент малочисленных семейств, состоящих из 1-2 видов. Таких здесь более половины - 46 (64,8 \%). В сумме они объединяют 62 вида (23,3 \% флоры заказника).

Флора заказника представлена 205 родами высших сосудистых растений. Среди них по 5 видов содержат Artemisia и Centaurea; по 4 вида - Potentilla, по 3 вида - Allium, Crataegus, Inula, Populus, Trifolium, Salix, и Viola; по 2 вида - Achillea, Ajuga, Althaea, Bromus, Carex, Cynoglossum, Echium, Euonymus, Euphorbia, Gagea, Galium, Geranium, Lamium, Lathyrus, Malva, Medicago, Menta, Morus, Nonea, Orchis, Plantago, Polygonum, Poa, Prunella, Prunus, Primula, Ranunculus, Rhamnus, Rubus, Rumex, Salvia, Sambucus, Solanum, Stachys, Typha, Ulmus, Verbascum, Veronica, Viburnum, Vicia. Суммарно перечисленные $50(24,4 \%)$ родов объединяют 115 (43,2 \%) видов.

Остальные 151 род содержат лишь по 1 виду: $A b u$ tilon, Acer, Agrimonia, Amygdalus, Alcea, Alliaria, Alnus, Arctium, Astragalus, Bidens, Calystegia, Cannabis, Capsella, Carpinus, Clematis, Clinopodium, Carthamus, Calamagrostis, Cephalanthera, Chelidonium, Cichorium, Cirsium, Convallaria, Cornus, Cynanchum, Cydonia, Cynodon, Cucubalus, Dactylis, Datura, Daucus, Descurainia, Dipsacus, Echinops, Elaeagnus, Epilobium, Erianrthus, Ficaria, Fragaria, Frangula, Fraxinus, Geum, Glycyrrhiza, Hedera, Hesperis, Humulus, Hypericum, Iris, Lapsana, Lavatera, Leonurus, Lepidium, Ligustrum, Linaria, Listera, Melandrium, Melilotus, Mespilus, Onosma, Ophioglossum, Origanum, Periploca, Phlomis, Phragmites, Platanthera, Quercus, Raphanus, Salvinia, Scabiosa, Scilla, Sisymbrium, Symphytum, Swida, Tamarix, Tamus, Taraxacum, Thlaspi, Tilia, Tulipa, Urtica, Verbena, Vinca, Vitis и др.

Флора Парабочевского заказника, как часть флоры Предкавказья, соответствует закономерностям Средиземноморских флор, так как в спектре крупнейших семейств ее ведущую роль, как и во флоре Предкавказья [15], занимают Asteraceae, Poaceae, Fabaceae. Особенностью их таксономичского спектра является расположение на первом месте семейства Asteraceae, а после него Rosaceae и Lamiaceae. Высокое положе- 
Общий систематический спектр флоры Парабочевского заказника General systematic range of flora of the Parabochevsky wildlife area

\begin{tabular}{|c|c|c|c|c|c|}
\hline № & $\begin{array}{c}\text { Семейства } \\
\text { Family }\end{array}$ & $\begin{array}{l}\text { Кол-во родов } \\
\text { Genus amount }\end{array}$ & $\begin{array}{l}\text { \% родов } \\
\text { Genus } \%\end{array}$ & $\begin{array}{l}\text { Кол-во видов } \\
\text { Species amount }\end{array}$ & $\begin{array}{l}\text { \% видов } \\
\text { Species \% }\end{array}$ \\
\hline 1 & 2 & 3 & 4 & 5 & 6 \\
\hline 1 & Asteraceae - Астровые & 24 & 11,77 & 35 & 13,16 \\
\hline 2 & Rosaceae- Розоцветные & 14 & 6,83 & 20 & 7,52 \\
\hline 3 & Lamiaceae - Яснотковые & 11 & 5,36 & 18 & 6,77 \\
\hline 4 & Fabaceae - Бобовые & 10 & 4,88 & 15 & 5,64 \\
\hline 5 & Poасеае - Мятликовые & 10 & 4,88 & 12 & 4,51 \\
\hline 6 & Boraginaceae - Бурачниковые & 8 & 3,90 & 11 & 4,13 \\
\hline 7 & Brassicaceae - Капустные & 10 & 4,88 & 10 & 3,75 \\
\hline 8 & Apiaceae-Сельдерейные & 8 & 3,90 & 8 & 3,00 \\
\hline 9 & Caryophyllaceae - Гвоздичные & 8 & 3,90 & 8 & 3,00 \\
\hline 10 & Malvaceae- Мальвовые & 5 & 2,44 & 7 & 2,63 \\
\hline 11 & Salicaceae - Ивовые & 2 & 0,97 & 6 & 2,25 \\
\hline 12 & Scrophulariaceae - Норичниковые & 4 & 1,97 & 6 & 2,25 \\
\hline 13 & Orchidaceae - Орхидные & 4 & 1,97 & 5 & 1,88 \\
\hline 14 & Ranunculaceae - Лютиковые & 4 & 1,97 & 5 & 1,88 \\
\hline 15 & Dipsacaceae - Ворсянковые & 4 & 1,97 & 4 & 1,50 \\
\hline 16 & Polygonaceae - Гречишные & 2 & 0,97 & 4 & 1,50 \\
\hline 17 & Rubiaceae-Мареновые & 3 & 1,46 & 4 & 1,50 \\
\hline 18 & Solanaceae- Пасленовые & 3 & 1,46 & 4 & 1,50 \\
\hline 19 & Liliaceae - Лилейные & 4 & 1,97 & 4 & 1,50 \\
\hline 20 & Alliaceae - Луковые & 3 & 1,46 & 3 & 1,13 \\
\hline 21 & Asclepiadaceae - Ластовневые & 3 & 1,46 & 3 & 1,13 \\
\hline 22 & Betulaceae - Березовые & 3 & 1,46 & 3 & 1,13 \\
\hline 23 & Geraniaceae - Гераниевые & 2 & 0,97 & 3 & 1,13 \\
\hline 24 & Rhamnaceae - Крушиновые & 2 & 0,97 & 3 & 1,13 \\
\hline 25 & Violaceae - Фиалковые & 1 & 0,48 & 3 & 1,13 \\
\hline 26 & Apocynaceae - Кутровые & 2 & 0,97 & 2 & 0,75 \\
\hline 27 & Cannabaceae - Коноплевые & 2 & 0,97 & 2 & 0,75 \\
\hline 28 & Sambucaceae - Бузиновые & 1 & 0,48 & 1 & 0,38 \\
\hline 29 & Celastraceae - Бересклетовые & 1 & 0,48 & 2 & 0,75 \\
\hline 30 & Convolvulaceae - Вьюнковые & 2 & 0,97 & 2 & 0,75 \\
\hline 31 & Cornaceae - Кизиловые & 2 & 0,97 & 2 & 0,75 \\
\hline 32 & Cурегасеае-Осоковые & 1 & 0,48 & 2 & 0,75 \\
\hline 33 & Euphorbiaceae - Молочайные & 1 & 0,48 & 2 & 0,75 \\
\hline 34 & Oleaceae - Маслиновые & 2 & 0,97 & 2 & 0,75 \\
\hline 35 & Onagraceae - Кипрейные & 2 & 0,97 & 2 & 0,75 \\
\hline 36 & Papaveraceae - Маковые & 2 & 0,97 & 2 & 0,75 \\
\hline 37 & Plantaginaceae - Подорожниковые & 1 & 0,48 & 2 & 0,75 \\
\hline 38 & Primulaceae- Первоцветные & 1 & 0,48 & 2 & 0,75 \\
\hline 39 & Typhaceae - Рогозовые & 1 & 0,48 & 2 & 0,75 \\
\hline 40 & Ulmaceae - Ильмовые & 1 & 0,48 & 2 & 0,75 \\
\hline 41 & Viburnaceae - Калиновые & 1 & 0,48 & 2 & 0,75 \\
\hline 42 & Moraceae-Tymoвble & 1 & 0,48 & 2 & 0,75 \\
\hline 43 & Equisetaceae-Хвощевые & 1 & 0,48 & 1 & 0,38 \\
\hline 44 & Ophioglosaceae - Ужовниковые & 1 & 0,48 & 1 & 0,38 \\
\hline 45 & Salviniaceae - Сальвиниевые & 1 & 0,48 & 1 & 0,38 \\
\hline 46 & Aceraceae - Кленовые & 1 & 0,48 & 1 & 0,38 \\
\hline 47 & Araceae-Ароидные & 1 & 0,48 & 1 & 0,38 \\
\hline
\end{tabular}




\begin{tabular}{|c|c|c|c|c|c|}
\hline \multicolumn{6}{|c|}{ Окончание / Ending } \\
\hline 1 & 2 & 3 & 4 & 5 & 6 \\
\hline 48 & Araliaceae - Аралиевые & 1 & 0,48 & 1 & 0,38 \\
\hline 49 & Asparagaceae - Спаржевые & 1 & 0,48 & 1 & 0,38 \\
\hline 50 & Campanulaceae - Колокольчековые & 1 & 0,48 & 1 & 0,38 \\
\hline 51 & Caprifoliaceae - Жимолостные & 1 & 0,48 & 1 & 0,38 \\
\hline 52 & Convallariaceae - Ландышевые & 1 & 0,48 & 1 & 0,38 \\
\hline 53 & Cutraceae - Кутровые & 1 & 0,48 & 1 & 0,38 \\
\hline 54 & Dioscoreaceae - Диоскорейные & 1 & 0,48 & 1 & 0,38 \\
\hline 55 & Elaeagnaceae - Лоховые & 1 & 0,48 & 1 & 0,38 \\
\hline 56 & Fagaceae - Буковые & 1 & 0,48 & 1 & 0,38 \\
\hline 57 & Hypericaceae - Зверобойные & 1 & 0,48 & 1 & 0,38 \\
\hline 58 & Juglandaceae - Ореховые & 1 & 0,48 & 1 & 0,38 \\
\hline 59 & Juncacea - Ситниковые & 1 & 0,48 & 1 & 0,38 \\
\hline 60 & Iridaceae - Ирисовые & 1 & 0,48 & 1 & 0,38 \\
\hline 61 & Lentibulariaceae - Пузырчатковые & 1 & 0,48 & 1 & 0,38 \\
\hline 62 & Lythraceae - Дербенниковые & 1 & 0,48 & 1 & 0,38 \\
\hline 63 & Orobanchaceae - Заразиховые & 1 & 0,48 & 1 & 0,38 \\
\hline 64 & Santalaceae - Санталовые & 1 & 0,48 & 1 & 0,38 \\
\hline 65 & Simaroubiaceae - Симарубовые & 1 & 0,48 & 1 & 0,38 \\
\hline 66 & Tamaricaceae - Гребенщиковые & 1 & 0,48 & 1 & 0,38 \\
\hline 67 & Tiliaceae - Липовые & 1 & 0,48 & 1 & 0,38 \\
\hline 68 & Urticaceae - Крапивные & 1 & 0,48 & 1 & 0,38 \\
\hline 69 & Valerianaceae - Валериановые & 1 & 0,48 & 1 & 0,38 \\
\hline 70 & Verbenaceae - Вербеновые & 1 & 0,48 & 1 & 0,38 \\
\hline 71 & Vitaceae - Виноградные & 1 & 0,48 & 1 & 0,38 \\
\hline & Итого / Total & 205 & 100 & 266 & 100 \\
\hline
\end{tabular}

ние в составе ведущих семейств Fabaceae указывает на принадлежность изучаемой экологической группы растений, как элементов флоры, к Туранской флористической подобласти.

Во флоре заказника присутствует много видов, занесенных в Красную книгу Чеченской Республики [20]: Allium paradoxum, Althaea armeniaca и A. officinalis, Amygdalus nana, Cephalanthera damasonium, Cucubalus baccifer, Cydonia oblonga, Eryanthus ravennae, Hedera pastuchovii, Iris pseudacorus, Malus orientalis, Ophyoglossum vulgatum, Orchis picta, и O. purpurea, Periploca graeca, Primulama crocalyx и $P$. woronowii, Salvinia natans, Tulipa biebersteiniana, Vitis sylvestris. Bce они подлежат строгой охране как редкие или ценные в хозяйственном или научном отношении виды.

Редкими на территории заказника являются также Allium ursinum, Chelidinium majus, Clematis orientalis, Listera ovata, Physalis alkekengi, Oenothera biennis, Orobanche coerulescens, Platanthera bifolia, Scilla sibirica, Viburnum lantana, Vinca herbacea. Учитывая малочисленность их популяций и бесконтрольные сборы некторых из них (Allium ursinum - для пищевых целей, а Scilla sibirica - на букеты как декоративное растение), необходимо предпринять меры по их охране и воспроизводству.

Древняя природа лесов Парабочевского заказника подтверждается обилием третичных реликтов как в древесной флоре (Euonymus europaea, Carpinus caucasica, Cornus mas, Corylus avellana, Cydonia oblonga, Ligustrum vulgare, Lonicera caprifolium, Malus orientalis, Periploca graeca, Populus hybrida, Pyrus caucasica, Quercus robur, Rubus caesius, Salix alba, Sambucus nigra, Tilia cordata, Ulmus suberosa, Viscum album, Vitis sylvestris), так и среди трав (Alliaria officinalis = A. petiolata, Allium ursinum, A. paradoxum, Arum maculatum, Convallaria transcaucasica, Humulus lupulus, Tamus communisи др.). Вопрос о реликтовости флоры заказника, особенно травянистой, требует дополнительных исследований.

Флора заказника богата хозяйственно полезными (пищевыми, лекарственными, декоративными, медоносными, древесно-сырьевыми и др.) видами. Размеры и численность популяций некоторых из них сильно сократились из-за бесконтрольных заготовок для пишевых целей (Allium ursinum, A. paradoxum) и на букеты для продажи (Convallaria transvaucasica, Primula woronowii u P. macrocalyx, Scilla sibirica).

Для сохранения естественного биоразнообразия и полезного генофонда флоры необходимо строгое соблюдение охранного режима заказника, на научной основе наладить мониторинг за состоянием популяций краснокнижных, раритетных, реликтовых видов и экосистемы. 
На лесных территориях Парабочевского заказника, где представлено большое количество травянистых и древесных видов, играющих неодинаковую роль в формировании растительного покрова и фитоценозов, представляет интерес дифференцированный подход к анализу флоры (травянистой и древесной). На наш взгляд, это позволит дополнить наши подходы к пониманию направлений исторической миграции видов, участвовавших в формировании флоры конкретных территорий.

Охрана реликтовых пойменных лесов, выполняющих комплекс природоохранных, средообразующих, социальных функций и содержащих богатый генофонд реликтовых, полезных в хозяйственном и научном отношениях видов - важнейшее условие сохранения экосистем и биоресурсного потенциала бассейна р. Терек.

\section{Заключение}

1. Во флоре Парбочевского заказника Чеченской Республики выявлено 266 видов высших сосудистых растений из 205 родов и 71 семейства.

2. Крупнейшими семествами флоры являются Asteraceae, Rosaceae, Lamiaceae, Fabaceae, Poaceae, Boraginaceae, Brassicaceae, Caryophyllaceae, Apiaceae, Malvaceae, объединяющие 111 (54,1\%) родов и 145 $(64,4 \%)$ видов.

3. Третичные реликты флоры представляют: Alliaria officinalis, Allium ursinum, A paradoxum, Arum maculatum, Euonymus europaea, Carpinus caucasica,

\section{ЛИТЕРАТУРА:}

1. Болотбиев Х.Р. Состояние заказников и памятников, расположенных на территории Чеченской Республики / Историко-культурное наследие народов Юга России: Материалы Всероссийской научно-практической конференции (г. Грозный, 25-26 июня 2009 г.). Т. II. Грозный. 2009. С. $119-129$.

2. Braun-Blanquet J., Furrer E. Remarques sur l'etude des groupements de plantes // Bull. Soc. Languedos. Georg. 1913. N36. Pp.20-41.

3. Braun-Blanquet J. Essaisur les notions «d'element» et de «territore» phytogeographiques // Archives des scieces physiques et naturalles. Geneve. 1919. Ser. 5. Vol. 1. Pp. 479512.

4. Braun-Blanquet J. L'origineet le developpement des floresdans massif central de France. Paris; Zurich, 1923. 282 p.

5. Koch W. Die Vegetationseinheiten der Linthebere unter Berucksichtigung der Verhaltnisse in der N.O. Schweiz // Jb. St. Gall. Naturw. Ges. 1925, N 61(2). Pp. 1-146.

6. Лавренко Е.М. Лесные реликтовые (третичные) центры между Карпатами и Алтаем // Журнал Русского ботанического общества. 1930. Т. 15, N 4. С 351-363.

7. Буш Н.А. Ботанико-географический очерк Кавказа. М. -Л.: Изд-во АН СССР, 1935. 108 с.

8. Davis P.H. Introduction // Flora of Turkey and the East Aegean Islands. Edinburg. 1965. Vol. 1. Pp. 1-26.

9. Walter H., Straka H. Arealkunde, Floristisch - historische Geobotanik. Stuttgart, 1970. 480 p.
Convallaria transcaucasica, Cornus mas, Corylus avellana, Cydonia oblonga, Humulus lupulus, Ligustrum vulgare, Lonicera caprifolium, Malus orientalis, Periploca graeca, Populus hybrida, Pyrus caucasica, Quercus robur, Rubus caesius, Salix alba, Sambucus nigra, Tamus communis, Tilia cordata, Ulmus suberosa, Viscum album, Vitis sylvestris.

4. К краснокнижным видам флоры отнсятся: Allium paradoxum, Althaea armeniacaи, A. officinalis, Amygdalus nana, Cephalanthera damasonium, Cucubalus baccifer, Cydonia oblonga, Eryanthus ravennae, Hedera pastuchovii, Iris pseudacorus, Malus orientalis, Ophyoglossum vulgatum, Orchis picta, и O. purpurea, Periploca graeca, Primulama crocalyx и P. woronowii, Salvinia natans, Tulipa biebersteiniana, Vitis sylvestris.

5. Редкими на территории заказника являются Allium ursinum, Chelidinium majus, Clematis orientalis, Listera ovata, Physalis alkekengi, Oenothera biennis, Orobanche coerulescens, Platanthera bifolia, Scilla sibirica, Viburnum lantana, Vinca herbacea.

6. Флора богата хозяйственно полезными видами, популяции некотрых из них резко сокращаются в связи с заготовками для пищевых целей (Allium ursinum, A. paradoxum) и на букеты для продажи (Convallaria transvaucasica, Primula woronowii u P. macrocalyx, Scilla sibirica).

7. Даны рекомендации по сохранению и воспоизводству биоресурсов флоры Парбочевского заказника.

10. Толмачев А.И. Введение в географию растений. Л.: Изд-во ЛГУ, 1974. 244 с.

11. Толмачев А.И. Методы сравнительной флористики и проблемы флорогенеза. Новосибирск: Наука, 1986. 195 с.

12. Камелин Р.В. Флорогенетический анализ естественной флоры горной Средней Азии. Л.: Наука, 1973. 355 С.

13. Юриев Б.А. Дискуссия на тему «Метод конкретных флор в сравнительной флористике» // Ботанический журнал. Т.59, N 9. 1974. С. 1399-1407.

14. Середин P.М. Анализ флоры Северного Кавказа// Региональные флористические исследования / Под ред. В.М. Шмидта. Л.: Изд-во ЛГУ, 1987. С. 5-20.

15. Иванов А.Л. Флора Предкавказья и ее генезиС. Ставрополь, 1998.204 с.

16. Иванов Л.А. Конспект флоры Ставрополья. Ставрополь. 2001. С. 200 с.

17. Галушко А.И. Растительный покров Чечено-Ингушетии / Грозный: Чечено-Ингушское кн. изд-во, 1975. С. 118.

18. Галушко А.И. Флора Северного Кавказа. Изд-во Ростовского университета, 1978-1980: Т. 1, 1978. - 317 с.; Т. 2 , 1980. -350 C. T. 3, 1980. -327 c.

19. Engler J. Syllabus der Pfanzenfomilien. Berlin: Borntrager, 1898. 204 p.

20. Красная книга Чеченской Республики. Рекдкие и находящиеся под угрозой исчезновения виды растений и животных. Грозный, 2007. 432 с. 


\title{
СВЕДЕНИЯ ОБ АВТОРАХ / Information about authors:
}

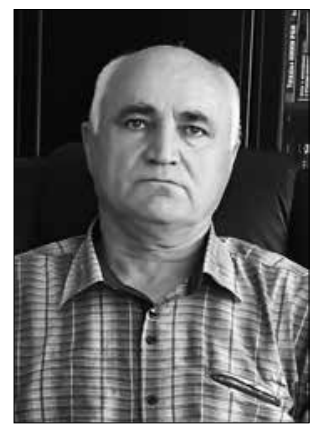

ГАПАЕВ Яндарбек СайдбекоВич - старший научный сотрудник лаборатории экологии, Академия наук Чеченской Республики; научный сотрудник лаборатории экологии Комплексного научно-исследовательского института им. Х. И. Ибрагимова Российской Академии наук, 364051, г. Грозный, Чеченская Республика, Россия

Тел.: 8(928)948-81-01 (моб.); e-mail:kniiran@.ru

Andarbek S. GAPEEV - senior researcher of the laboratory of ecology, Academy of Sciences of the Chechen Republic; researcher at the laboratory of ecology of the Kh. I. Ibragimov Integrated Research Institute, Russian Academy of Sciences.

364051, Grozny, Chechen Republic, Russia

Ph.: +7(928)948-81-01 (mob.);

e-mail:kniiran@.ru

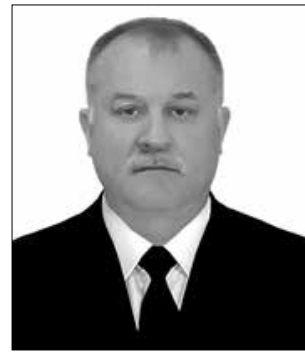

ТАЙСУМОВ Муса Анасович доктор биологических наук; главный научный сотрудник отдела экологии Комплексного научно-исследовательского института им. Х. И. Ибрагимова Российской Академии наук, 364051, г. Грозный, Чеченская Республика, Россия

Тел.: 8(929)890-32-13 (моб.). e-mail:musa_taisumov@mail.ru

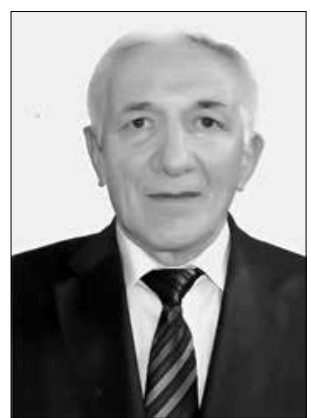

УМАРОВ Мухади Умарович доктор биологических наук; заведующий отделом биологии и экологии, Академия наук Чеченской Республики, академик Академии наук Чеченской Республики; заведующий лабораторией экологии Комплексного научно-исследовательского института им. Х. И. Ибрагимова Российской Академии наук. 364051, г. Грозный, Чеченская Республика, Россия

Тел.: 8(928) 737-43-91 (моб.);

e-mail: umarovbiolog@mail.ru

Mukhadi U. UMAROV - Doctor of Biological Sciences; head of the Department of biology and ecology, Academy of Sciences of the Chechen Republic, academician of the Academy of Sciences of the Chechen Republic; head of the laboratory of ecology of the Kh. I. Ibragimov Integrated Research Institute, Russian Academy of Sciences.

364051, Grozny, Chechen Republic, Russia

Ph.: 8(928) 737-43-91 ( mob.);

e-mail:umarovbiolog@mail.ru

Musa A. TAISUMOV-Doctor of Biological Sciences; chief researcher of the Department of ecology of the Kh. I. Ibragimov Integrated Research Institute, Russian Academy of Sciences. 364051, Grozny, Chechen Republic, Russia

Ph.: +7(929)890-32-13 (mob.);

e-mail:musa_taisumov@mail.ru

\section{PARABOCHEVSCIY RESER FLORA AND ITS SYSTEMATIC ANALYSIS}

\author{
1, 2 Umarov M. U., * \\ 1,2 Gapaev Y. C, \\ ${ }^{1,2}$ Taisumov M. A. \\ ${ }^{1}$ Complex Research Institute named after Kh. I. Ibragimov of the Russian Academy of Sciences, Grozny, Russia, \\ umarovbiolog@mail.ru \\ ${ }^{2}$ Academy of Sciences of the Chechen Republic, Grozny, Russia
}

DOI: $10.21177 / 1998-4502-2018-10-4-526-532$

Parabochevsky State Biological Reserve was founded in 1963 in the valley of the r. Terek (Chechen Republic) on an area of 12.0 thousand hectares. But information about its nature including flora is very limited.

The purpose of the work. The study of the composition and systematic analysis of the flora, the identification of rare, relict and resource-useful species.

Research methodology. Floristic studies were carried out in 2012-2015 in different seasons of the year along routes covering different sites and habitants of the reserve. To clarify the types 3-volume determinant A.I. Galushko "Flora of the North Caucasus" (1978-1980) was used. The attention is paid to the systematic composition of the flora, the presence of relics, rare and economically useful species.

Results. The reserve has revealed 266 species of vascular plants from 205 genera and 71 families. The largest 
families - Asteraceae, Rosaceae, Lamiaceae, Fabaceae, Poaceae, Boraginaceae, Brassicaceae, Caryophyllaceae, Apiaceae, Malvaceae - accounted for 111 (54.1\%) genera and $145(64.4 \%)$ species. The largest are genus, including by (Artemisia, Centaurea), 4 species (Potentilla), 3 species each (Allium, Crataegus, Inula, Populus, Trifolium, Salix, and Viola). 2 species contain 40 genera. A total of $50(24.4 \%)$ genera numbered $115(43.2 \%)$ species. In the remaining 155 genera - one type. The Red Book Books (Allium paradoxum, Althaea officinalis, Amygdalus nana, Cephalanthera damasonium, Cucubalus baccifer, Cydonia oblonga, Eryanthus ravens, sites, sites, sites, sites, sites, sites, sites, sites, sites . woronowii, Salvinia natans, Tulipa biebersteiniana, Vitis sylvestris), other rare species (Allium ursinum, Chelidinium majus, Clematis orientalis, Listera ovata, Physalis alkekengi, Oenothera biennis, Orobanche, you will also be looking for what you are looking for, if you are looking for what you and also your company is looking for, if you are looking for what you and also your company is looking for, this is what you and your company will be looking for. and tertiary relics (Euonymus europaea, Carpinus caucasica, Cornus mas, Corylus avellana, Lonicera caprifolium, Populus hybrida, Pyrus saucasica, Quercus robur, Rubus caesius, Sambucus nigra, Tilia cordata, Ulmus suberosa, herbal - Alliaria officinalis, Allium paradoxum, Arum maculatum, Convallaria transcauca sica, Humulus lupulus, Tamus communis, etc.).

Conclusions. The flora of the reserve which is rich in systematic composition (266 species from 205 genera and 71 families) contains many relict, rare and economically useful species, most of which should be protected and reproduced.

Keywords: Chechen Republic, Barabashevsky reserve, flora, family, genus, relicts, protected and rare species.

\section{References}

1. Bolotbiev H. R. State of reserves and monuments located on the territory of the Chechen Republic. Historical and cultural heritage of the peoples of the South of Russia. Proceedings of the All-Russian Scientific-Practical Conference (Grozny, June 25-26, 2009). Vol. II, Grozny, 2009, pp. 119-129.

2. Braun-Blanquet J., Furrer E. Remarques sur l'etude des groupements de plantes. Bull. Soc. Languedos. Georg, 1913, no 36 , pp. $20-41$.
3. Braun-Blanquet J. Essaisur les notions «d'element» et de «territore» phytogeographiques. Archives des scieces physiques et naturalles. Geneve, 1919, Ser. 5, vol. 1, pp. 479-512.

4. Braun-Blanquet J. L'origineet le developpement des floresdans massif central de France. Paris; Zurich, 1923, 282 p.

5. Koch W. Die Vegetation seinheiten der Linthebere unter Berucksichtigung der Verhaltnisse in der N.O. Schweiz . Jb. St. Gall. Naturw. Ges, 1925, No 61(2), pp. 1-146.

6. Lavrenko E. M. Forest relict (tertiary) centers between the Carpathians and Altai. Journal of the Russian Botanical Society, 1930, vol. 15, no 4, pp. 351-363.

7. Bush N. Ah. Botanical and geographical sketch of the Caucasus. Moscow-Leningrad, Izd-vo AN SSSR, 1935, 108 p.

8. Davis P.H. Introduction. Flora of Turkey and the East Aegean Islands, Edinburg, 1965, vol. 1, pp. 1-26.

9. Walter H., Straka H. Geography of the area, historical and floral geobotany. Stuttgart, 1970, $480 \mathrm{p}$.

10. Tolmachev I. I. Introduction to the geography of plants. Leningrad, Publishing house of LSU, 1974, 244 p.

11. Tolmachev A. I., Methods of comparative Floristics and problems of floro-genesis. Novosibirsk, Nauka, 1986,195 p.

12. Kamelin R. V. Florogenetic analysis of natural flora of mountain Central Asia. Leningrad, Nauka, 1973. 355 p.

13. Yurtsev B.A. A discussion on "the method of specific flora in comparative floristry". Botanical journal, 1974, Vol. 59, No 9, pp. 1399-1407.

14. Seredin R. M. Analysis of the flora of the North Caucasus. Regional floristic studies / ed. V. M. Schmidt. Leningrad, Publishing house of LSU, 1987, pp. 5-20.

15. Ivanov A. L. The flora of the forefathers and its Genesis. Stavropol, 1998, 204 p.

16. Ivanov L. A. Outline of the Stavropol flora. Stavropol, 2001, pp. 200.

17. Galushko A. I. Vegetation of the Chechen-Ingush. Grozny, Chechen-Ingush book. publishing house, 1975, pp. 118.

18. Galushko A. I. Flora Of The Northern Caucasus. Rostov University publ., 1978-1980: Vol. 1, 1978. - 317 p.; Vol. 2, 1980. - 350 p. Vol. 3, 1980. - 327 p.

19. Engler J. Syllabus der Pfanzenfomilien. Berlin, Borntrager, 1898, $204 \mathrm{p}$.

20. Red book of the Chechen Republic. Rare and endangered species of plants and animals. Grozny, 2007, 432 p.

Article received 12.05.2017. 


\section{МАТЕМАТИЧЕСКОЕ МОДЕЛИРОВАНИЕ ЭВОЛЮЦИИ ЛЕДНИКА ДЖАНКУАТ В СОВРЕМЕННЫХ КЛИМАТИЧЕСКИХ УслОвИЯх}

\section{Введение}

Стратегическое планирование социально-экономического развития горных регионов и их выход в перспективе на траекторию устойчивого развития требует оценки природных ресурсов территории и, не в последнюю очередь, водных ресурсов. Проблема оптимизации использования водных ресурсов остро стоит во многих регионах мира, которые можно отнести к горным и предгорным, и где речной сток в большой степени зависит от состояния горного оледенения.

В настоящее время регулирование водных ресурсов на Кавказе, впрочем, как в других регионах мира (в частности в Альпах), затруднено фрагментированным водопользованием, неравным доступом к воде, противоречивой правовой системой в области регулирования водопользования [1]. В условиях изменения климата, которое непосредственно затрагивает горные территории и выражается, прежде всего, в постепенном росте приземной температуры воздуха и в изменении режима выпадения осадков, прогностические расчеты ледникового стока представляются одной из наиболее актуальных задач разработки стратегий регионального развития.

Ледниковый сток является одним из основных источников пресной воды в обширных регионах. Петраков и др. [2], ссылаясь на отчет Международной группы экспертов по изменению климата, приводят данные о том, что в Средней Азии талая вода горных ледников составляет 20-40\% летнего стока рек. В жаркие засушливые годы эта доля доходит до 70-80\%. Согласно другим оценкам [3], во влажных климатических областях доля стока с гор составляет примерно 30-40\% (здесь, скорее всего, имеется в виду весь сток, а не только ледниковый). Этот факт объяснятся тем, что горы производят больше стока, чем предгорья и низменности в расчете на единицу площади, что связано со сравнительно высоким количеством осадков и сравнительно небольшим испарением. В засушливых областях вышеуказанная доля может составлять 50-95\% [3].

Горные ледники представляют собой, по-видимому, наиболее уязвимую для климатических изменений часть криосферы. В 20-м и начале 21-го века была отмечена устойчивая тенденция сокращения площади и объема горного оледенения Кавказа [4; 5]. В условиях изменяющегося климата эта тенденция, вероятно, сохранится [6]. Надежные прогностические оценки эволюции отдельных ледников возможно получить, используя метод математического моделирования. Проблема заключается в том, что исходных данных для аккуратного выполнения численных экспериментов крайне недостаточно, в связи с чем усилия по проведению прогностических расчетов приходится концентрировать на отдельных опорных (типичных по ряду показателей) ледниках, и в дальнейшем экстраполировать результаты на достаточно большой регион.

Для Центрального Кавказа таковым опорным ледником является ледник Джанкуат. Это уникальный природный объект с точки зрения обилия длительных и комплексных наблюдений. Например, непрерывные масс-балансовые наблюдения продолжаются здесь на протяжении последних пятидесяти лет.

\footnotetext{
${ }^{1}$ Филиал Института природно-технических систем, г. Сочи, Россия

${ }^{2}$ Сочинский научно-исследовательский центр РАН, г. Сочи, Россия, o.o.rybak@gmail.com,

${ }^{3}$ Институт глобального климата и экологии Росгидромета и РАН, г. Москва, Россия

${ }^{4}$ Московский государственный университет им. М.В. Ломоносова, г. Москва, Россия
}

1,2Рыбак O.O.*

1,2Рыбак E.A.,

1,3Корнева И.А.,

${ }^{4}$ Поповнин В.В.

УДК 551.89 551.583.7 DOI: 10.21177/1998-4502-201810-4-533-543

Рассматриваются результаты численных экспериментов, в которых реконструируется эволюция ледника Джанкуат (Центральный Кавказ) в современных климатических условиях. Показано, что для корректных прогностических расчетов ледникового стока необходимо учитывать бронирующую роль моренного чехла.

\section{КЛЮЧЕВЫЕ СЛОВА:}

горный ледник, математическая модель, баланс массы, моренный чехол, ледниковый сток

Статья поступила в редакцию 19.03.2018. 

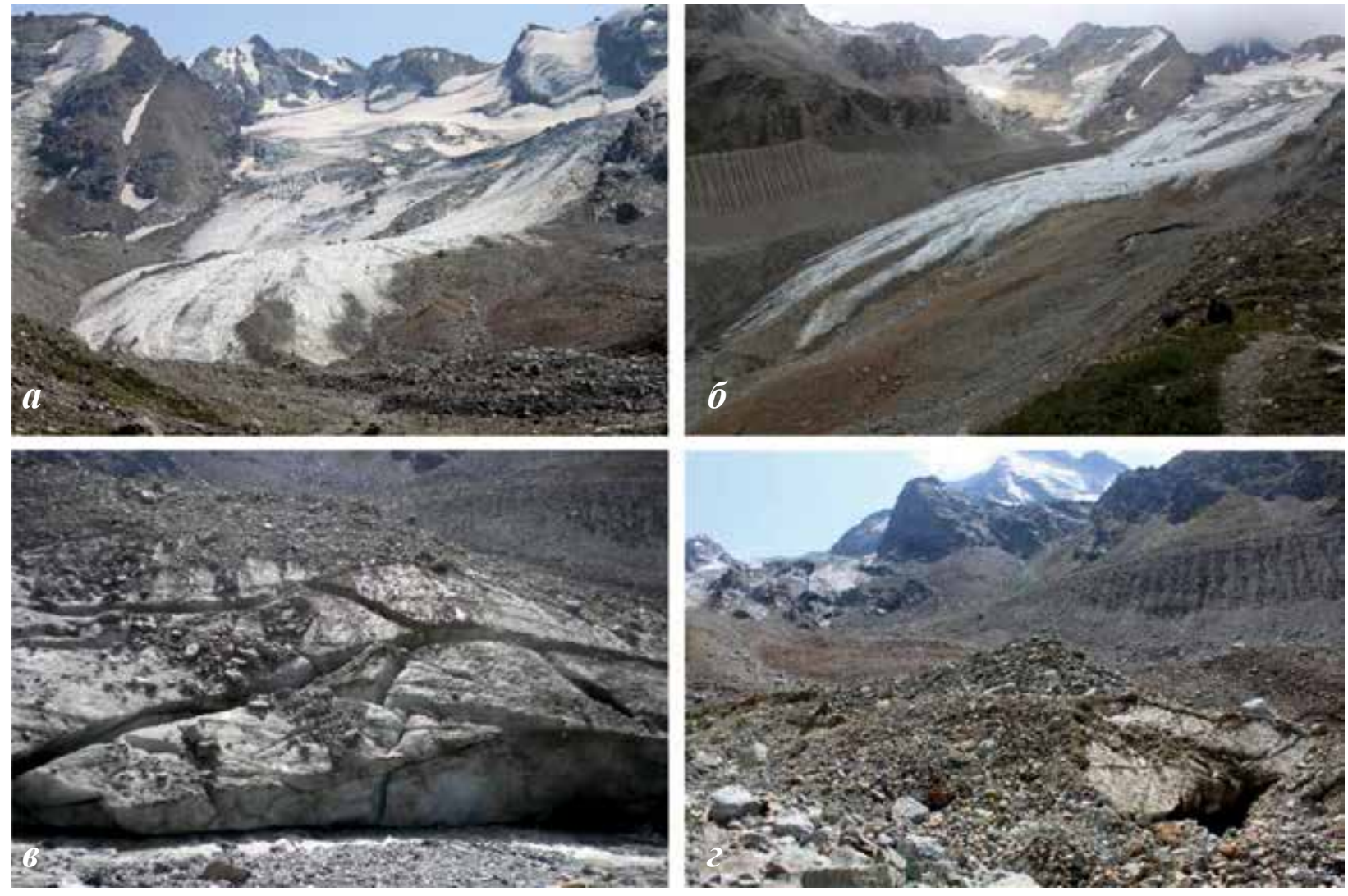

Pис. 1. Ледник Джанкуат: вид на фронтальную часть из ущелья Адыл-Су (а); вид на фронтальную часть с боковой морены (б); язык ледника, покрытый осыпным материалом (в); часть ледника в прифронтальной части, полностью скрытая под моренным чехлом (2)

Fig. 1. Djankuat Glacier: a view on the terminus from Adyl-Su valley (a); a view on the glacier terminus from the side moraine (6); terminus of the glacier covered with debris (b); frontal part of the glacier totally covered with debris (2)

Итоги первого десятилетия наблюдений были подведены в монографии [7], ставшей, по сути дела, классической, выводы и обобщения которой не потеряли актуальности до настоящего времени. По материалам наблюдений на Джанкуате написаны десятки статей, диссертаций, студенческих работ. Объем полученного и обработанного материала в значительной степени облегчает стандартные в математическом моделировании ледниковых объектов процедуры калибровки, верификации и валидации модели.

По своим морфометрическим и прочим характеристикам ледник Джанкуат (рис. 1) можно считать типичным для Центрального Кавказа. Его площадь 2,7 кв. км [8], площадь поверхностной морены на нем

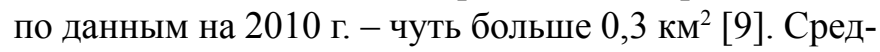
няя площадь долинных и карово-долинных ледников, составляющих основную массу оледенения Центрального Кавказа, составляет соответственно 3,6 и 1,6 км² при средней площади морены 0,3 и 0,1 кв. км [11]. Поверхностная морена по своим теплофизическим характеристикам резко отличается от чистой поверхности льда. Так, если характерное альбедо льда лежит в пределах $0,2-0,4$, то характерное альбедо осыпного материала $-0,05-0,15$. Соответственно, моренный чехол эффективнее поглощает коротковолновую радиацию, радикально меняет интенсивность абляции, следовательно, режим и объем стока талой воды [9]. В то же время моренный чехол выполняет теплоизолирующую (экранирующую) функцию. Если толщина моренного чехла не превышает критического значения («критической толщины»), то его наличие способствует усилению абляции через механизм уменьшения альбедо [12]. Максимального значения по сравнению с чистой поверхностью таяние достигает при толщине слоя, которая носит название «эффективной» [13]. Значения эффективной и критической толщин моренного чехла варьируются в широком диапазоне - от нескольких миллиметров до нескольких сантиметров (см. табл. 1 в [14]).

Задачи настоящего исследования заключались в том, чтобы выяснить:

1) находится ли ледник Джанкуат в равновесии с условными современными климатическими условиями;

2) какова роль поверхностной морены в формировании полей составляющих поверхностного баланса массы;

3) как поверхностная морена влияет на приспособление ледника к заданным климатическим условиям.

\section{Постановка и проведение численных экспериментов}

Основные блоки математической модели - динамический (для расчета скорости течения льда), 
климатический (для задания климатических переменных, используемых в численном эксперименте) и масс-балансовый (для расчета поверхностного баланса массы). Поскольку все перечисленные блоки и взаимодействие между ними достаточно подробно описаны ранее [15; 16 и ссылки в этих работах], мы не будем останавливаться на разборе структуры модели. Напомним лишь основные определения, которые используются ниже. В настоящей работе, удельный баланс массы (далее - баланс массы) горного ледника $S M B$ определяется как разность между суммарной аккумуляцией $A C C$ и суммарным стоком $R O: S M B=\sum_{1}^{365}[A C C-R O] . \quad$ Аккумуляция рассчитывается как сумма выпавших твердых осадков, из которой вычитается количество испарившейся влаги с поверхности $S U$, лавинного питания $L F$ и метелевого переноса $M F$ : $A C C=P S-S U+L F+M F$. Величина стока складывается из массы растаявшего снега и льда $M$, которая уменьшается на количество вторично замерзшей воды $R F$. Особенности оценки аккумуляции детально обсуждаются в [16], алгоритм расчета подморенного таяния - в $[17 ; 18]$.

В качестве исходных климатических переменных были использованы осредненные за десять балансовых лет (1999/2000 - 2008/2009) значения приземной температуры воздуха на метеостанции (MC) Терскол и суммы осадков на МС Местиа (рис. 2). Обе метеостанции расположены поблизости от ледника. На самом леднике вблизи от снеговой линии в течение последнего десятилетия в летний сезон работает автоматическая метеостанция (АМС Джанкуат). Сопоставление данных наблюдений за приземной температурой воздуха на ней и на МС Терскол позволил построить простую линейную зависимость между рядами и, таким образом, приводить наблюдения на MC Терскол к условиям ледника, учитывая также и температурный скачок. Расчет скорости таяния методом энергетического баланса представляет собой достаточно рутинную задачу и ранее выполнялся для ледника Джанкуат [15].

Сложнее обстоит дело с приходной частью баланса массы. Согласно оценке Панова и др. [5], основными источниками питания ледников Кавказа (приходной части баланса массы) являются атмосферные осадки (более $50 \%)$, метелевый перенос $(10-42 \%)$ и снежные лавины (3-76\%). Приблизительный подсчет, основанный на анализе данных регулярных снегомерных съемок, показывает, что зимние осадки на леднике Джанкуат должны вдвое превышать годовые суммы осадков измеренных на МС Терскол и МС Местиа (на обеих метеостанциях годовые суммы осадков приблизительно одинаковы). По всей видимости, причиной повышенного количества осадков являются особенности местной атмосферной циркуляции [7]. Разброс выше-
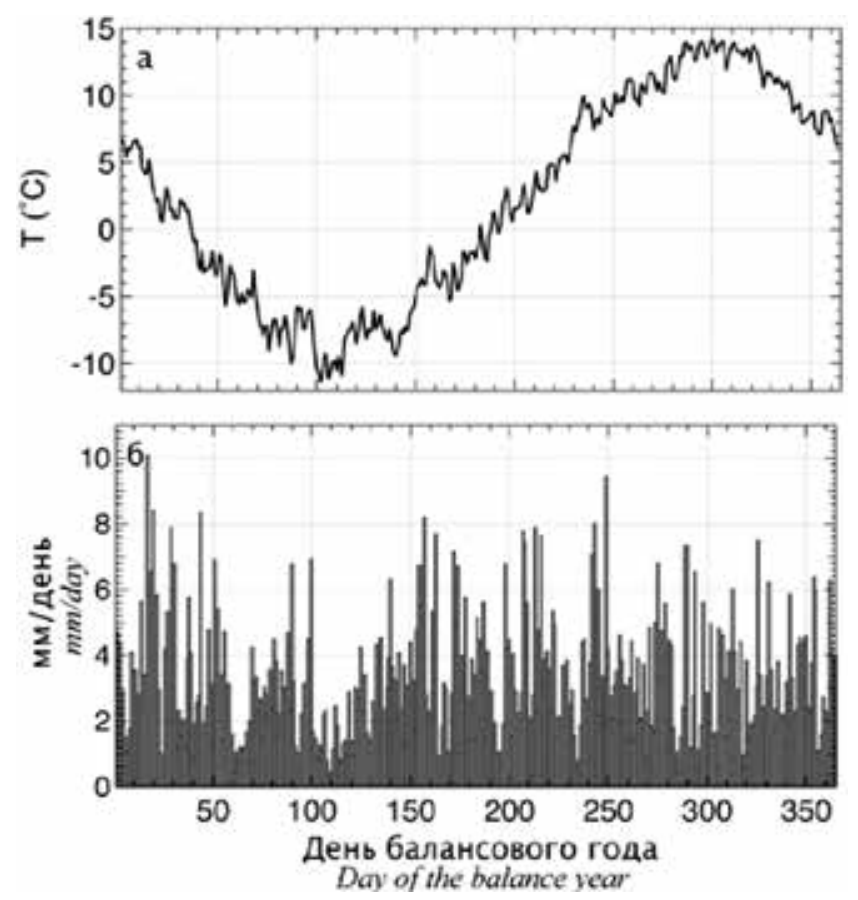

Puc. 2. Среднесуточная приземная температура воздуха $\left({ }^{\circ} \mathrm{C}\right)$ на метеостанщии Терскол (a); суточные суммы осадков (мм) на метеостанции Местиа. Данные осреднень для гидрологических лет 1999/2000-2008/2009.

Fig. 2. Mean daily surface temperature $\left({ }^{\circ} \mathrm{C}\right)$ at Terskol meteostation (a); daily precipitation ( $\mathrm{mm}$ ) at meteostation Mestia. Data were averaged for 1999/2000-2008/2009 hydrological years.

приведенных оценок метелевого переноса и лавинного питания не позволяет разработать единую параметризационную схему, которая бы обеспечивала реалистичные результаты для всех ледников. Вместо этого приходится производить калибровку и настройку формирования приходной части баланса для каждого отдельно взятого ледника. Настройка масс-балансового блока для условий ледника Джанкуат была выполнена для балансового десятилетия 1999/2000-2008/2009 гг. с учетом оценки вклада лавинного питания [15].

Нами было поставлено два численных эксперимента длительностью 90 модельных лет (2011-2100 гг.). В первом эксперименте моренный чехол не учитывался, во втором - учитывался. Выбор стартового года был обусловлен тем обстоятельством, что карта распределения мощности моренного чехла была составлена по состоянию на 2010 г. (рис. $3 a$ ) по данным полевых измерений [9]. Радиозондирование ледника Джанкуат и расчет толщины льда проводились в 2012-2013 гг. [8] (рис. 3б). Помимо этого, наиболее полные и с минимальным количеством пропусков ряды приземной температуры воздуха были получены в летний сезон 2007 и 2011 годы.

Перед началом экспериментов «климатические» ряды (рис. 2) считывались в модель каждый год, пока масс-балансовый блок модели (при отключенном динамическом блоке) не выходил на стационарный режим - расчеты повторялись до тех пор, пока составляющие баланса массы на достигали постоянных значе- 
ний, что потребовало нескольких модельных лет. Итоговые поля таяния и баланса массы показаны на рис. 4. Очевидно, что моренный покров выполняет только экранирующую функцию, поскольку его толщина повсеместно превышает 0,5 м. Различия в результатах, представленных на рис. 4а и 4б, 4в и 4г наблюдаются только в областях, покрытых моренным чехлом.

Горизонтальные компоненты скорости течения $u$ и $v$ находились путем решения системы нелинейных эллиптических уравнений [14]:

$4 \frac{\partial}{\partial x}\left(\eta \frac{\partial u}{\partial x}\right)+2 \frac{\partial}{\partial x}\left(\eta \frac{\partial v}{\partial y}\right)+\frac{\partial}{\partial y}\left(\eta \frac{\partial u}{\partial y}\right)+\frac{\partial}{\partial y}\left(\eta \frac{\partial v}{\partial x}\right)+\frac{\partial}{\partial z}\left(\eta \frac{\partial u}{\partial z}\right)=\rho_{i} g \frac{\partial s}{\partial x}$

$4 \frac{\partial}{\partial}\left(\eta \frac{\partial v}{\partial y}\right)+2 \frac{\partial}{\partial y}\left(\eta \frac{\partial u}{\partial x}\right)+\frac{\partial}{\partial x}\left(\eta \frac{\partial u}{\partial y}\right)+\frac{\partial}{\partial x}\left(\eta \frac{\partial v}{\partial x}\right)+\frac{\partial}{\partial z}\left(\eta \frac{\partial v}{\partial z}\right)=\rho_{i} g \frac{\partial s}{\partial y}$

,(1) водились на кластере (HP XC Cluster Platform 4000)

го участка, где толщина превышает 60 м (см рис. 3б), что, во-первых связано с труднодоступностью плато, a, во-вторых, с его пограничным положением (граница с Грузией проходит по плато, и часть его находится на территории сопредельного государства). Нельзя исключить, что граница ледника, проходящая по ледоразделу на Джантуганском плато, показанная на рис. 3б, постоянно мигрирует. Возможно, что фактическая площадь ледника меняется от положения этой границы. Напомним, что Джантуганское плато является областью питания и для ледника Лекзыр, самого большого ледника Грузии.

Все программы для расчетов написаны на языке FORTRAN90/95. Численные эксперименты произгде $\eta$ - эффективная вязкость, равная: водились на кластере (HP XC Cluster Platform 4000) компьютер$\eta=\frac{1}{2} A(T)^{-1 / n} \times\left[\left(\frac{\partial u}{\partial x}\right)^{2}+\left(\frac{\partial v}{\partial y}\right)^{2}+\frac{\partial u}{\partial x} \frac{\partial v}{\partial y}+\frac{1}{4}\left(\frac{\partial u}{\partial y}+\frac{\partial v}{\partial x}\right)^{2}+\frac{1}{4}\left(\frac{\partial u}{\partial z}\right)^{2}+\frac{1}{4}\left(\frac{\partial v}{\partial z}\right)^{2}\right]^{(1+n) / 2 n}$

(2) ного центра Свободного университета Брюсселя (Vrije

$A(T)$ - реологическая функция, зависящая от температуры льда; $s$ - высота поверхности ледника, $b$ - высота подстилающей поверхности, $\rho_{\imath}-$ плотность льда, $\mathrm{g}$ - ускорение свободного падения, $n=3$. В настоящей работе реологическая функция заменяется на параметр $\mathrm{A}_{\mathrm{fl}}$, поскольку ледник считается изотермическим и «теплым», то есть находящимся при температуре плавления. Вектор скорости базального (глыбового) скольжения считается пропорциональным напряжению на нижней границе в третьей степени:

$$
\left.u\right|_{b}=-A_{s l} \tau_{b}^{3}
$$

где $A_{s l}$ - коэффициент трения.

Для решения уравнений системы (1) применялся метод сопряженных градиентов. Сама система решалась итерационно методом Пикара с применением специального релаксационного алгоритма [14]: первое и второе уравнения из (1) решаются независимо друг от друга, далее найденные значения $u$ и $v$ подставляются в (2), после чего обновленное значение $\eta$ подставляется в оба уравнения (1), и процедура повторяется. Были использованы те же значения параметров $A_{f l}$ и $A_{s l}$, как и в моделях динамики ледника Марух и Мортерач [14]. Поля амплитуд скорости поверхностного течения и базального скольжения показаны на рис. $5 a$ и $5 б$. Максимальные значения скорости на поверхности ледника превышают 50 м/год на участке, где толщина льда превышает 100 м при относительно большой крутизне склона (рис. $5 a$ ). На всем протяжении правого притока и на практически ровном Джантуганском плато в верхней части ледника поверхностная скорость не превышает 0,1 м/год. Следует отметить, что толщина льда на Джантуганском плато не измерялась (за исключением небольшо-
Universiteit Brussel/Univerdité libre de Bruxelles).

\section{Результаты и обсуждение}

После того как масс-балансовый блок был выведен на стационарный режим, подключался динамический блок. Ввод рядов климатического форсинга осуществлялся ежегодно на протяжении девяноста модельных лет. Вполне естественно, что в результате свободной эволюции менялась конфигурация ледника. Очевидно, что на момент начала численных экспериментов, ледник не находится в равновесии с климатическими условиями 1999 2008 гг. Из-за этого происходит отступание ледника до достижения равновесного состояния (рис. 6). Характерно, что при неучете влияния моренного чехла происходит постепенное отступание языка ледника более, чем на 900 м и отчленение правого рукава (рис. 6a). В то же время, если учитывается экранирующий эффект поверхностной морены, то отступание языка ледника значительно меньше менее 200 м, и правый рукав остается соединенным с основным телом ледника (рис. 6б). При этом прифронтовой участок, защищенный моренным покровом, соединен с самим ледником лишь узкой перемычкой.

Сокращение толщины льда, что вполне естественно, учитывая экранирующий эффект моренного чехла, наиболее значительно на участках с чистым льдом (рис. 6в и 6г). Вдоль оси течения (рис. 5a) формируются участки уменьшения и увеличения толщины льда (рис. 6 в и 6г), которые, очевидно, носят динамический генезис (в частности, очаг уменьшения толщины находится в зоне аккумуляции). Сокращение толщины в прифронтовой области связано с процессом таяния, которое не может быть компенсировано 

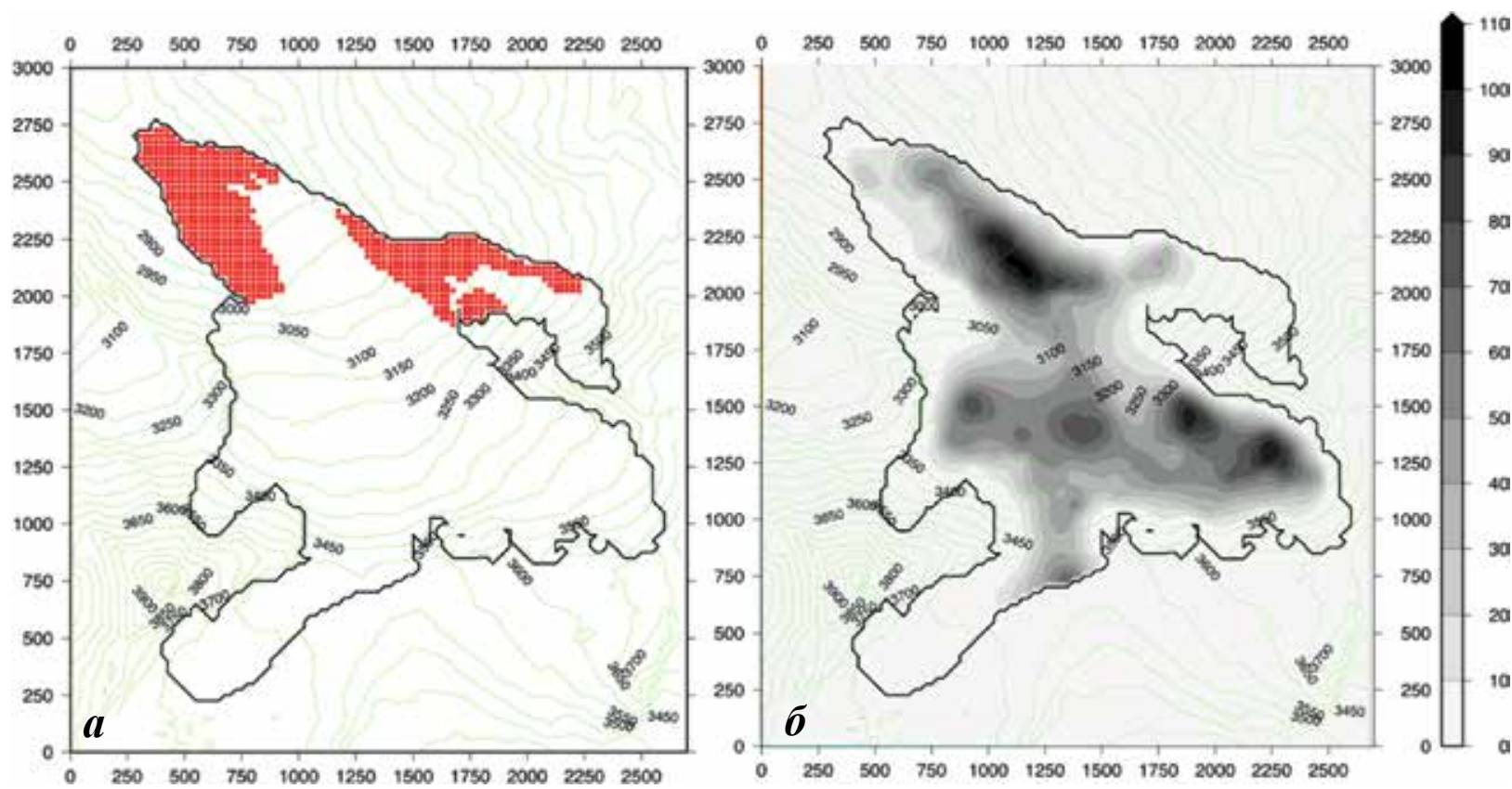

Pис. 3. Красным показаны ячейки пространственной сетки $25 x 25$ м, покрытые моренным чехлом (а); поле толщины льда (м) согласно данным радиозондирования (б). Здесь и на последующих рисунках на боковых границах обозначено

расстояние в метрах от условной нулевой точки. Зелеными изолиниями показана высота над уровнем моря (м)

Fig. 3. Shown in red, are debris covered cells of the spatial $25 x 25 \mathrm{~m}$ grid (a); ice thickness field (m) according to radio echo-sounding measurements (б). Hereafter numbers on the sides of the figures denote distance in meters from a conventional zero point. Shown in green, are isolines of altitude above sea level $(\mathrm{m})$

адвекцией льда с участков, расположенных выше по течению. Наконец, увеличение толщины льда на Джантуганском плато обусловлено тем, что снегонакопление здесь преобладает над таянием, а скорости течения крайне малы для эффективного перемещения льда вниз по течению. С этим же связано увеличение толщины льда в верхней части правого рукава, находящегося выше снеговой линии (и которая отчленяется от основной части ледника в численном эксперименте без учета экранирующей роли моренного чехла - рис. $6 a$ ).

То обстоятельство, что Джанкуат находится в дисбалансе с современными климатическими условиями, подтверждается сокрашением его площади в обоих численных экспериментах (рис. 7a) При этом, если моренный чехол учитывается, то сокращение площади идет относительно равномерно, постепенно затухая после 2080 г. Без учета экранирующей роли поверхностной морены ледник теряет 15\% площади в первое десятилетие, после чего процесс замедляется, и площадь ледника стабилизируется после 2065 г. на уровне $78 \%$ от современной.

Резкое уменьшение объема на 5\% сменяется ростом в 2030 г. до практически современного уровня в 2100 (рис. 7б). Интересно, что при учете моренного чехла при уменьшении площади происходит увеличение объема ледника приблизительно на $4 \%$ к 2100 г. При этом основной рост приходится на период 2050-2060 гг., после чего объем меняется крайне незначительно. По всей видимости, за 40-50 лет ледник приходит в равновесие с современным климатом. Если же влияние поверхностной морены не учитывается, то приспособление происходит за горизонтом 2100 г. (судя по продолжающемуся росту объема).

Для прогностических оценок доступных водных ресурсов важны расчеты ледникового стока. В более реалистических условиях, когда учитывается моренный чехол, ледниковый сток к концу столетия должен сократиться на 18-19\% (рис. $8 a$ ). Стабилизация стока после 2020 г. отчасти объясняется тем, что в стационарных климатических условиях площадь ледника меняется мало.

В целом по леднику учет экранирующей роли поверхностной морены позволяет уточнить прогноз ледникового стока на 9-10\% (рис. 8б). Максимальный экранирующий эффект достигается в прифронтовой части, где доля подморенного таяния составляет 35-55\% относительно таяния чистой поверхности льда (рис. 9). В меньшей степени этот эффект сказывается выше по течению на правом рукаве (60-80\%).

Полученные результаты сопоставимы со сделанными ранее оценками. Ламбрехт с соавторами [17] подсчитали, что годовая сумма абляции на заморененных участках ледника Джанкуат сокращается на $26 \%$, что вполне соответствует подморенному таянию на правом рукаве, но несколько ниже, чем в прифронтовой части. Оценки Пелто [18], сделанные для двух ледников в Британской Колумбии (Канада), более близки к нашим: годовая абляция под за- 

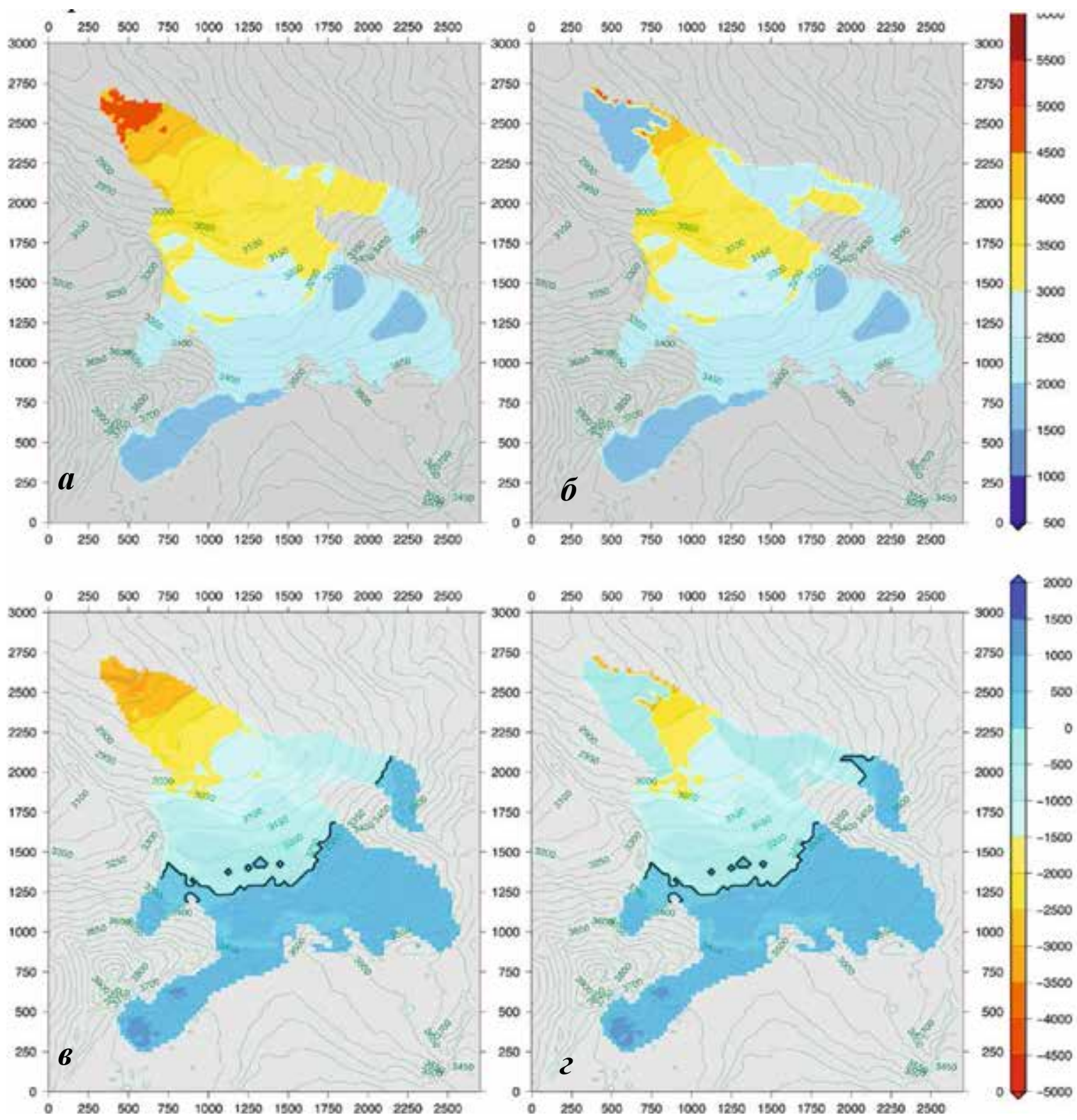

Pис. 4. Скорость поверхностного таяния (мм/год), (а, б), поверхностный баланс массы (в, г) при отсутствии (а, в) и при наличии $(б$, г) моренного чехла. Черной жирной линией показана снеговая линия $(6$, г)

Fig. 4. Melting rate (mm/year), ( $(, \sigma)$ ), surface mass balance $(6,2)$ under condition of absence $(a, b)$ and presence $(6,2)$ of the debris cover. Bold black line indicates equilibrium line

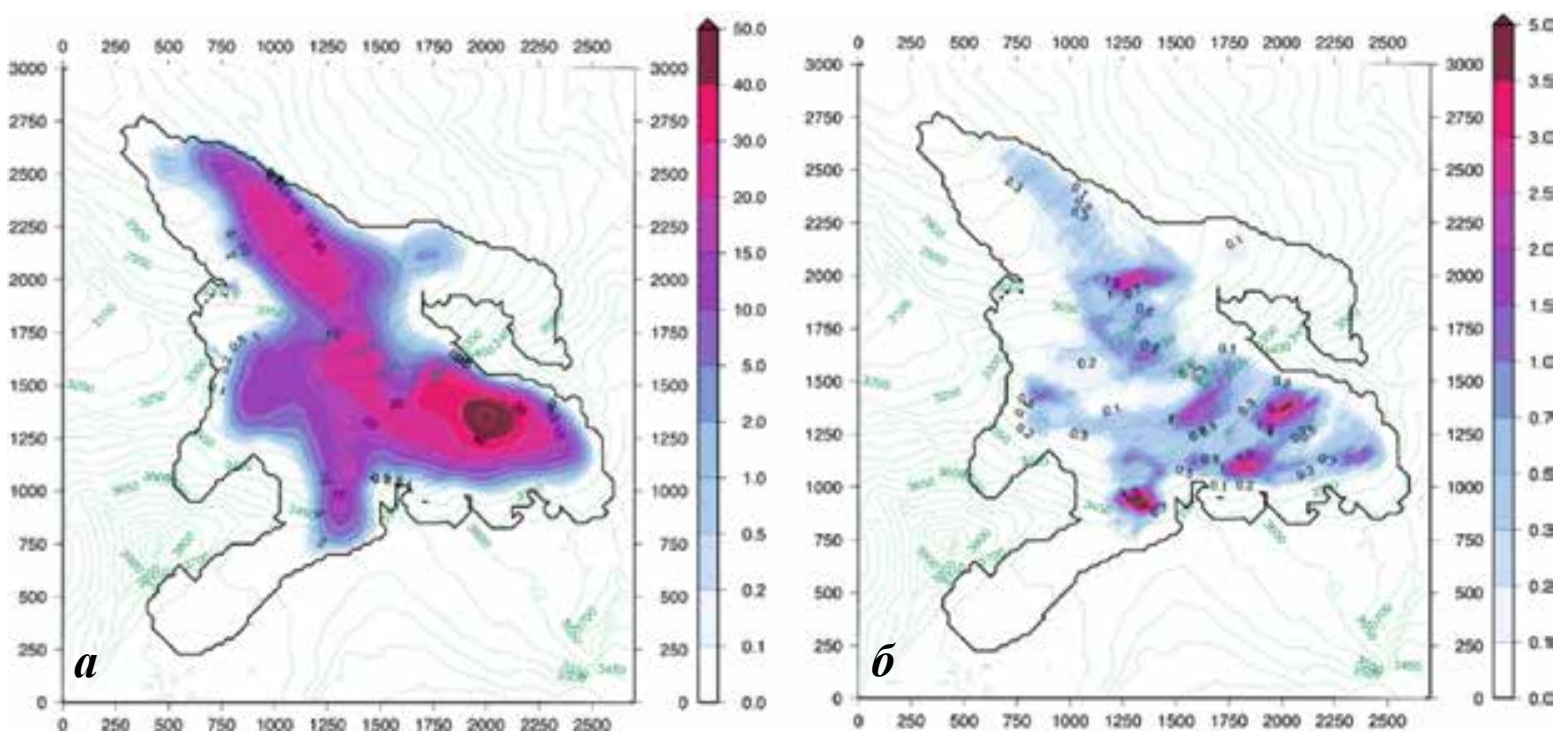

Pис. 5. Амплитуды поверхностной (а) и базальной (б) скоростей течения льда (м/год)

Fig. 5. Amplitudes of surface (a) and basal (б) ice flow velocities ( $m /$ year) 

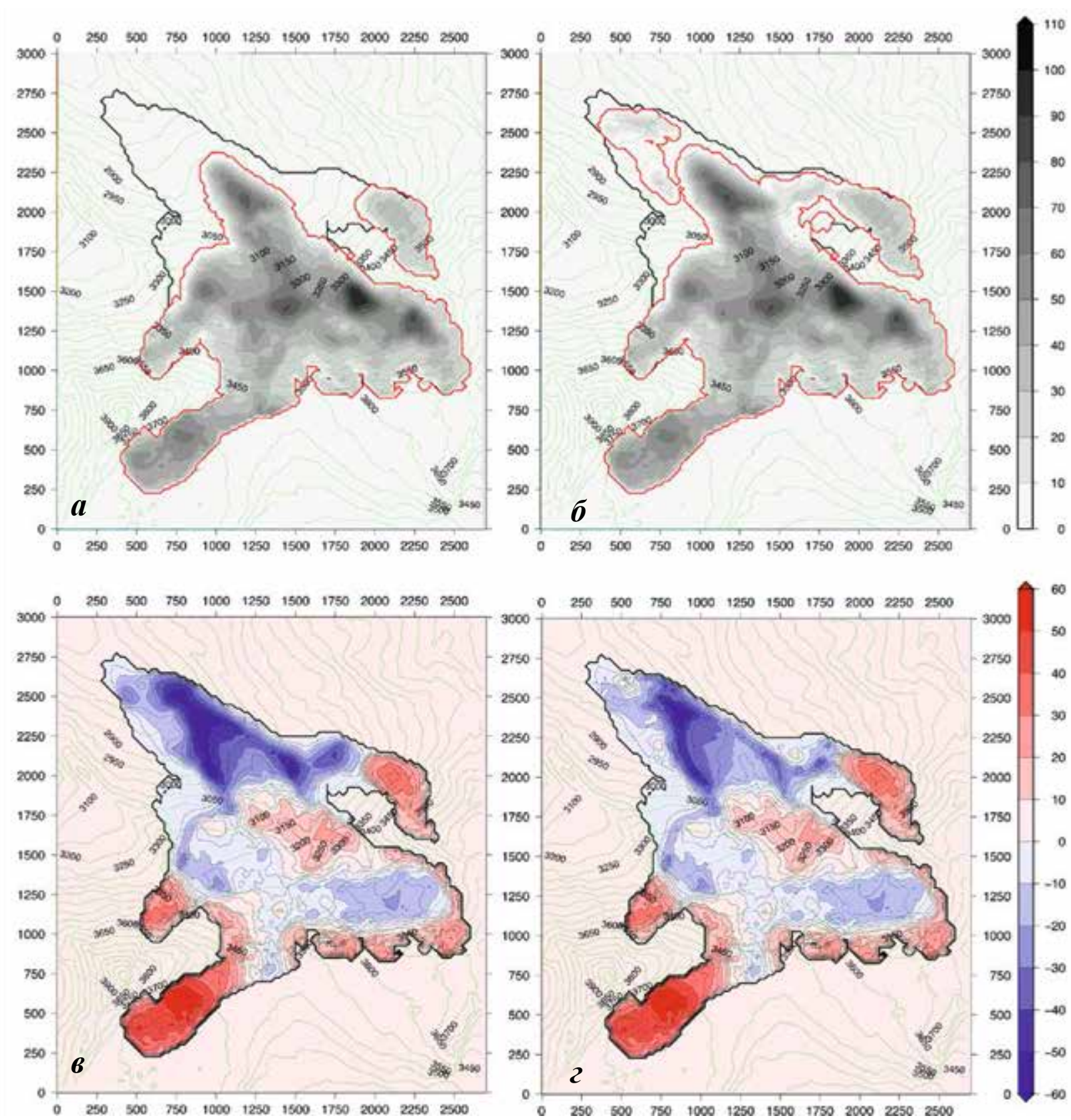

Pис. 6. Толщина льда (м) в конце численных экспериментов по состоянию на 2100 год (а, б). Красным цветом показаны финальные контуры ледника, черным ияветом - начальные. Разность между финальной и начальной толщиной льда $($ м), $(6,2)$. Рисунки $(a$, в) -моренный чехол отсутствует, $(6$, г) - моренный чехол присутствует

Fig. 6. Ice thickness $(m)$ in the end of numerical experiments as predicted for the year 2100, $(a, 6)$. Shown in red are final glacier contours, in black - initial contours. Difference between final and initial ice thicknesses $(m),(6,2)$. Figures $(a, b)$ - debris cover is absent, $(6,2)$ - debris cover is present

морененными участками сокращается на 25-30\% по сравнению с «чистыми», а абляция в поздний летний период, когда исчезает весь сезонный снежный покров - на $30-40 \%$.

Полученные оценки, разумеется, имеют смысл только в условно неизменном климате и к тому же не учитывают разрастание моренного покрова в будущем. Хотя, по мнению Поповнина и др. [9], за все время мониторинга не произошло принципиальной смены механизма, обусловливающего пространственные закономерности в распределении обломочного материала по поверхности ледника, однако масса литогенной мантии, влекомой ледником на своей поверхности, увеличилась в количественном исчислении. Последнее является причиной постоянного разрастания поверхностной морены. Оценить масштабы разрастания моренного покрова - задача чрезвычайно сложная. Обломочный материал попадает на поверхность ледника в результате трудно формализуемых процессов (камнепады, запыление, вытаивание и др.). Более трех десятков лет назад была разработана модель вытаивания моренного материала из тела ледника [13]. Однако большое количество допущений, принятых в модели, делают ее применение в прогностических расчетах с большой заблаговременностью очень проблематичным. 

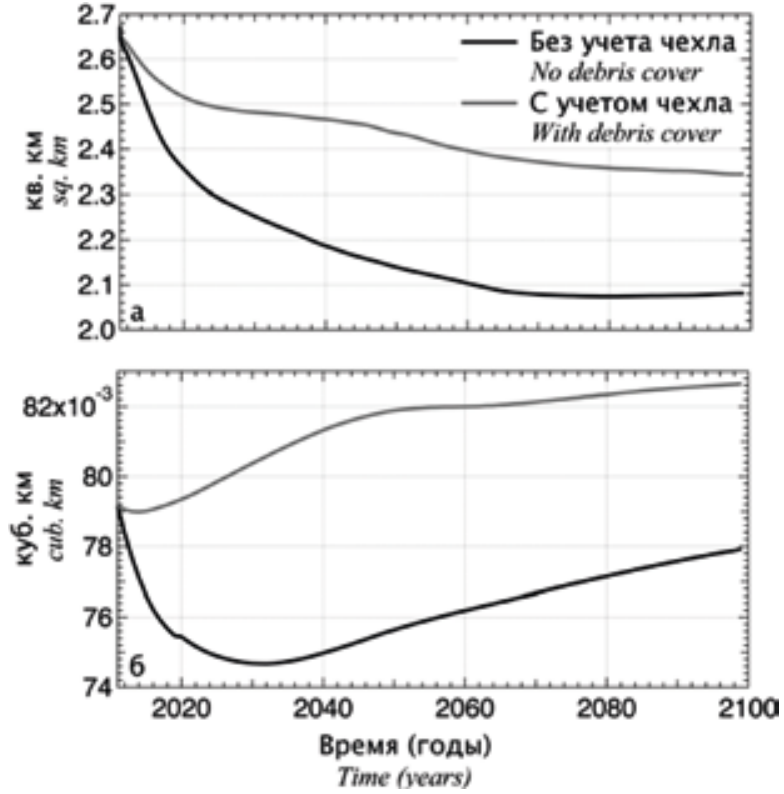

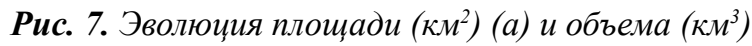
(б) ледника Джанкуат в численных экспериментах Fig. 7. Evolution of the area $\left(\mathrm{km}^{2}\right)(\mathrm{a})$ and of the volume $\left(\mathrm{km}^{3}\right)$ (б) of Djankuat glacier in numerical experiments
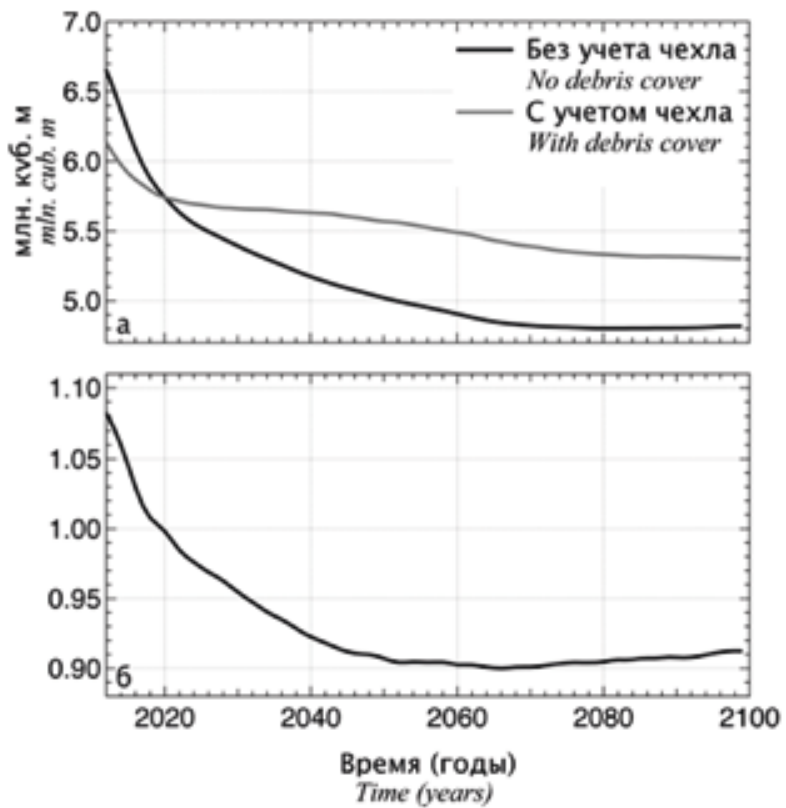

Pис. 8. Суммарный ледниковый сток с ледника Джанкуат (млн. м $^{3}$ (а); отношение суммарного ледникового стока в численном эксперименте с моренным чехлом к такой же величине в численном эксперименте без моренного чехла (б)

Fig. 8. Total glacier run-off from Djankuat glacier $\left(\mathrm{mln} . \mathrm{m}^{3}\right)$ (a); ratio of the total glacier run-off in the numerical experiment with debris cover and the similar characteristic in the numerical experiment without debris cover (б)

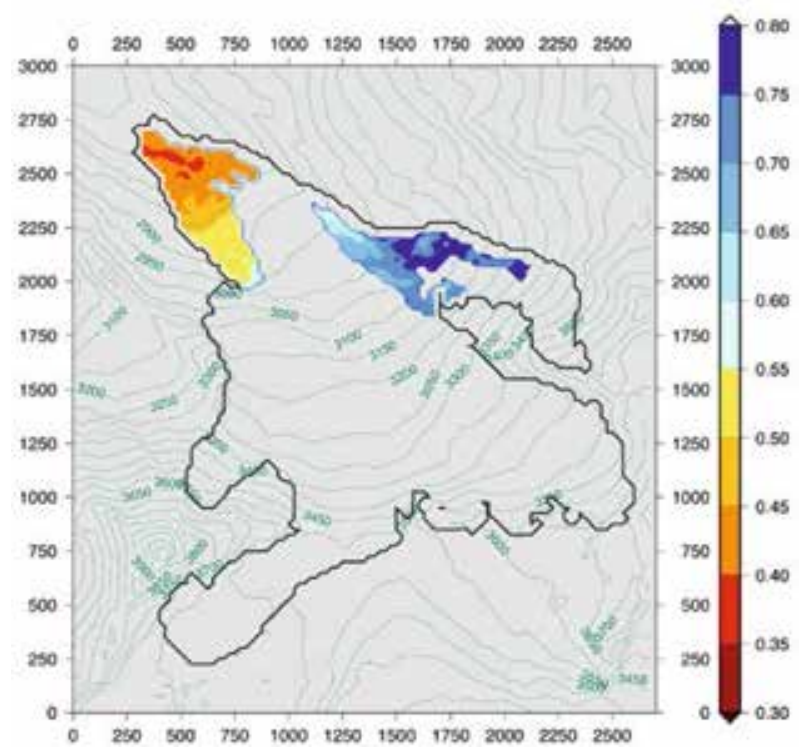

Pис. 9. Отношение подморенного таяния к поверхностному таянию на чистой поверхности льда

Fig. 9. Ratio of sub-debris melting rate to melting rate on the clean ice surface

\section{Заключение}

В работе были рассмотрены особенности эволюции ледника Джанкуат в современном климате, который условно считался неизменным до конца текущего столетия. Было установлено, что геометрия ледника находится в дисбалансе с климатом десятилетия 1999-2008 гг. Чтобы прийти в равновесие, леднику, с учетом влияния бронирующей роли моренного чехла, частично покрывающего зону абляции, требуется около полувека. Без учета такового ледник не достигает состояния равновесия до конца текущего столетия.

Бронирующая роль поверхностной морены выражается в том, что годовая сумма таяния под ним снижается на 20-65\% в зависимости от толщины чехла. В целом для ледника при учете моренного чехла годовая сумма талой воды снижается на 9-10\%, когда ледник приходит в равновесие с климатом. 


\section{КРИТЕРИИ АВТОРСТВА / Authorship criteria:}

Рыбак О.О. - является автором компьютерных программ, провел расчеты и написал черновой вариант статьи; Рыбак Е.А. - подготовила графический материал и исходные данные для численных экспериментов; Корнева И.А. - оформление, редактирование и корректировка статьи; Поповнин В.В. - участвовал в сборе данных полевых наблюдений, в написании и редактировании статьи / Rybak $\boldsymbol{O}$. O. - is the author of computer programs, made calculations and wrote a draft version of the article; Rybak $\boldsymbol{E}$. A. - prepared graphical data for numerical experiments; Korneva I. A. - edited and corrected the article; Popovnin V. V.-participated in the collection of field observations and in the writing and editing of the article.

\section{КОНФЛИКТ ИНТЕРЕСОВ / Conflict of interests:}

Авторы заявляют об отсутствии конфликта интересов / The authors state that there is no conflict of interests.

\section{ЛИТЕРАТУРА:}

1. Вайнгартнер Р., Гуня А.Н. Влияние изменений климата на сток и водное хозяйство горных регионов: опыт и уроки Альп для Кавказа // Устойчивое развитие горных территорий. 2017. T. 9. N1. С. 54-61. DOI: 10.21177/1998-45022017- 9-1-55-63.

2. Петраков Д.А., Лаврентьев И.И., Коваленко Н.В., Усубалиев Р.А. Толщина льда объем и современные изменения площади ледника Сары-Тор (Массив Ак-Шыйрак, внутренний Тянь-Шань) // Криосфера Земли. 2014. Т. 18. N3. C. $91-100$

3. Вайнгартнер Р., Гуня А.Н. Значение гор и необходимость активного участия в международных горных программах // Устойчивое развитие горных территорий. 2016. T. 8. N2. C. 119-126. DOI: 10.21177/1998-4502-20168-2-120-126.

4. Носенко Г.А., Хромова Т.Е., Рототаева О.В., Шахгеданова М.В. Реакция ледников Центрального Кавказа в 2001-2010 гг. на изменения температуры и количества осадков // Лед и Снег. 2013. N1. C. 26-33. DOI: http://dx.doi. org/10.15356/2076-6734-2013-1-26-33.

5. Панов В.Д., Лурье П.М., Ильичев Ю.Г. Состояние современного оледенения северного склона Большого Кавказа на начало XXI столетия // Устойчивое развитие горных территорий. 2010. Т. 2. N3. С. 69-73.

6. Лурье П.М., Панов В.Д. Изменение современного оледенения северного склона Большого Кавказа в XX в. и прогноз его деградации в XXI в. // Метеорология и гидрология. 2014. N4. C. 68-76. DOI: 10.3103/S1068373914040062.

7. Голубев Г.Н., Дюргеров М.Б., Маркин В.А. и др. Ледник Джанкуат (Центральный Кавказ). Водно-ледовый и тепловой баланс горноледниковых бассейнов. Л.: Гидрометеоиздат, $1978,183 \mathrm{c.}$

8. Лаврентьев И.И., Кутузов С.С., Петраков Д.А., Попов Г.А., Поповнин В.В. Толщина, объем льда и подледный рельеф ледника Джанкуат (Центральный Кавказ) // Лед и Снег. 2014. N4. C. 7-19. DOI: http://dx.doi.org/10.15356/20766734-2014-4-7-19.

9. Поповнин В.В., Резепкин А.А., Тиелидзе Л.Г. Разрастание поверхностной морены на языке ледника Джанкуат за период прямого гляциологического мониторинга // Криосфера Земли. 2015. Т. 19. N1. С. 89-98.

10. Bozhinsky A.N., Krass M.S., Popovnin V.V. Role of debris cover in the thermal physics of glaciers // Journal of Glaciology. 1986. V. 32. Pp. 255-266.
11. Коновалов В.Г. Моделирование и реконструкция параметров речного стока и баланса массы ледников на Северном Кавказе // Лед и снег. 2014. N3. C. 16-30. DOI: http:// dx.doi.org/10.15356/2076-6734-2014-3-16-30.

12. Ostrem G. Ice melting under a thin layer of moraine and the existence of ice cores in moraine ridges // Geografiska Annaler. Series A. 1959. V. 31. Pp. 228-230.

13. Adhikary S., Seko K., Nakawo M. Shakya B. Effect of surface dust on snow melt // Bulletin of Glacier Research. 1997. V. 15. Pp. 8592.

14. Kirkbride M.P., Dugmore A.J. Glaciological response to distal tephra fallout from the 1947 eruption of Hekla, south Iceland // Journal of Glaciology. 2003. V. 49. Pp. 420-428. DOI: 10.3189/172756503781830575.

15. Рыбак О.О., Рыбак Е.А., Кутузов С.С., Лаврентьев И.И., Морозова П.А. Калибровка математической модели динамики ледника Марух, Западный Кавказ // Лед и снег. 2015. N2. C. 9-20. DOI: http://dx.doi.org/10.15356/2076-67342015-2-9-20.

16. Рыбак О.О., Рыбак Е.А. Применение данных сетевых метеорологических станций для расчета баланса массы ледников (на примере ледника Джанкуат, Центральный Кавказ) // Системы контроля окружающей среды. 2017. Вып. 9 (29). С. 100-108.

17. Reid T.D., Brock B.W. An energy-balance model for debris-covered glaciers including heat conduction through the debris layer // Journal of Glaciology. 2010, v. 56 (199), pp. 903916. DOI: $10.3189 / 002214310794457218$.

18. Nicholson L., Benn D.I. Calculating ice melt beneath a debris layer using meteorological data // Journal of Glaciology. 2006. V. 52. P. 463-468.

19. Lambrecht A., Mayer C., Hagg W., Popovnin V., Rezepkin A., Lomidze N., Tielidze L. A comparison of glacier melt on debris-covered glaciers in the northern and southern Caucasus // The Cryosphere. 2011. V. 5. Pp. 525-538. DOI: 10.5194/tc-5-525-2011.

20. Pelto M. Mass balance of adjacent debris-covered and clean glacier ice in the North Cascades, Washington // IAHS Publications. 2000. V. 264. Pp. 35-42. 


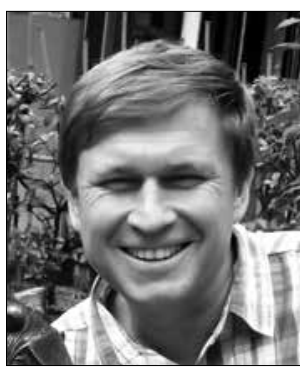

РЫБАК Олег Олегович - доктор физико-математических наук, главный научный сотрудник Филиала Института природно-технических систем; ВрИО директора Сочинского научно-исследовательского центра РАН, 354000, г. Сочи, Россия.

Тел.: 8(918)207-17-86,

o.o.rybak@gmail.com

Oleg O. RYBAK - Doctor of Science (Physics and Mathematics), chief researcher, Branch of Institute of Natural and Technical Systems (Sochi); Provisional director Sochi Research Center of RAS. 354000, Sochi, Russia.

Ph.:+7(918)207-17-86; o.o.rybak@gmail.com

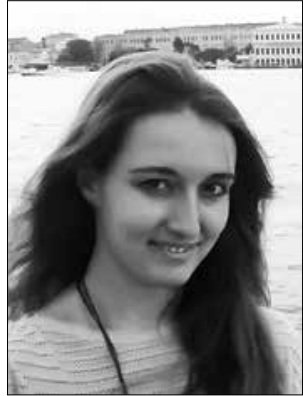

КОРНЕВА Ирина Алексеевна кандидат географических наук, научный сотрудник Филиала Института природно-технических систем; старший научный сотрудник Института глобального климата и экологии Росгидромета и РАН, 107258, г. Москва, Россия.

Тел.: 8(916)435-47-90,

comissa@mail.ru

Irina Al. KORNEVA - Candidate of Science (Geography), Branch of Institute of Natural and Technical Systems (Sochi), researcher; Institute of Global Climate and Ecology of Roshydromet and RAS, senior researcher. 107258, Moscow, Russia.

Ph.:8(916)435-47-90; comissa@mail.ru

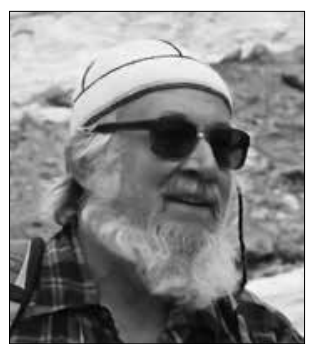

ПОПОВНИН Виктор Владимирович - кандидат географических наук, доцент, кафедры криолитологии и гляциологии географического факультета МГУ им. М.В. Ломоносова; 119234, г. Москва.

Тел.: 8(495)939-36-73;

begemotina@hotmail.com

Victor VI. POPOVNIN - Candidate of Science (Geography), department of cryolithology and glaciology, faculty of geography, Lomonosov Moscow State University, docent. 119234, Moscow, Russia.

Ph.:+7(495)939-36-73; begemotina@hotmail.com

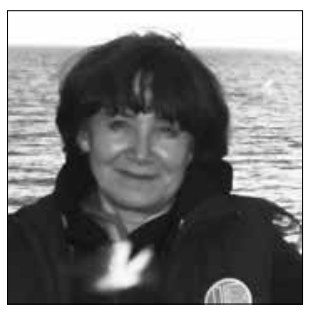

РЫБАК Елена Алексеевна кандидат физико-математических наук, ведущий научный сотрудник Филиала Института природно-технических систем; ведущий научный сотрудник Сочинского научно-исследовательского центра РАН, 354000 , г. Сочи, Россия.

elena.rybak@gmail.com

Elena Al. RYBAK-Candidate of Science (Physics and Mathematics), Branch of Institute of Natural and Technical Systems (Sochi), leading researcher; Sochi Research Center of RAS, leading researcher. 354000, Sochi, Russia, elena.rybak@gmail.com

\section{MATHEMATICAL MODELING OF DJANKUAT GLACIER EVOLUTION IN PRESENT-DAY CLIMATIC CONDITIONS \\ 1,2 O.O.Rybak, * \\ 1,2E.A.Rybak, \\ 1,3I.A.Korneva, \\ ${ }^{4}$ V.V Popovnin \\ ${ }^{1}$ Branch of Institute of Natural and Technical Systems, Sochi, Russia, o.o.rybak@gmail.com \\ ${ }^{2}$ Sochi Research Center of RAS, Sochi, Russia \\ ${ }^{3}$ Institute of Global Climate and Ecology of Roshydromet and RAS, Moscow, Russia \\ ${ }^{4}$ Lomonosov Moscow State University, Moscow, Russia}

DOI: $10.21177 / 1998-4502-2018-10-4-533-543$

Glaciers in the Caucasus have been continuously shrinking during the 20th and in the beginning of the 21 st century. Mountain glaciers provide up to $70 \%$ of the total river runoff in the adjacent territories. Realistic prediction of future glacial run-off is a key problem of water supply in mountain and piedmont regions. The task of prediction can be solved by means of dynamical modeling of mountain glaciers. Because of lack of regular observations, it is feasible to focus on several reference glaciers in the region and to further extrapolate modeling results on the whole glaciated area.

In the paper, we report about application of a 3D higherorder ice flow model coupled to a surface mass-balance model for carrying out prognostic numerical experiments aimed at simulation of future dynamics of Djankuat Glacier. Djankuat is a typical valley glacier on the northern slope of the main Caucasus chain. It is one of the most studied glaciers in Russia, which has been continuously monitored during the last fifty years. From the point of view of completeness and duration of observations, Djankuat is an ideal glacier for mathematical modeling. Considerable parts of the ablation zone of Djankuat are covered with debris. Heat and physical properties of the debris layer are very different from those of ice. Debris layer determines ablation rate and run-off regime. Dependently on thickness, it can accelerate ablation or totally isolate ice cover from melting.

To force the model, we utilized observations from the 
nearest weather stations (Terskol and Mestia), as well as accumulation and ablation field measurements as controls. In the prognostic numerical experiments, we simulated possible Djankuat evolution until the year 2100 under stationary climatic conditions.

We established that geometry of the glacier in imbalance with the climatic conditions of the decade 1999-2008 years. To reach the equilibrium, the glacier will need nearly half a century taking into account insulating role of the debris partially covering ablation zone. In case debris cover is not considered, the glacier does not reach equilibrium until the end of the current century. Supraglacial moraine is responsible for $20-65 \%$ reduction of the annual melting under the debris layer dependently on its thickness. For the whole glacier, with the debris cover taken into account, the annual amount of melt water reduces by $9-10 \%$ when the glacier equilibrates with climate.

Keywords: mountain glacier, mathematical model, mass balance, debris, glacial run-off

\section{References}

1. Weingartner R., Gunya A.N. Impact of climate changes on the runoff and water management of mountain regions: experience and lessons of the Alps for the Caucasus. Sustainable Development of Mountain Territories, 2017, vol. 9, no 1, pp. 55-61. DOI: 10.21177/1998-4502-2017-9-1-55-63. (in Russian).

2. Petrakov D.A., Lavrentiev I.I., Kovalenko N.V. Usibaliev R.A. Ice thickness, volume and modern change of the Sary-Tor glacier area (Ak-Shyirak massif, Inner Tian Shan). Earth's Cryoshphere, 2015, vol. 18, no 3, pp. 91-100. (in Russian).

3. Weingartner R., Gunya A.N. The value of mountains and the need for active participation in the international mountain programmes. Sustainable Development of Mountain Territories, 2016, vol. 8, no 2. pp. 120-126. DOI: 10.21177/1998-4502-2016-8-2-120-126. (in Russian).

4. Nosenko G.A., Khromova T.E., Rototaeva O.V., Shakhgedanova M.V. Glacier reaction to temperature and precipitation change in Central Caucasus, 2001-2010. Ice and Snow, 2013, vol. 53, no. 1, pp. 26-33. DOI: http://dx.doi. org/10.15356/2076-6734-2013-1-26-33. (in Russian).

5. Panov V.D., Lurie P.M., Ilyichev Y.G. The state of present-day glaciation of the northern slope of the Great Caucasus at the beginning of the XXI century. Sustainable Development of Mountain Territories, 2010, vol. 2, no. 3. pp. 69-73. (in Russian).

6. Lurie P.M., Panov V.D. Changes in present-day glaciation of the northern slope of the Great Caucasus in the XX century and prediction of its degradation in the XXI century. Meteorology and Hydrology, 2014, no 4, pp. 68-76. DOI: 10.3103/S1068373914040062. (in Russian)

7. Golubev G.N., Duyrgerov M.B., Markin V.A. et al. Lednik Dzhankuat (Tsentral'nyj Kavkaz). Vodno-ledovyj i teplovoj balans gornolednikovykh bassejnov [Djankuat Glacier (Central Caucasus). Water-ice and heat balance of the mountain glaciers bassins]. Leningrad, Gidrometeoizdat, 1978, 183 p. (in Russian).

8. Lavrentiev I.I., Kutuzov S.S., Petrakov D.A., Popov G.A., Popovnin V.V. Ice thickness, volume and subglacial relief of Djankuat Glacier (Central Caucasus). Ice and Snow, 2014, vol. 54, no 4, pp 7-19. DOI: http://dx.doi. org/10.15356/2076-6734-2014-4-7-19. (in Russian).

9. Popovnin V.V., Rezepkin A.A., Tielidze L.G. Superficial moraine expansion on the Djankuat glacier snout over the direct glaciological monitoring period. Earth's Cryoshphere, 2015, vol. 19, no 1, pp. 89-98. (in Russian).

10. Bozhinsky A.N., Krass M.S., Popovnin V.V. Role of debris cover in the thermal physics of glaciers. Journal of Glaciology, 1986, vol. 32, pp. 255-266.

11. Konovalov V.G. Simulation and reconstruction of parameters of streamflow and glacier mass balance in the Northern Caucasus. Ice and Snow, 2014, vol. 54, no. 3, pp. 16-30. https://doi.org/10.15356/2076-6734-2014-3-1630 (in Russian)

12. Ostrem G. Ice melting under a thin layer of moraine and the existence of ice cores in moraine ridges. Geografiska Annaler. Series A, 1959, vol. 31, pp. 228-230.

13. Adhikary S., Seko K., Nakawo M. Shakya B. Effect of surface dust on snow melt. Bulletin of Glacier Research, 1997, vol. 15, pp. 85-92.

14. Kirkbride M.P., Dugmore A.J. Glaciological response to distal tephra fallout from the 1947 eruption of Hekla, south Iceland. Journal of Glaciology, 2003, vol. 49, pp. 420-428. DOI: $10.3189 / 172756503781830575$.

15. Rybak O.O., Rybak E.A., Kutuzov S.S., Lavrentiev I.I., Morozova P.A. Calibration of a mathematical model of Marukh Glacier, Western Caucasus. Ice and Snow, 2015, vol. 55, no. 2, pp. 9-20. DOI: http://dx.doi.org/10.15356/20766734-2015-2-9-20. (in Russian).

16. Rybak O.O., Rybak E.A. Implementation of observations at regular meteorological stations for mass balance calculation of mountain glaciers (case study of Djankuat glacier, Central Caucaus). Systems of Environmental Control, 2017, no 9(29), pp. 100-108. (in Russian).

17. Reid T.D., Brock B.W. An energy-balance model for debris-covered glaciers including heat conduction through the debris layer. Journal of Glaciology, 2010, vol. 56, pp. 903-916. DOI: 10.3189/002214310794457218.

18. Nicholson L., Benn D.I. Calculating ice melt beneath a debris layer using meteorological data. Journal of Glaciology, 2006, vol. 52, pp. 463-468.

19. Lambrecht A., Mayer C., Hagg W., Popovnin V., Rezepkin A., Lomidze N., Tielidze L. A comparison of glacier melt on debris-covered glaciers in the northern and southern Caucasus. The Cryosphere, 2011, vol. 5, pp. 525-538. DOI: 10.5194/tc-5-525-2011.

20. Pelto M. Mass balance of adjacent debris-covered and clean glacier ice in the North Cascades, Washington. IAHS Publications, 2000, vol. 264, pp. 35-42.

Article received 19.03.2018. 


\title{
ТЕХНИЧЕСКИЕ НАУКИ
}

\author{
ENGINEERING
}

Если бы я захотел читать, еще не зная букв, это было бы бессмыслицей.

Точно так же, если бы я захотел судить о явлениях природы, не имея никакого представления о началах вещей, это было бы такой же бессмыслицей.

Михаил ЛОМОНОСОВ

\section{ADAPTIVE CONTROL SYSTEM FOR THE MAGNETIC SEPARATION PROCESS}

\section{Introduction}

An important component of Global Goals for Sustainable Development is a goal associated with industry and innovation. Minerals are raw materials essential for modern society. The mining and quarrying industry is very important to industrial, social, and technological progress.

One of the basic characteristics determining significance of raw materials for metallurgical enterprises is their permanent high recovered grade in the fed ore concentrate. It can be provided only when all processes of ore processing from mining to concentration and sintering are subject to continuous efficient control [1-4].

Automated control systems (ACS) of processes are widely used in mining and metallurgy. At magnetic and concentrating plants, their efficiency depends greatly on the choice of controlling algorithms and the capacity of systems to provide IT support them [5-7].

Thus, increasing efficiency of automated control over iron ore magnetic concentration is a research problem which is essential for Ukraine's economy. Its solution allows improving the end product quality and reducing energy consumption at current mining enterprises' operating capacity [8-11].

\section{Problem statement}

The research is aimed at developing a system of adaptive control of magnetic separation of iron ores to reduce the period of searching for the extremum of objects dynamic characteristics under disturbances and noises in controlled signals.

\section{Review of the literature}

In $[12 ; 13]$ and others, iron ore concentration controlled through improving operation of magnetic separators of iron ores of primary concentration is substantiated. The choice of the control structure, application of some criteria in creating systems of automated optimization are determined by their software and algorithmic support, i.e. the possibility to receive online data on current parameters of concentration and their efficient application to controlling impacts.

${ }^{1}$ Kryvyi Rih National University, Kryvyi Rih, Ukraine, morkunv@gmail.com

${ }^{2}$ Academy of Mining Sciences of Ukraine, Kryvyi Rih, Ukraine
${ }^{1}$ Morkun V.S., ${ }^{*}$

1Morkun N.V., 1Tron V.V.,

2Dotsenko I.A.
УДК: 622.778

DOI: 10.21177/1998-4502-201810-4-545-557

The developed adaptive system controlling magnetic separation of iron ores allows reducing the period of searching for the objective control function, maintaining the optimal ratio of the concentrate yield and the grade contained under conditions of changing quality of initial ores and the equipment state. There are determined conditions and the best parameters of searching for the extremum in the system of adaptive control over iron ore magnetic separation under disturbances and noises in controlled signals. They can be achieved when deviations of static and dynamic characteristics from rated ones do not exceed $\pm 25 \%$.

\section{KEYWORDS:}

adaptive control system, magnetic separation, iron ore, slurry, search for extremum 
Magnetic separators of iron ores are basic concentrating machines in a technological line of iron ore magnetic and concentrating plants. In [12-16], a magnetic separator is regarded as a controlled object with a single input (feed) and two outputs (tailings and concentrate). Fig. 1 shows basic parameters determining magnetic separation. It includes controlled variables: (the magnetic iron content in the middling product $\left(\beta_{n n}\right)$, the middling product yield $\left(\gamma_{n n}\right)$; disturbing impacts (the magnetic iron content in the fed product (the magnetic separator feed) $(\alpha)$ and the recovered grade $(\psi)$; controlling impacts (the classifier drain density $\left(\rho_{c \eta}\right)$, the auxiliary water consumption in the separator bath $\left(Q_{B}\right)$, the magnetic field strength of the separator $\left(H_{0}\right)$, the rotation rate of the separator drum $\left(n_{\sigma}\right)$.

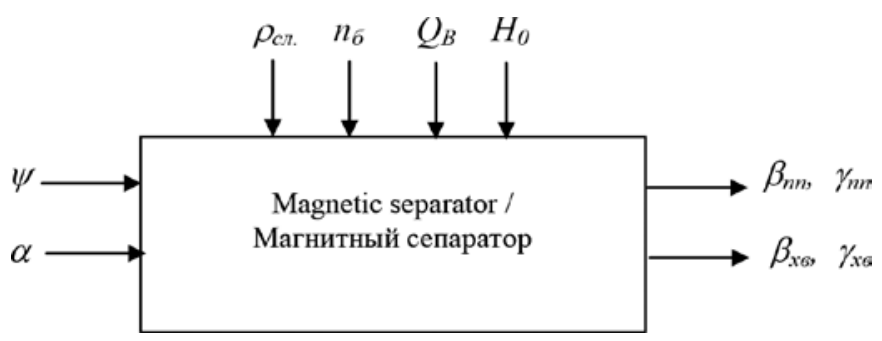

Fig. 1. Basic parameters of magnetic separation

Рис. 1. Основные параметры процесса магнитной сепарации

As shown in $[12 ; 17-18]$, the magnetic iron content $\alpha$ and the degree of mineral release in the classifier drain $\psi$ are basic disturbing impacts in magnetic separation. The slurry density changed in case of classifier drain causes changes in the granularmetric composition of the solid phase slurry, thus altering ratios between its strongly-, feebly- and non-magnetic fractions. The $\rho_{c \text { in }}$ increased reduces the yield of released ore grains while that of strongly-magnetic fraction $\gamma_{n n}$ increases because of the increased yield of strongly-magnetic aggregates. The strongly-magnetic fraction yield is proportional to the magnetic iron content $\alpha$ in the fed ore. The reduced density of the classifier drain makes the strongly-magnetic fraction yield be close to the output equal to $\alpha$ (the magnetic iron content).

In [18], there are suggested simple expressions determining the yield of strongly-magnetic fraction $\gamma_{n n}$, the yield of released ore grains $\gamma_{p 3}$ and strongly-magnetic ore aggregates $\gamma_{p c}$ :

$$
\begin{aligned}
& \gamma_{m}=\alpha+K_{1} \cdot \bar{d} \cdot(0,7-\alpha) ; \\
& \gamma_{p 3}=\alpha-K_{3} \cdot \bar{d} \cdot(0,7-\alpha) ; \\
& \gamma_{p c}=\left(K_{1}+K_{3}\right) \cdot \bar{d} \cdot(0,7-\alpha),
\end{aligned}
$$

where $\bar{d}=K_{2}\left(\rho_{c r}-\rho_{s}\right)$ is the average size of solid particles in the slurry; $K_{1}$ and $K_{2}$ are coefficients depending on the size of ore impregnations; $K_{3}$ is the coefficient depending on physical and mechanical properties of the fed ore and grinding modes.
The changed textural and structural characteristics of the fed ore change coefficients $K_{1}, K_{2}$ and $K_{3}$ causing changes in the quality of separation products. Thus, coefficients $K_{1}, K_{2}$ and $K_{3}$, determine the value of basic disturbing impacts in relation to magnetic separation. A. $\mathrm{N}$. Mariuta received the ratio equation of the solid slurry density of the classifier drain $\rho_{\dot{\delta}}$ and the iron content $\alpha$ :

$$
\rho_{T}=\frac{\rho_{M} \rho_{K}}{\rho_{M}^{\prime}-\alpha\left(\rho_{M}^{\prime}-\rho_{K}\right)}=\frac{14}{5-2,2 \alpha},
$$

where $\rho_{\mu}^{\prime}$ is pure magnetite density; $\rho_{k}$ is quarts density.

A detailed analysis and systematized criteria of improving mineral concentration including technological, thermodynamic, kinetic, static, technical-economic, economic ones, etc were proposed in [19]. It is indicated that technological criteria mathematically expressed as a combination of basic concentration parameters are notable for their efficiency, simplicity and visualization.

Analysis of technological criteria results in the Hancock criterion substantiated by Luiken, Birbauer, Din, Chechott, Verkhovskyi [19] and others.

This criterion can be expressed as follows

$$
J=\frac{\gamma(\beta-\alpha)}{\alpha\left(1-\frac{\alpha}{\beta_{T}}\right)},
$$

where $\gamma$ is the concentrate yield; $\alpha$ is the recovered grade in the feed product; $\beta$ is the recovered grade in the concentrate; $\beta_{T}$ is theoretically maximum recovered grade.

The popularity of this criterion is explained not only by its physical and geometrical interpretation, but also by the fact that it is simple, universal, contains all basic parameters $(\gamma, \beta, \alpha)$ and is statistically efficient [19].

A.N. Mariuta indicates that it is reasonable to apply this criterion to evaluation of the magnetic separator efficiency [18]. Formula (5) reveals that maximum values of $E$ for various values of $\alpha$ can be achieved only when there is a certain ratio between $\gamma$ and $(\beta-\alpha)$. The classifier drain increased makes the concentrate yield $\gamma$ greater and reduces the difference $\beta-\alpha$. The reduced drain density produces the reverse effect.

In [18], Mariuta suggests a complex criterion of efficiency $E_{1}$, which partially reflects the course of the process from both the technological and the economic viewpoints

$$
J_{1}=\beta+k_{E} \gamma \rightarrow \max ,
$$

where $k_{E}$ is the coefficient characterizing weight ratios between variables $\beta$ and $\gamma$

The coefficient $k_{E}$ indicates how the Fe content can be reduced in the concentrate to increase its yield and vice versa. The values of $k_{E}$ depend on $\alpha$ and other properties of the fed ore. Formulae (5) and (6) allow controlling magnetic separation in the most efficient way.

\section{Materials and methods}

The mentioned above allows us to conclude that the classifier drain density is the basic controlling impact in 
the "classifier-magnetic separator" system. Operation of the magnetic separator can be assessed on the basis of the data on the recovered grade $(\mathrm{Fe})$ in its products or the solid slurry density considering (4). The model of magnetic separation should consider changed textual and structural characteristics of processed ores, grinding modes and equipment conditions. Overall quality indices of concentration are determined by the ore quantity fed to the mill.

The material-balance equation for the magnetic separator looks like [19; 20]

$$
\frac{d m}{d t}=M-\left(M_{k}-M_{x s}\right),
$$

or considering that $M_{k}=\beta Q_{k}, M_{x \varepsilon}=\vartheta Q_{x \varepsilon}, M=\alpha Q$,

$$
V \frac{d m}{d t}=\alpha Q-\beta Q-\vartheta Q_{x s}
$$

where $M, M_{k,} M_{x,} Q, Q_{k}, Q_{x \varepsilon}$ indicate weight and volume consumption of the fed material, concentrator and tailings; $V$ is the volume of the working area of the magnetic separator; $\mathrm{m}$ is the iron quantity in the slurry in the working area of the separator.

Considering the fact that under the current mode, the Fe content in the working area of the separator is equal to that in the concentrator we obtain

$$
W(p)=\frac{\beta}{\alpha}=\frac{K_{e}^{-\tau p}}{T p+1},
$$

where $T=\frac{V}{Q}, K=\frac{\beta_{y c m}}{\alpha}, \beta_{y c m}=\beta$ with $t \rightarrow \infty, \beta_{y c m}$ is the established Fe content in the concentrator at the separator output.

Synthesize and study models of technological aggregates and a concentration line as a whole were presented in $[14 ; 15 ; 18 ; 20]$. For instance, [20] provides a system of equations combining characteristics of the output product of the classifier with parameters of the middling product and tailings of the magnetic separator.

$$
\begin{gathered}
5 \frac{d \vartheta}{d t}+\zeta=0,53 \zeta_{u}(t-2) ; \\
\beta^{\prime}=-0,695 \zeta_{u}^{2}+0,893 \zeta_{u}+0,712 ; \\
9 \%<\zeta_{u}<32 \% ; \\
5 \frac{d \beta}{d t}+\beta=\beta(t-2),
\end{gathered}
$$

where $\zeta_{\dot{u}}$ is the slurry density at the classifier drain; $\beta$ and $\zeta$ indicate the $\mathrm{Fe}$ content in the middling product and tailings.

As is shown, the magnetic separator represents a sequence of two links - non-linear static and output linear ones. To consider dynamic properties of the input part of the magnetic separator, the given model should be supplemented with input dynamic links along each control channel.

Taking into account the the fed material Q balance equation, the concentrate $C$ and tailings $T$ for the magnetic separator it can be written as follows [19; 21]

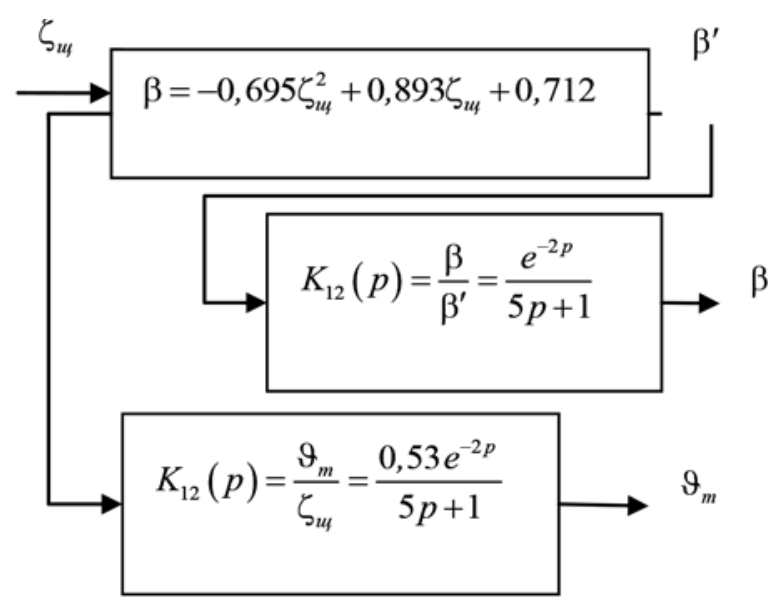

Fig. 2. The structural scheme of the magnetic separator model Pис. 2. Структурная схема модели магнитного сепаратора

$$
\begin{aligned}
& Q \alpha=C \beta+(Q-C) \vartheta ; \\
& Q \alpha=(Q-T) \beta+T \vartheta,
\end{aligned}
$$

where $Q, C, T$ indicate the mass of the feed material, concentrate and tailings; $\alpha, \beta, \vartheta$ are the Fe content in the feed material, concentrate and tailings.

Then the concentrate yield is determined by the expression

$$
\gamma_{k}=\frac{C}{Q} \cdot 100=\frac{\alpha-\vartheta}{\beta-\vartheta} \cdot 100 \% .
$$

Thus, (5) results in

$$
E=\frac{\gamma(\beta-\alpha)}{\alpha\left(1-\frac{\alpha}{\beta_{T}}\right)}=\frac{(\alpha-\vartheta)(\beta-\alpha)}{\alpha\left(1-\frac{\alpha}{\beta_{m}}\right)(\beta-\vartheta)} .
$$

It follows from (16) that the Hancock criterion can be calculated either on the basis of measurements of the $\mathrm{Fe}$ content in the feed material, concentrate and tailings or measurements of the feed material and concentrate mass and the Fe content in these products. In the latter case, the values of $Q$ and $C$ can be measured by one of the known methods, e.g. the ultrasonic one.

In this case, the object equation looks like

$$
x=J(\beta+f, \alpha) ; \quad y=x+\kappa,
$$

where $f(t)$ is the external disturbance applied to the object input with the controlling parameter; $k(t)$ is the disturbance accompanying the measurement of the object $x$ output; $y(t)$ is the measured variable (the result of the $x$ measurement).

Functions $f(t)$ and $x(t)$ are random processes with unknown laws of distribution. Yet, it is known that they have zero mathematical expectation and limited dispersion. One should find the algorithm of searching for the extremum under which the mathematical expectation of the output $M\{J(\beta+\mathrm{f}), \alpha)+\mathrm{k}\}$ reaches the minimum value [22-27].

To simplify the solution of the problem, let us consider $f=0$ and then the equation (17) will look like

$$
x=J(\beta, \alpha) ; y=x+\kappa \text {. }
$$


According to the stochastic approximation method, every measured condition of an object should be used to measure the controlling impact so that the condition is observed at the limit [32]

$$
M\{J(\beta, \alpha)+\mathrm{k}\}=\min .
$$

Let us measure the controlling impact according to the algorithm

$$
\begin{aligned}
& \beta[(k+1) T]=\beta(k T)-\frac{a_{k}}{2 \Delta \beta_{k}}\left[\begin{array}{l}
J^{\prime}\left(\beta(k T)+\Delta \beta_{k}, \alpha\right)- \\
-J^{\prime}\left(\beta(k T)-\Delta \beta_{k}, \alpha\right)
\end{array}\right], \\
& k=0,1,2, \ldots .
\end{aligned}
$$

Here, the measurement results are used

$$
\begin{gathered}
J^{\prime}\left(\beta(k T)+\Delta \beta_{k}, \alpha\right)=J\left(\beta(k T)+\Delta \beta_{k}, \alpha\right)+\kappa_{k}^{(1)} ; \\
J^{\prime}\left(\beta(k T)-\Delta \beta_{k}, \alpha\right)=J\left(\beta(k T)-\Delta \beta_{k}, \alpha\right)+\kappa_{k}^{(2)},
\end{gathered}
$$

where $\kappa_{k}^{(1)}, \kappa_{k}^{(2)}$ are random values realizing measurement disturbances in the interval $[(k-1) T, k T]$, while $\kappa_{k}^{(1)} \neq \kappa_{k}^{(2)}$ as they are measured at different time periods within the given interval. It should be noted that unlike (20), the value $\Delta \beta_{\mathrm{k}}$ of testing steps is not constant and measured with $k=0,1,2, \ldots$.

The stochastic approximation method allows finding parameters of the working and testing steps $b_{h}, \Delta \beta_{\mathrm{k}}(k=$ $0,1,2, \ldots)$, under which the algorithm (20) provides the extremum $J^{\prime}$ (fulfillment of condition (19) under disturbances. They are known to have zero mathematical expectation and limited dispersion.

Let us determine parameters of the working and testing steps. To achieve the search algorithm convergence (20) the parameters of the working and testing steps should satisfy the condition

$$
\begin{aligned}
& \lim _{k \rightarrow \infty} a_{k}=0, k=0,1,2, \ldots ; \sum_{k=1}^{\infty} a_{k}=\infty ; \\
& \sum_{k=1}^{\infty}\left[\frac{a_{k}}{\Delta \beta_{k}}\right]^{2}<\infty .
\end{aligned}
$$

The given conditions are observed if

$$
\begin{aligned}
& a_{k}=1 / k^{\rho} ; \quad \Delta \beta_{k}=1 / k^{\mu} ; \\
& 2(\rho-\mu)>1, \\
& \text { where } 0 \leq \rho \leq 1 ; \mu>0 .
\end{aligned}
$$

Considering (21) and (22), let us write down the algorithm (20) as follows

$$
\begin{aligned}
& \beta[(k+1) T]= \beta(k T)-\frac{a_{k}}{2 \Delta \beta_{k}}\left[\begin{array}{l}
J\left(\beta(k T)+\Delta \beta_{k}, \alpha\right)- \\
-J\left(\beta(k T)-\Delta \beta_{k}, \alpha\right)
\end{array}\right]+ \\
&+\frac{a_{k}}{2 \Delta \beta_{k}}\left(\kappa_{k}^{(1)}-\kappa_{k}^{(2)}\right)= \\
&=\beta(k T)-a_{k} \hat{r}_{k}+\frac{a_{k}}{2 \Delta \beta_{k}}\left(\kappa_{k}^{(1)}-\kappa_{k}^{(2)}\right), \quad k=0,1,2, \ldots .
\end{aligned}
$$

As the testing steps are quite small $\left(f_{k}=r_{k}\right)$ and considering $M\left\{\kappa_{k}^{(i)}\right\}=0, i=1,2$, we calculate the mathematical expectation of the $k$-th step efficiency:

$$
\begin{aligned}
M\left\{v_{k}\right\} & =M\left\{\frac{\beta[(k+1) T]-\beta^{*}}{\beta(k T)-\beta^{*}}\right\}= \\
& =1-a_{k} \frac{r_{k}}{\beta(k T)-\beta^{*}}
\end{aligned}
$$

Proceeding to the condition (24), we calculate the mathematical expectation and dispersion of the working step $\Delta_{p} \beta(k T)$. It is evident that

$$
\begin{aligned}
& M\left\{\Delta_{p} \beta(k T)\right\}=-\frac{a_{k}}{2 \Delta \beta_{k}}\left[\begin{array}{l}
J\left(\beta(k T)+\Delta \beta_{k}, \alpha\right)- \\
-J\left(\beta(k T)-\Delta \beta_{k}, \alpha\right)
\end{array}\right] \\
& M\left\{\Delta_{p} \beta(k T)-M\left\{\Delta_{p} \beta(k T)\right\}\right\}^{2}=M\left\{\frac{a_{k}}{2 \Delta \beta_{k}}\left(\kappa_{k}^{(1)}-\kappa_{k}^{(2)}\right)\right\}^{2}= \\
& =\frac{a_{k}^{2}}{4 \Delta \beta_{k}^{2}}\left[\sigma_{k}^{2}+\sigma_{2 k}^{2}\right], \quad k=0,1,2, \ldots .
\end{aligned}
$$

where $\sigma_{i k}^{2}(i=1,2)$ - are dispersions of random values $\kappa_{k}^{(1)}, \kappa_{k}^{(2)}$.

It is evident that the sum of dispersions of the arbitrary large number of working steps taken during the search should be limited

$$
\begin{aligned}
& \sum_{k=1}^{\infty} \frac{a_{k}^{2}}{2 \Delta \beta_{k}^{2}}\left[\sigma_{k}^{2}+\sigma_{2 k}^{2}\right]<\sigma^{2} \sum_{k=1}^{\infty} \frac{a_{k}^{2}}{\Delta \beta_{k}^{2}}<\infty, \\
& \text { where } \sigma^{2}=\max \left[\sigma_{k}^{2}+\sigma_{2 k}^{2}\right] / 4<\infty .
\end{aligned}
$$

Hence follows a condition (24) indicating that the value of the testing step $\Delta \beta_{k}$ should go to zero more slowly than $a_{k}$, as otherwise dispersion values of the working steps will become intolerably large according to (27).

Let us consider the search for the extremum of multiparameter objects under disturbances

$$
x=J\left(\beta_{1}, \beta_{2}, \alpha_{1}, \alpha_{2}\right) ; \quad y=x+\kappa .
$$

In this case, adaptation algorithms will be written as:

$$
\begin{aligned}
& \beta_{1}[(k+1) T]=\beta_{1}(k T)- \\
& -\frac{a_{k}}{2 \Delta \beta_{k}}\left[\begin{array}{l}
J^{\prime}\left(\beta_{1}(k T)+\Delta \beta_{k}, \beta_{2}(k T), \alpha_{1}, \alpha_{2}\right)- \\
-J^{\prime}\left(\beta_{1}(k T)-\Delta \beta_{k}, \beta_{2}(k T), \alpha_{1}, \alpha_{2}\right)
\end{array}\right],
\end{aligned}
$$

$k=0,1,2, \ldots$;

$\beta_{2}[(k+1) T]=\beta_{2}(k T)-$

$-\frac{a_{k}}{2 \Delta \beta_{k}}\left[\begin{array}{l}J^{\prime}\left(\beta_{1}(k T), \beta_{2}(k T)+\Delta \beta_{k}, \alpha_{1}, \alpha_{2}\right)- \\ -J^{\prime}\left(\beta_{1}(k T), \beta_{2}(k T)-\Delta \beta_{k}, \alpha_{1}, \alpha_{2}\right)\end{array}\right]$,

$k=0,1,2, \ldots$;

where the measurement results are 


$$
\begin{aligned}
& J^{\prime}\left(\beta_{1}(k T)+\Delta \beta_{k}, \beta_{2}(k T), \alpha_{1}, \alpha_{2}\right)= \\
& =J\left(\beta_{1}(k T)+\Delta \beta_{k}, \beta_{2}(k T), \alpha_{1}, \alpha_{2}\right)+\kappa_{k}^{(1)} ; \\
& J^{\prime}\left(\beta_{1}(k T)-\Delta \beta_{k}, \beta_{2}(k T), \alpha_{1}, \alpha_{2}\right)= \\
& =J\left(\beta_{1}(k T)-\Delta \beta_{k}, \beta_{2}(k T), \alpha_{1}, \alpha_{2}\right)+\kappa_{k}^{(2)} ; \\
& J^{\prime}\left(\beta_{1}(k T), \beta_{2}(k T)+\Delta \beta_{k}, \alpha_{1}, \alpha_{2}\right)= \\
& =J\left(\beta_{1}(k T), \beta_{2}(k T)+\Delta \beta_{k}, \alpha_{1}, \alpha_{2}\right)+\kappa_{k}^{(3)} ; \\
& J^{\prime}\left(\beta_{1}(k T), \beta_{2}(k T)-\Delta \beta_{k}, \alpha_{1}, \alpha_{2}\right)= \\
& =J\left(\beta_{1}(k T), \beta_{2}(k T)-\Delta \beta_{k}, \alpha_{1}, \alpha_{2}\right)+\kappa_{k}^{(4)} ;
\end{aligned}
$$

where $\Delta \beta_{k}$ is a testing step taken as the same for both controlling impacts; $\kappa_{k}^{i}, i=1,2,3,4$, indicate realization of the random process $x(t)$ with four measurements of the object output at the interval $[(k-1) T, k T]$.

For determining the search convergence, parameters of the working and testing steps should satisfy conditions (23) and (24) for a single-parameter object as well. The condition (24) looks like

$$
\sum_{k=1}^{N \rightarrow \infty} \frac{a_{k}^{2}}{\Delta \beta_{k}^{2}}<\infty
$$

and indicates that the increased $k$ should make the testing step greater and exceed the working step parameter. It should be noted that the stochastic approximation method suggests that

$$
\lim _{k \rightarrow \infty} \Delta \beta_{k}=0 .
$$

Besides, the method imposes an auxiliary condition on the function $J$ as in the area of its extremum an inequality should be observed

$$
\left(\beta_{1}-\beta_{1}^{*}\right) \frac{\partial J}{\partial \beta_{1}}+\left(\beta_{2}-\beta_{2}^{*}\right) \frac{\partial J}{\partial \beta_{2}}>0,
$$

and the rate of increase of $J$ should not exceed that of the square parabola when leaving the target.

To optimize the system dynamic characteristics determined by the initial linear part of the controlled object, a method determining the constant value of $z(\infty)$ of the initial signal $z$ of the object, i.e. the object's initial signal on the basis of the initial part of the transfer process caused by the changed input signal at the step $\Delta \chi$ is applied. The value $z(\infty)$ can be calculated for a small time period and the time lag $\Delta t$ between steps can be insignificant, which reduces the search time of the extremum greatly.

With complete compensation of dynamics and time delays in the object, the search for the extremum would be based on the object's static characteristics. In this case, the actuator's reversion is determined by the following inequality

$$
f\left(x_{n}\right)-f\left(x_{n-1}\right)+\delta \leq 0,
$$

where $\delta$ is the optimizer's insensibility area.

The change of the object's output signal as a result of the $n$-th step of the actuator is determined by

$$
\begin{aligned}
& \Delta z_{n}=f\left(x_{n}\right) A-f\left(x_{n-1}\right) C-z_{n-1} B ; \\
& z_{n-1}=z_{0}+\sum_{i=1}^{n-1} \Delta z_{i} ; \\
& A=1-q_{1} ; B=1-q_{2} ; C=q_{1}-q_{2} ; \\
& q_{1}=e^{-\frac{\Delta t-\tau}{T_{1}}} ; q_{2}=e^{-\frac{\Delta t}{T_{1}}} .
\end{aligned}
$$

For $f\left(x_{n}\right)$ and $f\left(x_{n-1}\right)$ recurrent formulae look like

$$
\left.\begin{array}{l}
f\left(x_{n}\right)=\left[\Delta z_{n}-f\left(x_{n-1}\right) C+\left(z_{0}+\sum_{i=1}^{n-1} \Delta z_{i}\right) B\right] A^{-1} ; \\
f\left(x_{n-1}\right)=\left[\Delta z_{n-1}-f\left(x_{n-2}\right) C+\left(z_{0}+\sum_{i=1}^{n-2} \Delta z_{i}\right) B\right] A^{-1}
\end{array}\right\} .
$$

According to the mentioned results, the control is formed in compliance with this expression

$$
U=\left(\Delta z_{n}-\Delta z_{n-1} q_{1}\right) A^{-1}-\left[\Delta z_{n}(\tau)-\Delta z_{n-1}(\tau)\right] q_{1} A^{-1} .
$$

Thus, to calculate the operator $U$, two recent changes of the object's output coordinate are measured in the time period $\Delta t$ between the actuator's steps $\Delta z_{n}$ and $\Delta z_{n-1}$, as well as two recent changes of the output $z$ during the pure time delay $\tau$ read from the actuator's step moment.

\section{Experiments}

Fig. 3 presents an experimental dependency between the Fe content increment in the concentrate of the primary magnetic separators and the classifier drain density, while Fig. 4 depicts dependency of the concentrate yield on this parameter.

The given dependencies were obtained at the concentration plant of the PJSC “ArcelorMittal Kryvyi Rih". The research suggested that with formed constant levels of the section capacity and the identical initial raw materials, the classifier drain density and the size of the material fed for the primary separation changed. Changes in the Fe content of the middling product and tailings were traced as well as the yield of these products. Besides, the influence of the changed capacity of the feed ore section on the magnetic separator operation characteristics was determined when the classifier drain density was maintained at a given level by changing the auxiliary water fed to its bath. Fluctuations of the magnetic iron content in the feed ore were insignificant and as a result of obtained data, while calculating the weight-average content for each density, they were in the limits of an admissible error. During the whole set of experiments, feed density, strength and working parameters of the separators remained constant.

Fig. 5 shows experimental dependencies of the $\mathrm{Fe}$ content in the middling product of primary concentration. Fig. 6 depicts dependencies of the middling product yield of primary concentration on the initial feed at the following formed levels of the classifier drain slurry density: 1 - $1700 \mathrm{~g} / 1 ; 2-1800 \mathrm{~g} / 1 ; 3-1900 \mathrm{~g} / \mathrm{l} ; 4$ - $2000 \mathrm{~g} / \mathrm{l}$; $5-2100 \mathrm{~g} / \mathrm{l} ; 6-2200 \mathrm{~g} / \mathrm{l}$.

The dependencies in Fig. 3 and 4 reveal that the in- 


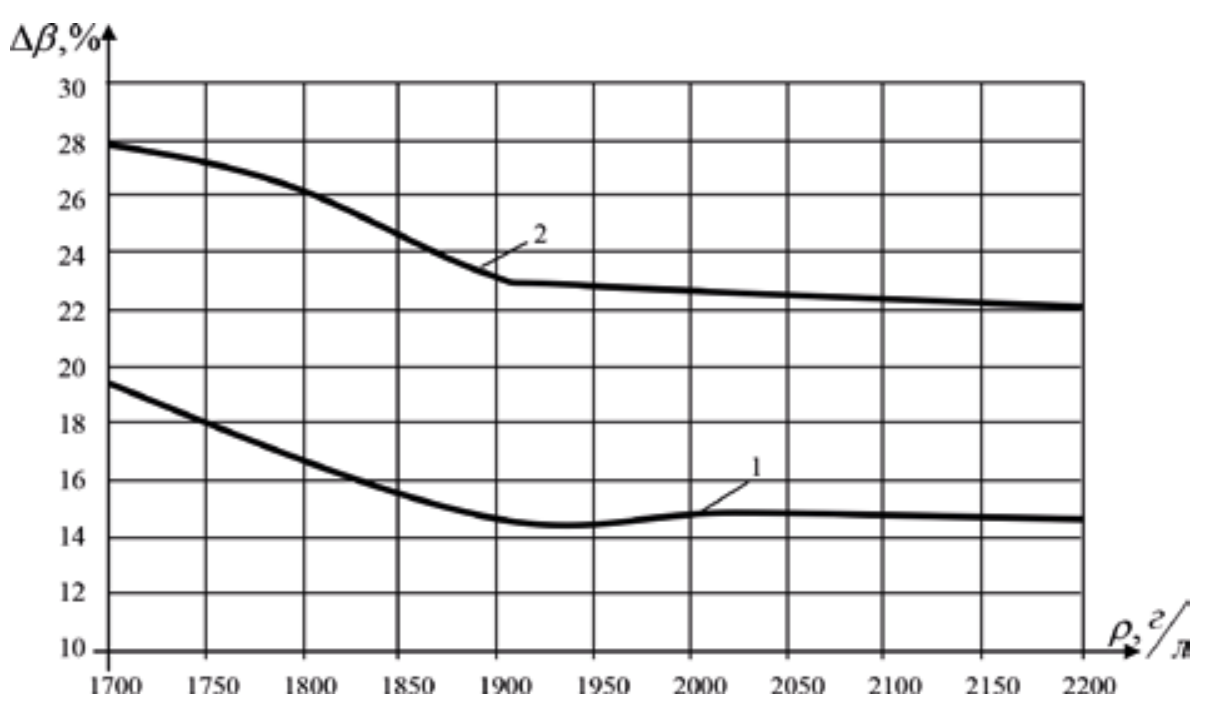

Fig. 3. Experimental dependencies between the Fe content increment in the concentrate of the primary magnetic separators and the classifier drain density, the capacity of the initial feed section of $230 \mathrm{t} / \mathrm{h}: 1-\beta-\alpha ; 2-\beta-\alpha_{\mathrm{M}}$

Pис. 3. Экспериментальная зависимость между приращением содержания железа в обогащенном продукте магнитных сепараторов I стадии и плотностью слива классификатора, производительность секции по исходному питанию 230 m/час: $1-\beta-\alpha ; 2-\beta-\alpha_{\mathrm{M}}$

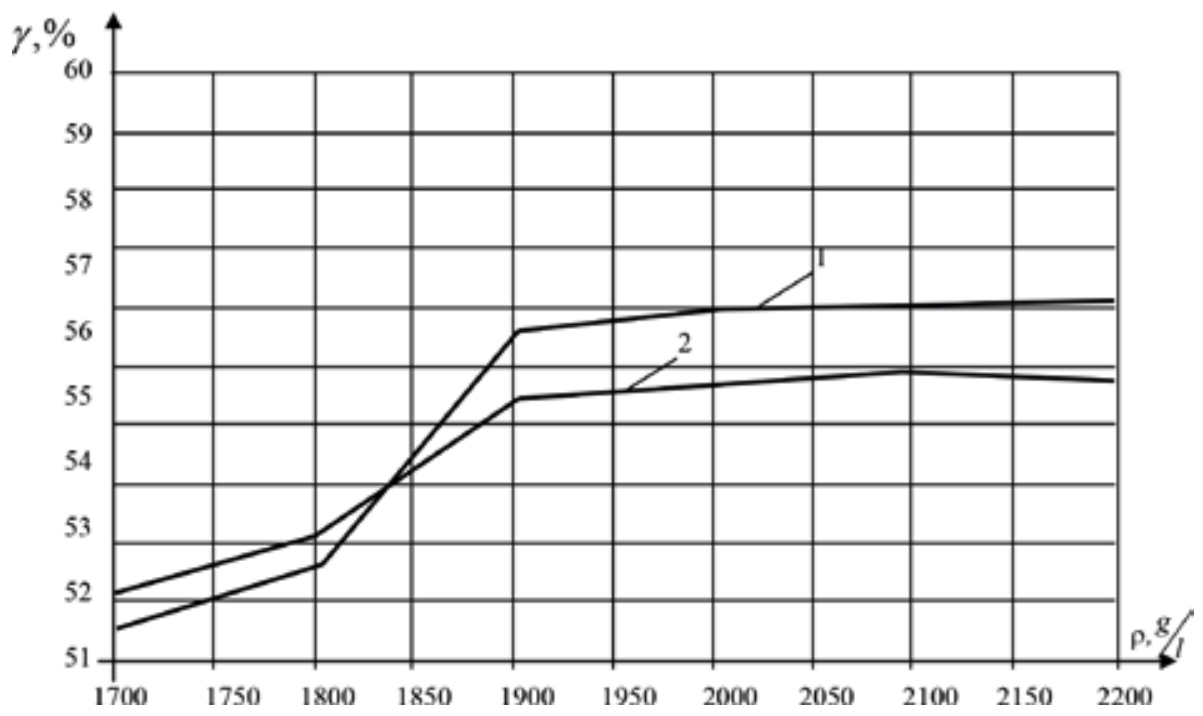

Fig. 4. Dependencies between the classifier drain density and the concentrate yield The capacity of the initial feed section: $1-230 \mathrm{t} / \mathrm{h} ; 2-205 \mathrm{t} / \mathrm{h}$

Рис. 4. Зависимость между плотностью слива классификатора и выходом обогащенного продукта, производительность секции по исходному питанию: $1-230 \mathrm{~m} / \mathrm{u} ; 2-205 \mathrm{~m} / \mathrm{u}$

creased classifier drain density increases the middling product yield, while the Fe increment in the middling product reduces. Thus, controlling the classifier drain density, one can achieve an optimal ratio between quantity and quality of the primary middling product.

Analysis of dependencies in Fig. 3 and 4 shows that although their overall view remains the same for different levels of the classifier drain density, the impact of the feed ore section capacity on operation of the magnetic separator is notable for significant ambiguity and depends on particular maintained density.

The increased classifier drain density and the ore section capacity increase this ambiguity caused by the classifier's unstable mode under conditions changing the granulometric composition of the magnetic separator feed.

\section{Results}

With the improved search, testing and working disturbances within controls $u_{1}$ and $u_{2}$ are formed so that corresponding transients should attenuate in a minimum of time in the object's input linear parts. All necessary limitations as to controls $u_{1}$, $u_{2}$ and phase coordinates $x_{1}, x_{2}$ are observed. At the same time formed disturbances are used to change increments of the value $z$ to indentify static characteristics of the object's non-linear part for each control channel.

Fig. 7 provides a model of the developed system of adaptive control of iron ore magnetic separation, which is synthesized in the subsystem Simulink 4 of Matlab 6.01 [28-31].

The static characteristics of the non-linear controlled object is set in block Fen 4 as function $f(u)$.

Inertial properties of the nonlinear controlled object are simulated by means of transfer function blocks (aperiodic links) Transfer Fcn2 and Transfer Fen3. To form transport delay for the object's input and output, blocks of fixed signal delay (Transport Delay) are used. Input dynamic links are united into the block Subsystem, the output ones - into the block Subsystem 1. As in real control systems there are some disturbances, the model includes blocks imitating them: Dead Zone, Backlash и Band-Limited White Noise.

Functions of the extreme regulator are simulated by means of signum-reley Sign1. The object's static characteristics are pre-computed in the block Subsystem 5 (Fig. 7). The control adaptation algorithm is realized in the block Subsystem 2. Parameters of separate elements of the ACS are optimized by means of the block Nonlinear Control Design (NCD).

Fig. 8 provides the flowchart of the system of adaptive control over magnetic separation on the basis of ultrasonic control in the Hancock criterion variant.

The system of adaptive control over magnetic separation functions according to the above mentioned algorithm.

The behavior of the ASAC (Automated System of 


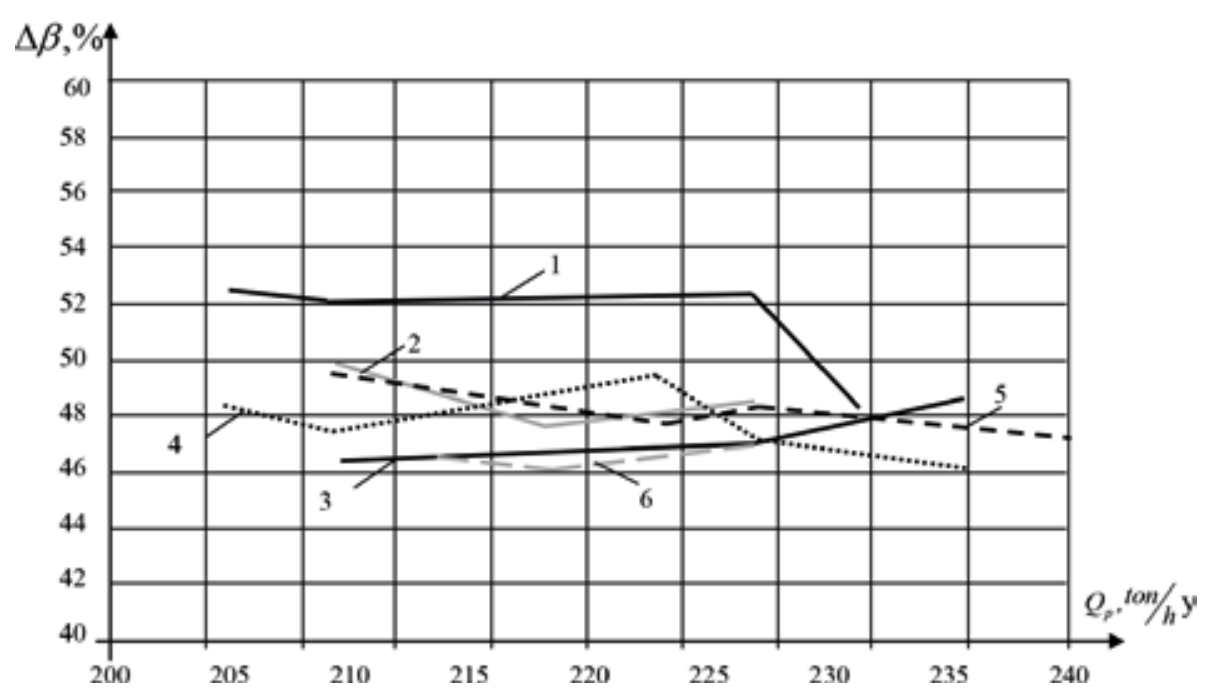

Fig. 5. Experimental dependencies of the Fe content in the middling product of primary concentration on the capacity of the initial feed section, the classifier drain density: $1-1700 \mathrm{~g} / \mathrm{l} ; 2-1800 \mathrm{~g} / \mathrm{l} ; 3-1900 \mathrm{~g} / \mathrm{l} ; 4-2000 \mathrm{~g} / \mathrm{l}$;

$$
5-2100 \mathrm{~g} / \mathrm{l} ; 6-2200 \mathrm{~g} / \mathrm{l}
$$

Pис. 5. Экспериментальные зависимости содержания железа в промпродукте I стадии обогащения от производительности секиии по исходному питанию. Плотность пульпы на сливе классификатора: 1 - 1700 г/л; 2 - 1800 г/л; 3 - 1900 г/л; $4-2000$ г/л; 5-2100 г/л; 6-2200 г/л

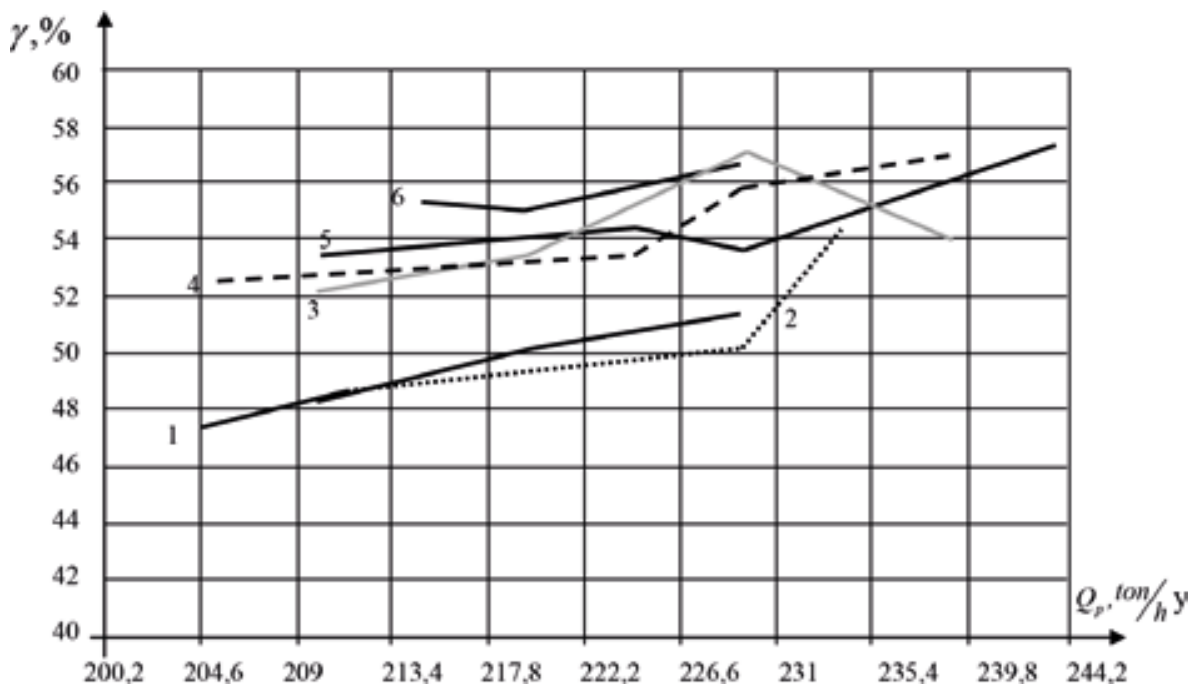

Fig. 6. Dependencies of the middling product yield of primary concentration on the initial feed section capacity, the classifier drain density: $1-1700 \mathrm{~g} / \mathrm{l}$; $2-1800 \mathrm{~g} / \mathrm{l} ; 3-1900 \mathrm{~g} / \mathrm{l} ; 4-2000 \mathrm{~g} / \mathrm{l} ; 5-2100 \mathrm{~g} / \mathrm{l} ; 6-2200 \mathrm{~g} / \mathrm{l}$

Рис. 6. Зависимости выхода промпродукта I стадии обогащения от производительности секции по исходному питанию, плотность пульпы на сливе классификатоpa: 1 -1700 г/л; 2 - 1800 г/л; 3 - 1900 г/л; 4 - 2000 г/л; 5 - 2100 г/л; 6 - 2200 г/л

changes of the object's static and dynamic characteristics, the best parameters of the search, the trajectory of which does not change, are achieved if these characteristics change within $\pm 25 \%$ thus fully meeting the technological requirements.

There are formulated conditions and specified regularities of the search for the objective function extremum in the discrete system of automated optimization of iron ore magnetic separation. It is determined that with changing physicalmechanical and chemical-mineralogical characteristics of processed ores, the minimum search period can be provided if the controlling impact is formed on the basis of differences of not less than two simultaneously changed values of the controlled object's input coordinate between the actuator's steps during the pure time delay. The latter is determined considering the current position of the controlled coordinate regarding the extremum point in the form of piecewise constant functions with limited values of acceptable controls, the parameters of which are conditioned by the object's input dynamic characteristics.

There are determined regularities of forming the extreme control over inertial objects with time delays and changing static and dynamic characteristics ensuring the minimum time of transients in the system of control over magnetic separation based on measured values of the controlled coordinate at intervals between the actuator's steps formed according to the object's current static and dynamic characteristics, which are

Adaptive Control) with changed static and dynamic characteristics of the object, parameters of disturbing impacts and noises are studied. Fig. 9 shows results of the search for the objective function extremum in the adaptive system of extreme control with noises in the controlled signal.

\section{Discussion}

Conducted investigations indicate that the period of searching for the extremum in the ASAC is stable if the static characteristic drifts within $\pm 50 \%$ of the rated value, the dynamic link parameters change within $\pm 70 \%$ and noise power from 0 to 0.12 . In case of arbitrary and short determined under intensive disturbances in the form of unclear sets, the membership of which is set by ratio predicates.

There are determined conditions and parameters of the stable search for the extremum in the system of automated control over iron ore magnetic separation, which realizes suggested search principles under intensive disturbing impacts on the object in controlled signals.

\section{Conclusions}

The developed adaptive system controlling magnetic separation allows reducing time of searching for the ob- 


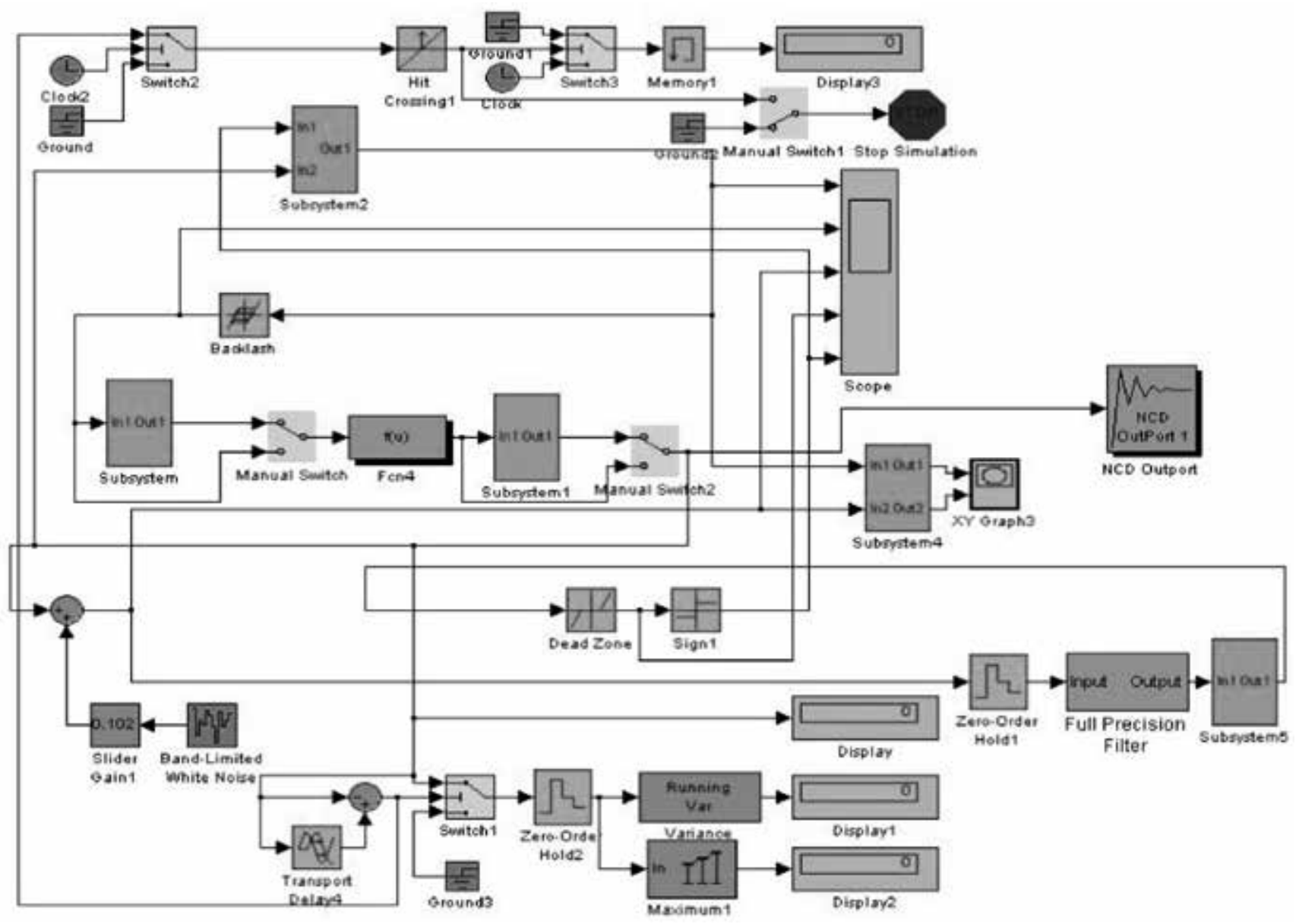

Fig. 7. The flowchart of the model of the system of the adaptive control over iron ore magnetic separation

Рис. 7. Блок-схема модели адаптивной системы управления проиессом магнитной сепараиии железных руд

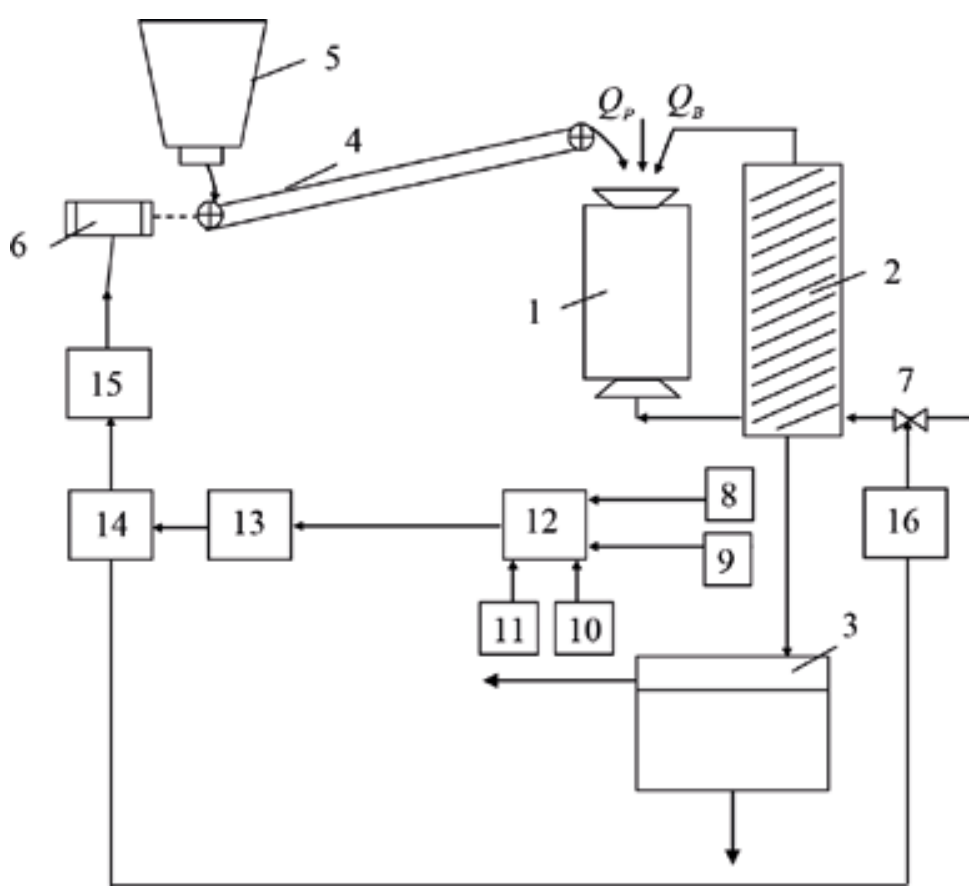

Fig. 8. The flowchart of the system of adaptive control over magnetic separation: 1 - mill; 2 - classifier; 3 - magnetic separator; 4 -feeder-conveyor; 5 - bin; 6 -actuating motor; 7 -controlled valve of water consumption; $8,10-F e$-content sensors; 9, 11 -flowmeters; 12 - input signal former; 13 -optimizer; 14 -controlling impact former; 15 - system controlling water feed into the mill; 16 - system controlling water consumption in the classifier

Pис. 8. Блок-схема адаптивной системы управления процессом магнитной сепарации: 1 - мельница; 2 - классификатор; 3 магнитный сепаратор; 4-конвейер-питатель; 5 - бункер; 6 - приводной двигатель; 7 - регулируемый клапан расхода водыл в классификатор; 8, 10-датчики содержания железа; 9, 11 - расходомеры; 12 - формирователь входного сигнала; 13 - оптимизатор; 14 - формирователь управляющих воздействий; 15 - система управления подачей руды в мельнииу; 16 - система управления расходом воды в классификатор 

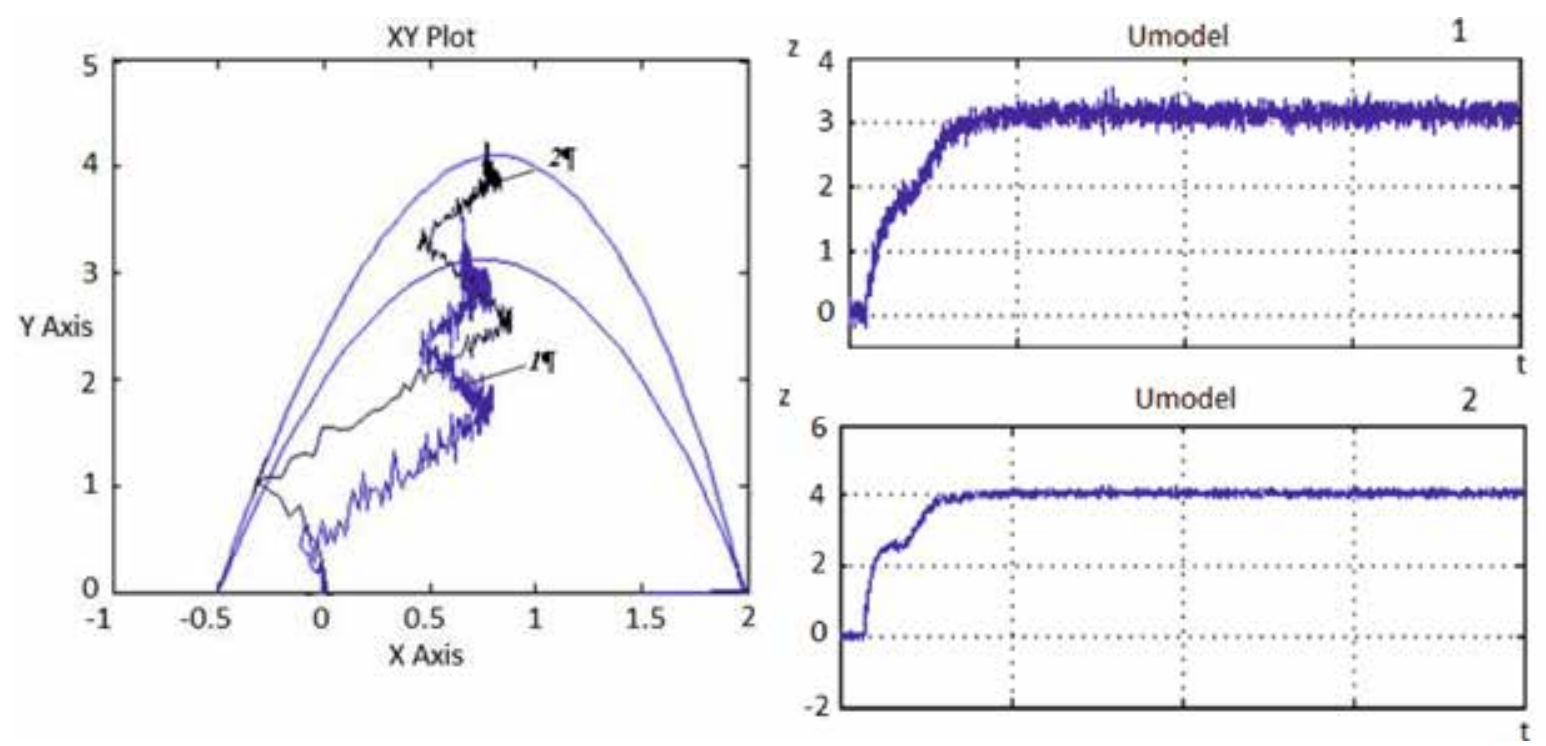

Fig. 9. Results of the search for the objective function extremum in the control system: $1-y=f(x), \delta=0,1 ; 2-y=1,33 f(x)$,

$$
T_{1}^{*}=1,3 T_{1}, \tau_{1}^{*}=1,2 \tau_{1}, T_{3}^{*}=1,4 T_{3}, \tau_{3}{ }^{*}=0,7 \tau_{3}, \delta=0,05
$$

Рис. 9. Результаты поиска экстремума целевой функиии в системе управления: $1-y=f(x), \delta=0,1 ; 2-y=1,33 f(x), T_{1}^{*}=1,3 T_{1}$,

$$
\tau_{1}{ }^{*}=1,2 \tau_{1}, T_{3}{ }^{*}=1,4 T_{3}, \tau_{3}^{*}=0,7 \tau_{3}, \delta=0,05
$$

jective control function, maintaining the optimal ratio of the concentrate yield and the grade contained under conditions of changing quality of initial ores and equipment. There are determined conditions and the best parameters of searching for the extremum in the system of adaptive control over iron ore magnetic separation under disturbances and noises in controlled signals. They can be achieved when deviations of the object's static and dynamic characteristics from rated ones do not exceed $\pm 25 \%$.

\section{CONTRIBUTION / Долевое участие авторов}

Morkun V.S. - carried out research and analysis of regularities of formation of extreme control of inertial objects with delay with varying static and dynamic characteristics; Morkun N. V. - developed the theoretical basis for the formation of control actions in the system of extreme control of dynamic objects; Tron V. V. - conducted the development of the structure of the adaptive control system of the magnetic separation process in the process of ore material enrichment and the study of its operation under various conditions; Dotsenko I. A. - conducted a study of the control system in conditions of disturbances and noises in controlled signals.

Моркун В. С. - проводил исследование и анализ закономерностей формирования экстремального управления инериионными объектами с запаздыванием с изменяющимися статическими и динамическими характеристиками; Моркун Н. В. - разработала теоретическую базу формирования управляющих воздействий в системе экстремального управления динамическими объектами; Тронь В. В. - проводил разработку структуры системы адаптивного управления процессом магнитной сепаращии в процессе обогащения рудного материала и исследование ее работы в различных условиях; Доценко И. А. - проводила исследование системы управления при наличии возмущений и шумов в контролируемых сигналах.

\section{CONFLICT OF INTEREST / Конфликт интересов}

The authors declare no conflict of interest / Авторы заявляют об отсутствии конфликта интересов. 


\section{ЛИТЕРАТУРА:}

1. Piven V. A. Economic efficiency of quality increase of mining and metallurgical raw materials. Gornyi zhurnal, 2003, no. 9, pp. 57-58 (in Russian).

2. Golik V. I., Hasheva Z. M., Galachieva S. V. Diversification of the economic foundations of depressive mining region. The Social Sciences (Pakistan), 2015, vol. 10, iss. 6, pp. 746-749.

3. Evdokimov S. I., I Trotsenko I. G., Meshkov E. I., Maksimov R. N. Small mining enterprises as a factor of sustainable development of territories. Sustainable development of mountain territories, 2017, vol. 9, no. 4(34), pp. 387-397. (in Russian).

4. Azaryan A. A., Kolosov V. A., Lomovtsev L. A., Uchitel A. D. Quality of mineral materials. 2001. Kryvoy Rig, Mineral (in Russian).

5. Kupin A., Muzyka I., Kuznetsov D., Kumchenko Y. Stochastic optimization method in computer decision support system. Advances in Intelligent Systems and Computing, 2019, vol. 754, pp. 349-358.

6. Morkun V., Morkun N., Pikilnyak A. Ultrasonic phased array parameters determination for the gas bubble size distribution control formation in the iron ore flotation. Metallurgical and Mining Industry, 2014, No. 3, pp. 28-31.

7. Golik V. I., Razorenov Y. I., Polukhin O. N. Metal extraction from ore benefication codas by means of lixiviation in a dis-integrator. International Journal of Applied Engineering Research, 2015, v. 10, no 17, pp. 38105-38109.

8. Mykhailov O. M., Temchenko A. H., Kovalevskyi V. O. Resource-saving and low-waste technology. 2003, Kryvyi Rih, Mineral (in Ukrainian).

9. Morkun V., Morkun N., Tron V. Formalization and frequency analysis of robust control of ore beneficiation technological processes under parametric uncertainty. Metallurgical and Mining Industry, 2015, no. 5, pp. 7-11.

10. Minnitt R. The costs of sampling errors and bias to the mining industry. Journal of the Southern African Institute of Mining and Metallurgy. 2018, vol. 118, iss. 8, pp. 787-798.

11. Inanloo Arabi Shad H., Sereshki F., Ataei M., Karamoozian M. Effect of magnetite content on Bond work index and preconditioning: Case study on Chadormalu iron ore mine. Journal of Central South University, 2018, vol. 25, iss. 4, pp. 795-804.

12. Osipova N. V. The use of Kalman filter in automatic control of indicators of iron ores magnetic concentration. Izvestiya Vysshikh Uchebnykh Zavedenij. Chernaya Metallurgiya, 2018, vol. 61, iss. 5, pp. 372-377.

13. Maryuta A. N., Kachan Yu. G., Bunko V. A. Automated control of processes at concentration plants. Moscow, $\mathrm{Ne}$ $d r a, 1983$. (in Russian).
14. Dechevsky L. T., Sziebig G., Korondi, P. Optimizing the automation of an iron ore production line - A case study, part II: Optimal automated quality control. Proceedings. 2016. IEEE International Power Electronics and Motion Control Conference, PEMC, 2016, pp. 753-762.

15. Tikhonov O. N. Solving problems of automation in concentration and metallurgy. Moscow-Leningrad, Nedra, 1969. (in Russian).

16. Alekseyev M. A. Alhori, F. S. R. Automatic control of magnetic separator productivity based on spectral signal converter of electric motor active power, Naukovyi Visnyk Natsionalnoho Hirnychoho Universytetu, 2014, iss. 1, pp. 56-61.

17. Stener J. F., Carlson J. E., Pålsson B. I., Sand, A. Direct measurement of internal material flow in a bench scale wet low-intensity magnetic separator. Minerals Engineering, 2016, vol. 91, pp. 55-65.

18. Maryuta A. N. Automated optimization of ore concentration at magnetic-concentration plants. Moscow, Nedra, 1975. (in Russian).

19. Barskyi L. A., Kozin V. Z. System-based analysis in mineral concentration. Moscow: Nedra. 1978. (in Russian).

20. Nesterov G. S., Nesterova N. A., Batanov A. I. Process control at concentration plants. Moscow, Nedra, 1966. (in Russian).

21. Khan G. A. Testing and control of concentration processes. Moscow, Nedra, 1979. (in Russian).

22. Chinayev P. I. (Ed) Self-adjusting systems. Kyiv, Naukova dumka, 1969. (in Russian).

23. Bellman R., Dreyfus S. Applied tasks of dynamic programming. Moscow, Nauka, 1965. (in Russian).

24. Bandi B. Optimization methods. Introductory course. Moscow, Radio i svyaz, 1988. (in Russian).

25. Venttsel Ye. S. Investigation of operations. Moscow, Sovetskoye radio, 1972. (in Russian).

26. Gabassov R. F., Kirillova V. O. Collection of tasks on mathematical programming. Minsk, Izd. BGU, 1981. (in Russian).

27. Zaychenko Yu. P. Investigation of operations. Kyiv, Vyshcha shkola, 1975. (in Russian).

28. Leonenkov A. Fuzzy simulation in MATLAB and fuzzy TECH. St. Petersburg, BHV-Sankt-Peterburg, 2003. (in Russian).

29. Kruglov V., Dli M., Golunov Fuzzy logic and artificial neural networks. Moscow, Fizmatlit, 2001. (in Russian).

30. Gultyayev A. MATLAB 5.2. Simulation in Windows environment. Moscow, Korona print, 1999. (in Russian).

31. Potemkin V. MATLAB system: Reference book. Moscow, Dialog, 1997. (in Russian).

32. Arefyev B. A. Optimization of inertial processes. Leningrad, Mashinostroyeniye, 1969. (in Russian). 


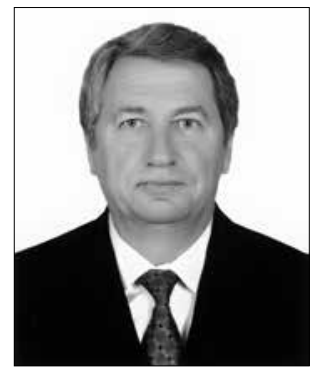

Vladimir St. MORKUN - Doctor of Technical Sciences, Professor, ViceRector in Research.

Kryvoi Rogh National University, Kryvoi Rogh, Ukraine, 50027.

E-mail: morkunv@gmail.com

Ph.: +380679762925.

Number ORCID: http://orcid.

МОРКУН Владимир Станиславович - доктор технических наук, профессор, проректор по научной работе. Криворожский национальный университет, 50027, г. Кривой Рог, Украина.

e-mail:morkunv@gmail.com

Тел.: +380679762925

Hомер ORCID: http://orcid.org/0000-0003-1506-9759 org/0000-0003-1506-9759

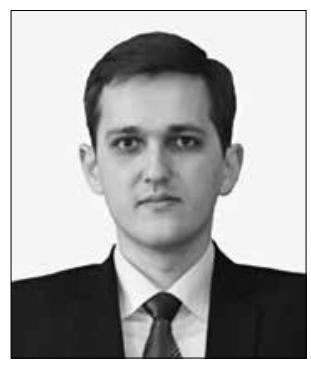

org/0000-0002-6149-5794

Vitaliy V. TRON - PhD, Associated Professor.

Department of automation, computer science and technology Kryvoi Rogh National University, Kryvoi Rogh, Ukraine, 50027.

E-mail: vtron@ukr.net

Ph.: +380961149797.

Number ORCID: https://orcid.

ТРОНЬ Виталий Валериевич - кандидат технических наук, доиент.

Кафедра автоматизачии, компьютерных наук и технологий, Криворожский начиональный университет, 50027, г. Кривой Рог, Украина.

E-mail:vtron@ukr.net

Тел.: +380961149797

Hомер ORCID: https://orcid.org/0000-0002-6149-5794

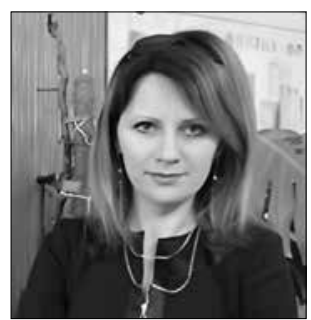

Natalia Vl. MORKUN - Doctor of Technical Sciences, Associated Professor, Department of automation, computer science and technology.

Kryvoi Rogh National University, Kryvoi Rogh, Ukraine, 50027.

E-mail: nmorkun@gmail.com

Ph.: +380936770659

Number ORCID: http://orcid.org/0000-0002-1261-1170

Ph.: +380564262407

Number ORCID: https://orcid. org/0000-0001-7912-2497

ДОЦЕНКО Ирина Алексеевна - научный сотрудник.

Научно-производственный комплекс железных, марганцевых и полиметаллических руд Академии горных наук Украины, 50002, г. Кривой Рог, Украина.

E-mail: i.a.dotsenko@i.ua

Тел.: +380564262407

Hомер ORCID: https://orcid.org/0000-0001-7912-2497
МОРКУН Наталья Владимировна - доктор технических технологий, Криворожский наџиональный университет, 50027,

г. Кривой Рог, Украина.

e-mail:nmorkun@gmail.com

Тел.: +380936770659

Hомер ORCID: http://orcid.org/0000-0002-1261-1170 наук, доцент. Кафедра автоматизации, компьютерных наук и

\section{АДАПТИВНАЯ СИСТЕМА УПРАВЛЕНИЯ ПРОЦЕССОМ МАГНИТНОЙ СЕПАРАЦИИ}

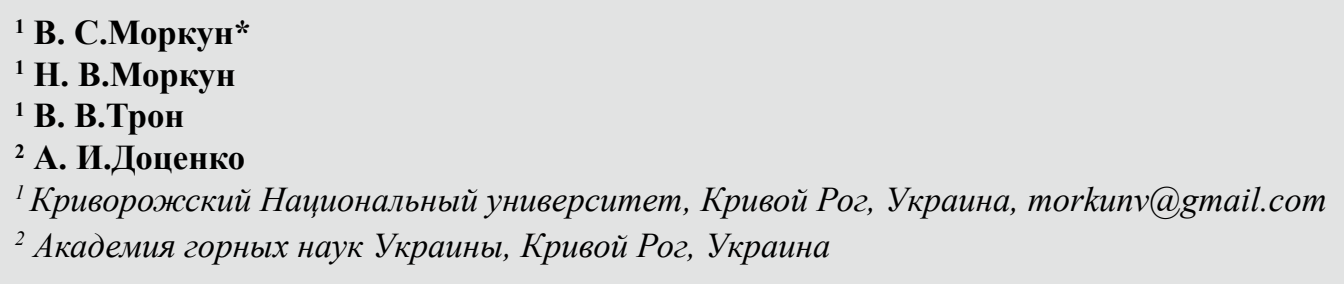

DOI: $10.21177 / 1998-4502-2018-10-4-545-557$

Цель. В рамках устойчивой индустриализации целью работы является создание теоретической базы и разработка адаптивной системы управления процессом магнитной сепарации железных руд, минимизирующей время поиска экстремума характеристик динамических объектов в условиях воздействия возмущений и помех в контролируемых сигналах.
Методы. В статье использованы методы оптимального управления, метод стохастической аппроксимации для повышения эффективности оптимального управления, методы численного моделирования для синтеза и анализа математической модели системы экстремального управления, компьютерные информационные и программные технологии для реализации разработанного 
алгоритма поиска экстремума в виде программного обеспечения.

Результаты. В статье приведена теоретическая база формирования управляющих воздействий в системе экстремального управления динамическими объектами, позволяющих при наличии возмущений и помех в контролируемом сигнале достигнуть экстремума характеристики объекта управления за минимальное время. Установлены закономерности формирования экстремального управления инерционными объектами с задержкой и изменяющимися статическими и динамическими характеристиками, обеспечивающие минимальное время переходных процессов в системе управления процессом магнитной сепарации железных руд на базе измеренных значений регулируемой координаты через промежутки времени между шагами исполнительного механизма, формируемые в соответствии с текущими значениями статических и динамических характеристик объекта, которые определяются в условиях действия интенсивных возмущений. Разработана адаптивная система управления процессом магнитной сепарации железных руд, минимизирующей время поиска экстремума характеристик динамических объектов в условиях воздействия возмущений и помех в контролируемых сигналах.

Выводы. Разработанная адаптивная система управления процессом магнитной сепарации железных руд позволяет минимизировать время поиска целевой функции управления, поддерживать оптимальное соотношение между выходом концентрата и содержанием полезного компонента в нем в условиях изменяющегося качества исходной руды и состояния технологического оборудования. Установлены условия и впервые определено, что наилучшие параметры поиска экстремума в системе автоматического управления процессом магнитной сепарации железных руд, которая реализует предложенные принципы поиска, при наличии возмущений и шумов в контролируемых сигналах достигаются в том случае, когда отклонение статических и динамических характеристик объекта управления от номинального значения не превышает $\pm 25 \%$.

Ключевые слова: адаптивная система управления, магнитная сепарация, железная руда, пульпа, поиск экстремума.

\section{Лuтература}

1. Пивень В. А. Экономическая эффективность повышения качества горно-металлургического сырья // Горный журнал. 2003. N 9. С. 57-58.

2. Golik V. I., Hasheva Z. M., Galachieva S. V. Diversification of the economic foundations of depressive mining region // The Social Sciences (Pakistan). 2015. Vol. 10. Iss. 6. Рp. 746-749.

3. Евдокимов С. И., Троценко И. Г., Мешков Е. И., Максимов Р. Н. Малые горнодобывающие предприятия как фактор устойчивого развития территорий // Устойчивое развитие горных территорий. 2017. Том. 9, N 4 (34). C. 387-397.

4. Азарян А. А., Колосов В. А., Ломовцев Л. А., Учитель А. Д. Качество минеральных материалов. Кривой Рог: Минерал, 2001.

5. Kupin A., Muzyka I., Kuznetsov D., Kumchenko Y.
Stochastic optimization method in computer decision support system // Advances in Intelligent Systems and Computing. 2019. Vol.754. Pp. 349-358.

6. Morkun V., Morkun N., Pikilnyak A. Ultrasonic phased array parameters determination for the gas bubble size distribution control formation in the iron ore flotation // Metallurgical and Mining Industry. 2014. No 3. Pp. 28-31.

7. Golik V. I., Razorenov Y. I., Polukhin O. N. Metal extraction from ore benefication codas by means of lixiviation in a dis-integrator // International Journal of Applied Engineering Research. 2015. T. 10. No 17. Pp. 38105-38109.

8. Mykhailov O. M., Temchenko A. H., Kovalevskyi V. O. Resource-saving and low-waste technology. 2003. Kryvyi Rih: Mineral (in Ukrainian).

9. Morkun V., Morkun N., Tron V. Formalization and frequency analysis of robust control of ore beneficiation technological processes under parametric uncertainty // Metallurgical and Mining Industry. 2015. No5. Pp. 7-11.

10. Minnitt R. The costs of sampling errors and bias to the mining industry // Journal of the Southern African Institute of Mining and Metallurgy. 2018. Vol. 118, iss. 8. Pp. 787-798.

11. Inanloo Arabi Shad H., Sereshki F., Ataei M., Karamoozian M. Effect of magnetite content on Bond work index and preconditioning: Case study on Chadormalu iron ore mine // Journal of Central South University. 2018. Vol. 25, iss. 4. Pp. $795-804$.

12. Osipova N. V. The use of Kalman filter in automatic control of indicators of iron ores magnetic concentration // Izvestiya Vysshikh Uchebnykh Zavedenij. Chernaya Metallurgiya. 2018. Vol. 61, iss. 5. Pp. 372-377.

13. Марьюта А. Н., Качан Ю. Г., Бунко В. А. Автоматизированное управление процессами на обогатительных фабриках. М.: Недра, 1983.

14. Dechevsky L. T., Sziebig G., Korondi, P. Optimizing the automation of an iron ore production line - A case study, part II: Optimal automated quality control. Proceedings // 2016 IEEE International Power Electronics and Motion Control Conference, PEMC. 2016. Pp. 753-762.

15. Тихонов О. Н. Решение задач автоматизации в концентрации и металлургии. М.-Л.: Недра, 1969.

16. Alekseyev M. A., Alhori F. S. R. Automatic control of magnetic separator productivity based on spectral signal converter of electric motor active power // Naukovyi Visnyk Natsionalnoho Hirnychoho Universytetu. 2014. Iss. 1. Pp. 56-61.

17. Stener J. F., Carlson J. E., Pålsson B. I., Sand, A. Direct measurement of internal material flow in a bench scale wet low-intensity magnetic separator // Minerals Engineering. 2016. Vol. 91. Pp. 55-65.

18. Марьюта А. Н. Автоматизированная оптимизация обогащения руд на магнитно-обогатительных фабриках. Москва: Недра, 1975.

19. Барский Л. А., Козин В. З. Системный анализ концентрации полезных ископаемых. М.: Недра, 1978.

20. Нестеров Г. С., Нестерова Н.А., Батанов А. И. Управление технологическими процессами на обогатительных фабриках. М.: Недра, 1966.

21. Хан Г. А. Тестирование и контроль концентрационных процессов. М.: Недра, 1979. 
22. Шинаев П. И. (ред.) Самонастраивающиеся системы. Киев: Наукова думка, 1969.

23. Беллман Р., Дрейфус С. Прикладные задачи динамического программирования. М.: Наука, 1965.

24. Банди Б. Методы оптимизации. Вводный курС. М.: Радио и связь, 1988.

25. Венцель В.С. Исследование операций. М.: Советское радио, 1972.

26. Габасов Р. Ф., Кириллова В. О. Сборник задач по математическому программированию. Минск: Изд. БГУ, 1981.

27. Зайченко Ю. П. Исследование операций. Киев: Вища школа, 1975.
28. Леоненков А. Нечеткое моделирование в MATLAB и ТЕСН. СПб.: БХВ-Санкт-Петербург. 2003.

29. Круглов В., Дли М., Голунов Нечеткая логика и искусственные нейронные сети. М.: Физматлит, 2001.

30. Гултяев А. Матлаб 5.2. Моделирование в среде Windows. М.: Корона принт, 1999.

31. Потемкин В. Система MATLAB: справочник. М.: Диалог, 1997.

32. Арефьев Б. А. Оптимизация инерционных процессов. Л.: Машиностроение, 1969.

Статья поступила в редакцию 30.07.2018 
${ }^{1}$ Гиясов А.А.,

2 Тускаева 3.P., *

${ }^{3}$ Гиясова И.В.
УДК: 711(23)

DOI: 10.21171/1998-4502-2018-

10-4-558-565

Рассматриваются особенности проектирования и совершенствования объемнопланировочной структуры городов и жилой застройки в условиях сложного рельефра с учетом орографических особенностей строения и климатических условий рельефной территории. Изучается проблема освоения горного региона с целью разработки планировочной структуры жилых образований и развития поселений, учитывая местные климатические особенности рельефа.

Изучена территория сложного рельефа с морфологической, микроклиматической и биоклиматической позиции с выявлением градостроительной маневренности рельефной ситуации, актуализирована, дополнена и уточнена, сформированная в ее рамках методика проектирования. На этой основе разработаны методика организации объемно-пространственной и архитектурно-планировочной структуры городов, населенных пунктов и зданий.

\section{ИСПОЛЬЗОВАНИЕ ОСОБЕННОСТЕЙ СЛОЖНОГО РЕЛЬЕФА ДЛЯ УСТОЙЧИВОГО РАЗВИТИЯ ГОРНЫХ ТЕРРИТОРИЙ}

\section{Введение}

Последнее десятилетие ознаменовалось пристальным вниманием мировой общественности к вопросам горной тематики и связанным с ней развитием человеческой цивилизации. Общественность приходит к осознанию того, что устойчивость и стабильность развития стран невозможны без всесторонней поддержи горных районов и их населения, являющихся хранилищами и хранителями ценнейших природных ресурсов и этнокультурного наследия и находящихся в неравных условиях по сравнению с равнинными и урбанизированными территориями.

В связи с обострением экологической и социальной ситуации в горных регионах отмечается усиление внимания к комплексному изучению градостроительной проблемы в аспекте среды зон «Горы-город-человек».

Горы влияют на градоэкологическое состояние атмосферной городской среды большими колебаниями высотных отметок, сложным рельефом, обусловливая исключительное многообразие и пестроту климатических условий, в отличие от равнинных территорий, где климатические изменения прослеживаются по горизонтали, в горах резкие различия наблюдаются и по вертикали. Здесь что ни склон или долина, то своеобразный климат. Все это затрудняет проблему зонирования территории сложного горного рельефа по климатическим характеристикам и впоследствии принцип проектирования зданий и их комплексов.

Сложный рельеф, с учетом освоения под застройку территорий, характеризуется совокупностью форм расчленения земной поверхности. По величине этого расчленения делится на мега-, макро-, мезо-, микро- и нанорельеф, который в разной степени используется при решении конкретных градостроительных задач.

Изучению режима ветров в горах был посвящен ряд исследований отечественных и зарубежных ученых [1-4]. Значительный вклад в проблему градостроительного аспекта освоения сложного рельефа внесли авторы, представленные в трудах [5-20]. Горной тематикой занимаются многие международные организации, градостроительные аспекты освоения горных районов изучались рядом исследовательских институтов, отечественными и зарубежными учеными [5-20]. В них отмечается, что основным циркуляционным процессом, формирующим климатические условия в пределах горно-долинных систем (ГДС) низкогорья и среднегорья является горно-долинная циркуляция (ГДЦ).

Цель исследования. С целью устойчивого развития горного рельефа с учетом уникальности природно-экологического ландшафта застраиваемых территорий на сложном рельефе, а также специфичности климатических особенностей, обусловленных местными условиями ландшафта, существующая архитектурная типология жилых зданий и их планировочная организация для территорий освоения систематизирована, дополнена и уточнена, сформированная в ее рамках методика проектирования актуализирована.

${ }^{1}$ Московский государственный строительный университет, 129337, Москва, Россия, adham52@mail.ru

${ }^{2}$ Северо-Кавказский горно-металлургический институт (государственный технологический университет), 362021, г. Владикавказ, Россия, tuskaevazalina@yandex.ru

3 Тамбовский государственный технический университет, 392000, г. Тамбов, Россия, timrus64@mail.ru 
Формообразования рельефа потенцильного строительства Relief shape formation of potential construction

\begin{tabular}{|c|c|c|c|c|c|}
\hline \multirow[b]{2}{*}{$\begin{array}{c}\text { Размеры, } \\
\text { формы } \\
\text { Dimensions, } \\
\text { shapes }\end{array}$} & \multicolumn{5}{|c|}{ Формы рельефа } \\
\hline & $\begin{array}{c}\text { Крупнейшие } \\
\text { (мегорельеф) } \\
\text { The largest } \\
\text { (megorelief) }\end{array}$ & $\begin{array}{c}\text { Крупные } \\
\text { (макрорельеф) } \\
\text { Large } \\
\text { (macrorelief) }\end{array}$ & $\begin{array}{c}\text { Средние } \\
\text { (мезорельеф) } \\
\text { Medium } \\
\text { (mesorelief) }\end{array}$ & $\begin{array}{c}\text { Мелкие } \\
\text { (микрорельеф) } \\
\text { Small (microrelief) }\end{array}$ & $\begin{array}{c}\text { Мельчайшне } \\
\text { (нанорельеф) } \\
\text { The smallest } \\
\text { (nanorelief) }\end{array}$ \\
\hline $\begin{array}{l}\text { Горизонтальныс } \\
\text { Horizontal }\end{array}$ & $\begin{array}{l}\text { Десятки и сотни } \\
\text { тысяч квадратиых } \\
\text { километров } \\
\text { Tens and humdreds } \\
\text { of thousands } \\
\text { of square } \\
\text { kilometers }\end{array}$ & $\begin{array}{l}\text { Сотни тысяч } \\
\text { квадратных } \\
\text { километров } \\
\text { Hundreds of } \\
\text { thousands } \\
\text { of square } \\
\text { kilometers }\end{array}$ & $\begin{array}{l}\text { Сотни тысяч } \\
\text { квадратных } \\
\text { километров } \\
\text { Hundreds } \\
\text { of thousands } \\
\text { of square } \\
\text { kilometers }\end{array}$ & $\begin{array}{l}\text { Десятки и сотни } \\
\text { квадратных } \\
\text { метров } \\
\text { Tens and } \\
\text { hundreds } \\
\text { of square } \\
\text { meters }\end{array}$ & $\begin{array}{l}\text { Метры, десятки } \\
\text { метров } \\
\text { Meters, tens } \\
\text { of meters }\end{array}$ \\
\hline $\begin{array}{l}\text { Вертикальныс } \\
\text { Vertical }\end{array}$ & $\begin{array}{l}\text { Сотни и тысячи } \\
\text { метров } \\
\text { Hundreds and } \\
\text { thousands } \\
\text { of meters }\end{array}$ & $\begin{array}{l}\text { Сотни и тысячи } \\
\text { Метров } \\
\text { Hundreds } \\
\text { and thousands } \\
\text { of meters }\end{array}$ & $\begin{array}{l}\text { Десятки метров } \\
\text { Tens of meters }\end{array}$ & $\begin{array}{l}\text { Метры, реже } \\
\text { десятки метров } \\
\text { Meters, less than } \\
\text { tens of meters }\end{array}$ & $\begin{array}{l}\text { Метры, десятки } \\
\text { метры } \\
\text { Meters, tens } \\
\text { of meters }\end{array}$ \\
\hline $\begin{array}{l}\text { Примеры } \\
\text { рельефа } \\
\text { Examples } \\
\text { of relief }\end{array}$ & $\begin{array}{l}\text { Горные страны, } \\
\text { нагорья, обширные } \\
\text { возвышенности и } \\
\text { низменности } \\
\text { Mountainous } \\
\text { countries, highlands, } \\
\text { vast hills } \\
\text { and lowlands }\end{array}$ & $\begin{array}{l}\text { Отдельные горы, } \\
\text { горные хребты, } \\
\text { большие речные } \\
\text { долины, мсжторные } \\
\text { впадины, котловины } \\
\text { Separate mountains, } \\
\text { mountain ranges, } \\
\text { large river valleys, } \\
\text { intermontane } \\
\text { depressions, hollows }\end{array}$ & $\begin{array}{l}\text { Холмы, овраги, } \\
\text { барханные цепи } \\
\text { Hills, ravines, } \\
\text { barchan chains }\end{array}$ & $\begin{array}{l}\text { Бугры, курганы, } \\
\text { промоины } \\
\text { Hillocks, barrows, } \\
\text { gullies }\end{array}$ & $\begin{array}{l}\text { Склоны котловин, } \\
\text { долин } \\
\text { Slopes of hollows, } \\
\text { valleys }\end{array}$ \\
\hline $\begin{array}{l}\text { Формы рельефа } \\
\text { Forms of relief }\end{array}$ & & & & & \\
\hline $\begin{array}{l}\text { Градостроительн } \\
\text { ос освосние } \\
\text { Urban } \\
\text { development }\end{array}$ & $\begin{array}{l}\text { Строение целых } \\
\text { стран, города } \\
\text { крупныс, крупные } \\
\text { населенныс пункты } \\
\text { The structure of } \\
\text { entire countries, } \\
\text { cities are large, large } \\
\text { settlements }\end{array}$ & $\begin{array}{l}\text { Города средние и } \\
\text { мелкие, крупныс } \\
\text { населснныс пункты } \\
\text { Cities are meditm and } \\
\text { small, large settlements }\end{array}$ & $\begin{array}{l}\text { Города средние и } \\
\text { мелкие, населенные } \\
\text { пункты } \\
\text { Cities are medium and } \\
\text { small, settlements }\end{array}$ & $\begin{array}{l}\text { Населенные } \\
\text { пункты, здания } \\
\text { и комплексы } \\
\text { Settlements, } \\
\text { buildings and } \\
\text { complexes }\end{array}$ & $\begin{array}{l}\text { Здания и } \\
\text { комплексы } \\
\text { Buildings and } \\
\text { complexes }\end{array}$ \\
\hline $\begin{array}{l}\text { Объемно- } \\
\text { планировочная } \\
\text { структура } \\
\text { городов, } \\
\text { населенных } \\
\text { пунктов изданий } \\
\text { Volumetric and } \\
\text { planning } \\
\text { stricture of cities, } \\
\text { settlements and } \\
\text { buildings }\end{array}$ & & $d^{2}$ & $=125$ & & \\
\hline
\end{tabular}

Разработать методические предложения по планированию объемно-пространственной структуры городской застройки, проектированию жилья и жилых комплексов, по способу компоновки в формообразованиях рельефа и относительно склона.

На основе изучения отечественного и зарубежного опыта проектирования и строительства зданий и застройки на сложном рельефе обобщена и систематизирована проблема формообразования рельефа с выявлением зон потенциального строительства. На базе методики оценки фоновых и разработанной авторами методике оценки местных особых климатических условий сформулированы формы рельефа по крупности для градостроительного освоения.

Изучена территория сложного рельефа с морфологической, микроклиматической и биоклиматической позиции с выявлением градостроительной маневренности рельефной ситуации. На этой основе разработаны объемно-пространственные и архитектурно-планировочные структуры городов, населенных пунктов и зданий. 
Таблица 2 / Table 2

Формирования планировочной организации объектов Formation of planning organization of objects

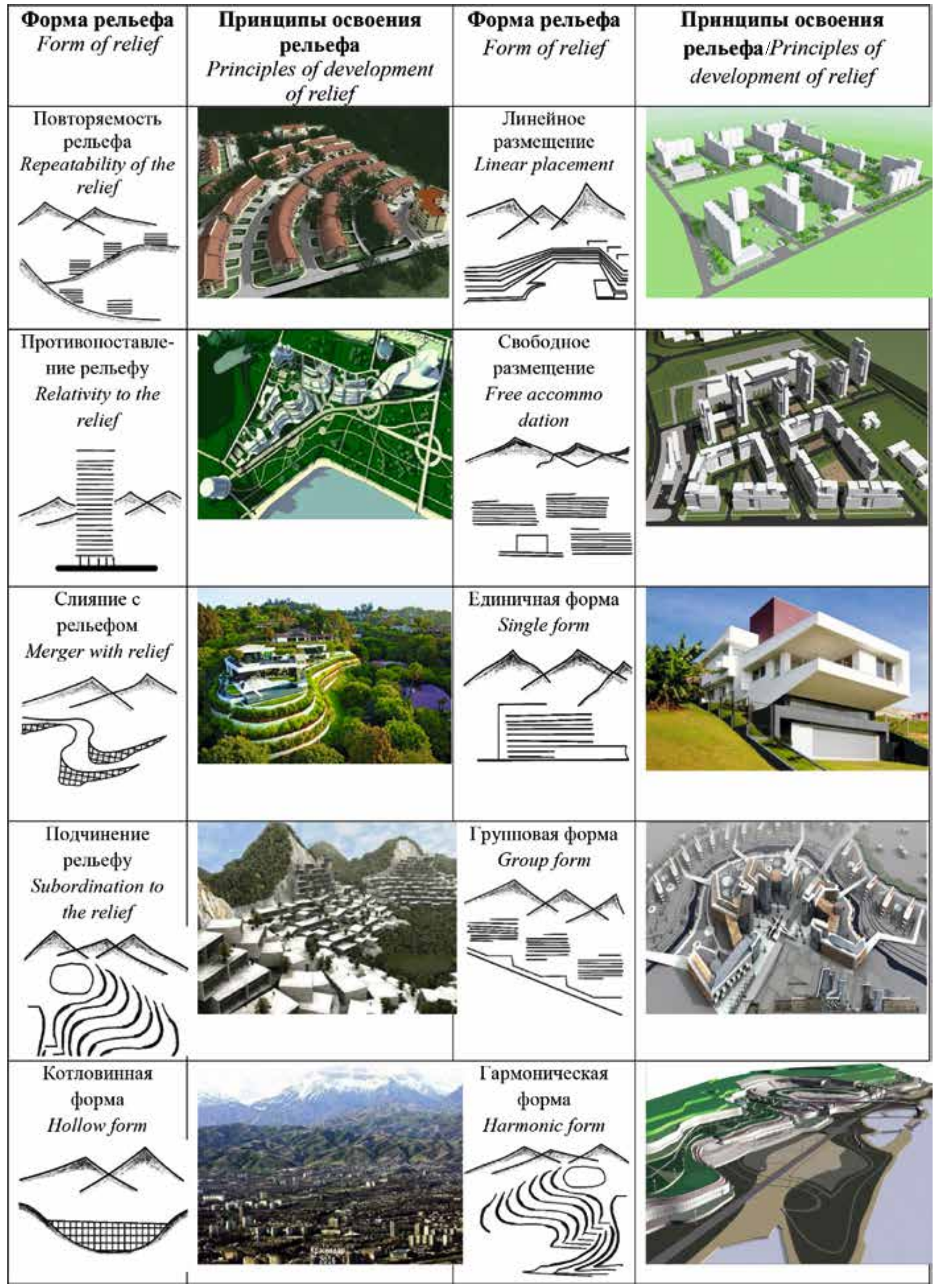


Составленная классификация рельефа местности по степени сложности, а также материалы градостроительной науки, освещающие особенности формирования городских структур и строительства зданий на территориях со сложным рельефом, позволили оценить влияние сложного рельефа на планировочные и проектные решения объектов градостроительного проектирования.

\section{Формулировка и метод решения задачи оптимизации}

При анализе проблем градостроительства на сложном рельефе становится ясно, что существует некий пробел в области градоэкологических исследований в особых экстремальных жарко-штилевых климатических условиях.

Несмотря на множество исследований по изучению вопросов формирования тепло-ветровых процессов горного района, вызванных природно-климатическими условиями и орографией, а также термическими условиями деятельного слоя склона, имеется ряд проблем.

Главной причиной формирования горно-долинного и склонного ветра пересеченной местности является неравномерное распределение важного климатообразующего фактора - солнечной радиации по склонам разной экспозиции и крутизны.

В пределах территории горного рельефа формируются следующие виды направленности действия ГДС: широтные, меридиональные, раскрытые на север, раскрытые на восток, раскрытые на юг, раскрытые на запад.

В условиях развития городов и населенных пунктов эти зоны преобразуются в потенциальные очаги наибольшей концентрации загрязнения вредными и ядовитыми примесями антропогенного происхождения, что делает их опасными в экологическом отношении.

Ветровой режим в горных районах определяется в значительной степени орографическими особенностями местности. В высокогорных районах наблюдается наибольшая повторяемость (50...60\%) маловетреных условий. Во внутригорном пространстве и горной котловине преобладает штиль.

Климат южных регионов в целом характеризуется обилием тепла и сухостью. Однако существуют большие различия в характеристике климата горной и равнинной частей. Во внутригорном районе климат умеренный полусухой и довольно жаркий в долинах. Внешнегорный район имеет сухой климат с жарким летом со средней температурой воздуха в июле $+23^{\circ} \mathrm{C}$. Низменная зона характеризуется жарким летом со средней температурой июля $+25^{\circ} \mathrm{C}$.

Солнечная радиация является основным источником тепловой энергии для всех природных процессов, развивающихся в атмосфере и в верхних слоях литосферы. Наряду с этим использование энергии для формирования микроклимата имеет исключительное значение в архитектурно-строительной практике. Распределение по территории прямой солнечной радиации на горизонтальную поверхность соответствует распределению при ясном небе: приход в целом по территории увеличивается с севера на юг (от 2605 до 3110 Мдж/м²). Выделяется район открытых горных котловин, где прямая радиация достигает 4325 Мдж/м².

На температурный режим горных районов, кроме высоты местности, оказывает влияние также форма рельефа. Дневные нагревания воздуха и ночные охлаждения его имеют минимальные значения на выпуклых формах (вершинах, открытых склонах), а максимальные - над вогнутыми (замкнутыми впадинами, долинами).

Наиболее высокие температуры отмечаются в июле. В низменно-степных районах территории средняя температура июля составляет $+26 \ldots+27^{\circ} \mathrm{C}$.

В жаркое лето абсолютный максимум температуры воздуха в июле - августе может достигать $+42 \ldots+44^{\circ} \mathrm{C}$ в котловине и в низменных частях территории.

По гипсометрическому положению, характеру и форме рельефа территории по вертикали разделены на:

горы по высоте от уровня моря: низкие $1000 \ldots 1500$ м, средние - около 2000 м, высокие - более $3000 \mathrm{M}$;

равнины по высоте от уровня моря: низменности $0 . .250$ м, возвышенности - 250 . .500 м, плоскогорья более $500 \mathrm{M}$.

По величине уклона участки делятся на:

ровные $-<3 \%$;

с малым уклоном - 3-8\%;

со средним уклоном $-<20 \%$;

с крутым уклоном $->20 \%$.

Результаты оптимального проектирования

В зависимости от масштабности климатических явлений, изучаемые под строительство территории были подразделены на макро-, мезо-, микро-зоны и нано-зону, которые имеют свою специфику.

Для оценки мезо-, микро- и нано-климатических явлений территорий со сложным рельефом, применяя методы количественной и качественной оценки масштабных климатических явлений для каждой зоны, основываясь на экспедиционных измерениях параметров климата, откорректирована методология оценки геоморфологической характеристики (уклон, экспозиция, крутизна, расчлененность, геометрическая высота) рельефа с целью применения в строительстве зданий и градостроительстве.

Морфометрическая карта конкретных участков исследования выявила характеристики конкретной формы рельефа, что позволило определить объемно-планировочные структуры городских застроек в зависимости от формообразования рельефа потенциального строительства. 


\section{Выводы}

На основе ландшафтной структуры горного региона, общего климатического фона, микроклиматического фона, морфологической специфики рельефной ситуации, инсоляционного режима сформулирован ряд архитектурно-планировочных и объемно-пространственных композиций жилых комплексов городов и населенных пунктов (табл. 1 и 2).

Учитывая уникальность природного ландшафта застраиваемых территорий со сложным рельефом, а также климатические особенности, обусловленные местными условиями ландшафта, существующая архитектурная типология жилых зданий и их планировочная организация для территорий со сложным рельефом с учетом особенности местного климата ландшафта систематизирована, дополнена и уточнена, а сформированная в ее рамках методика проектирования актуализирована. Разработаны методические предложения по планированию планировочно-пространственной структуры жилой застройки, проектированию жилья и жилых комплексов, по способу компоновки в формообразованиях рельефа и относительно склона. При применении предлагаемых планировочно-пространственных схем на практике необходимо:

- выделить характерные для каждой планировочной структуры застройки и типа домов особенности, учитывающие местные климатические условия рельефа, которые в наибольшей степени определяют архитектурно-композиционное и объемно-планировочное решение здания и застройки в зависимости от способа компоновки относительно склона и преобразование рельефа для целей застройки;

- архитектурное формирование планировочной организации следует направить на создание таких объемно-планировочных решений жилых групп, которые вписываются в структуру горного ландшафта, создавая архитектурно-планировочную и объемнопространственную композицию комплексов, образуя архитектурно-строительную ситуацию, исключающую негативное воздействие на рельеф.

На основе проведенного исследования созданы качественные архитектурно-градостроительные решения населенных пунктов, жилых образований и комплексов на сложном рельефе и склонах, которые способствуют формированию реального градостроительного элемента в общем образе поселений в гармонии со специфическими природно-климатическими особенностями местности.

\section{Рекомендации}

В каждой конкретной ситуации необходимо учесть целостность восприятия градостроительного потенциала естественного рельефа, обеспечить подчинение объемно-планировочной организации объектов объемным формам рельефа, органичному включению архитектурного объекта в орографическую ситуацию и окружающую среду.

Работа выполнена в соответствии планом научно-исследовательских работ «Функция, конструкция и среда в архитектуре зданий и городов» / The work was carried out in accordance with the plan of scientific research "Function, design and environment in the architecture of buildings and cities».

\section{ЛИТЕРАТУРА:}

1. Бурман Э. А. Местные ветры. Л.: Гидрометеоиздат, 1969. $340 \mathrm{c}$.

2. Гельмгольц Н. Ф. Горно-долинная циркуляция северных склонов Тянь-Шаня. Л.: Гидрометеоиздат, 1963. 320 с.

3. Дроздов О. А. О некоторых особенностях местных циркуляций горных районов // Вестник ЛГУ. Сер. геол. и геогр. 1960. Т. 24, вып. 4. С. 25-31.

4. Роджерс Г. Барри. Погода и климат в горах (пер. с англ.). Л.: Гидрометеоиздат, 1984. 310 с.

5. Крогиус В. Р. Город и рельеф. М.: Стройиздат, 1979. $124 \mathrm{c}$.

6. Градостроительство на склонах. Под ред. Крогиуса Ю.И. М.: Стройиздат, 1988. 328 с.

7. Горниак Л. Использование территории со сложным рельефом под жилую застройку. М.: Стройздат, 1982. 72 С.

8. Курбатов Ю.И. Архитектурные формы и природный ландшафт: композиционные связи. Л.: Изд-во Ленинградского ун-та, 1988. 76 с.
9. Калабин А. В. Дом на рельефе. Екатеринбург: Вебстер, 2012. $160 \mathrm{c}$.

10. Суворов В. О. Типология жилья в условиях сложного рельефа по архитектурно-пространственной компоновке относительно склона // Фундаментальные и прикладные проблемы науки: Мат. VIII Междунар. симпоз. Т. 7. M.: 2013. C. $11-16$.

11. Левина Е. К., Кузьбиных Е.В. Архитектура в гармонии с природой. Красноярск: СФУ, 2011. С. 13-18.

12. Харченко С. В. Развитие представлений о рельефе как факторе ветрового микроклимата города // Геоморфологи. Новое поколение / Отв. ред. М. Е. Кладовщикова, Э. А. Лихачева М.: Медиа-ПРЕСС, 2013. С. 38-45.

13. Трухачева Г. А., Хитева Е. О. Принципы создания архитектурной среды проживания с учетом природного окружения в условиях сложного рельефа как способ повысить качество жилища // Технические науки - от теории к практике: Сборник материалов XXXIII междунар. 
науч.-практ. конф. N 4(29). Новосибирск: СибАК, 2014. C. $155-166$.

14. Defant F. Lokalwind. Compendium of Meteorology, 1. Boston, 1951. P.454.

15. Abbott D Pollit K 1980 Hill housing. London. P. 308.

16. Saini B S 1962 Hausing in the hot arid tropics // Architectural Science Review. Vol.5, No.1. Pp. 342-347.

17. Sekiguti T. Thermal situations of urban areas horizontally and vertically. WMO // Tech. Note. 1970. N108. Pp. 336341 .
18. Allegrini J., Dorer V., Carmeliet J. Wind tunnel measurements of buoyant flows in street canyons // Building and Environment. 2013. N59. Pp. 315-326.

19. Hang J., Sandberg M., Li Y. Effect of urban morphology on wind condition in idealized city models // Atmospheric Environment. 2009. Vol. 43(4). Pp. 869-878.

20. Miller C. A., Davenport A. G. Guidelines for the calculation of wind speed-ups in complex terrain // J. of Wind Engineering and Industrial Aerodynamics, 1998. Vol. 74-76. Pp. 189-197.

\section{СВЕДЕНИЯ ОБ АВТОРАХ / Information about authors:}

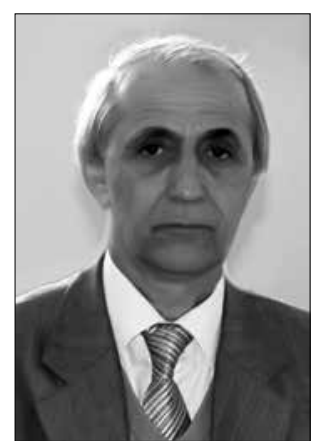

ГИЯСОВ Адхам - доктор технических наук, профессор кафедры «Проектирования зданий и сооружений».

Область научных интересовэнергоэффективные здания, архитектурно-строительная физика, инсоляция, аэродинамика, градоэкология. Автор более 200 научно-практических и методических трудов, более 10 учебных пособий.

Научно-исследовательский университет Московского государственного строительного университета, 129337, Москва, Россия

Тел.: 8(985)4818033; E-mail: adham52@mail.ru

Adham GIYASOV - Dr of Technical sciences, professor of the Department of "Design of Buildings and Structures".

Research interests-energy efficient buildings, architectural and construction physics, insolation, aerodynamics, urban ecology. Author of more than 200 scientific, practical and methodical works, more than 10 textbooks.

Research University of Moscow State University of Civil Engineering, 129337, Moscow, Russia

Ph.:+7(985)4818033; E-mail: adham52@mail.ru

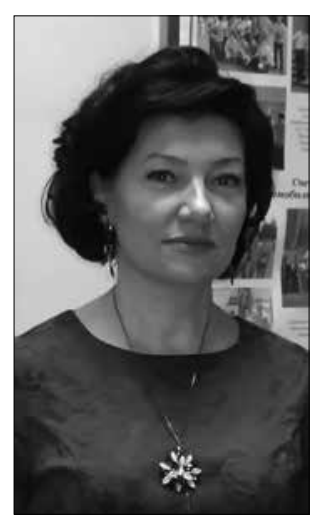

ГИЯСОВА Ирина Викторовна - кандидат экономических наук, доцент.

Сфера научных интересов - энергоэффективность в строительстве, проблемы развития рынка арендного жилья в РФ, оценка экономической эффективности реконструкции зданий.

Автор 50 научных публикаций, 15 учебно-методических разработок, 1 изобретения.

Тамбовский государственный технический университет, 392000, Тамбов, Россия

Тел.: 8(910)651-63-52; e-mail: timrus64@mail.ru

Irina V. GIYASOVA - Candidate of Economic Sciences, associate professor.

Research interests: energy efficiency in construction, problems of development of the rental housing market in the Russian Federation, assessment of economic efficiency of reconstruction of buildings.

Author of 50 scientific publications, 15 educational and methodical developments, 1 invention.

Tambov State Technical University, 392000, Tambov, Russia

Ph.:+7 (910)651-63-52; e-mail: timrus64@mail.ru

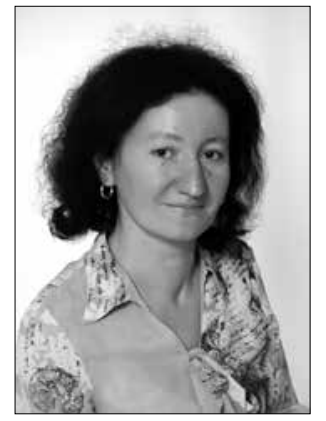

ТУСКАЕВА Залина Руслановна - доцент, заведующая кафедрой «Строительное производство».

Сфера научных интересов - конкурентоспособность строительных организаций, экологическая безопасность в строительстве, управление парком строительной техники, организационные структуры в строительстве, энергоэффективность зданий.

Автор свыше 150 научных публикаций, 30 учебно-методических пособий.

Северо-Кавказский горно-металлургический институт (государственный технологический университет), 362021, г. Владикавказ, Россия, e-mail: tuskaevazalina@yandex.ru

Zalina R. TUSKAEVA - Associate Professor, head of the Department "Construction production".

North-Caucasian Institute of Mining and Metallurgy (State Technological University), 362021, Vladikavkaz, Russia,e-mail: tuskaevazalina@yandex.ru

Research interests: competitiveness of construction companies, environmental safety in construction, management of construction equipment Park, organizational structures in construction, energy efficiency of buildings.

Author of more than 150 scientific publications, 30 teaching AIDS. 


\title{
COMPLEX LANDSCAPES PECULIARITIES USE FOR SUSTAINABLE DEVELOPMENT OF MOUNTAIN TERRITORIES
}

\author{
${ }^{1}$ A. Giyasov, \\ ${ }^{2}$ Z.R. Tuskaeva,* \\ ${ }^{3}$ I.V. Giyasova \\ ${ }^{1}$ Moscow State University of Civil Engineering, 129337, Moscow, Russia \\ ${ }^{2}$ North-Caucasian Institute of Mining and Metallurgy (State Technological University), 362021, Vladikavkaz, Russia, \\ e-mail: tuskaevazalina@yandex.ru \\ ${ }^{3}$ Tambov State Technical University, 392000, Tambov, Russia
}

DOI: $10.21177 / 1998-4502-2018-10-4-558-565$

Purpose. In order to develop the architectural typology of the residential buildings and their planning organization for the development territories, the analysis of the problem of the sustainable development of mountainous territories, taking into account the uniqueness of the natural and ecological landscape of the built-up areas in the difficult territories, the specific climatic features due to local conditions of the landscape was carried out.

The article deals with the features of designing and improving the volume-planning structure of cities and residential buildings in the complex territories, taking into account the orographic features of the structure and climatic conditions of the area. The problem of the mountain region development for the purpose of planning structure of the inhabited formations and settlements considering the local climatic features is studied.

In the practice of complex areas urban development, there is a significant gap in the field of the urban environmental studies in terms of the comfortable eco-environment for cities and settlements formation, characterized by a complex orographic situation, causing specific local climatic conditions.

Methods. The study area of the complex topography with morphological, microclimatic and bioclimatic positions with the identification of the urban maneuverability of the relief situation, updated, expanded and refined is shaped in the framework of the design procedure . On this basis, the method of organization of spatial and architecturalplanning structure of cities, settlements and buildings was carried out.

Results. Based on the study of domestic and foreign experience in the design and construction of buildings and buildings on complex terrains the problem of shaping the terrain to identify the areas of the potential construction were generalized and systematized. Using the method of background evaluation and method of assessment of local special climatic conditions formulated landforms for urban development elaborated by the authors.

For the purpose of the sustainable development of mountain relief, taking into account the uniqueness of the natural and ecological landscape of built-up areas on difficult terrain, as well as the specificity of climatic features due to local landscape conditions, the existing architectural typology of residential buildings and their planning structure for development areas is systematized and refined. The methodological proposals for planning the spatial structure of urban development, design of housing and residential complexes, the method of layout in the landforms and relative to the slope were developed.

The classification of the terrain according to the degree of complexity, as well as the materials of urban science, covering the features of the formation of the urban structures and construction of buildings in areas with complex terrain allowed to estimate the impact of complex terrain on the planning and design solutions of urban design.

Conclusions. The developed methodological proposals for the planning - spatial structure design of residential buildings, housing design and residential complexes, the method of layout in the formation of the relief and the slope are scientific and practical skills for the sustainable development of mountain areas.

Keywords: relief, mountain relief, urban planning, sustainable development, planning, building, orography, morphology.

\section{References}

1. Burman E. Local winds. Leningrad, Hydrometeoizdat, 1969 , p. 340.

2. Helmholtz, H. F. Mountain-valley circulation in the Northern slopes of the Tien Shan. Leningrad, Hydrometeoizdat, 1963, pp. 320.

3. Drozdov O. A. Some peculiarities of the local circulations of mountain regions. Vestnik $L G U$, Ser. Geol. and geogr., 1960, vol. 24, issue. 4, pp. 25-31.

4. Rogers G. Barry. Weather and climate in the mountains (lane.). Leningrad, Hydrometeoizdat, 1984, 310 p.

5. Krogius V. R. The city and the terrain. Moscow, Stroyizdat, 1979.124 p.

6. Urban development on the slopes. Edited by Krogius Y. I. Moscow, Stroyizdat, 1988, 328 p.

7. Gorniak L. Use of the territory with difficult relief for residential development. Moscow, Stroyizdat, 1982, 72 p.

8. Kurbatov Y. I. Architectural forms and natural landscape: composite connection. Leningrad, Publishing house of Leningrad University, 1988, 76 p.

9. Kalabin A. V. House on the terrain. Ekaterinburg, Webster, 2012, pp. 160.

10. Suvorov V. O. Typology of housing in conditions of complex relief on the architectural and spatial layout relative to the slope. Fundamental and applied problems of science, Materials of the 8th International Symposium, Moscow, vol. 7, 2013, pp. $11-16$.

11. Levin E. K., Cosimini E. V. Architecture in harmony with nature. Krasnoyarsk, SFU, 2011, pp. 13-18.

12. Kharchenko S. V. Development of ideas about relief 
as a factor of wind microclimate of the city. Geomorphologists. A new generation / Ed. ed Kladovschikov M. E., Likhachev E. A. Moscow, Media-PRESS, 2013, pp. 38-45.

13. Trukhacheva G. A., Khiteva E. O. Principles of creation of the architectural environment of residence taking into account the natural environment in conditions of difficult relief as a way to improve the quality of housing. Technical Sciences - from theory to practice, Collection of materials of the XXXIII International Scientific and Practical Conference. No4 (29), Novosibirsk, SibAK, 2014, pp. 155 -166.

14. Defant F. Lokalwind. Compendium of Meteorology, 1. Boston, 1951, p. 454.

15. Abbott D Pollit K 1980 Hill housing. London, p. 308.

16. Saini B S 1962 Hausing in the hot arid tropics. Architectural Science Review, vol. 5, no1, pp. 342-347.
17. Sekiguti T. Thermal situations of urban areas horizontally and vertically. WMO. Tech. Note, 1970, no108, pp. 336-341.

18. Allegrini J., Dorer V., Carmeliet J. Wind tunnel measurements of buoyant flows in street canyons. Building and Environment, 2013, No 59, pp. 315-326.

19. Hang J., Sandberg M., Li Y. Effect of urban morphology on wind condition in idealized city models. Atmospheric Environment, 2009, vol. 43 (4), pp. 869-878.

20. Miller C. A., Davenport A. G. Guidelines for the calculation of wind speed-ups in complex terrain. $J$. of Wind Engineering and Industrial Aerodynamics, 1998, vol. 74-76, pp. 189-197.

Article received 05.10.2018. 
${ }^{1}$ Алешин Б.С. 1Черноморский А. И., ${ }^{1}$ Курис Э.Д.*

\section{НАЗЕМНЫЕ КОЛЕСНЫЕ ТРАНСПОРТНЫЕ МОДУЛИ ДЛЯ РЕШЕНИЯ ЗАДАЧ МОНИТОРИНГА ОКРУЖАЮЩЕЙ СРЕДЫ ГОРНЫХ ТЕРРИТОРИЙ}

\section{УДК 62-50 \\ DOI: 10.21177/1998-4502-2018- 10-4-566-576}

Представлены полученные в Московском авиационном институте результаты теоретических исследований и разработок транспортных одноосных колесных модулей (ОКМ) как носителей апnаратуры мониторинаа: покрытий дорог; инфраструктуры аэродромов; окружающего воздушного пространства горных территорий. Рассмотрены варианты построения ОКМ, в которых управление угловой ориентацией их платформ реализуется посредством направленного формирования инерционных, гравитационных, гироскопических и реактивных маховичных силовых воздействий. Представлена обобщенная математическая модель движения ОКМ как модель гироскопического стабилизатора, располагающего платформой с верхней маятниковостью и перемещающегося без проскальзывания по подстилающей поверхности. Изложен обобщенный принцип управления движением ОКМ по заданной пространственно-временной траектории и указань возможности обеспечения инвариантности угловых движений его платформы по отношению к порождаемым траекторными движениями моментам сил инерции. Приведены особенности аnпаратно-программного обеспечения OKM.

\section{КЛЮЧЕВЫЕ СЛОВА:}

одноосный колесный модуль, платформа, мониторине, горная территория управление ориентацией, управление движением по траектории

Статья поступила в редакцию 03.10 .2018$.
Введение
Применительно к решению разнообразных народнохозяйственных задач на больших устойчиво развивающихся, в частности горных и предгорных, территориях необходим регулярный и разнообразный по функциональному назначению мониторинг окружающей среды [1; 2], а именно: динамики состояния дорожных покрытий; придорожных природных образований и инженерных сооружений, дорожных уклонов; состояния и уклонов аэродромных покрытий, а также послеполетного состояния наружных поверхностей фюзеляжа; крыльев и шасси воздушных судов; окружающего воздушного пространства с целью выявления, например, беспилотных летательных аппаратов в стратегически значимых районах. Перспективным является применение для этих целей наземных транспортных колесных модулей как носителей аппаратуры мониторинга, размещаемой на дополнительных управляемых стабилизированных платформах, устанавливаемых на борту носителя. Традиционно в качестве таких носителей используются специально оборудованные четырехколесные транспортные средства. Вместе с тем представляет существенный интерес применение в качестве носителей одноосных колесных модулей (ОКМ). Основным достоинством ОКМ является то обстоятельство, что он представляет собой фактически наземный колесный гироскопический стабилизатор с одно- или двухстепенной управляемой стабилизированной платформой. Физической основой построения такого стабилизатора является наличие у ОКМ естественной степени свободы его платформы относительно земной поверхности вокруг оси колесной пары.

Таким образом, ОКМ, в отличие от двухосных трехколесной или четырехколесной конструкций, совмещает функции наземного транспортного модуля и стабилизированной платформы с возможностью автономного управления угловой ориентацией платформы с носимой аппаратурой; при этом отсутствует необходимость в использовании на борту ОКМ дополнительной управляемой платформы. Кроме того, ОКМ, как компактные высокоманевренные транспортные средства- носители разнообразной измерительной и управляющей аппаратуры, удобно также использовать в качестве объектов студенческих исследований в учебно-научных лабораториях университетов $[3 ; 4]$.

Известны публикации [5-8], посвященные разработке и исследованию ОКМ, включающих платформу, обладающую верхней маятниковостью и имеющую одну вращательную степень свободы относительно оси колесной пары, перемещающихся без проскальзывания по подстилающей поверхности. В этих работах рассматриваются режимы функционирования ОКМ только как средства транспортировки полезной нагрузки по заданной пространственно-временной траектории (ПВТ). При этом решается задача стабилизации неустойчивого положения платформы в плоскости горизонта на основе принципа инерционной стабилизации моментами сил инерции относительно оси колесной пары, развиваемыми за счет направленного ускоренного перемещения модуля, как это реализуется, в частности, в известном транспортном средстве Segway.

${ }^{1}$ Московский авиационный институт (национальный исследовательский университет), Москва, Россия 
Однако в указанных работах практически отсутствует решение задачи управления угловой ориентацией платформы ОКМ относительно плоскости горизонта при произвольном поступательно-вращательном движении модуля. В ОКМ с инерционной стабилизацией платформы, обладающей только одной вращательной степенью свободы относительно оси колесной пары, невозможно обеспечить полное совмещение платформы с плоскостью горизонта при движении по неровной поверхности.

Кроме того, существует необходимость курсовых разворотов ОКМ при наведении линии визирования аппаратуры мониторинга, жестко привязанной к платформе, на заданную точку в пространстве. Последнее обстоятельство существенно влияет на характер траекторного движения ОКМ, в то время как эффективный мониторинг предполагает независимость процессов траекторного движения и наведения линии визирования.

Целью настоящей работы является обобщение результатов теоретических исследований и разработок ОКМ, проводимых на кафедре «Автоматизированные комплексы систем ориентации и навигации» Московского авиационного института (МАИ). Эти работы направлены на создание ОКМ как эффективных транспортных средств для решения задач мониторинга и осуществляются в направлениях: формирования альтернативных структур ОКМ; разработки принципов и алгоритмов управления угловой ориентацией их платформ; разработки принципов и алгоритмов управления движением ОКМ по заданной ПВТ. Разработано соответствующее аппаратное и программное обеспечение.

\section{1. Варианты структур и физические модели ОКМ}

В основу формирования структур разрабатываемых ОКМ положены основные функциональные признаки, определяющие количество степеней свободы платформы относительно оси колесной пары (используются одна или две), а также способы управления угловой ориентацией платформы, в частности, стабилизации ее относительно плоскости горизонта (инерционный, гравитационный, силовой гироскопический, маховичный, комбинированный). Во всех конструкциях применяется двухконтурная (траекторно-локомоционная) система управления (ДСУ) движением ОКМ по заданной ПВТ [9]. Решение задач определения навигационных параметров и параметров угловой ориентации осуществляется в общем случае комплексной системой навигации, включающей бесплатформенную инерциальную навигационную систему (БИНС) с коррекцией по информации от датчиков угловых скоростей и ускорений колес, приемника спутниковой навигационной системы (CHC), видеокамеры. Находит применение также комплексная система навигации и локального картографирования [10]. На рис.1a,б,в представлены характерные варианты структур ОКМ разрабатываемого ряда.

Все рассматриваемые модули представляют собой
ОКМ с платформой, устанавливаемой тем или иным образом на оси колесной пары. ОКМ включают: собственно колесную пару с колеей $2 b$ и с осью вращения $O y_{\text {т. }}\left(O_{\text {c }}-\right.$ центр оси колесной пары $)$, на которой расположены управляемые приводными двигателями колеса радиусом $r$ и массой $m_{k}$ (на осях вращения колес установлены датчики их угловых скоростей и ускорений); платформу с приборным кронштейном общей массой $m_{n}$, (в вариантах $1 a$ и 16 она установлена непосредственно на оси колесной пары $O y_{\text {т }}$ и имеет относительно нее одну степень свободы, в варианте 1,6 она установлена в промежуточной раме, имеющей степень свободы относительно оси $O{ }_{\text {с }}$, и может разворачиваться вокруг оси рамы $O_{c} x_{\mathrm{p}}$ ). Таким образом, в вариантах $1 a$ и $1 \sigma$ платформа имеет одну степень свободы относительно оси колесной пары, а в варианте 1в - две. На приборных кронштейнах платформ ОКМ в общем случае размещены: ДСУ; БИНС; видеокамера; приемник СНC; аппаратура мониторинга. Центры масс платформ ОКМ расположены в точке $O_{u}$, отстоящей от оси колесной пары на расстоянии $l_{u}$ (верхняя маятниковость платформ).

На рис. 1 использованы следующие общие для всех ОКМ системы координат (СК): $O_{x y z}$ - стартовая инерциальная (оси $O_{x}, O_{y}$ лежат в горизонтальной плоскости); $O_{c} x y_{c} z_{c}-$ сопровождающая (ее оси параллельны соответствующим осям СК $\left.O_{x y z}\right) ; O_{c} x_{T} y_{T} z_{T}$ - траекторная (ось $O_{c} x_{T}$ лежит в горизонтальной плоскости, ось $O y_{\text {T }}$ совпадает с осью колесной пары, ось $O_{c} z_{\text {T }}$ дополняет СК до правой тройки); $O_{c} x_{\Pi} y_{\Pi} z_{\Pi}-$ связанная с платформой $\left(O_{c} x_{\Pi}, O_{c} y_{\Pi}-\right.$ соответственно продоль-

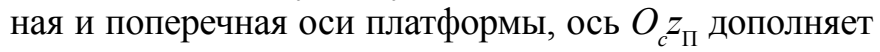
СК до правой тройки, в вариантах $1 a$ и 16 ось $O y_{\text {п }}$ совпадает с осью колесной пары, в варианте $18-$ ось $O x_{\Pi}$ совпадает с осью рамы $\left.O_{c} x_{\mathrm{p}}\right)$. Дополнительно на рис. 1 в введена СК $O_{c} x_{\mathrm{p}} y_{\mathrm{P}} z_{\mathrm{p}}$, связанная с рамой $\left(O_{c} x_{\mathrm{P}}-\right.$ продольная ось рамы, $O y_{\mathrm{P}}-$ поперечная ось рамы ось ее стабилизации, совпадающая с $O y_{\mathrm{T}}$, ось $O_{c} z_{\mathrm{p}}$ дополняет СК до правой тройки). На рис. 1 обозначены также: линейная скорость $V$ перемещения центра оси колесной пары $O_{c}$ ОКМ относительно подстилающей поверхности; $\gamma_{l}, \gamma_{2}-$ углы собственного вращения соответственно первого и второго колес; $\alpha$ - угол отклонения платформы от плоскости горизонта вокруг оси стабилизации платформы $O_{c} y_{\Pi}$ в ОКМ на рис. $1 a$, $\sigma$ (рамы с платформой от плоскости горизонта вокруг оси стабилизации рамы $O y_{\mathrm{P}}$ в ОКМ на рис. 18$) ; \beta-$ угол отклонения платформы от плоскости горизонта вокруг оси стабилизации платформы $O_{c} x_{\Pi}$ в ОКМ на рис. $18 ; \Psi_{1}, \Psi_{2}, \Psi_{3}$ - углы поворотов маховиков соответственно относительно рамы и платформы вокруг осей их собственного вращения; $p_{1}, p_{2}$ - перемещения управляемых грузов по направляющим соответственно на раме и платформе; $\delta_{1}, \delta_{2}-$ углы прецессии соответственно первого и второго силовых двухстепенных гироскопов; $x, y$ - координаты центра $O_{c}$ в стартовой 

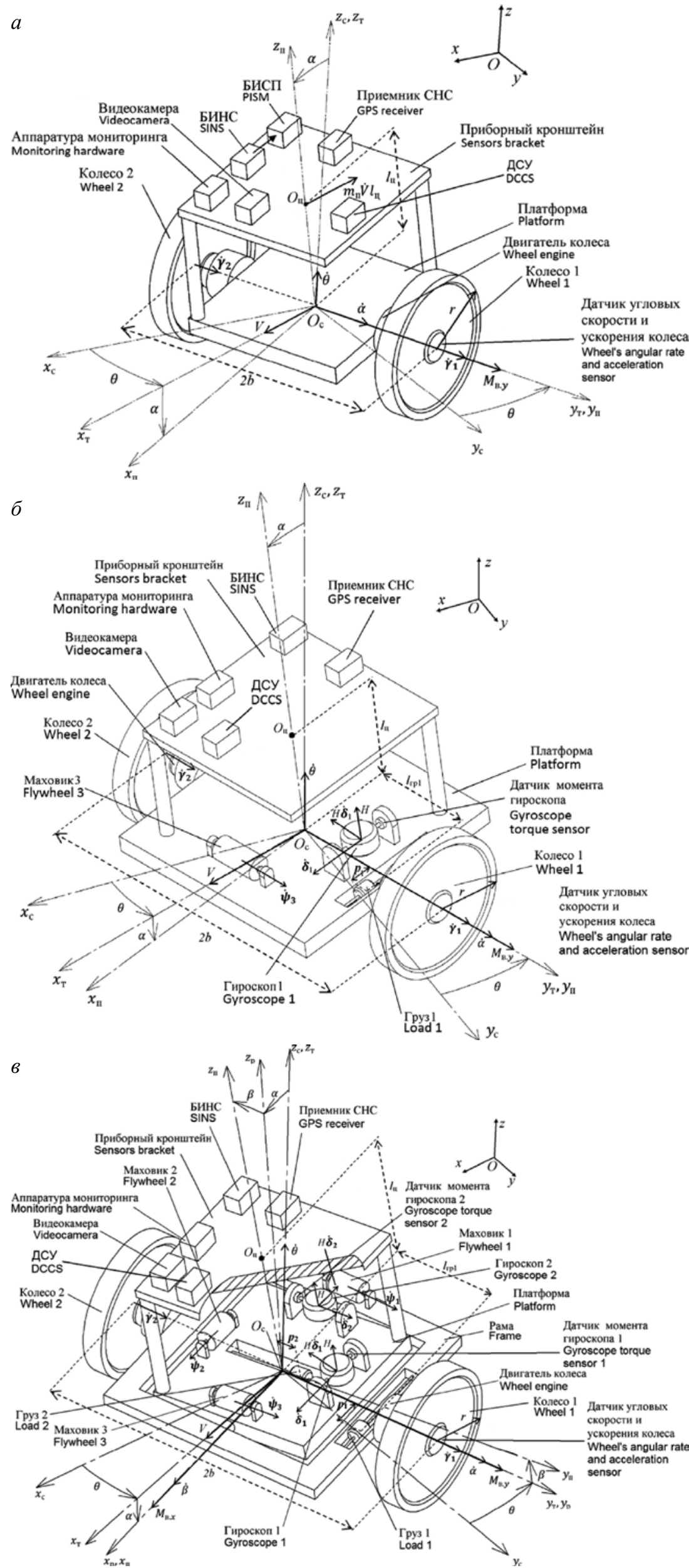

Puc. 1. Варианты структур ОКМ / Fig.1. Variants of UWM structures
СК; $\theta$ - угол курса, отсчитываемый вокруг оси $O_{\mathrm{c}} z_{\mathrm{T}}$ (угол между осями $O_{\mathrm{c}} x_{\mathrm{c}}$ и $O_{\mathrm{c}} x_{\mathrm{T}}$ ).

В ОКМ на рис. $1 a$ стабилизация платформы в плоскости горизонта вокруг оси колесной пары по углу $\alpha$ осуществляется на основе принципа инерционной стабилизации моментом силы инерции $m_{\mathrm{n}} \dot{V} l_{\text {ш }}$. При этом линейное ускорение центра оси колесной пары $\dot{V}$ формируется за счет направленного ускоренного вращения колес, на двигатели которых от блока инерционной стабилизации платформы (БИСП) поступают управляющие сигналы в функции измеряемого БИНС угла $\alpha$.

Управление угловой ориентацией платформы по углу $\alpha$ и стабилизация ее относительно плоскости горизонта вокруг оси колесной пары в ОКМ на рис. 16 осуществляются на основе принципа силовой гироскопической стабилизации при помощи гироскопа $l$ с кинетическим моментом $H[11 ; 12]$. При наличии возмущающего момента $M_{\varepsilon, y}$, приложенного к платформе вокруг ее оси $O{ }_{\mathrm{d}}$, гироскоп прецессирует относительно платформы с угловой скоростью $\dot{\delta}_{1}$ и первоначально парирует возмущающий момент гироскопическим моментом Н $\dot{\delta}_{1}$. Одновременно по сигналу об угле прецессии $\delta_{1}$ гироскопа осуществляется перемещение груза 1 массой $m_{\text {гр }}$ параллельно оси $O_{\text {с }} X_{\text {п }}$ на величину $p_{l}$, что порождает момент силы тяжести $m_{\text {гр }} g p_{1}(g-$ ускорение силы тяжести), парирующий в конечном счете $M_{\beta, y}$. Собственно управление угловой ориентацией платформы по углу $\alpha$ осуществляется с помощью датчика момента (ДМ) гироскопа, на который поступает управляющий сигнал о потребной ориентации платформы.

Дополнительно на платформе установлен маховик 3 с осью вращения, параллельной $O y_{\text {п }}$. В соответствии с принципом А.Ю. Ишлинского скорость вращения маховика $\dot{\psi}_{3}$ формируется на основе соотношения

$$
\dot{\psi}_{3}=-m_{n} l_{u} V / J_{y}^{M 3},
$$

где $J_{y}^{\mathrm{m} 3}-$ момент инерции маховика 3 относительно оси его вращения.

При выполнении приложенный к платформе момент сил инерции $m_{\text {п }} \dot{V} l_{\text {ц }}$ компенсируется реактивным моментом $J_{y}^{\mathrm{M} 3} \ddot{\psi}_{3}$, приложенным к платформе со 


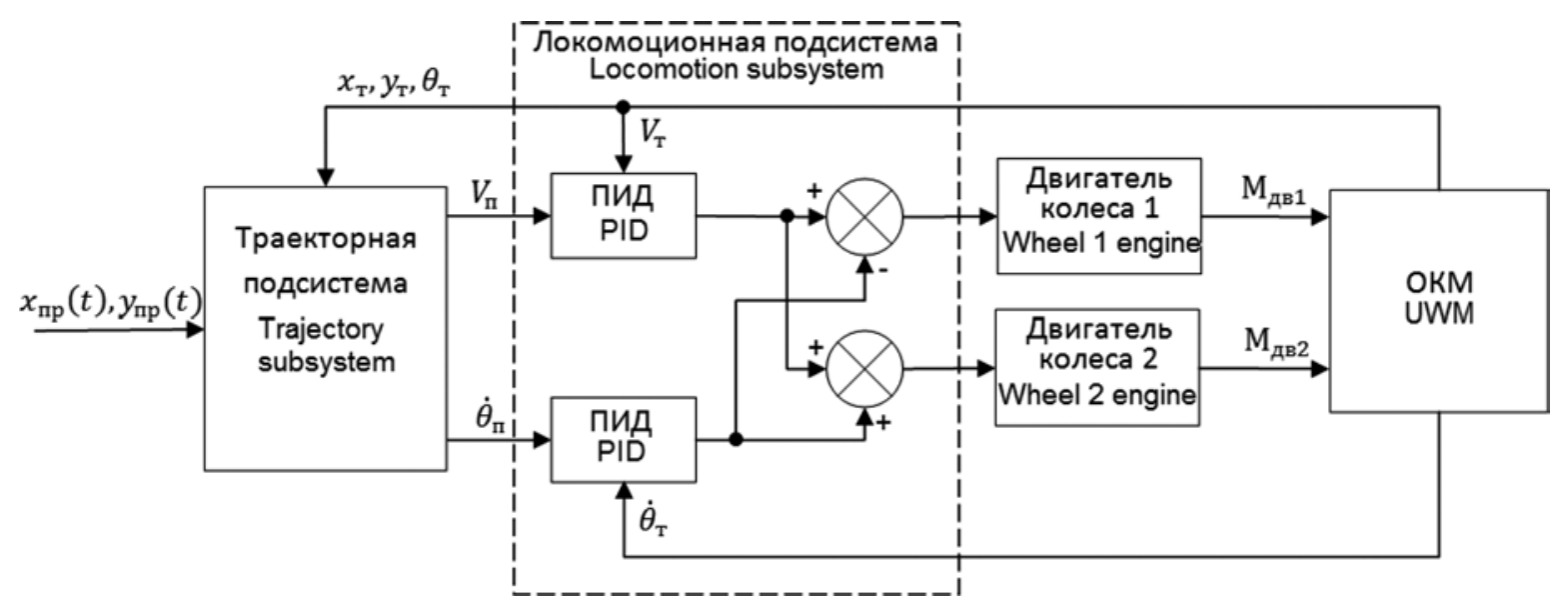

Pис. 2. Функииональная схема управления движением по заданной ПВТ

Fig. 2. Functional diagram of motion control for a given STT

стороны приводного двигателя третьего маховика [13]. Тем самым обеспечивается инвариантность платформы ОКМ по отношению к силам инерции, порождаемым его ускорением $\dot{V}$.

В ОКМ на рис.1в управление угловой ориентацией платформы и стабилизация ее относительно плоскости горизонта вокруг оси рамы $O y_{\mathrm{p}}$ по углу $\alpha$ и вокруг оси платформы $O_{\text {c }}$ п по углу $\beta$ также осуществляются на основе принципа силовой гироскопической стабилизации при помощи гироскопов 1,2 с кинетическими моментами $H$ [14]. При этом возмущающие моменты, приложенные к раме $M_{\text {в.у }}$ и к платформе $M_{\text {в.х }}$, компенсируются соответствующими гироскопическими моментами $H \dot{\delta}_{1}$ и $H \dot{\delta}_{2}$, а также моментами сил тяжести $m_{\text {гр }} g p_{1}$ и $m_{\text {гр }} g p_{2}$, создаваемыми при управляемых перемещениях первого и второго грузов. Дополнительные соответствующие стабилизирующие моменты формируются как реактивные моменты - $J_{y}^{\mathrm{M} 1} \ddot{\psi}_{1}$ маховика 1 , установленного на раме, и $J_{x}^{\text {м2 }} \ddot{\psi}_{2}$ маховика 2 , установленного на платформе $\left(J_{y}^{\mathrm{m} 1}, J_{x}^{\mathrm{M} 2}-\right.$ моменты инерции соответственно маховиков 1, 2 относительно их осей собственного вращения). Управляющие моменты двигателей этих маховиков являются функциями соответствующих углов прецессии гироскопов $\delta_{1}$ и $\delta_{2}$. Ограничение скоростей вращения маховиков $\dot{\psi}_{1}$ и $\dot{\psi}_{2}$ осуществляется естественным образом за счет управляемых перемещений $p_{1}$ груза 1 и $p_{2}$ груза 2 в функции соответственно $\dot{\psi}_{1}$ и $\dot{\psi}_{2}$. Собственно управление угловой ориентацией платформы по углам $\alpha$ и $\beta$ реализуется с помощью ДМ соответственно гироскопов 1 и 2. Маховик 3, помимо функции компенсации момента сил инерции $m_{\text {п }} \dot{V} l_{\text {ц }}$ (по аналогии с ОКМ на рис. 1б), обеспечивает при выполнении (1.1) и компенсацию своим гироскопическим моментом $J_{y}^{\mathrm{m} 3} \dot{\psi}_{3} \dot{\theta}$ момента центробежных сил инерции $-m_{\Pi} l_{\text {ц }} V \dot{\theta}$, приложенного к платформе вокруг оси $O_{\text {c }} X_{\text {п }}$ в процессе разворотов ОКМ по углу курса $\theta$. При этом обеспечивается инвариантность платформы по отношению к силам инерции, порождаемым как ускорением $\dot{V}$, так и ускорением $V \dot{\theta}$. По существу ОКМ на рис. $1 \sigma$ и в представляют собой соответственно одноосный и двухосный силовые гироскопические стабилизаторы с несбалансированными платформами, инвариантные по отношению к силам инерции, возникающим при поступательно-вращательном движении ОКМ по горизонтальной подстилающей поверхности.

\section{2. Обобщенная математическая модель ОКМ}

Наиболее общей математической моделью для модулей разрабатываемого ряда является модель ОКМ, представленного на рис. 1в. Состояние ОКМ, перемещающегося без проскальзывания по горизонтальной подстилающей поверхности, будем определять указанными на этом рисунке координатами $\gamma_{1}, \gamma_{2}, \alpha, \beta$, $\psi_{1}, \psi_{2}, \psi_{3}, \mathrm{p}_{1}, \mathrm{p}_{2}, \delta_{1}, \delta_{2}, x, y, \theta$. Перемещения ОКМ по координатам $x, y$, его развороты по углу курса $\theta$ и изменения скорости $V$ центра оси колесной пары в процессе навигации ОКМ по заданной ПВТ реализуются путем управления вращениями колес с помощью моментов сил, развиваемых приводными двигателями колеС. При отсутствии проскальзывания колес имеют место следующие соотношения для скоростей ОКМ:

$$
V=\frac{r}{2}\left(\dot{\gamma}_{1}+\dot{\gamma}_{2}\right), \dot{\theta}=\frac{r}{2 b}\left(\dot{\gamma}_{2}-\dot{\gamma}_{1}\right) .
$$

Используя уравнения Лагранжа для неголономных систем [15], соотношение (2.1), а также соотношение $V= \pm \sqrt{\dot{x}^{2}+\dot{y}^{2}}$, пренебрегая динамикой малоинерционных исполнительных двигателей элементов ОКМ, можно получить систему из одиннадцати уравнений движения ОКМ в координатах $\alpha, \beta, \delta_{1}, \delta_{2}, \mathrm{p}_{1}, \mathrm{p}_{2}, \psi_{1}, \psi_{2}, \psi_{3}, \theta, V$. В частности, применительно к задаче стабилизации платформы ОКМ в плоскости горизонта при его произвольных движениях по ПВТ в предположении малости величин $\alpha, \beta, \delta_{1}, \delta_{2}, \dot{\alpha}, \dot{\beta}, \dot{\delta}_{1}, \dot{\delta}_{2}, \dot{p}_{1}, \dot{p}_{2} \dot{\theta}, \ddot{\theta} \quad$ соответствующая система упрощенных уравнений имеет вид [14]:

$$
\begin{aligned}
& J_{y} \ddot{\alpha}-m_{n} g l_{u} \alpha-H\left(\dot{\beta}+\dot{\delta}_{1}\right)-m_{2 p} g p_{1}+J_{x}^{M 2} \dot{\psi}_{2} \dot{\theta}+m_{n} l \dot{V}= \\
& =-M_{M 1}-M_{M 3}-M_{\partial b 1}-M_{\partial b 2}+M_{b . y} ;
\end{aligned}
$$




$$
\begin{aligned}
& J_{x} \ddot{\beta}-m_{n} g l_{u} \beta+H\left(\dot{\alpha}+\dot{\delta}_{2}\right)+m_{c p} g p_{2}-J_{y}^{M 3} \dot{\Psi}_{3} \dot{\theta}-m_{n} l_{u} V \dot{\theta}= \\
& =-M_{\mathcal{M} 2}+M_{\text {B.x }} \text {; } \\
& J_{x}^{2 l}\left(\ddot{\beta}+\ddot{\delta}_{1}\right)+H \dot{\alpha}=M_{\text {д.м. } 21} ; \\
& J_{y}^{\mathrm{r} 2}\left(\ddot{\alpha}+\ddot{\delta}_{2}\right)-H \dot{\beta}=M_{\text {д.м. . } 2} ; \\
& m_{\text {гр }}\left(\ddot{p}_{1}-g \alpha+\dot{V}-l_{\text {гр1 }} \ddot{\theta}\right)=\frac{M_{\text {гр1 }}}{n} \text {; } \\
& m_{\mathrm{rp}}\left(\ddot{p}_{2}+g \beta+V \dot{\theta}\right)=\frac{M_{\mathrm{rp} 2}}{n} ; \\
& J_{y}^{\mathrm{M} 1}\left(\ddot{\alpha}+\ddot{\psi}_{1}\right)=M_{\mathrm{M} 1} ; \\
& J_{x}^{\mathrm{M} 2}\left(\ddot{\beta}+\ddot{\psi}_{2}\right)=M_{\mathrm{M} 2} ; \\
& J_{y}^{\mathrm{M} 3}\left(\ddot{\alpha}+\ddot{\psi}_{3}\right)=M_{\mathrm{M} 3} ; \\
& \left(m r+2 \frac{J_{y}^{\mathrm{k}}}{r}\right) \dot{V}=M_{\text {дв }} j+M_{\text {дв } 2} j+M_{f 1}+M_{f 2} ; \\
& \left(J \frac{r}{b}+2 b \frac{J_{y}^{\mathrm{K}}}{r}\right) \ddot{\theta}-\frac{J_{x}^{\mathrm{M} 2} r}{b}\left(\dot{\psi}_{2} \dot{\alpha}+\ddot{\psi}_{2} \alpha\right)+ \\
& +\frac{J_{y}^{\mathrm{M} 3} r}{b}\left(\dot{\psi}_{3} \dot{\beta}+\ddot{\psi}_{3} \beta\right)=M_{\text {дв } 2} j-M_{\text {дв } 1} j+M_{f 2}-M_{f 1},
\end{aligned}
$$

где $M_{\text {дв1 }}$ и $M_{\text {дв2 } 2}, M_{\text {дам.г.1 }}$ и $M_{\text {дам.г.2 }}, M_{\text {гр1 }}$ и $M_{\text {гр2}}, M_{\text {м1 }}, M_{\text {м2 }}$ и $M_{\text {м3 }}$ - моменты сил, развиваемые соответственно двигателями первого и второго колес, датчиками моментов на осях прецессии первого и второго гироскопов, двигателями первого и второго грузов, двигателями первого, второго и третьего маховиков; $M_{f 1}, M_{f 2}-$ моменты трения качения, приложенные соответственно к первому и второму колесам; $M_{\text {в }}$ и $M_{\text {вx }}$ - возмущающие моменты, приложенные соответственно вокруг осей стабилизации рамы и платформы; $j$ - передаточное отношение редукторов приводных двигателей колес; $n-$ передаточное отношение угла поворота ротора приводного двигателя груза к поступательному перемещению груза; $m$ - суммарная масса ОКМ; $J$ - суммарный момент инерции ОКМ вокруг вертикальной оси; $J_{v}$ и $J_{x}$ - суммарные моменты инерции рамы и платформы вокруг соответствующих связанных с ними осей; $J_{y}^{\text {к. }}$ $J_{y}^{\text {г1 }}$ и $J_{y}^{\text {г2 }}-$ главные центральные моменты инерции вокруг соответствующих осей колеса, идентичных первому и второму гироскопу (верхние индексы означают принадлежность соответствующему типу и номеру элемента ОКМ, нижние индексы - соответствующей главной центральной оси элемента).

Моменты трения качения $M_{\mathrm{f} 1}, M_{\mathrm{f} 2}$ в $(2.11),(2.12)$ таковы [11]:

$$
M_{f 1}=-a R_{z 1} \operatorname{sign}\left(\frac{V-b \dot{\theta}}{r}\right) ; M_{f 2}=-a R_{z 2} \operatorname{sign}\left(\frac{V+b \dot{\theta}}{r}\right),
$$

где $\alpha$ - продольный снос нормальных реакций подстилающей поверхности $R_{z 1}=m g / 2-J_{y}^{\mathrm{s} 1} \dot{\dot{\psi}_{1}} \dot{\theta} / 2 b$, $R_{z 2}=m g / 2+J_{y}^{\mathrm{M1}} \dot{\psi_{1}} \dot{\theta} / 2 b$, приложенных соответственно к первому и второму колесам.
Условия отсутствия продольного и поперечного проскальзывания колес при этом имеют вид [11]:

$$
\lambda_{1} \leq \phi_{\text {long1 }} R_{z 1} ; \lambda_{2} \leq \phi_{\text {long } 2} R_{z 2} ; \lambda_{3} \leq \phi_{\text {lat1 }} R_{z 1}+\phi_{\text {lat } 2} R_{z 2},
$$

где $\phi_{\text {long1 }}, \phi_{\text {long2 }}$ и $\phi_{\text {lat1 }}, \phi_{\text {lat2 }}-$ коэффициенты соответственно продольного и поперечного сцеплений с подстилающей поверхностью первого и второго колес.

В системе уравнений (2.2) - (2.12) подсистема (2.2) - (2.10) определяет процессы угловой стабилизации и ориентации относительно плоскости горизонта платформы ОКМ, а подсистема (2.11), (2.12) - движение центра оси колесной пары по ПВТ. При этом в подсистеме (2.2) - (2.10) стабилизация платформы реализуется рациональным выбором управляющих моментов маховиков $M_{\mathrm{м1}}, M_{\mathrm{м} 2}, M_{\text {м3 }}$ и грузов $M_{\text {гр1 }}$ и $M_{\text {гр2 }}$, а управление угловой ориентацией - выбором моментов $M_{\text {д.м.г1 }}$ и $M_{\text {д.м.г.2 } 2}$ развиваемых датчиками моментов гироскопов. В подсистеме (2.11), (2.12) формирование движения ОКМ по заданной ПВТ реализуется выбором моментов $M_{д в 1}$ и $M_{д в 2}$, развиваемых двигателями колес.

Трансформацией системы (2.2) - (2.12) путем удержания в ней только тех уравнений, которые описывают динамику элементов, из которых состоит тот или иной ОКМ, с учетом функциональных особенностей формирования в них управляющих моментов нетрудно получить математические модели ОКМ, представленных на рис. $1 a$ и 16.

\section{3. Управление движением ОКМ по заданной пространственно-временной траектории}

В процессе мониторинга возникает задача, в общем случае, вывода ОКМ на заданную ПВТ из произвольной точки подстилающей поверхности и последующего движения по ПВТ. Эта задача эффективно решается на основе использования ДСУ, включающей траекторную и локомоционную подсистемы (рис. 2) [9].

В траекторной подсистеме вырабатываются потребные значения скоростей $V_{\text {т }} \dot{\theta}_{\text {п }}$ ОКМ, реализация которых обеспечивает устойчивый выход ОКМ на заданную ПВТ и движение по ней. Эти скорости совместно с их текущими значениями $V_{\mathrm{T}}$ и $\dot{\theta}_{\mathrm{T}}$, измеряемыми БИНС ОКМ, поступают на формирование моментов $M_{\text {дв1 }}$ и $M_{\text {дв2 }}$ двигателей колес через ПИДрегуляторы локомоционной подсистемы. Потребные значения скоростей $V_{\text {п }}$ и $\dot{\theta}_{\text {п }}$ управляющих локомоционной подсистемой, вырабатываются в траекторной подсистеме. Собственно заданная ПВТ определяется программным вектором $\mathrm{q}_{\text {пр }}$ :

$$
\mathbf{q}_{\text {пр }}=\left[\begin{array}{lll}
x_{\text {пр }}(t) & y_{\text {пр }}(t) & \theta_{\text {пр }}(t)
\end{array}\right]^{T},
$$

где $x_{\text {пр }}(t) y_{\text {пр }}(t) \theta_{\text {пр }}(t)$ - соответствующие программные координаты; $T$ - символ транспонирования.

Учитывая отсутствие проскальзывания ОКМ в поперечном направлении (вдоль оси колесной пары), условие которого имеет вид: 


$$
-\dot{x}_{\text {пр }} \sin \theta_{\text {пр }}+\dot{y}_{\text {пр }} \cos \theta_{\text {пр }}=0,
$$

кинематическую модель движения ОКМ можно представить так:

$$
\dot{\mathrm{q}}_{\text {пр }}=\left[\begin{array}{cc}
\cos \theta_{\text {пр }} & 0 \\
\sin \theta_{\text {пр }} & 0 \\
0 & 1
\end{array}\right]\left[\begin{array}{l}
V_{\text {пр }} \\
\dot{\theta}_{\text {пр }}
\end{array}\right] .
$$

Эту модель можно трактовать как уравнение движения объекта с вектором состояния (3.1) и вектором программного управления $\mathrm{U}_{n p}$

$$
\mathrm{U}_{\text {пр }}=\left[\begin{array}{l}
V_{\text {пр }} \\
\dot{\theta}_{\text {пр }}
\end{array}\right] .
$$

где $V_{\text {пр }}= \pm \sqrt{\dot{x}_{\text {пр }}^{2}+\dot{y}_{\text {пр }}^{2}}, \dot{\theta}_{\text {пр }}=\frac{\ddot{y}_{\text {пр }} \dot{x}_{\text {пр }}-\ddot{x}_{\text {пр }} \dot{y}_{\text {пр }}}{\dot{x}_{\text {пр }}^{2}+\dot{y}_{\text {пр }}^{2}}$.

Текущие координаты $x_{\text {т }} y_{\text {т }}, \theta_{\text {т }}$ отличаются от программных $x_{\text {пр }}, y_{\text {пр }}, \theta_{\text {пр }}$, на участках выхода из произвольной точки на программную траекторию, а также, в частности, вследствие нарушения условий неголономности и воздействия на ОКМ разнообразных возмущений.

В работах [16-19] показано, что в общем случае для колесных машин различных типов потребные значения скоростей $V_{\text {п }}$ и $\dot{\theta}_{\text {п }}$ обеспечивающие устойчивый выход и движение по ПВТ, применительно к неголономной кинематической модели машины (модуля) вида (3.3), целесообразно формировать так:

$$
\left[\begin{array}{c}
V_{\text {пा }} \\
\dot{\theta}_{\text {п }}
\end{array}\right]=\left[\begin{array}{c}
V_{\text {пр }} \operatorname{cose}_{3}+k_{1} e_{1} \\
\dot{\theta}_{\text {пр }}+V_{\text {пр }} k_{2} e_{2}+k_{3} \sin e_{3}
\end{array}\right],
$$

где $e_{1}, e_{2}$ и $e_{3}$ соответственно тангенциальная, нормальная и угловая компоненты вектора ошибки е траекторного управления

$$
\mathbf{e}=\left[\begin{array}{ccc}
\cos \theta_{\text {т }} & \sin \theta_{\text {т }} & 0 \\
-\sin \theta_{\text {т }} & \cos \theta_{\text {т }} & 0 \\
0 & 0 & 1
\end{array}\right]\left[\begin{array}{c}
x_{\text {пр }}-x_{\text {т }} \\
y_{\text {пр }}-y_{\text {т }} \\
\theta_{\text {пр }}-\theta_{\text {т }}
\end{array}\right] ;
$$

$k_{1}, k_{2}$ и $k_{3}$ - положительные коэффициенты [18-20].

Основные характерные параметры ОКМ, представленного на рис. 16, указаны в таблице.

В [14] применительно, например, к режиму управляемого движения ОКМ по заданной траектории с одновременной стабилизацией его платформы в плоскости горизонта приведены результаты синтеза моментов $M_{\text {м1 }}$, $M_{\mathrm{м} 2}, M_{\mathrm{м} 3}$ и моментов $M_{\text {гр1 }}$ и $M_{\text {гр2 }}$, являющихся линейными функциями координат ОКМ, развиваемых соответственно приводными двигателями управляющих маховиков и управляемых грузов, и обеспечивающих высокоточную стабилизацию платформы в плоскости горизонта. Показано также, что эффективное управление движением ОКМ по заданной пространственно-временной траектории достигается при формировании весовых коэффициентов ошибок в (3.6) на основе соотношений:

$$
\begin{aligned}
& k_{1}=k_{3}=2 \xi \cdot\left(\dot{\theta}^{2}+(\zeta v)^{2}\right) ; \\
& k_{2}=\eta \cdot|v|,
\end{aligned}
$$

где $\xi, \zeta, \eta$ - положительные параметры.

На рис. 3 представлена обозначенная цифрой 1 характерная траектория типа «змейка» $(x(t)=40 \sin (t / 100), y(t)=40 \sin (t / 1000))$, по которой осуществлялась навигация ОКМ в процессе численного эксперимента.

Цифрами 2 и 3 обозначены траектории ОКМ с участками выхода на траекторию 1 из произвольных точек подстилающей поверхности. На всех участках характерной траектории условия (2.14) отсутствия проскальзывания колес выполняются. На рис. 4 приведены соответствующие процессы стабилизации платформы ОКМ, на которых всплески отклонений по $\alpha$ и $\beta$ возникают на участках курсовых разворотов и при изменениях скорости.

Укрупненно на рисунке представлены процессы стабилизации платформы на участке начального разгона ОКМ. Видно, что отклонения платформы от плоскости горизонта, порождаемые собственно траекторными возмущениями, при характерном плавном изменении скорости малы.

\section{4. Особенности аппаратного и программного обеспечения ОКМ}

БИНС каждого из ОКМ включает инерциальный измерительный модуль (изделие Analog Device), coстоящий из трех микромеханических датчиков угловой скорости, трех микромеханических акселерометров со взаимно ортогональными осями чувствительности и векторного магнитометра, а также включает цифровой сигнальный процессор [21;22]. Электропривод колес состоит из двух блоков, содержащих контроллеры и двигатели постоянного тока Faulhaber с энкодерами, на базе сигналов которых формируются измерения угловых скоростей и ускорений колес. Центральный вычислитель реализует функции управления аппаратным обеспечением ОКМ в

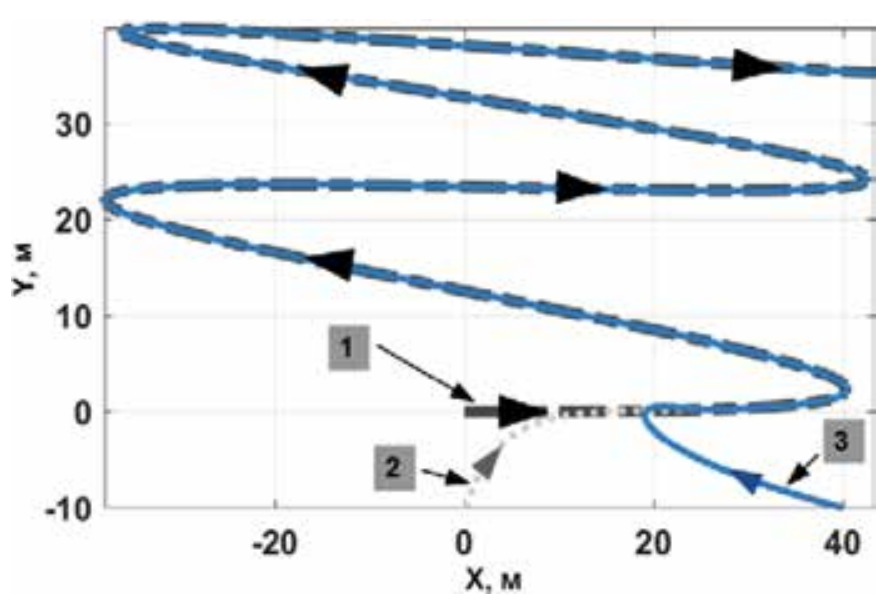

Puc. 3. График выхода на ПВТ

Fig. 3. Moving to the space-time trajectory graph 


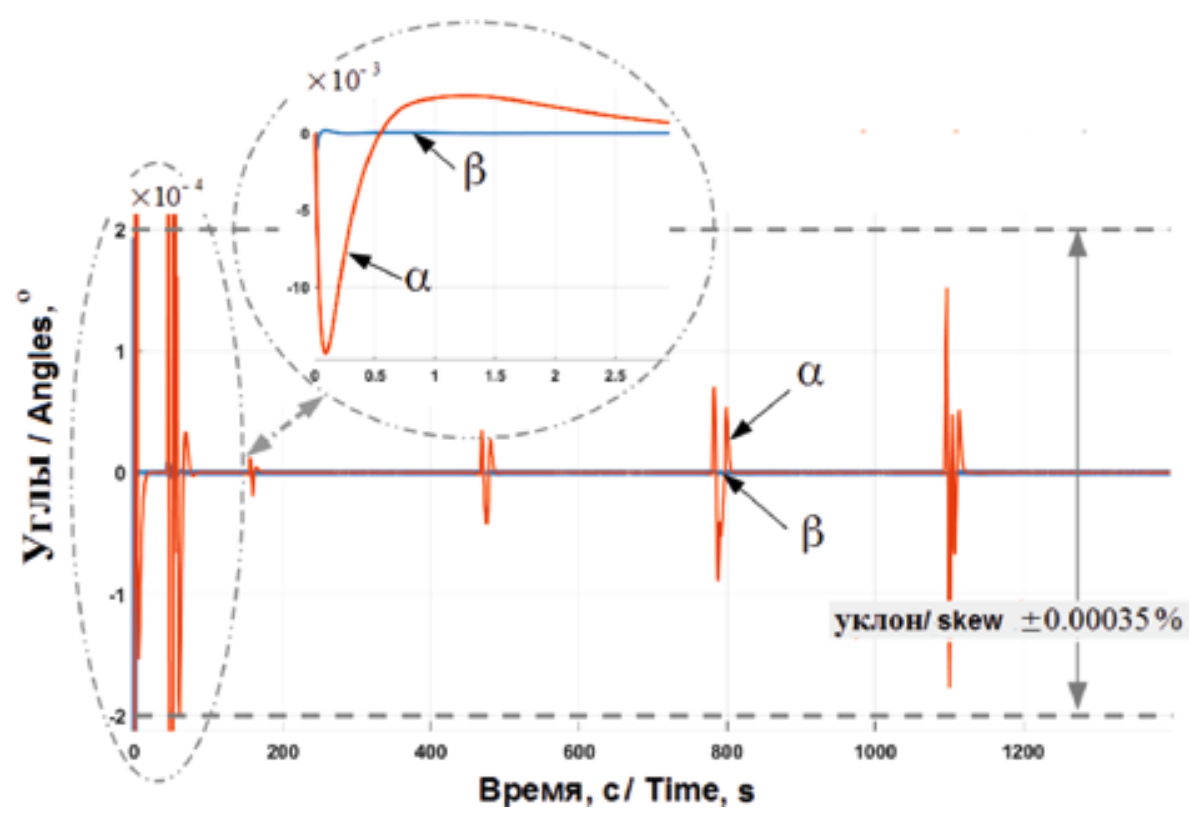

Pис. 4. Переходные процессы при стабилизации платформы

Fig. 4. Transition processes during platform stabilization

Характерные параметры ОКМ / Characteristic parameters of UWM

\begin{tabular}{|c|c|c|c|c|c|}
\hline \multirow{2}{*}{ Элемент / Element } & \multirow{2}{*}{$\begin{array}{c}\text { Параметры } \\
\text { Parameters }\end{array}$} & \multirow{2}{*}{$\begin{array}{c}\text { Масcа, кг } \\
\text { Mass, } k g\end{array}$} & \multicolumn{3}{|c|}{ Моменты инерции, кгм²/ Moments of inertia, $\mathrm{kgm}^{2}$} \\
\hline & & & $J_{x}$ & $J_{y}$ & $J_{z}$ \\
\hline Маховик 1 / Flywheel 1 & - & 2 & $4.23 \cdot 10^{-2}$ & $8.7 \cdot 10^{-2}$ & $4.23 \cdot 10^{-2}$ \\
\hline Маховик 2 / Flywheel 2 & - & 2 & $8.7 \cdot 10^{-2}$ & $4.23 \cdot 10^{-2}$ & $4.23 \cdot 10^{-2}$ \\
\hline Маховик 3 / Flywheel 3 & - & 2 & $4.23 \cdot 10^{-2}$ & $8.7 \cdot 10^{-2}$ & $4.23 \cdot 10^{-2}$ \\
\hline Грузы 1, 2 / Loads 1, 2 & $\begin{array}{c}\mathrm{n}=0.1 \mathrm{M} \\
1_{\mathrm{rp1}}=0,3 \mathrm{M}\end{array}$ & 3 & - & - & - \\
\hline Гироскопы 1, 2 / Gyroscopes 1, 2 & $H=17 \mathrm{H} \cdot \mathrm{M} \cdot \mathrm{c}$ & 2 & $4.23 \cdot 10^{-2}$ & $4.23 \cdot 10^{-2}$ & $8.7 \cdot 10^{-2}$ \\
\hline Колеса 1, 2 / Wheels 1, 2 & $\begin{array}{l}b=0.4 \mathrm{M} \\
r=0.25 \mathrm{M} \\
j=1 \\
a=1 \cdot 10^{-3} \mathrm{M} \\
\phi_{\text {long1 }}=\phi_{\text {long2 }}=0.7 \\
\phi_{\text {lat1 }}=\phi_{\text {lat2 } 2}=0.7\end{array}$ & 1 & $3.29 \cdot 10^{-2}$ & $6.25 \cdot 10^{-2}$ & $3.29 \cdot 10^{-2}$ \\
\hline Платформа / Platform & $1_{\mathrm{u}}=0,2 \mathrm{M}$ & 12 & 0.512 & 0.461 & 0.247 \\
\hline Рама / Frame & - & 6 & 0.357 & 0.211 & 0.175 \\
\hline
\end{tabular}

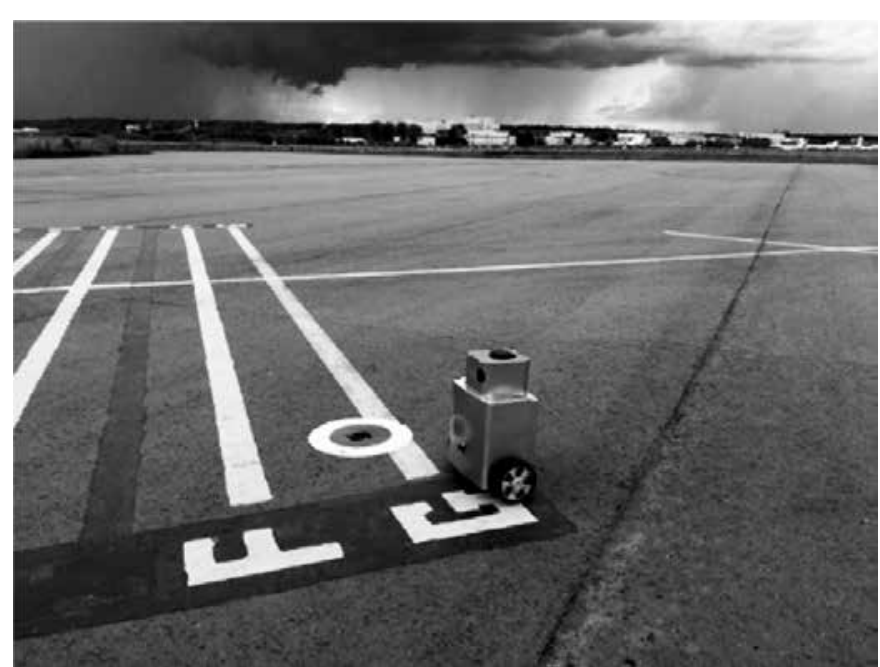

Puc. 5. ОКМ для мониторинга аэродромной инфраструкmypbl / Fig. 5. UWM for aerodrome infrastructure monitoring целом, синхронизирует время в различных подсистемах, обеспечивает взаимодействие с оператором. Программное обеспечение (ПО) центрального вычислителя разделено на ряд отдельных подпрограмм, объединенных при помощи пакета Robot Operation System (ROS). Каждая подпрограмма выполняет одну узкоспециализированную задачу, что позволяет учитывать специфику каждого из разрабатываемых ОКМ. ПО состоит из следующих основных подпрограмм: опроса датчиков; расчета навигационных координат в стартовой СК, а также параметров угловой ориентации ОКМ; определения запретных зон (препятствий); планирования ПВТ; реализации алгоритмов в ДСУ; связи с интерфейсом оператора.

На рис.5 для примера представлен разработанный в МАИ вариант ОКМ, предназначенного для 
решения задач мониторинга аэродромной инфраструктуры.

\section{Заключение}

Изложены проводимые в Московском авиационном институте (национальном исследовательском университете) результаты исследований и разработок одноосных колесных модулей как носителей аппаратуры мониторинга окружающего пространства, в частности, в условиях предгорных территорий. Осуществлено обобщение этих результатов в части: разработки структур ОКМ; построения их математических моделей как устройств с неголономными связями; формирования способов управления угло- вой ориентацией и стабилизацией их платформ; разработки алгоритмов управления движением ОКМ по заданной пространственно-временной траектории. Указаны некоторые общие для всех ОКМ особенности их аппаратного и программного обеспечения. Моделирование и экспериментальные исследования показали эффективность предложенных технических решений ОКМ. В целом создан инструментарий, обеспечивающий возможность эффективного выбора того или иного типа из ряда разрабатываемых ОКМ применительно к требованиям, выдвигаемым решаемой задачей мониторинга

Работа выполнена при финансовой поддержке Министерства образования и науки РФ (Задание №8.2118.2017/4.6 на выполнение НИР в рамках проектной части госзадания в сфере научной деятельности) / The work is carried out under the financial support of Ministry of Education and Sience of RF (Task N 8.2118.217/4.6 for the scientific research in the frames of the project part of the state order in the scientific activity sphere.

\section{БЛАГОДАРНОСТИ / Gratitudes}

Авторы выражают благодарность сотрудникам Московского авиационного института: научному сотруднику Максимову В.Н., инженеру Лелькову К.С., аспиранту Михееву В.В. за обсуждение текста при подготовке статьи и помощь в ее оформлении.

Отдельно выражаем благодарность рецензенту Р. Клюеву за замечания, позволившие улучшить статью.

The authors express their gratitude to the staff of the Moscow Aviation Institute: researcher V. N. Maksimov, engineer Lelkov K.S., graduate student Mikheev $\boldsymbol{V} . \boldsymbol{V}$. for the discussion of the text in the preparation of the article and assistance in its design.

Special thanks to the reviewer $\boldsymbol{R}$. Klyuev for the comments that allowed to improve the article.

$\overline{\text { КОНФЛИКТ ИНТЕРЕСОВ / Conflict of interests }}$

Авторы заявляют об отсутствии конфликта интересов / The authors state that there is no conflict of interest.

\section{ДОЛЕВОЕ УЧАСТИЕ / Equity participation}

Авторы в написании статьи участвовали в равных долях / The authors participated in the writing of the article in equal parts.

\section{ЛИТЕРАТУРА:}

1. Умаров Р.Д., Бекеев А.Х., Магомедов Ф.М., Меликов И.М. Ресурсосберегающая технология и устройство для механизации технологических операций по уходу за виноградниками для устойчивого развития горных территорий // Устойчивое развитие горных территорий. 2015. N3. С 39-43

2. Кортиев Л. И., Кортиев А. Л., Ванеев С. Д., Тедеев В. Б. Подпорные стены и их применение для обеспечения безопасности движения на дорогах при освоении горных территорий // Устойчивое развитие горных территорий. 2016. N3. C 231-235

3. https://youtu.be/fRj34o4hN4I

4. http://www.diva-portal.org/smash/record.jsf?pid=diva2 $\% 3$ A916184\&dswid=116

5. Белотелов В. Н., Мартыненко Ю. Г. Управление пространственным движением перевернутого маятника, установленного на колесной паре // Изв. РАН. Механика твердого тела. 2006. N 6. С. 10-28.
6. Agrawal S., Franch J., Pathak K. Velocity control of a wheeled inverted pendulum by partial feedback linearization // 43rd IEEE Conf. on Decision and Control. Unevercity of Delaware. Newark. USA, 2004.

7. F. Grasser, A. D'Arrigo, S. Colombi, A. C. Rufer JOE: a mobile, inverted pendulum // IEEE Trans. on Industrial Electronics. 2002.V. 49. N 1. Pp. 107-114.

8. Ориентация, навигация и стабилизация одноосных колесных модулей / Алешин Б.С., Черноморский А.И., С.В. Фещенко и др. / Под ред. Алешина Б. С., Черноморского А. И. М.: Изд-во МАИ, 2012.

9. Максимов В.Н., Черноморский А.И. Система управления неголономным одноосным колесным модулем для мониторинга геометрических параметров аэродромных покрытий // Изв. РАН ТиСУ. 2015. N3. С. 156-167.

10. Максимов В.Н., Черноморский А.И. Комплексная система навигации и локального картографирования для 
одноосного колесного модуля // Гироскопия и навигация. 2016. T.92, N 1. C. 116-132.

11. Алешин Б.С., Курис Э.Д., Лельков К.С., Максимов В.Н., Черноморский А.И. Управление угловой ориентацией платформы одноосного колесного модуля при его движении по подстилающей поверхности без проскальзывания // Изв. РАН ТиСУ. N1. 2017. С. 150-160.

12. Ишлинский А.Ю. Механика гироскопических систем. М.: Наука, 1975. 592 с.

13. Ишлинский А.Ю. Полная компенсация внешних возмущений вызванных маневрированием в гироскопических системах / В сборнике трудов АН УССР «Теория инвариантности и ее применение в автоматических устройствах» М., 1959. С. 81-92.

14. Алешин Б.С., Максимов В.Н., Михеев В. В., Черноморский А.И. Стабилизация в плоскости горизонта двухстепенной платформы одноосного колесного модуля, перемещающегося по заданной траектории на подстилающей поверхности // Изв. РАН ТиСУ. N3. 2017. С. 135-147.

15. Добронравов В.В. Основы механики неголономных систем М.: Высшая школа. 1970. 272 с.

16. Kolmanovsky I., McClamroch N. Developments in nonholonomic control problems // Control Systems, IEEE. Japan. 1995. Vol. 14, N6. Pp. 20-36.

17. Bloch A. M. Nonholonomic Mechanics and Control. Interdisciplinary Applied Mathematics. New York: SpringerVerlag, 2003. 484. P.157

18. De Luca A., Oriolo G., Vendittelli M. Control of wheeled mobile robots: Anexperimental overview // Lecture Notes in Control and Information Sciences.London, 2001. Vol. 270. Pp. 181-226.

19. Oriolo G. De Luca A., Vendittelli M. WMR Control Via Dynamic Feedback Linearization: Design, Implementation, and Experimental Validation // IEEE Transactions On Control Systems Technology 2002. Vol. 10, N 6. Pp. 835-852.

20. A Stable Tracking Control Method for a Nonholonomic Mobile Robot / A. Kanayama [et. al.] // IEEE/RSJ Intern. Workshop on Intelligent Robotsand Systems. Japan, 1991. Pp. 384-389.

21. Распопов В. Я. Микромеханические приборы: учебное пособие. М.: Машиностроение, 2007. 400 с.

22. Черноморский А. И., Максимов В. Н., Плеханов В. Е. Микромеханическая курсовертикаль одноосного колесного модуля // Вестник Московского авиационного института. 2011. T. 18, N 3. C. 170

\section{СВЕДЕНИЯ ОБ АВТОРАХ / Information about authors:}

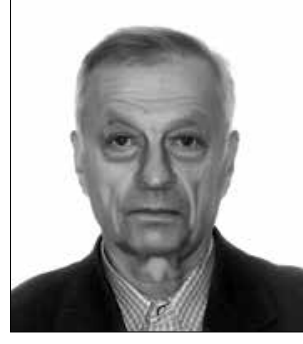

КУРИС Эдуард Давыдович кандидат технических наук, старший научный сотрудник кафедры «Автоматизированные комплексы систем ориентации и навигации», Московский авиационный институт, 125993, Москва, Россия.

Тел.: 8(499)-158-43-60;

ekuris@mail.ru

KURIS Eduard Davydovich - Candidate of Technical Sciences, senior researcher, Department of Automated systems of orientation and navigation, Moscow Aviation Institute, 125993, Moscow, Russia.

Ph.:+7(499)-158-43-60; ekuris@mail.ru

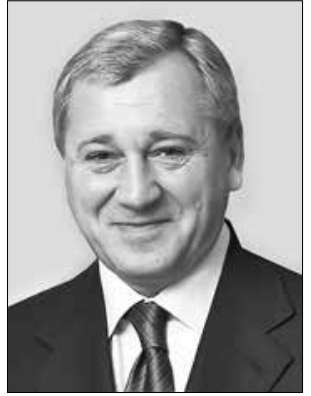

АЛЕШИН Борис Сергеевич доктор технических наук, академик РАН, заведующий кафедрой «Автоматизированные комплексы систем ориентации и навигации», Московский авиационный институт, 125993, Москва, Россия.

Тел.: 8(499)158-43-59.

Boris S. ALESHIN - Dr of Technical Sciences, Academician of the Russian Academy of Sciences, head of the Department "Automated systems of orientation and navigation", Moscow Aviation Institute, 125993, Moscow, Russia.

Ph.: +7 (499)158-43-59.

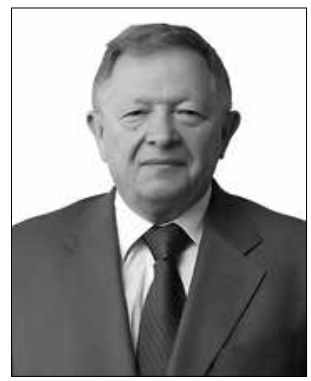

ЧЕРНОМОРСКИЙ Александр Исаевич - кандидат технических наук, доцент, профессор кафедры «Автоматизированные комплексы систем ориентации и навигации», Московский авиационный институт, 125993, Москва, Россия.

Тел.: 8(499)158-43-59.

CHERNOMORSKIY Alexander - Candidate of Technical Sciences, associate Professor, Professor of the Department "Automated systems of orientation and navigation systems", Moscow Aviation Institute, 125993, Moscow, Russia.

Ph.: +7 (499)158-43-59. 


\section{GROUND VEHICLE MODULES FOR SOLVING THE TASKS OF ENVIRONMENTAL MONITORING IN THE MOUNTAINOUS AREAS}

B. S. Aleshin,

A. I. Chernomorskiy,

E. D. Kuris*

Moscow Aviation Institute (National Research University), Moscow, Russia, ekuris@mail.ru

\section{DOI: $10.21177 / 1998-4502-2018-10-4-566-576$}

The purpose. This paper is devoted to the generalization of the theoretical research and uniaxial wheeled modules (UWM) development results, conducted at the department of "Automated complexes of orientation and navigation systems" of the Moscow Aviation Institute (MAI). This work is aimed at the development of UWM as efficient vehicles for solving various monitoring tasks in the steady developing areas, in particular - mountains and foothills. It includes monitoring the state of pavement dynamics, roadside natural formation and engineering structures as well as the airfield infrastructure and the surrounding airspace.

The methods. In the UWM structures development process we used the gyroscopic stabilizers construction methods, in particular, the method of ensuring UWM's platform invariance to the inertia forces arising from its arbitrary movement along the space-time trajectory (STT). The generalized UWM's mathematical model is obtained based on the second kind Lagrange equations for non - golonomic systems. When forming the signals for UWM platforms angular orientation control and stabilizing them in the horizon plane, we used inertial, gyroscopic, gravitational and flywheel methods and their combinations. For the stable UWM's movement along given STT all structures use two-circuit control method.

The results. The functional features defining the variants of the UWM structures and including the number of platform's degrees of freedom relative to the wheels set' axis, as well as the ways to control its angular orientation are summarized. A generalized UWM mathematical model has been constructed, and the particular UWM models can be derived from it. It is proposed to use a unified approach to the UWM movements along given STT control system construction. Common UWM's software and hardware features are revealed. Presented UWM simulation results have confirmed the effectiveness of the proposed technical solutions.

Conclusion. The generalizations of the work done at MAI was carried out, in particular, UWM structures development, mathematical models development, the formation of ways to control the angular orientation and stabilization of UWM platforms, development of the motion control algorithms for UWMs moving along given STT. In general, we have created the toolkit that makes it possible to effectively select one or another type of the developed UWMs in relation to the current monitoring task requirements.

Keywords: uniaxial wheel module, platform, monitoring, mountain area orientation control, trajectory control

\section{References}

1. Umarov R. D., Bakaev A. H., Magomedov F. M., Melikov I. M. Resource-Saving technology and device for mechanization of technological operations on care of vineyards for sustainable development of mountain areas. Sustainable development of mountain territories, 2015, vol. 7, no 3, pp. 39-43.

2. Kortiev L. I., Kortiev A. L., Vaneev S. D., Tedeev V. B.
Retaining walls and their application to ensure the safety of traffic on the roads during the development of mountain areas. Sustainable development of mountain territories, 2016, vol. 8, no 3, pp. 231-235.

3. https://youtu.be/fRj34o4hN4I

4. http://www.diva-portal.org/smash/record.jsf?pid=diva2 $\% 3$ A916184\&dswid=116

5. Belotelov V. N., Martynenko Yu. G. Control of spatial motion of an inverted pendulum mounted on a wheeled pair. Izv. RAS. Solid mechanics, 2006, no 6, pp. 10-28.

6. Agrawal S., Franch J., Pathak K. Velocity control of a wheeled inverted pendulum by partial feedback linearization. 43rd IEEE Conference on Decision and Control, Unevercity of Delaware, Newark, USA, 2004.

7. F. Grasser, A. D'Arrigo, S. Colombi, A. C. Rufer JOE: a mobile, inverted pendulum. IEEE Trans. on Industrial Electronics, 2002, v. 49, no 1, pp. 107-114.

8. Orientation, navigation and stabilization uniaxial wheeled module / Aleshin B. S., black A. I., S. V. Feshchenko et al. Under the editorship of B. S. Aleshin, the black sea A. I. Moscow, Publishing house of Moscow Aviation Institute, 2012.

9. Maksimov V. N., Chernomorskiy A. I. Control System of nonholonomic uniaxial wheeled module for monitoring the geometrical parameters of airfield pavements. Proceedings of the Russian Academy of Sciences. Theory and control systems, 2015, no 3, pp. 156-167.

10. Maksimov V. N., Chernomorskiy A. I. Complex navigation and local mapping system for single-wheel module. $G y$ roscopy and navigation, 2016, vol. 92, no 1, pp. 116-132.

11. Aleshin B. S., Kuris, E. D., Lenkov K. S., Maksimov V. N., The black sea A. I. Control the angular orientation of the uniaxial wheeled platform module, moving on the underlying surface without slipping. Izv. RAS, Theory and control systems, 2017, no 1, pp. 150-160.

12. Ishlinsky A. Yu. Mechanics of gyroscopic systems. Moscow, Nauka, 1975, 592 p.

13. Full compensation of external disturbances caused by maneuvering in the gyroscopic systems / in the collection of works of the USSR "Theory of invariance and its application in automatic devices". Moscow, 1959, pp. 81-92.

14. Aleshin B. S., Maksimov V. N., Miheev V. V., Chernomorsky A. I. Stabilization in the plane of the horizon of a two-stage platform of a wheel module moving along a given trajectory on the underlying surface. Izvestiya RAS. Theory and control systems, 2017, no 3, pp. 135-147.

15. Dobronravov V. V. Foundations of mechanics of nonholonomic systems. Moscow, Vysshaya Shkola, 1970, 272 p.

16. Kolmanovsky I., McClamroch N. Developments in nonholonomic control problems. Control Systems, IEEE. Japan, 1995, vol. 14, no 6, pp. 20-36.

17. Bloch A. M. Nonholonomic Mechanics and Control. 
Interdisciplinary Applied Mathematics. New York, SpringerVerlag, 2003, 484, p.157

18. De Luca A., Oriolo G., Vendittelli M. Control of wheeled mobile robots: Anexperimental overview. Lecture Notes in Control and Information Sciences. London, 2001, vol. 270, pp. 181-226.

19. Oriolo G. De Luca A., Vendittelli M. WMR Control Via Dynamic Feedback Linearization: Design, Implementation, and Experimental Validation. IEEE Transactions on Control Systems Technology, 2002, vol. 10, no 6, pp. 835-852.
20. A Stable Tracking Control Method for a Nonholonomic Mobile Robot / A. Kanayama [et. al.]. IEEE/RS J Intern. Workshop on Intelligent Robotsand Systems. Japan, 1991, pp. 384-389.

21. Raspopov V. Ya. Micromechanical devices: a training manual. Moscow, Mechanical Engineering, 2007, 400 p.

22. The Black Sea A. I., Maksimov V. N., Plekhanov V. E. Microexamination uniaxial wheeled module. Vestnik of the Moscow Aviation Institute, 2011, vol. 18, no 3, p. 170.

Article received 03.10.2018. 


\section{ОБЕСПЕЧЕНИЕ ЭКОЛОГИЧЕСКОЙ БЕЗОПАСНОСТИ ПРИ РАЗРАБОТКЕ КТИ-ТЕБЕРДИНСКОГО ВОЛЬФРАМОВОГО МЕСТОРОЖДЕНИЯ}

\section{Введение}

По мере истощения общемировых запасов твердых полезных ископаемых безопасность России все больше зависит от своевременного воспроизводства минерально-сырьевой базы и ее эффективной промышленной эксплуатации [1]. В настоящее время особенно актуальным является добыча руд редких металлов, из которых одним из важнейших для обеспечения технологической и экономической безопасности нашей страны является вольфрам.

Вольфрам используется как конструкционный материал для космических и других аппаратов, эксплуатируемых при высоких температурах, для изготовления бронебойных снарядов, деталей самолетов и двигателей, незаменим в атомной промышленности, ракетостроении и других высокотехнологичных отраслях. Несмотря на то, что Россия занимает второе место после Китая по объемам добычи и получения вольфрама, на внутреннем рынке наблюдается значительный дефицит вольфрамового сырья, который может быть частично или полностью скомпенсирован за счет ввода в эксплуатацию новых месторождений.

Северо-Кавказский регион является одним из главных производителей вольфрама в России. Правительством Карачаево-Черкесской Республики принято решение о строительстве Аксаутского горно-обогатительного комбината (ГОКа) для добычи и переработки вольфрамовых руд КтиТебердинского месторождения. Строительство Аксаутского ГОКа позволит не только увеличить производство вольфрама в России, но и заметно повысить промышленный потенциал Карачаево-Черкесской Республики и создать порядка 600 новых рабочих мест [2].

Между тем Кти-Тебердинское месторождение находится в непосредственной близости от Тебердинского государственного биосферного заповедника, включенного во Всемирную сеть природных резерватов [3]. Тебердинский заповедник является природоохранным, научно-исследовательским и эколого-просветительским учреждением федерального значения. В центре заповедника расположен широко известный и активно развивающийся спортивно-оздоровительный комплекс и горнолыжный курорт «Домбай». Популярные туристические маршруты проложены по всей территории заповедника. В связи с этим даже незначительные негативные изменения географической и природной обстановки территории месторождения могут нанести серьезный урон уникальной природной зоне заповедника, а следовательно, они недопустимы.

Общие концепции модернизации и развития горных территорий Северного Кавказа достаточно подробно рассмотрены в работах [4-7], однако конкретные мероприятия и условия развития промышленного производства в непосредственной близости от особо охраняемых природных территорий в них не отражены.

Таким образом, предметом рассмотрения настоящей статьи являются технологические решения по освоению Кти-Тебердинского месторождения, обеспечивающие экологическую безопасность прилегающих территорий, в том числе Тебердинского заповедника.

${ }^{1}$ Институт горного дела Уральского отделения Российской Академии наук,

Екатеринбург, Россия, geotech@igduran.ru
${ }^{1}$ Соколов И.В., * ${ }^{1}$ Смирнов А.A., ${ }^{1}$ Никитин И.В.
УДК: 622.7

DOI: 10.21177/1998-4502-2018-104-577-585

Целью настоящей работы явились разработка и оценка технологических решений и мероприятий по обеспечению экологической безопасности и сохранности окружающей территории, особенно близлежащего Тебердинского государственного биосферного заповедника, при строительстве и эксплуатации Аксаутского горно-обогатительного комбината на базе КтuТебердинского вольфрамового месторождения.

Проведены анализ горногеологических условий и изучение опыта разработки месторождений цветных металлов, оценка экологической обстановки территории залегания месторождения. Предложены технические решения и организационные мероприятия, позволяющие экономически эфрфективно и экологически безопасно отрабатывать КтuТебердинское вольфррамовое месторождение.

\section{КЛЮЧЕВЫЕ СЛОВА}

вольфрамовое месторождение, горная территория, экологическая безопасность, горнообогатительный комбинат, схема вскрытия, система разработки, технология обогащения

Статья поступила в редакцию 07.06.2018 


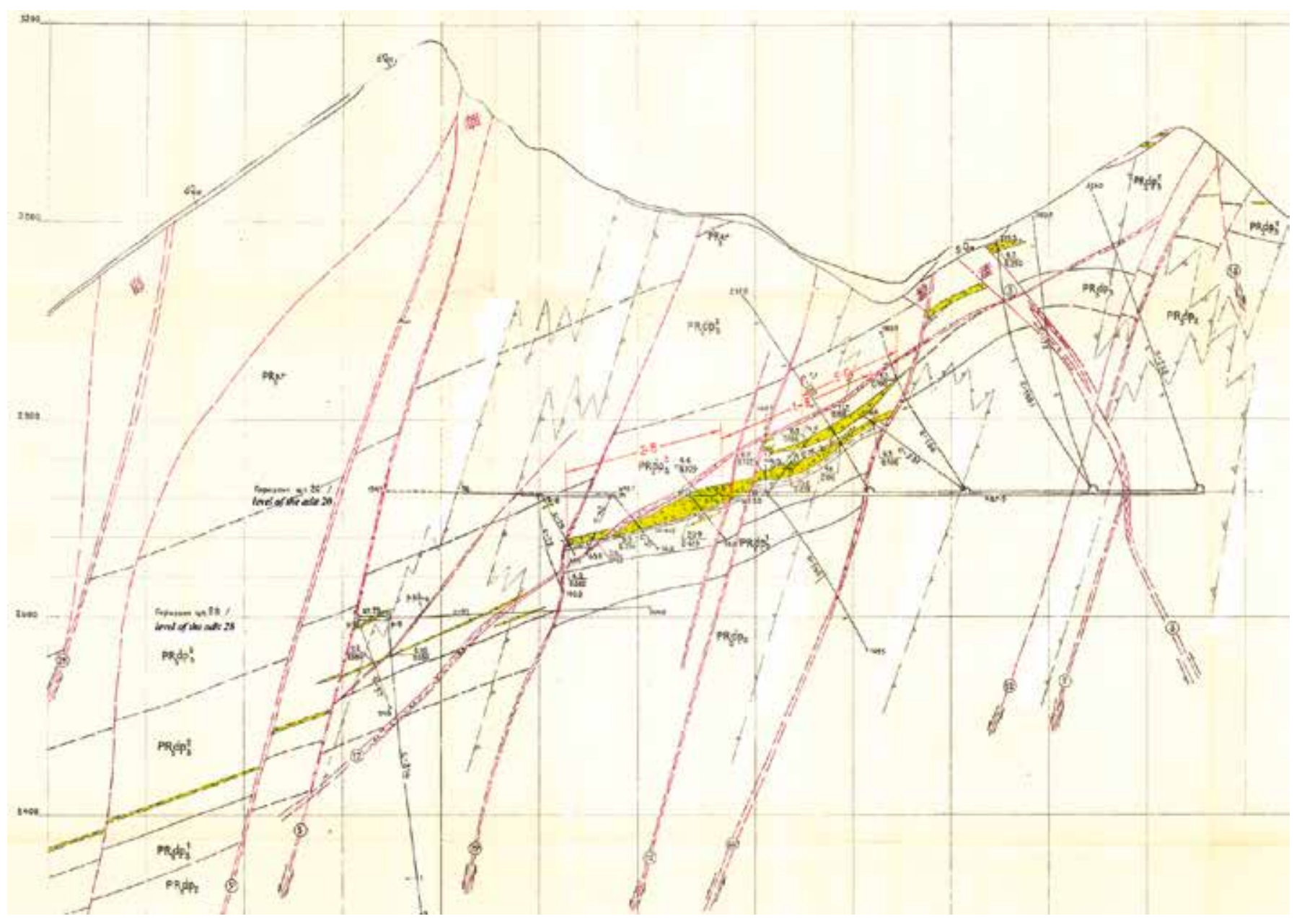

Pис. 1. Геологический разрез по Кти-Тебердинскому месторождению

Fig. 1. Geological section of the Kti-Teberda tungsten deposit

Общие сведения о месторождении

Кти-Тебердинское месторождение расположено в Зеленчукском районе Карачаево-Черкесской Республики на северном склоне Главного Кавказского хребта в истоках реки Аксаут и приурочено к горному массиву Кургашин-Чат с абсолютной отметкой вершины 3302 м [8]. Район месторождения является типичной высокогорной областью с резко расчлененным рельефом. Склоны ущелий имеют форму отвесных скал, водоразделы изобилуют гребневидными и пикообраными вершинами. Склоны горных массивов крутые (30-40 $)$, часто с обрывами. Превышение водоразделов над руслами рек составляет 1000-1700 м.

Особенности рельефа местности обуславливают перемещение четвертичных отложений и скатывание обломков коренных пород с высоких отметок на низкие. Наиболее опасными являются камнепады, обвалы, осыпи, оползни. Высока степень лавинной опасности в зимний период. Данные природные явления потенциально опасны для всех возможных участков размещения зданий и сооружений производственной и социальной инфраструктуры вблизи месторождения, а также для транспортных коммуникаций.

Климатические условия района характеризуются коротким дождливым летом и холодной снегообильной зимой. Количество осадков составляет 1300-
1900 мм в год, преимущественно в виде снега. Толщина снежного покрова 2-3 м, в понижениях рельефа до 8 м. Среднемесячная положительная температура $+9^{\circ} \mathrm{C}$, отрицательная $-6^{\circ} \mathrm{C}$.

Основной водной артерией района является река Аксаут с притоками Кти-Теберда и Джаловчет с непостоянным водным режимом, зависящим от интенсивности таяния ледников и снежников.

Рядом с месторождением находится поселок геологоразведчиков, от которого по долине реки Аксаут проходит грунтовая дорога до автотрассы Черкесск-Зеленчукская.

Приуроченность месторождения к Южному крылу Кти-Тебердинской антиклинали обуславливает моноклинальное залегание пород, осложненное большим количеством разрывных нарушений с амплитудами смещения от первых до нескольких сотен метров (рис. 1). Вкрапленнопрожилковые (вольфрамовые) руды залегают в амфиболитах на одном структурном уровне, в пределах которого выделено четыре рудных тела с углом падения 20-40 и мощностью 2-15 м, на отдельных участках до 25 м [9]. Руды и породы средней крепости и крепкие, средне- и малотрещиноватые, в основном достаточно устойчивые; в зонах дробления, приуроченных к тектоническим нарушениям - сильнотрещиноватые и неустойчивые.

Гидрогеологические условия месторождения достаточно благоприятные в связи с тем, что большая 


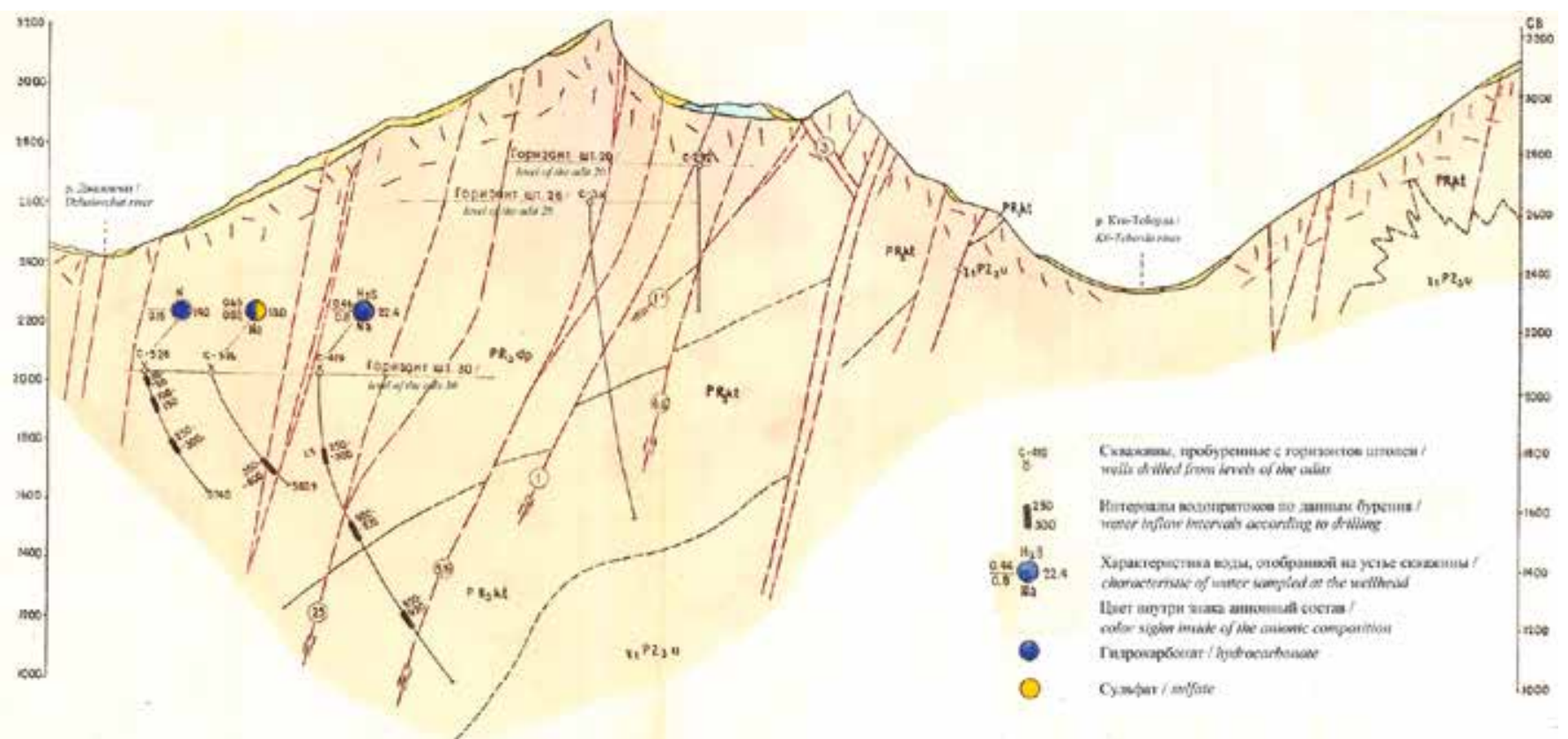

Pис. 2. Гидрогеологический разрез по Кти-Тебердинскому месторождению

Fig. 2. Hydrogeological section of the Kti-Teberda tungsten deposit

часть запасов находится выше русла прилегающих рек (рис. 2). Приток воды определяется уровнем атмосферных осадков и интенсивностью таяния ледников и снежников. В связи с этим объем водопритоков оценивается от $170 \mathrm{~m}^{3} /$ час (зимой) до $650 \mathrm{~m}^{3} /$ час (летом), в среднем около $370 \mathrm{~m}^{3} /$ час.

Выполнена детальная разведка месторождения. Для этого пройдены три геологоразведочные штольни и достаточно большое количество протяженных разведочных выработок на трех горизонтах.

Для месторождения на основании ТЭО постоянных кондиций (Институт «Гипроцветмет», 1986 г.) подсчитаны и утверждены балансовые запасы руды в количестве около 30 млн. т.

Основной рудообразующий минерал - шеелит (около 98\%).

Среднее содержание триоксида вольфрама $\mathrm{WO}_{3}$ в рудах - 0,366\%, присутствие других полезных компонентов незначительно.

\section{Основные технические решения по освоению} месторождения, обеспечивающие экологическую безопасность прилегающих территорий

При выборе способа разработки Кти-Тебердинского месторождения одним из основных требований является полное сохранение земной поверхности. Это требование предопределяет подземный способ разработки всех запасов, в том числе находящихся непосредственно у земной поверхности [10].

Институтом «Гипроцветмет» при разработке ТЭО кондиций годовая производительность рудника принята 650 тыс. т руды в год. Исходя из анализа запасов месторождения и ориентировочной оценки горных возможностей можно принять производственную мощность рудника в 1 млн. т руды в год.
На основании исследований и полупромышленных испытаний по обогащению руды Кти-Тебердинского месторождения, выполненных в ВИМСе и Центральной лаборатории ПГО «Севкавказгеология», авторами [11] предложена схема обогащения руды с получением шеелитового концентрата с содержанием триоксида вольфрама $\mathrm{WO}_{3}$, равным 55-60\%. Схема включает дробление добытой руды, ренгено-люминесцентную сепарацию, измельчение обогащенного продукта в мельницах, трехстадийную флотацию и химическую доводку концентрата. Извлечение триоксида вольфрама $\mathrm{WO}_{3}$ в концентрат составит $85 \%$, выход концентрата $-0,5-0,6 \%$.

При данной схеме обогащения выход хвостов обогащения очень высок: сухие хвосты ренгено-люминесцентной сепарации составят около $40 \%$ от объема добытой руды, шламы флотации - почти 60\%. Таким образом, общий объем шламов при отработке месторождения составит около 18 млн. т (примерно 8,2 млн. $\mathrm{M}^{3}$ ), для размещения которого потребуется выделение значительных площадей. При этом необходимо строительство гидротехнических сооружений для обезвоживания шламов и очистных сооружений шламовых вод, предотвращающих загрязнение водных источников района месторождения. Следует учитывать, что шламохранилища являются источником мощного техногенного воздействия на окружающую природную среду [12-16]. Вследствие этого, основным способом обеспечения экологической безопасности при освоении Кти-Тебердинского месторождения является максимально полное размещение отходов обогатительного производства и прежде всего шламов в выработанном пространстве [17-20]. Данное положение в значительной степени определяет выбор технологии подземной добычи руды. 


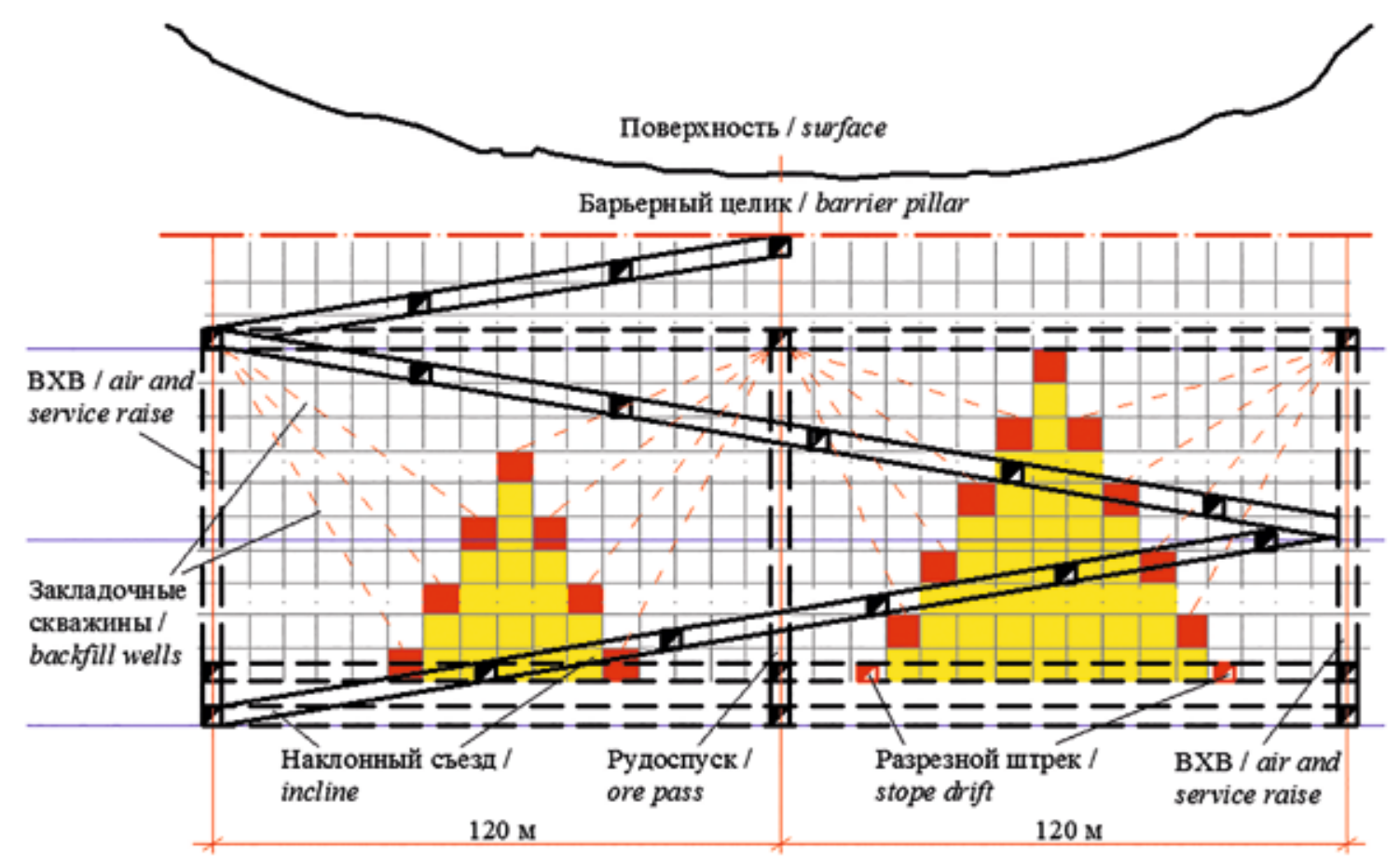

Pис. 3. Система разработки горизонтальными слоями снизу-вверх с закладкой Fig. 3. Upward filling system of horizontal slicing

Малая мощность рудных тел и значительная глубина их залегания на большей части месторождения в принципе позволяет применить системы с обрушением руды и вмещающих пород. Обрушение при этом не выйдет на поверхность, но не исключаются локальные подвижки налегающего массива, образование в нем трещин с аэродинамической связью с поверхностью и нарушение температурного режима вышележащих ледников. Кроме того, при данных системах практически исключено размещение в выработанном пространстве пустых пород и отходов обогащения.

Вследствие этого наиболее целесообразным выглядит применение систем разработки с закладкой выработанного пространства хвостами обогащения. При этом оптимальным является восходящий порядок отработки рудных тел, поскольку их сравнительно небольшой угол падения практически исключает подработку вышележащих запасов.

Перспективной в рассматриваемых условиях выглядит камерно-столбовая система разработки восходящими горизонтальными слоями с сухой или гидравлической закладкой выработанного пространства. В этом случае поддержание налегающих пород обеспечивается оставлением неизвлекаемых столбчатых или ленточных целиков. После выемки очередного слоя выработанное пространство заполняется сухой или гидравлической закладкой из хвостов обогащения. Закладка служит почвой вышележащего отрабатываемого слоя. Все производственные процессы добычи руды выполняются при помощи комплекса самоходных машин, что позволяет обеспечить достаточную экономическую эффективность и высокую производительность труда. Данная система разработки успешно применяется при отработке Саткинского месторождения магнезита [21].

Основным недостатком камерно-столбовой системы является высокий уровень потерь руды в неизвлекаемых целиках до 20-25\%. Для снижения указанных потерь возможна полная или частичная замена рудных целиков на искусственные (бетонные), в том числе в виде искусственных потолочин добычных блоков [22].

Вторым возможным вариантом является применение системы разработки с закладкой выработанного пространства твердеющими смесями (рис. 3). При данных системах происходит достаточно полное заполнение выработанного пространства закладкой с надежным поддержанием висячего бока и минимальным оседанием налегающих пород [23]. Несомненным преимуществом системы является высокое извлечение руды (потери 3-4\%) при незначительном разубоживании. Недостатком системы с твердеющей закладкой является повышенная на 25-30\% по сравнению с другими системами разработки себестоимость добычи руды. Для оценки возможности использования отходов обогащения руды для приготовления твердеющих смесей должны быть проведены специальные исследования.

Следует учитывать, что объем выработанного пространства будет недостаточен для размещения всех хвостов обогащения, к которым следует прибавить и пустую породу от проходки выработок. Поэтому некоторую часть сухих хвостов и пустых пород придется складировать в отвалах на поверхности, а в выработанное пространство помещать шламы флотации.

Наиболее распространенным способом транспортировки закладочных смесей на рудниках является 


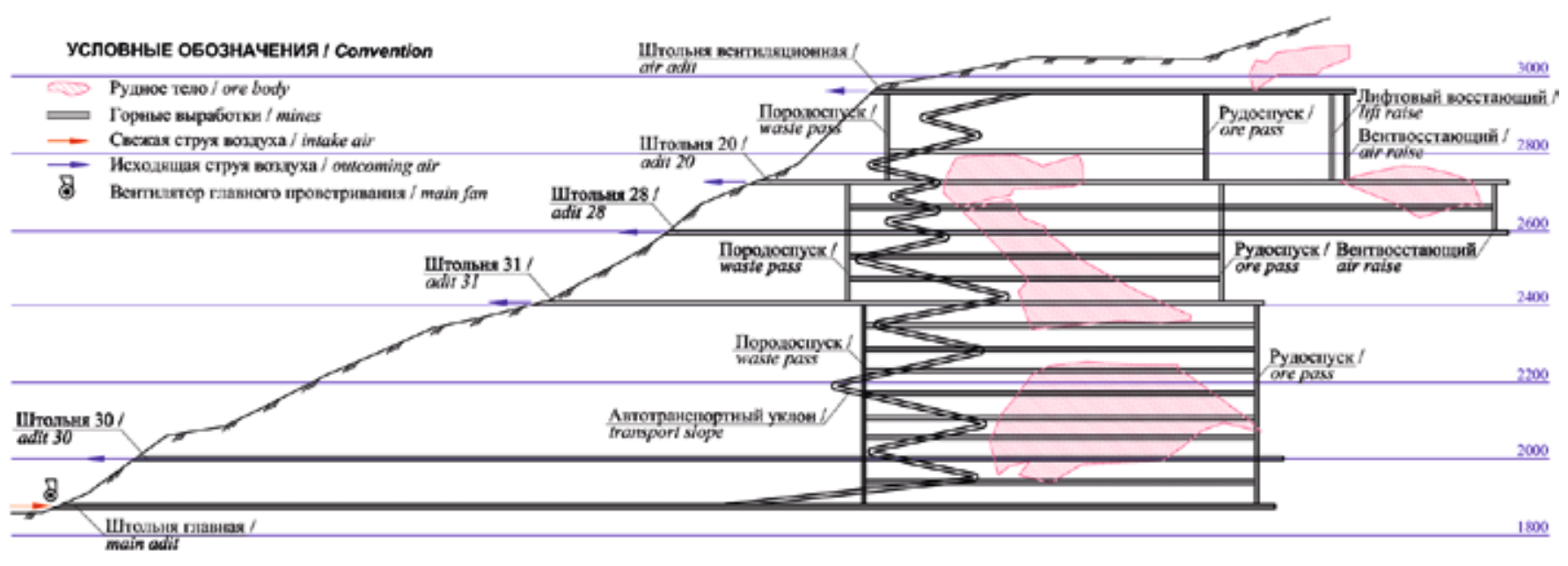

Pис. 4. Предлагаемая схема вскрытия Кти-Тебердинского месторождения

Fig. 4. Designed scheme of opening of the Kti-Teberda tungsten deposit

самотечный трубопроводный транспорт, но для его осуществления комплекс приготовления закладочных смесей должен располагаться выше отрабатываемых рудных тел. В нашем случае строительство такого комплекса вблизи вершины горного массива Кургашин-Чат затруднительно и экологически небезопасно, а подъем всего объема закладочного материала к нему нерационален. Кроме того, при использовании жидкой гидравлической или твердеющей закладки выработанного пространства возникают сложности в ее обезвоживании, отводе воды и строительстве перемычек. Вследствие этого наиболее предпочтительным выглядит предварительное сгущение и обезвоживание шламов и размещение их в выработанном пространстве в виде сухой закладки, транспортируемой автотранспортом или конвейерами [24; 25]. Однако это потребует введения в состав обогатительного комплекса специального отделения для сгущения и обезвоживания шламов. Такое решение позволит обеспечить оборотное водоснабжение обогатительного производства, что также является немаловажным для предотвращения загрязнения водных источников района месторождения (реки Аксаут с ее притоками).

Институтом «Гипроцветмет» при разработке ТЭО постоянных кондиций предложено вскрывать месторождение штольнями и двумя вертикальными стволами (клетевым и вентиляционным) при средней высоте этажа 65 м.

Учитывая расположение рудных тел и восходящий порядок их отработки вскрытие месторождения целесообразно осуществлять штольнями и автотранспортным уклоном для транспорта руды и перемещения самоходной техники (рис. 4), отказавшись при этом от проведения вертикальных стволов. Наряду с исключением ресурсо- и трудоемкого процесса строительства вертикальных стволов, предлагаемая схема позволяет осуществить поэтапное восходящее вскрытие месторождения, тем самым сократить капитальные затраты и срок ввода рудника в эксплуатацию. Кроме этого, существующие геологоразведочные выработки, в том числе штольни, после их обследования и восстановления можно использовать для вентиляции рудника и в качестве запасных выходов. Наиболее целесообразной выглядит нагнетательная схема проветривания с размещением главной вентиляторной установки на нижней главной штольне и выдачей загрязненного воздуха через вышерасположенные штольни.

Характер поверхности, опасность оползней и камнепадов, лавиноопасность как в пределах горного отвода, так и в ближайшей местности вызывает трудности с выделением достаточных подходящих площадей для размещения обогатительного комплекса, особенно с учетом размещения рудных складов, отвалов и сопутствующих коммуникаций. Вследствие этого в проекте комбината должен быть рассмотрен альтернативный вариант с полным или частичным размещением обогатительного передела в подземном пространстве. Выполненные нами исследования [26; 27] показывают, что стоимость строительства подземного обогатительного комплекса сопоставима или даже несколько ниже стоимости строительства аналогичного поверхностного комплекса. Подземный обогатительный комплекс может быть расположен в околорудном горном массиве с горизонтальной площадью 200х200 м и высотой 100-120 м, при этом объем горно-капитальных выработок составит не более 120-150 тыс. м $^{3}$.

Достаточная глубокая переработка руды приводит к тому, что объем конечной продукции комбината сравнительно невелик - от 4 до 6 тыс. т шеелитового концентрата в год. Учитывая имеющиеся транспортные коммуникации и перспективы их развития в высокогорной местности, целесообразно ориентироваться на автомобильный транспорт концентрата до объектов его переработки. Для строительства рудника и транспортировки продукции комбината потребуется реконструкция существующей автодороги до станицы Зеленчукская длиной около 70 км.

Безопасные площади для размещения объектов 
промышленной и социальной инфраструктуры вблизи месторождения весьма ограничены и требуют защиты от лавин и обвалов. Так, например, поселок для работников комбината можно расположить только ниже по течению реки Аксаут в 7 км от месторождения. Вследствие этого на Аксаутском комбинате целесообразна вахтовая организация работы со строительством вахтового поселка.

\section{Заключение}

1. При строительстве и эксплуатации Аксаутского ГОКа основным требованием является обеспечение экологической безопасности и сохранность окружающей территории, а особенно прилегающего к району месторождения Тебердинского государственного биосферного заповедника.

2. Для сохранения земной поверхности рекомендуется подземный способ разработки системами с закладкой выработанного пространства и восходящим порядком выемки рудных тел. Наиболее рациональным является применение системы горизонтальных слоев с сухой или гидравлической закладкой и использованием самоходной техники. Альтернативными вариантами являются камерностолбовая система с оставлением незвлекаемых целиков или система с твердеющей закладкой для поддержания висячего бока.

\section{ЛИТЕРАТУРА:}

1. Каплунов Д.Р., Рыльникова М.В., Радченко Д.Н. Реализация концепции устойчивого развития горных территорий - базис расширения минерально-сырьевого комплекса России // Устойчивое развитие горных территорий. 2015. N3 (25). C. 46-50.

2. Ахмат Текеев. Масштабный инвестиционный проект по разработке Кти-Тебердинского месторождения шеелита и созданию горно-металлургического комбината. 2018. [Электронный ресурс]. Режим доступа: http://www. vestnikstroy.ru/articles/building/2018/15533.html, свободный (Дата обращения 06.06.2018).

3. Салпагаров А.Д., Текеев Д.К. Тебердинский заповедник как особо охраняемая природная территория и его роль в сохранении природы Северного Кавказа // Материалы международной научно-практической конференции «Проблемы экологической безопасности и сохранение природно-ресурсного потенциала». Ставрополь, 2009. С. $37-42$.

4. Гуня А.Н. Социально-ориентированные концепции и подходы в исследовании горных территорий Кавказа и обеспечении устойчивого развития // Устойчивое развитие горных территорий. 2015. N 3 (25). С. 15-22.

5. Баденков Ю.П., Дунец А.Н., Мудуев Ш.С., Мухаббатов Х.М. Модернизация и развитие горных районов: советский и российский опыт // Устойчивое развитие горных территорий. 2016. N 4 (30). С. 323-337.

6. Галачилаева С.В., Хачетлова Е.Р., Попова Т.В., Баранская М.Ф. Стратегические направления развития промышленного комплекса региона в контексте масштабной
3. Схема обогащения руды Кти-Тебердинского месторождения предполагает глубокую переработку с высоким выходом (до 99\%) сухих хвостов обогащения и шламов флотации. Для исключения неблагоприятного воздействия шламохранилищ на окружающую среду шламы следует размещать в выработанном пространстве, при этом целесообразно предварительное сгущение и обезвоживание шламов с транспортировкой их конвейерами или автосамосвалами.

4. Вскрытие месторождения рекомендуется производить штольнями и автотранспортным уклоном, отказавшись от проведения вертикальных стволов.

5. Для строительства и эксплуатации Аксаутского ГОКа необходима реконструкция автодороги до станицы Зеленчукская длиной около 70 км. Наряду с обслуживанием нужд комбината и перевозки шеелитового концентрата автодорога позволит улучшить транспортную доступность района и расширить возможности развития в регионе других отраслей экономики Карачаево-Черкесской республики.

Работа выполнена при поддержкке Комплексной программы фундаментальных исследований УрО РАН (Проект 18-5-5-10) / The work is carried out under the support of the complex program of the fundamental research of Ur. branch RAN (Project 18-5-5-10)/

модернизации // Устойчивое развитие горных территорий. 2014. N 3 (21). C. 79-84.

7. Онищенко В.В., Уртенова 3.У. Геоэкологические аспекты устойчивого развития горных территорий (на примере Карачаево-Черкесской республики). // Устойчивое развитие горных территорий. 2014. N 4 (22). С. 75-79.

8. Потапенко Ю.Я. Геологические маршруты в Приэльбрусье. Карачаевск: КЧГПУ, 2002. 165 с.

9. Николаев И.Л., Цепин А.И., Гурбанов А.Г., Рехарский В.И., Андрианов В.И. Минеральные включения в шеелитах Кти-Тебердинского вольфрамового месторождения: (Северный Кавказ) как индикатор рудообразующих гидротермально-метасоматических процессов // Записки PMO. 1993. Часть 122. Вып. 2. С. 107-114.

10. Moran C., Lodhia S., Kunz N., Huisingh D. Sustainability in mining, minerals and energy: new processes, pathways and human interactions for a cautiously optimistic future // Journal of Cleaner Production. 2014. Vol. 84. N 1. Pp. 1-15.

11. Иванков С.И., Литвинцев 3.Г., Петкевич Д.Г. Проблемы создания современных экологически малонапряженных технологий переработки комплексных вольфрамовых руд и пути их решения // Научные и технические аспекты охраны окружающей среды: обзорная информация. М.: ВИНИТИ, 2013. Вып. 4. С. 2-138.

12. Jarvie-Eggart M.E. Responsible mining: case studies in managing social \& environmental risks in the developed world. Englewood, Colorado: Society for Mining, Metallurgy and Exploration, 2015. 804 p.

13. Gandhi S. M., Sarkar B. C. Essentials of mineral 
exploration and evaluation. Amsterdam: Elsevier, 2016. 406 p.

14. Антонинова Н.Ю., Шубина Л.А. Геоэкологические аспекты рекультивации техногенно-минеральных образований предприятий горно-металлургического комплекса // Биологическая рекультивация нарушенных земель: материалы X всероС. науч. конф. с междунар. участием, г. Екатеринбург, 4-7 сентября 2017 г. Екатеринбург: Изд-во УГЛТУ, 2017. С. 22-29.

15. Дедегкаев А.Г., Хмара В.В., Лобоцкий Ю.Г., Элбакян В.Л. Обеспечение экологической безопасности в зоне действия обогатительных фабрик // Устойчивое развитие горных территорий. 2017. N 1 (31). С. 65-73.

16. Adiansyah J., Rosano M., Vink S., Keir G. A framework for a sustainable approach to mine tailings management: disposal strategies // Journal of Cleaner Production. 2015. Vol. 108 (part A). Pp. 1050-1062.

17. Комащенко В.И. Эколого-экономическая целесообразность утилизации горнопромышленных отходов с целью их переработки // Известия Тульского государственного университета. Науки о Земле. 2015. N 4. С. 23-30.

18. Golik V.I., Hasheva Z.M. Economical efficiency of utilization of allied mining enterprises waste // Medwell Journals. The Social Sciences. 2015. Vol. 5. No 10. Pp. 682-686.

19. Polukhin O.N., Komashchenko V.I., Golik V.I., Drebenstedt C. Substantiating the possibility and expediency of the ore beneficiation tailings usage in solidifying mixtures production // Scientific Reports on Resource Issues Innovations in Mineral Ressource Value Chains: Geology, Mining, Processing, Economics, Safety, and Environmental Management. Freiberg, 2014. Pp. 402-412.

20. Matani A.G., Doifode S.K. Effective industrial waste utilization technologies towards cleaner environment // International Journal of Chemical and Physical Sciences. 2015. Vol. 4. No 1. Pp. 536-540.
21. Смирнов А.А. Особенности применения камерностолбовой системы разработки на шахте «Магнезитовая» // Горный информационно-аналитический бюллетень. 2007. N 5. C. 291-293.

22. Голик В.И., Разоренов Ю.И., Лукьянов В.Г. Искусственные потолочины при подземной добыче руд как альтернатива рудным целикам // Известия Томского политехнического университета. Инжиниринг георесурсов. 2016. N 3. C. 87-94.

23. Габараев О.3., Хулелидзе К.К., Кожиев Х.Х., Битаров В.Н. Ресурсосберегающие технологии закладки выработанного пространства при добыче богатых медно-никелевых руд // Устойчивое развитие горных территорий. 2012. N 4. C. 31-34.

24. Sheshpari M. Review of underground mine backfilling methods with emphasis on cemented paste backfill // The Electronic Journal of Geotechnical Engineering. 2015. Vol. 20. N 13. Pp. 5183-5208.

25. Lee C. Case study - a hight strength paste aggregate backfill at Randgold's Loulo mine in Mali // Minefill 2014: Proceeding of the 11th International Symposium on Mining with Backfill. 2014. Pp. 231-242.

26. Medvedev A., Sokolov I., Gobov N., Smirnov A. Cleaner production in mining industry: a flowsheet for underground mining of iron ore deposit // 14th SGEM GeoConference on Science and Technologies In Geology, Exploration and Mining, SGEM2014 GeoConference Proceedings. 2014. Book 1. Vol. 3. Pp. 85-90.

27. Соколов И.В., Смирнов А.А., Гобов Н.В., Антипин Ю.Г. Целесообразность применения подземных обогатительных комплексов на железорудных шахтах // Горный информационно-аналитический бюллетень. 2014. N 6. C. 197-206.

\section{$\overline{\text { СВЕДЕНИЯ ОБ АВТОРАХ / Information about authors: }}$}

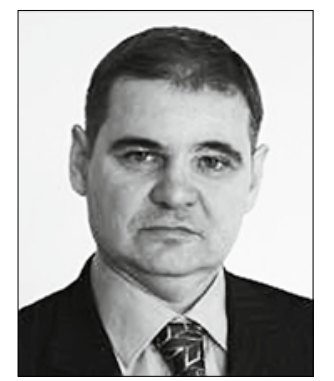

СОКОЛОВ Игорь Владимирович - доктор технических наук, заведующий лабораторией подземной геотехнологии, действительный член академии горных наук. ORCID 00000001-7841-5319.

Институт горного дела Уральского отделения Российской академии наук.

620075, г. Екатеринбург, Россия.

Тел.: 8(343)350-71-28, E-mail: geotech@igduran.ru

Igor VI. SOKOLOV - doctor of technical sciences, the head of the laboratory of underground geotechnology, current member of the Academy of mining Sciences. Institute of Mining of the Ural branch of Russian Academy of Sciences. ORCID 0000-0001-7841-5319.

620075, Ekaterinburg, Russia.

Ph.: +7(343)350-71-28; E-mail: geotech@igduran.ru

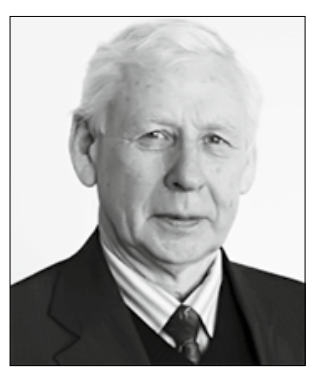

СМИРНОВ Алексей Алексеевич - кандидат технических наук, старший научный сотрудник; старший научный сотрудник лаборатории подземной геотехнологии.

Институт горного дела Уральского отделения Российской академии наук.

Тел.: 8(343)350-71-28

620075, г. Екатеринбург, Россия.

Alexey Al. SMIRNOV-candidate of technical sciences, senior research worker; senior research worker of the laboratory of underground geotechnology. Institute of Mining of the Ural branch of Russian Academy of Sciences.

620075, Ekaterinburg, Russia.

Ph.: +7(343)350-71-28. 


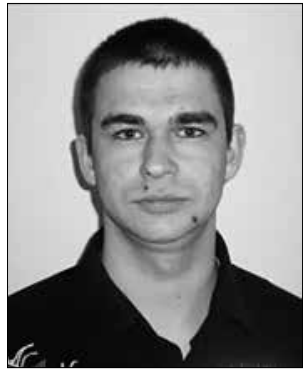

НИКИТИН Игорь Владимирович - научный сотрудник лаборатории подземной геотехнологии. Институт горного дела Уральского отделения Российской Академии наук. 620075 , г. Екатеринбург, Россия.

Тел.: +7(343)350-71-28, E-mail: geotech910@yandex.ru

Igor VI. NIKITIN - research worker of the laboratory of underground geotechnology. Institute of Mining of the Ural branch of Russian Academy of Sciences.

620075, Ekaterinburg, Russia.

Ph.:+7(343)350-71-28, E-mail: geotech910@yandex.ru

\title{
ENSURING ECOLOGICAL SAFETY AT THE MINING OF THE KTI-TEBERDA TUNGSTEN DEPOSIT
}

\author{
I.V. Sokolov, *
}

A.A. Smirnov,

I.V. Nikitin

Institute of Mining of the Ural branch of Russian Academy of Sciences, Ekaterinburg, Russia, geotech@igduran.ru

\section{DOI: $10.21177 / 1998-4502-2018-10-4-577-585$}

The purpose of this work is the development and evaluation of technological solutions and measures to ensure ecological safety and preservation of the surrounding area, especially the nearby Teberdinsky state biosphere reserve, during the construction and operation of the Aksaut mining and processing plant on the basis of the Kti-Teberda tungsten deposit.

Method of research. Analysis of mining and geological conditions and studying the experience of development of deposits of nonferrous metals, evaluation of the ecological situation of the territory of occurrence of the deposit.

Results. According to the results of the research it was established:

- for ensure ecological safety and preservation of the surrounding area is recommended that the underground method of development of the Kti-Teberda tungsten deposit of systems with the tab of the developed space and the ascending order of excavation of ore bodies. The most rational is the use of a system of horizontal layers with a dry or hydraulic tab and the use of self-propelled machinery. The most rational is the use of mining system of horizontal slicing with a dry or hydraulic backfill and the use of self-propelled machinery. Alternative options are a chamber-and-pillar system with the leaving of non-attracted pillars or a system with a hardening tab to maintain the hanging side.

- the scheme of ore processing of the deposit involves deep enrichment with a high yield (up to 99\%) of dry tailings and flotation sludge. To eliminate the adverse impact of sludge storage on the environment, sludge should be placed in the developed space, with the appropriate pre-thickening and dehydration of sludge.

- the opening of deposit is recommended by adits and transport slope, while refusing the carrying out of vertical shafts. Given the existing transport communications and prospects of their development in the highlands, it is advisable to focus on road transport concentrate to its processing facilities.

- for the construction of the underground mine and transportation of products of the mining and processing plant, it is necessary to reconstruct the existing road to the village Zelenchukskaya with a length of about $70 \mathrm{~km}$. Along with servicing the needs of the plant, the road will improve the transport accessibility of the district and expand the development opportunities in the region of other sectors of the economy of the Karachay-Cherkessia Republic.

Conclusions. The proposed technical solutions and organizational measures allowing economic efficiency and ecological safety to mining of the Kti-Teberda tungsten deposit.

Keywords: tungsten deposit, mountain territories, ecological safety, mining and processing plant, scheme of opening, mining system, enrichment technology.

\section{References}

1. Kaplunov D.R., Ryl'nikova M.V., Radchenko D.N. The implementation of the concept of sustainable development of mountain territories is the basis of the extension of the mineral resource complex of Russia. Sustainable Development of Mountain Territories, 2015, No 3, pp. 46-50.

2. Ahmad Tekeev. Scale investment project for the development of the Kti-Teberda sheelite deposit and the creation of the mining and metallurgical combine. 2018. [Electronic resource]. Access mode: http://www.vestnikstroy.ru/articles/ building/2018/15533.html, free (request date 06.06.2018).

3. Salpagarov A.D., Tekeev D.K. Teberdinsky reserve as a specially protected natural area and its role in the conservation of the North Caucasus. Materials of the international scientific and practical conference "Problems of environmental safety and conservation of natural resource potential". Stavropol, 2009, pp. 37-42. (in Russian).

4. Gunya A.N. Socially-oriented concepts and approaches in the study of mountain territories of the Caucasus and ensuring sustainable development. Sustainable Development of Mountain Territories, 2015, Vol. 7, No3 (25), pp. 15-22.

5. Badenkov Y.P. Dunets A.N., Muduev Sh.S., Muhabbatov H.M. Modernization and development of mountain regions: the Soviet and Russian experience. Sustainable Development of Mountain Territories, 2016, No 4, pp. 323-337.

6. Galachieva S.V., Kochetova E.R., Popova T.V., Baranskaya M.F. Strategic directions of development industrial complex in the region in the context of the region scale modernization. Sustainable Development of Mountain Territories, 2014 No 3, pp. 79-84.

7. Onishchenko V.V., Artenova Z.U. Geoecological aspects of sustainable development of mountain territories (on the 
example of the Karachay-Cherkessia Republic). Sustainable Development of Mountain Territories, 2014, No4, pp. 75-79.

8. Potapenko Y.Y. Geological routes in the Elbrus region. Karachaevsk: KHGPU, 2002. 165 p. (in Russian).

9. Nikolaev I.L., Tzepin A.I., Gurbanov A.G., Rekharsky V.I., Andrianov I.V. Mineral inclusions within sheelite of the Kti-Teberda tungsten deposit (North Caucasus) as an indicator of the ore-forming hydrothermal metasomatic process. Zapiski RMO (Proceedings of the Russian Mineralogical Society), 1993, part 122, Vol. 2, pp. 107-114. (in Russian).

10. Moran C., Lodhia S., Kunz N., Huisingh D. Sustainability in mining, minerals and energy: new processes, pathways and human interactions for a cautiously optimistic future. Journal of Cleaner Production, 2014, vol. 84, No1, pp. 1-15.

11. Ivankov S.I., Litvintsev Z.G., Pyatkevich D.G. Problems of creation of modern ecologically low-stress technologies for the processing of complex tungsten ores and ways of their solution. Scientific and technical aspects of environmental protection: an overview. Moscow, VINITI, 2013, vol. 4, pp. 2-138. (in Russian).

12. Jarvie-Eggart M.E. Responsible mining: case studies in managing social \& environmental risks in the developed world. Englewood, Colorado, Society for Mining, Metallurgy and Exploration, 2015, 804 p.

13. Gandhi S. M., Sarkar B. C. Essentials of mineral exploration and evaluation. Amsterdam, Elsevier, 2016, 406 p.

14. Antoninova N.Y., Shubina L.A. Geoecological aspects of reclamation of technogenic mineraleducations of the mining and metallurgical industries. Materials of $X$ all-Russia scientific conference with international participation "Biological recultivation of disturbed lands", Ekaterinburg, September 4-7, 2017. Ekaterinburg, Publ. UGLTU, 2017, pp. 22-29.

15. Dedegkaev A.G., Khmara V.V., Lobotsky Y.G., Elbakyan V. L. Environmental security of mountain territories in validity areas of dressing plants. Sustainable Development of Mountain Territories, 2017, No 1, pp. 65-73.

16. Adiansyah J., Rosano M., Vink S., Keir G. A framework for a sustainable approach to mine tailings management: disposal strategies. Journal of Cleaner Production, 2015, vol. 108 (part A), pp. 1050-1062.

17. Komashenko V.I. Ecological and economic feasibility of disposal of mining waste with the purpose of their processing. Proceedings of the Tula state University. Earth science, 2015, no 4, pp. 23-30.
18. Golik V.I., Hasheva Z.M. Economical efficiency of utilization of allied mining enterprises waste. Medwell Journals, The Social Sciences, 2015, vol. 5, no 10, pp. 682-686.

19. Polukhin O.N., Komashchenko V.I., Golik V.I., Drebenstedt C. Substantiating the possibility and expediency of the ore beneficiation tailings usage in solidifying mixtures production // Scientific Reports on Resource Issues Innovations in Mineral Ressource Value Chains: Geology, Mining, Processing, Economics, Safety, and Environmental Management. Freiberg, 2014, pp. 402-412.

20. Matani A.G., Doifode S.K. Effective industrial waste utilization technologies towards cleaner environment. International Journal of Chemical and Physical Sciences, 2015, vol. 4, no 1, pp. 536-540.

21. Smirnov A.A. Features of application of the chamberand-pillar system of development at the mine «Magnesite». Mining informational and analytical bulletin, 2007, No 5, pp. 291-293.

22. Golik V.I., Razorenov Y.I., Lukyanov V.G. Faux ceiling at underground mining as an alternative tore pillar. Bulletin of the Tomsk Polytechnic University, Geo Assets Engineering, 2016, no 3, pp. 87-94.

23. Gabaraev O.Z., Koghiev Kh.Kh., Khulelidze K.K., Bitarov V.N. Resource saving technologies for the gob flushing during rich copper - nickel ores extraction. Sustainable Development of Mountain Territories, 2012, no 4, pp. 31-34.

24. Sheshpari M. Review of underground mine backfilling methods with emphasis on cemented paste backfill. The Electronic Journal of Geotechnical Engineering, 2015, vol. 20, no 13, pp. 5183-5208.

25. Lee C. Case study - a hight strength paste aggregate backfill at Randgold's Loulo mine in Mali. Minefill 2014. Proceeding of the 11th International Symposium on Mining with Backfill, 2014, pp. 231-242.

26. Medvedev A., Sokolov I., Gobov N., Smirnov A. Cleaner production in mining industry: a flowsheet for underground mining of iron ore deposit. 14th SGEM GeoConference on Science and Technologies In Geology, Exploration and Mining, SGEM 2014 GeoConference Proceedings, 2014, Book 1, vol. 3, pp. 85-90.

27. Sokolov I.V., Smirnov A.A., Gobov N.V. Antipin Yu.G. Expediency of application of underground concentrating complexes at iron ore mines. Mining informational and analytical bulletin, 2014, No 6, pp. 197-206. 
${ }^{1}$ Хасцаев Б. Д., ${ }^{*}$ ${ }^{1}$ Маслаков М. П., ${ }^{1}$ Карлов В. В. ${ }^{1}$ Олисаева О.В.

\section{РАЗРАБОТКА АВТОМАТИЗИРОВАННЫХ СИСТЕМ УПРАВЛЕНИЯ ДЛЯ ГОРНОДОБЫВАЮЩИХ ПРЕДПРИЯТИЙ}

\section{УДК 519.86669 DOI: 10.21177/1998-4502-2018- 10-4-586-594}

Рассматривается проблема отрицательного влияния горнодобывающих предприятий на устойчивое развитие горных территорий и предложен один из наиболее эффективных путей решения этой проблемы, предусматривающий разработку автоматизированных систем управления с новыми функциональными возможностями для горнодобывающих предприятий. Основное внимание в работе уделено разработке автоматизированных систем управления технологическими процессами (АСУ ТП), используемыми на горнодобывающих предприятиях. Важнейшеe свойство этих систем определяется возможностью обеспечения предотвращения вредных и опасных выбросов в атмосферу, исключения загрязнения близлежащих к предприятию территорий, исключения аварийных ситуаций. Внедрение разработанной АСУ ТП будеm npedonpeделять устойчивое развитие горных территорий за счет повышения экономических показателей горнодобывающих предприятий и обеспечения экологического благосостояния этих территорий.

\section{КЛЮЧЕВЫЕ СЛОВА:}

устойчивое развитие, горнодобывающие предприятия, горные территории, технологический процесс, производ ственные риски, предупреждение аварий, автоматизированная система управления, подсистема исключения производственных аварий

Статья поступила в редакцию 04.05.2018.

\section{Введение}

Известна высокая значимость предприятий горнодобывающей промышленности как для экономики республик Северного Кавказа и всей страны, так и для устойчивого развития горных территорий. В то же время указанные предприятия, располагающиеся на горных территориях, могут представлять опасность своими выбросами в атмосферу вредных и опасных веществ, авариями и т.д. Поэтому исключение выбросов и предотвращение аварий и предаварийных ситуаций, ситуаций, связанных с рисками для производства, является актуальной проблемой. Решение этой проблемы, таким образом, имеет огромное значение как для сохранения естественной инфраструктуры горных регионов, так и для устойчивого развития этих регионов.

Анализ литературных источников показал, что длительное время как отечественные, так и зарубежные ученые посвящали свои работы решению обозначенной проблемы [1-17].

Однако на основе разработки общей теории построения АСУ для горнодобывающих предприятий [1-5], улучшения их технического оснащения [6; 14], внедрения в процессы управления производством математических моделей [7; 8] и программных продуктов [9; 10], развития методов управления горнодобывающими предприятиями [11-17] известные исследователи в своих работах решали отдельные задачи по повышению эффективности горнодобывающих предприятий и по устойчивому развитию горных территорий. Проведенный анализ также позволил сделать вывод, что перспективным путем решения обозначенной проблемы является путь, предусматривающий совершенствование современных производств, находящихся в инфраструктуре горных регионов, на основе применения высоко информационных, интеллектуальных автоматизированных систем управления всем предприятием (АСУП), значение которых, главным образом, определяется возможностями используемыми в АСУП автоматизированных систем управления технологическими процессами (АСУТП) производства. Эти системы обеспечивают, в первую очередь, снижение брака и повышение производительности труда, а значит, значительное повышение эффективности производства. Но известные АСУТП при этом не обеспечивают выявление и исключение рискованных для производства ситуаций, т.е. не обеспечивают исключение производственных рисков, включая аварийные ситуации, тем самым не обеспечивают сохранение экологического благосостояния горных территорий [1-17]. В связи с этим в работе ставится задача разработки АСУТП с возможностями выявления, предупреждения и предотвращения рискованных для производства ситуаций, а также обеспечения в целом устойчивого развития горных территорий. Разработка АСУТП с указанными возможностями является актуальной задачей, решение которой, по существу, предопределяет создание нового класса АСУТП [18-22], а значит нового класса АСУП.

Таким образом, предлагаемая работа является актуальной, так как посвящена решению проблемы, связанной с разработкой АСУТП с расширенными функциональными возможностями.

${ }^{1}$ Северо-Кавказский горно-металлургический институт (государственный технологический университет), Владикавказ, Россия

2ООО МИП "ИРСОФТ", Владикавказ, Россия 


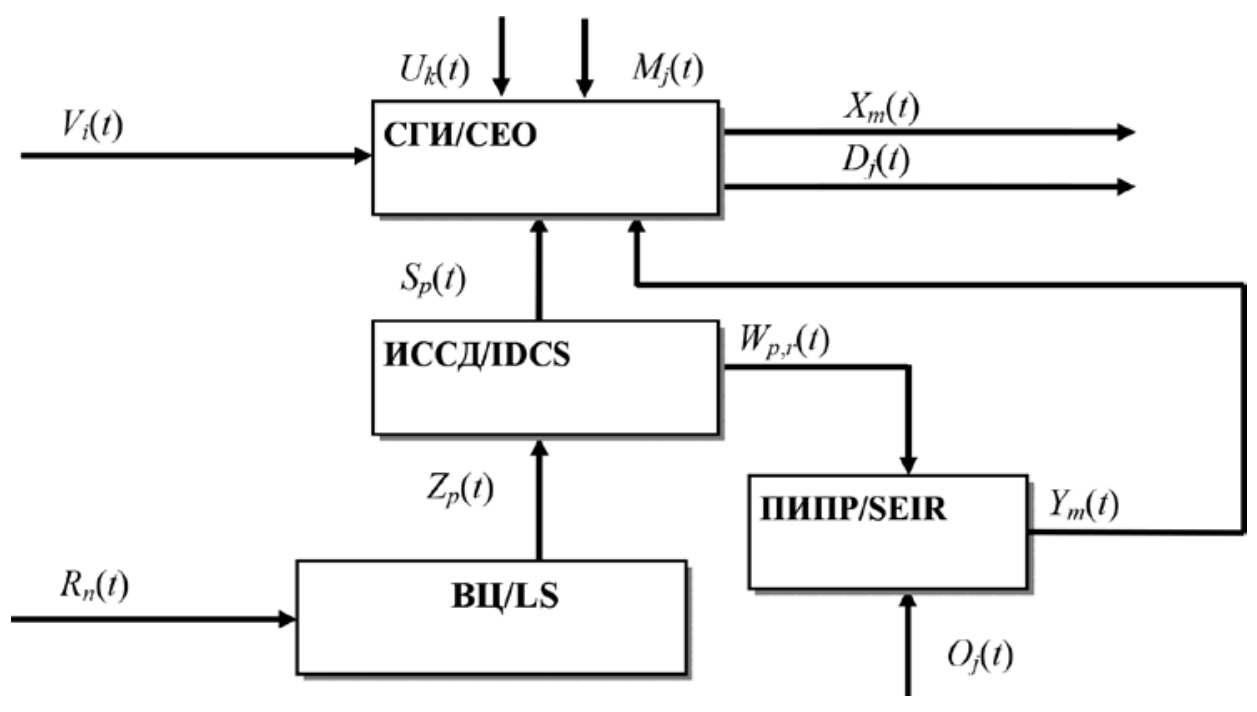

Рис. 1. Блок-схема АСУ ТП выщелачивательного изеха (ВЦ) с подсистемой исключения производственных рисков (ПИПР) / Fig. 1. A block-scheme of the ACS TP leaching shop (LS) with industrial risks (SEIR) exception subsystem (the scheme notation: $C E O$ - the chief engineer's office, IDCS - the intelligent data acquisition system, LS - the leaching shop)

\section{Постановка задачи по разработке АСУТП}

Задача разработки АСУТП рассматривается в работе для случая автоматизации технологического процесса, связанной с выщелачиванием цинка. Следует отметить, что в производстве по выщелачиванию цинка возникают по ряду причин неблагоприятные ситуации (рискованные ситуации или риски), которые должны обнаруживаться на ранней стадии и исключаться до свершения аварии. Для реализации этих функций и разрабатывается АСУ ТП с подсистемой исключения производственных рисков, включая риски, приводящие к аварийным ситуациям.

Известно, что функционирование АСУТП в настоящее время основано на безупречных информационных технологиях (ИТ), основной задачей которых в производстве по выщелачиванию цинка является информирование службы главного инженера (СГИ), принимающей решение, о текущем состоянии подконтрольного ему производства, в том числе информацию о протекании этапов технологического процесса, соответствии их параметров нормативным показателям, о параметрах работающего в цеху оборудования и т.д. Вполне понятно, что основой ИТ является интеллектуальная система сбора данных (ИССД), одной из подзадач которой является сбор информации в цифровой форме с контрольно-измерительных приборов (КИП), выполняющих функции измерения параметров технологического процесса на всех его стадиях.

Однако ввиду наличия большого количества оборудования, непрерывности технологического процесса, нестабильности технологических параметров и зачастую низкого качества сырья, подготовка и принятие оперативного управляющего воздействия на объектах контроля и управления могут быть серьезно затруднены. Стоит отметить, что при поступлении большого объема информации у СГИ уменьшается эффективность принимаемых решений, поэтому передаваемая на СГИ информация по объему должна соответствовать нормативному показателю.

Здесь целесообразно отметить, что с проблемой устранения аварий и предаварийных ситуаций тесно связаны задачи обеспечения контроля, безопасности окружающей среды в соответствии с Федеральными Законами, в которых содержатся требования, определяющие необходимость наличия на металлургических предприятиях подсистем, позволяющих: повысить экономическую и экологическую оценки деятельности предприятия; снизить затраты, связанные с природоохранной деятельностью; поддерживать стабильную работу агрегатов и химического состава сырья в пределах нормативов; обеспечить рост рейтинга предприятия на российском и международном рынках.

Анализ возможных путей создания АСУТП позволил выявить, что один из перспективных вариантов решения вышеперечисленных задач основывается на включении в состав АСУТП подсистемы исключения производственных рисков (ПИПР), позволяющей оценивать сложившуюся производственную ситуацию на участках цеха выщелачивания цинка и определять наиболее эффективные решения по управлению технологическим процессом. При этом основная задача ПИПР - это не допускать отклонений технологических параметров за допустимые нормы (в противном случае: выявлять причины отклонений и места их возникновения, определять степень возможных последствий от отклонений, оперативно подготавливать решения по ликвидации сложившихся производственных рисков, включая аварийные ситуации и пр.).

\section{Разработка блок-схемы АСУТП, имеющей в своем составе ПИПР}

Для разработки наиболее оптимальной структуры АСУТП по выщелачиванию цинка были изучены управляющие и информационные сигналы в реально действующем производстве ОАО «Электроцинк» 


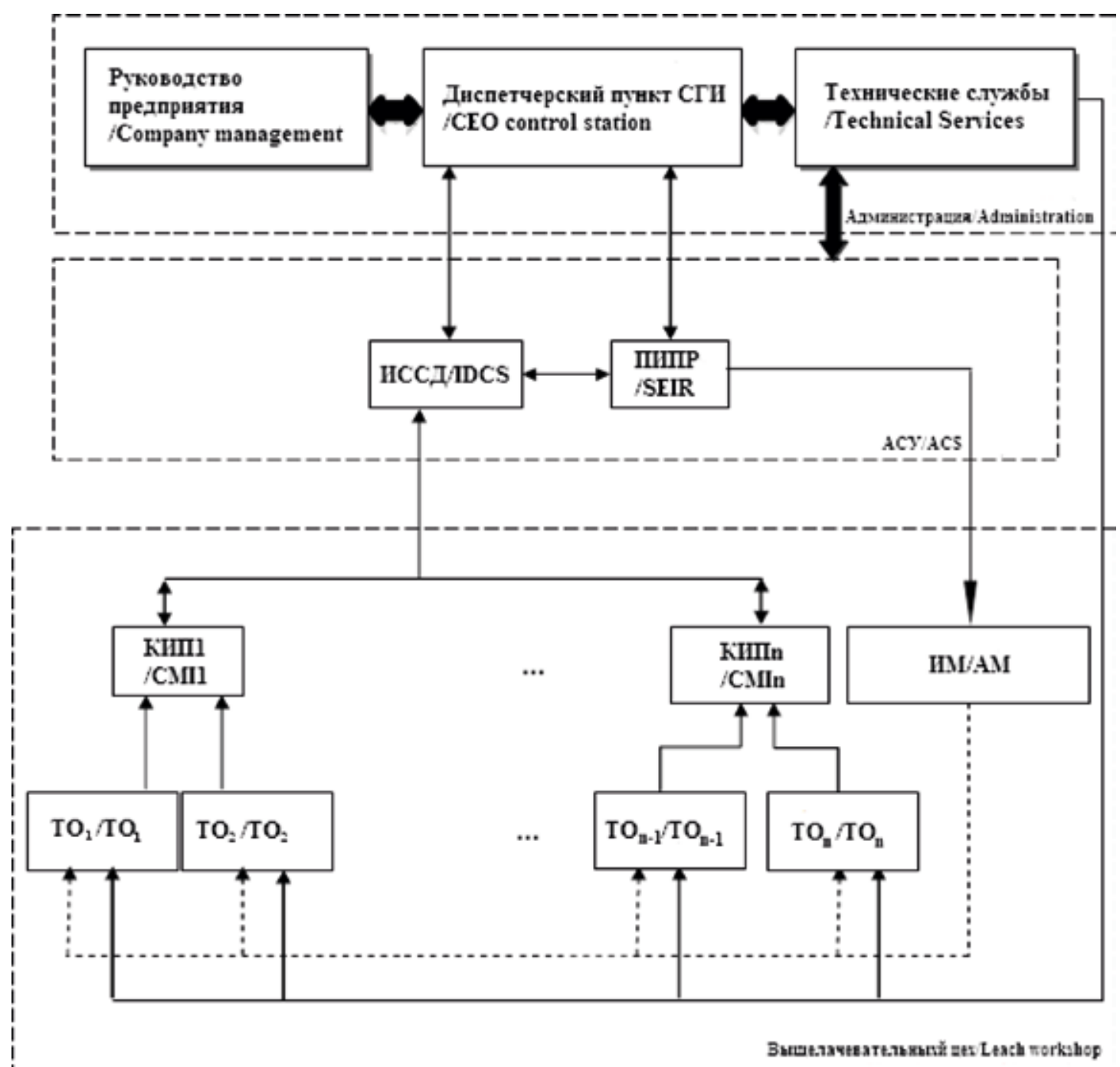

Pис. 2. Структурная схема АСУ ТП производства по выщелачиванию ичинка

Fig. 2. Structure scheme of the ACS TP production on zinc leaching (the scheme notation: CEO - the chief engineer's office, IDCS - the intelligent data acquisition system, SEIR - the subsystem exception of industrial risks, CMI-the control and measuring instruments, $A M$ - the actuator mechanism, TO - technological object)

(г. Владикавказ), была проведена их классификация, были определены их особенности и взаимосвязь. Там же были исследованы структурные составляющие производства цинка, были учтены возможные схемы их взаимодействия, исследованы разные варианты совместной работы таких блоков АСУТП, как СГИ, ИССД, ПИПР. На основании этих исследований и была разработана блок-схема АСУТП, приведенная на рис. 1.

В блок-схеме АСУТП показаны возможные управляющие и информационные сигналы, используемые для обеспечения высоких эффективных показателей функционирования предприятия. Эти сигналы условно разделяются на следующие виды:

- сигналь управления 1-го уровня $U_{k}(t)(k=1, \ldots, K)$ необходимые для модернизации производственно-технологической деятельности цеха и внедрения рекомендаций по предотвращению нарушений в ходе технологического процесса выщелачивания цинка;

- сигналы воздействия 1-го уровня $M_{j}(t)(j=1$, $\ldots, J)$ - обеспечивающие систему управления априорной информацией о: производственном плане, заявленных мощностях оборудования, подаваемом количестве и качестве сырья, плановом изменении структуры управления, сбоях агрегатов цеха, отклонениях в работе самой АСУТП, нарушениях состава растворов;

- сигналь, соответствующие входным контролируемым параметрам $V_{i}(t)(i=1, \ldots, I)$ - предоставляющие данные о показателях качества подаваемого электролита, огарка; информацию о техническом состоянии агрегатов цеха, растворов; информацию о структурных характеристиках оборудования и т.д.;

- сигналы, соответствующие выходным параметрам 1-го уровня $X_{m}(t)(m=1, \ldots, M)$ - предоставляющие данные об объемах производства, количестве извлеченного цинка в раствор, информацию о текущем состоянии оборудования, информацию для надзорных органов власти;

- сигналы управления 2-го уровня $D_{j}(t)(j=1, \ldots, J)$ необходимые для обеспечения информацией о выработке решений по воздействию на сложившуюся ситуацию в выщелачивательном цехе; 


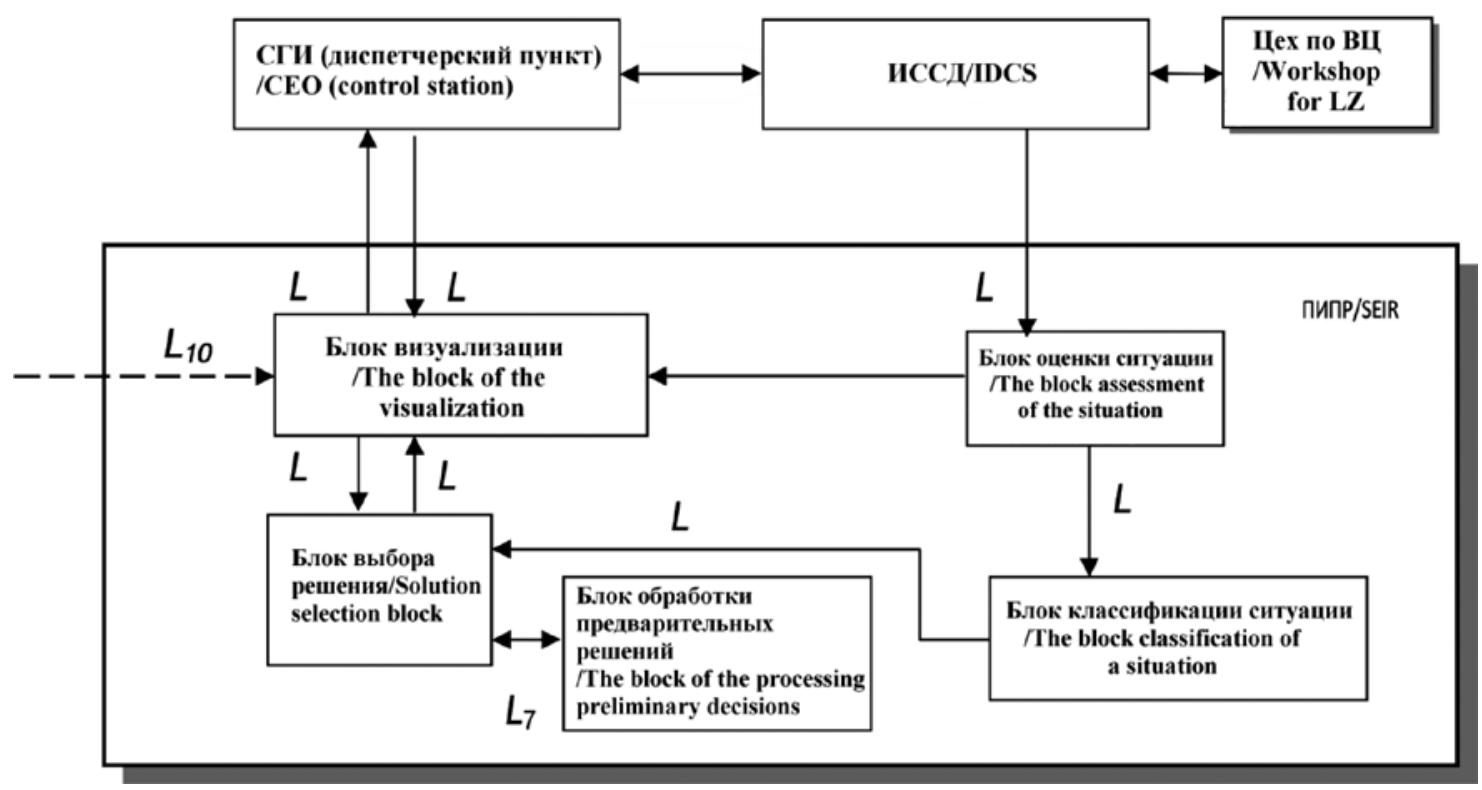

Рис. 3. Функциональная схема подсистемы исключения производственных рисков (ПИПР), входящая в состав АСУ ТП

Fig. 3. Functional scheme of the industrial risks (SEIR) exception subsyste; , a member of the ACS TP (the scheme notation: $C E O$ - the chief engineer's office, IDCS - the intelligent data acquisition system, LZ - the leaching of zinc)

- сигнальг о технологических параметрах $S_{p}(t)$, $Z_{p}(t)(p=1, \ldots, P)$ - представляющих информационные сигналы от КИП, передающиеся в ИССД, которые после обработки должны передаваться в СГИ в определенном виде;

- сигнальы дополнительного характера $W_{p, r}(t)$ (p= $=1, \ldots, P, r=1, \ldots, R)$ - важные для обеспечения информацией, необходимой ПИПР для выработки решения по сложившейся негативной ситуации;

- сигналы о выходных параметрах 2-го уровня $Y_{m}(t)(m=1, \ldots, M)$ - соответствующие обработанным данным, показывающим СГИ возможность разрешения сложившейся ситуации в цехе;

- сигналы воздействия 2-го уровня $O_{j}(t)(j=1, \ldots, J)-$ обеспечивающие информацией о возможности настройки, обучения ППАС на основании возможных сценариев развития ситуаций и причин нарушения технологического режима;

-сигнальг воздействия 3-го уровня $R_{n}(t)(n=1$, $\ldots, N)$ - используемые для обеспечения информацией о качестве подаваемого в цех сырья, включая электричество, природный газ, электролит и т.д., о спросе на рынке цветных металлов, о климатических условиях и др.

С учетом проанализированных информационных сигналов выщелачивательного цеха можно заключить, что ПИПР должна непрерывно реагировать на сигналы управления, воздействия и на сигналы, соответствующие технологическим параметрам. В этом случае можно ожидать полное исключение неблагоприятных производственных ситуаций [18-20].

\section{Разработка структурной схемы АСУ ТП с ПИПР}

На основании разработанной блок-схемы АСУ ТП и анализа ее информационных и управляющих сигналов была разработана структурная схема АСУ ТП, эф- фективность функционирования которой, как понятно, во многом определяется тем, насколько активно ПИПР в составе АСУ будет в состоянии поддерживать работу СГИ в принятии управленческого решения по исключению производственных рисков и неблагоприятных ситуаций.

Главными функциями АСУ ТП с ПИПР представляются следующие:

- определение вероятных причин, вызывающих производственные риски в технологическом процессе выщелачивания цинка;

- выбор наилучшего решения по ликвидации сложившейся негативной ситуации;

- самообучение, которое предопределяет развитие интеллектуальных возможностей, что возможно на основе применения нейронных сетей или нечеткой логики (понятно, что применение элементов искусственного интеллекта в ПИПР существенно улучшает решение вопросов исключения производственных рисков и неблагоприятных ситуаций на предприятии).

Разработанная структурная схема АСУ ТП производства по выщелачиванию цинка приведена на рис. 2, из которого видно, что вся структура производства разделена условно на 3 уровня: администрации, АСУ, выщелачивательного цеха. Рассмотрение взаимодействия этих уровней между собой и работы подсистем уровней не представляется возможным в настоящей работе, поэтому отметим только основные задачи, решаемые системой в автоматизированном режиме:

- пополнение новой информацией о состоянии технологического оборудования (от $\mathrm{TO}_{1}$ до $\mathrm{TO}_{\mathrm{n}}$ ), о возможных ситуациях выщелачивательного цеха и о способах воздействия на них;

- поиск и выбор решений в случаях предрискованных 
и рискованных ситуаций, случившихся ранее, в том числе ситуаций предаварийного и аварийного характера;

- формирование ответов на запросы, поступающие от СГИ.

Так как выщелачивательный цех предприятия представляется большим количеством технологического оборудования с различными технологическими параметрами, исполнительными механизмами (ИМ), контрольно-измерительными приборами (КИП ${ }_{1}$.. КИП ${ }_{n}$ ) в большом объеме, то система управления характеризуется высокой сложностью.

\section{Разработка функциональной схемы ПИПР}

Предлагаемая ППАС в системе управления должна обладать возможностью корректировки имеющихся в ней данных на этапе обучения и настройки, а СГИ должна обеспечивать возможность корректировки способов воздействия на сложившуюся рискованную ситуацию на всех участках производства [21; 22]. С учетом этих требований была разработана функциональная схема ППАС, приведенная на рис. 3. Надо отметить, для улучшения функциональных возможностей ПИПР в ней достаточно использование элементов нечеткой логики [21].

В структуре ПИПР выделены 5 основных блоков и соответствующие им связи $L_{1} \ldots L_{10}$ по передаче информации следующего назначения:

$L_{1}$ - информация о текущей ситуации, имеющей место в выщелачивательном цехе, и используемой для оценки необходимости выработки решения СГИ;

$L_{2}$ - информация для СГИ о ненадобности вмешательства в процесс выщелачивания цинка, что возможно при регламентированном ходе выщелачивания цинка;

$L_{3}$ - информация о сложившейся негативной ситуации, при которой необходимо определить тип текущей ситуации;

$L_{4}$ - информация о классифицированной ситуации, при которой в блок выбора решения (БВР) передается информация;

$L_{5}$ - информация о «найденном» решении по сложившейся ситуации, преобразуемая в вид, понятный СГИ;

$L_{6}$ - информация для ИССД о выбранном решении по сложившейся предаварийной ситуации (используется только в случае отсутствия действий со стороны СГИ);

$L_{7}-$ информация по данной связи передается только в случае отсутствия одного решения сложившейся предрискованной ситуации, при которой прибегают к помощи блока обработки предварительных решений (БОПР) для выбора наилучшего альтернативного решения, передаваемого впоследствии в БВР;

$L_{8}$-информация для СГИ о решении по выходу из сложившейся ситуации или об отсутствии такового;

$L_{9}$ - информация для ввода запроса СГИ о возмож- ных ситуациях или ввод собственных решений по возможным ситуациям;

$L_{10}$ - информация о необходимости обучения БВР.

После описания связей, используемых в ПИПР, важно рассмотреть основные функции этих блоков, тем более, что работа ПИПР находится в прямой зависимости от выполняемых блоками ПИПР функций.

Блок оценки ситуации (БОС) предназначен для оценки и определения необходимости вмешательства СГИ в сложившуюся ситуацию производственного процесса. Если текущая ситуация не требует вмешательства, то БОС не передает информацию на дальнейшую обработку в ПИПР. Одновременно БОС информирует СГИ через блок визуализации (БВ) об отсутствии необходимости воздействия на объект с параметрами, вызывающими риски. Если БОС определил ситуацию как инцидент, риск или предаварийная ситуация, аварийная ситуация или авария, то

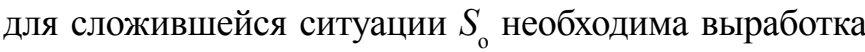
управляющего воздействия в ПИПР.

Поступающая информация в БОС может быть нескольких типов: четкая, нечеткая, нечетко множественная. Это накладывает особенности на алгоритм действия, который включает следующие шаги.

Если в БОС поступают только хорошо определенные (относительно порога равенства) ситуации So, то отношение нечеткого равенства на множестве $S 1=S s \cup$ So (где $S o-$ множество входных ситуаций) и является отношением нечеткой эквивалентности.

Ситуации, входящие в набор $S_{s}$, назовем "эталонными" (выявленными экспертами) для анализируемого процесса. Набор $S_{s}=\left\{s_{1}, s_{2}, \ldots, s_{n}\right\}$ эталонных ситуаций не содержит нечетко равных при заданном пороге равенства ситуаций. Это способствует уменьшению размерности входящей анализируемой информации процесса выщелачивания и не снижает эффективности модели управления в пределах достоверности, ограничиваемых порогом равенства.

Так как множество $S s$ нечетко равных ситуаций, то число классов эквивалентности нечеткого разбиения множества $S 1$ совпадает с числом эталонных ситуаций $s l$. Каждая ситуация $s l \in S s$ и является представителем класса эквивалентности $A l$, соответствующей этой ситуации. Классу $A l$, помимо $s l$, принадлежат все нечетко равные $s l$ входные ситуации из множества возможных So.

Следовательно, любая входная ситуация Sо нечетко равна только одной эталонной ситуации $s i \in S s$, которая определяется последовательным сравнением So с каждой ситуацией $s l \in S s(l \in I=\{1,2, \ldots, n\})$.

Если в БОС поступает плохо определенная ситуация So, то в этом случае отношение нечеткого равенства на множестве S1 является отношением нечеткой толерантности. Число классов сопряженного с ним не- 
четкого покрытия равно $n$, каждая ситуация $s l \in S s$ coответствует классу Al покрытия множества $S 1$.

Однако классы покрытия могут иметь нечетко пустые пересечения, которые состоят из плохо определенных входных ситуаций So. Следовательно, плохо определенная входная ситуация So может быть четко равна эталонным ситуациям [20].

В случае оценки типа ситуации как "опасной", информация передается в блок классификации ситуации (БK $\boldsymbol{C}$ ). В нем происходит разделение ситуаций на классы, каждый из которых однозначно или с определенными приоритетами соответствует тем или иным возможным решениям по воздействию на участки выщелачивательного цеха. Разработанный блок обладает такими возможностями, как поиск прагматических признаков, обеспечивающих нахождение обобщенных описаний ситуаций, позволяющих, в свою очередь, решать задачи поиска решений для эффективного воздействия на объект; обеспечение работы с именами, которые присваиваются отдельным понятиям и ситуациям; обобщение процедур, основанных на структуре отношений, присутствующей в описании ситуаций.

\section{Алгоритм работы БКС}

Его можно представить следующим образом. На множестве различных ситуаций $\{\mathrm{Si}\}$ производится их разбиение на классы, при котором каждый класс Si имеет в пределах данной модели управления некоторую адекватную интерпретацию процесса управления ситуацией. На множестве полных ситуаций $\{\mathrm{Si}\}$ выделяется такое множество классов $\mathrm{Si}$, при котором каждый из них допускал бы адекватную интерпретацию для процедуры поиска решения по воздействию на объект. В частности, классификация $S i$ по некоторому основанию должна быть согласована с классификацией на множестве управляющих воздействий $\{F k\}$.

БВР определяет эталонную ситуацию sieSs (где $S s-$ множество эталонных ситуаций) для наиболее близкой входной ситуации So и выдает СГИ управляющее решение $F k$, соответствующее ситуации $s i$. Управляющее решение выражается нечетко, то есть имеет форму, предпочтительную для СГИ. Для случаев отсутствия единственного решения по управлению в ПИПР предусмотрена процедура обращения к БОПР, которая обеспечивает поиск из множества альтернативных решений наилучшего решения. На основании мнения экспертов каждому управляющему решению присваивается вес $W \in[0 ; 1]$, и решение с наибольшим весом выдается СГИ.

Таким образом, БВР, БКС и БОПР совместно формируют решения, необходимые для предотвращения производственных рисков.

\section{Заключение}

В работе решена актуальная проблема, определяемая как значимостью сохранения естественного со- стояния горных ландшафтов, так и значимостью обеспечения экологического благосостояния горных территорий, близлежащих к предприятиям горнодобывающей промышленности. Для решения выбранной проблемы и разработана интеллектуальная АСУ ТП, способная исключать вредные выбросы в атмосферу, предотвращающая рискованные ситуации, включая аварии и т.д. Таким образом, внедрение на предприятиях подобных АСУ ТП обеспечивает сохранение инфраструктуры горных регионов, а значит устойчивое развитие горных территорий.

Предложенный в работе подход к обеспечению благосостояния горных территорий, включая повышение эффективности работы горнодобывающих предприятий, обеспечение безопасности работников предприятий, применим для обеспечения благосостояния и равнинных территорий, на которых располагаются предприятия с «вредными» производствами, и безопасности работников этих предприятий.

Рассмотренные в работе принципы построения АСУ ТП, подходы к повышению их интеллектуальных способностей (возможностей) применимы при построении АСУ для многих отраслей промышленности, для многих направлений научных исследований. 


\section{ЛИТЕРАТУРА:}

1. Потресов Д.К., Пучков Л.А., Федунец Н.И. Автоматизированные системы управления в горнодобывающей промышленности Учебник. М.: Недра, 1987. 285 с.

2. Батицкий В.А., Куроедов В.И., Рыжков А.А. Автоматизация производственных процессов и АСУ ТП в горной промышленности. Учебник. М.: Недра, 1991. 303 с.

3. Толпежников Л.И. Автоматическое управление процессами шахт и рудников. М.: Недра, 1985. 352 с.

4. Батицкий В.А. Автоматизация производственных процессов и АСУ ТП в горной промышленности/ В.А. Батицкий, В.И. Куроедов, А.А. Рыжков. М.: Недра, 1991. 303 с.

5. Vielsietiges Motion Control-System in einem IndustriePC // AT Mineral Processing. 2015. N6. P. 52-53.

6. Эдварс Р., Виен А. Стратегия применения КИП и автоматики в циклах измельчения // Mineral Processing Plant Design, Practice and Control: материалы симпозиума. Канада. Ванкувер, 20-24 октября 2002.

7. Data science and big data analytics: discovering, analizing, visualizing and presenting data. - Indianapolis, Indiana: John Wiley \& Sons, Inc., 2015. 432 p.

8. Rasmuson A., Andersson B., Andersson R., Ollson L. Mathematical Modelling in Chemical Engineering / University Printing House, publ. in the United States of America by University Cambridge Press. New York. 2014. 183 p.

9. Remes A. Advanced Process Monitoring and Control Methods in Mineral Processing Applications. Espoo: Aalto University, 2012. 76 p.

10. Shean B.I., Cillers J.J. A review of froth flotatin control // International Journal of Mineral Processing. 2011. Vol. 100. Iss. 3-4. Pp.57-71.

11.Sbarbaro D., Rene del Villar. Advanced Control and Supervision of Mineral Processing Plant. London: Springer. 2010. 310 p.

12. Hodouin D. Methods for automatic control, observation and optimization in mineral processing plants // Journal of Process Control. 2011. Vol. 21. Iss. 2. Pp. 211-225.

13. Cohen O., Fedurco E. Fundamentals of the theory of constraints. Tallin: TOC Strategic Solutions, 2012. 331 p.

14. Кубрин С.С., Решетняк С.Н. Автоматизированная информационно-измерительная система технического учета электроэнергии для подземных горных работ // Горный журнал. 2016. N1. C.87-90.

15.Матвеев В.А. Концепция автоматизированного управления флотационной практикой // Горный журнал. 2016. N4. C.84-87.

16. Башков Д.А., Веселов Д.А., Исаев Е.А. Опыт создания АСУТП на Николаевской обогатительной фабрике // Горный журнал. 2016. N11. C.85-88.

17. Ершов Е.Е., Исаев Е.А. Усовершенствованное управление технологическими процессами на горно-обогатительных предприятиях: общий обзор и специальное программное обеспечение // Горный журнал. 2016. N11. С. 89-92.

18. Хасцаев Б. Д., Хасцаев М. Б., Антипов К. В. Разработка интеллектуального устройства для автоматизированной системы управления металлургическим предприятием // 6-я Международная научная конференция "Прикладные науки и технологии в США и Европе: общие проблемы и научные открытия». Нью-Йорк, 2014. С. 134-137.

19. Хасцаев Б. Д., Хасцаев М. Б., Антипов К. В. Разработка интеллектуальной системы управления процессом выщелачивания цинка // 9-я Конференция “Европейские прикладные науки: современные подходы в научных исследованиях". Штутгарт, Германия, 2014. С. 99-103.

20. Хасцаев Б. Д., Антипов К. В., Тинаев В. В. Разработка аппаратного, программного и информационного обеспечений ППАС для АСУ предприятия // Сборник научных трудов СОО АН ВШ РФ. Владикавказ: Издательство «Терек», 2013. N11.

21. Антипов К. В., Хасцаев Б. Д. Разработка подсистемы предупреждения аварийных ситуаций при выщелачивании цинка // Интернет-журнал "Технологии техносферной безопасности" (http://ipb.mos.ru/ttb). 2012 . Выпуск No 6 (46). C. $1-7$.

22. Антипов К. В., Хасцаев Б. Д. Разработка алгоритмов работы подсистемы предупреждения аварийных ситуаций в системе управления выщелачивательным цехом // Электронный научный журнал «Современные проблемы науки и образования». 2013. N 1. С. 169.

\section{СВЕДЕНИЯ ОБ АВТОРАХ / Information about authors:}

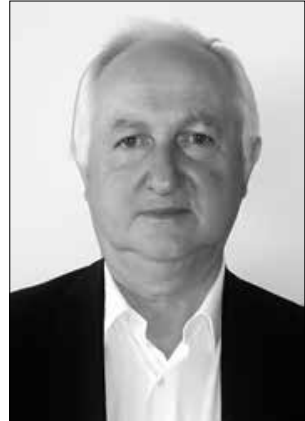

ХАСЦАЕВ Борис ДзамболатоВич - доктор технических наук, профессор, кафедра «Промышленная электроника», Северо-Кавказский горно-металлургический институт (государственный технологический университет), 362021, г. Владикавказ, Россия.

Тел.: 8(928)982-78-28

e-mail: bordsamhas@rambler.ru

Boris Dz. KHASTSAEV - Dr. Tech. Sc., Professor, Department "Industrial electronics", North-Caucasian Institute of Mining and Metallurgy (State Technological University), 362021, Vladikavkaz, Russia

Ph.: +7(928)982-78-28.

e-mail: bordsamhas@rambler.ru

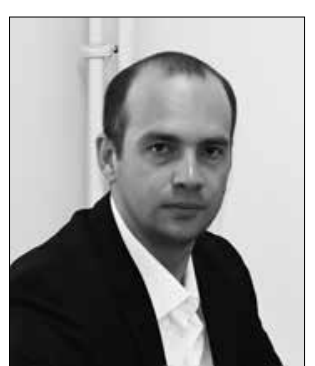

МАСЛАКОВ Максим Петрович - кандидат технических наук, заведующий кафедрой «Промышленная электроника», Северо-Кавказский горно-металлургический институт (государственный технологический университет), 362021, г. Владикавказ, Россия.

Maxim P. MASLAKOV - Candidate of Technical Sciences, head of the Department "Industrial electronics", North-Caucasian Institute of Mining and Metallurgy (State Technological University), 362021, Vladikavkaz, Russia 


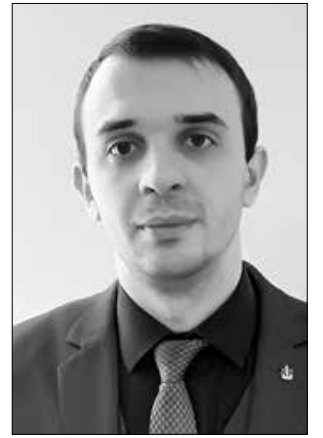

КАРЛОВ Вадим Валерьевич ведущий инженер отдела экспортного контроля, генеральный директор ООО МИП "ИРСОФТ", 362021, г. Владикавказ, Россия.

Vadim V. Karlov - General Director of LTD "IRSOFT", 362021, Vladikavkaz, Russia.

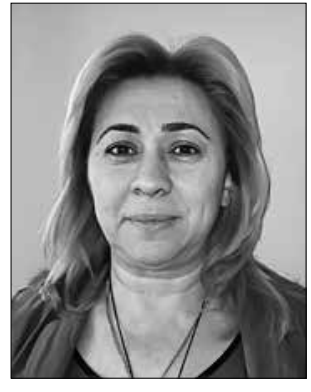

Олисаева Оксана Викторовна - кандидат педагогических наук, профессор, кафедра иностранных языков, Северо-Кавказский горнометаллургический институт (государственный технологический университет), 362021, Владикавказ, Россия.

Oksana V. Olisaeva - Candidate of Pedagogic Sciences, Professor, North-Caucasian Institute of Mining and Metallurgy (State Technological University), 362021, Vladikavkaz, Russia.

\author{
DEVELOPMENT OF AUTOMATED CONTROL SYSTEMS FOR MINING ENTERPRISE \\ B. Dz. Khastsaev* \\ M. P. Maslakov \\ V. V. Karlov \\ O.V. Olisaeva \\ North-Caucasian Institute of Mining and Metallurgy (State Technological University), Vladikavkaz, Russia, \\ e-mail: bordsamhas@rambler.ru \\ DOI: 10.21177/1998-4502-2018-10-4-586-594
}

The aim of the work is to solve one of the important problems of sustainable development of mountain areas, providing for the development of mining enterprises of high-performance, intelligent automated production management systems (ACS P).

The methods used in the work: the method of system analysis, methods of control theory technical objects, methods of mathematical modeling event situations, the method of the theory of fuzzy sets, etc.

The results of the work. Based on the analysis of the literary sources chosen way forward for sustainable development of mountainous areas, providing for the introduction of mining enterprises with the purpose of meaningful ACS P improve both efficiency of production of these enterprises, and improve the environmental well-being of the territories adjacent to the enterprises.

A flowchart of ACS P, as well as structural diagram and operation algorithm of ACS TP with improved functionality were developed. These ACS TP correspond to many conditions and mining development is a significant part of ACS P. Designed for ACS TP the intelligent subsystem elimination of production risks (SEPR), defining emergency situations. The algorithm of action and the functional scheme of this SEPR are offered.

The work is also developed for the information support of ACS TP intelligent data collection system, one of the subtasks of which is the collection of information in digital form from control and measuring devices that perform the function of measuring the parameters of the process at all its stages. The main functions of the developed process control system are defined: identification of the probabilistic reasons causing production risks in technological processes; selection of the best solution to eliminate the current negative situation; selflearning, which predetermines the development of intellectual capabilities of the process control system, which is performed on the basis of fuzzy logic.

An important part of the work is the development of blocks that are part of the SEPR, the development of the structure of their interaction and algorithms for their op- eration. The names of the blocks: a visualization block, the block decision, the processing unit prior decision, the evaluation unit situation unit classification of the situation, "say" about the importance and complexity of the tasks specified blocks.

Conclusions. The main conclusion of this work is the high desirability of introducing developed APCS in mining enterprises to successfully meet the challenges of sustainable development of mountainous areas and infrastructure conservation in mountain regions. Other findings of the work are: the proposed work approaches to ensure the well-being of mountain territories and increased mining operations, including enhancing the safety of workers, apply for enterprises available in plain areas; the design principles of ACS TP, including those involving enhancement of intellectual ability (capacity) of the individual blocks of ACS TP, apply when designing ACS for many industries, with design of ACS for scientific research.

Keywords: mountain territories, sustainable development, mining enterprises, technological process, production risks, accident prevention, automated control system, subsystem of elimination of industrial accidents.

\section{References}

1. Potresov, L. K., Puchkov, D. Fedunets And. Automated control systems in mining Tutorial. Moscow, Nedra, 1987, $285 \mathrm{p}$.

2. Batitsky V. A., Kuroedov V. I., Ryzhkov V. A. Automation of production processes and process control in the mining industry. Textbook. Moscow, Nedra, 1991, 303 p.

3. Tolpezhnikov L. I. Automatic process control of mines. Moscow, Nedra, 1985, 352 p.

4. Batitsky V. A. Automation of production processes and process control in the mining industry/ V. A. batitsky, V. I. Kuroedov, A. A. Ryzhkov. Moscow, Nedra, 1991, 303 p.

5. Vielsietiges Motion Control-System in einem IndustriePC. AT Mineral Processing, 2015, no 6, pp. 52-53.

6. Edwards R., Vien, A. The Strategy of applying instrumentation and automation in the cycles of grinding. Mineral Processing Plant Design, Practice and Control, 
Proceedings of the Symposium. Canada. Vancouver, 20-24 October 2002.

7. Data science and big data analytics: discovering, analyzing, visualizing and presenting data. Indianapolis, Indiana, John Wiley \& Sons, Inc., 2015, 432 p.

8. Rasmuson A., Andersson B., Andersson R., Ollson L. Mathematical Modeling in Chemical Engineering. University Printing House, publ. in the United States of America by University Cambridge Press. New York, 2014, 183 p.

9. Remes A. Advanced Process Monitoring and Control Methods in Mineral Processing Applications. Espoo, Aalto University, 2012. 76 p.

10. Shean B.I., Cillers J.J. A review of froth flotatin control. International Journal of Mineral Processing, 2011, vol. 100, iss. $3-4$, pp. $57-71$.

11. Sbarbaro D., Rene del Villar. Advanced Control and Supervision of Mineral Processing Plant. London, Springer, 2010, $310 \mathrm{p}$.

12. Hodouin D. Methods for automatic control, observation and optimization in mineral processing plants. Journal of Process Control, 2011, vol. 21, iss. 2, pp.211-225.

13. Cohen O., Fedurco E. Fundamentals of the theory of constraints. Tallin, TOC Strategic Solutions, 2012, 331 p.

14. Kubrin S. S., Reshetnyak S. N. Automated informationmeasuring system of technical accounting of electricity for underground mining . Mining journal, 2016, no 1, pp. 87-90.

15. Matveev V. A. The Concept of automated management of flotation practice. Gorny Zhurnal, 2016, no 4, pp. 84-87.

16. Bashkov, D. A., Veselov D. A., Isaev E. A. Experience of ASUTP at the Nikolayevsky concentrator. Mining journal, 2016, no 11, pp. 85-88.
17. Ershov E. E., Isaev E. Improved management of technological processes at mining and processing enterprises: General overview and special software. Mining journal, 2016, no 11 , pp. 89-92.

18. Gazzaev B. D., Jaszai M. B., Antipov K. V. Development of intelligent devices for automated control system of metallurgical enterprise. 6th International scientific conference "Applied Sciences and technologies in the United States and Europe: common challenges and scientific findings", 21 April 2014, New York, pp. 134-137.

19. Gazzaev B. D., Jaszai M. B., Antipov K. V. The Development of intelligent control systems leaching process of zinc. 9-th Conference "European Applied Sciences: modern approaches in scientific researches", Stuttgard, Germany, 2014, pp. 99-103.

20. Gazzaev B. D., Antipov K. V., Minaev V. V. Development of hardware, software and information support of PPAS for ACS enterprises. Collection of scientific works, soo an VSH of the Russian Federation. Vladikavkaz: Terek Publishing House, 2013. no11.

21. Antipov K. V., Gazzaev B. D. Development of system of prevention of emergency situations in the leaching of zinc. Internet journal "Technologies of technospheric safety" (http://ipb.mos.ru/ttb), 2012, no 6 (46), pp. 1-7.

22. Antipov K. V., Khastsaev B. D. Development of algorithms for the subsystem of emergency prevention in the control system of the leaching shop . Electronic scientific journal "Modern problems of science and education", 2013, no 1, pp. 169.

Article received 04.05.2018. 


\section{APPLICATION OF KNOTHE-BUDRYK THEORY AND RIGID BODY CONDITION FOR ASSESSMENT OF SUBSIDENCE}

\section{Introduction}

Mining influences on the surface depend on many factors, like depth and thickness of seams, types of bedrocks and soil, excavation method and soil, the load of constructions [1]. In open pit mines the damages are clearly visible - the soil is removed from the wide areas, the landscape is changed by tonnes of exploitation wastes, the ground water level is lowered, the ground vibrations appear and the pollution of water, ground, and air (dust, noise) around the excavation area [2-5]. In underground mining where some of these problems do not occur, mining dust can be filtered out from the air, the noise level is lower due to the depth, and the damages on the surface are smaller. On the other hand, the area influenced by subsidence is larger due to the depth of excavation, the underground water may be polluted and its level lowered. Also, there appear different types of deformations [1;6-8].

Proper assessment of mining influences and monitoring surface's subsidence is mine surveyors' task. The main goal is to prevent damaging buildings and constructions on the surface, measuring of and restraint upon the inevitable influences of exploitation $[9 ; 10]$ and eliminating existing damages. For many years, scientists have been trying to describe deformation processes with mathematical and empirical models [11-14].

In the beginning, the data was received from classic survey techniques like leveling. Nowadays, more common become the use of state-of-the-art tools like GIS [15], GNSS [16; 17], satellite interferometry [18-20], prediction by artificial neural networks [21] and many others.

The Knothe-Budryk model $[11 ; 12 ; 22]$, with further developments, is one of the most important prediction models in polish mine industry. It describes horizontal and vertical displacements, inclinations and deformations. The Knothe's generalized differential equation for description of subsidence of a point over time was compared with two-parameter Sroka-Schober's model [23] leading to the conclusion that both models have some imperfections. Knothe's model is easier to applied, while the Sroka-Schober's model is better for a description of deformations for pillar-chamber extraction.

The Knothe-Budryk model was applied in numerous case studies. The theory was successfully applied to assess the deformation of the urban area of Bytom city in Poland [24] and horizontal displacements of coal mine BW Prosper Haniel in Germany [25]. Niedojadło, Jura [26] applied the model with fixed parameters for pillar-chamber extraction in LGOM area (Poland). Authors proved the need of changing theory's parameters describing rock mass for a wider observation area.

The constructions, or their isolated parts, are considered as a rigid body after the end of a construction process. However, due to different factors, they may be cracked or bent, and may not be longer considered as a rigid body [27]. Mattern, Blankenhorn [28] have presented the results and the comparisons of building collapse simulation from finite element and rigid body models. Kuras [29] used rigid

\footnotetext{
${ }^{1}$ AGH University of Science and Technology, Kracow, Poland

${ }^{2}$ Hanoi University of Mining and Geology, Hanoi, Vietnam

e-mail: nguyenquoclong@humg.edu.vn
}

${ }^{1}$ Michał M. Buczek, ${ }^{2}$ Nguyen Quoc Long*, ${ }^{2}$ Xuan-Nam Bui, ${ }^{2}$ Hoang Nguyen

\section{УДК: 622.83}

DOI: 10.21177/1998-4502-2018-104-595-605

The objective of this study is to assess the surface subsidence due to mining activities at a study site in Upper Silesia Region (Poland). For this purpose, the geodetic time-series monitoring data was used from the period of 3 years (2009-2012). KnotheBudryk theory was adopted for the influence of underground mining on the subsidence and inclination whereas the rigid body condition method was used to evaluate the stable of buildings. The final inclination values, computed from the rigid body method, are few times bigger than the prediction of the Knothe-Budryk theory. Therefore, we conclude that computation of rigid body condition would be a proper tool to verify the predicted inclinations from deformation models like Knothe-Budryk theory.

\section{KEYWORDS:}

Knothe-Budryk theory, Rigid body condition, subsidence, tensions, reservoirs, Poland 
body method to evaluate deformations of retaining walls due to the weather conditions and the natural use of the object. The rotation of the rigid body is one of the parameters used in the evaluation of damages and the danger to the constructions placed on the mining influence areas [30;31].

The paper's authors present assessment of mining influences on the water reservoirs supplying water to the cities of Upper Silesian Coal Basin (Poland). In this area, the underground coal mining has a long history. For a few centuries, the area of around $5000 \mathrm{~km}^{2}$ has been used to develop coal and metal industry. The industry growth was accompanied by the growth of population and urbanization of those lands [32]. Due to the essential role in the water supply system, the installation cannot be turned off during the excavation process underneath. Despite the mining activity, the reservoirs were still in use during the excavation and subsidence process. Each one of them was emptied and filled up with water few times. In order to assess the mining influence and evaluate the risk the structural health monitoring network was established.

The main objective of this study is to assess the influence of exploitation on the water tanks and evaluate the health of the reservoirs. The computation of rigid body condition was used to determine the stability of concrete monolith construction and to make a conclusion about its further working. In contrast to the aforementioned literature, in this study, the results of rigid body method are used for the verification of the predicted values from KnotheBudryk theory. The authors point no-mining factors, not included in the models, which could negatively be influenced on the object during the deformation process.

\section{Methodology}

\section{Knothe-Burdyk theory}

Land subsidence is a vertical movement (downward) relatively to a datum. In mining areas, it is usually caused by post-excavation voids and abandoned workings. The changes of pressure equilibrium in the rock mass causing the collapse of rocks into the empty spaces. As the result, the deformations appear on the surface [33]. The surface damages caused by excavation of underground coal seams can be divided into the discontinuous and continuous de- formations. The phenomena from the first group appear mostly randomly and they are difficult to predict. The phenomena from the second group are easier to predict due to their clear correlation with mining activity. Scientists have been researching the problem of mathematical description of continuous deformations.

In Upper Silesia Coal Basin, excavation was conducted with longwall mining system. The longwall is the working face advancing laterally towards the mine boundary. The excavation takes place in the narrow open strip (face working) between mined-out seam (goaf) and the coalface. Space is protected against roof falls by an array of vertical props capped with horizontal bars, or by composite supports having broader roof canopies [1].

Budryk and Knothe [22] created the subsidence theory, especially for the Upper Silesia region. In order to compute the maximal predicted subsidence $W_{\max }$, one has to know the thickness of excavating seam $g$, and exploitation parameter $a$ (values between 0 and 1).

$$
W_{\max }=a^{*} g \text {. }
$$

The maximal area of exploitation influences contains mining area and area in the influence range of exploitation $r$ (Figure 1). To compute the range $r$ (Eq. 2), one has to know the depth of seam $h$, and the rock mass parameter $\tan (\beta)$ (where $\beta$ is the angle of main influences). With known values of maximal subsidence $W_{\max }$ and range $r$, one can compute the inclination $T$ (Eq. 3 ) in the distance $x$ from the edge of exploited seam.

$$
\begin{gathered}
r=\frac{h}{\operatorname{tg} \beta}, \\
T=\frac{W_{\max }}{r} e^{-\pi \frac{x^{2}}{r^{2}}} .
\end{gathered}
$$

For standard geological conditions of Upper Silesia Coal Basin, the assumption of $\tan (\beta)=2$ is usually made. With known parameters of exploitation and empirical values of subsidence, one can determine, if exploitation is the only cause of displacements. If the real values of subsidence are bigger than theoretical ones, then one can assume there is more than one cause of deformations. This theory assumes that above the sidewall of longwalls, subsidence

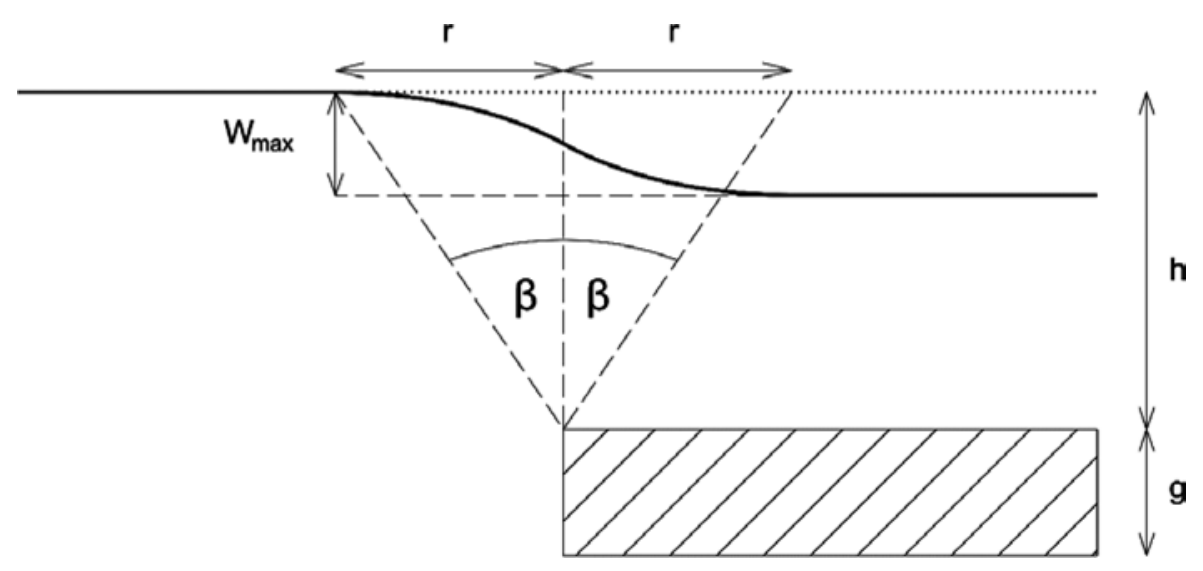

Fig.1. Parameters of the Knothe-Budryk Theory / Puc. 1. Параметры теории Кнота-Будрика 
occurs only the half of maximal predicted descending. In addition, in this area, maximal inclination appears. In the neighborhood, maximal tensions also occur (extending and compressing forces). Thus, to protect the constructions on the surface in the proper way, they should be located outside the area of the range of exploitation. Buildings inside the range of exploitation area are endangered by tensions and uneven subsidence causes inclination.

\section{Rigid body condition method}

Buildings in the mining areas are endangered with damages caused by uneven subsidence of ground under them. Despite vertical movements, there are also horizontal movements causing tensions in the ground (extension and compression). As the result, the construction can change its shape. To prevent from cracking, different building techniques are applied, like expansion joints and separated foundations. The goal is to raise construction from smaller objects considered as rigid bodies. The rigid body's shape remains unchanged in time, and its elements cannot move against each other.

External tensions can violate the stability of the rigid body. In order to check the rigid body condition, surveyors conduct different kinds of measurements. As the result, the geometrical features of the measured object are established. With a few series of observations, one can compute the changes in shape with time. If the changes are smaller than boundary value (tolerance), then the rigid body condition is met. Otherwise, the object cannot be considered as a rigid body.

Before deformation process, the building can be considered as the rigid body. If the surface is lowering uniformly, all points of the object are lowering in the same way and one is able to calculate the mathematical plane for them. It can be described using the least square method. In the matrix $A$, each row contains control point's $X$ and $Y$ coordinates. The matrix $L$ contains deformation values for each control point correspondingly to matrix $A$ [27].

$$
\begin{gathered}
\left|\begin{array}{ccc}
\mathrm{X}_{1} & \mathrm{Y}_{1} & 1 \\
\mathrm{X}_{2} & \mathrm{Y}_{2} & 1 \\
\mathrm{X}_{3} & \mathrm{Y}_{3} & 1 \\
\cdots & \cdots & \cdots \\
\mathrm{X}_{\mathrm{n}} & \mathrm{Y}_{\mathrm{n}} & 1
\end{array}\right|\left|\begin{array}{c}
\Delta \\
\Delta \mathrm{L}_{1} \\
\Delta \mathrm{L}_{2} \\
\Delta \mathrm{L}_{3} \\
\cdots \\
\Delta \mathrm{L}_{\mathrm{n}}
\end{array}\right| \begin{array}{c}
\boldsymbol{X} \\
\mathrm{E}_{\mathrm{X}} \\
\mathrm{E}_{\mathrm{Y}} \\
\mathrm{W}_{\mathrm{C}}
\end{array} \mid \\
\quad X=\left(A^{\mathrm{T}} A\right)^{-1} * A^{\mathrm{T}} L
\end{gathered}
$$

The least mean square method (Eq. 4 ) is used to compute the result matrix $X$. The matrix $X$ contains values of plane inclination in directions $X\left(E_{X}\right)$ and $Y\left(E_{Y}\right)$, and the coordinates system origin point's subsidence $\left(W_{C}\right)$. Therefore, all computations should be conducted in the local coordinate system. The computed values are relative to the beginning plane before the deformation process. The first two values can also be assumed as the rotation $R$ around axes $X$ and $Y$ (Eq. 5). Using those two values one can calculate maximal inclination $E_{\max }$ (Eq. 6) and its azimuth $A z_{\text {Emax }}$ (Eq. 7).

$$
\begin{gathered}
\left\{\begin{array}{l}
R_{X}=-E_{X} \\
R_{Y}=-E_{Y}
\end{array}\right. \\
E_{\text {max }}=\sqrt{E_{X}^{2}+E_{Y}^{2}} . \\
A z_{\text {Emax }}=\tan ^{-1}\left(\frac{E_{Y}}{E_{X}}\right) .
\end{gathered}
$$

\section{Statistical measure}

Using equation 8 the differences between real values of displacement and theoretical ones are computed. The accuracy of the models is measured using the standard deviation (Eq. 9) of the least square method and the variance-covariance matrix (Eq. 10), where $n$ is the number of observations and $u$ is the number of the computed parameters. The variances of the observations are along the covariance matrix diagonal.

$$
\begin{gathered}
V=A X-L . \\
\mathrm{m}_{0}=\sqrt{\frac{\sum \mathrm{V}^{2}}{\mathrm{n}-\mathrm{u}}} . \\
\operatorname{Cov}(\mathrm{X})=m_{0}^{2} \cdot\left(A^{\mathrm{T}} A\right)^{-1} .
\end{gathered}
$$

The value $m_{\mathrm{o}}$ is compared with the boundary value multiplied by the statistical significance value $k(k=2$ for $P=95.5 \%, k=3$ for $P=99,7 \%$ ). If the value $m_{0}$ is bigger, the object cannot be considered as a rigid body anymore. The different points of object do not behave in a linear way and move against each other.

\section{Description of the study site and the data used}

\section{The coal exploitation before reservoirs' construction}

Coal seams under reservoirs were excavated several times during the years. From the middle of XIX century shallow seams were exploited (depths around $60 \mathrm{~m}$ ). Some years before constructing works, there were also excavated seams on depth around $90 \mathrm{~m}, 150 \mathrm{~m}$, and $370 \mathrm{~m}$ in the longwall system. Before putting reservoirs into operation, the deformation process has already ended. Thus, one can assume that the construction was not influenced by the previous mining activities. For the next decades, water tanks had not been monitored due to the lack of mining works underneath.

The coal exploitation after reservoirs' construction

After the year 2000, a new exploitation in the longwall system (lwA) was designed on the depth up to $400 \mathrm{~m}$. The distance to the reservoirs from the closest point was not smaller than $200 \mathrm{~m}$. Thus, the object was placed on the borderline of excavation's mining influences area and the influences are negligible.

The exploitation of the two next seams was planned as follows: the sidewall of the next longwall $(\mathrm{lwB})$ was placed exactly under one of the reservoirs, and close to the others. The third longwall (lwC) was planned to run under the whole object. As the result, the influence on the object was unambiguous and inevitable. 
Object and the health monitoring network

Each of six reservoirs is based on the concrete monolith foundation. The constructions' walls are made out of a reinforced concrete and according to the project could be considered as a monolith.

In order to assess the water tanks' stability, a monitoring network was established. It contained control network points, ground benchmarks, benchmarks on the buildings, inclinometers and control points on the pillars of buildings. Measurements were conducted with $1 \mathrm{~mm}$ accuracy. The measurements were taken every two weeks, and during the period of biggest deformations, even more often. 24 benchmarks were used to monitor water tanks (four on each of buildings).

\section{Results}

Mining influence assessment using the KnotheBudryk Theory

The excavation parameters used in Knothe-Budryk theory were presented in Table 1 (with rock mass parameter $\tan (\beta)=2$ ). The distances to the furthest water tank were almost $200 \mathrm{~m}$. According to the predictions of Knothe-Budryk theory (Table 1), all water tanks were in the influence range of exploitation lwB. The exploitation of $1 \mathrm{wB}$ was conducted around $300^{\text {th }}$ day after the beginning of survey observations.

The longwall $1 w C$ was designed under reservoirs and parallel to the lwB. During the mining works on lwC, the influences of $1 w B$ had appeared on the surface and damaged unequally the construction. The damages and further danger to the water tanks resulted in a decision to stop exploitation $1 \mathrm{wC}$ around 1100 day of observations. Its parameters in the moment of abandon are presented in table 1 .

The described object was in the influence area of two longwalls ( $1 w B$ and $1 w C)$. Figure 2 depicts localization of object and exploitation fields. For both excavations, the water tanks were placed in the incline and tensions occurring area.

The displacements and tensions were revealed on all elements of the structural health monitoring network. Figure 3 depicts subsidence of benchmark on the wall of one of the reservoirs. Dotted line presents the moment of exploitation $\mathrm{lwB}$ under the water tanks, and dashed line denotes the moment of stopping lwC. The displacements of the benchmark are distributed randomly before the mining works. After mining excavation, the points lowered up to around $0.5 \mathrm{~m}$. In the end, the distribution once again is random. The first subsidence caused damages on the construction. Due to these damages, the decision to stop lwc was made to prevent from escalating the danger. Thus, the influence of lwc have not revealed on all the control points of the monitoring network.

For each water tank, the maximal subsidence $W_{\max }$ and distance to excavated seam $x$ were found and used to compute the inclination $T_{x}$ (Eq. 3). The results are presented in Table 2. The maximal theoretical inclination $T_{\max }$ was computed to compare with the results of rigid body method. All computations were conducted in local coordinate space, separate for each water tank. The center point $(0,0,0)$ was placed in the middle point of the construction (Fig. 2 - black dots), and axes were directed to benchmarks n-2 (north) and n-3 (east), where $\mathrm{n}$ is the number of a water tank.

\section{Result of Health of buildings evaluation using the rigid body condition method}

The rigid body condition was calculated in the local coordinate system with the beginning at the center of each water tank. The boundary error $m_{u}$ was assumed as the mean error of accuracy of measurements. The parameters of space orientation (rotation, inclination, inclination's azimuth) were computed for each water tank in succeed-

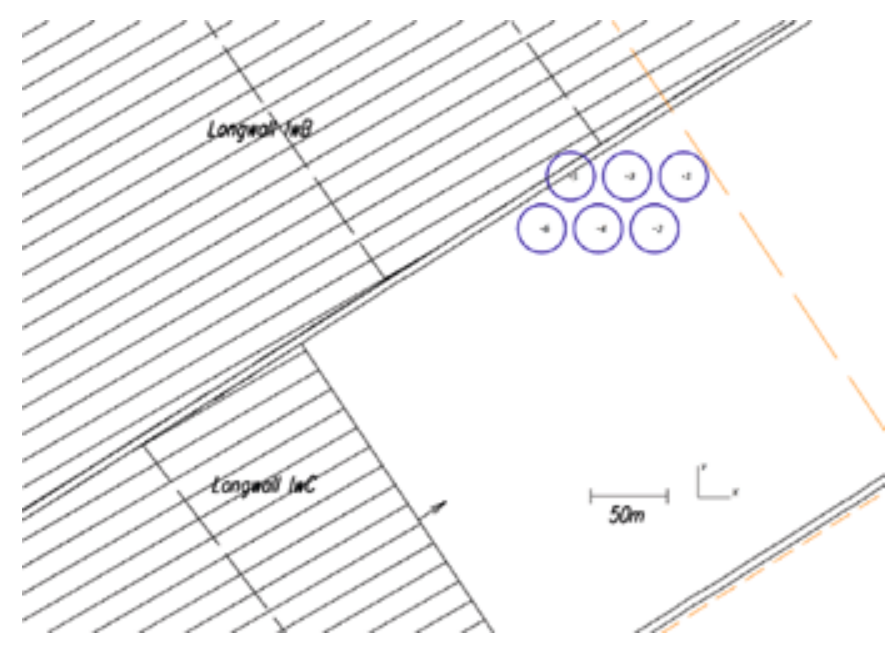

Fig. 2. Localization of reservoirs (blue) on the plan of coal exploitation and influence range (lwB - short dashed line, lwC-long dashed line)

Pис. 2. Локализация коллекторов (синий) по плану эксплуатации угля и диапазон воздействия (lwB - короткая пунктирная линия, lwC - длинная пунктирная линия)

Table 1 / Таблица 1

The parameters of excavation and the results of Knothe-Budryk Theory Параметры раскопок и результаты теории Кноте-Будрика

\begin{tabular}{c|c|c|c}
\hline \multirow{2}{*}{ ID } & $\begin{array}{c}\text { Depth, } \mathbf{m} \\
\text { Глубина, } \boldsymbol{M}\end{array}$ & $\begin{array}{c}\text { Influence range, } \mathbf{m} \\
\text { Диапазон влияния, } \boldsymbol{M}\end{array}$ & $\begin{array}{c}\text { Distances to reservoirs, } \mathbf{m} \\
\text { Расстояние до резервуаров, } \boldsymbol{M}\end{array}$ \\
\hline lwA & $\sim 400$ & $\sim 200$ & $>200$ \\
lwB & $\sim 570$ & $\sim 285$ & $0-200$ \\
lwC & $\sim 570$ & $\sim 285$ & $>150$ \\
\hline
\end{tabular}




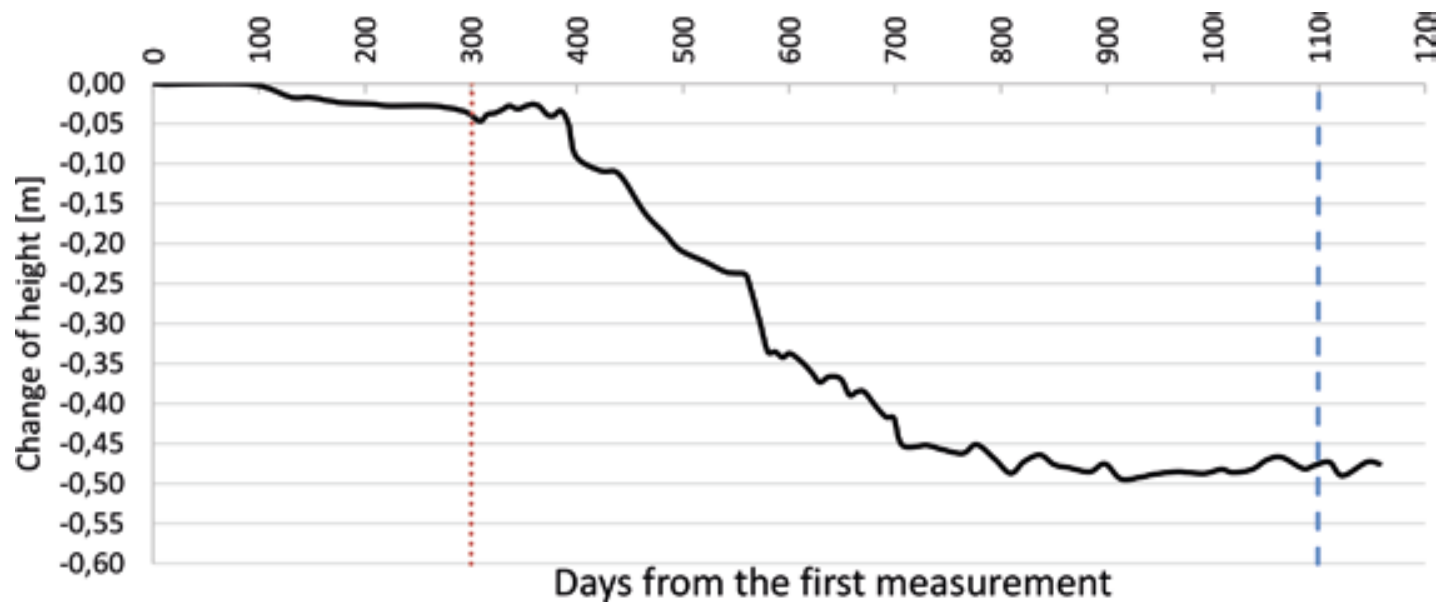

Fig. 3. Subsidence of benchmark 1-1 / Puc. 3. Оседание уровня 1-1

Maximal inclinations of each water tank for lwB and lwC

Table 2 / Таблиия 2 Максимальные наклоны каждого резервуара для воды для lwB и lwC

\begin{tabular}{c|c|c|c|c|c|c}
\hline \multirow{2}{*}{$\begin{array}{c}\text { Tank num. } \\
\text { № резервуара }\end{array}$} & \multirow{2}{*}{$W_{\max }[\mathbf{m}]$} & $T_{\max }[\mathbf{m m} / \mathbf{m}]$ & \multicolumn{2}{|c|}{$\mathbf{l w} B$} & \multicolumn{2}{|c}{ lwC } \\
\cline { 4 - 7 } & -0.41 & -1.45 & 46.3 & -1.33 & 267.5 & -0.09 \\
\hline 1 & -0.37 & -1.30 & 65.0 & -1.10 & 233.0 & -0.16 \\
2 & -0.57 & -2.00 & 26.6 & -1.94 & 237.0 & -0.23 \\
3 & -0.52 & -1.83 & 45.4 & -1.69 & 202.4 & -0.37 \\
4 & -0.73 & -2.57 & 7.0 & -2.56 & 206.4 & -0.49 \\
5 & -0.67 & -2.35 & 25.7 & -2.29 & 171.8 & -0.75 \\
\hline
\end{tabular}

Table 3 / Таблицча 3

Parameters of space orientation for reservoirs (series 77)

Параметры пространственной ориентации водохранилищ (серия 77)

\begin{tabular}{|c|c|c|c|c|c|c|c|c|c|c|c|c|}
\hline \multirow[b]{2}{*}{ Series 77 / Серия 77} & \multicolumn{2}{|c|}{$\begin{array}{c}\text { Tank 1 } \\
\text { Резервуар 1 }\end{array}$} & \multicolumn{2}{|c|}{$\begin{array}{c}\text { Tank } 2 \\
\text { Pезервуар } 2\end{array}$} & \multicolumn{2}{|c|}{$\begin{array}{c}\text { Tank } \mathbf{3} \\
\text { Резервуар } 3\end{array}$} & \multicolumn{2}{|c|}{$\begin{array}{c}\text { Tank } 4 \\
\text { Pезервуар } 4\end{array}$} & \multicolumn{2}{|c|}{$\begin{array}{c}\text { Tank } 5 \\
\text { Pезервуар } 5 \\
\end{array}$} & \multicolumn{2}{|c|}{$\begin{array}{c}\text { Tank } 6 \\
\text { Pезервуар } 6\end{array}$} \\
\hline & \begin{tabular}{|c|} 
Value \\
величи- \\
на \\
\end{tabular} & $\begin{array}{c}\text { Dev. } \\
\text { погрешн }\end{array}$ & \begin{tabular}{|c|} 
Value \\
величи- \\
на \\
\end{tabular} & $\begin{array}{c}\text { Dev. } \\
\text { погрешн. }\end{array}$ & \begin{tabular}{|c|} 
Value \\
величи- \\
на \\
\end{tabular} & $\begin{array}{c}\text { Dev. } \\
\text { погрешн. }\end{array}$ & \begin{tabular}{|c|} 
Value \\
величи- \\
на \\
\end{tabular} & $\begin{array}{c}\text { Dev. } \\
\text { погрешн. }\end{array}$ & $\begin{array}{c}\text { Value } \\
\text { величина }\end{array}$ & $\begin{array}{c}\text { Dev. } \\
\text { погрешн }\end{array}$ & $\begin{array}{c}\text { Value } \\
\text { величина }\end{array}$ & $\begin{array}{c}\text { Dev. } \\
\text { погрешн }\end{array}$ \\
\hline $\begin{array}{c}\text { Center point } \\
\text { subsidence, mm / По- } \\
\text { нижение централь- } \\
\text { ной точки, мм }\end{array}$ & -403.7 & 0.7 & -333.3 & 13.3 & -539.3 & 3.7 & -489.0 & 5.0 & -690.5 & 12.5 & -639.5 & 0.5 \\
\hline $\begin{array}{l}\text { Rotation around axis } \\
X, \mathrm{~mm} / \mathrm{m} / \text { Врамение } \\
\text { вокруг оси } X, \text { мм/м }\end{array}$ & 2.54 & 0.06 & 2.02 & 1.096 & 2.310 & 0.31 & 3.45 & 0.41 & 5.146 & 1.034 & 1.696 & 0.04 \\
\hline $\begin{array}{l}\text { Rotation around axis } \\
\text { Y, mm/m / Вращчение } \\
\text { вокруг оси Y, мм/м }\end{array}$ & -4.44 & 0.06 & -4.33 & 1.09 & 2 & 0.31 & -4.91 & 0.41 & -4.56 & 1.03 & -4.56 & 0.04 \\
\hline $\begin{array}{c}\text { Inclination in axis } X \text {, } \\
\mathrm{mm} / \mathrm{m} / \text { Склонность } \\
\text { в оси } Х, м м / м\end{array}$ & -2.54 & 0.06 & -2.02 & 1.09 & -2.31 & 0.31 & -3.45 & 0.41 & -5.15 & 1.03 & -1.69 & 0.04 \\
\hline $\begin{array}{c}\text { Inclination in axis } Y \text {, } \\
\mathrm{mm} / \mathrm{m} / \text { Склонность } \\
\text { в оси } Y, м м / м\end{array}$ & 4.44 & 0.06 & 4.33 & 1.09 & 3.22 & 0.31 & 4.91 & 0.41 & 4.56 & 1.03 & 4.56 & 0.04 \\
\hline $\begin{array}{l}\text { Overall inclination, } \\
\mathrm{mm} / \mathrm{m} / \text { Полная } \\
\text { склонность, мм/м }\end{array}$ & 5.12 & 0.01 & 4.78 & 0.23 & 3.96 & 0.08 & 6.00 & 0.07 & 6.88 & 0.15 & 4.87 & 0.01 \\
\hline $\begin{array}{l}\text { Inclination azimuth, } \\
\text { grads / Азимут } \\
\text { склонности, гради- } \\
\text { ент }\end{array}$ & 366.90 & 0.74 & 372.23 & 14.61 & 360.35 & 4.99 & 361.02 & 4.39 & 346.17 & 9.57 & 377.34 & 0.54 \\
\hline
\end{tabular}




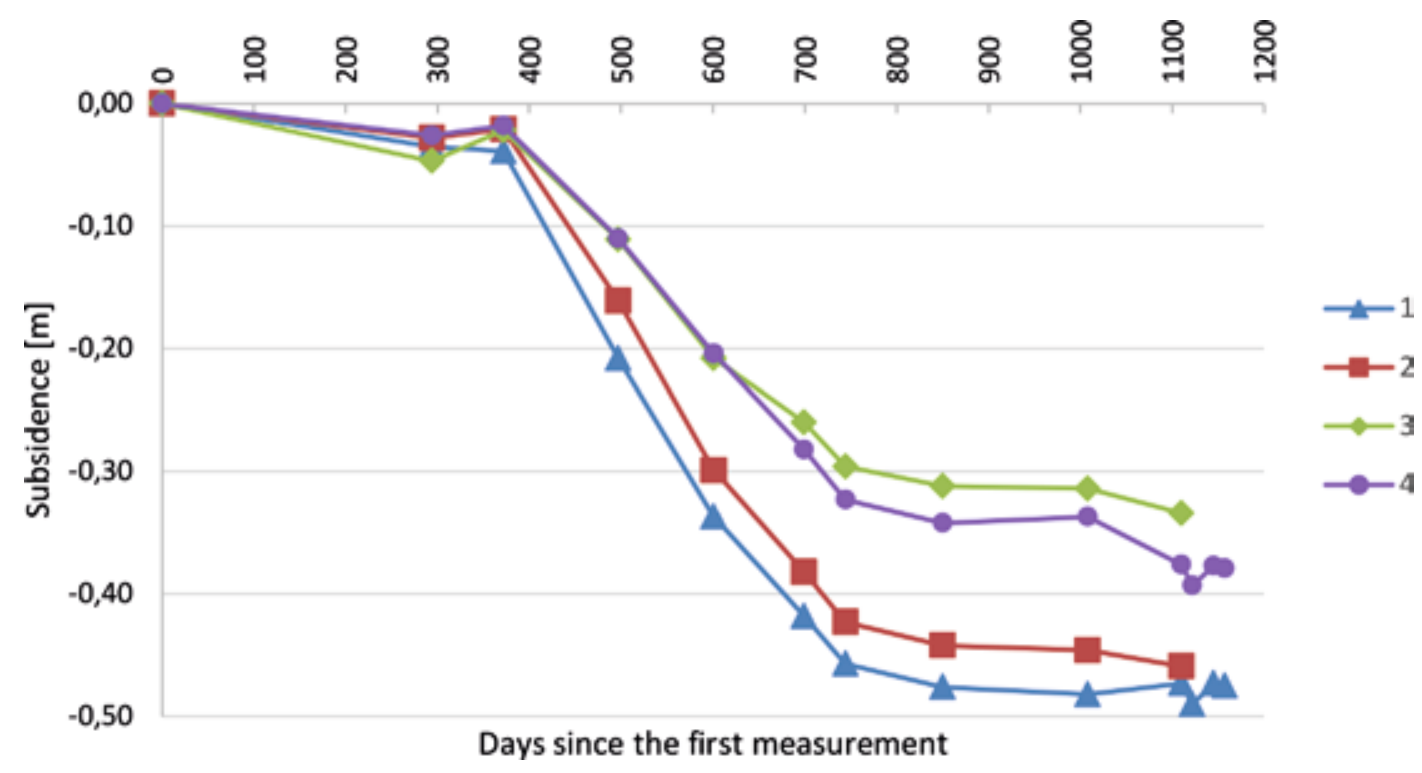

Fig. 4. Averaged subsidence of benchmarks on the 1st water tank

Pис. 4. Усредненная просадочность уровней на 1 резервуаре для воды

ing series. The example for the series 77 is presented in Table 3 .

For comparison, three measurement series were picked up. The series 7 was made on 179 days after the beginning of observation, but still before the start of exploitation lwB. Series 42 was made on 613 days, during the period of the fastest subsidence, and series 77 on 1085 day, when the process of lowering was almost over.

The parameters of planes for each water tank were used in the computation of the differences between theoretical and real values of vertical displacements, and the mean errors $m_{0}$. The results for the series 7, 42 and 77 are presented in Table 4 . The fulfilled rigid body conditions are marked in gray.

\section{Discussions}

The trend for all benchmarks is the same - pairs of point 1-2 and 3-4 are lowering with different speed, but with similar to each other. In the other words - points 1 and 2 are lowering faster than 3 and 4 . Figure 4 presents these phenomena. As a result, all constructions inclined in direction of line 4-1 (north-east), the $1^{\text {st }}$ water tank in about $0^{\circ} 21.3$ '. Figure 5 presents localization of benchmarks on the reservoirs, the final subsidence of them presented with Kriging interpolation.

The direction of contour lines is approximately parallel to the sidewalls of longwalls lwB and lwC. The computed parameters of mathematical planes for each reservoir confirm these observations. Table 2 presents the maximal values of inclination of objects computed using the KnotheBudryk theory.

This inclination and subsidence are clearly caused by exploitation of $1 \mathrm{wB}$. The influences of $1 \mathrm{wC}$ could elimi-

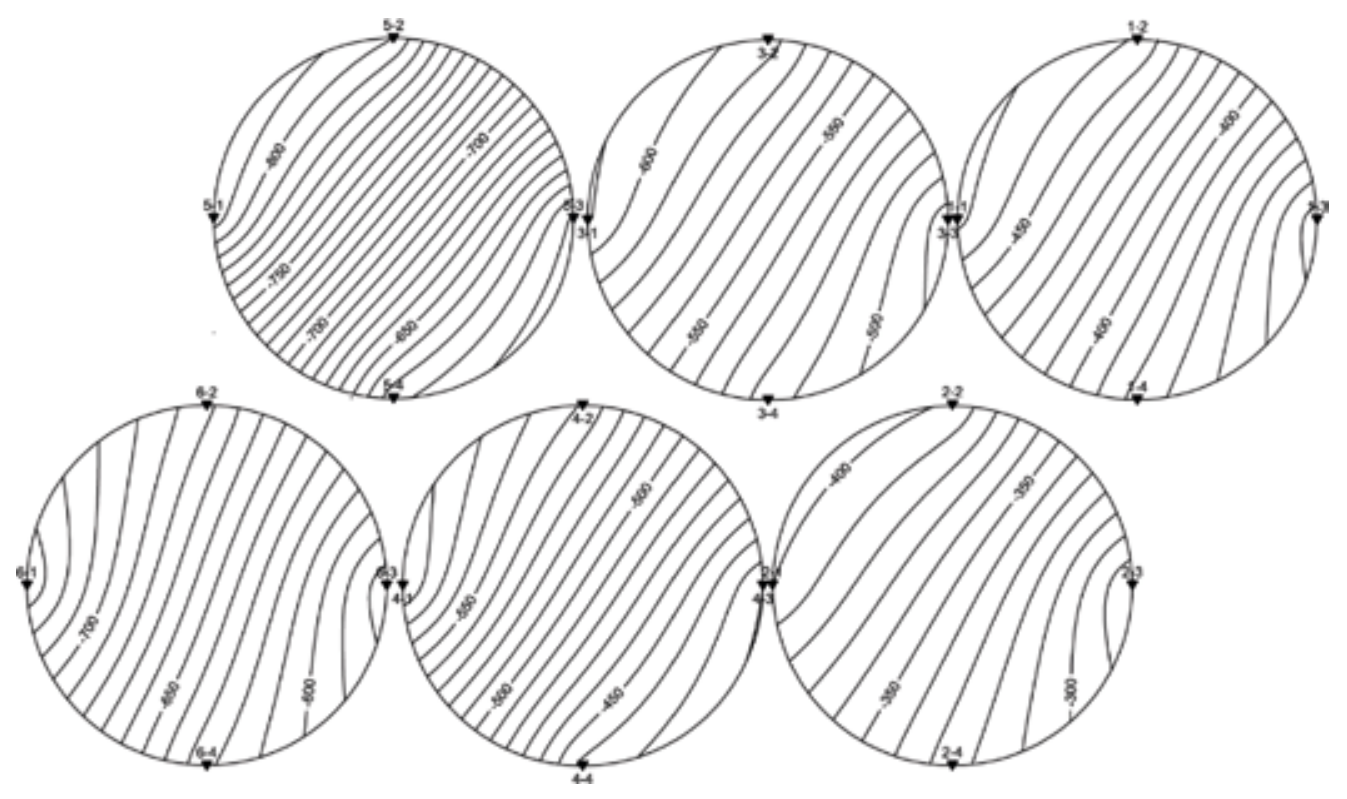

Fig. 5. Final subsidence contours (Kriging method) with localization of benchmarks (values in millimeters)

Pис. 5. Контуры окончательного оседания (метод Кригинга) с локализачией уровней (в миллиметрах) 
Table 4 / Таблица 4

The rigid body condition (parameter $k=2$ and $k=3$ ) with $m_{0}$ error for series 7, 42 and 77

Состояние твердого тела (параметр $k=2$ и $k=3$ ) с ошибкой $m_{0}$ для рядов 7, 42 и 77

\begin{tabular}{|c|c|c|c|c|c|c|}
\hline $\begin{array}{l}\text { Series } 7 \\
\text { Серия } 7\end{array}$ & $\begin{array}{c}\text { Tank } 1 \\
\text { Резервуар1 }\end{array}$ & $\begin{array}{c}\text { Tank } 2 \\
\text { Резервуар } 2\end{array}$ & $\begin{array}{c}\text { Tank } 3 \\
\text { Резервуар3 }\end{array}$ & $\begin{array}{c}\text { Tank } 4 \\
\text { Резервуар } 4\end{array}$ & $\begin{array}{c}\text { Tank } 5 \\
\text { Peзервуар } 5\end{array}$ & $\begin{array}{c}\text { Tank } 6 \\
\text { Резервуар } 6\end{array}$ \\
\hline$m_{0}$ & 2.31 & 1.00 & 9.00 & 2.00 & 0.50 & 2.50 \\
\hline $2 m_{\mathrm{u}}$ & 2.83 & 2.83 & 2.83 & 2.83 & 2.83 & 2.83 \\
\hline $3 m_{\mathrm{u}}$ & 4.24 & 4.24 & 4.24 & 4.24 & 4.24 & 4.24 \\
\hline $\begin{array}{l}\text { Series } 42 \\
\text { Серия } 42\end{array}$ & $\begin{array}{c}\text { Tank } 1 \\
\text { Резервуар } 1\end{array}$ & $\begin{array}{c}\text { Tank } 2 \\
\text { Резервуар } 2\end{array}$ & $\begin{array}{c}\text { Tank } 3 \\
\text { Резервуар } 3\end{array}$ & $\begin{array}{c}\text { Tank } 4 \\
\text { Резервуар } 4\end{array}$ & $\begin{array}{c}\text { Tank } 5 \\
\text { Резервуар } 5\end{array}$ & $\begin{array}{c}\text { Tank } 6 \\
\text { Резервуар } 6\end{array}$ \\
\hline$m_{0}$ & 12.12 & 2.00 & 2.50 & 17.50 & 2.50 & 2.00 \\
\hline $2 m_{\mathrm{u}}$ & 2.83 & 2.83 & 2.83 & 2.83 & 2.83 & 2.83 \\
\hline $3 m_{\mathrm{u}}$ & 4.24 & 4.24 & 4.24 & 4.24 & 4.24 & 4.24 \\
\hline $\begin{array}{l}\text { Series } 77 \\
\text { Серия } 77\end{array}$ & $\begin{array}{c}\text { Tank } 1 \\
\text { Pезервуар 1 }\end{array}$ & $\begin{array}{c}\text { Tank } 2 \\
\text { Резервуар } 2\end{array}$ & $\begin{array}{c}\text { Tank } 3 \\
\text { Резервуар } 3\end{array}$ & $\begin{array}{c}\text { Tank } 4 \\
\text { Резервуар } 4\end{array}$ & $\begin{array}{c}\text { Tank } 5 \\
\text { Peзервуар } 5\end{array}$ & $\begin{array}{c}\text { Tank } 6 \\
\text { Резервуар } 6\end{array}$ \\
\hline$m_{0}$ & 1.44 & 26.50 & 7.50 & 10.00 & 25.00 & 1.00 \\
\hline $2 m_{\mathrm{u}}$ & 2.83 & 2.83 & 2.83 & 2.83 & 2.83 & 2.83 \\
\hline $3 m_{\mathrm{u}}$ & 4.24 & 4.24 & 4.24 & 4.24 & 4.24 & 4.24 \\
\hline
\end{tabular}
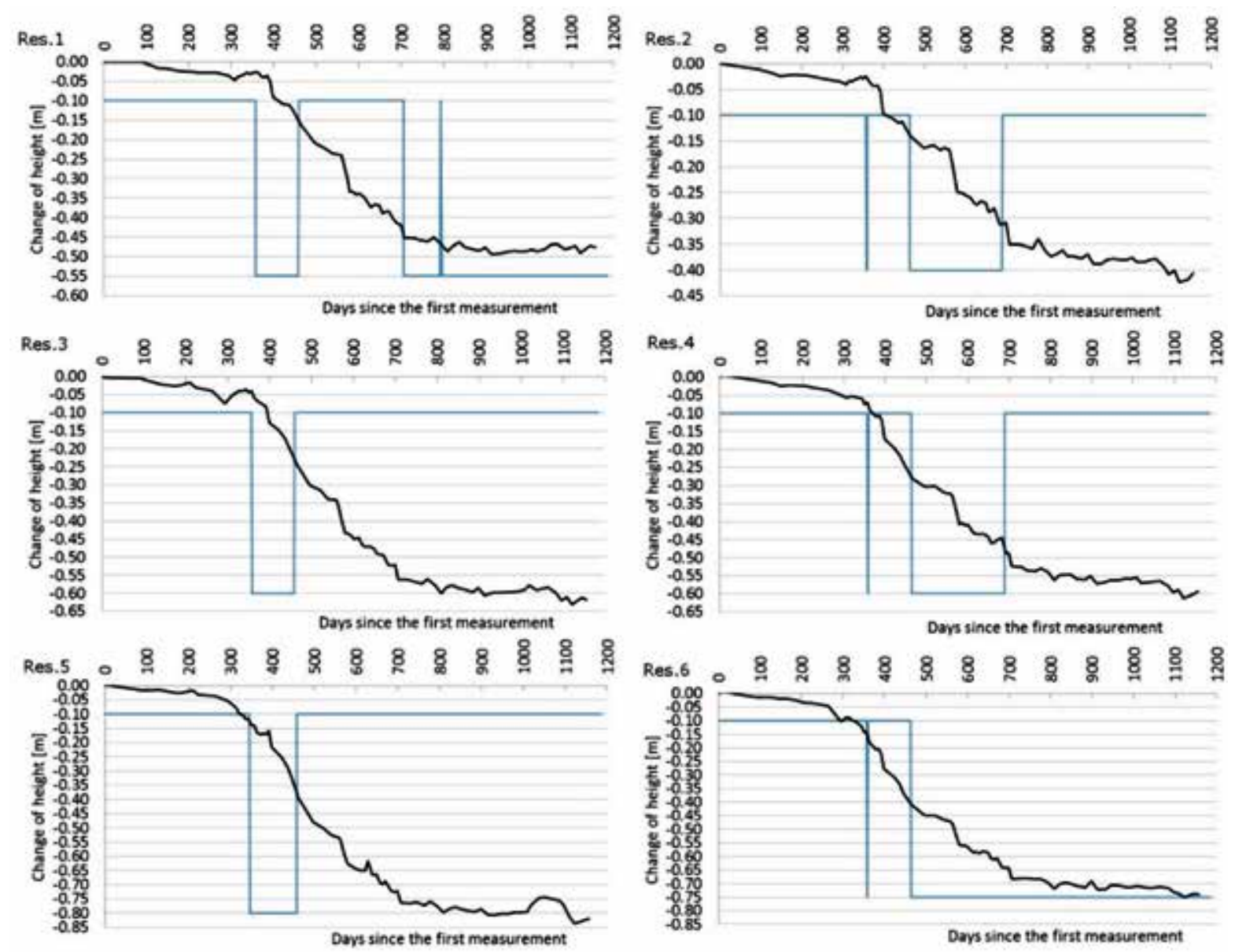

Fig. 6. Periods of filling up (blue line) water tanks with subsidence of benchmarks on each reservoir Pис. 6. Периоды заполнения (голубая линия) резервуаров для воды с просадкой уровней на каждом резервуаре 
nate them if the works did not stop before going underneath the buildings. However, due to the abandoning of $1 w C$, constructions remained inclined. In addition, some of the lwC's influences occurred on the water tanks, are closest to the lwC. The 6 th water tank started to incline in direction of line 3-4 (south-west).

The theoretical inclination values from the Knothe- $\mathrm{Bu}-$ dryk theory are a few times smaller than the overall inclination values computed from the rigid body method (e.g. for the series 77 in Table 3). Even the maximal theoretical values still do not present the observed scale of the phenomena. Thus, this theory cannot be applied to all objects and conditions to predict inclinations. This can be also a clue, that the mining factor is not the only one influencing the object, and the observations of subsidence are not enough.

The results between the series may differ due to the different speed of lowering as well as the errors made during the measurements. Thus, to establish the rigid body condition, the computations were conducted for the different series. The final values for three example series, 7,42 and 77, are presented in Table 4.

The series 7 was conducted before the excavation under the reservoirs. Almost all results are positive, only the results for the $3^{\text {rd }}$ water tank are negative. However, other measurement series from that period give positive values for that building as well. One can assume that all objects can be considered as the rigid bodies.

The series 42 was conducted during the period of the fastest displacements. The condition of the rigid body is fulfilled only by some objects. Depending on the series from that period of time, the objects sometimes meet the condition, and sometimes not. Despite the measurements errors, it can mean that buildings are no longer the rigid bodies.

The series 77, in the end of the subsidence process, reveals that almost all constructions were damaged and cannot be longer considered as rigid bodies, most of the results are negative. This can be considered as an assumption for further investigation of construction. For series 77 only $5^{\text {th }}$ reservoir fulfills the rigid body condition and $6^{\text {th }}$ fulfills for $\mathrm{k}=3$, and almost for $\mathrm{k}=2$. But with other series from that period, one cannot confirm the buildings are still rigid bodies.

During the exploitation and subsidence process, the reservoirs were fully operational. In different times, they were filled up with water and emptied. Figure 6 presents periods of filling up water tanks. One can notice, that short after water release the subsidence doesn't occur or slower down (around days 350, 700 and 800). Around day 400 , the first vertical movements are revealed. Highly recommended, and inevitable was to refill the tanks during the period of lowering movements. The influence of installation working (mass changes, the pressure of water on the reservoirs' walls) wasn't considered during the planning of exploitation, and in the displacement's measurements. The lack of data and scientific knowledge makes it impossible to establish only the influence of mining activity on reservoirs in case of occurrence of filled up/emptied factors.

The differences in the rigid body parameters between series can be caused by uneven vertical movements caused by stopping $1 w C$, the work of reservoirs (filling up and emptying) during the process of deformation, damaging the control points and measurements errors and mistakes.

\section{Concluding remarks}

checking the condition of a rigid body on the object can bring information about the influence of underground exploitation on the buildings and installations on the surface. Due to the tensions constructions, may not remain rigid bodies. For the presented constructions results suggest, that all buildings were damaged. They will demand further inspection and repairs if they remain in working.

The reservoirs were lowering uneven due to the mistakes in the process of excavation. If lwC wasn't stopped in front of the object, the surface subsidence would be made even again. In another way, the constructions remained inclined in the direction north-west (to the $1 \mathrm{wB}$ ) and slightly to the south-west (lwC). Inclination can have further negative results due to future work of object e.g. damage caused by bigger water pressure only on the part of walls.

In the excavation with longwall system under the building important is to consequently remove a similar thickness of seams. In another way, it causes horizontal movements and tensions, causing bigger damages of the structures on the surface. The presented object was in the zone of extending movements. If the longwall $\mathrm{C}$ was finished, according to the plan, the whole object would be in the area free of tensions, with surface lowering equally.

The discrepancy of theoretical and practical values of inclination suggest investigating other factors during the subsidence process. One of them could be the changing mass of construction during the subsidence process due to filling/emptying with water. Stopping the use of reservoirs for the period of mining works and deformation process could help in preventing the occurrence of damages. Unfortunately, there are no plans for next excavations in this area due to the existing damages. 


\section{ACKNOWLEDGEMENT / Благодарности}

This research was fund by the European Community Action Scheme for the Mobility of University Students (ERASMUS); Department of Mine Surveying and Department of Surface Mining (Hanoi University of Mining and Geology) and The Katowicki Holding Węglowy SA (Poland).

\section{CONFLICT OF INTEREST / Конфликт интересов}

The authors declare that there is no conflict of interest / Авторы заявляют об отсутствии конфликта интересов.

\section{REFERENCES:}

1. Kratzsch, H. Mining subsidence engineering. 2012, Springer Science \& Business Media.

2. Hustrulid, W.A., M. Kuchta, and R.K. Martin. Open Pit Mine Planning and Design, Two Volume Set \& CD-ROM Pack. 2013, CRC Press.

3. Kahriman, A., et al. Environmental impacts of bench blasting at Hisarcik Boron open pit mine in Turkey. Environmental geology, 2006. 50(7), pp. 1015-1023.

4. Golik, V.I., Y.I. Razorenov, and K.G. Karginov. The basis of sustainable development of North Ossetia-Alania is the mining industry. Sustainable development of mountain territories, 2017, 9(2(32)), pp. 163-172.

5. Borshchevsky, S., et al. Prospects for extraction of metals from mine drains. Sustainable development of mountain territories, 2017, 9(1), pp. 81-92.

6. Altun, A.O., I. Yilmaz, and M. Yildirim. A short review on the surficial impacts of underground mining. Scientific research and essays, 2010, 5(21), pp. 3206-3212.

7. Tiwary, R. Environmental impact of coal mining on water regime and its management. Water, Air, and Soil Pollution, 2001, 132(1-2), pp. 185-199.

8. Younger, P.L. Mine water pollution in Scotland, nature, extent and preventative strategies. Science of the Total Environment, 2001, 265(1), pp. 309-326.

9. Rogusz, Z. and P. Gruchlik. Parameters in Knothe-Budryk theory, case study of the neighbourhood of the trunk road no. 4 in Będzin city. Przeglad Górniczy, 2003, pp. 27-35.

10. Marschalko, M., et al. Variations in the building site categories in the underground mining region of Doubrava (Czech Republic) for land use planning. Engineering Geology, 2011, 122(3-4), pp. 169-178.

11. Budryk, W. Computing of surface horizontal displacements. Archiwum Górnictwa i Hutnictwa, 1953, 1(1).

12. Knothe, S.M. The prediction of mining excavation influences. 1984, Wydaw. Ślask.

13. Hejmanowski, R. and A. Sroka. Time-space ground subsidence prediction determined by volume extraction from the rock mass. In Proc. 6th Int. Symp. Land Subsidence. 2000.

14. Cui, X., et al. Improved prediction of differential subsidence caused by underground mining. International Journal of Rock Mechanics and Mining Sciences, 2000, 37(4), pp. 615627.

15. Malinowska, A. and R. Hejmanowski. Building damage risk assessment on mining terrains in Poland with GIS application. International Journal of Rock Mechanics and Mining Sciences, 2010, 47(2), pp. 238-245.

16. Chen, G., et al. GPS-based slope monitoring systems and their applications in transition mining from open-pit to under- ground. International Journal of Mining and Mineral Engineering, 2014, 5(2), pp. 152-163.

17. Bian, H.F., et al. Monitoring large-area mining subsidence by GNSS based on IGS stations. Transactions of Nonferrous Metals Society of China, 2014, 24(2), pp. 514-519.

18. Amelung, F., et al. Sensing the ups and downs of Las Vegas, InSAR reveals structural control of land subsidence and aquifer-system deformation. Geology, 1999, 27(6), pp. 483-486.

19. Tao, L., et al. Monitoring city subsidence by D-InSAR in Tianjin area. In Geoscience and Remote Sensing Symposium, 2004, IGARSS'04. Proceedings. 2004 IEEE International. 2004. IEEE.

20. Ng, A.H.M., et al. Assessment of radar interferometry performance for ground subsidence monitoring due to underground mining. Earth, Planets and Space, 2009, 61(6), pp. 733745.

21. Ambrožič, T. and G. Turk. Prediction of subsidence due to underground mining by artificial neural networks. Computers \& Geosciences, 2003, 29(5), pp. 627-637.

22. Budryk, W. and S. Knothe. The influence of underground excavation on surface and the protected buildings and constructions, 1950(11).

23. Kwinta, A., R. Hejmanowski, and A. Sroka. A time function analysis used for the prediction of rock mass subsidence. Gui yuguang, Golosinski TS (eds) Mining science and technology. AA Balkema, Rotterdam, 1996, pp. 419-424.

24. Klabis, L. and A. Kowalski. Mining excavation in mining protection area under Bytom downtown, history and present days. Przeglad Górniczy, 2015, T. 71, no 5, pp. 33-43.

25. Tajduś, K. Mining-induced surface horizontal displacement, The case of BW Prosper Haniel mine. Archives of Mining Sciences, 2013, 58(4), pp. 1037-1055.

26. Niedojadło, Z., et al. Horizontal deformation modelling in Knothe-Budryk theory for conditions in LGOM. Przeglad Górniczy, 2014, T. 70, no 8, pp. 157-164.

27. Prószyński, W. and M. Kwaśniak. Survey theory of measuring displacements, terms and elements of methodology. 2015, Oficyna Wydawnicza Politechniki Warszawskiej.

28. Mattern, S., et al. Comparison of Building Collapse Simulation Results From Finite Element and Rigid Body Models, in IUTAM Symposium on Multiscale Problems in Multibody System Contacts, Proceedings of the IUTAM Symposium held in Stuttgart, Germany, February 20-23, 2006, P. Eberhard, Editor. 2007, Springer Netherlands, Dordrecht. pp. 257-267.

29. Kuras, O.M. Contactless methods to measure dispalcements and deformations of retaining walls. 2015.

30. Voss, F. Evaluating damage potential in buildings affected by excavations. 2003, MS thesis, Northwestern University, Evanston, IL. 
31. Boscardin, M.D. and E.J. Cording, Building response to excavation-induced settlement. Journal of Geotechnical Engineering, 1989. 115(1), pp. 1-21.

32. Różkowski, A. History of research and the state of hy- drological recognition of Upper Silesian Coal Basin and the sorounding areas. 2008, Wydawn. Uniw. Śląskiego.

33. Borecki, M. and S. Knothe. Surface protection against mining excavation damages. Wydawnictwo Śląsk, Katowice, 1980.

\title{
СВЕДЕНИЯ ОБ АВТОРАХ / Information about authors:
}

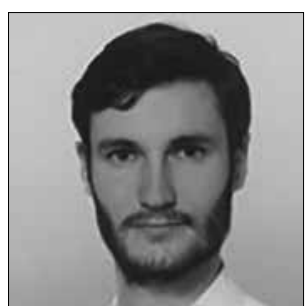

Michal M. BUCZEK - Lecturer of Faculty of Mining Surveying and Environmental Engineering.

AGH University of Science and Technology, Krakow, Poland. e-mail:mibuczek@agh.edu.pl

БУШЕК Михаил М. - преподаватель факультета маркшейдерского дела и природопользования. Университет науки и технологии, Академия горных наук, Краков, Польша.

e-mail:mibuczek@agh.edu.pl

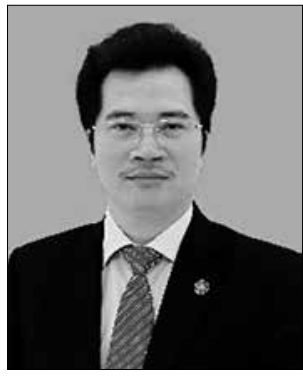

Prof. Dr. Bui Xuan Nam - Vice Rector.

Hanoi University of Mining and Geology Duc Thang - Bac Tu, Liem, Hanoi - Vietnam.

e-mail: buixuannam@humg.edu.vn

Буй Сюань Нам - профессор, доктор; проректор. Ханойский горно-геологический университет, Ханой, Вьетнам.

e-mail: buixuannam@humg.edu.vn

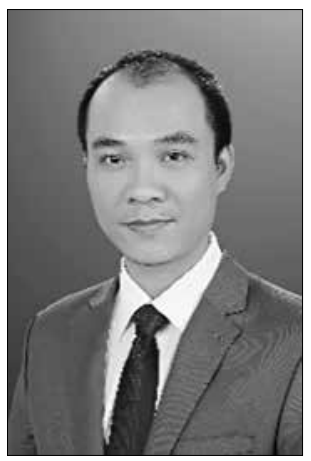

Mr. Nguyen Quoc Long - Lecturer of Faculty of Geodesy. Hanoi University of Mining and Geology Duc Thang - Bac Tu Liem, Hanoi, Vietnam

e-mail: nguyenquoclong@humg. edu.vn

Нгуен Квок Лонг - преподаватель факультета геодезии. Ханойский горно-геологический университет Ханой, Вьетнам.

e-mail:nguyenquoclong@humg.edu.vn

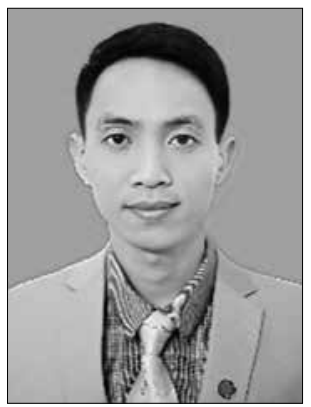

Mr. Nguyen Hoang - Lecturer of Faculty of Mining.

Hanoi University of Mining and Geology Duc Thang - Bac Tu Liem, Hanoi, Vietnam.

e-mail: nguyenhoang@humg.edu.vn

Нгуен Хоанг - преподаватель Горного факультета. Ханойский горно-геологический университет, Ханой, Вьетнам. e-mail:nguyenhoang@humg.edu.vn

\section{ПРИМЕНЕНИЕ ТЕОРИИ КНОТЕ-БУДРИКА И УСЛОВИЯ ТВЕРДОГО ТЕЛА ДЛЯ ОЦЕНКИ ОСЕДАНИЯ}

\author{
${ }^{1}$ Бушек М.M., \\ ${ }^{2}$ Нгуен Квок Лонг, \\ Нгуен Хоанг*, \\ Буй Сюань Нам \\ ${ }^{1}$ Академия Горного дела, Краков, Польша \\ ${ }^{2}$ Ханойский горно-геологический университет, Ханой, Bьетнам, e-mail: nguyenquoclong@humg.edu.vn
}

\section{DOI: $10.21177 / 1998-4502-2018-10-4-595-605$}

Целью данного исследования является оценка поверхностного оседания в результате горнодобывающей деятельности на исследуемом участке в Верхней Силезии (Польша). Для этого использовались данные геодезического мониторинга временных рядов за трехлетний период (2009-2012 гг.). Теория Кноте-Будрика была принята для оценки влияния подземных горных работ на просадочность и наклон, в то время как для оценки устойчивости зданий использовался метод твердого тела. Конечные значения наклона, вычисленные по методу твердого тела, в несколько раз больше, чем прогнозы теории Кноте-Будрика. Следовательно, вычисление состояния твердого тела было бы правильным инструментом для проверки предсказанных наклонов из деформационных моделей, таких как теория Кнота-Будрика.
Ключевые слова: теория Кнота-Будрика, твердое тело, просадка, напряжение, резервуары, Польша.

\section{Литература:}

1. Kratzsch, H. Mining subsidence engineering. 2012, Springer Science \& Business Media.

2. Hustrulid, W.A., M. Kuchta, and R.K. Martin. Open Pit Mine Planning and Design, Two Volume Set \& CD-ROM Pack. 2013, CRC Press.

3. Kahriman, A., et al. Environmental impacts of bench blasting at Hisarcik Boron open pit mine in Turkey. Environmental geology, 2006. 50(7), pp. 1015-1023.

4. Golik, V.I., Y.I. Razorenov, and K.G. Karginov. The basis of sustainable development of North Ossetia-Alania is 
the mining industry. Sustainable development of mountain territories, 2017, 9(2(32)), pp. 163-172.

5 . Borshchevsky, S., et al. Prospects for extraction of metals from mine drains. Sustainable development of mountain territories, 2017, 9(1), pp. 81-92.

6. Altun, A.O., I. Yilmaz, and M. Yildirim. A short review on the surficial impacts of underground mining. Scientific research and essays, 2010, 5(21), pp. 3206-3212.

7. Tiwary, R. Environmental impact of coal mining on water regime and its management. Water, Air, and Soil Pollution, 2001, 132(1-2), pp. 185-199.

8. Younger, P.L. Mine water pollution in Scotland, nature, extent and preventative strategies. Science of the Total Environment, 2001, 265(1), pp. 309-326.

9. Rogusz, Z. and P. Gruchlik. Parameters in Knothe-Budryk theory, case study of the neighbourhood of the trunk road no. 4 in Będzin city. Przegląd Górniczy, 2003, pp. 27-35.

10. Marschalko, M., et al. Variations in the building site categories in the underground mining region of Doubrava (Czech Republic) for land use planning. Engineering Geology, 2011, 122(3-4), pp. 169-178.

11. Budryk, W. Computing of surface horizontal displacements. Archiwum Górnictwa i Hutnictwa, 1953, 1(1).

12. Knothe, S.M. The prediction of mining excavation influences. 1984, Wydaw. Śląsk.

13. Hejmanowski, R. and A. Sroka. Time-space ground subsidence prediction determined by volume extraction from the rock mass. In Proc. 6th Int. Symp. Land Subsidence. 2000.

14. Cui, X., et al. Improved prediction of differential subsidence caused by underground mining. International Journal of Rock Mechanics and Mining Sciences, 2000, 37(4), pp. 615-627.

15. Malinowska, A. and R. Hejmanowski. Building damage risk assessment on mining terrains in Poland with GIS application. International Journal of Rock Mechanics and Mining Sciences, 2010, 47(2), pp. 238-245.

16. Chen, G., et al. GPS-based slope monitoring systems and their applications in transition mining from open-pit to underground. International Journal of Mining and Mineral Engineering, 2014, 5(2), pp. 152-163.

17. Bian, H.F., et al. Monitoring large-area mining subsidence by GNSS based on IGS stations. Transactions of Nonferrous Metals Society of China, 2014, 24(2), pp. 514-519.

18. Amelung, F., et al. Sensing the ups and downs of Las Vegas, InSAR reveals structural control of land subsidence and aquifer-system deformation. Geology, 1999, 27(6), pp. 483-486.

19. Tao, L., et al. Monitoring city subsidence by D-InSAR in Tianjin area. In Geoscience and Remote Sensing Symposium, 2004, IGARSS'04. Proceedings. 2004 IEEE International. 2004. IEEE.
20. $\mathrm{Ng}$, A.H.M., et al. Assessment of radar interferometry performance for ground subsidence monitoring due to underground mining. Earth, Planets and Space, 2009, 61(6), pp. 733-745.

21. Ambrožič, T. and G. Turk. Prediction of subsidence due to underground mining by artificial neural networks. Computers \& Geosciences, 2003, 29(5), pp. 627-637.

22. Budryk, W. and S. Knothe. The influence of underground excavation on surface and the protected buildings and constructions, 1950(11).

23. Kwinta, A., R. Hejmanowski, and A. Sroka. A time function analysis used for the prediction of rock mass subsidence. Gui yuguang, Golosinski TS (eds) Mining science and technology. AA Balkema, Rotterdam, 1996, pp. 419-424.

24. Klabis, L. and A. Kowalski. Mining excavation in mining protection area under Bytom downtown, history and present days. Przegląd Górniczy, 2015, T. 71, no 5, pp. 33-43.

25. Tajduś, K. Mining-induced surface horizontal displacement, The case of BW Prosper Haniel mine. Archives of Mining Sciences, 2013, 58(4), pp. 1037-1055.

26. Niedojadło, Z., et al. Horizontal deformation modelling in Knothe-Budryk theory for conditions in LGOM. Przeglad Górniczy, 2014, T. 70, no 8, pp. 157-164.

27. Prószyński, W. and M. Kwaśniak. Survey theory of measuring displacements, terms and elements of methodology. 2015, Oficyna Wydawnicza Politechniki Warszawskiej.

28. Mattern, S., et al. Comparison of Building Collapse Simulation Results From Finite Element and Rigid Body Models, in IUTAM Symposium on Multiscale Problems in Multibody System Contacts, Proceedings of the IUTAM Symposium held in Stuttgart, Germany, February 20-23, 2006, P. Eberhard, Editor. 2007, Springer Netherlands, Dordrecht. pp. 257-267.

29. Kuras, O.M. Contactless methods to measure dispalcements and deformations of retaining walls. 2015.

30. Voss, F. Evaluating damage potential in buildings affected by excavations. 2003, MS thesis, Northwestern University, Evanston, IL.

31. Boscardin, M.D. and E.J. Cording, Building response to excavation-induced settlement. Journal of Geotechnical Engineering, 1989. 115(1), pp. 1-21.

32. Różkowski, A. History of research and the state of hydrological recognition of Upper Silesian Coal Basin and the sorounding areas. 2008, Wydawn. Uniw. Śląskiego.

33. Borecki, M. and S. Knothe. Surface protection against mining excavation damages. Wydawnictwo Śląsk, Katowice, 1980.

Article received 14.08.2018. 
1 Демин В.Ф.,*

1 Демина Т.В.,

2 Кайназаров А.C.,

2 Кайназарова А.C.

УДК 622.86:622.26.004.5

DOI: 10.21171/1998-4502-20184-606-616

Исследование посвящено повышению эффективности проведения выработок для повышения устойчивости их контуров в условиях Карагандинского угольного бассейна. Даны результаты оценки горнотехнических условий применения технологических схем анкерного крепления горных выработок при подготовительных работах. Предложены эффрективные технологические схемы проведение и крепления подготовительных горных выработок угольных шахт. Сформулированы методы повышения устойчивости их контуров. Рекомендовань рациональные технологические принципы управления устойчивостью контуров горных выработок с учетом проявлений горного давления прилегающего массива и изменения его геомеханического состояния при техногенном вмешательстве. Исследования выполнены в рамках научноисследовательской работы: «Разработка эффрективной технологии проведения подготовительных выработок с анкерным креплением с учетом напряженно-деформированного состояния массива горных пород».

\section{КЛЮЧЕВЫЕ СЛОВА:}

бионаноробототехника, когнитивная инфокоммуникационная система, бионаносенсоры, интеллектуальные экспертные системы, базы знаний, мониторине состояния биосистем, медицинский онлайн-сервис

Статья поступила в редакцию 07.05.2018.

\section{ОЦЕНКА ЭФФЕКТИВНОСТИ ПРИМЕНЕНИЯ ТЕХНОЛОГИЧЕСКИХ СХЕМ ПРОВЕДЕНИЯ ВЫРАБОТОК ДЛЯ ПОВЫШЕНИЯ УСТОЙЧИВОСТИ ИХ КОНТУРОВ}

\section{Введение}

Кровля пластов в проводимых горных выработках Карагандинского угольного бассейна имеют невысокую устойчивость и при обнажении более одного метра, обрушаются, а также склонны к размоканию и пучению. В тектоническом отношении разрабатываемые угольные пласты относятся к сложным. Широкое внедрение технологических схем бесцеликовой выемки пластов обусловило высокие затраты на подержание кровли, необходимость проведения горных выработок в присечку к выработанному пространству. Поведение горной кровли угольных пластов Карагандинского бассейна определяется их составом, физико-химическими свойствами, расслоением и трещиноватостью. Непосредственная кровля угольных пластов чаще всего представлена аргиллитами, реже алевролитами и, в единичных случаях, песчаниками, основная кровля обычно сложена песчаниками. В почве угольных пластов также преобладают аргиллиты [1-4].

Целью настоящего исследования является научное обоснование технологии управления устойчивостью контуров горных выработок с учетом проявлений горного давления в породном массиве при изменении его геомеханического состояния.

\section{Методика исследований}

Поставленная цель достигается решением ряда задач на основе анализа научного и практического опыта, систематизации и критического обобщения аналогов с моделированием новаций в местных условиях и прогнозирование перспектив реализации нетрадиционных решений по упрочнению массива при техногенном вмешательстве.

\section{Результаты исследований}

В работе приведен краткий анализ исследований отечественной и зарубежной практики применяемых схем подготовки и отработки выемочных полей, оказывающих влияние на создание зон повышенного и опорного горного давления, интенсивных деформаций кровли, бортов и почвы горной выработки, находящихся в пределах областей их воздействия.

В угольных шахтах Западной Европы при увеличении глубины разработки проводятся выработки большого сечения, которые осуществляют их крепление с использованием комплекса комбинации набрызг-бетонной, анкерной системы и металло-рамной крепи с расположением выемочных выработок параллельно направлению главных горизонтальных напряжений [5 - 9].

Английская высокопрочная анкерная система с установкой анкеров предназначена для обеспечения повышенной прочности сцепления и высокого сопротивления сдвижения горных пород.

Традиционный производственный опыт Западный Европы предусматривает расположение лав рядом друг с другом для повторного использования горной выработки предыдущей лавы или проходкой дополнительной - обычно на расстоянии от 0 до 5,0 м от него. Данная технологическая схема подготовки не способствует высокопроизводительной лавной выемке обратным ходом.

В Великобритании разработана технология угледобычи, которая с увели-

\footnotetext{
${ }^{1}$ Карагандинский государственный технический университет, г. Караганда, Республика Казахстан

${ }^{2}$ Екибастузский инженерно-технический институт имени академика К. Сатпаева, г. Экибастуз, Респу-
} блика Казахстан 


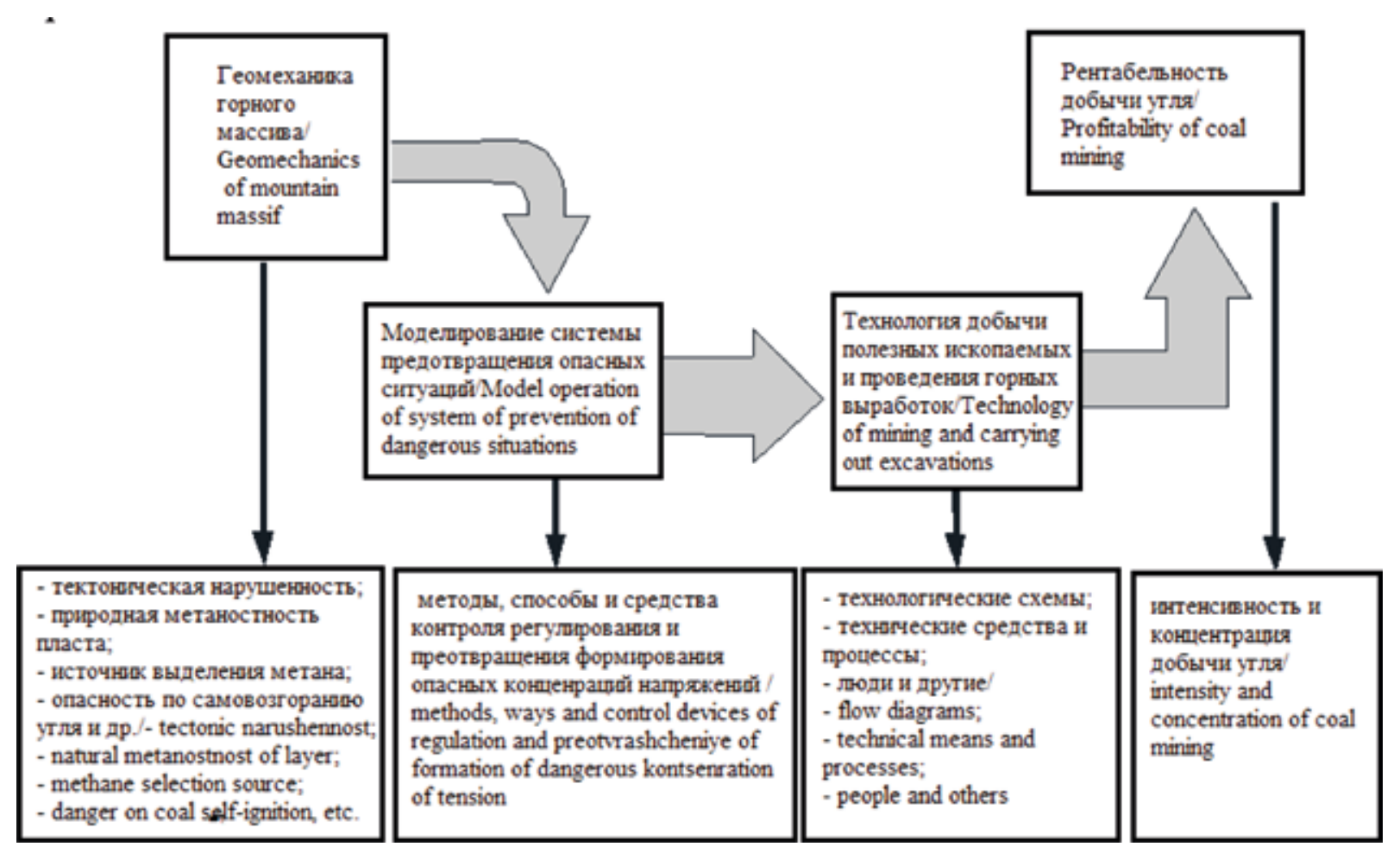

Puc. 1. Методический подход к выбору эффективных способов и средств крепления горных выработок

Fig. 1. Methodical approach to the choice of effective ways and means for fixing mine workings

чением глубины разработки угольных пластов с подготовкой одноустьевых штреков с целиком (столбом угля) значительных размеров между лавами позволяет осуществить скоростную проходку с применением анкерного крепления, независимо от смежного забоя.

В отличие от добычи угля в странах Западной Европы, в Соединенных Штатах Америки и в Австралии практически с такими же горно-геологическими условиями достигаются положительные результаты при использовании многоштрековых технологических схем ведения угледобычи с проведением выемочных штреков прямоугольного сечения и крепления их анкерами. В США и Австралии многоштрековые технологические схемы используются главным образом при столбовой разработке при длине лавы от 200,0 до 250,0 м. Выемочные штреки прямоугольного сечения проводятся группами из двух и четырех параллельных вентиляционных и конвейерных выработок (шириной от 5,0 до 6,0 м). Штреки, непосредственно примыкающие к лаве, погашаются вслед за ее проходом, остальные в большинстве случаев, используют повторно.

На угольных шахтах в Соединенных Штатах Америки наибольшее применение имеют трехштрековая подготовка (52\%), затем четырехштрековая (46\%) и незначительно двухштрековая (2\%).

В угледобывающих странах СНГ преимущественно применяются бесцеликовые системы разработки [10-14].

На сегодняшний период преобладающая доля угледобывающих шахт проводится с применением анкерной системы. При этом происходит расшире- ние технологических возможностей подземной угледобычи.

В Карагандинском бассейне применяются технологические схемы разработки выемочных целиков по простиранию и по падению угольного пласта.

Модификации схем разработки вместе с горнотехнологическими факторами оказывают существенное влияние на способы и средства крепления горных выработок.

В табл. 1 приведены факторы, обусловленные горно-геологическим особенностями разработки в странах с развитой угольной промышленностью.

Горные выработки Карагандинского бассейна имеют как арочное, так и прямоугольное сечение. Оценка технологических факторов эксплуатации систем анкерного крепления показывает, что эффективное и надежное крепление подготовительных выработок в условиях залегания в кровле слабых трещиноватых пород с увеличением глубины разработки и в различных зонах влияния очистных работ может быть обеспечено при применении сталеполимерных анкеров, закрепляемых по всей длине шпура быстротвердеющими смолами с несущей способностью 250,0-300,0 кН и длиной от 2,0 до 3,0 м; для использования в сложных горно-геологических условиях предусмотрено их усиление специальными (канатными) анкерами длиной до 95,0 $(6,0-7,0)$ м.

Основной задачей анкерной системы крепления является мобилизация и сохранение свойственной данному массиву прочности с тем, чтобы он становился самоподдерживающим. Анкерная система крепит горную породу, сохраняя ограничение движения кровли 
Таблица 1 / Table 1

Факторы, обусловленные горно-геологическим особенностями разработки

Factors due to mining and geological features of development

\begin{tabular}{|c|c|c|c|c|c|}
\hline Параметры / Options & $\begin{array}{l}\text { Германия } \\
\text { Germany }\end{array}$ & $\begin{array}{c}\text { Великобритания } \\
\text { Great Britain }\end{array}$ & $\begin{array}{c}\text { Австралия } \\
\text { Australia }\end{array}$ & $\begin{array}{c}\text { CWA } \\
\text { USA }\end{array}$ & $\begin{array}{c}\text { Карагандинский } \\
\text { бассейн } \\
\text { The Karaganda } \\
\text { Basin }\end{array}$ \\
\hline $\begin{array}{l}\text { Глубина разработки, м } \\
\text { Depth of development, } m\end{array}$ & $1000-1200$ & $600-800$ & $200-260$ & $200-360$ & $550-820$ \\
\hline $\begin{array}{c}\text { Вертикальное горное давле- } \\
\text { ние, МПа / Vertical compo- } \\
\text { nent of rock pressure, MPa }\end{array}$ & $20-23$ & $10-13$ & $5,5-6,0$ & $7-9$ & $10-15$ \\
\hline $\begin{array}{l}\text { Горизонтальное горное дав- } \\
\text { ление, МПа / Horizontal com- } \\
\text { ponent of rock pressure, } M P \text { Pa }\end{array}$ & $0-23$ & $20,0-21,5$ & $10-13$ & $13-17$ & $10-14$ \\
\hline $\begin{array}{c}\text { Средняя добываемая мощ- } \\
\text { ность угольных пластов, м } \\
\text { Average recoverable thickness } \\
\text { of coal seams, } m\end{array}$ & 1,12 & 2,5 & 3,1 & 1,5 & $\begin{array}{c}1,0-8,5 \\
\text { средняя } \\
\text { mean } 2,28\end{array}$ \\
\hline $\begin{array}{l}\text { Средний угол падения раз- } \\
\text { рабатываемых угольных пла- } \\
\text { стов, град / The average angle } \\
\text { of occurrence of the layers } \\
\text { under development, deg }\end{array}$ & $5-10$ & 5 & 5 & 5 & $7-20$ \\
\hline $\begin{array}{c}\text { Свойства горных пород } \\
\text { кровли пластов } \\
\text { Properties of the rock layers } \\
\text { of the seams }\end{array}$ & $\begin{array}{c}\text { аргиллиты, } \\
\text { алевролиты, } \\
\text { песчаники с } \\
\text { прочностью на } \\
\text { сжатие 40-80 } \\
\text { МПа } \\
\text { argillites, silt- } \\
\text { stones you, } \\
\text { sand stones } \\
\text { with durability } \\
\text { compression } \\
\text { ratio of } 40 \text { to } \\
80 \mathrm{MPa}\end{array}$ & $\begin{array}{c}\text { аргиллиты, алев- } \\
\text { ролиты, песчани- } \\
\text { ки с прочностью } \\
\text { на сжатие } 25-65 \\
\text { МПа } \\
\text { argillites, siltstones } \\
\text { you, sand stones } \\
\text { with durability } \\
\text { compression ratio } \\
\text { of 25-65 MPa }\end{array}$ & $\begin{array}{c}\text { аргиллиты, } \\
\text { алевролиты, } \\
\text { песчаники с } \\
\text { прочностью } \\
\text { на сжатие 5-80 } \\
\text { МПа } \\
\text { argillites, silt } \\
\text { stones you, } \\
\text { sand stones } \\
\text { with durability } \\
\text { compression } \\
\text { for 5-80 MPa }\end{array}$ & $\begin{array}{c}\text { аргиллиты, } \\
\text { алевролиты, } \\
\text { песчаники, } \\
\text { известняки с } \\
\text { прочностью на } \\
\text { сжатие 10-80 } \\
\text { МПа / argil- } \\
\text { lites, silt stones } \\
\text { you, limestone } \\
\text { sandstones } \\
\text { with durability } \\
\text { compression of } \\
\text { 10-80 MPa }\end{array}$ & $\begin{array}{c}\text { аргиллиты, алев- } \\
\text { ролиты, песчаники } \\
\text { с прочностью на } \\
\text { сжатие 10-80 МПа } \\
\text { argillite, siltstones } \\
\text { you, limestone } \\
\text { sandstones } \\
\text { with durabil- } \\
\text { ity compression of } \\
10-80 \mathrm{MPa}\end{array}$ \\
\hline $\begin{array}{l}\text { Свойства горных пород по- } \\
\text { чвы, прочность на одноосное } \\
\text { сжатие, МПа / Properties of } \\
\text { soil rocks, uniaxial compres- } \\
\text { sion strengthin, MPa }\end{array}$ & $\begin{array}{c}\text { аргиллиты, } 45 \\
\text { argillites, } 45\end{array}$ & $\begin{array}{c}\text { аргиллиты, } 45 \\
\text { argillites, } 45\end{array}$ & $\begin{array}{c}\text { аргиллиты, } 40 \\
\text { argillites, } 40\end{array}$ & $\begin{array}{c}\text { аргиллиты, } \\
\text { частично пес- } \\
\text { чаники, } 40 \\
\text { argillites, part- } \\
\text { ly sandstones, } \\
40\end{array}$ & $\begin{array}{c}\text { аргиллиты, } 20 \\
\text { argillites, } 20\end{array}$ \\
\hline
\end{tabular}

и позволяя горизонтальному напряжению удерживать кровлю на месте, не давая ей выпадать. Для поддержания горной кровли в подготовительной выработке требуется достаточное горизонтальное напряжение для ограничения движения кровли и ее эффективной фиксации. Горная кровля склонна к обрушению, отслаиваясь по напластованию. Взрывные работы способствуют выпадению ослабленных пластовых горных пород, что создает небезопасные условия труда. Чтобы под такой горной кровлей безопасно работать, необходимо создать анкерованием несущую балку в кровле. Первостепенной задачей анкерной крепи при образовании балки являет- ся противостояние сдвижению слоев горной породы по горизонтальным напластованиям.

Воздействие анкерных крепей больше всего проявляется там, где возникают высокие напряжения сдвига в изогнутой балке, то есть на концах балки.

Установка анкерной крепи вблизи горных выработок обеспечивает относительную незначительность сдвижения горных пород и максимальное сцепление между отдельными частями. Сохранение такого сцепления является непременным условием самоподдержания горного массива, и любая потеря сцепления ведет к значительной потере прочности. 
Таблица 2 / Table 2

Факторы, связанные с технологическими схемами проведения горных выработок и ведения очистных работ Factors associated with mine workings and cleanup operations

\begin{tabular}{|c|c|c|c|c|c|c|}
\hline $\begin{array}{c}\text { Технологиче- } \\
\text { ские параметры } \\
\text { Technological parameters }\end{array}$ & \multicolumn{2}{|c|}{$\begin{array}{c}\text { Германия } \\
\text { Germany }\end{array}$} & $\begin{array}{c}\text { Великобритания } \\
\text { Great Britain }\end{array}$ & $\begin{array}{c}\text { Австралия } \\
\text { Australia }\end{array}$ & $\begin{array}{c}\text { CША } \\
\text { USA }\end{array}$ & $\begin{array}{c}\text { Карагандинский } \\
\text { бассейн } \\
\text { The Karaganda } \\
\text { Basin }\end{array}$ \\
\hline $\begin{array}{c}\text { Схема подготовки } \\
\text { выемочных забоев } \\
\text { Scheme of preparation of } \\
\text { excavation sites }\end{array}$ & $\begin{array}{l}\text { прямоточ- } \\
\text { ная } \\
\text { cross-flow }\end{array}$ & $\begin{array}{l}\text { возвратно } \\
\text { точная } \\
\text { recurrent }\end{array}$ & $\begin{array}{c}\text { прямоточная } \\
\text { cross-flow }\end{array}$ & $\begin{array}{c}\text { прямоточная } \\
\text { cross-flow }\end{array}$ & $\begin{array}{c}\text { прямоточная } \\
\text { cross-flow }\end{array}$ & $\begin{array}{c}\text { прямоточная, } \\
\text { возвратноточная } \\
\text { cross-flow, recurrent }\end{array}$ \\
\hline $\begin{array}{c}\text { Оставление целиков } \\
\text { Leaving the lobes }\end{array}$ & & - & $\begin{array}{l}\text { жесткие, 80-120 м } \\
\quad \text { rigid, } 80-120 \mathrm{~m}\end{array}$ & $\begin{array}{c}\text { податливые, } \\
\mathbf{1 0 - 2 0 ~ м} \\
\text { compliant, } \\
10-20 \mathrm{~m}\end{array}$ & $\begin{array}{c}\text { податливые, } \\
\mathbf{1 0 - 3 0 ~ м} \\
\text { compliant, } \\
10-30 \mathrm{~m}\end{array}$ & $\begin{array}{c}\text { - } \\
\text { (по специаль- } \\
\text { ному проекту) } \\
\text { (according to special } \\
\text { project) }\end{array}$ \\
\hline $\begin{array}{c}\text { Форма сечения гор- } \\
\text { ных капитальных, } \\
\text { вспомогательных и } \\
\text { выемочных горных } \\
\text { выработок } \\
\text { Cross-sectional form of } \\
\text { capital } \\
\text { auxiliary, and excavation } \\
\text { workings }\end{array}$ & $\begin{array}{l}\text { Арочное } \\
\text { arched }\end{array}$ & $\begin{array}{c}\text { прямоугольное } \\
\text { rectangular }\end{array}$ & $\begin{array}{l}\text { Прямоугольное } \\
\text { rectangular }\end{array}$ & $\begin{array}{l}\text { прямоуголь } \\
\text { ное } \\
\text { rectangular }\end{array}$ & $\begin{array}{l}\text { прямоуголь } \\
\text { ное } \\
\text { rectangular }\end{array}$ & $\begin{array}{l}\text { арочная, } \\
\text { прямоугольная } \\
\text { rectangular arched, } \\
\text { rectangular }\end{array}$ \\
\hline $\begin{array}{l}\text { Размеры горной } \\
\text { выработки, м } \\
\text { Working } \\
\text { dimensions, } m \text { : } \\
\text { Высота / height: } \\
\text { Ширина /width: }\end{array}$ & $\begin{array}{l}4,1-4,8 \\
6,1-7,5\end{array}$ & $\begin{array}{l}2,5-4,1 \\
5,1-5,8\end{array}$ & $\begin{array}{l}2,5-5,1 \\
4,5-6,1\end{array}$ & $\begin{array}{l}2,1-4,2 \\
5,1-6,2\end{array}$ & $\begin{array}{l}2,1-3,5 \\
4,7-6,1\end{array}$ & $\begin{array}{l}3,5-3,7 \\
5,5-6,5\end{array}$ \\
\hline
\end{tabular}

Горно-технологические параметры применения анкерной крепи

таблица 3 / Table 3 Mining and technological parameters of anchor support use

\begin{tabular}{|c|c|c|c|c|c|c|}
\hline $\begin{array}{l}\text { Параметры } \\
\text { Options }\end{array}$ & \multicolumn{2}{|c|}{$\begin{array}{c}\text { Германия } \\
\text { Germany }\end{array}$} & $\begin{array}{c}\text { Великобритания } \\
\text { Great Britain }\end{array}$ & $\begin{array}{c}\text { Австралия } \\
\text { Australia }\end{array}$ & $\begin{array}{c}\text { CША } \\
U S A\end{array}$ & $\begin{array}{c}\text { Карагандин- } \\
\text { ский бассейн } \\
\text { The Karaganda } \\
\text { Basin }\end{array}$ \\
\hline \multicolumn{7}{|c|}{ Технологические факторы / Technological factors } \\
\hline $\begin{array}{c}\text { Длина анкерной крепи, м } \\
\text { Length of anchor, } m\end{array}$ & \multicolumn{2}{|c|}{$25,0-30,5$} & 22,0 & $19,0-21,0$ & $16,0-19,0$ & 22,0 \\
\hline $\begin{array}{c}\text { Длина анкера крепи по гор- } \\
\text { ной породе, м } \\
\text { Anchor length by breed, } m\end{array}$ & \multicolumn{2}{|c|}{$2,1-2,4$} & $2,1-2,4$ & $1,5-2,4$ & $2,1-2,4$ & $2,3(2,9)$ \\
\hline $\begin{array}{c}\text { Расчетная несущая способ- } \\
\text { ность, кН ( в зависимости } \\
\text { от материала) } \\
\text { Estimated load-carrying capacity, } \\
\text { kN (depending on the material) }\end{array}$ & \multicolumn{2}{|c|}{$360-540$} & 310 & $220-320$ & $150-220$ & $250 / 130$ \\
\hline \multicolumn{7}{|l|}{ 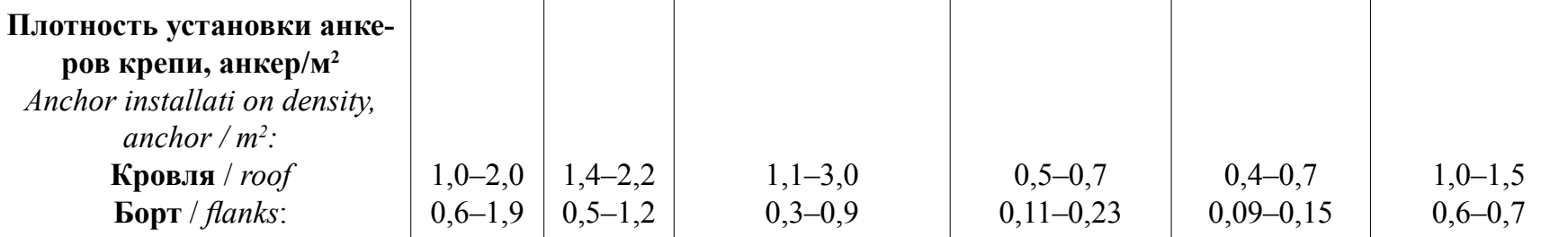 } \\
\hline
\end{tabular}




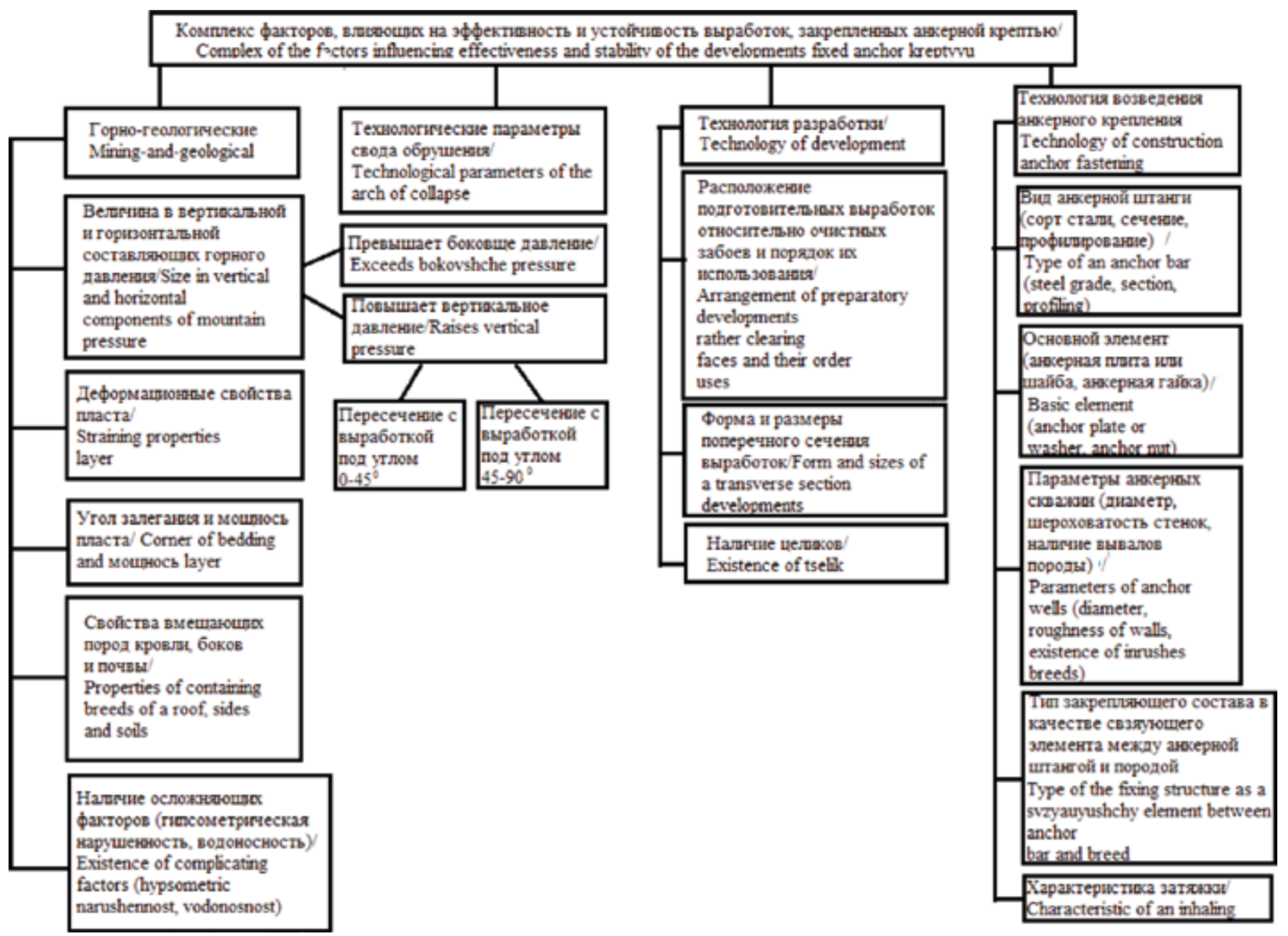

Puc. 2. Комплекс факторов, влияющцих на эффективность и устойчивость горных выработок, закрепленных анкерной крепью / Fig. 2. A complex of the factors influencing effectiveness and stability of the developments fixed by anchor timbering

$a$

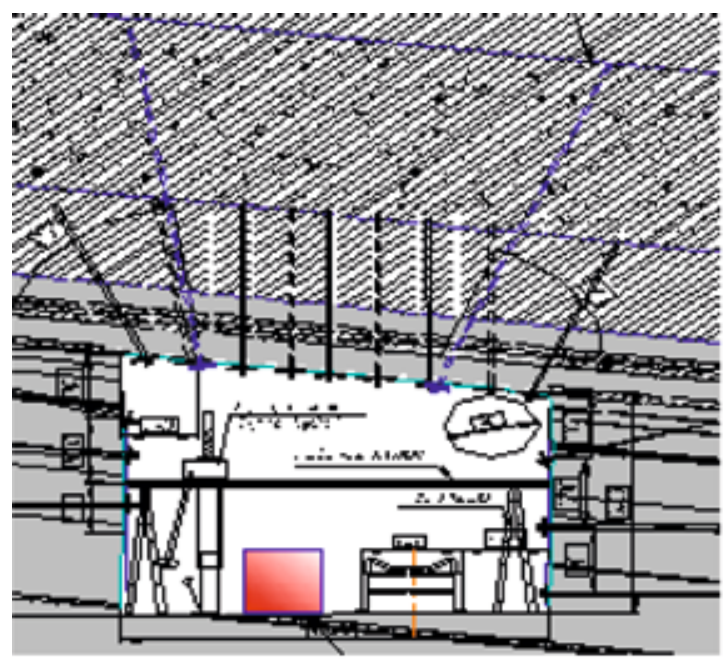

$b$

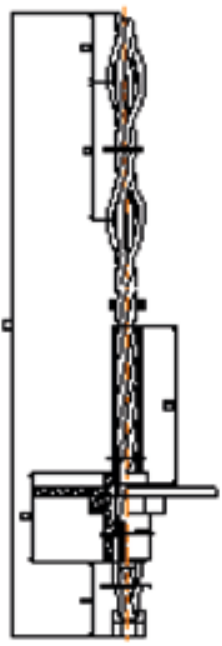

$c$

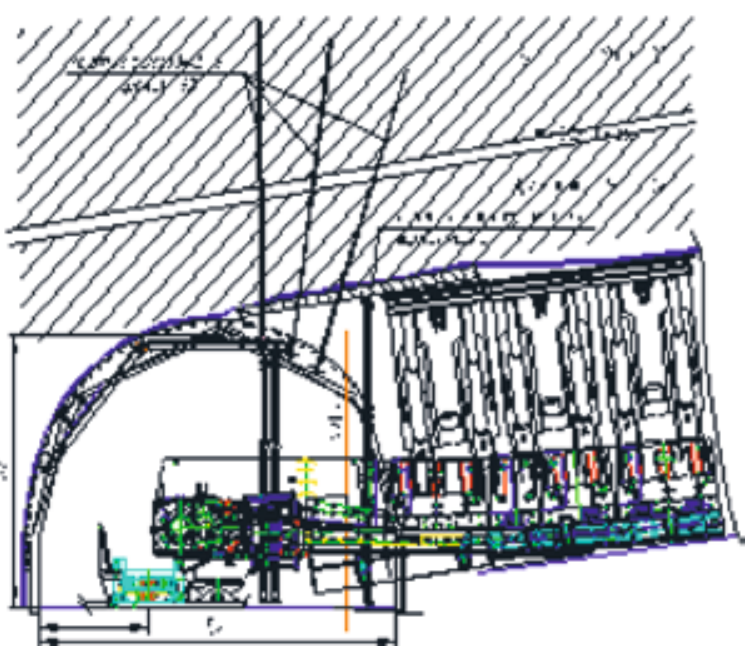

Pис. 3. Вентиляционный штрек 42К12-з шахты имени Кузембаева с канатными анкерами и усиление крепления сопряжения лавы 45K1-з с помощью канатных анкеров: a-поперечный разрез схемы анкерного крепления; $b$ - схема канатного анкера; с-усиление канатными горными анкерами

Fig. 3. The ventilating drift 42K12-z mines of Kuzembayev with rope anchors and strengthening of fastening of interface of a lava $45 \mathrm{~K} 1-z$ by means of rope anchors: $a$-cross - section of the anchors scheme of fastening; $b$-the scheme of rope anchor; 


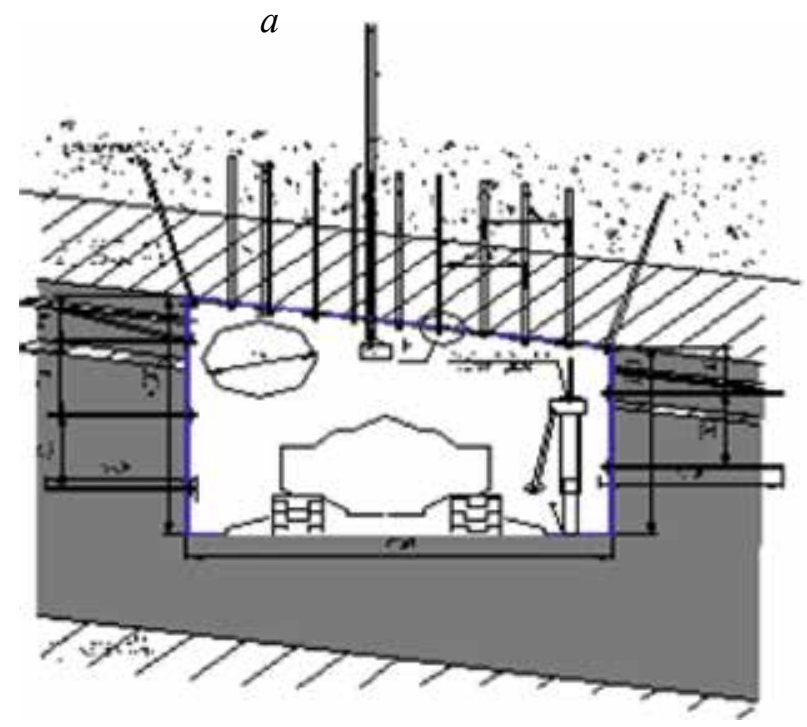

$b$

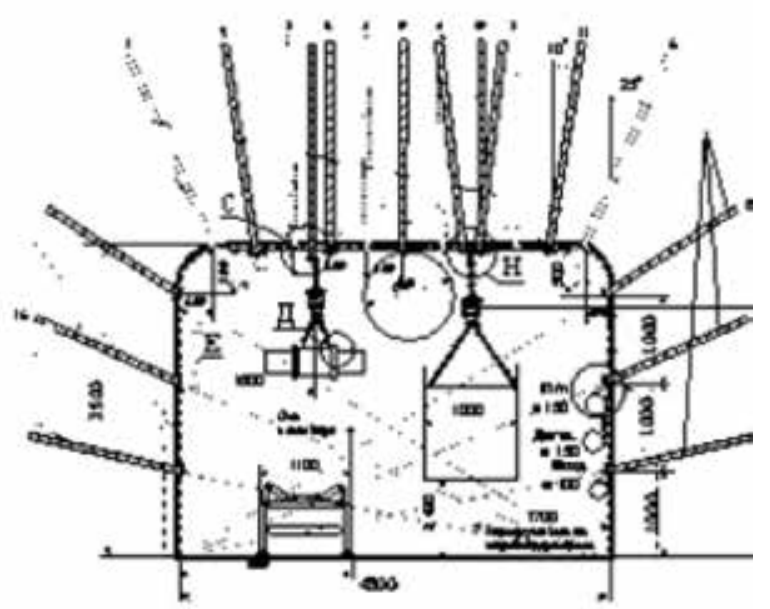

Рис. 4. Вентиляционный шттрек $42_{K 12}$-з шахты имени Кузембаева (b) со сталеполимерными анкерами вне зоны влияния добычных работ: $a$-сечение в проходке; $b$-сечение при эксплуатачии выработки

Fig. 4. The ventilating drift $42_{K 12-z}$ mines of Kuzembayev (b) with steel polymer anchors out of a zone of influence of clearing works: $a$-the section in the penetration; $b$-cross section during operation of the mine

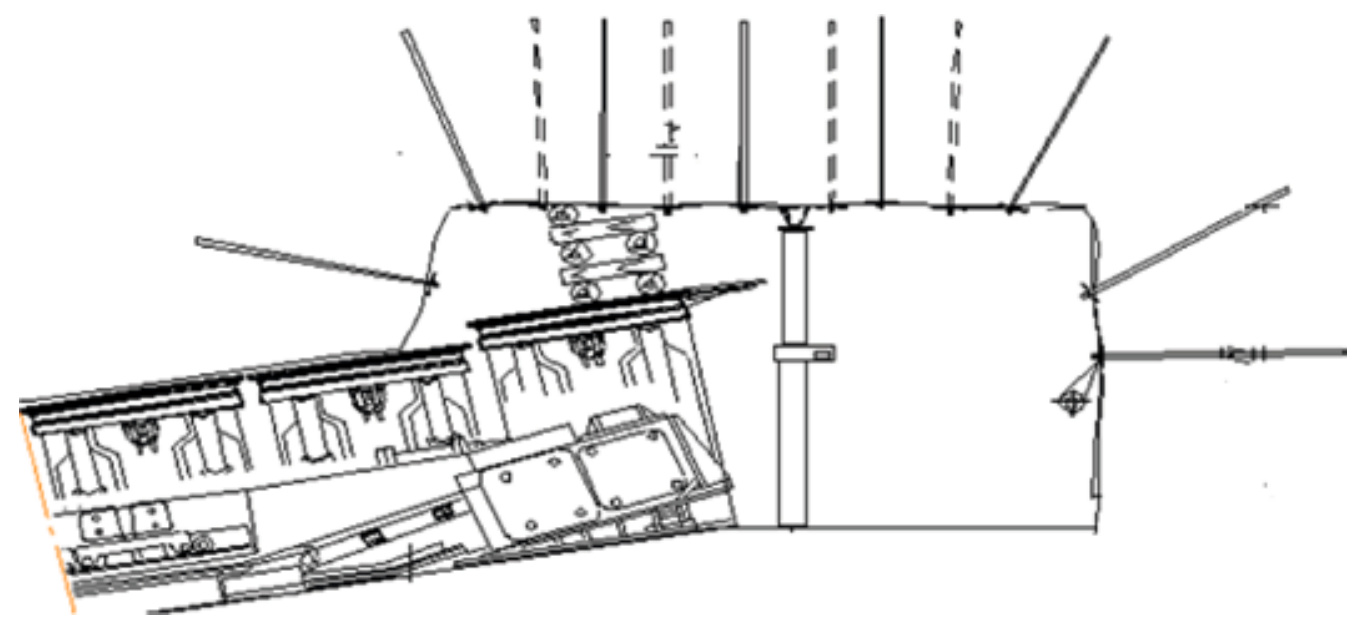

Puc. 5. Сопряжение лавы с вентиляционным штреком $23 \kappa_{7}-3$ шахты имени Кузембаева Fig. 5. Interface of a lava to a ventilating drift $23_{k 7-z}$ mines of a name of Kuzembayeva

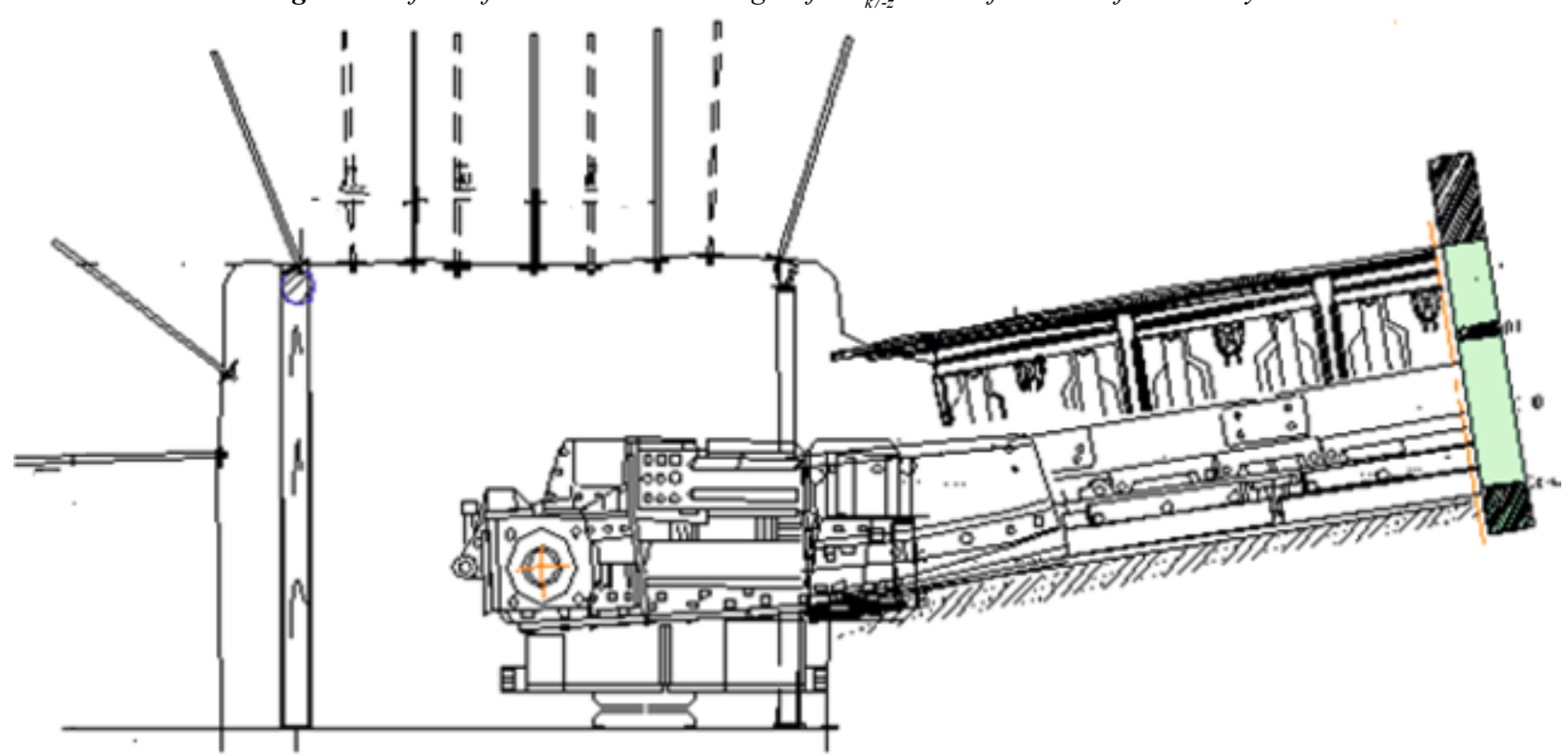

Pис. 6. Технология крепления сопряжения лавы с конвейерным штреком 23к--з шахты имени Кузембаева

Fig. 6. Technology of fastening interface of a lava to a conveyor drift $23 \mathrm{k} 7-z$ mines of a name of Kuzembayeva 
$a$

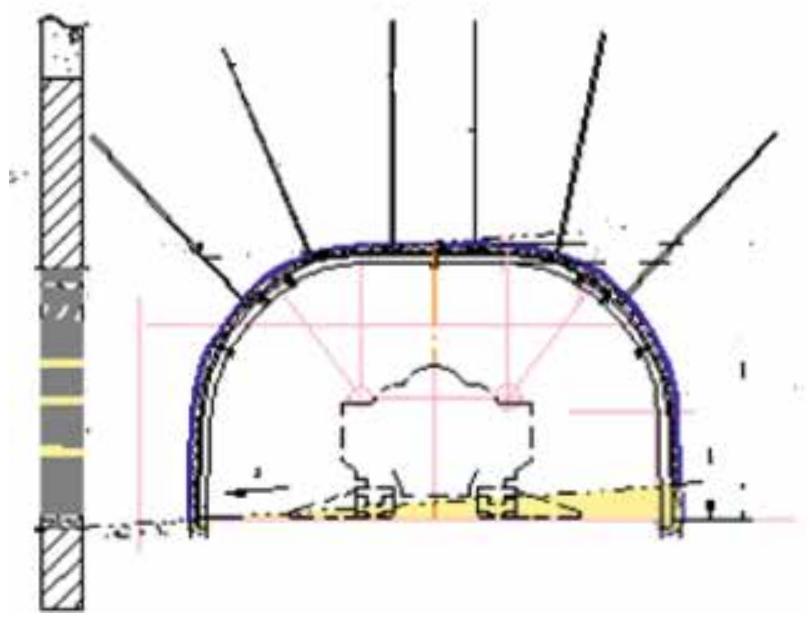

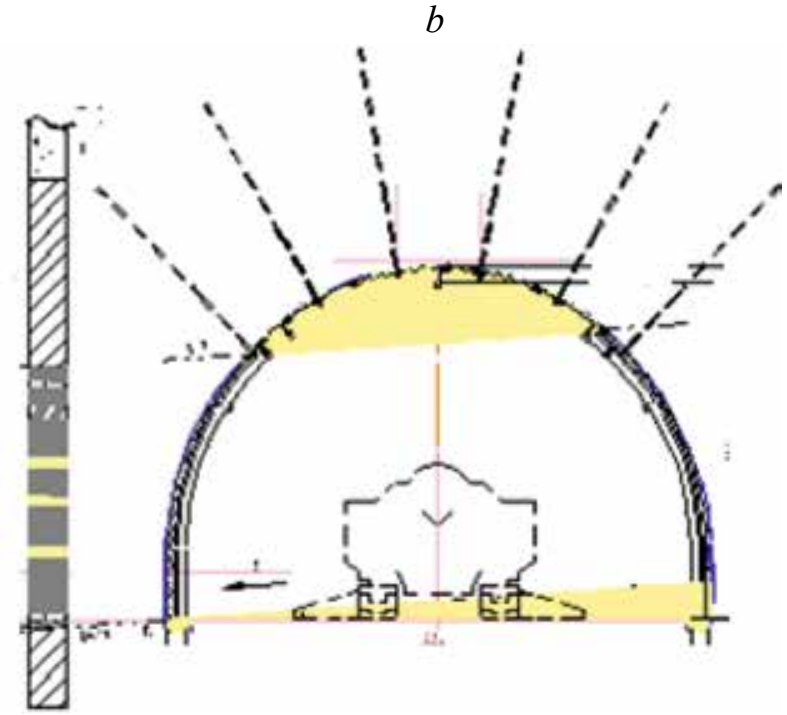

Рис. 7. Варианты комбинированного крепления выработок по пласту К10 шахты имени Кузембаева: $a-c$ плоским верхняком; $b$ - арочной формь

Fig. 7. Options of the mixed fastening of developments on layer K10 mines of Kuzembayev: $a$ - with a flat roof; $b$ - arch form

Анкерная система крепления, состоящая из анкеров, устанавливаемых и закрепляемых в пробуренных в кровлю и бока выработок скважинах, опорных элементов для анкеров и межанкерной затяжки пород на контуре, в отличие от металлических рамных и других поддерживающих крепей, сразу же после установки осуществляет связывание и упрочнение массива в кровле и бортах выработки и активно противодействует развитию смещений и разрушения горных пород. Это преимущество позволяет при наименьшем расходе металла обеспечить повышение устойчивости и надежности поддержания выработок. Другим преимуществом анкерной системы является возможность полной механизации крепления, в результате чего значительно снижается трудоемкость проходческих горных работ и возрастает проведение горных выработок.

Анкерная крепь предназначена для использования в производстве работ по возведению анкерной системы на шахтах в течение всего срока службы выработок в различных горно-геологических и горнотехнических условиях, включая зоны интенсивного повышенного горного давления, в выработках, пройденных по угольному пласту, в слабых трещиноватых горных породах, на удароопасных и выбросоопасных угольных пластах, на подработанных и надработанных участках шахтных полей.

Выбор типа и параметров анкерной крепи зависит от множества факторов, к которым относятся: строение и физико-механические характеристики горных пород, степень нарушенности и водоносность месторождений, глубина разработки, расстояние между пластами, конфигурация, назначение и срок службы горной выработки, условия ее эксплуатации, расход, стоимость, дефицитность и прочностные свойства материалов анкерной крепи, технологичность изготовления и возведения анкерной системы.
В табл. 3 приведены горно-технологическими факторы, обусловленные горно-геологическими особенностями разработки, применением технологии анкерного крепления в подготовительных выработках, вертикальной и горизонтальной составляющих критерия нагруженности массива горных пород, технологических условий применения анкерной крепи в странах с развитой угольной промышленностью.

В работе приведен (рис. 1) методический подход к выбору эффективных видов и средств анкерного крепления горных работ при проведении очистных выработок.

На выбор способов и средств горного анкерного крепления оказывают горно-геологические и горнотехнические условия угледобычи, осложняющие факторы ведения горных выработок (рис. 2). Также оказывают влияние параметры крепления и поддержания горных выработок, схемы развития горных работ и вентиляции, их количественные параметры и соотношения добычных и подготовительных горных работ, фронтов подработки и надработки угольных пластов [16-20].

Технологические схемы бесцеликовой отработки угольных пластов при проведении выработок вприсечку к выработанному пространству обеспечивают необходимость гарантирования указанных выше разрывов во времени между обрушением пород и проведением присечных выработок. Но в то же время это создает на угледобывающих шахтах определенные трудности по подготовке и вводу в эксплуатацию нового фронта очистных работ. Проблемы по подготовке очистных работ можно будет решить путем реализации следующих задач: оставление временных целиков угля на всю длину или часть длины выемочного поля с последующим их погашением; групповой подготовкой слоев и проведением присечных 
выработок отдельными участками между промежуточными квершлагами (гезенками) вне зоны влияния горного давления очистного забоя; отработкой целиков в шахматном порядке; поочередной отработкой столбов в крыльях двусторонних выемочных полей, панелях; проведением присечной горной выработки вслед за лавой смежного столба со вспомогательной фланговой горной выработки, бремсберга [21-23].

При проведении горных выработок в Карагандинском угольном бассейне в зависимости от схем развития и эксплуатационного назначения горных выработок применяются следующие технологические схемы крепления приконтурных горных пород по контурам выработок (рис. 3-7).

На рис. 3 приведена технология схемы крепления по угольному пласту К12 вентиляционного штрека 42K12-3 шахты имени Кузембаева по кровле и бокам (со стороны лавы - стеклопластиковые анкера) сталеполимерными и канатными горными анкерами (трехуровневая система крепления).

Технологическая схема позволяет устойчиво поддерживать горную выработку в зоне влияния добычных работ на участке перед фронтом подвигания лавы. Канатные анкера устанавливаются впереди зоны опорного давления лавы на расстоянии от 100,0 до 120,0 м.

В вентиляционный штрек 42K12-3 шахты имени Кузембаева сталеполимерные анкеры вне зоны влияния добычных работ закреплены в одноуровневые и двухуровневые технологические схемы и в зоне влияния очистных работ (рис. $4, a, b)$.

На рис. 5 и 6 приведена технология анкерного крепления по угольному пласту К12 сопряжения лавы с вентиляционным штреком и конвейерным штреком 23K7-3 с использованием двухуровневой системы крепления в Карагандинском угольном бассейне, позволяющие поддерживать слоевую кровлю в добыч- ном состоянии горной выработки за лавой на границе с выработанным пространством.

На примере шахты имени Кузембаева приведены технологические схемы (рис. 7) комбинированного крепления (арочная крепь с анкерами) горных выработок по пласту к 10 с сечением в свету 11,9 м² (рис. 7,a) и 14,5 м² (рис.7,b) и в проходке соответственно 14,0 м ${ }^{2}$ и $18,1 \mathrm{M}^{2}$, в том числе по угольному пласту, составляет $13,0 \mathrm{M}^{2}$ и $14,7 \mathrm{M}^{2}$, а также $1,0 \mathrm{M}^{2}$ и 3,4 м $^{2}$ по горной породе. Использование анкеров крепления в бортах забоя в этой технологической схеме со смешанным креплением не предусмотрено.

\section{Заключение}

Приведена оценка горнотехнических условий применения технологических схем крепления выработок при подготовительных работах и установлении эффективных технологических схем проведения и крепления контуров подготовительных выработок на угольных шахтах для повышения устойчивости их контуров.

Представленный методический подход позволяет произвести выбор эффективных способов и средств крепления горных выработок для угольных шахт, а обобщенные паспорта крепления выработок позволяют сформировать базу данных, которую можно рассматривать в качестве основы и предпосылки для создания прогрессивных типовых технологических схем проведения, поддержания выработок и обоснования параметров крепления.

Особенность представленной методики по технологии и средствам контурного анкерного крепления состоит в том, что повышается эффективность использования несущей способности вмещающих горных пород со снижением материалоемкости, стоимости крепи и при повышении устойчивости контуров горных выработок.

\section{$\overline{\text { ЛИТЕРАТУРА: }}$}

1. Junker M. Gebirgsbeherrschungv on Flözstrecken. Essen: Verlag Gluckauf GmbH, 2006. 656 p.

2. Лушников В. Н., Еременко В. А., Сэнди М. П., Бухер Р. Крепление горных выработок в условиях деформируемых и удароопасных массивов горных пород // Горный журнал. 2014. N 4. C. 37-43.

3. Пат. 2438018 РФ. Способ борьбы с пучением почвы горных выработок / А. Н. Осипов, А. В. Булкин, Л. М. Гусельников, С. Н. Курка; заявл. 06.08.2010 ; опубл. 27.12.2011, Бюл. N 36.

4. Eremenko V. A., Neguritsa D. L. Efficient and active monitoring of stresses and strains in rock masses // Eurasian Mining. 2016. N 1. C. 21-24. DOI: 10.17580/em.2016.02.10

5. Кузьмин С.В., Сальвассер И. А., Мешков С. А. Механизм развития пучения пород почвы и способы борьбы с ним // Горный информационно-аналитический бюллетень. 2014. Отдельный выпуск N 3. Промышленная безопасность. С. 120-126.

6. Pivnyak G., Bondarenko V., Kovalevs'ka I., Illiashov M. Mining of Mineral Deposits: Annual Scientific-Technical Collection. London: CRC Press, 2013. 382 p.

7. Розенбаум М. А., Демехин Д. Н. Определение деформационных критериев устойчивости пород кровли и анкерной крепи // Физико-технические проблемы разработки полезных ископаемых. 2014. N 2. С. 82-86.

8. Миренков В. Е. К вопросу о зональной дезинтеграции горных пород вокруг подземной выработки // Физикотехнические проблемы разработки полезных ископаемых. 2014. N 1. C. 39-43. 
9. Серяков В. М. О методе расчета напряженного состояния горных пород с учетом особенностей их контактного взаимодействия с крепью выработок // Физико-технические проблемы разработки полезных ископаемых. 2016. N 5. C. 23-29.

10. Kalmykov V. N., Strukov K. I., Kulsaitov R. V., Esina E. N. Geomechanical features of underground mining at Kochkar deposit // Eurasian Mining. 2017. N 2. C. 41-45. DOI: 10.17580/ em.2017.02.03.

11. Gendler S. G., Grishina A. M., Kochetkova E. A. Optimization of expenditures for labor protection at deep mining // Eurasian Mining. 2017. N 2. C. 55-58. DOI: 10.17580/ em.2017.02.09.

12. Цимбаревич П. М. Механика горных пород. 2-е изд., перераб. М.: Углетехиздат, 1948. 184 с.

13. Пат. 2338066 РФ. Способ охраны участковых подготовительных выработок / А. С. Зацепин, И. В. Плескунов; заявл. 19.04.2007; опубл. 10.11.2008, Бюл. N 31.

14. Миренков В. Е. Взаимодействие вмещающих пород и крепи при ведении очистных работ // Физико-технические проблемы разработки полезных ископаемых. 2017. N 5. C. $15-22$.

15. Rogachkov A. V. Compliance test of ground support designs and established standards for temporary roadways in coal mines // Eurasian Mining. 2017. N 2. C. 40-43. DOI: 10.17580/em.2017.02.10

16. Tikhonov N. O., Ivanov A. N. Ore pretreatment reengineering at operating processing plants using high pressure grinding rolls - A promising area of activity (in terms of Erdenet Mining Corporation) // Eurasian Mining. 2015. N 1. C. 9-12.
17. Cognitive simulation of incident risks in the structure of loading and transport enterprise / S. V. Shishkina, Yu. D. Pristupa, L. D. Pavlova, V. N. Fryanov // IOP Conference Series: Earth and Environmental Science. 2017. Vol. 84. Pp. 1-7 (012027).

18. Fryanov, V. N. Theoretical approaches to creation of robotic coal mines based on the synthesis of simulation technologies / V. N. Fryanov, L. D. Pavlova, M. V. Temlyantsev // IOP Conference Series: Earth and Environmental Science. 2017. Vol. 84. Pp. 1-8 (012001).

19. Голик В.И., Разоренов Ю.И. Основа устойчивого развития РСО-Алания - горнодобывающая отрасль // Устойчивое развитие горных территорий. Владикавказ. 2017. N 2(32). C.163-172.

20. Разоренов Ю.И., Голик В.И., Лукьянов В.Г. Искусственные потолочины при подземной добыче руд как альтернатива рудным целикам // Известия Томского политехнического университета. Инжиниринг георесурсов. 2016. T. 327. N 3. C. 87-94.

21. Голик В.И. Оптимизация технологии разработки маломощных пологих рудных тел на геомеханической основе // Известия Тульского государственного университета. Науки о Земле. 2016. N 4. С. 139-152.

22. Демина Т.В., Демин В.Ф. и др. Управление геомеханическими процессами для повышения устойчивости углепородного массива // Научный вестник НГУ (Днепропетровск, Украина). 2016. N 2. С. 5-10.

23. DeminV. F., Nemova N.A., Demina T. V., Karataev A.D. Deformation of Enclosing Rocks Near Mine Workings Depending on Factors Affecting // Scientific bulletin of National Mining University. 2015. No 4. Pp. 35-39.

\section{СВЕДЕНИЯ ОБ АВТОРАХ / Information about authors:}

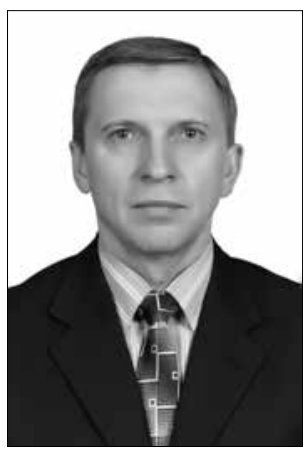

ДЕМИН Владимир Федорович - доктор технических наук, профессор, профессор кафедры «Разработка месторождений полезных ископаемых».

Автор более 450 трудов, в том числе, 25 монографий, 7 учебников, более 150 инновационных (предварительных) патентов РК на изобретения

Научное направление: совершенствование технологии проведения горных выработок с анкерным креплением с учетом геомеханического состояния горных пород.

Карагандинский государственный университет, г. Караганда, Республика Казахстан.

Тел.: 8(7212) 56-26-19, E-mail: vladfdemin@mail.ru

Vladimir F. DEMIN - Doctor of Technical Sciences, Professor, Professor of the Department of "Development of mineral deposits".

Author of more than 450 works, including 25 monographs, 7 textbooks, more than 150 innovative (preliminary) patents of Kazakhstan for inventions.

Scientific direction: improving the technology of mining with anchorage, taking into account the geo-mechanical state of rocks.

Karaganda State University, Karaganda, Republic of Kazakhstan.

Tel: +7(7212) 56-26-19, e-mail: vladfdemin@mail.ru.

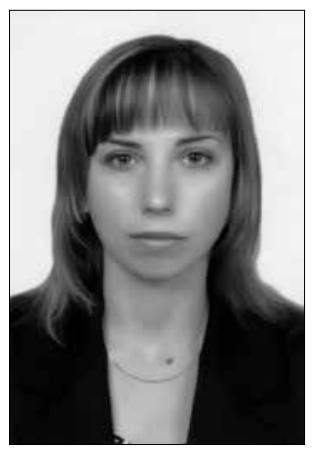

ДЕМИНА Татьяна Владимировна - кандидат технических наук, доцент кафедры «Рудничная аэрология и охрана труда».

Автор более 150 трудов. Научное направление: безопасность технологических процессов с учетом геомеханического состояния горных пород.

Карагандинский государственспублика Казахстан ный университет, г. Караганда, Ре-

Tatyana V. DEMINA - Candidate of Technical Sciences, associate Professor of mine aero logy and labor protection.

Author of more than 150 works. Scientific direction: safety of technological processes taking into account the geo-mechanical state of rocks.

Karaganda State University, Karaganda, Republic of Kazakhstan 


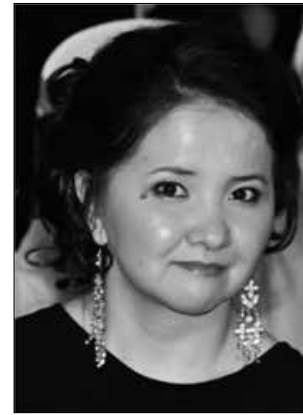

КАЙНАЗАРОВА Айнаш Сабитовна - магистр технических наук, старший преподаватель кафедры «Разработка месторождений полезных ископаемых». Автор более 20 трудов. Основное научное направление: технология стабилизации качества рудной массы при подземной разработке пластообразных залежей.

Екибастузский инженерно-технический институт имени академика К.И. Сатпаева, г. Экибастуз, Республика Казахстан

Inas S. KAINAZAROVA-Master of Technical Sciences, senior lecturer of the chair "Development of mineral deposits". Author of more than 20 works. The main scientific direction: technology of stabilization of quality of ore mass at underground development of plats deposits.

Ekibastuz Engineering-Technical Institute named after academician K. I. Satpayev, Ekibastuz, Republic of Kazakhstan

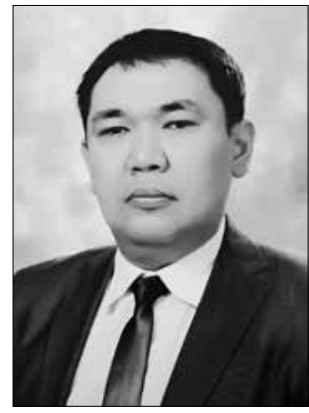

КАЙНАЗАРОВ Арман Серикович - кандидат технических наук, заведующий кафедрой «Разработка месторождений полезных ископаемых». Автор более 50 трудов. Основное научное направление: Технология стабилизации качества рудной массы при подземной разработке пластообразных залежей.

Екибастузский инженерно-технический институт имени академика

К.И. Сатпаева, г. Экибастуз, Казахстан

Arman S. KAINAZAROV - Candidate of Technical Sciences, head of the chair "Development of mineral deposits". Author of more than 50 works. The main scientific direction: technology of stabilization of quality of ore mass at underground development of Plast-like deposits.

Ekibastuz Engineering and Technical Institute named after academician K. I. Satpayev, Ekibastuz, Kazakhstan

\title{
EVALUATION OF THE WORKINGS TECHNOLOGICAL SCHEMES EFFECTIVENESS TO INCREASE THE STABILITY OF THEIR CONTOURS
}

\author{
${ }^{1}$ W. F. Demin,* \\ ${ }^{1}$ T.In. Demina, \\ ${ }^{2}$ A.S. Kaynazarov, \\ ${ }^{2}$ A.S. Kaynazarova \\ ${ }^{1}$ Karaganda State Technical University, Karaganda, Republic of Kazakhstan, vladfdemin@mail.ru \\ ${ }^{2}$ Ekibastuz Engineering and Technical Institute named after academician K. Satpayev, Ekibastuz, Republic of Kazakhstan
}

DOI: $10.21177 / 1998-4502-2018-10-4-606-616$

The purpose of the work is to assess the mining conditions of application of technological schemes of fastening workings in the preparatory work and the establishment of effective technological schemes of holding and fixing the contours for the preparatory workings in the coal mines to improve the stability of their contours.

The idea of the work is to establish technological principles for managing the stability of mine workings contours taking into account the manifestations of the mountain pressure of the adjacent massif and changes in its geo - mechanical state.

The widespread introduction of technological schemes for beztselikovuju dredging of reservoirs has led to high cost of borrowing workings, the need for the workings at the worked-out space. The behavior of rocks of the coal seams roof of the Karaganda basin is determined by their composition, physical and chemical properties, stratification and fracturing. The direct roof of coal seams is most often represented by mudstones, less often siltstones and in isolated cases sandstones, the main roof is usually composed of sandstones. The soil of coal seams is dominated by mudstone.

The method of solving the tasks on the basis of the analysis of domestic and foreign experience in the development of technological schemes of mining in the conditions of reservoir mineral deposits; technological and technical evaluation of the effectiveness of solutions in industrial conditions.

The work was carried out within the framework of research works on the theme "development of effective technology of preparatory workings with anchorage, taking into account the stress-strain state of the rock mass".
In carrying out this work, we used a set of methods of experimental and theoretical research and the following conclusions:

- the presented methodical approach will allow to make a choice of effective ways and means of fastening of mine workings for coal mines and generalized passports of fastening of workings-to form a database that can be considered as a basis and prerequisite for the creation of progressive standard technological schemes of workings and justification of the parameters of fastening and maintenance of workings;

the peculiarity of the presented approach to technology, systems and means of contour fastening is that it allows the most effective use of the bearing capacity of the host rocks, which significantly reduces the material consumption and the cost of the support, increases the stability of the contours and reduces the defect of the cross sections of the supported workings.

Keywords: mining and geological conditions of development, influencing factors, technology, holding, fastening, methods and means of fastening, mining, coal mines.

\section{References}

1. Junker M. Mountain control of seam distances. Food: Verla Gluckauf GmbH, 2006. 656 p.

2. Lushnikov V. N., Eremenko V. A., Sandie M. P., Bukher River. Fastening of excavations in the conditions of deformed and the break-dangerous rock massifs. Mountain magazine, 2014, no 4, pp. 37-43.

3. Stalemate. 2438018. Russian Federation. Way of fight 
against a pucheniye of the soil of excavations / A.N. Osipov, A.V. Bulkin, L.M. Guselnikov, S.N. Kurka; report 06.08.2010; publ.27.12.2011, Bulletin No 36.

4. Eremenko V. A., Neguritsa D. L. Efficient and active monitoring of stresses and strains in rock masses. Eurasian Mining, 2016, no 1, pp. 21-24. DOI: 10.17580/em.2016.02.10.

5. Kuzmin S. V., Salvasser I. A., Meshkov S.A. Mechanism of development of a pucheniye of breeds of the soil and ways of fight against it. Mountain informational and analytical bulletin, 2014, Separate release No 3. Production safety, pp.120-126.

6. Pivnyak G., Bondarenko V., Kovalevs'ka I., Illiashov M. Mining of Mineral Deposits: Annual Scientific-Technical Collection. London: CRC Press, 2013. 382 p.

7. Rosenbaum M.A., Demekhin D. N. Definition of straining stability criterions of breeds of a roof and anchor timbering. Physics and technology problems of development of minerals, 2014, no 2, pp. 82-86.

8. Mirenkov V. E. To a question of zonal disintegration of rocks around underground development. Physics and technology problems of development of minerals, 2014, no 1, pp. 39-43.

9. Seryakov V. M. About a computational method of a stress of rocks taking into account features of their contact interaction with a timbering of developments. Physics and technology problems of development of minerals, 2016, no 5, pp. 23-29.

10. Kalmykov V. N., Strukov K. I., Kulsaitov R. V., Esina E. N. Geomechanical features of underground mining at Kochkar deposit. Eurasian Mining, 2017, no 2, pp. 41-45. DOI: 10.17580/em.2017.02.03.

11. Gendler S. G., Grishina A. M., Kochetkova E. A. Optimization of expenditures for labor protection at deep mining. Eurasian Mining, 2017, no 2, pp. 55-58. DOI: 10.17580/em. 2017.02.09.

12. Tsimbarevich P. M. Mechanics of rocks. 2nd prod., reslave. Moscow, Ugletekhizdat, 1948, 184 p.

13. Stalemate. 2338066. Russian Federation. Way of protection of local preparatory developments/Ampere-second. Zatsepin, I.V. Pleskunov; 19.04.2007; publ.10.11.2008, Bulletin No 31.

14. Mirenkov V. E. Interaction of the containing breeds and a timbering when conducting clearing works. Physics and technology problems of development of minerals, 2017, no 5, pp.15-22.
15. Rogachkov A. V. Compliance test of ground support designs and established standards for temporary roadways in coal mines. Eurasian Mining, 2017, no 2, pp. 40-43. DOI: 10.17580/em.2017.02.10

16. Tikhonov N. O., Ivanov A. N. Ore pretreatment reengineering at operating processing plants using high pressure grinding rolls - A promising area of activity (in terms of Erdenet Mining Corporation). Eurasian Mining, 2015, no 1, pp. 9-12.

17. Cognitive simulation of incident risks in the structure of loading and transport enterprise / S. V. Shishkina, Yu. D. Pristupa, L. D. Pavlova, V. N. Fryanov. IOP Conference Series: Earth and Environmental Science, 2017, vol. 84, pp. 1-7 (012027).

18. Fryanov, V. N. Theoretical approaches to creation of robotic coal mines based on the synthesis of simulation technologies / V. N. Fryanov, L. D. Pavlova, M. V. Temlyantsev. IOP Conference Series: Earth and Environmental Science, 2017, vol. 84, pp. 1-8 (012001).

19. Golik V.I., RazorenovYu.I. A basis of sustainable development RSO-Alania - mining branch. Sustainable development of mountain territories, Vladikavkaz, 2017, no 2(32), pp. 163-172.

20. Golik V.I., RazorenovYu.I., Lukyanov V.G. Simulated potolochina at underground extraction of ores as an alternative ore entirely. News of Tomsk Polytechnic University.Engineering of georesources, 2016, v. 327, no 3, pp. 87-94.

21. GolikV.I. Optimization of technology of development of low-current flat ore bodies on a geomechanical basis. News of the Tula State University. Earth Sciences, 2016, no 4, pp. 139-152.

22. Demin T.V., Demin V.F. and others. Management of geomechanical processes for increase in stability of the ugleporodny massif (article). Scientific bulletin of NSU (Dnipropetrovsk, Ukraine), 2016, no 2, pp. 5-10.

23. Demin V. F., NemovaN. A.,DeminaT. V., KarataevA. D. Deformation of Enclosing Rocks Near Mine Workings Depending on Factors Affecting. Scientific Bulletin of National Mining University, 2015, no 4, pp. 35-39.

Article received 07.05.2018. 


\section{РАЗРАБОТКА МЕТОДОВ КОРРЕКТИРУЮЩИХ АЛГОРИТМОВ ДЛЯ ПОСТРОЕНИЯ ОПТИМАЛЬНОЙ СТРАТЕГИИ РАЗВИТИЯ ГОРНЫХ ТЕРРИТОРИЙ}

1Лютикова Л.А., ${ }^{2}$ Махошева C.A., * ${ }^{1}$ Шматова Е.В., ${ }^{2}$ Кандрокова М.М.

\section{Введение}

Задачи развития горных территорий требуют особого подхода. Надо заметить, что отсутствие единой модели развития горных территорий приводит к разнообразию рекомендаций, которые не всегда могут оказаться согласованными. Для достижения устойчивого развития необходимо провести комплексную оценку природно-ресурсного потенциала и уровня экономического развития анализируемой территории; рассмотреть совокупность ранее разработанных моделей оценить преимущество и недостатки каждой из них.

В настоящей работе предлагается метод комплексной оценки множества моделей развития горных территорий для выявления наиболее оптимальной модели из предложенных или построения оптимальной в результате синтеза и коррекции уже существуюших. Данный метод основан на логико-математическом аппарате, адаптированном для решения поставленной задачи. В рамках предлагаемого подхода каждая модель развития выступает в качестве алгоритма. Решение данной задачи состоит в построении такой оптимальной концепции развития заданных горных территорий, которая включает в себя преимущества исследуемых концепций и при этом лишена их недостатков. Построенная оптимальная концепция развития и будет выступать в качестве искомой модели оптимального развития.

Методы математической логики могут служить основой для синтеза устойчивых концепций развития целого ряда регионов на базе уже существующих. Это позволяет создавать новые методы автоматизированного построения концепции развития горных территорий, близкие по качеству к рассуждению эксперта [6].

Поскольку каждый рассматриваемый горный регион имеет определенный набор ресурсов, измеряемых своей шкалой развитости этого ресурса в данном регионе, то удобно кодировать каждый признак предикатами разной значности, соответствующей шкале, используемой для рассматриваемого ресурса.

\section{Постановка задачи}

В качестве характеристик развития территории, как правило, выступают экономика, социальная сфера, ресурсный потенциал развития и т.д. Эти сферы развития в формальной постановке задачи будут именоваться свойствами или характеристиками объекта. Все объекты, регионы горных территорий обладают своими характерными признаками. Например, ресурсный потенциал любого региона определяется земельными, водными, биологическими, энергетическими, трудовыми и прочими. Поскольку признаки обладают разнообразием и различными шкалами измерения, представляется удобным кодировать их переменно-значными предикатами. В рамках предлагаемого подхода задачу поиска оптимальной стратегии развития горных территорий можно сформулировать на языке математической логики.

Описание каждого региона будет представлено $m$-мерным вектором $X=\left\{x_{1}, x_{2}, \ldots ., x_{\mathrm{m}}\right\}$, где $m$ - число используемых в данном регионе ресурсов для построения концепции развития региона, $j$-я координата этого векто-

${ }^{1}$ Институт прикладной математики и автоматизации КБНЦ РАН, Нальчик, Россия.

${ }^{2}$ Институт информатики и проблем регионального управления КБНЦ РАН, Нальчик, Россия.

\section{УДК: 519.7}

DOI: 10.21177/1998-4502-2018-104-617-623

\section{Предлагается метод}

интеллектуального анализа концепций развития горных территорий с целью выработки оптимальной устойчивой путем логической коррекции всех существующих. B предлагаемой модели каждая территориальная область описывается множеством ресурсов и коммуникаций, интерпретируется как некий математический объект (регион), обладающий свочми признаками (ресурсами) в предикатах переменно-значной логики. Сопоставление регионов и соответствующих им ресурсов образуют предметную область, для которой уже существуют концепции развития. В ходе исследования предложен логический метод анализа существующих концепций, заключающийся в построении функции классификатора рассматриваемых регионов, что позволяет сформировать базу знаний для заданных регчонов, выделяющих уникальное множество ресурсов, необходимое для развития региона или группы регионов, а также в случае необходимости провести коррекцию существующих концепций с целью выработки оптимальной.

\section{КЛЮЧЕВЫЕ СЛОВА:}

концепция развития, регион, данные, база знаний, предметная область, переменно-значная логика, устойчивое развитие, классификатор концепций

Статья поступила в редакцию 20.12.2017. 
ра - закодированное значение, отражающее состояние ресурса под $j$-м номером в соответствии со шкалой измерения состояния данного ресурса, $j=1, \ldots, m$. В описании региона возможно отсутствие знания о значении того или иного ресурса. Множество заданных регионов и ресурсов, рассматриваемых для построения концепции устойчивого развития, представляют собой предметную область, на которой было рассмотрено $n$ концепций (предлагаемых моделей развития). Для всех существующих концепций имеется экспертная оценка, которую можно представить булевой функцией, принимающей значение: или плохо, или хорошо. Можно предположить, что ни одна из рассматриваемых концепций не является идеальной. Поэтому предлагается применить методы логической коррекции существующих концепций для построения наиболее успешной по отношению к исследуемым регионам.

\section{Математическая постановка задачи}

Будем рассматривать предметную область, состоящую из множества регионов и их ресурсов, а также ряд концепций развития $A_{1}, A_{2}, \ldots ., A_{n}$.

Будем считать $X=\left\{x_{1}, x_{2}, \ldots ., x_{\mathrm{m}}\right\}, x_{i} \in\left\{0,1, \ldots, k_{\mathrm{r}}-1\right\}$, где $k_{r} \in[2, \ldots, \mathrm{N}], N \in Z-$ множество ресурсов заданного региона, представленных предикатами, значность которых соответствует шкале для оценки данного ресурса; $X_{i}=\left\{x_{1}\left(y_{\mathrm{i}}\right), x_{2}\left(y_{\mathrm{i}}\right), \ldots ., x_{\mathrm{m}}\left(y_{\mathrm{i}}\right)\right\}, i=1, \ldots, l-$ вектор признаков региона $y_{i} \in Y, Y=\left\{y_{1}, y_{2}, \ldots, y_{i}\right\}-$ множество регионов; $A=\left\{A_{1}, A_{2}, \ldots ., A_{n}\right\}-$ множество концепций развития, $a_{j}\left(X_{i}, y_{i}\right) \in\{0,1\} ; i=1,2, \ldots, l ; j=1,2, \ldots, n-$ качество данной концепции на заданном наборе ресурсов $X_{i}=\left\{x_{1}\left(y_{\mathrm{i}}\right)\right.$, $\left.x_{2}\left(y_{\mathrm{i}}\right), \ldots ., x_{\mathrm{m}}\left(y_{\mathrm{i}}\right)\right\}, i=1,2, \ldots, l$ : определяемое формулой

$$
a_{j}\left(y_{i}\right)=\left\{\begin{array}{ll}
1, & A_{j}\left(X_{i}\right)=y_{i} \\
0, & A_{j}\left(X_{i}\right) \neq y_{i}
\end{array}, \quad i=1,2, \ldots, l, j=1,2, \ldots, n,\right.
$$

т.е. 1 - концепция развития $A_{j}$ хороша для региона $y_{i}$ по заданным ресурсам $x_{i}$,

0 - концепция развития $A_{j}$ не хороша для региона $y_{i}$ по заданным ресурсам $x_{i}$.

Все ранее описанное может быть представлено в виде таблицы (табл. 1).

$\left.A^{\prime}{ }_{i}=\left\{a_{i}\left(y_{1}\right), a_{i}\left(y_{2}\right)\right), \ldots, a_{i}\left(y_{l}\right)\right\}, i=1,2, \ldots, n-$ вектор, представленный столбцом значений оценки качества работы концепции $A_{i}$ в каждом из заданных регионов.

Некоторые из заданных регионов не имеют оценки ни одной концепции развития. Математически это выглядит так:

$$
\begin{aligned}
& \exists y_{i} \in Y \mid A_{1}\left(X_{i}\right) \neq y_{i}, A_{2}\left(X_{i}\right) \neq y_{i}, \ldots, A_{n}\left(X_{i}\right) \neq y_{i}, \\
& i=1,2, \ldots, l, j=1, \ldots, n .
\end{aligned}
$$

Необходимо разработать концепцию на основе уже существующих, которая обеспечит устойчивое развитие всех регионов, представленных в заданной предметной области. Т.е. найти $A_{n+1}\left(X_{i}\right) \mid A_{n+1}\left(X_{i}\right)=y_{i}$ и $A_{n+1}(X) \mid A_{n+1}(X)=Y$.

Определение. Будем говорить, что концепция развития региона устойчива на множестве регионов $Y$, определяемых совокупностью ресурсов $X$ если $\forall y_{i} \in Y: a_{j}\left(X_{i}, y_{i}\right)=1, i=1,2, \ldots, l ; j=1, \ldots, n$.

С целью проведения анализа рассмотренной выше предметной области, применим алгебру переменно-значной логики [3; 4]. Это позволяет осуществить формализованное описание разнородных параметров. Предоставляя для каждого из них удобную шкалу описания, Таким образом, каждый отдельный ресурс представим в виде: $x_{i} \in\left\{0,1, \ldots, k_{r}-1\right\}$.

\section{Операции переменно-значной логики}

Определение. Высказывания переменно-значной логики являются высказываниями, истинность которых определяется следующими значениями $\left\{0,1, \ldots, k_{r}-1\right\}, k_{r} \epsilon[2, \ldots, N], N \epsilon Z, B$ - формула высказывания, определенная тремя операциями:

- отрицание или обобщенная инверсия (унарная операция),

- \& конъюнкция (бинарная),

- дизъюнкция (бинарная).

Используются также константы:

$$
0,1 \ldots k_{r}-1, k_{r} \epsilon[2, \ldots, N], N \epsilon Z \text {. }
$$

Пусть $X_{i}$ - независимая многозначная переменная величина, $X_{i} \in\left[0, \ldots, k_{r}-1\right]$, являющаяся одной из характеристик региона. Введем еще несколько функций и свойств переменно-значной логики.

Перечислим функции переменно-значной логики, которые называются элементарными.

1. Значение переменной:

$$
x_{i}^{j}=\left\{\begin{array}{ll}
j, & x_{i}=j \\
0, & x_{i} \neq j
\end{array},\right.
$$

2. Инверсия, которую будем называть обобщенной:

$$
\overline{x^{j}}=x^{0} \vee x^{1} \vee \ldots \vee x^{j-1} \vee x^{j+1} \vee \ldots \vee x^{k-1} \text {. }
$$

таблица 1 / Table 1

Входные данные и оценки концепций развития / Input and assessment of development concepts

\begin{tabular}{|cccc|c|cccc|}
\hline$x_{i}$ & $x_{2}$ & $\ldots$ & $x_{m}$ & $Y$ & $\dot{A}_{1}$ & $\dot{A}_{2}$ & $\ldots$ & $\dot{A}_{\mathrm{n}}$ \\
\hline$x_{i}\left(y_{1}\right)$ & $x_{2}\left(y_{1}\right)$ & $\ldots$ & $x_{\mathrm{m}}\left(y_{1}\right)$ & $y_{1}$ & $a_{1}\left(y_{1}\right)$ & $a_{2}\left(y_{1}\right)$ & $\ldots$ & $a_{\mathrm{n}}\left(y_{1}\right)$ \\
$x_{1}\left(y_{2}\right)$ & $x_{2}\left(y_{2}\right)$ & $\ldots$ & $x_{\mathrm{m}}\left(y_{2}\right)$ & $y_{2}$ & $a_{1}\left(y_{2}\right)$ & $a_{2}\left(y_{2}\right)$ & $\ldots$ & $a_{\mathrm{n}}\left(y_{2}\right)$ \\
$\ldots$ & $\ldots$ & $\ldots$ & $\ldots$ & $\ldots$ & $\ldots$ & $\ldots$ & $\ldots$ & $\ldots$ \\
$x_{i}\left(y_{1}\right)$ & $x_{2}\left(y_{1}\right)$ & $\ldots$ & $x_{\mathrm{m}}\left(y_{1}\right)$ & $y_{1}$ & $a_{1}\left(y_{1}\right)$ & $a_{2}\left(y_{1}\right)$ & $\ldots$ & $a_{\mathrm{n}}\left(y_{1}\right)$ \\
\hline
\end{tabular}


Данное представление дает возможность учесть любые интерпретации отрицания в различных многозначных логических системах.

3. Пусть переменные $X \in\left[0, \ldots, k_{i}-1\right], Y \in\left[0, \ldots, k_{j}-1\right]$ имеют разную значность, тогда обобщенная дизьюнкция:

$$
\begin{gathered}
X \vee Y=\max \left[\frac{X}{k_{i}-1} ; \frac{Y}{k_{i}-1}\right] * l, \\
\text { где } l=\left\{\begin{array}{lc}
k_{i}-1 & \text { при } \frac{X}{k_{i}-1}>\frac{Y}{k_{i}-1} \\
k_{j}-1 & \text { иначе }
\end{array}\right.
\end{gathered}
$$

4. Обобщенная конъюнкция:

$$
\begin{gathered}
X \& Y=\min \left[\frac{X}{k_{i}-1} ; \frac{Y}{k_{j}-1}\right] * l, \\
\text { где } l=\left\{\begin{array}{lc}
k_{i}-1 & \text { при } \frac{X}{k_{i}-1}<\frac{Y}{k_{j}-1} \\
k_{j}-1 & \text { иначе }
\end{array} .\right.
\end{gathered}
$$

5. Импликацию для переменно-значной логики зададим следующим выражением: $X \rightarrow Y=\bar{X} \vee Y$.

Элементарные функции переменно-значной логики обладают следующими свойствами [4]:

$$
\begin{gathered}
0 \& X=0, \\
1 \& X=X, \\
(k-1) X=(k-1), \\
0 X=X, \\
x^{j} \& x^{k}= \begin{cases}x^{j}, & j=k \\
0, & j \neq k\end{cases}
\end{gathered} .
$$

Функция оценки концепции устойчивого развития горных территорий

Определение: Решающим правилом назовем:

$$
\&_{j=1}^{m} x_{j}\left(y_{i},\right) \rightarrow y_{i}
$$$$
i=1, \ldots, l, x_{j}\left(y_{i}\right) \in\left\{0,1, \ldots, k_{i}-1\right\}, k_{i} \epsilon[2, \ldots, N], N \epsilon Z
$$

В нашем случае правило утверждает, что каждый регион характеризуется совокупностью своих ресурсов [5].

Пусть имеется $n$ концепций развития горных территорий $\left\{A_{1}, A_{2}, \ldots ., A_{n}\right\}$, частично устойчивых на заданном множестве регионов. Для каждого заданного множества ресурсов $X_{i}$ строим оценку устойчивости концепции развития и получаем набор векторов $\left.A^{\prime}{ }_{j}=\left\{a_{j}\left(y_{1}\right), a_{j}\left(y_{2}\right)\right), \ldots, a_{j}\left(y_{l}\right)\right\}, j=1,2, \ldots, n \quad$ в виде столбца $\dot{A}^{1}$. Получаем результат оценки концепции на каждой заданной строке, соответствующей региону $y_{i}$, которому соответствует продукционное правило:

$$
\begin{aligned}
& \&_{s=1}^{m} x_{s}\left(y_{i}\right) \rightarrow y_{i}, \\
& x_{s}\left(y_{i}\right) \in\left\{0,1, \ldots, k_{r}-1\right\}, i=1, \ldots, l, s=1, \ldots, m .
\end{aligned}
$$

\section{Логический подход к реализации расииряющей концепции устойчивого развития горных территорий}

Очевидна целесообразность выбора концепции устойчивого развития, имеющей свойства: $A_{j}\left(X_{i}\right)=y_{i}, a_{j}\left(X_{i}, y_{i}\right)=1$. В случае если хотя бы одна концепция развития нашла решение вида: $A_{j}\left(X_{i}\right)=y_{i}$, то $\vee_{j=1}^{n} a_{j}\left(y_{i}\right)=1$. Если ни одна из рассматриваемых концепций не устойчива в регионе $y_{i}, m o \vee_{j=1}^{n} a_{j}\left(y_{i}\right)=0$.

Представим всю предметную область в виде решающих правил:

$$
\begin{aligned}
& \&_{s=1}^{m} x_{s}\left(y_{i}\right) \rightarrow y_{i}, \\
& i=1, \ldots, l, x_{s}\left(y_{i}\right) \in\left\{0,1, \ldots, k_{r}-1\right\}, k_{r} \in[2, \ldots, N], N \epsilon Z .
\end{aligned}
$$

Для каждой концепции развития выберем те правила, по которым концепция устойчива в данном регионе если $\exists a_{j}\left(y_{i}\right)=1$, то $\&_{s=1}^{m} x_{s}\left(y_{i}\right) \rightarrow y_{i}$, $i=1, \ldots, l, x_{s}\left(y_{i},\right) \in\left\{0,1, \ldots, k_{r}-1\right\}, k_{r} \in[2, \ldots, N], N \epsilon Z$

Составим функцию, которая будет являться конъюнкцией таких правил для рассматриваемой концепции. Руководствуясь следующими логическими рассуждениями: концепция развития $A_{j}$ устойчива в регионе $y_{j}$ и концепция развития $A_{j}$ устойчива в регионе $y_{p}$ и в остальных регионах, заданных, как регионы, в которых данная концепция устойчива:

$$
F_{j}\left(X_{i}\right)=\&_{a_{j\left(y_{i}\right)}=1}\left(\&_{s=1}^{m} x_{s}\left(y_{i}\right) \rightarrow y_{i}\right)=\&_{a_{j\left(y_{i}\right)}=1}\left(\vee_{s=1}^{m} \overline{x_{s}\left(y_{i}\right)} \vee y_{i}\right) .
$$

В результате данная булева функция может быть записана в виде СДНФ и сокращена. Для заданной концепции развития $A_{j}$ мы получили функцию $F_{j}$, значение которой равно единице там, где данная концепция развития является устойчивой, и равна нулю - в случае, когда концепция неустойчива.

Эта булева функция играет роль оценочного функционала качества и обладает рядом свойств [2].

Логический подход к построению устойчивой концепции развития горных территорий на заданном множестве регионов

Добавим в предыдущую таблицу требования к устойчивости $A_{n+1}(X)$ и составим таблицу (см. табл. 2):

T.e. для $A_{n+l}(X)$ все значения $a_{n+l}\left(y_{1}\right)=1, i=1,2 \ldots, l$.

Поскольку $a_{\mathrm{j}}\left(y_{\mathrm{i}}\right)$ является булевой переменной, то $A_{n+1}^{\prime}\left(A_{1}^{\prime}, A_{2}^{\prime} \ldots A_{n}^{\prime}\right)$ - булева функция, принимающая значения 1 на всех заданных в предметной области наборах $\left(A_{1}^{\prime}, A_{2}^{\prime} \ldots A_{n}^{\prime}\right)$. Запишем это в следующем виде:

$A_{n+1}^{\prime}\left(A_{1}^{\prime}, A_{2}^{\prime} \ldots A_{n}^{\prime}\right)=\vee_{i=1}^{l} \&_{j=1}^{n} A^{\sigma^{\prime}}{ }_{j}\left(y_{i}\right), i=1,2, \ldots, l, j=1,2, \ldots, n$.

$$
A_{j}^{\sigma^{\prime}}\left(y_{i}\right)=\left\{\begin{array}{ll}
A^{\prime}{ }_{j}, & a_{j}\left(y_{i}\right)=1 \\
A_{j}^{\prime}, & a_{j}\left(y_{i}\right)=0
\end{array},\right.
$$

Понятно, что $A_{j}{ }^{\prime}$ - это совокупность решающих правил, на которых концепция устойчива, $\overline{A^{\prime}}{ }_{j}-$ совокупность решающих правил, на которых концепция не устойчива. 
Входные данные и оценочная функция корректирующей концепции Input data and evaluation function of the corrective concept

\begin{tabular}{|c|c|c|c|c|c|c|c|c|c|}
\hline$x_{i}$ & $x_{2}$ & $\cdots$ & $x_{m}$ & $Y$ & $\dot{A}_{1}$ & $\dot{A}_{2}$ & $\ldots$ & $\dot{A}_{\mathrm{n}}$ & $\dot{A}_{\mathrm{n}+1}$ \\
\hline$x_{i}\left(y_{1}\right)$ & $x_{2}\left(y_{1}\right)$ & $\ldots$ & $x_{\mathrm{m}}\left(y_{1}\right)$ & $y_{1}$ & $a_{1}\left(y_{1}\right)$ & $a_{2}\left(y_{1}\right)$ & $\ldots$ & $a_{\mathrm{n}}\left(y_{1}\right)$ & 1 \\
\hline$x_{1}\left(y_{2}\right)$ & $x_{2}\left(y_{2}\right)$ & $\ldots$ & $x_{\mathrm{m}}\left(y_{2}\right)$ & $y_{2}$ & $a_{1}\left(y_{2}\right)$ & $a_{2}\left(y_{2}\right)$ & $\ldots$ & $a_{\mathrm{n}}\left(y_{2}\right)$ & 1 \\
\hline$\ldots$ & $\ldots$ & $\ldots$ & $\ldots$ & $\ldots$ & $\ldots$ & $\ldots$ & $\ldots$ & $\ldots$ & $\ldots$ \\
\hline$x_{1}\left(y_{1}\right)$ & $x_{2}\left(y_{1}\right)$ & $\ldots$ & $x_{\mathrm{m}}\left(y_{1}\right)$ & $y_{1}$ & $a_{1}\left(y_{1}\right)$ & $a_{2}\left(y_{1}\right)$ & $\ldots$ & $a_{\mathrm{n}}\left(y_{1}\right)$ & 1 \\
\hline
\end{tabular}

таблица 3 / Table 3

Зависимости между ресурсами в указанных регионах, степень устойчивости развития предлагаемых концепций The dependence between the resources in these regions, the degree of sustainability of the proposed concepts

\begin{tabular}{|ccc|c|cccc|}
\hline$x_{i}$ & $x_{2}$ & $x_{3}$ & $Y$ & $A_{1}$ & $A_{2}$ & $A_{3}$ & $A_{4}$ \\
\hline 0 & 0 & 1 & $a$ & 1 & 0 & 1 & 1 \\
0 & 2 & 1 & $b$ & 0 & 0 & 1 & 1 \\
2 & 1 & 2 & $\mathrm{c}$ & 0 & 1 & 0 & 0 \\
1 & 2 & 0 & $d$ & 0 & 0 & 0 & 0 \\
\hline
\end{tabular}

$$
\begin{aligned}
& A_{j}^{\prime}=\&_{i=1}^{l}\left(\&_{s=1}^{m} x_{s}\left(y_{i}\right) \rightarrow y_{i}\right) \text { когда } a_{j}\left(y_{i}\right)=1, \\
& \overline{A^{\prime}{ }_{j}}=\overline{\&_{i=1}^{l}\left(\&_{s=1}^{m} x_{s}\left(y_{i}\right) \rightarrow y_{i}\right)} \text { когда } a_{j}\left(y_{i}\right)=0,
\end{aligned}
$$

Можно записать в следующем виде:

$$
\begin{aligned}
& A_{j}^{\prime}=\&_{i=1}^{l}\left(\vee_{s=1}^{m} \overline{x_{s}\left(y_{i},\right)} \vee y_{i}\right) \text { когда } a_{j}\left(y_{i}\right)=1, \\
& \overline{A^{\prime}{ }_{j}}=\&_{i=1}^{l}\left(\&_{s=1}^{m} x\left(y_{i}\right) \& \overline{y_{i}}\right) \text { когда } a_{j}\left(y_{i}\right)=0 .
\end{aligned}
$$

Пример.

Пусть заданы следующие условия: $X=\left\{x_{1}, x_{2}, x_{3}\right\}$, $x_{i} \in\{0,1,2\}$, где $X$ - это набор ресурсов, например, минеральные ресурсы и разработка месторождений полезных ископаемых в горных условиях, водные ресурсы гор, земельные ресурсы горных территорий и все они оцениваются трехбалльной шкалой. 0 - ресурс отсутствует, 1 - ресурса мало, 2 - ресурса достаточно. Рассматриваются четыре региона $\{a, b, c, d\}$, для развития которых предложены соответствующие концепции $\left\{A_{1} A_{2} A_{3} A_{4}\right\}$. Зависимости между ресурсами в указанных регионах, степень устойчивости развития предлагаемых концепций отражены в табл. 3 .

На основе представленных данных построим корректирующую концепцию устойчивого развития ре- гионов, включающую в себя положительные свойства заданных концепций и добавляющие определенные правила, компенсирующие их недостатки.

$$
F=A_{n+1}^{\prime}\left(A_{1}^{\prime}, A_{2}^{\prime} \ldots A_{n}^{\prime}\right)=\vee_{i=1}^{l} \&_{j=1}^{n} A_{j}^{\sigma^{\prime}}\left(y_{i}\right)
$$

$F=A_{1} \& \overline{A_{2}} \& A_{3} \& \overline{A_{4}} \vee \overline{A_{1}} \& \overline{A_{2}} \& A_{3} \& A_{4} \vee \overline{A_{1}} \& \overline{A_{3}} \& A_{2} \& A_{4} \vee \overline{A_{1}} \& \overline{A_{2}} \& \overline{A_{3}} \& \overline{A_{4}}$

Запишем решающие правила и преобразуем их:

$A_{5}=\left(x_{1}^{0} \& x_{2}^{0} \& x_{3}^{1} \rightarrow a\right) \&\left(x_{1}^{0} \& x_{2}^{2} \& x_{3}^{1} \rightarrow b\right) \&\left(x_{1}^{1} \& x_{2}^{2} \& x_{3}^{0} \rightarrow d\right)=$ $=x_{1}^{2} \vee x_{3}^{2} \vee x_{2}^{1} \vee x_{1}^{1} x_{2}^{0} \vee x_{1}^{1} x_{3}^{1} \vee x_{1}^{0} x_{3}^{0} \vee x_{2}^{0} x_{3}^{0} \vee$

$\vee x_{3}^{0} d \vee b x_{1}^{0} x_{2}^{2} \vee b x_{2}^{2} x_{3}^{1} \vee b d x_{2}^{2} \vee a x_{1}^{0} x_{2}^{0} \vee a x_{2}^{0} \vee a x_{2}^{0} x_{3}^{1} \vee x_{1}^{1} d$

Концепция развития $A_{5}$ выделяет индивидуальные признаки региона $d$.

\section{Заключение}

В результате проведенного исследования можно сделать вывод о целесообразности использования математической логики для интеллектуального анализа качества концепции устойчивого развития горных территорий. Провести синтез и коррекцию уже существующих концепций. Полученный результат применить для выработки высокоэффективных экспертных оценок и рекомендаций с целью построения оптимальной стратегии развития горных территорий.

\section{Исследование выполнено при финансовой поддержке РФФИ в рамках научного проекта № 18-010-00943}

\section{ЛИТЕРАТУРА:}

1. Журавлев Ю. И. Об алгебраическом подходе к решению задач распознавания или классификации // Проблемы кибернетики. 1978. Т. 33. С. 5-68.

2. Shibzukhov, Z.M. Correct aggregation operations with algorithms (2014) Pattern Recognition and Image Analysis. 24 (3). Pp. 377-382. http://www.springer.com/sgw/cda/frontp age/0,11855,1-40109-70-62708648-0,00.html". doi: 10.1134/ S1054661814030171

3. Тимофеев А.В., Лютикова Л.А. Развитие и применение многозначных логик и сетевых потоков в интеллектуальных системах // Труды СПИИРАН. 2005. Вып. 2. С. 114-126.

4. Лютикова Л.А. Моделирование и минимизация баз 
знаний в терминах многозначной логики предикатов. Препринт. Нальчик, НИИ ПМА КБНЦ РАН, 2006. 33 с.

5. Лютикова Л. А., Шматова Е. В. Анализ и синтез алгоритмов распознавания образов с использованием переменно-значной логики // Информационные технологии. 2016. Том 22, N4. C. 292-297.

6. Воронцов К. В. Оптимизационные методы линейной и монотонной коррекции в алгебраическом подходе к проблеме распознавания // Журнал вычислительной математики и математической физики. 2000. Т. 40, N 1. С. 166-176.

7. Журавлев Ю. И., Рудаков К. В. Об алгебраической коррекции процедур обработки (преобразования) информации // Проблемы прикладной математики и информатики. 1987. С. 187-198.

8. Нестик Т.А. Модели управления знаниями в российских организациях: социально-психологический анализ // Современные технологии управления. 2014. N1(37). Режим доступа: http://sovman.ru/article/3705/

9. Жуликова О.В. Функция управления знаниями как система аккумулирования интеллектуального капитала // Вестник Тамбовского университета. Серия Гуманитарные науки. 2013. N12(128). С. 370-375.

10. Шурупова А.С. Управление знаниями как фактор социально-экономического развития // Креативная экономика. 2013. N 12 (84). C. 133-143. URL: http://bgscience.ru/lib/4986/

11. Мильнер Б.З., Румянцева 3.П., Смирнова В.Г., Блинникова А.В. Управление знаниями в корпорациях / Под ред. Б.3. Мильнера. М.: Дело, 2006.

12. Цыренов Д. Д., Гармаев А.Д. Концептуальные подходы к построению системы управления знаниями на региональном уровне // Вестник Бурятского государственного университета. 2015. Вып. 2а. С.52-56.

13.Тощев А.С. Применение моделей мышления в интел- лектуальных вопросно-ответных системах // Russian Digital Libraries Journal. 2015. V. 18. N 5. Pp. 222-228.

14. Макаров О.Н. Национальные особенности построения интегрированных информационных систем для регионального управления: http://old.ci.ru/inform02_03/p_14-15. htm

15. Svetlana A. Tumenova, Marina M. Kandrokova, Salima A. Makhosheva, Gumar H. Batov, Svetlana V. Galachieva. Organizational Knowledge and its Role in Ensuring Competitiveness of Modern Socio-Economic Systems // Revista Espacios. 2018. Vol. 39. No 26. P. 12. URL: http://www. revistaespacios.com/a18v39n26/18392633.html

16. Salima A. Makhosheva, Natalia Y. Rud, Marina M. Kandrokova, Magamed V. Israilov, Fatimat B. Shinahova. The paradigm of sustainable development and innovation in the region // Revista Espacios. 2018. Vol. 39, No 47. P. 28. URL: http://http://www.revistaespacios.com/a18v39n47/18394728. html

17. Mesiar, R., Komornikova, M., Kolesarova, A., Calvo, T. (2008) Aggregation Functions: A Revision Fuzzy Sets and Their Extensions: Representation, Aggregation and Models. Springer, Berlin, Heidelberg, 2008.

18. Grabich, M., Marichal, J.-L., Pap, E. (2009) Aggregation Functions: Encyclopedia of Mathematics and Its Applications. 2009. P. 127.

19. Calvo, T., Beliakov, G. Aggregation functions based on penalties (2010) // Fuzzy Sets and Systems. 2010. 161 (10). Pp. 1420-1436. doi: 10.1016/j.fss.2009.05.012

20. Mesiar, R., Komornikova, M., Kolesarova, A., Calvo, T. (2008) Fuzzy Aggregation Functions: A revision. Sets and Their Extensions: Representation, Aggregation and Models. SpringerVerlag, Berlin, 2008.

\section{СВЕДЕНИЯ ОБ АВТОРАХ / Information about authors:}

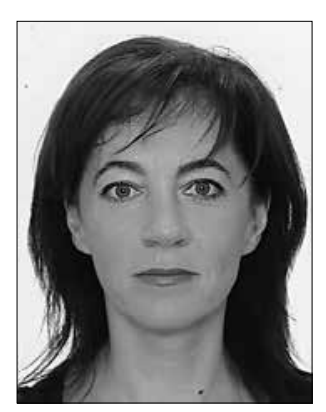

ЛЮТИКОВА Лариса Адольфовна - кандидат физико-математических наук, заведующая отделом нейроинформатики машинного обучения; Институт прикладной математики и автоматизации - филиал Федеральное государственное бюджетное научное учреждения «Федеральный научный центр «Кабардино-Балкарский научный центр Российской академии наук», 360000, г. Нальчик, Кабардино-Балкарская Республика, Россия

Тел.: +7(963)1664014

E-mail: lylarisa@yandex.ru

Larissa A. LYUTIKOVA-Candidate of Physico-Mathematical Sciences, head of the Department of Machine Learning Neuroinformatics, Institute of applied mathematics and automation-branch of the Federal state budgetary scientific institution "the Federal scientific center" Kabardino-Balkar scientific center of the Russian Academy of Sciences", 360000, Nalchik, Kabardino-Balkar Republic, Russia

Ph.: +7(963) 1664014

e-mail:lylarisa@yandex.ru

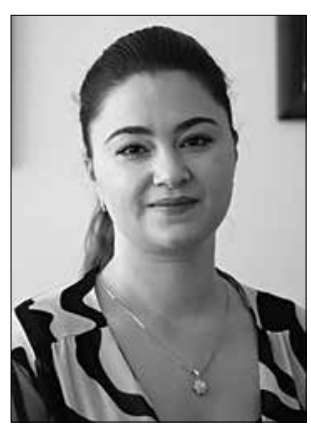

МАХОШЕВА Салима Александровна - доктор экономических наук, заведующая отделом "Экономика знаний и опережающее региональное развитие"; Институт информатики и проблем регионального управления - филиал Федеральное государственное бюджетное научное учреждения «Федеральный научный центр «Кабардино-Балкарский научный центр Российской академии наук», 360000, г. Нальчик, Кабардино-Балкарская Республика, Россия

Тел.: +7(928)7210204

E-mail: salima@list.ru

Salima A. MAKHOSHEVA - Doctor of Economic Sciences, head of the Department "Economics of knowledge and advanced regional development", Institute of Informatics and problems of regional management-branch of the Federal state budgetary scientific institution " Federal scientific center "Kabardino-Balkar scientific center of the Russian Academy of Sciences", 360000, Nalchik, Kabardino-Balkar Republic, Russia

Ph.: +7 (928) 7210204

E-mail: salima@list.ru 


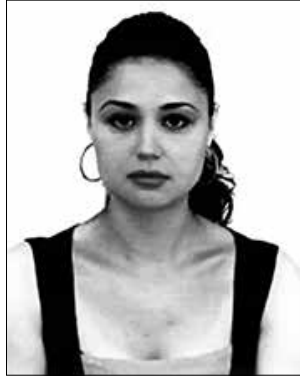

КАНДРОКОВА Марина Мухарбиевна - кандидат экономических наук, старший научный сотрудник отдела "Экономика знаний и опережающее региональное развитие", Институт информатики и проблем регионального управления - филиал Федеральное государственное бюджетное научное учреждения «Федеральный научный центр «Кабардино-Балкарский научный центр Российской академии наук», 360000, г. Нальчик, Кабардино-Балкарская Республика, Россия.

Тел.: +7(938)0781849;

E-mail: kandrokova-marina@mail.ru

Marina M. KANDROKOVA - Candidate of Economic Sciences, senior researcher of the Department "Knowledge economy and advanced regional development", Institute of Informatics and regional management problems-branch of the Federal state budgetary scientific institution "Federal scientific center" Kabardino-Balkarian scientific center of the Russian Academy of Sciences", 360000, Nalchik, Kabardino-Balkarian Republic, Russia.

Ph.: +7 (938)0781849;

e-mail:kandrokova-marina@mail.ru

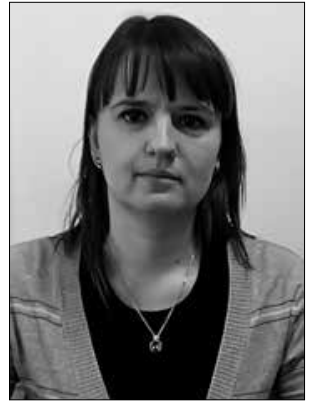

ШМАТОВА Елена Витальевна - младший научный сотрудник отдела Нейроинформатики машинного обучения, Институт прикладной математики и автоматизации филиал Федеральное государственное бюджетное научное учреждения «Федеральный научный центр «Кабардино-Балкарский научный центр Российской академии наук», 360000 , г. Нальчик, Кабардино-Балкарская Республика, Россия, e-mail: lenavsh@yandex.ru.

Elena V. SHMATOVA - Junior researcher of the Department of Machine Learning Neuroinformatics, Institute of applied mathematics and automation-branch of the Federal state budgetary scientific institution "Federal scientific center" Kabardino-Balkar scientific center of the Russian Academy of Sciences", 360000, Nalchik, Kabardino-Balkar Republic,Russia,e-mail: lenavsh@yandex.ruahhh!

\title{
METHODS DEVELOPMENT FOR CORRECTING ALGORITHMS FOR CONSTRUCTING OPTIMAL STRATEGY OF MOUNTAIN AREAS DEVELOPMENT
}

\author{
${ }^{1}$ L. A. Lyutikova, \\ ${ }^{2}$ C.A.Makhosheva* \\ ${ }^{1}$ E. V. Shmatova \\ ${ }^{2}$ M. M. Kandrokova \\ ${ }^{1}$ Institute of Applied Mathematics and Automation KBSC RAS, Nalchik, Russia \\ ${ }^{2}$ Institute of Informatics and Problems of Regional Management of KBSC of RAS, Nalchik, Russia, salima@list.ru
}

DOI: $10.21177 / 1998-4502-2018-10-4-617-623$

The study of mountain areas has always been given great attention by science. However, the lack of a single model for the development of mountain areas leads to a variety of recommendations that may not always be consistent. To achieve sustainable development, it is necessary to conduct a comprehensive assessment of the natural resource potential and the level of economic development of the analyzed territory. To considers previously developed models of development and assess the possibility of their implementation and orientation.

The purpose of this work is to build an optimal strategy for the development of mountain areas on the basis of previously known models by extracting the most optimal solutions from them.

As a working method, a logical analysis of a given subject area is proposed, in which the objects are different spheres that determine the level of development of mountain areas, and the signs are their characteristics presented in terms of the variable-valued logic of predicates. As the characteristics of the development of the territory can be the economy, social sphere, resource potential of development, etc., these areas of development in the formal formulation of the problem will be called objects.

Description of the object (characteristics) is represented by a set of features that can accurately diagnose the desired object. The set of a number of objects and their features is a sample, which worked a certain number of algorithms (proposed models of development). The quality of each algorithm of the model is estimated by the Boolean function. None of the considered algorithms performed perfectly on the whole set of given objects. We propose a logical method for constructing a new algorithm (correction model), which is optimal for the entire set of recognized objects. The method is based on the construction of a new logical function of the classifier.

The result of the study is an optimal model that includes the positive properties of the previously considered models and at the same time corrects their shortcomings.

The proposed approach can be the basis for obtaining expert assessments and recommendations in order to build an optimal strategy for the development of mountain areas.

Keywords: concept of development, region, data, knowledge base, subject area, variable-valued logic, sustainable development, classifier of concepts.

\section{References}

1. Zhuravlev I. On the algebraic approach to solving the problems of recognition or classification. Cybernetics problems, 1978, vol. 33, pp. 5-68. 
2. Shibzukhov Z. M. Correct aggregation operations with algorithms (2014) Pattern Recognition and Image Analysis, 24 (3), pp. 377-382. http://www.springer.com/sgw/cda/ frontpage/0,11855,1-40109-70-62708648-0,00.html". DOI: $10.1134 / \mathrm{S} 1054661814030171$

3. Timofeev V. A., Lyutikova L. A. Development and application of many-valued logics and network flows in intelligent systems. Proceedings of SPIIRAS, 2005, vol. 2, pp. 114-126.

4. Lyutikova L. A., Modeling and minimization of knowledge bases in terms of many-valued logic of the predicates. Preprint. Nalchic, Research Institute PMA KBSC of RAS, 2006, 33 p.

5. Lyutikova L., Shmatova E. V. Analysis and synthesis of pattern recognition algorithms using variable-valued logic. Information technologies, 2016, vol. 22, no 4, pp. 292-297.

6. Vorontsov K. V. Optimization methods for linear and monotone correction in the algebraic approach to the problem of recognition. Computational mathematics and mathematical physics, 2000, vol. 40, no 1, pp. 166-176.

7. Zhuravlev Yu. I., Rudakov K. V. On the algebraic correction of information processing (transformation) procedures. Problems of applied mathematics and Informatics, 1987, pp. 187-198.

8. Nestik T. A. Model of knowledge management in Russian institutions: social and psychological analysis . Modern technologies of management, 2014, no 1 (37). Mode of access: http://sovman.ru/article/3705/

9. Zhulikova O. V. The function of knowledge management as a system of accumulation of intellectual capital. Bulletin of Tambov University. Series of Humanitarian Sciences, 2013, no12 (128), pp. 370-375.

10. Shurupova A. S. Knowledge Management as a factor of socio-economic development . Journal of Creative economy, 2013, no12 (84), pp. 133-143. URL: http://bgscience. $\mathrm{ru} / \mathrm{lib} / 4986 /$

11. Milner B. V., Rumyantseva Z. P., Smirnova V. G., Blinnikov A. V. knowledge management in corporations. Moscow, Delo, 2006.
12. Tsyrenov D. D., D. Garmaev A. Conceptual approaches to the construction of a knowledge management system at the regional level. Vestnik of Buryat State University, 2015, vol. 2A, pp. 52-56.

13. Application of thinking models in intelligent question-answer systems. Russian Digital Libraries Journal, 2015, v. 18 , no 5, pp. 222-228.

14. Makarov O. N. National features of building integrated information systems for regional management. http://old. ci.ru/inform02_03/p_14-15.htm

15. Svetlana A. Tumenova, Marina M. Kandrokova, Salima A. Makhosheva, Gumar H. Batov, Svetlana V. Galachieva. Organizational Knowledge and its Role in Ensuring Competitiveness of Modern Socio-Economic Systems. Revista Espacios, 2018, Vol. 39, No 26, pp. 12. URL: http:// www.revistaespacios.com/a18v39n26/18392633.html

16. Salima A. Makhosheva, Natalia Y. Rud, Marina M. Kandrokova, Magamed V. Israilov, Fatimat B. Shinahova. The paradigm of sustainable development and innovation in the region. Revista Espacios, 2018, vol. 39, no 47, p. 28.

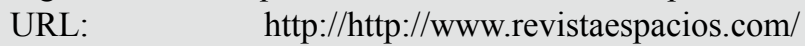
a18v39n47/18394728.html

17. Mesiar, R., Komornikova, M., Kolesarova, A., Calvo, T. (2008) Aggregation Functions: A Revision Fuzzy Sets and Their Extensions: Representation, Aggregation and Models. Springer, Berlin, Heidelberg, 2008.

18. Grabich M., Marichal, J.-L., Pap, E. (2009) Aggregation Functions: Encyclopedia of Mathematics and Its Applications, 2009, pp. 127.

19. Calvo T., Beliakov G. Aggregation functions based on penalties (2010). Fuzzy Sets and Systems. 2010. 161 (10). Pp. 1420-1436. DOI: 10.1016/j.fss.2009.05.012

20. Mesiar, R., Komornikova, M., Kolesarova, A., Calvo, T. (2008) Fuzzy Aggregation Functions: A revision. Sets and Their Extensions: Representation, Aggregation and Models. Springer-Verlag, Berlin, 2008.

Article received 20.12.2017. 
1 Поспелов П. И., ${ }^{2}$ Кортиев А. Л. ${ }^{*}$

\section{НОРМЫ ПРОЕКТИРОВАНИЯ ДОРОГ В ГОРНЫХ УСЛОВИЯХ С УЧЕТОМ ОБЕСПЕЧЕНИЯ БЕЗОПАСНОСТИ ДВИЖЕНИЯ}

\section{УДК: 625.7 (470.65) \\ DOI: 10.21177/1998-4502-2018- 4-624-630}

Освещаются сложности проектирования элементов плана и профиля автомобильной дороги в сложных горных условиях с учетом современных требований комфортности, безопасности и информированности участников движения, т.e. условий интеллектуальной транспортной связи. На примере Транскама, самой высокогорной автомобильной дороги в России, проведен анализ ДТП, связанных с элементами плана дороги применением в проектных разработках предельно допустимых продольных уклонов и малых радиусов кривых. На конкретных примерах обосновывается, что смягчение продольных уклонов и увеличение минимальных радиусов кривых снижает общее количество ДТП, материальный и моральный ущерб, повышается безопасность движения и др. Так как на современном этапе государством уделяется особое внимание созданию интеллектуальных транспортных систем, то проблема, рассматриваемая в статье достаточно актуальна. Она актуальна особенно в контексте эксплуатации Транскама, которая в будущем должна превратиться в международную транспортную систему в виде транспортного коридора РФ в страны Передней Азии.

\section{КЛЮЧЕВЫЕ СЛОВА}

горная дорога, элементы плана дороги, безопасность, уклоны, радиусы кривых, ДТП, склоны, обвалы, лавины, оползни

Статья поступила в редакцию 15.01.2018.

\section{Введение}

Как известно, горные территории при освоении и в своем развитии в определенной степени отстают от равнинных. По сути, любое начинание в горной местности экономического, социального и другого характера начинается с решения транспортной проблемы. В настоящее время к транспортным проектам предъявляются особые требования в части высокой интеллектуальности с применением инновационных разработок, безопасности, информированности о дорожной обстановке, комфортности, экологичности и бесшумности.

Если на равнине при выборе направлений дорог нет практически ограничений, то в горных условиях прокладывание дороги сталкивается с множеством проблем, связанных с расчлененным рельефом, требующих применения более обоснованных максимальных уклонов и малых радиусов кривых, а также с определенными географическими особенностями ущелья, которые иной раз меняют направление дороги на фронтальное от необходимого. На склонах этих ущелий развиты экзогенные процессы в виде оползней, обвалов, осыпей, селей, лавино-ледниковых образований и наледей, динамика которых осложняет проектирование, строительство и эксплуатацию транспортных артерий. Создание проекта транспортных коммуникаций в горных условиях крайне сложный процесс.

Проблемы проектирования горных дорог в последнее время усложняются еще и в связи необходимостью внедрения интеллектуальных транспортных систем. Такие системы для горных дорог у нас пока находятся в стадии формирования. Например, проблеме уменьшения уровня шума в рамках интеллектуальной транспортной системы в горных условиях не уделяется внимания, несмотря на ее достаточно хорошую разработанность для автомобильных дорог в равнинных условиях [1].

Целью работы является мониторинг аварийности при эксплуатации горных дорог на примере Транскавказской автомагистрали (Транскам) и применение действующих норм и правил при изыскании и проектировании дорог.

Методы исследований. Исследования велись методом анализа существующих проектных разработок, мониторинга эксплуатации горных дорог и аварийности.

Результаты исследований. Стесненные условия изысканий и проектирования дорог в горных условиях вынуждают исполнителей проекта из-за сложного рельефа применять максимальные и предельно допустимые продольные уклоны, малые радиусы кривых, что, соответственно, в период эксплуатации создает опасные условия дорожного движения и приводит к увеличению частоты чрезвычайных происшествий (ЧП) и дорожно-транспортных происшествий (ДТП) [2].

Расчетные параметры движения автотранспортных средств на горных дорогах берутся в два раза меньше, чем для равнинной местности. К примеру, для III-й категории дорог расчетная скорость принимается 50 км/ч, которая для нормальных равнинных условий составляет 100 км/ч. Указанная расчетная скорость принимается при эксплуатации дорог в нормальных погодных условиях и сцеплении шин автомобилей с поверхностью асфальто-бетонного

\footnotetext{
${ }^{1}$ Московский автомобильно-дорожный государственный технический университет, Москва, Россия

${ }^{2}$ Северо-Кавказский горно-металлургический институт (государственный технологический универси-
} тет), Владикавказ, Россия, kortiev73@mail.ru 


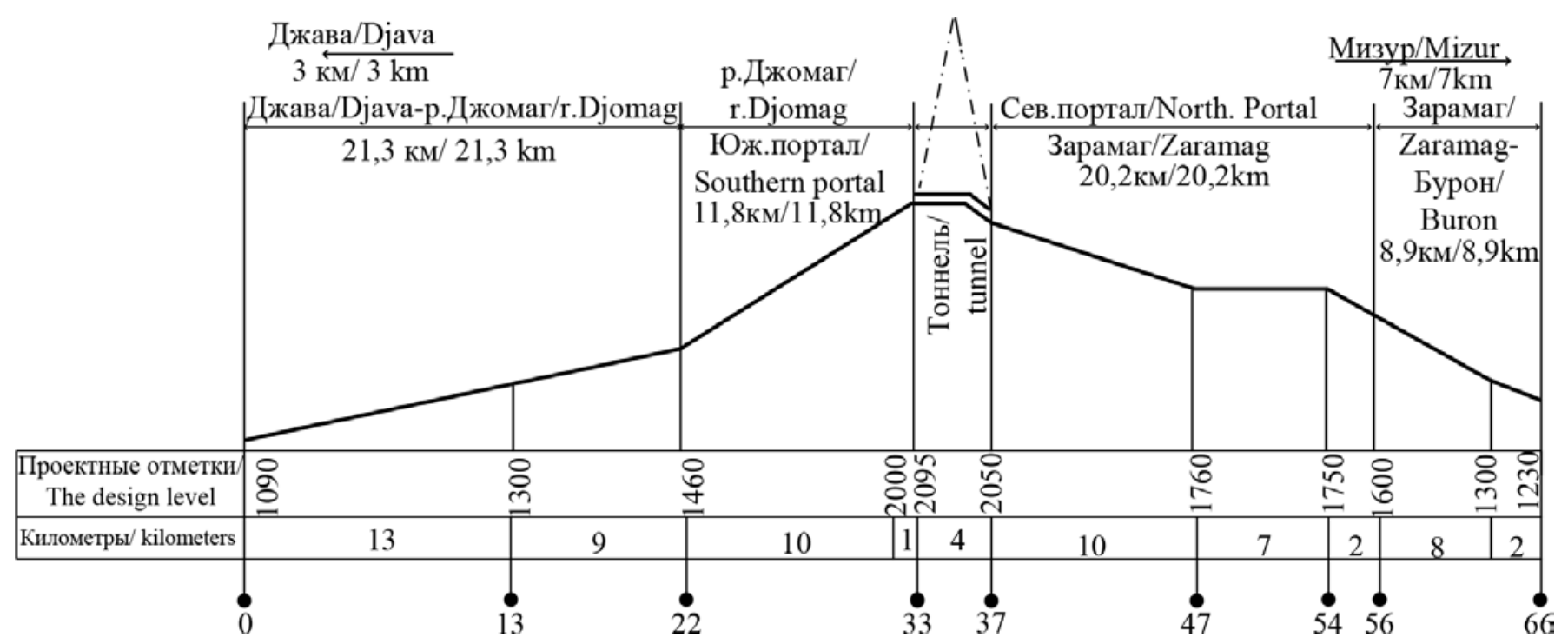

Puс. 1. Сжатый продольный профиль дороги

Fig. 1. Compressed longitudinal profile of the road

покрытия. Максимальные продольные уклоны для той же III-й категории дороги допускается принять $80 \%$, а минимальные радиусы кривых - 100 м. При таких конструкционных параметрах эксплуатация дороги крайне осложняется.

На примере Транскам практическое применение норм проектирования дорог в горных условиях было осуществлено проектным институтом «Союздорпроект» в 1970-1973 гг. [3]. По сложности технических решений эта дорога не имеет аналогов в отечественной и европейской практике, поскольку пересекает горы на абсолютной высоте свыше 2000 м и по сути $80 \%$ всей длины дороги находится в опасной, с точки зрения ДТП, зоне из-за зимних и неблагоприятных склоновых процессов. Устройство и монтаж конструкций галереи с применением в проекте [6] допустимых норм проектирования максимальных продольных уклонов и минимальных радиусов кривых осложняли эксплуатационные условия Транскам [3] и выявили за период 30-летней эксплуатации дороги немало проблем.

Продольный профиль Транскам показан на рис. 1 [4] и представляет собой схему преодоления горного перевала. Продольные уклоны до 40-50 \% на первых
22 километрах Южного участка и на 37-54 километрах Северного участка говорят о наличии здесь слабой опасности с точки зрения аварийности.

Что же касается последних 10 километров Южного участка и 8 километра участка Северного подхода, то здесь заложены 70-80\% \% -ные уклоны. С такими уклонами эксплуатация дороги в зимнее время представляет собой большие сложности, в результате чего количество ДТП многократно возрастает.

Аварийность на горных дорогах усугубляется и из-за климатических условий. Движение большегрузных транспортных средств с низкой скоростью на подъемах дороги создает для легковых автомашин аварийную обстановку, так как снижается возможность обгона из-за встречного транспорта, слабой видимости и др. В зимний период, когда из-за атмосферно-климатических условий проезжая часть покрывается гололедом и коэффициент сцепления шин транспортного средства с поверхностью проезжей части достигает нулевого значения, аварийность увеличивается в несколько раз.

По результатам мониторинга за эксплуатационными условиями Транскам, Военно-Грузинской дороги

Аварийность в зависимости от продольного уклона для дороги III-й технической категории в горных условиях Accident rate depending on the longitudinal slope for the road of the third technical category in mountain conditions

\begin{tabular}{|c|c|c|}
\hline $\begin{array}{c}\text { Средний уклон, \%о } \\
\text { Average slope, \%o }\end{array}$ & $\begin{array}{c}\text { Средний рост количества ДТП, в \% } \\
\text { на 1 км дороги } \\
\text { Average increase in the number of road accidents, } \\
\text { \% per 1 km of road }\end{array}$ & $\begin{array}{c}\text { \% от общего количества } \\
\% \text { of the total }\end{array}$ \\
\hline 10 & 0,33 & 0,7 \\
\hline 20 & 0,56 & 1,2 \\
\hline 30 & 0,8 & 3,7 \\
\hline 40 & 1,7 & 6,95 \\
\hline 50 & 3,25 & 15,7 \\
\hline 60 & 7,1 & 26,7 \\
\hline 70 & 12,5 & 44,8 \\
\hline
\end{tabular}



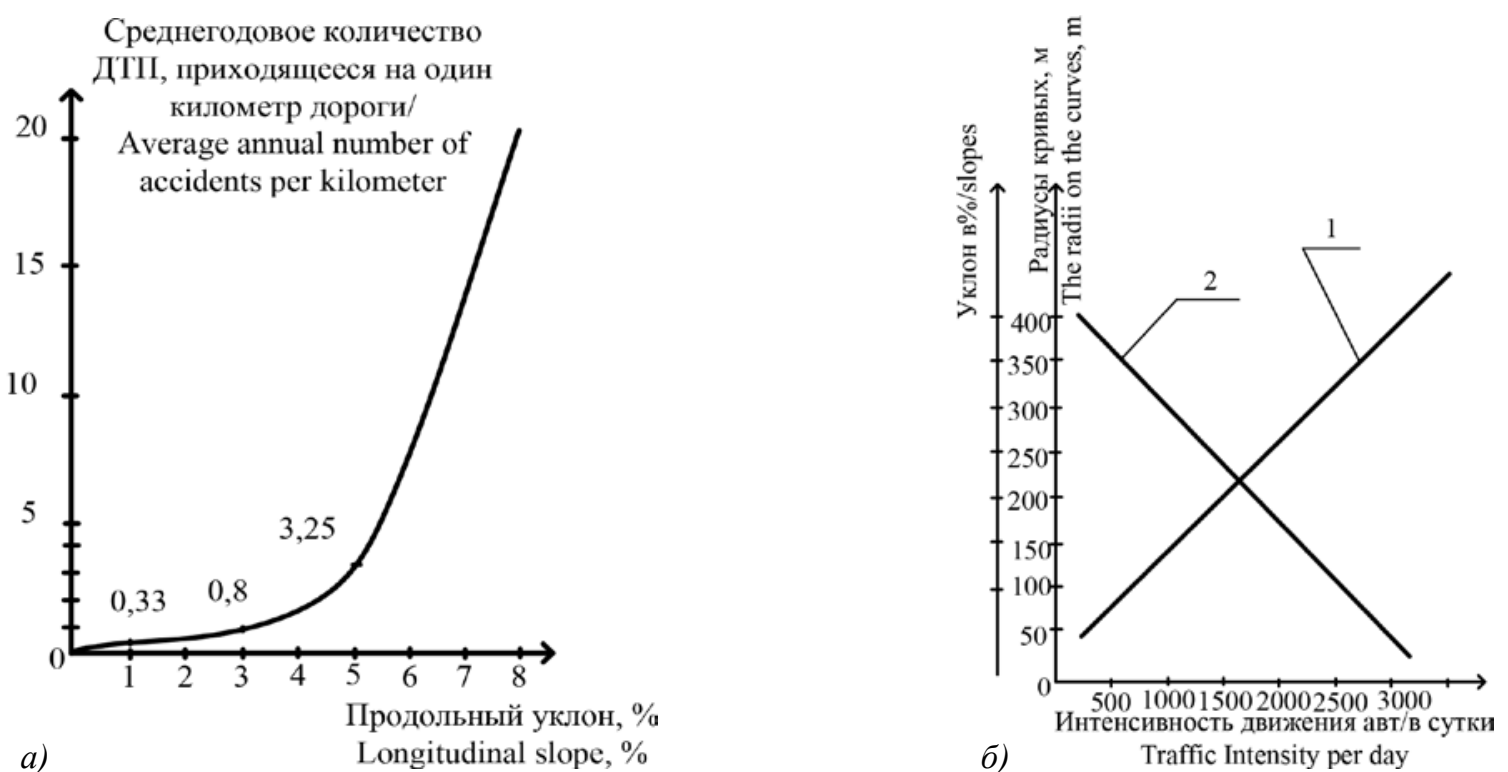

Pис. 2. Графики роста ДТП: а) на одном километре дороги в зависимости от продольного уклона (на примере Южного участка Транскама); б) при интенсивности движения в зависимости от продольного уклона (1) и радиусов кривых (2)

Fig. 2. Schedules of growth of the road accidents: a) on one kilometer of the road depending on a longitudinal bias (on the example of the Southern site of Transkam); b) at intensity of the movement depending on a longitudinal bias (1) and radiuses of curves (2)

и других горных дорог, анализа ДТП из статистических данных ГИБДД РСО-Алания и Южной Осетии и их сравнения с такими же показателями аналогичных участков других горных дорог, составлена таблица аварийности в зависимости от продольных уклонов для III-й технической категории дорог (таблица). При этом проведенные сравнения показателей показывают высокую степень их сходства [5; 6].

Таблица и рис. 2 показывают, что степень риска аварий резко повышается с увеличением продольных уклонов горной дороги. На рис. 26 приведен график зависимости роста ДТП при определенной интенсивности движения и одновременном наличии на дороге продольных уклонов и радиусов кривых. Пересечение диаграмм при различных факторах риска (уклонов и кривых) показывает, что оптимальным для дороги III-й технической категории является 40\% -ный уклон и радиус кривой не менее 200 м.

Изучив результаты аварийности (таблица, рис.2), следует сделать вывод, что к применению норм максимально допустимых уклонов при проектировании горных дорог следует относиться осторожно.

Исследуя отрицательное влияние повышения норм при проектировании, следует отметить:

По нормам проектирования при продольном уклоне более $30 \%$ н на дорогах III-й категории следует предусмотреть дополнительную полосу для обгона при движении в сторону подъема и смешанном составе транспортного потока. Соблюдение указанного требования норм проектирования снизило бы до определенной степени аварийность, но исполнители проекта зачастую пренебрегают вероятной ожидаемой опасностью. В настоящее время интенсивность грузоперевозок на Транскам низкая, но по мере воз- рождения экономических связей между Закавказскими государствами и Россией интенсивность возрастет в несколько раз. Проводимые ныне работы по реконструкции Транскам проводятся без учета требований отдельных норм проектирования и перспектив опасности движения.

С учетом вышеизложенного следует сделать выводы:

- при проектировании горной дороги III-й технической категории следует применять допустимые уклоны в 60\%о вместо 80\%о;

- экспертиза норм проектирования должна проводиться для каждого конкретного объекта с особым подходом и учетом военно-стратегического значения горной дороги, не ограничиваясь только фактором интенсивности транспортных средств;

- процесс проектирования объектов транспортных артерий должен в обязательном порядке обеспечиваться научно-техническим сопровождением по вопросам дорожно-транспортной безопасности.

Схематическое решение одного из опасных участков Транскам, с учетом применения изложенных в данном исследовании допустимых и безопасных норм проектирования, показано на рис. 3 .

Следует отметить, что в источнике [5] приведен не лучший вариант реконструкции дороги, поскольку перенос трассы на противоположный склон заметно увеличивает стоимостные показатели за счет следующих причин:

- необходимо строительство двух переходных мостов через реку Рукдон;

- возведение принципиально нового участка дороги;

- увеличение элементов опасностей и рисков схода лавин. 


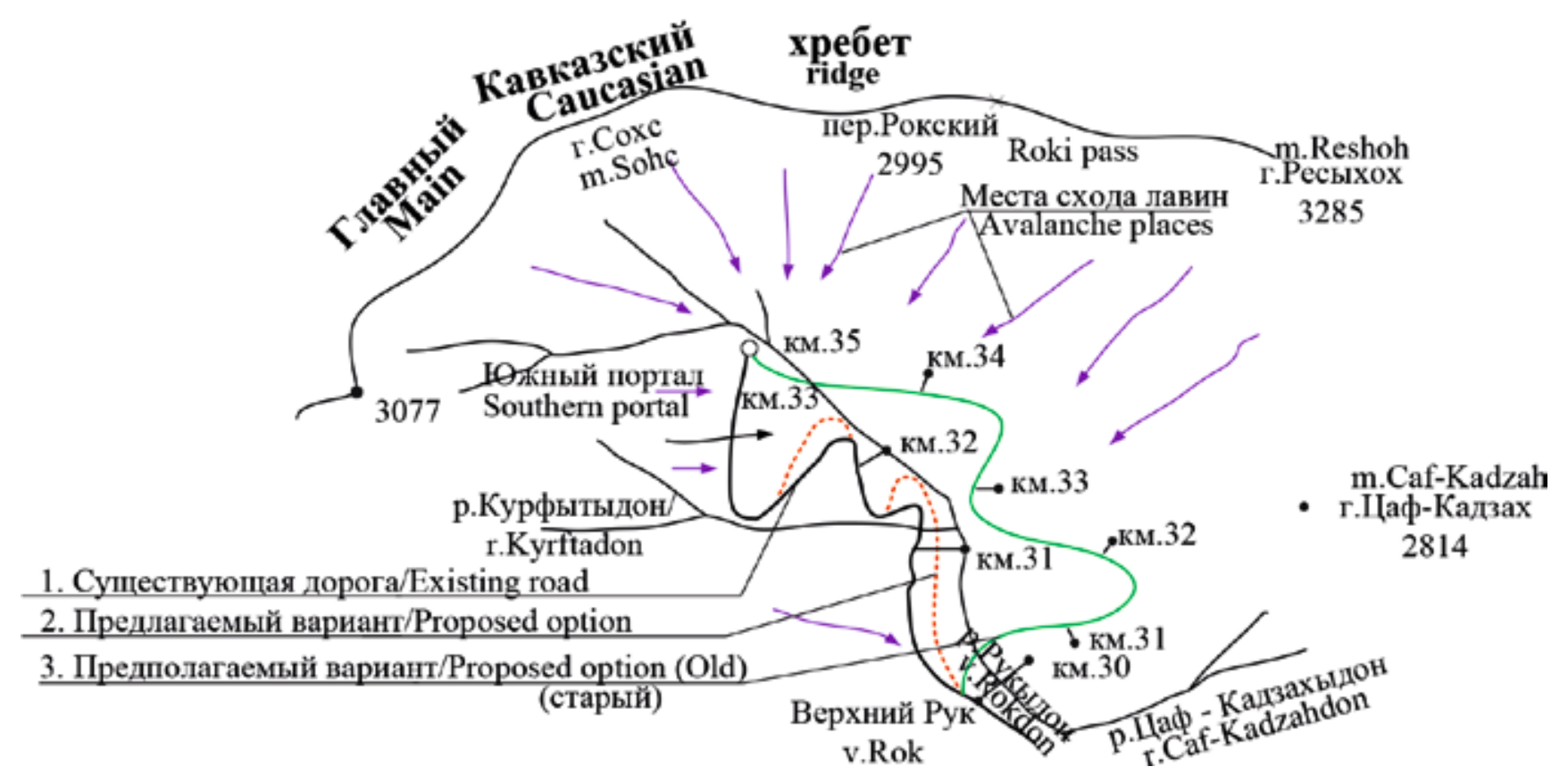

Pис. 3. Фрагмент предполагаемого развития опасного участка из-за продольного максимального уклона

Fig. 3. Fragment of the expected development of the dangerous area due to the longitudinal maximum slope

В предлагаемом авторами настоящего исследования варианте (рис. 3) эти минусы исключены. На основании изложенного следует сделать вывод, что при увеличении длины опасных участков дороги в целях снижения норм проектирования, и соответственно количества ДТП, следует применять в нормах проектирования значение максимального продольного уклона не более $60 \%$.

С указанным уклоном участки дороги в достаточной мере апробированы на Транскам с точки зрения безопасности, что показано в таблице и на рис. 2 [5; 7].

При рассмотрении вопроса влияния норм продольных уклонов на интенсивность ДТП, нельзя не затронуть эксплуатационные условия лавинозащитных сооружений, таких как галереи. На рассматриваемом участке Транскам (рис. 3) было возведено лавинозащитное сооружение прямоугольной формы из сборных железобетонных конструкций с уклоном оси сооружения $70 \%$, соответствующим уклону самой дороги на этом отрезке дороги. В результате неудовлетворительной эксплуатации сооружения, запазушное пространство внутренней стены галереи заполнялось водой, образовалась жижеобразная масса, которая давила на внутреннюю стену галереи, в результате чего лавинозащитное сооружение рухнуло [8]. Вместо разрушенной части защитного сооружения была построена железобетонная подпорная стена без надлежащего технического обоснования, которая заметно снизила условия безопасности дорожного движения. Подобные варианты "реконструкции" в зарубежной практике не возможны [9].

В настоящее время эволюционное развитие практики строительства лавинозащитных сооружений достигло на ТрансКАМ таких размеров, что один погонный метр сооружения обходится государственной казне в 1,9 млн. руб. Это явная тенденция к удорожанию сооружения и в целом транспортного объекта, но как видно из приведенного примера, подобное развитие налогоплательщику страны обходится слишком дорого и поэтому следует использовать, изучать и применять в том числе и зарубежный опыт [10-12]. В этом же русле следует ориентироваться на создание интеллектуальных транспортных систем и развитие их элементов [13-15]. Внедрение зарубежного опыта в исследованиях, проектировании и строительстве [16-18] дает свои положительные результаты.

В последние десять лет учеными СКГМИ (ГТУ) по примеру Скандинавских стран разработан ряд малозатратных и инновационных лавинозащитных сооружений, одобренных Роспатентом и обобщенных в научно-технической российской и зарубежной литературе [19], в том числе примененных при разработке проектных предложений Евроазиатской железной дороги [20].

\section{Выводы}

1. Анализ статистических данных аварийности и мониторинга сложных участков горных дорог дает основания для ограничения нормы продольного максимального уклона в $60 \%$.

2. Ряд наблюдений за 40-50-летний период показывает, что подпорные стены со стороны внутреннего откоса не дают эффективной защиты горных дорог от оползней, обвалов, лавин и др., а зачастую ухудшают условия безопасности. Это значит, что их строительство должно быть достаточно серьезно обосновано и ограниченно.

3. Строительство на горных дорогах защитных сооружений от склоновых явлений должно сопровождаться экспертным научно-техническим заключением, составленным специалистом, владеющим нор- 
мами проектирования, строительства и эксплуатации горных дорог.

4. Проблема проектирования горных дорог и развитие территорий должны стать общей проблемой

\section{ЛИТЕРАТУРА:}

1. Поспелов П. И. Борьба с шумом на автомобильных дорогах. М.: Транспорт, 1981. 88 с.

2. Пучкин В. А., Гасанов Б. Г., Лозовой В. И., Бесарабов А. Н. Оценка дорожной ситуации, предшествовавшей ДТП // Сборник докладов восьмой Международной конференции «Организация и безопасность дорожного движения в крупных городах». Санкт-Петербург,18-19 сентября 2008. С. 359-363

3. Долгов Д. В., Кортиев А. Л. Зимнее содержание горных дорог в условиях лавинной опасности // Международный научно-технический журнал МАДИ «Наука и техника в дорожной отрасли». Москва. 2015. N4. С. 14-16.

4. Кортиев Л. И. Транскам. Владикавказ: Ирыстон, 2000.334 c.

5. Кортиев Л. И. Нормы проектирования дорог в целях обеспечения их конструктивной и экологической безопасности (на примере Транскама) // Сборник докладов восьмой Международной конференции «Организация и безопасность дорожного движения в крупных городах». Санкт-Петербург, 18-19 сентября 2008. С. 183-186.

6. Алексиков С. В., Лищинский С. А. Обоснование ширины проезжей части на закруглениях местных дорог для движения большегрузного транспорта // Техническое регулирование в транспортном строительстве. Саратов. 2015. N5 (13). C. 47-52.

7. Выскребенец А.С., Кортиев А.Л., Чочиев Р.С., Тедеев В.Б. Мониторинг процессов экзогенных (склоновых) явлений на дорогах к горно-рудным предприятиям Осетии в целях устойчивого сохранения склонов // Устойчивое развитие горных территорий. Владикавказ. 2015. N1(23). C. 29-34.

8. Музаев И. Д., Харебов К. С., Кортиев А. Л. Фрикционная математическая модель движения снежной лавины по ее выбросу в зоне отложения на высокогорных склонах // Устойчивое развитие горных территорий. Владикавказ. 2013. N1(15). C. 18-20.

9. Karl Geabl, Bernard Lackinjer. Lawinen hand buch. Tirol. 1996. 247 p.

10. Zyryanov V. Sanamov R. Improving Urban Public Transport Operation: Experience of Rostov-on-Don (Russia) // International Journal of Transport Economics. 2009. Vol.36, N1. Pp. 83-96. для всех горных стран и усилия в этом направлении должны быть сконцентрированы во имя безопасности людей и защиты их жизни.
11. Безопасность дорожного движения - концепция нулевой смертности // Государственное дорожное управление Швеции. Стокгольм: HENNJWQS-ONS, апрель 2006. $20 \mathrm{c}$.

12. Олещенко Е. М., Лазарева Е. В. Зарубежный опыт обеспечения безопасности дорожного движения: приоритетные малозатратные мероприятия // Сборник докладов восьмой Международной конференции «Организация и безопасность дорожного движения в крупных городах». Санкт-Петербург, 18-19 сентября 2008. С. 194-199.

13. Ratrout, N. T., \& Issa, Y. Effectiveness of Newly Introduced Variable Message Signs in Al-Khobar, Saudi Arabia, Intelligent Transportation Systems (ITS) Review. 2014. Pp. 169-177.

14. Mohammed, A., Umar, S. Y., Samson, D., \& Ahmad, T. Y. (2015). The Effect of Pavement Condition on Traffic Safety: A Case Study of Some Federal Roads in Bauchi State // IOSR Journal of Mechanical and Civil Engineering (IOSRJMCE). 2015. Volume 12, Issue 3 Ver. I (May. - Jun. 2015). Pp. 139-146.

15. Owolabi, A. O., Sadiq, O. M., \& Abiola, O. s. Development of Performance Models for a Typical Flexible Road Pavement in Nigeria // International Journal for Traffic and Transport Engineering. 2012. 2(3). Pp. 178-184.

16. Black, J. A., Paez, A., \& Suthanaya, P. A. (2002). Sustainable urban transportation: performance indicators and some analytical approaches // Journal of urban planning and development. 2002. 128(4). 184-209

17. Emberger G., Kenig I., Krpata R. Public Transport for (Disabled) Peopie - The Vienna Experience / 13-th World Conference of Transport Research. Rio de Janeiro. 2013. 26 p.

18. Firth D. (2012) Urban Mobility Strategy. The City of Stockholm Traffic Administration. 2012. 72 p.

19. Galachieva S. V., Kortiev L. I., Kortiev A. L. Analysis of economic interests and losses in practice of avalanche protection of mountain roads // The European Journal of Economics and Manegment Sciences. 2017. N4. Pp. 147-155

20. Kortiev L. I., Kortiev A. L. Geographical spread of Euro-Asian high-speed railway of Paris-Delhi through the Caucasus and the prospect of its construction as International Transport Corridor. Premier Publishing s.r.o. Accent Graphics Communications \& Publishing, Hamilton, Canada. 2017. 28 p. (E-book) 


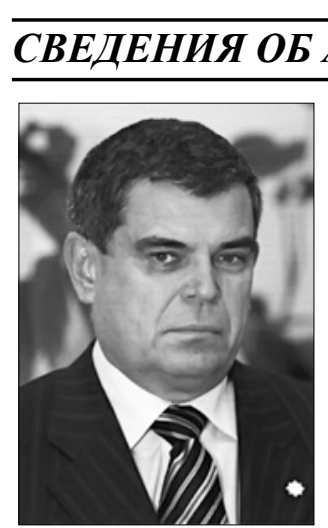

Pavel I. POSPELOV - Doctor of Technical Sciences, Professor, head of the Department of Research and design of roads, Moscow Automobile and Road State Technical University, 125319, Moscow, Russia.

Ph.:+7(499)155-07-31,pospelov@madi.ru

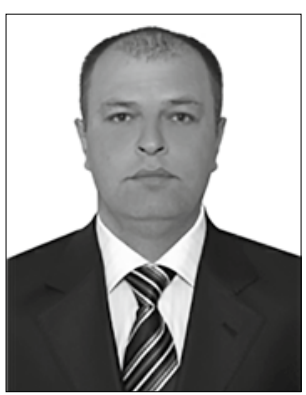

КОРТИЕВ Алан Леванович кандидат технических наук, доцент, кафедра «Автомобильные дороги и транспортные процессы», СевероКавказкий горно-металлургический институт (государственный технологический университет), 362021, Владикавказ, Россия

Тел.: +7(962)748-40-00,

kortiev73@mail.ru

Alan L. KORTIEV - Candidate of Technical Sciences, associate Professor, Department of Roads and Transport Processes North-Caucasian Institute of Mining and Metallurgy (State Technological University), 362021, Vladikavkaz, Russia.

Ph.:+7(962)748-40-00, kortiev73@mail.ru

\section{DESIGN STANDARDS FOR ROADS IN MOUNTAINOUS CONDITIONS WITH A VIEW TO ENSURING TRAFFIC SAFETY}

${ }^{1}$ P. I. Pospelov,

${ }^{2}$ A. L. Kortiev *

${ }^{\prime}$ Moscow State Automobile and Road Technical University, Moscow, Russia

${ }^{2}$ North-Caucasian Institute of Mining and Metallurgy (State Technological University), Vladikavkaz, Russia, kortiev73@mail.ru

DOI: $10.21177 / 1998-4502-2018-10-4-624-630$

Introduction. As you know, mountain areas in their development to some extent lag behind the plains. In fact, any undertaking in the highlands of an economic, social, agricultural or other nature aspects begins with the solution of the transport problem. At present, transport projects are subject to the requirements of high intelligence with innovative developments, safety, awareness of the road environment, comfort, environmental friendliness and quietness.

If on the plain when choosing the directions of the road there are practically no restrictions than in mountain conditions the laying of the road faces a lot of difficulties of relief character, requiring the use of maximum slopes and small radii on the curves, as well as a certain geographical location of the gorge, which sometimes is frontal from the required direction of the road. On the slopes of these gorges to some extent surface exogenous phenomena were developed in the form of landslides, landslides, mudflows, avalanche-glacial and ice formations, the processes of collapse which complicate the design, construction and operation of the transport artery. Creating a transport project in such difficult mountain conditions is extremely difficult, but important. The urgency of this problem increases the need to present to the promising transport communications intelligence that is not yet sufficiently formed for mountain roads.

The purpose of the work is to monitor the operation of mountain roads by accident on the example of the Transcaucasian highway (Transcam) and the application of existing rules and regulations in the search and design.

Method of research. The research was conducted by the method of analysis of existing design developments, monitoring of mountain roads operation and accident rate.

Research result. Complicated conditions of the survey and design of roads in mountainous conditions forced project implementers because of relief conditions to apply the maximum and the maximum allowable longitudinal slope, small radius curves, respectively, that during operation creates a hazardous traffic condition and leads to road accidents.

Keywords: mountain road, elements of the road plan, safety, slopes, radii of curves, road traffic accidents, slopes, landslides, avalanches

\section{References}

1. Pospelov P. I. noise Control on roads. Moscow, Transport, 1981, $88 \mathrm{p}$.

2. Puchkin V. A., Gasanov B. G., Lozovoi V. I., Bessarabov A. N. Assessment of the traffic situation that preceded the accident. A collection of papers of the eighth International conference "Organization and safety of traffic in large cities". St. Petersburg, 18-19 September 2008, pp. 359-363

3. Debt V., Kortiev L. L. Winter maintenance of mountain roads in the conditions of avalanche danger. Science and technology in the road industry. Moscow, 2015, no 4, pp. 14-16.

4. Kortiev L. I. Transcam. Vladikavkaz, Iriston, 2000, 334 p.

5. Kortiev L. I. Norms of road design in order to ensure their constructive and environmental safety (on the example of Transcam). Collection of reports of the eighth International conference "Organization and safety of road traffic in large cities". St. Petersburg, 18-19 September 2008, pp. 183-186.

6 . The Substantiation of the width of the roadway on the local roads for the movement of heavy transport. Technical regulation in transport construction. Saratov, 2015, no 5 (13), pp. 47-52.

7. Miscreants A. S., Kortiev A. L., Chochiev R. S., Tedeyev V. B. Monitoring of exogenous Processes (erosion) events on the road to mining companies Ossetia for sustainable conserva- 
tion of slopes. Sustainable development of mountain territories. Vladikavkaz, 2015, no 1 (23), pp. 29-34.

8. Muzaev I. D., Kharebov K. S., Kortiev A. L. Friction mathematical model of the motion of an avalanche on its release in the area of deposits on the mountain slopes of. Sustainable development of mountain territories. Vladikavkaz, 2013, no 1 (15), pp. 18-20.

9. Karl Geabl, Bernard Lackinjer. Lawinen hand buch. Tirol, 1996, $247 \mathrm{p}$.

10. Zyryanov V. Sanamov R. Improving Urban Public Transport Operation: Experience of Rostov-on-Don (Russia). International Journal of Transport Economics, vol.36, no 1, pp.83-96 (2009).

11. Road safety - the concept of zero mortality. State road administration of Sweden. Stockholm, HENNJWQSONS, April 2006, 20 p.

12. Oleshchenko E. M., Lazareva E. V. Foreign experience in road safety: priority low-cost activities. Collection of reports of the eighth International conference "Organization and safety of road traffic in large cities". St. Petersburg, 18-19 September 2008, pp. 194-199.

13. Ratrout, N. T., \& Issa, Y. Effectiveness of Newly Intoduced Variable Message Signs in Al-Khobar, Saudi Arabia, Intelligent Transportation Systems (ITS) Review, 2014, pp.169-177.

14. Mohammed, A., Umar, S. Y., Samson, D., \& Ahmad, T. Y. (2015). The Effect of Pavement Condition on Traffic Safety:
A Case Study of Some Federal Roads in Bauchi State. IOSR Journal of Mechanical and Civil Engineering (IOSR-JMCE), Volume 12, Issue 3 Ver. I (May. - Jun. 2015), pp. 139-146.

15. Owolabi, A. O., Sadiq, O. M., \& Abiola, O. s. Development of Performance Models for a Typical Flexible Road Pavement in Nigeria. International Journal for Traffic and Transport Engineering, 2012, 2(3), pp.178-184.

16. Black, J. A., Paez, A., \& Suthanaya, P. A. (2002). Sustainable urban transportation: performance indicators and some analytical approaches. Journal of urban planning and development, 128(4), 184-209.

17. Emberger G., Kenig I., Krpata R. Public Transport for (Disabled) Peopie - The Vienna Experience. 13-th World Conference of Transport Research. Rio de Janeiro. 26 p. (2013)

18. Firth D. (2012) Urban Mobility Strategy. The City of Stockholm Traffic Administration. 72 p. (2012)

19. Galachieva S. V., Kortiev L. I., Kortiev A. L. Analysis of economic interests and losses in practice of avalanche protection of mountain roads. The European Journal of Economics and Manegment Sciences, 2017, No 4, pp.147-155

20. Kortiev L. I., Kortiev A. L. Geographical spread of Euro-Asian high-speed railway of Paris-Delhi through the Caucasus and the prospect of its construction as International Transport Corridor. Premier Publishing s.r.o. Accent Graphics Communications \& Publishing, Hamilton, Canada, 2017. 28 p. (E-book)

Article received 15.01.2018 


\section{ГЛУБОКОУВАЖАЕМЫЕ КОЛЛЕГИ!}

В соответствии с Заключением Президиума ВАК Минобрнауки РФ от 19.12.2014 2. №47/307 с 2015 года статьи для публикации в журнале «Устойчивое развитие горных территорий» принимаются по следующим отраслям и группам наук:

25.00.00 Науки о Земле (вся отрасль наук о Земле);

05.00.00 Технические науки (три группы из отрасли):

05.05.00 Транспортное, горное и строительное машиностроение,

05.13.00 Информатика, вычислительная техника и управление,

05.14.00 Энергетика;

08.00.00 Экономические науки (вся отрасль экономических наук).

В соответствии с градацией наук, принятой в международных системах цитирования Scopus и Web of Science, статьи для публикации в журнале «Устойчивое развитие горных территорий» принимаются по следующим отраслям и группам наук:

1. Engineering (технические науки);

2. Earth and Planetary Sciences (науки о Земле и планетарные науки);

3. Environmental Science (наука об окружающей среде).

В журнале «Устойчивое развитие горных территорий» печатаются:

- статьи с изложением новых научных результатов, объемом не более 10 машинописных страниц, включая иллюстрации и таблицы;

- краткие сообщения, содержащие информацию о важных результатах предварительных исследований, объемом 3-5 страниц (эти материалы впоследствии могут использоваться в тексте полной статьи);

- обзоры печатных работ по актуальным проблемам устойчивого развития горных территорий, объемом 20-25 страниц по заказу редакции.

К опубликованию также принимаются платные рекламные сообщения о новых материалах, технологиях, приборах и аппаратуре, соответствующие тематике журнала.

Все работы должны соответствовать тематике журнала. Предоставленные рукописи проходят этапы предварительного и итогового рецензирования, и в случае необходимости, направляются авторам на исправление и доработку. Рукописи в журнале публикуются на русском либо английском языках, аннотации на русском и английском языках.

Журнал публикует исключительно оригинальные статьи. Автор несет полную ответственность за соблюдение этого требования. Рукописи, не принятые к опубликованию, авторам не возвращаются. Редакция также не возвращает присылаемые материалы.

Редакция оставляет за собой право производить сокращение и редакторскую правку текста статьи. Исправления в тексте и иллюстрациях авторы могут вносить только на стадии подготовки статьи к набору. Корректура авторам для просмотра не высылается.

Несоблюдение правил оформления рукописи приведет к отклонению статьи.

Публикация бесплатна для авторов статей, написанных по заказу редакции, и для аспирантов.

За сведения в рекламных материалах редакция ответственности не несет.

Перепечатка допускается только с разрешения редакции и с обязательной ссылкой на журнал «Устойчивое развитие горных территорий».

\section{Инструкция для авторов}

В редакцию необходимо предоставить следующие материалы:

- статья (структуру и правила оформления смотри ниже); представляется как в бумажном (2 экз.), так и в электронном виде. Второй экземпляр обязательно подписывается авторами;

- на отдельном листе: сведения об авторах, содержащие фамилию, имя, отчество, ученую степень, звание, название организации, служебный и домашний адрес и телефоны, e-mail (если есть) и указание, с кем из авторов предпочтительнее вести переписку;

- направление от организации, если предоставляемые материалы являются результатом работы, выполненной в этой организации; в направлении следует указать название рубрики журнала;
- экспертное заключение или другой документ, разрешающий опубликование в открытой печати, утвержденные руководителем организации и заверенные гербовой печатью (представляют только авторы из России);

- компакт-диск, содержащий обязательный пакет электронных файлов (подробные инструкции приведены ниже);

- рекомендации для переводчика, включающие научные термины, ключевые слова, сокращения, фамилии и т. п. (если предполагается издание переводного варианта за рубежом)

\section{Правила оформления статьи}

На первой странице должны быть указаны: УДК; название статьи на русском языке (прописными буквами, без кавычек, переносы не допускаются, точка в конце не ставится, подчеркивание не используется), кегль 14 полужирный, выравнивание по центру; инициалы и фамилии авторов (кегль 
12 полужирный курсив, выравнивание по правому краю), название учреждения, город, страна представляющих рукопись для опубликования.

Текст статьи набирается шрифтом Times New Roman размером 14 пт через одинарный интервал, выравнивание по формату. Подзаголовок - шрифт курсивный, выравнивание по левому краю. При написании статьи используются общепринятые термины, единицы измерения и условные обозначения, единообразные по всей статье. Расшифровка всех используемых авторами обозначений дается при первом употреблении в тексте. Буквы латинского алфавита набираются курсивом, буквы греческого алфавита - прямым шрифтом. Математические символы $\mathrm{lim}, \mathrm{lg}, \ln , \arg$, const, sin, cos, min, max и т.п. набираются прямым шрифтом. Символ не должен сливаться с надсимвольным элементом в химических элементах $\left(\mathrm{H}_{2} \mathrm{O}\right)$ и единицах измерений $\left(\mathrm{MBT} / \mathrm{cm}^{2}\right)-$ прямым (обычным) шрифтом. Не следует смешивать одинаковые по написанию буквы латинского, греческого и русского алфавитов, использовать собственные макросы. Буквы $I$ и $J$, v и v, $e$ и $l, h$ и $n, q$ и $g, V$ и $U, O$ (буква) и 0 (нуль) должны различаться по начертанию.

Между цифровым значением величины и ее размерностью следует ставить знак неразрывного пробела. Переносы в словах либо не употреблять, либо пользоваться командой «расстановка переносов». Не использовать в тексте для форматирования знаки пробела. Различать дефис «-», знак минус «-» и тире «-».

Формулы создаются с помощью встроенного редактора формул Microsoft Equation с нумерацией в круглых скобках - (2), выравниваются по правому краю, расшифровка всех обозначений (букв) в формулах дается в порядке упоминания в формуле. Формулы должны быть аккуратно набраны на компьютере. Во избежание недоразумений и ошибок редакция рекомендует авторам использовать в формулах буквы латинского, греческого и других (не русских) алфавитов; при наборе формул необходимо соблюсти размеры по умолчанию. Следует учитывать, что при верстке формулы должны помещаться на половине страницы (8 см). Большие формулы необходимо будет разбивать на отдельные фрагменты. Фрагменты формул по возможности должны быть независимы (при использовании формульного редактора каждая строка - отдельный объект). Нумерацию и по возможности знаки препинания следует ставить отдельно от формул обычным текстом. Нумеровать следует только те формулы, на которые есть ссылки в тексте.

Таблицы, рисунки, фотографии размещаются внутри текста и имеют сквозную нумерацию по статье (не по разделам!) и собственные заголовки. Названия всех рисунков, фотографий и таблиц приводятся на русском языке 11 кеглем, курсивом. Нумерация обозначений на рисунках дается по порядку номеров по часовой стрелке или сверху вниз. Рисунки необходимо выполнять в компьютерном виде, желательно в программе Word 97, Corel Draw (до 13 версии) по следующим правилам: ширина рисунка не более $8 \mathrm{cm;} \mathrm{толщина} \mathrm{ли-}$ ний: основных - 1 пт, вспомогательных - 0,5 пт; для обозначений в поле рисунка использовать шрифт Times New Roman размером - 9 пт. Рисунки с большим количеством деталей (сложные схемы, графики) размещаются на всю ширину страницы (16,5 см). Векторные рисунки записываются в от- дельные файлы документов. Фотоснимки должны быть контрастными и выполненными на матовой бумаге. Отсканированные фотографии записываются в файлы в формате TIFF, JPEG. Сканировать изображение следует с разрешением 300 dpi для контрастных черно-белых рисунков и 600 dpi - для полутоновых. Цветные иллюстрации допускаются по согласованию с редакцией.

Обозначения, термины, иллюстративный материал, список литературы должны соответствовать действующим ГОСТ.

Библиографические ссылки в списке литературы нумеруются в той последовательности, в какой упоминаются в тексте. Описание литературных источников по ГОСТ 7.0.5-2008.

\section{Приложения к статье}

1. Аннотация (на отдельной странице - не более 100 слов). В ней не рекомендуется использовать формулы и ссылки на литературу. Если рукопись подается на русском языке, то аннотация должна быть продублирована на английском с указанием названия статьи, фамилий и инициалов авторов на этих языках. Если рукопись подается на английском языке, необходимо привести также аннотацию на русском. Аннотация печатается шрифтом Times New Roman (12 кегль) в одном файле в следующем порядке: название статьи, авторы, наименование организации, текст аннотации на русском языке; далее, через 2 строки, в той же последовательности на английском языке. Аннотация также публикуется на сайте журнала www.naukagor.ru. (на русском и английском языках).

2. Сведения об авторах на русском и английском языках печатается шрифтом Times New Roman (10 кегль) и должно содержать следующую информацию: должность, научное звание, ученая степень, награды и научные премии, круг научных интересов, количество публикаций, место работы, e-mail, номер телефона.

3. Фотографии авторов для резюме в формате TIFF или JPEG (300 dpi).

4. Реферат статьи (от 300 слов). Параметры страницы: формат A4 (210х297 мм); межстрочный интервал полуторный; шрифт Times New Roman (12 кегль) в одном файле в следующем порядке: наименование статьи, авторы, наименование организации, реферат на русском языке; далее, через 2 строки, в той же последовательности - на английском языке.

5. Электронная версия статьи представляется в редакцию на CD-R-диске или по электронной почте. Запись файлов выполняется в текстовом редакторе Microsoft Word (расширения .doc или .rtf), для набора формул применять редактор Equation 3.0.

Должны присутствовать следующие файлы:

- основной, содержащий текст статьи, включая формулы, таблицы, рисунки, подрисуночные подписи, список литературы, аннотация и ключевые слова на русском и английском языках;

- содержащий только иллюстрации, которые должны быть именованы таким образом, чтобы было понятно, к какой статье они принадлежат и каким по номеру рисунком статьи они являются. Каждый файл должен содержать один рисунок.

Электронная и бумажная версии статьи должны быть абсолютно идентичны.

Если авторы не могут полностью или частично удовлетворить требования по оформлению рукописи на диске, им необходимо проконсультироваться в редакции. 


\section{Адрес редакции:}

Россия, РСО-Алания, 362021, Владикавказ, ул. Николаева, 44. Северо-Кавказский горно-металлургический институт (государственный технологический университет).

Редакция журнала «Устойчивое развитие горных территорий».

Тел.: 8(8672) 40-73-60; 8(8672) 40-72-28 (служ.),+7(918)707-39-25 (моб.). E-mail: editor@naukagor.ru.

\section{DEAR COLLEAGUES!}

In accordance with the Conclusion of the Presidium of the Higher Attestation Commission of the Ministry of Education and Science of the Russian Federation from 12.19.2014 №47/307 from 2015 articles for publication in the journal "Sustainable Development of Mountain Territories" are accepted for the following Industries and groups of Sciences:

25.00.00 Earth Sciences (all branches of the Earth Sciences);

05.00.00 Engineering Sciences (three groups of industries):

05.05.00 Transport, Mountain and Building Mechanical Engineering,

05.13.00 Computer Sciences, Computer facilities and Management,

05.14.00 Energetics;

08.00.00 Economic sciences (all branches of Economic Sciences).

According to the gradation of Sciences accepted in international citation systems Scopus and Web of Science articles for publication in the journal "Sustainable development of mountain territories" are accepted by the following branches and groups of Sciences:

1. Engineering;

2. Earth and Planetary Sciences;

3. Environmental Science.

The journal «Sustainable Development of the Mountain Territories» publishes:

- articles interpreting the new scientific- research results of volume not more than 10 type written pages including illustrations and tables;

- brief messages containing information on the important results of the preliminary research of volume 3-5 pages (these materials can be used in the full article text);

- reviews of the typewritten articles on the actual problems of the sustainable development of the mountain territories, volume 20-25 pages by the editor's order, also the paid advertisements concerning new materials, devices and equipment in terms of the journal theme are accepted to the publication.

All papers must correspond to the journal theme.

The presented manuscripts pass the preliminary and total reading stages and if necessary are sent back to the authors for the correction and finishing.

The manuscripts are published in Russian and in English, the abstracts in Russian and in English as well.

The journal publishes only the original articles. The author is fully responsible for the requirement.

The manuscripts are not returned to the authors in case of being rejected in publication. The editor has a right to make reductions and corrections of the article text. All corrections in the text and figures can be done by the authors only at the stage of the typesetting preparations. The correction isn't sent to the authors for revision.

The infringement of the manuscript lay-out rules will lead to the publication delay or the article rejection.

The publication is free of charge for the authors, the fees aren't paid.

The authors (or the author) of each article having been published in the regular number of the journal have the right to get the authors' copies or their articles from the editorship.

The editorship isn't responsible for the advertisement information.

Reprinting is allowed only with the editorship permission with the obligatory references to the journal «Sustainable Development of the Mountain Territories»».

\section{INSTRUCTIONS FOR THE AUTHORS}

The following materials should be presented to the editorial office:

- an article, both in paper ( 2 copies) and in the electronic version. The second copy must be signed by the authors;

- a separate sheet with the information: about the authors (surname, name, patronymic name, scientific degree, rank, name of the organization, office and home address and telephone number, E-mail (if exists) and the reference to the author to contact with;

- a confirmation from the organization in case the presented materials are the result of the work carried out in that organization; the journal heading should be pointed out in the confirmation;
- an expert conclusion or any other document allowing the publication in the open press confirmed by the organization head and proved with the stamped seal; the expert conclusion is presented only by the authors from Russia;

- CD or a diskette with the files containing an obligatory set of the electronic files;

- recommendations for the translation including scientific terms, key words, cuttings, surnames, etc. (if the translated version is supposed to be published abroad).

\section{THE ARTICLE LAY-OUT RULES}

The following information should be pointed out on the first page: the article heading in Russian (in capital letters, without quotation marks, without division of a word, without a full stop at the end, underlining isn't used), point 14 semi bold, centre 
aligning; the authors surnames (point 12 semi bold type, the right-edge aligning), the organization name, town, country, a person responsible for the manuscript publication.

The article text is typed in Times New Roman (14 pt) through an ordinary interval aligning along the format. A subtitle is typed in italics, aligning along the left edge. The common terms, measurement units and conventional symbols similar for the whole article are used. The decoding of all symbols is given for the first text use. The Latin alphabet letters are typed in the italics while the Greek and Latin letters in the straight type. The mathematical symbols lim, lg, ln, arg, const, sin, cos, min, max, etc. are typed in the straight type. The symbol shouldn't coincide with the over symbol element in the chemical elements $\left(\mathrm{H}_{2} \mathrm{O}\right)$ and measurement units $(\mathrm{MBt} / \mathrm{cmI})$ and must be of the straight (ordinary) type. You shouldn't mix similar written letters of the Latin, Greek and Russian alphabets and should use the proper macros. The letters L and J, e and I, h and n, q and g, V and U, O (letter) and 0 (zero) must differ in inscribing.

There must be a sign of the continuous gap between a value figure meaning and its dimension. The hyphens are not used otherwise the command «hyphens arrangement», the gap signs also mustn't be used in the text for the lay-out and a hyphen «-»), a minus sign «-», and a dash «-» should be differentiated.

The formulas are designed with the help of the built-in formulas processor (Microsoft Equation), the enumeration being done in the round brackets (2), aligned along the right edge; the decoding of all signs (letters) in the formulas is given in the order of the formula reference. The formulas should be typed on computer. To avoid the errors and misunderstandings, the editorial staff recommends the authors to use the Latin, Greek and other (not Russian) alphabet letters in the formulas and to keep to the omission sizes while the formulas printing. One should account that during the page-making the formulas must be placed on the half of the page $(8 \mathrm{sm})$, the big formulas being split into the separate fragments. If possible, the fragments must be independent; each line is a separate object. The enumeration and stops should be put into an ordinary text separately from the formulas. Only the formulas having the text references should be numerated.

The tables, pictures and photos are placed inside the text and must have a through numeration along the text (not by the sections!) and their own headings. The titles of all tables, pictures and photos are presented in Russian (11 point, italics). The numeration of the picture symbols is given in clockwise order or from up to down. The pictures should be done in the computer form, preferably in Word 97 program using the following rules: a picture width - not more than $8 \mathrm{sm}$, a line thickness: the main $-1 \mathrm{pt}$, auxiliary $-0,5 \mathrm{pt}$; for the symbols in the picture area - «Times New Roman» type of 9 pt must be used.

The pictures with the great amount of details (complex schemes, graphs) are placed on the whole page width $(16,5 \mathrm{sm})$. The vector pictures are written into the separate documentary files. The photo pictures must be contrast and performed on the mat paper. The scanned photos are written into the files of TIFF, JPEG format. To scan the image one should use the resolution of $300 \mathrm{dpi}$ for the contrast black-white pictures and $600 \mathrm{dpi}$ for semitone ones. The colour illustrations are admitted on the editorial is agreement.

All symbols, terms and illustrations should correspond to the operative standards.
The literature sources should be numerated in the order of the text reference (not in the alphabetic order). The literature sources list is given as a total list at the end of the article. The list is composed according to the references consequence in the text. References should be designed according to GOST 7. 1-84. All references to the literature sources are applied in the square brackets [3].

\section{SUPPLEMENTS TO THE ARTICLE}

1. Abstract (on a separate page - not more than 100 words), without formulas and literature references. In case a manuscript is presented in Russian, the abstract should be repeated in English with the article heading, surnames and names in this language. In case a manuscript is presented in English, the Russian variant must be supplied. The abstracts are typed in Times New Roman (12 point) in one file in the following order: the article heading, the authors, the name of the organization, the abstract text in Russian with the further information in 2 lines in the same sequence in English. The abstracts are also published in the journal site www. naukagor.ru (in Russian and in English).

2. Resume in Russian and English is typed in Times New Roman (10 point) and must contain the following information: a place of work, a post, a scientific rank, degree, awards and scientific grants, professional experience, the main sphere of the scientific interests, the number of the publications for each author.

3. The authors' photographs for the resume should be done in TIFF or JPEG format.

4. The essay text (one page) for the publication in the essay journals. The page parameters: A4 $(210 \times 297 \mathrm{~mm})$ format; interline interval - one and a half; Times New Roman (12 point) type in one file in the following order: the article heading, the authors, the organization name, an essay in Russian, then in 2 lines in English.

5. The electronic version of the article.

To reduce the material preparation time for the publication and to avoid errors during typing, the materials should be presented on the CD-R disks. The files are written in the word processor Microsoft Word (doc or rtf), the formulas being printed with Equation 3.0. The author's name should be pointed out in the file title. Several file copies are preferable.

The following files are to be present on the diskette:

- the main file containing the article text, formulas, tables, pictures, under picture signatures, reference list, abstracts in Russian and English;

- the file containing only the illustrations for to the exact articles or pictures. Each file must have one picture.

The electronic and paper versions should be identical.

In case the authors fail to meet the requirements on the manuscript design on the disk, they should consult the editorials.

The editorial office address: 44 Nikolaev Str., Vladikavkaz, North Ossetia-Alania, Russia, 362021, The North Caucasian Institute of Mining and Metallurgy (The State Technological University), the Editorials of the journal «Sustainable Development of Mountain Territories»».

Phone: +7(8672) 40-73-60, +7(918)707-39-25 (mob.).

E-mail: editor@naukagor.ru. 

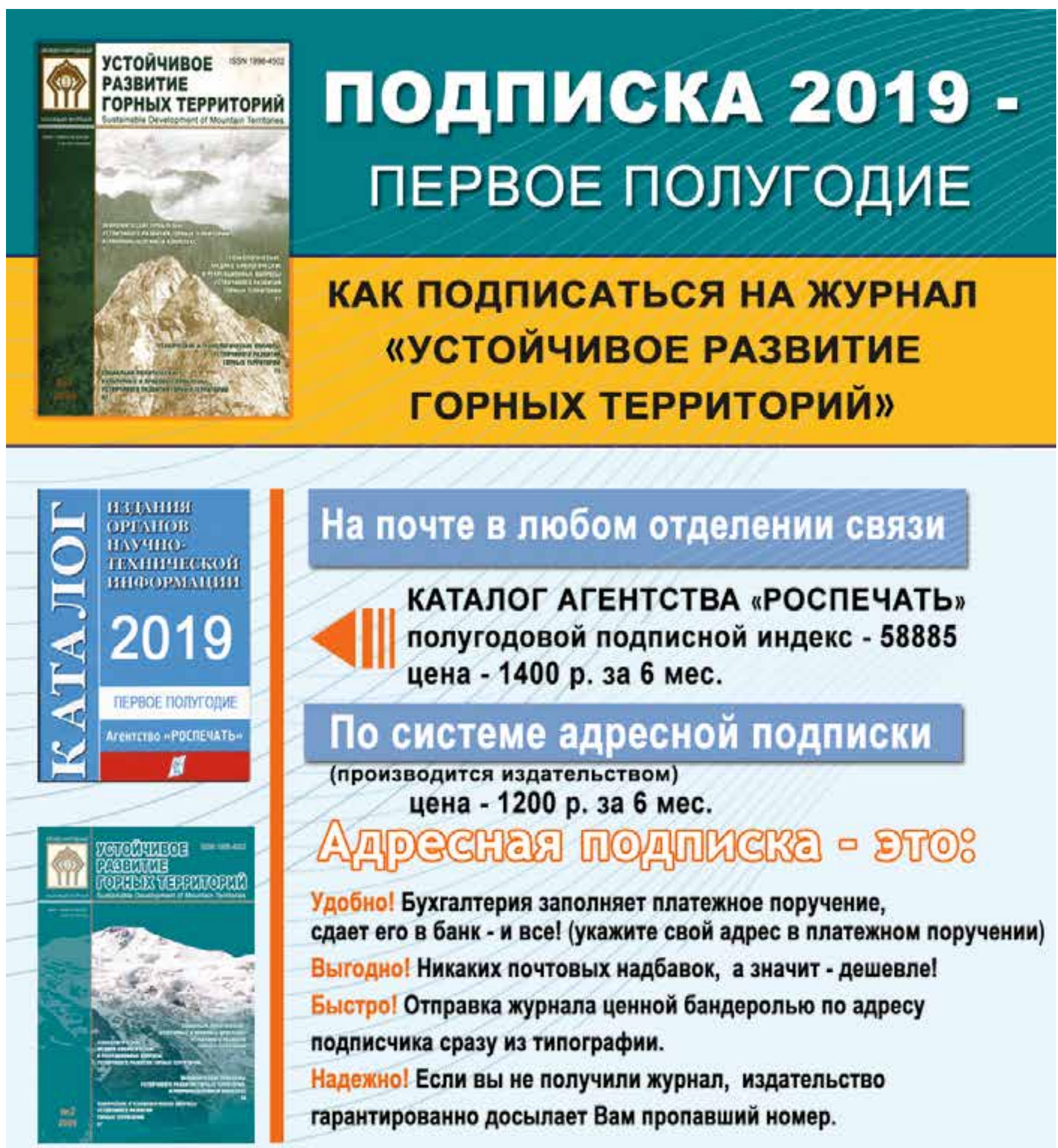

КАТАЛОГ АГЕНТСТВА "РОСПЕЧАТЬ" полугодовой подписной индекс - 58885 цена - 1400 р. 3 а 6 мес.

\section{По оистеме адресноЙ подписки (производится издательством)} цена - 1200 р. 3 а 6 мес. A.

Удобно! Бухгалтерия заполняет платежное поручение, сдает его в банк - и все! (укажите свой адрес в платежном поручении) Выгодно! Никаких почтовых надбавок, а значит - дешевле! БыстроI Отправка журнала ценной бандеролью по адресу подписчика сразу из типографии.

Надежно! Если вы не получили журнал, издательство гарантированно досылает Вам пропавший номер.
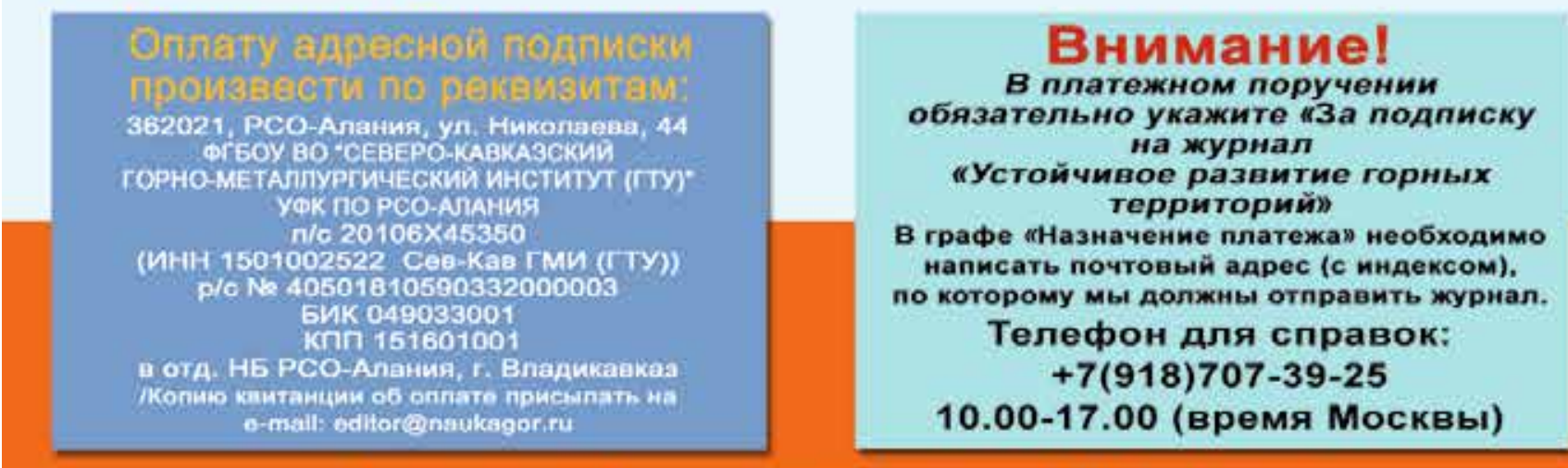

Стоимость адресной подписки для любоб региона PФ НАС не облагается стоимость доставки включена. 


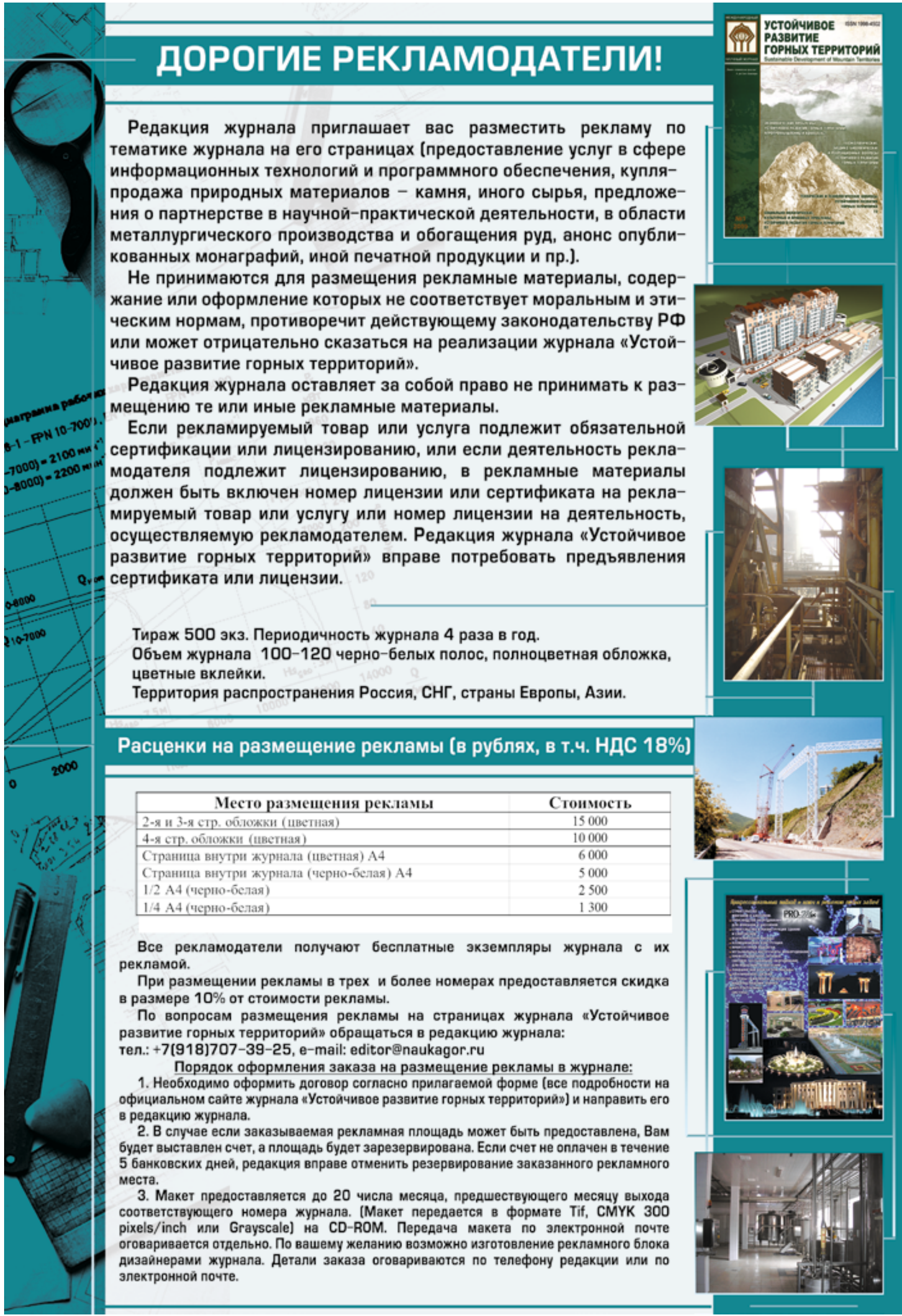





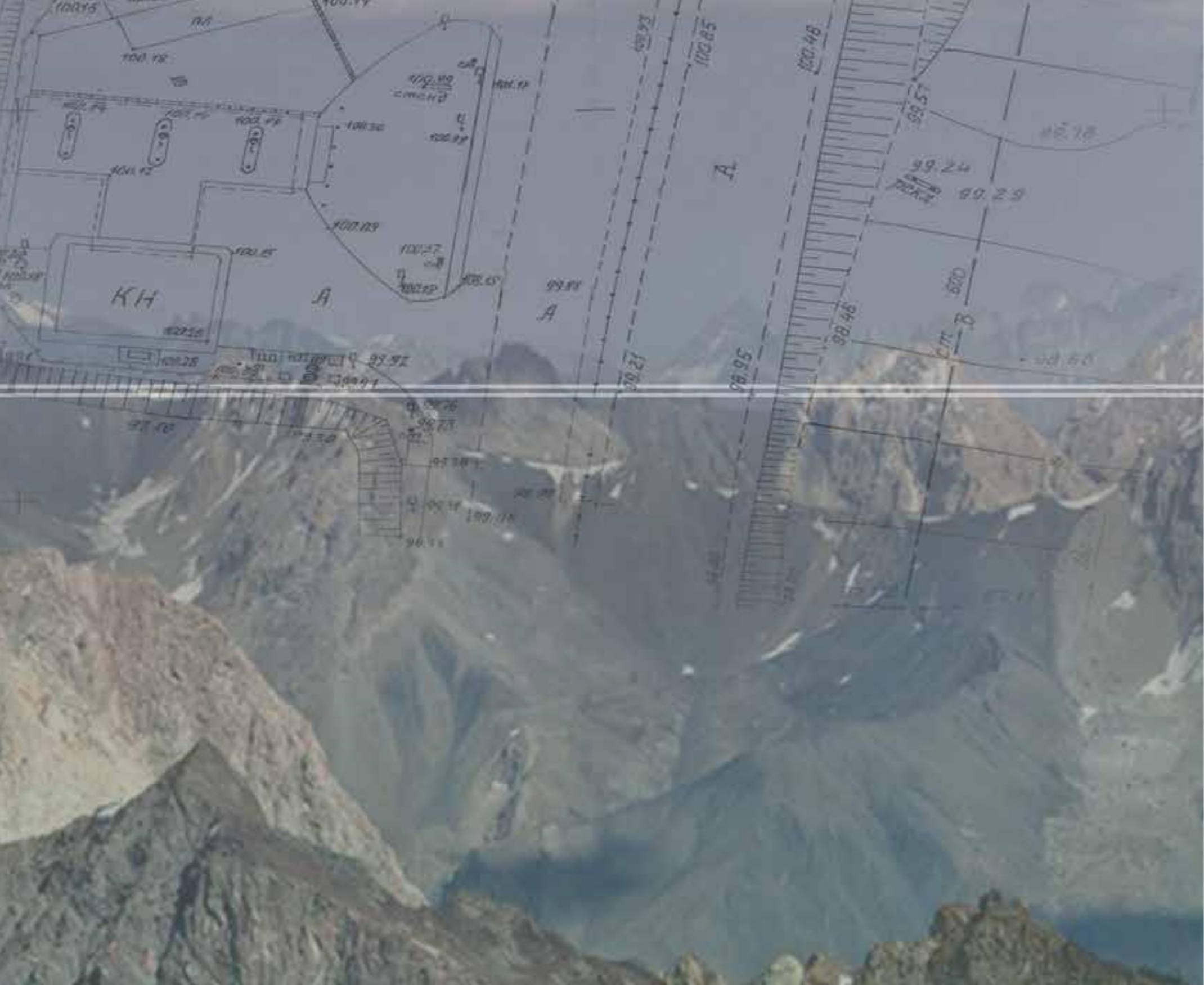

